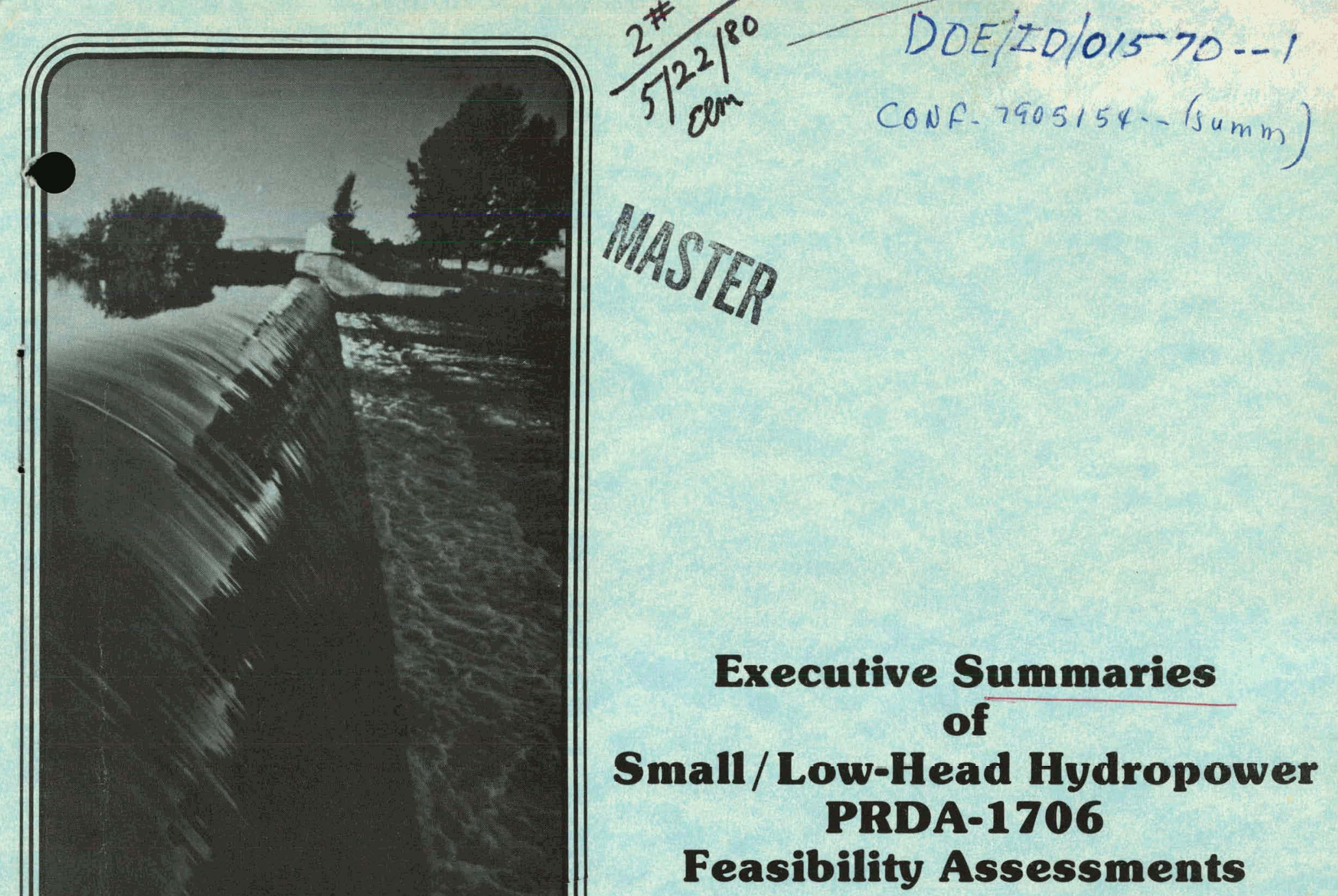

May, 1979 


\section{DISCLAIMER}

This report was prepared as an account of work sponsored by an agency of the United States Government. Neither the United States Government nor any agency Thereof, nor any of their employees, makes any warranty, express or implied, or assumes any legal liability or responsibility for the accuracy, completeness, or usefulness of any information, apparatus, product, or process disclosed, or represents that its use would not infringe privately owned rights. Reference herein to any specific commercial product, process, or service by trade name, trademark, manufacturer, or otherwise does not necessarily constitute or imply its endorsement, recommendation, or favoring by the United States Government or any agency thereof. The views and opinions of authors expressed herein do not necessarily state or reflect those of the United States Government or any agency thereof. 


\section{DISCLAIMER}

Portions of this document may be illegible in electronic image products. Images are produced from the best available original document. 
EXECUTIVE SUMMARIES

\author{
SMALL/LOW-HEAD HYDROPOWER \\ PRDA-1706 \\ FEASIBILITY ASSESSMENTS
}

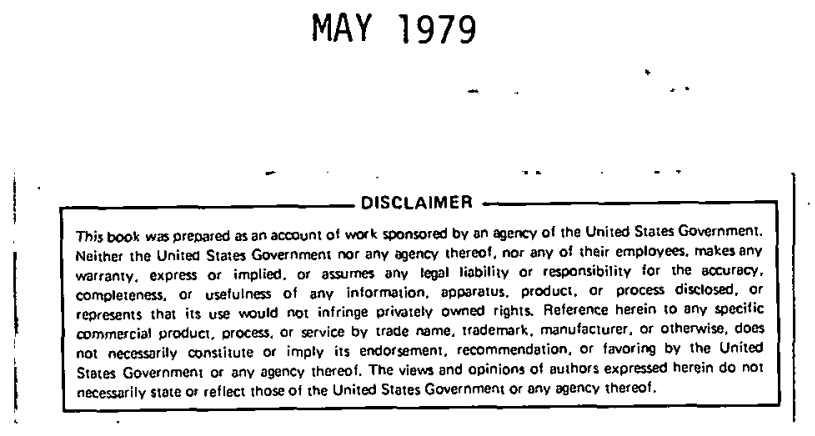

EG\&G IDAHO, INC.

IDAHO FALLS, IDAHO 83401

\title{
PREPARED FOR THE
}

U. S. DEPARTMENT. OF ENERGY

IDAHO OPERATIONS OFFICE

UNDER CONTRACT NO. DE-AM07-76ID01570 
FORWARD

The executive summaries of 49 of the 54 feasibility assessments performed under DOE's Program Research and Development Announcement (PRDA) ET-78-D-07-1706 are contained in this report. The remaining five summaries $(1771,1781,1797$, 1803,1818 ) were not received in time for publication. They will appear in an addendum in the "Proceedings" of the Sma11/Low-Head Hydropower PRDA-1706 Contractors' Symposium, Albany, New York, May 8-10, 1979.

Appreciation is expressed to each of the organizations and individuals that participated in the preparation of these summaries, which made this document possible. This publication provides the hydropower community with information on the feasibility assessments of actual small hydro sites. The sites were selected to provide widespread geographical distribution, as well as a variety of water resources, hydroelectric power capacities, and dam or diversion structures. It is intended that these assessments will: 1) encourage the development of renewable resources for power generation; 2) provide insight into the requirements for a good feasibility assessment; and 3) provide engineering, economic, environmental, safety, and institutional information on small hydropower development.

For further information on specific sites or assessments, you are encouraged to contact the individual organizations involved. 


\section{TABLE OF CONTENTS}

The Bethlehem Dam Hydroelectric Project - No.1759 . ........ I Pelton Reregulating Dam on the Deschutes River - No. 1758. . . . 4

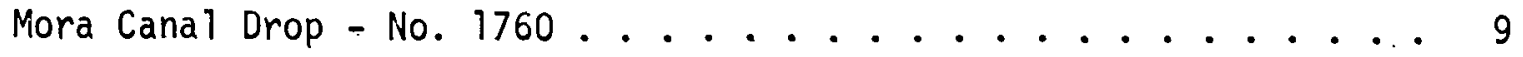
Archusa Creek Dam - No. 1761 . . . . . . . . . . . 14 High Falls Dam on Towaliga River - No. 1762. . . . . . . 15 Jackson Bluff Dam on the Ochlockonee River - No. 1763. . . . . . 19 Normanskill Hydroelectric Facility - No. 1765. . . . . . . . . . 23 Peninsular Paper Company Dam on the Huron River - No. 1766 . . . . . 27 Woodruff Narrows Dam on the Bear River - No. 1767. . . . . . . 31 Lowell Creek - No. 1768. . . . . . . . . . . . . . 35 The Carlyle Reservoir on the Kaskaskia River - No. 1769. . . . . . 39 Restoration of Frog Hollow Mill Hydroelectric Plant - No. 1770 . . . 43 French Landing Dam on the Huron River - No. 1772 . . . . . . . . 46 Zumbro Dam on the South Fork Zumbro River - No. 1773 . . . . . . 50 Big Blue River Hydroelectric Development - No. 1774. . . . . . 54 Vulcan Power Facility on the Fox River - No. 1775. . . . . . . 64 Max Starcke Park Dam - No. 1776. . . . . . . . . . . . . 68 Four Sites on the Mousam River - No. 1777. . . . . . . . . . 74 Tremont Dam on the Weweantic River - No. 1778. . . . . . . . 78 Johnson Lake Inlet - No. 1779. . . . . . . . . . . . 81 Piqua Hydroelectric Project on the Great Miarni River - No. 1780. . . 85 Phillips Hydroelectric Project - No. 1782. . . . . . . . . . . 89 Lower Ma in Canal Hydro Stations - No. 1783 . . . . . . . . . . . 99 Chicopee Falls Dam - No. 1784............... 100 Lewiston Canal Development - No. 1785. . . . . . . . . . . 104 High Falls Hydroelectric Plant - No. 1786. . . . . . . . . 106 Brighton Dam Hydroelectric Redevelopment - No. 1787. . . . . . 111 Woonsocket Falls Dam. - No. 1788 . . . . . . . . . 121 Low-Head Hydropower on the Mill River - No. 1789 . . . . . . . 125 North Harland Dam Project - No. 1790 . . . . . . . . . 129 Enloe Dam on the Similkameen River - No. 1791. . . . . . . 137 Brown Bridge, Keystone, Boardman, Sabin and Union Street Dams on

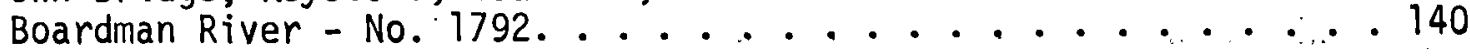




\section{TABLE OF CONTENTS}

(Cont'd)

Otter Creek Hydroelectric Feasibility Report - No. 1793. . . . . 141

Lake Frances Power Generating Facilities - No. 1794. . . . . . . 147

St. Joseph River Hydroelectric Plants - No. $1795 \ldots \ldots 1$

Cataract Power Plant Expansion on the Saco River - No. 1796. . . 162

Tuttle Creek Dam on the Big Blue River - No. 1798 . . . . . . 167

Joint Irrigation Districts Hydropower Assessment Study - No. $1799 \quad 171$

Dan River - No. 1800 . . . . . . . . . . . . . 174

Additional Power Generation at Upriver Dan on the Spokane River -

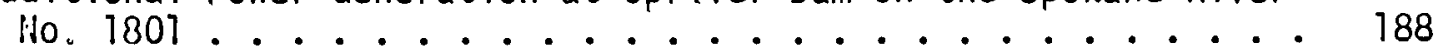

Patillas Reservoir - No. 1804. . . . . . . . . . 194

O'Shaugnessy and Griggs Dams on the Scioto River - No. 1805. . . 197

Pawtucket Dam and Northern Canal - No. 1807. . . . . . . . 201

Dam and Power Facilities on the Merrimack River - No. 1808 . . . 204

Barge Canal on the Mohawk River - No. 1809 . . . . . . . . 208

Dry Falls Dam Potential Hydroelectric Power - No. 1811 . . . 220

Expansion of Shawmut Hydroelectric Project - No. 1812. . . . 224

Maxwe11 Locks and Dam - No. 1813 . . . . . . . . . . 223

Broadwater Hydroelectric Project - No. 1822. . . . . . 232 
THE BETHLEHEM DAM HYDROELECTRIC PROJECT,

BETHLEHEM, N. H. .

Bethlehem Mink Farm

Richard Polonsky, Principal Investigator

PRDA Proposal Contract No. EW-78-F-07-1759

The Bethlehem Dam is located in Northern New Hampshire, on the Ammonoosuc River. It has a 96 square mile drainage area and includes the western slopes of Mt. Washington. It is a run-of-che-river site with no ponding and an average flow of 209 cfs.

The history of the dam and its property is typical of the development of New England hydropower at a run-ofthe-river site. The property has been associated with agriculture and lumber operations for over a century and a half. The present dam was built in 1927 and utilized a 1,500 long steel penstock with a $300 \mathrm{KW}$ francis turbine and Woodard generator. Public Service Co. of New Hampshire decommissioned the site in 1958 and sold it to Dr. Arnold Polonsky, President of Bethlehem Mink Farm.

The Bethlehem Mink Farm is a third generation family business, started in 1937 as a hobby of "Grandpa" Joseph Polonsky (a retired pharmacist from New York City). His son, Arnold, after graduating from veterinary schocl in 1945, took over management of the farm and through the next 26 years built it into the largest mink ranch on the East Coast. A million dollar a year aggregate business, the Bethlehem Mink Farm was a totally selfsufficient operation.

In 1971, BMF's herd was dessimated by a PCB (polychlorinated byphenyls) contaminated ingredient. Thirty years of work and 18,000 mink died in five days. Today, BMF's operatons include farming, the raising of 1,300 calves a year; service operations - refrigerated warehousing and trucking; real estate - rental of commercial and industrial properties, and land development. Bethlehem Mink Farm plans to recommission the site with the intent of utilizing the power in its current operations as well as future expansion and diversification of its agricultural production.

New Hampshire has a short growing season and imports $90 \%$ of its food from Sunbelt regions of the U.S. The Farm will extend the growing season by developing an enclosed, biologically integrated growing facility for raising fish and vegetables. There are three existing masonry structures currently at the site which are not in use. Of these, the former Public Service co. Transformer Service building located about loo feet from the dam is favorably suited to re-use as a Prototype Acquaculture/Agriculture Production Facility which could serve as an experimental model for a larger facility to be constructed at the site for greater utilization of the power produced at a later date.

Electricity generated would be used to produce light to supplement natural daylight and waste heat from the lighting would be used to control the temperature in the growing facility. An integrated, controlled environment (e.g. for growing trout, tomatoes, lettuce and/or processing) would provide for balanced load management on a seasonal and daily basis which would be compatible with the electricity generating pattern of the plant.

The Farm is planning its agricultural operations to match the flow of the river. Therefore, an early emphasis was placed upon low stream flows in order to have power available year round. This led to sizing turbines which could operate over a wide range of flows. Stream duration curves, based on 5 cfs increments over a 0 - 200+ cfs range, were compiled for each month of the year from 11 years of data.

The Farm compared three basic types of turbines against the 12 models of monthly stream flow. These turbines were: a tube (Allis Chalmers), a francis (Brown-Boveri) and a cross-flow (Ossberger). Manufacturers were asked to supply information for two sites utilizing 42 feet of head at $500 \mathrm{KW}$ and $62 \mathrm{feet}$ of head at $750 \mathrm{KW}$ capacities with a $200 \mathrm{cfs}$. stream flow. The original turbine was a $300 \mathrm{KW}$ francis at the 42 feet head, but was not seriously investigated berause of its high cost.

The monthly comparisons for the turbine/generators' performances utilizing the monthly flow models were: 
MONTHLY POWER POTENTIALS

\begin{tabular}{|c|c|c|c|c|c|c|}
\hline \multirow[b]{2}{*}{ MONTH } & \multicolumn{3}{|l|}{ 42' Head } & \multicolumn{2}{|c|}{$62^{\prime}$ Head } & \multirow[b]{2}{*}{ Allis-C } \\
\hline & Ossberger & Brown-B & Allis $-\mathrm{C}$ & Ossberger & Brown-B & \\
\hline OCT & 285 & 256 & 245 & 406 & 378 & 360 \\
\hline NOV & 339 & 343 & 322 & 509 & 466 & 508 \\
\hline DEC & 320 & 331 & 324 & 490 & 488 & 478 \\
\hline JAN & 245 & 197 & 189 & 339 & 290 & 276 \\
\hline FEB & 259 & 217 & 194 & 382 & $3 ? 1$ & 288 \\
\hline MAR & 292 & 288 & 270 & 451 & 420 & 400 \\
\hline APR & 465 & 470 & 447 & 694 & 702 & 629 \\
\hline MAY & 496 & 499 & 497 & 74.3 & 748 & 745 \\
\hline JUN & 421 & 428 & 424 & 625 & 641 & 630 \\
\hline JUL & 276 & 253 & 240 & 402 & 374 & 353 \\
\hline AUG & 203 & 158 & 139 & 299 & 230 & 205 \\
\hline SEP & 210 & 1.68 & 152 & 308 & 248 & 216 \\
\hline Monthly Ave & 317 & 299 & 286 & 467 & 442 & 426 \\
\hline Yearly MegaWh & 2785 & 2629 & 2515 & 4097 & 3889 & 3738 \\
\hline
\end{tabular}

The Bethlehem Mink Farm will continue its active role in the development of its hydro site. It intends to take part in the installation and operation of the equipment. The cost analysis for the various turbine/. generator packages and installatiors, including the replacement turbine, are shown below. These costs are stated in terms of April, 1979 dollars.

COST ANALYSIS OF POTENTIAL TURBINE PACKAGES

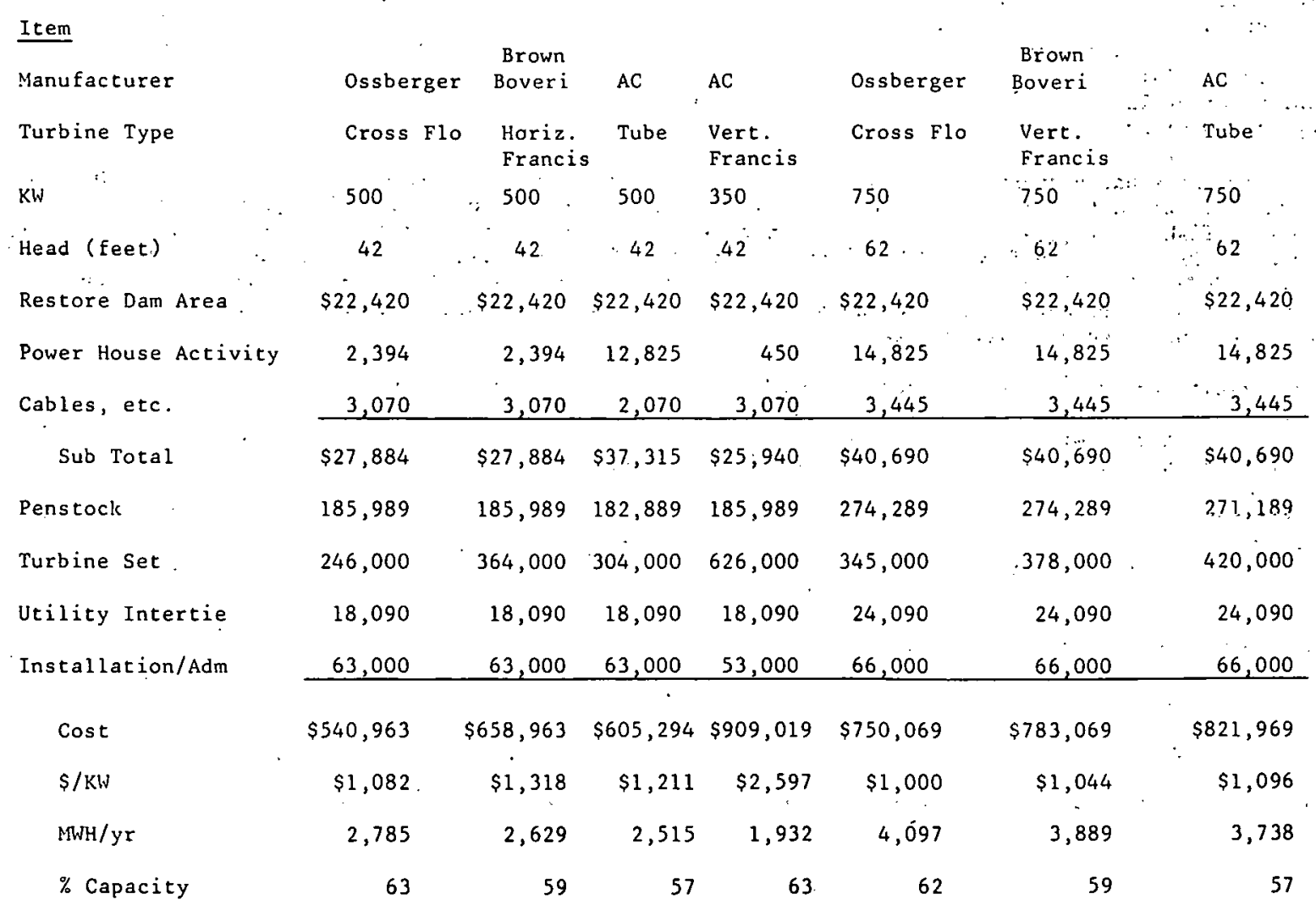


The major surprise was the cross-flow turbine. Its lack of peak efficiency was more than offset by its wide operating range with the stream flow. The cross-flow is also less affected by high tail water, leaf and ice conditions. The francis and tube turbines also clearly demonstrated the major advances in turbine technology which have been made in the last 40 years. The choice for the site seems obvious: a cross-flow turbine at the higher head.

The Farm has gathered a great deal of information. It sent representatives to hydro manufacturers, hydro conferences, hydrosites, universities and public and private agencies. Its research will continue until the plant becomes operational. The short form FERC License is available but is untested by practice.' The environmental concerns are identified but some specifics have not been defined by certain agencies. Multiple use is being evaluated with the help of local and regional special interest groups. In general, the Farm has found an open attitude useful in dealing with the still formidable legal and institutional obstacles/barriers to small scale hydro development.

The realistic key to bringing this hydroelectric site on line is an in-hand power contract with a suitable buyer. The New Hampshire Legislature passed laws instructing the New Hampshire Public Utilities Commission to establish a reasonable rate to be paid to small (under $5 \mathrm{MW}$ ) producers of power. Now after extensive hearings the Commission is expected to announce the rate by June 1979. The Federal.Energy Regulatory Commission is cxpected to have similar rate structures published in 1980. The Farm's goal for agricultural utilization of the Dam's power should start to materialize on a commercial scale in 1981. 
PELTON REREGULATING DAM ON THE DESCHUTES RIVER

Warm Springs, Oregon

Confederated Tribes of Warm Springs Reservation of Oregon

Edward Fitzgerald Dibble, Consulting Engineer

Redlands, California

In Association With

Haner, Ross \& Sporseen, Inc., Civil Engineers

Portland, Oregon

and

Engineering \& Dccign Associates, Electrical Engineers

Tigard, Oregon

PRDA Proposal Contract No. EW-78-F-07-1758

\section{INTRODUCTION}

The Confederated Tribes of the Warm Springs Reservation of Oregon are considering building a hydroelectric power plant in the existing Pelton Reregulating Dam about nine miles northwest of Madras in Central Oregon. The dam is 1ocated on the Deschutes River which flows along the easterly edge of the Warm Springs Reservation.

\section{AGREEMENTS}

In 1955 the Confederated Tribes entered into an agreement with Portland General Electric Company, an investor-owned utility, to allow the company to build and operate Pelton Reregulating Dam and two hydroelectric dams, Pelton Dam, three miles upstream and Round Butte, seven miles further upstream. At that time it was not considered economically feasible to install a hydroelectric plant in the Reregulating Dam. In the 1955 agreement, the Confederated Tribes retained the right to install, operate, and maintain a hydroelectric generating unit or units in the Reregulating Dam at their own expense with the design, construction, and operation to be subject to the approval of the power company, who is responsible for maintaining the flow in the Deschutes River as prescribed in its FPC license. The Pelton Reregulating Dam was built and is operated by the power company to provide temporary reregulation storage solely to hold the varying flow from the peaking operation at Pelton and Round Butte and to release said flow at uniform rates to the Deschutes River downstream.

\section{WARM SPRINGS RESERVATION AND DESCHUTES RIVER}

The Warm Springs Reservation of Oregon, covers about 680,000 acres from the crest of the Cascade Range on the west down to the Deschutes River on the east. Forests cover the land in the higher elevations. Large open areas with scattered juniper vegetation, interspersed with deep canyons cover the lower elevations. The main community on the Reservation is Warm Springs, lcoated 3 miles north of the Pelton Reregulating Dam. The proposed project will be entirely within the reservation.

The Deschutes River drainage area upstream from the Pelton Reregulating Dam is 7,820 square miles in Central Oregon and the east side of the Cascade Range. There are several large manmade reservoirs upstream which store water for irrigation projects and near Bend, Oregon, about 50 miles upstream almost all the flow is diverted leaving less than $200 \mathrm{cfs}$. But above the Round Butte and Pelton Projects the Deschutes River becomes "born again" and is one of the most uniformly flowing rivers in the United States, because of ground water which emerges in the canyons from porous lava rocks as large steady-flowing springs. The recorded flows at the reregulating dam in the last twenty years have varied from a low of about $2600 \mathrm{cfs}$ to a high of about $15,800 \mathrm{cfs}$. The average flow for the last fifty-four years has been 4,475 cubic feet per second.

PROPOSED PROJECT

The proposed project will include a construction of a power house to harness 
the head and flow at the existing Pelton Reregulating Dam, and construction of a transmission line 3 miles long to connect to the existing power system at Warm Springs.

The power house will include one horizontal bulb turbine and generator with nameplate rating of 15,000 kilowatts. The head on the plant will normally fluctuate each day from a low of about 18 feet at 6 a.m. to a high of about 42 feet at $11 \mathrm{p} . \mathrm{m}$. each night. The plant will operate under an average head of 36 feet. The net average annual production will be $81,135,000$ kilowatt-hours, which is an annul output of 9,262 average kilowatts, resulting in a plant factor of 62 percent.

The plan of development contemplates removal of a section of the existing earth and rockfill dam just west of the existing concrete spillway structure and constructing the power plant adjacent to the spillway. During the construction period it would be necessary to install cofferdams, both upstream and downstream around the area where the section of the dam will be removed so that the area can be dewatered while construction work proceeds.

The single unit bulb turbine installation was selected as the most economically feasible arrangement. Two units would produce slightly more power because the units could be operated near maximum efficiency over a broader range than with a single unit. However, the two unit installation would cost approximately $\$ 1,000,000$ more, which is approximately three times as much as the value of power saved due to the greater efficiency.

Consideration was given to three types of units-Bulb, Kaplan, and Tube Turbines. The tube turbine was eliminated because of its lower efficiency, appearing to be about $1.5 \%$ less at point of peak efficiency and about $3 \%$ at minimum and maximum operating load. The efficiency for the Kaplan turbines appeared to be fairly close to that of the Bulb trubine, but the power house for the Kaplan would need to be about $20 \%$ wider. The depth of excavation would have been about the same, and the length would have been about the same because of the requirements relating to fishway design.

Ultimately, therefore, the bulb turbine was selected as preferred, with recognition of a need to review at time of final design. It will be important to specify that the Bulb turbine-generator contractor guarantee the overall efficiency of the entire unit, after losses for the exciter, cooling pumps or fans, oil pressure pumps, etc., required in operating the complete unit.

The existing facilities include fishways which lead to a fish ladder, trap and loading station. The proposed project will include additional fishway entrances above the draft tube exist of the new power house, with control weirs to operate automatically by remote control.

The power supply on the Warm Springs Reservation is presently from one 69-kv line of Pacific Power \& Light, Company from Madras to a substation at Warm Springs from which various parts of the reservation are served radially. This line has been subject to occasional outages. The proposed project will include a 3-mile long transmission circuit, 69-kv, from the Pelton Reregulating Dam to the Warm Springs substation. This will provide a nearby source of dependable power to the reservation.

The power output from the proposed project will be more than the present needs of the reservation. In 1977, the total electric energy delivered to the Reservation was about 32 million kwh, whereas, the project will produce about 81 million kwh, which is two and half times as much as the present needs of the Reservation. The interconnection at the Warm Springs substation will allow the production from the project to help serve the Pacific Northwest which has a growing need for energy.

CAPITAL COST

At 1978 cost levels, the capital cost of the proposed project would be $\$ 19,374,000$. If the project were to be moved along on a fairly tight time schedule, it could be completed in 1982. Including allowances for escalation during that time it is estimated cpaital cost of the project, if completed in 1982, would be $\$ 25,831,000$. Deferral or delay of the project would cause the cost of the 
project to escalate about $\$ 175,000$ for each month of delay or about $\$ 2,000,000$ for a delay of a year.

ANNUAL COST

The annual costs of the project will include operation and maintenance, administrative and general costs, replacement of short-life items, insurance, depreciation and payment of principal and interest on outstanding debt. These are shown in the following table with three columms showing respectively, the annual costs for the project at 1978 cost levels, 1982 cost levels, and the "levelized" costs during the entire project payout period. The levelized costs represent the amount of equal annual payments during the 25 year payout period, 1983 through 2007 , of the present worth value, using 1982 as the base year, of ali project costs, including allowance for inflation of annual costs during the 25 years.

ESTIMATE OF ANNUAL COSTS

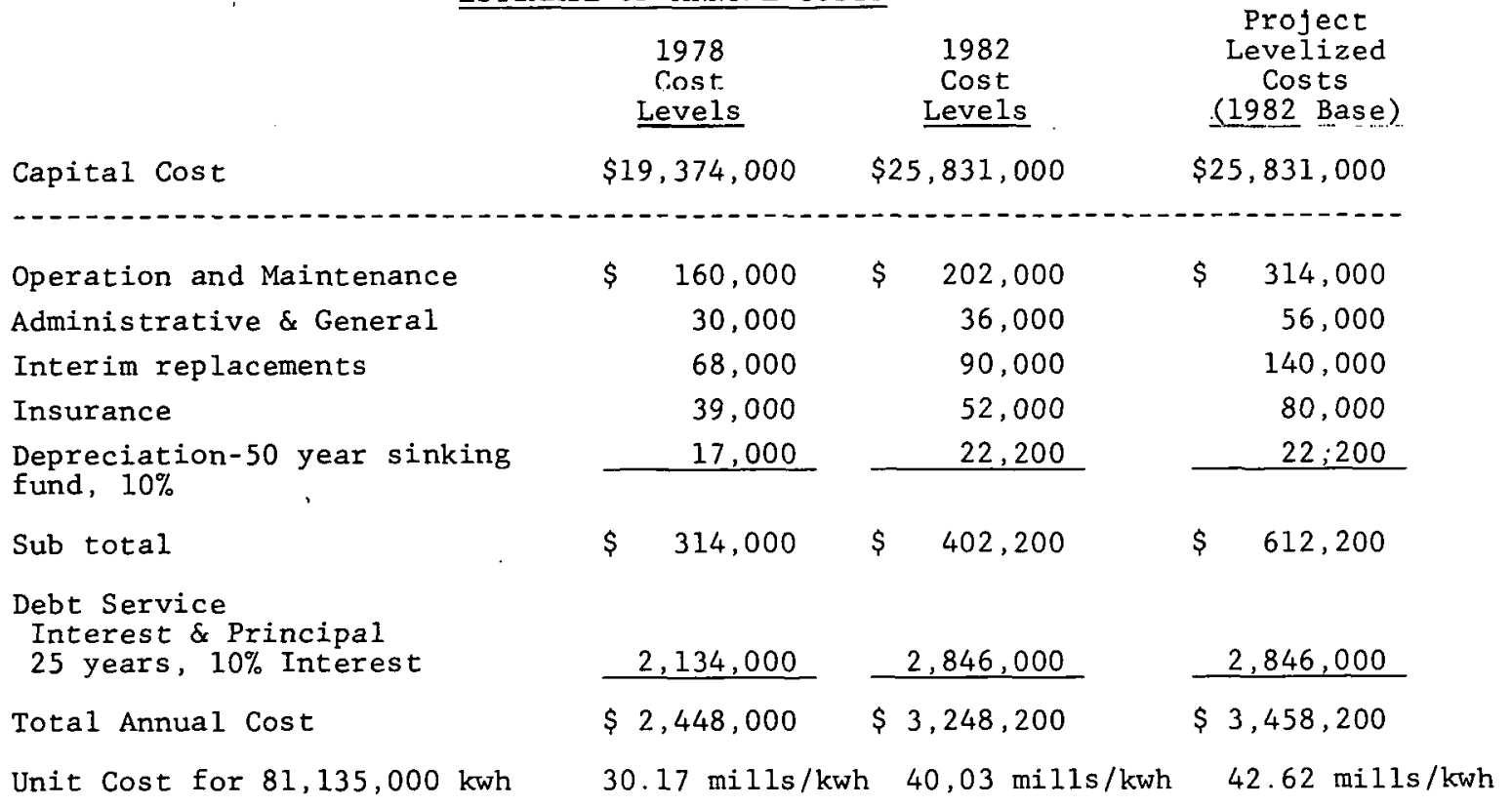

It is proposed that the project be operated as a.tribal venture or corporation in which case it is anticipated it will be located within the Warm Springs Reservation and therefore will not be subject to county ad valorem property taxes.

The payout period for debt service used is the 25 years 1983-2007, because 2007 is the year the FPC license for the existing facilities expires.

\section{ENERGY GENERATION}

Studies indicate that by operating the pool at the higher levels instead of at the historical levels the gross generation will increase about 2,025 average kilowatts. Of this, the loss of generation at Pelton would be 1,250 average kilowatts, which would have to be repaid to that plant. However, there would be a net increase in average energy output at the proposed power plant at the Reregulating Dam of 672 average kilowatts. This has been included in the estimate of average energy output of 9,262 kilowatts. This will result in total net energy production of $81,135,000$ kilowatt hours per year, which is the net production to be anticipated. 


\section{ENVIRONMENTAL ANALYSIS}

Existing facilities include fishways at each side of the spillway, and a fish ladder and trap. They are designed and operated to provide steady releases to the Deschutes River to maintain desirable conditions for fish.

The proposed project will be operated in the same manner. A new fishway will be added which will release water to the river at a shallow depth above the draft tube. The draft tube from the turbine is purposely designed to discharge at a considerable depth so as to separate the turbine discharge form the fish attraction water.

From an environmental standpoint, the proposed project will be converting the energy of the flowing water and its head into electric energy without degrading the environmental conditions at the site. The use of this renewable natural resource will produce an annual average of $81,135,000$ kilowatt-hours which is the equivalent of 135,000 barrels of oil per year for generating an equal amount of electric energy. 


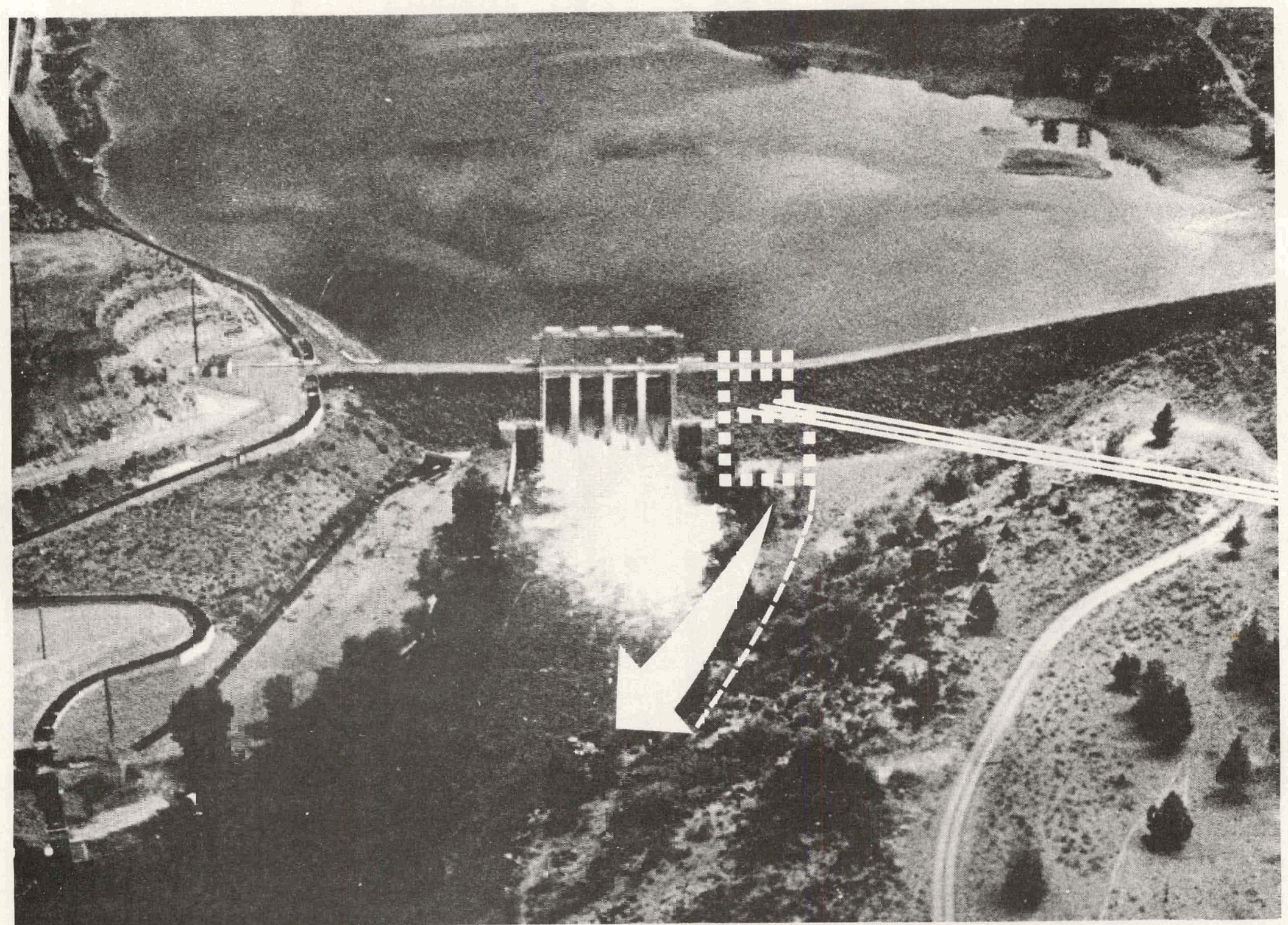

Rereculating Dam site 
MORA CANAL DROP

near Bolse, Idaho

Bolse Project Board of Control

Tudor Engineering Company

PRDA Proposal Contract No. EW-78-F-07-1760

\section{INTRODUCTION}

The Botse Project Board of Control entered into a cooperative agreement with the United States Department of Energy to conduct a study to investigate the feasibility of developing hydroelectric power at an existing canal drop structure on the Boise project in southwestern Idaho. The Board, In turn, issued a subcontract to Tudor Engineering Company to perform the study.

The primary objective of the study was to develop information which would serve as a basis for a decision whether or not to proceed with construction of the power facilities.

The study concluded that the construction of the power facilities is feasible in all respects. The plant would have an installed capacity of 1,900 kilowatts with an estimated annual energy output of $8,113,000$ kflowatthours. The initial cost of the project would be approximately $\$ 1,800,000$. The annual cost, including amortization, would range between $\$ 165,000$ and $\$ 180,000$, depending on the financing methods adopted. Energy production costs would range between $\$ 0.0203 \$ 0.022$ per kilowatt-hour.

The energy production curve closely matches the energy demand curve for the surrounding area. The Idaho Power Company has indicated a need for the energy and has offered to purchase all energy produced at the Mora Canal Drop for $\$ 0.026$ per k1lowatt-hour, thus making the project financially feasible under any of the current financing options.

The study examined marketing potential, environmental impacts, social impacts and licensing requirements. A final step in the study was to develop a schedule for constructing the plant and putting power on line.

\section{EXISTING CONDITIONS}

The Mora Canal is part of a large canal system known as the Arrowrock Division of the Boise Project, a development of the United States Bureau of Reclamation (U.S.B.R.). The Arrowrock Division provides for 1rrigation of approximately 200,000 acres of farm lands located to the west of Boise between the Bolse and Snake Rivers. of this total, the Bolse Project Board of Control operates and malntalns the canal system for 167,500 acres. The Boise Project Board of control is an entity formed under contracts between the U.S. Department of Interior and the five irrigation districts in the Bolse valley. The districts are the New York Irrigation District, the Nampa and Meridian Irrigation District, the BolseKuna Irrigation District, the Wilder Irrigation District and the Big Bend Irrigation District.

The overall system is comprised of three upstream reservolrs on the Boise River, a downstream diversion dam, a canal network and one off-channel reservolr. Uppermost in the system is Anderson Ranch Dam and Reservoir on the South Fork of the Boise River approximately 60 miles upstream from Bolse, Idaho. Arrowrock Dam is located on the Boise River about four miles below the function of the North and South Forks, and about 22 miles upstream from Bolse. Lucky Peak Dam is located on the Bolse River downstream from Arrowrock Dam approximately ten miles above Bolse. Two miles downstream of Lucky Peak Dall, the 68 font high rubble concrete Boise River Diversion Dam diverts the profect flows into the Boise Project canal system. The New York Canal flows southwesterly from this polnt, eventually ending at Lake Lowell. 
The Mora Canal branches from the New York Canal 26 miles downstream of the diversion polnt. The canal runs westward from this point to the south side of Lake Lowell, a distance of approximately 27 miles. Wasteways located at the southeast and southwest ends of the lake can each divert 100 second-feet from the Mora Canal.

The Mora Drop structure is located approximately 12 miles below the point at which the Mora Canal diverges from the New York Canal. The structure is located approximately 20 miles southwest of Bolse. The purpose of the existing facility is to drop flows of the Mora Canal a vertical distance of 36 feet. The existing factlities consist of the Upper Mora Canal with an approximate capacity of l, 100 cfs, a headworks structure that controls the flow of up to 300 cfs into the Waldvogel Canal, the Mora Canal Drop structure, a downstream stiling basin and the Lower Mora Canal with a capacity of 850 cfs. The layout of the existing drop structure can be seen in Plate II.

\section{RECOMMENDED DEVELOPMENT}

The first step in determining a recommended development was a conceptualization of the new facilities. At the Mora Drop, the facllities will consist of a new headgate structure for the Waldvogel Canal to be located downstream of 1 ts present location; new gates for the existing chute, which will remain in place as an emergency bypass of the turbines; the power plant intake works with a condult connecting to the turbine; the power plant 1tself; and outlet works that tfe into the Mora Canal just downstream of the existing stilling basin. The general layout of these new factlities is shown on Plate II.

Within the general conceptual development described above, the type of turbine and generator, the size and number of units and the configuration of the power plant and penstock still remain to be determined. In assessing the number and size of units, a series of marginal cost comparisons was made based on the design hydrograph and the hydrailic head. The results indicated that the optimal installation for the site would be one unit of 1900 kilowatts with adjustable blades.

In selecting the type of turbine and corresponding plant configuration, the general methodology used was to first solicit estimates for a single 1900 kw turbine and generator from the varlous manufacturers. After the estimates were recelved, a preliminary design of the required clvil and structural works for each was then performed. The total costs were then determined by adding the mechanical and electrical cost to the corresponding civil and structural costs; the totals were then compared. Turbines considered were open flume vertical shaft propeller turbine, vertical shaft propeller turbine with concrete penstock and scroll case, tube turblne, bulb turbine and ossberger turbine. only a synchronous generator was considered due to requirements of the local utility.

The results of the cost comparison showed that the vertical shaft propeller with concrete penstock and scroll case had the lowest overall cost. However, the open flume vertical shaft propeller turbine and the tube turbine configuration were very close. Since the cost results were effectually equal, and since the efficiencies and power outputs are the same, detalled configurations of the vertical shaft propeller turbine with concrete penstock and scroll case and the tube turbine were prepared. No such conflguration was prepared for the open flume vertical shaft tubine due to the potentially high but unknown quantity of rock excavation which could substantially increase project costs. The detalled layouts of the two alternate installations are shown on plate III.

In order to convert the power to a usable voltage and transmit it to an existing power grid, it will be necessary to construct a switchyard and transmisston line. The switchyard would be constructed on a concrete base slab adjacent to the plant. A transmission line will be constructed to convey the electrical energy to Idaho Power Company's Bowmont substation approximately five miles southwest of the Mora Canal Drop. The configuration will be a 34.5 kilovolt, single pole, three wire line on 200 foot centers.

\section{PROJECT ENERGY PRODUCTION}

Based on discussions with the Bolse Project Board of Control, it was determined that by a modest change in canal operating practice, more than historic flows can be conveyed in the Mora Canal. On the average, 250,000 AF of 1rrigation water per year 1s delivered to Lake Lowell through the New York Canal during the period of March through November. Because of the two Mora Canal wasteways that discharge into Lake Lowell, some of this New York Canal flow could be diverted into the Mora Canal at its headgates. This water would 
then flow through the Mora Drop turbine, continue in the canal to near Lake Loweli, and be diverted into Lake Lowell through the two wasteways. If the Mora Drop power plant 1s constructed, the Board of Control intends to change their operating practice to take advantage of this additional flow. Consequently, the flow schematics used for the power studies assume this change will be made.

A performance curve was ut $111 z$ ed in determining plant output. Utilizing the curve and the previously discussed flows, it was determined that the plant could be expected to produce an average of $8,113,000$ kflowat-hours annully. The season for power production would be from March 16 to November 15, with the peak comfig in July and August.

\section{PROJECT $\operatorname{cosTS}$}

The Initial capital costs consist of construction costs, interest during construction and 1ndirect costs. For this project, construction cost was estimated at $\$ 1,373,750 ; 1$; terest during construction was estimated at $\$ 65,000$; indirect costs were estimated at $\$ 345,000$. The indirect costs include englneering, surveys, 11 cense and permit applications, construction management, financial consultants, bond counsel and admintstrative costs. The construction cost estimate is relatively low because the Bolse Board of Control intends to do much of the civil and structural work with its own forces. As an example of this low construction cost, the unit price for concrete was considered to be $\$ 70$ per cubic yard. The total inftial investment of approximately $\$ 1,800,000$ represents an investment of $\$ 947$ per installed kilowatt.

The project annual costs are comprised of bond repayment costs and operation and malntenance costs. The bond repayment cost depends on the method of financing utilized, the length of repayment time and the interst rate. In the report, two methods of financing were considered: the traditional method of selling revenue bonds and the newer method of obtaining a loan from the Department of Energy. The bond repayment costs for these options would be $\$ 155,650$ and $\$ 139,910$ respectively. Adding an annual operation and maintenance cost of $\$ 24,700$, the total annual cost for the revenue bond option would be $\$ 180,350$ wh1ch, for an average annual energy of $8,113,000 \mathrm{kWh}$, represents an energy production cost of $\$ 0.0222$ per kWh. With the D.0.E. option, the total annual cost would be $\$ 164,610$, representing an energy production cost of $\$ 0.0203$ per kWh.

\section{ECONOMIC EVALUATION}

The economic evaluation of the profect is basically a comparison of the benefits and costs over the $11 \mathrm{fe}$ of the project. The method used in the report was the benefit-cost ratio. An economic life of 50 years was chosen. A benefit of $\$ 0.026$ per $k$ Wh was used as Idaho Power Company has expressed their interest in purchasing the energy at that price. Discount rates of $6 \%, 8 \%$ and $10 \%$ were used because of the current state of flux of interest rates. For an average annual energy of $8,113,000$ kWh the benefit cost ratios ranged from 1.41 to 1.18 depending on the discount rate and method of financing. Inflation was not considered in the derivation of the above ratios. A brief analysis showed that if inflation were considered, the benefit-cost ratio would increase dramatically.

\section{OTHER CONSIDERATIONS}

The study investigated the potential environmental impacts of the project and found that no significant impacts were expected. No major safety hazards will be introduced by the power plant. There would be a slightly beneficial socio-economic impact.

A plan to inftiate project construction, implement all activities and bring power on line was developed. The plan includes a timetable for a power sale agreement, 11 cense and permit acquisition, design, construction, testing and start up. The plan concludes that energy from the Mora Canal Drop Hydroelectric Project could be put on line by the 1982 irrigation season. 


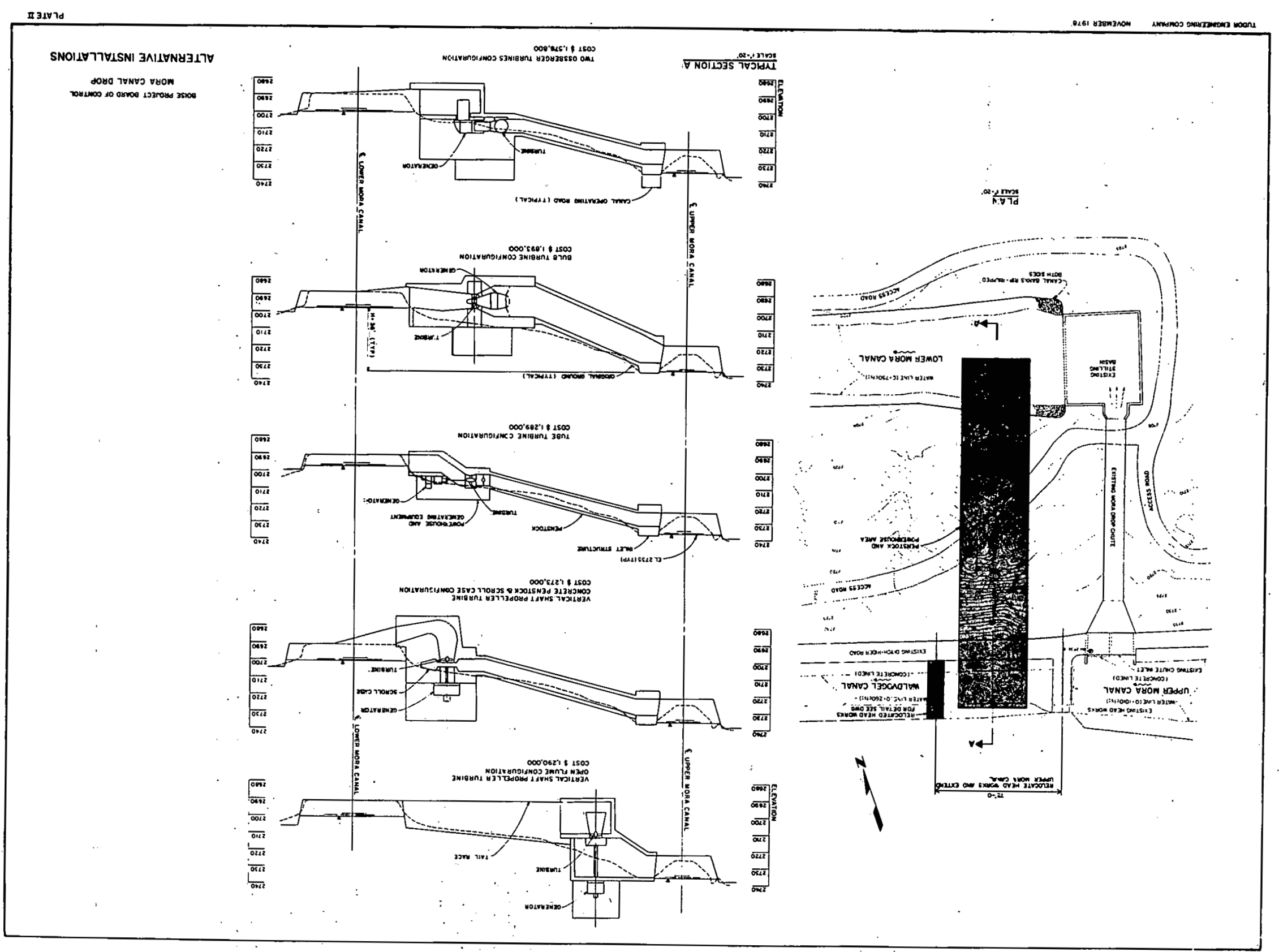




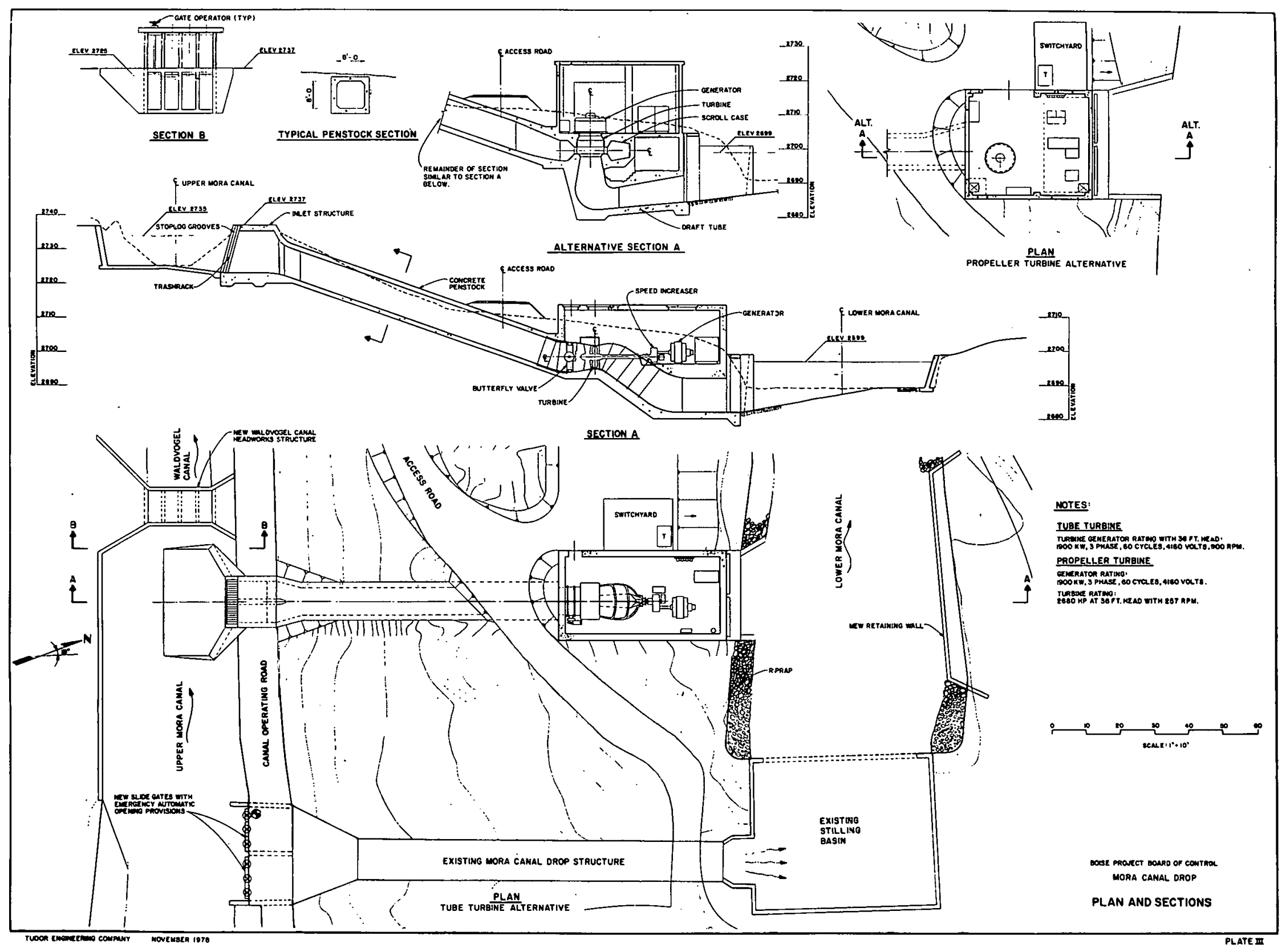




\section{ARCHUSA CREEK DAM}

Quitman, MS

Pat Harrison Waterway District

Karl W. Carlson \& John Herring

PRDA Proposal Contract No. 1761

\section{INTRODUCTION}

The rising costs, uncertain future supply, and environmental problems have resulted in serious investigation of energy sources that have not previously been considered economically and technically feasible.

One such source involves low head hydro-electric generators. The Department of Energy has funded several feasibility studies for the installation of hydro-electric generators at existing low head dams. This report deals with such a feasibility study for the Archusa Creek Dam near Quitman, Mississippi.

\section{PERTINENT PROJECT FACTS}

The lake and dam are owned by the Pat Harrison Waterway District and is intended primarily for recreational purposes. The installation of a hydro-electric unit should be compatible with recreational activities. The study indicates that there are no apparent technical difficulties to prevent such a project and that a suitable turbine generator could be obtained. The study further indicates that the project should be economically feasible.

The lake has an area of approximately 450 acres and the proposed installation would have an approximate head of $25^{\prime}$. The average annual flow is $90 \mathrm{cfs}$ during the period June through November. In order to provide maximum power during peak load periods, a turbine/generator unit with an output of $250 \mathrm{kw}$ is proposed. With this size unit and a variation of $1^{\prime}$ in the level of the water to provide for storage, the unit could provide peaking power for at least nine hours per day, five days per week, assuming average flows.

\section{CONCLUSION}

An Ossberger turbine is proposed for two reasons. First, the initial cost is less; second, the controls are simple but it is stili possible to obtain $1 / 3$, $2 / 3$, or full rated output with essentially the same efficiency. Simplicity of controls is important from the standpoint of both cost and maintenance.

An induction generator is proposed again for the sake of cost and simplicity of operation. This requires a source of exciting energy which can be derived from the interconnection with the local utility. A capacitor bank is included to improve the power factor. The local utility (Mississippi Power Company) has expressed an interest in the project and has provided a tentative offer concerning the amount they would pay for the energy. The critical consideration in the feasibility study involves economics. An economic analysis which the investigators considers conservative indicates the project would be feasible as the Pat Harrison Waterway District owns the facility and markets the energy to the Mississippi Power Company. 
HIGH FALLS DAM ON TOWALIGA RIVER

High Falls, Georgia

\author{
State of Georgia (Office of Energy Resources \\ and Department of Natural Resources), \\ Georgia Institute of Technology and Cadre Corporation \\ Neil B. Hilsen, Principal Investigator
}

Cooperative Agreement No. EW-78-F-07-1762

\title{
I. INTRODUCTION
}

The Office of Energy Resources (OER) and the Department of Natural Resources (DNR) responded to the Department of Energy's Program Research and Development Announcement with a proposed study based on an existing dam structure in High Falls State Park. The present dam, located approximately 50 miles south of Atlanta, impounds the Towaliga River, part of the Altamaha drainage basin, capturing a reservoir of 740 acres. High Falls Dam was built in 1905 and used for generation purposes until 1958 when the site was abandoned due to economic problems. In 1961, the dam site and several adjacent parcels of land were donated to the State of Georgia, and are under the management of the Department of Natural Resources. Since the original generating facility had a head of $34 \mathrm{~mm}(100 \mathrm{ft})$, the 20 meter limitation in the PRDA precluded this location from the assessment. Other locations were assessed that fell within the low-head constraint of the PRDA.

\section{OBJECTIVE}

The overall objectives of this project are to (1) assess the feasibility of a hydropower facility at High Falls State Park from technical, environmental, and economic view points; (2) assess the economic, environmental, social, inst itutional, and marketing constraints and impacts that affect the development of a hydropower facility; (3) prepare a set of conceptual design drawings and specifications concerning the facility, distribution system, location, equipment size, duty cycle, and other performance parameters; (4) develop a construction schedule with estimated costs; and (5) prepare a report that provides the basis for a design proposal for the facility implementation.

The site was selected for study because it would provide a large array of variables in the technical, economic, environmental, and social aspects of revitalizing the generating potential of the Towaliga. In order to determine the optimum facility configuration from these variables, a systems approach was used for the assessment. The overall program plan consisted of: (1) Site Assessment, (2) Facility Design, (3) Energy Production Estimates, (4) Economic Analysis and (5) Environmental and Socio-Institutional Assessment.

\section{CONCEPT}

The design concept employed for this study was to take maximum advantage of standardized and pre-engineered package systems. The specific resources, constraints, and limitations were identified and a design was selected; this design was utilized to conduct further economic analyses.

\section{RESULTS}

The results of this study are presented briefly in the following order: (1) Flow data, (2) Constraints, (3) Potential sites, (4) Selected system, (5) Environmental assessment, and (6) System cost and economic analysis.

(1) Flow data - There was a stream flow gauge located on the Towaliga River at the highway bridge on State

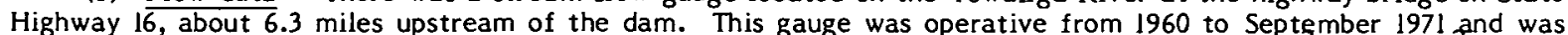
recorded daily during that period. We measured the watershed of the gauge to be $266 \mathrm{~km}^{2}\left(102.8 \mathrm{mi}^{2}\right)$ which corresponds very closely to the USGS measurement. From the defined dam watershed, $525 \mathrm{~km}^{2}\left(202.9 \mathrm{mi}{ }^{2}\right)$, the gauge flow values were adjusted using the appropriate adjustment factors and formula. The mean flow is approximately $7.8 \mathrm{~m} / \mathrm{s}(275 \mathrm{cfs})$. The monthly flow distributions were used for analytical purposes to account for seasonal variations. 
(2) Constraints -- The assessment included a number of factors that would often be less important or unrelated to a private sector analysis. These factors are centered around the legal mandates of DNR which provide that sites, such as High Falls State Park, serve multiple public functions. Thus, the DNR had to set reasonable constraints to insure compatibility of the final design with primary park functions such as fisheries management, camping and recreation, and natural and cultural resource interpretation. The constraints imposed by DNR were: maintain flow over spillway and falls between sun-rise and $10 \mathrm{pm}$; maintain vegetation and topography to maximum extent possible; maintain flow downstream; and design the powerhouse to be compatible with existing park structures, as well as aesthetically pleasing.

(3) Potential sites - From a preliminary analysis of the flow characteristics, precipation patterns, and topography, three candidate sites were selected with different available heads of $9.14 \mathrm{~m}(30 \mathrm{ft}$.), $12.5 \mathrm{~m}(41 \mathrm{ft}$.), and 20 $\mathrm{m}(65.6 \mathrm{ft}$.). For a combination of reasons (environmental, historical and economic) the $9.14 \mathrm{~m}(30 \mathrm{ft}$.) head site at the base of the dam was selected. Figure 1 is an artist's rendering of the completed in-place facility and the surrounding area.

(4) Selected System - Turbine systems were considered initially by generic type, and information was obtained on the availability and system characteristics. Specific types considered were axial flow and cross-flow turbines. The turbine selected for this application is a $1150 \mathrm{~mm}$ vertical axis turbine with an open flume arrangement. Figure 2 is a section view of the turbine configuration. This arrangement has several advantages in this particular application; dam modifications are minimized, size and environmental protection of the power house are minimized, and the structure can be designed to have minimal visual impact. The generator is 8 pole $750 \mathrm{rpm}$ asynchronous machine that can deliver $597 \mathrm{~kW}$ at rated operating conditions. The energy will be fed into the Georgia Power Company distribution system through a substation that presently exists $140 \mathrm{~m}(450 \mathrm{ft}$ ) from the proposed power house location. All transformer and switch gear must conform to Georgia Power specifications. It is estimated that this turbine can produce approximately $2,600,000 \mathrm{kWh}$ per year subject to the seasonal variations of water flow.

(5) Environmental Assessment -- The small size of this facility combined with the operating constraints defined by DNR, will result in minimal environmental impact, with only minimal variations in the present flow conditions of the reservoir and the stream. There will be no impact in the availability of the recreational uses of the park. The facility will be constructed in the river bed in such a way that the historical features of the old mill site and the canal are not disturbed. Only the immediate area of the facility will display the effects of a modification of the existing flow patterns. It is anticipated that the park will broaden its interpretative presentations to include a progression of water use technology for power generation as illustrated by the old mill foundation, the old powerhouse and the proposed low head facility.

(6) System Cost and Economic Analysis -- A cost estimate was made based on the selected system (see Table 1). The result is a total project cost of $\$ 1,050,200$ or $\$ 1760$ per $\mathrm{kW}$. This amount includes several costs that are related to satisfying existing constraints and government regulatory and licensing requirements. If they are relaxed, the project could realistically enjoy a savings of as much as $\$ 150,000$ of the total cost. It should be noted that the cost of the generating equipment, installation, and utility intertie is only $\$ 411,100$, which is $40 \%$ of the total cost. This points out the economy of scale problems associated with constructing a small facility, because the nonequipment cost would be almost the same if the generating capacity were doubled or tripled.

Table 1. COST ESTIMATE

$\begin{array}{lr}\text { Construction } & \$ 295,100 \\ \text { Hydroelectric genera ting unit } & 280,000 \\ \text { Installation of genera ting unit } & 80,000 \\ \text { Contractors overhead \& profit } & \underline{140,000} \\ \quad \text { TOTAL CONSTRUCTION ESTIMATE } & \$ 795,100 \\ \text { Contingency } & 42,000 \\ \text { Utility Intertie } & 51,100 \\ \text { Design Fees \& other professional } & \\ \text { services } & 162,000 \\ \text { TOTAL PROJECT COST } & \$ 1,050,200\end{array}$

The decision criterion for an investment such as this is whether the benefits exceed the costs, and in comparison to other projects whether the excess of benefits is greater than that of other alternative projects. The choice is made among the alternative locations and technological options. The evaluation of benefits is based on the assumption that the capital investment is made with money borrowed with general obligation bonds at the prevailing 
rate of interest, requiring annual payments of equal size for the term of the bond to pay it off. Costs and benefits accruing in the future are discounted at the social discount rate (assumed at a value of 5.5\%).

The State of Georgia has historically borrowed money with a levelized debt service. Thus, $\$ 1,050,200$ (Table 1), borrowed at $5.5 \%$ interest may be paid back in equal installments of $\$ 68,492$. Because of the effects of inflation, the real value of that amount is smaller every year. That is, the dollar amount remains constant while the buying power of the dollar decreases.

The nominal values assigned in this analysis were derived from the most conservative viewpoint possible. The capital costs have been discussed. The growth in the price of energy is likely to be positive due to rising costs in the utility industry. The imposition of a social discount rate of $5.5 \%$ reduced the evaluation of benefits. Finally, the life span of the facility will probably be more than 30 years. The price per $\mathrm{kWh}$, calculated in real terms, will likely be contracted in nominal dollars and thus be larger than included in the model. The net present value of the stream of benefits and costs of the facility under these conditions is $\$ 110,000$. The nature of the assumptions imply that this amount is a lower bound on the expected NPV of the facility. By removing some of the less binding constraints, and by assuming a rise in energy prices of two per cent per year, the net present value of the facility comes to $\$ 441,000$. This amount is not an extreme; there are still constraints and assumptions that could realistically be modified to result in higher net present value. Nominal parameter values are given in Table 2. All dollar amounts in this table are in real terms or constant dollars.

\section{Table 2. NOMINAL PARAMETER VALUES}

$\begin{array}{ll}\underline{\text { Variable }} & \underline{\text { Value (in real terms or constant dollars) }} \\ \text { Initial capital expense } & \$ 1,050,200 \\ \text { General obligation bond rate } & 5.5 \% \\ \begin{array}{l}\text { Weighted average cost of } \\ \text { displaced energy }\end{array} & 22.8 \mathrm{mils} / \mathrm{kWh} \\ \text { Price paid for energy } & \text { Slightly lower than cost of displaced energy } \\ \text { Growth of price of energy } & \text { Average just under zero over } 30 \text { years } \\ \text { Operating and Maintenance Cost } & \$ 170 / \mathrm{mo}=\$ 2,040 / \text { year } \\ \text { Annual generation } & 2,622,000 \mathrm{kWh} \\ \text { Social discount rate } & 5.5 \%\end{array}$

\section{v. CONCLUSIONS}

The analysis of this proposed project shows the hydroelectric generating facility to be technically, environmentally, and economically feasible. On the other hand, there are institutional constraints that bear heavily on the economic value of the proposed facility. The mission of the Department of Natural Resources appears to conflict with the economically efficient operation of the generators. As of this writing, the DNR is taking under consideration the trade-offs between park operation and fishery management constraints and projected state income from the facility.

This paper was authored by George Fletcher, Rob Harvey, Edward Jacobson, and M. John Moskaluk, with assistance and input from Jim Austin, Don Battles, Jim Marks, Gary Poole, and Steve Schmidt. 


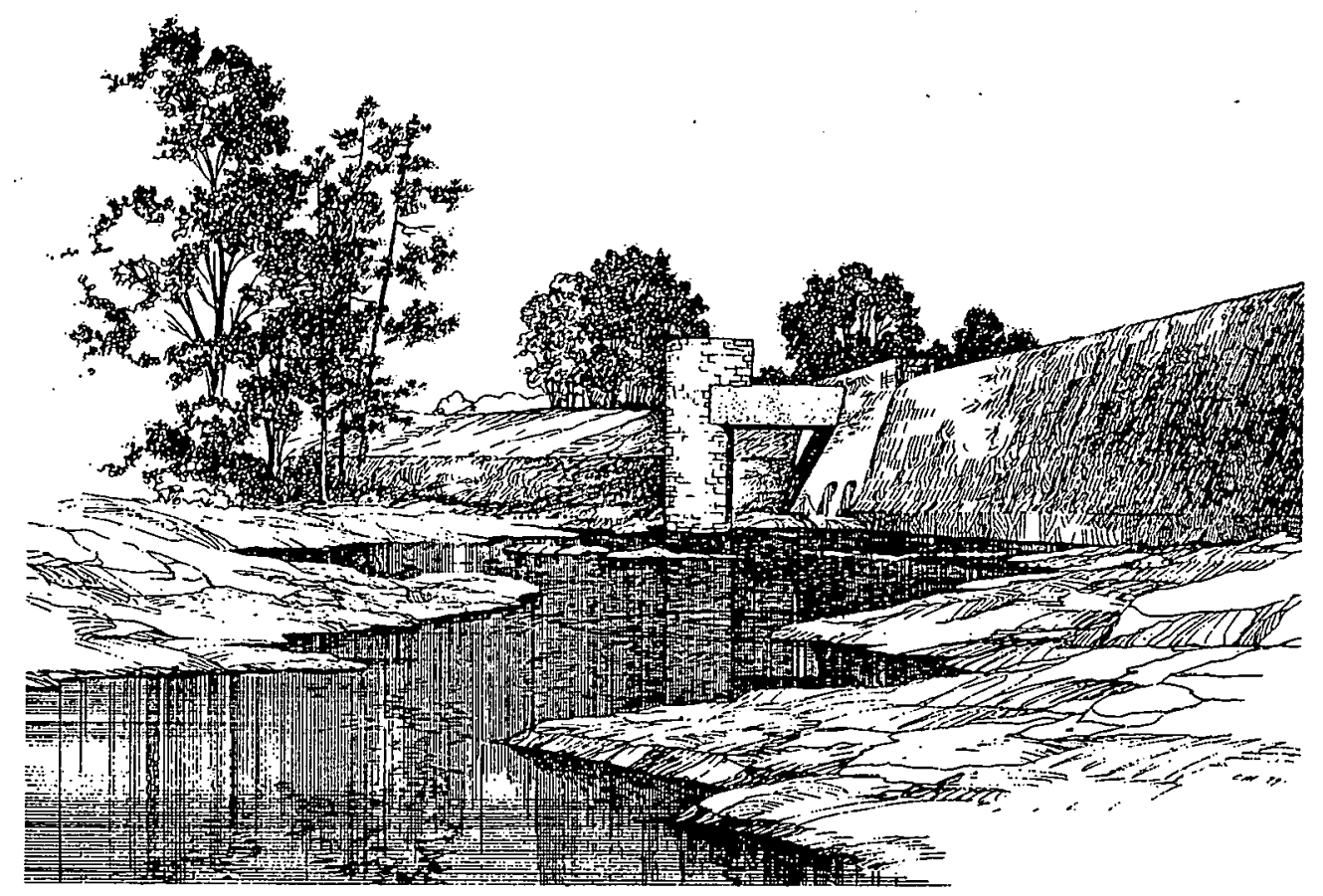

Figure 1. Artist's Rendering of Hydroelectric Facility and the Surrounding Area:

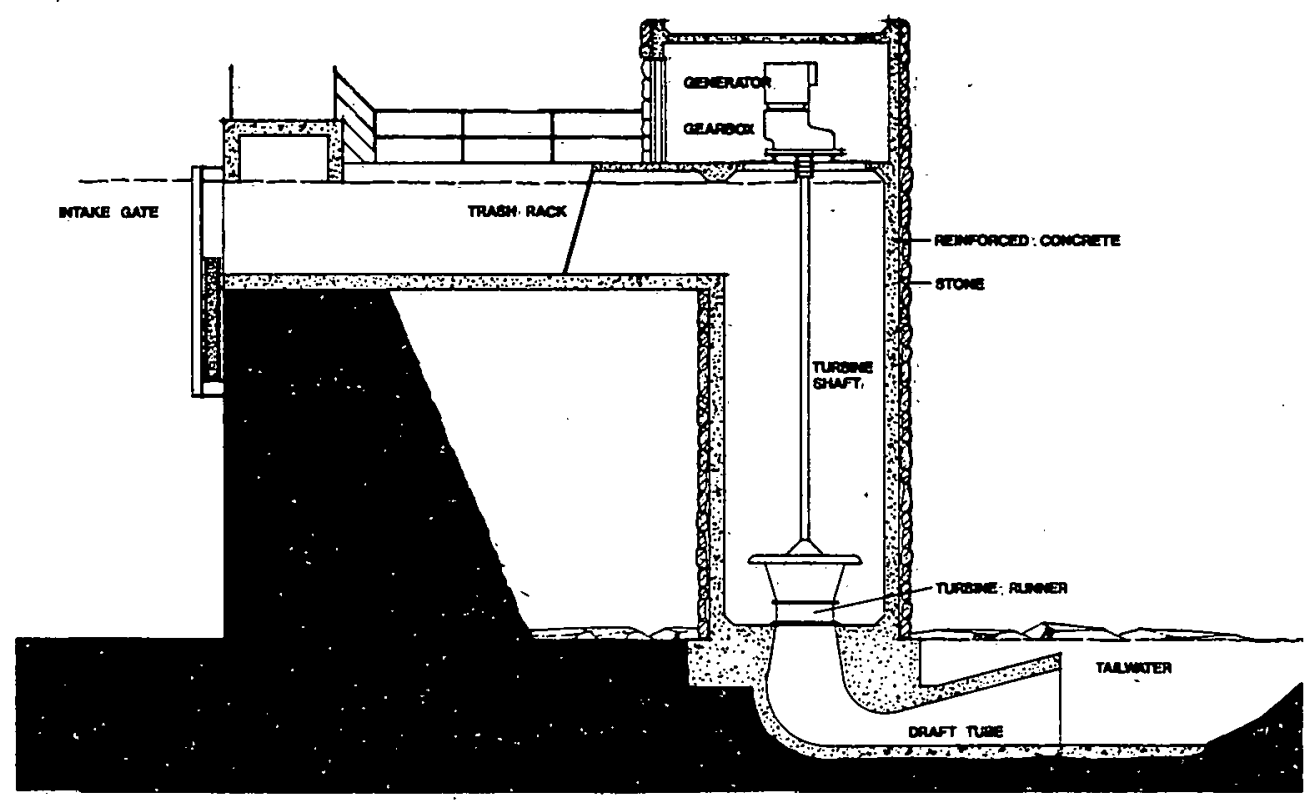

Figure 2. Sectional View of Hydroelectric Facility: , 
JACKSON BLUFF DAM ON THE OCHLOCKONEE RIVER

Tallahassee, Florida

C1ty of Tallahassee

R. W. Beck and Associates.

PRDA Proposal Contract No, EW-78-F-07-1763

\section{INTRODUCTION}

In response to a Program and Research Development Announcement by the Department of Energy (DOE), the City of Tallahassee, Florida (C1ty) submitted a proposal dated February 13, 1978, to study the feasibility of re-installing hydroelectric generating facllities at the existing Jackson Bluff Dam with financial assistance from the DOE.

The City's proposal was approved by the DOE and the grant was awarded to the City with the feastibility study work to be performed pursuant to the agreement between the City and the DOE.

The studies and investigations undertaken in conjunction with this feastbility assessment have included site reconnalssance, system loads, growth rate, site hydrology, conceptual project arrangements and layouts, power output, estimates of construction costs and annual costs, economic analyses, development of a design and construction schedule and a preliminary environmental review of the proposed Project.

\section{EXISTING DEVELOPMENT}

In January 1927, the Federal Power Commission ișsued a Liçense (FPC Project No, 682) to the Central Florida Power and L1ght Company for construction of a hydroelectric facility at Jackson Bluff on the Ochlockonee River, near the City of Bloxham, Florida, about 20 miles west-southwest of Tallahassee as shown on Exhib1t A. The Ochlockonee River has a drainage area of 1,720 square miles above the dam site and has an average annual flow of 1,692 cfs for the perlod of water year 1927 through 1975 . The Project was constructed in 1928 and 1929 and consists of a powerhouse on the south side of the river adjoining a limestone bluff, a gated concrete spillway occupying the main part of the riverbed, an earth dam extending northerly from the spillway across the floodplain to the low lying hills beyond and a low saddle dam which lies north of the north end of the main dam.

The main dam has a length of 3,600 feet and a crest at El 77. The saddle dam is approximately 550 feet long, located about 1,000 feet north of the main dam, with a crest elevation 4,7 feet below that of the main dam (EI 72.3). The service spillway has an ogee-shaped crest and seven radial gates, The crest elevation of the splllway is E1 52.0 and the top of the gates are located at E1 69 .

The Project was operated as a hydropower plant by the Central Florlda Power and Light Company, and its successor, the Florida Power Corporation, until 1970. Notice for Surrender of License by the Florida Power Corporation was received by the Federal Power Commission on November 4, 1969 when the former Ifcensee donated the reservoir and 30,060 acres of land to the State of Florida for use as a public park. At the time of this transfer of rights, all turbogenerators were removed by the former Licensee. The current right of ownership is held by the State of Florida, Department of Natural Resources.

\section{PROPOSED PROJECT ARRANGEMENT}

The Jackson Bluff Hydroelectric Project would consist of the relnstallation of power generating equipment at the Jackson Bluff powerhouse, addition of electrically driven holsts for five spillway gates and the construction of a fuse-plug type auxillary spillway.

The new power generating equipment would be comprised of three turbine-generator units along with accessory transformers, switching gear and other mechanical and electrical equipment as shown on Exhibit B. It is currently proposed to reinstall fixed blade propeller turbines similar to those removed in 1970 , thus eliminating the need for any modifications to the existing powerhouse substructure or superstructure. The Project would have an installed capactty of $8,800 \mathrm{~kW}$, consisting of two 3,200-kW units and one 2,400-kW unit, the same size as installed previously, operating under a net head of $32 \mathrm{feet}$. The dependable capacity from the Project delivered at the City's load center would be $6,659 \mathrm{~kW}$. The average annual energy $1 \mathrm{~s}$ $24,920,000 \mathrm{kWh}$ of which $6,753,000 \mathrm{kWh}$ is considered firm (prime), delivered at the load center. 
At the present time the 7 radial gates at the service spillway are operated mechanically from 2 hoisting gantries which are moved manually from gate to gate on the splilway operating deck. These two exist ing gantries would be permanently installed over two gates and 5 new motorized gate holsts would be installed over the remaining 5 gates. The new holsts would require erection of a structure supporting frame for each.

A permanent concrete control sill would be constructed on a 1,000-foot long earth overpour section. This overpour section is currently being considered for construction by the State of Florida as a damsafety related item as discussed below. The saddle dam would be replaced by a 550-foot long erodible fuse plug embankment section. The crest elevation for the overpour section control sill would be 72,3 feet, The crest at the top of the fuse plug would also be 72.3 feet with the fuse plug sill elevation at 66.5 feet. The width of the fuse plug crest would be 15 feet with side slopes of 2 to 1 .

In addition to the above Project-related items, the State of Florida is currently considering constructing certain safety-related measures for Jackson Bluff Dam including repairs to, or replacement of, a downstream wall on the north side of the spillway; addition of a three-foot high retaining wall on the south side of the powerhouse; improvements to the approach wall conditions at the north end of the spillway, and the excavation of an earth overpour emergency (auxiliary) spillway in the saddle dam area.

\section{ECONOMIC ANALYSIS}

It is estimated that the Jackson Bluff Hydroelectric Project, for an October 1983 scheduled on-1ine date, would have a total investment cost of $\$ 9,882,000$ (equal to $\$ 1,123 / \mathrm{kW}$ installed at the time frame) not Including the State safety related measures which have been estimated on a broad basis to cost $\$ 552,000$ at current price levels.

The estimated total annual cost of the Project for the first year of operation 1 s $\$ 1,156,000$, based on 30-year, $6.5 \%$ flnancing. An economic analysis of the Project shows a benefit-cost ratio of 1,27 during the first year of operation when compared to. the most economic alternative of an equivalent new simple-cycle combustion turbine unit (dependable capacity and firm energy), combined with fuel replacement of existing older oil-burning steam units (secondary energy). This economic analysis for the first year of operation is shown in Table A. A comparison of the Project to this alternative over the first ten years of Project. operation shows a total ten-year present worth savings (October 1983 level) of $\$ 4,486,000$. Th1s savings and the benefit-cost ratio are reduced respectively to $\$ 4,160,000$ and 1.23 if the costs of the safety-related remedial measures now being considered by the State are reimbursed as part of the cost of the. Project,

\section{CONCLUSION}

The Project poses no unusual technical problems and no significant adverse environmental effects are anticipated. It shows sufficlent promise of technical, economic and financial feasibility to justify the City entering into the next phase of work, the FERC License Application, as soon as posstble so that the Pro.ject can be completed within. the proposed time frame. Concurrently with this, the City should initiate efforts to arrange financing for the Project Including making application to the DOE for a demonstration project grant under the seçond. PON, responses to which will be soliclted shortly. 


\section{TABLE A}

JACKSON BLUFF HYDROELECTRIC PROJECT

ANNUAL PROJECT BENEFITS AND COSTS (I)

It em

Reimbursement of Safety-Related Items Currentiy Belng Considered

PROJECT ANNUAL COSTS:

Total Amortization Cost ........\$ \$786,000

Operating costs ............. $\quad 370,000$

$\$ 830,000$

TOTAL PROJECT COSTS ..........\$ \$1,156,000 by State

PROJECT ANNUAL BENEFITS:

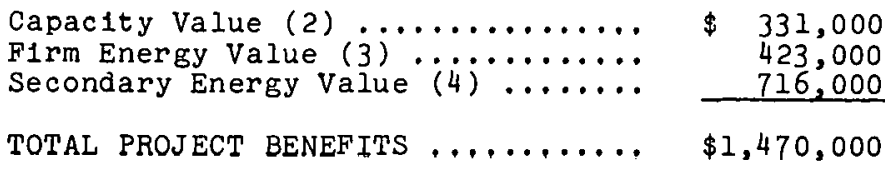

BENEFIT-COST RATIO ............. 1.27

$\frac{370,000}{\$ 1,200,000}$

(1) - Values shown are for the first year of operation, october 1983 through September 1984.

(2) $-6,326 \mathrm{~kW}(6,900 \mathrm{~kW}$ less $3.5 \%$ for transmission losses and $5 \%$ Forced Outage Reserves) at $\$ 52.30 / \mathrm{kW}$.

(3) - 6,753,000 kWh $(6,998,000 \mathrm{kWh}$ less $3.5 \%$ for transm1ssion losses) at $62.7 \mathrm{m1lls} / \mathrm{kWh}$.

(4) - $18,167,000 \mathrm{kWh}(18,826,000 \mathrm{kWh}$ less $3.5 \%$ for transm1ssion losses ) at

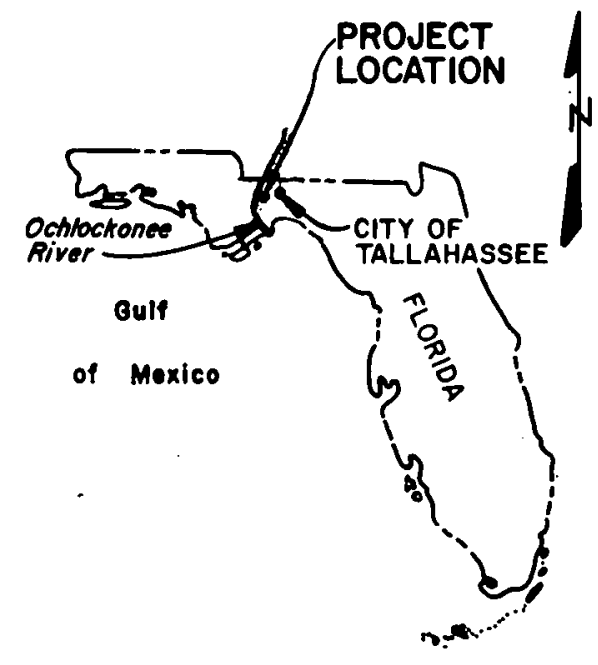

KEY MAP

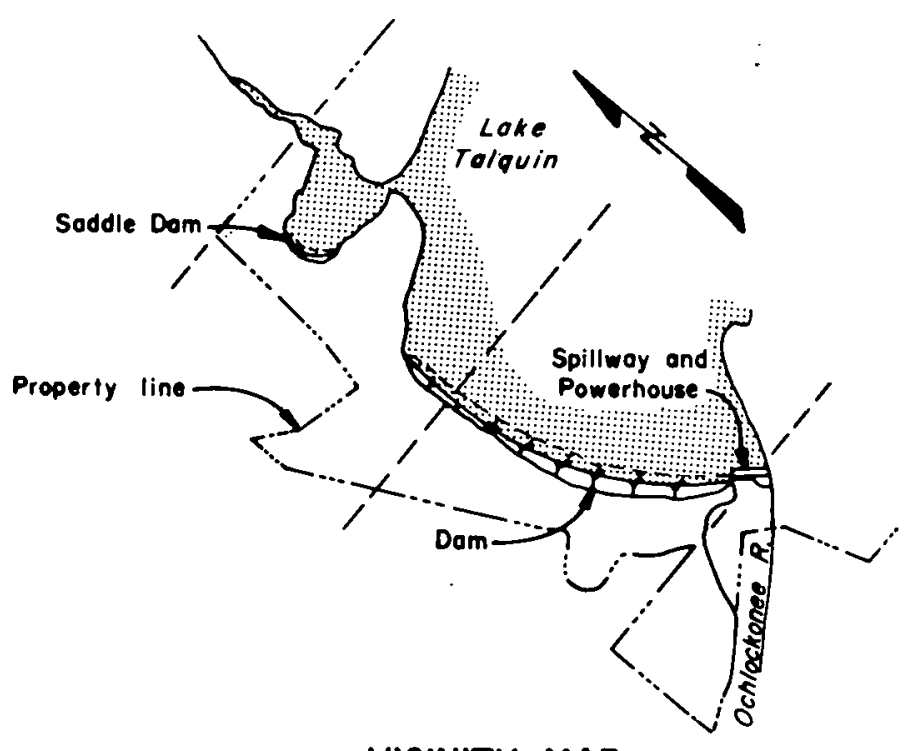

VICINITY MAP 


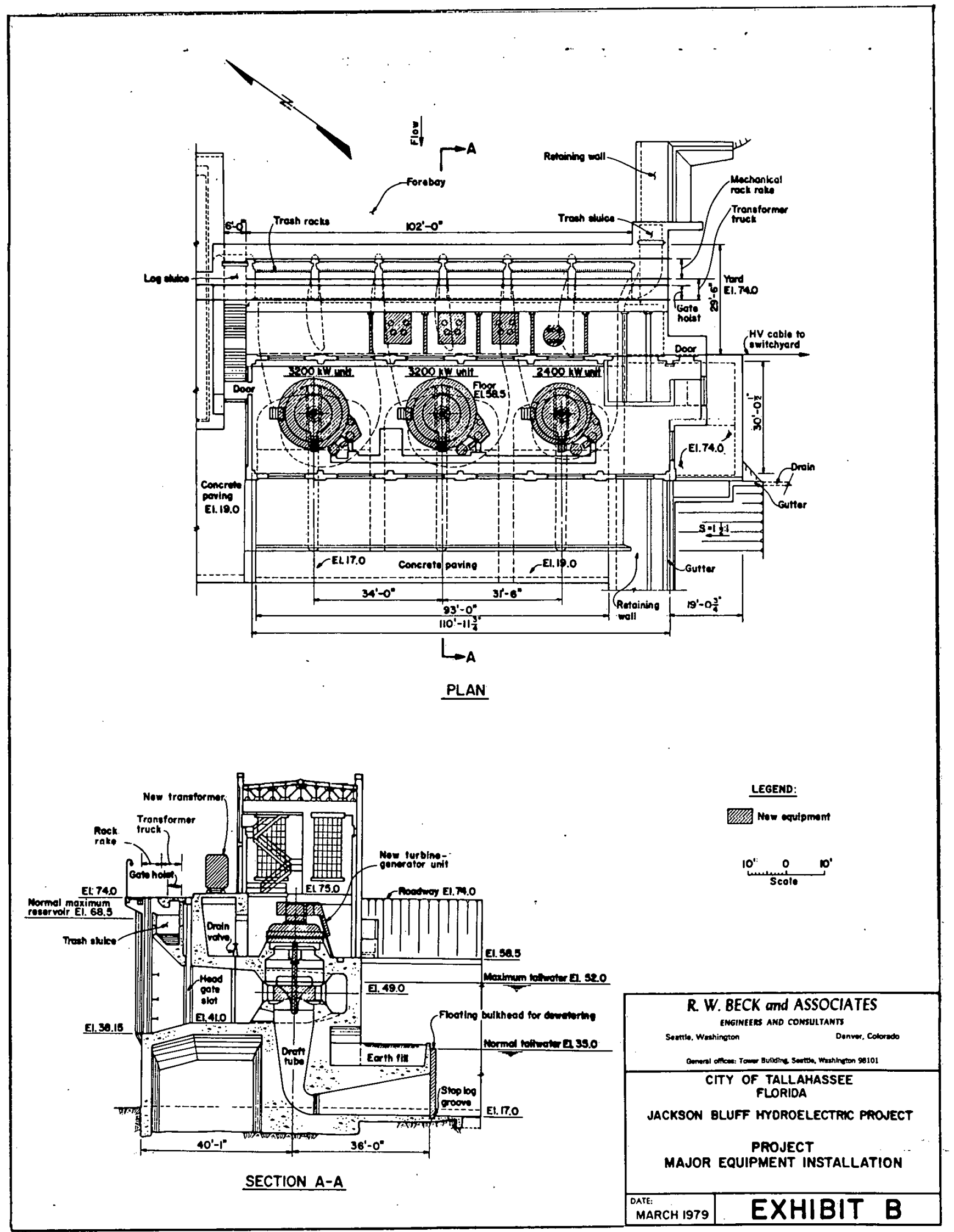


NORMANSKILL HYDROELECTRIC FACILITY

GUILDERLAND, N, Y.

N.Y.S.E.R.D.A. and City of Watervliet, N. Y. $J$. Kenneth Fraser and Associates, P. C.

PRDA Proposal Contract No. 1765

\section{INTRODUCTION}

The Normanskill Hydroelectric Feasibility Assessment has been a multidisciplinary evaluation of hydroelectric generation potential at the site and the associated economic recreational, environmental, historical, regulatory and institutional constraints.

The site is a water supply reservoir with limited recreational access. A hollow reinforced concrete dam impounds 1.6 billion gallons. Gross head of the selected project is 64.4 feet with a design flow of 200 cubic feet per second. An existing pumping station served by a 48 inch steel penstock houses two $S$. Morgan Smith hydraulic turbines rated at $110 \mathrm{H}$.P. each. These turbines, of 1916 vintage, power centrifugal pumps supplying water to the city of Watervijet some 20 miles distant.

II. ASSESSMENT

The hydrologic analysis has used a stochastic stream flow model extending the available data base and creating a 500 year stream flow trace. The reservoir operation has been extensively simulated to determine the impacts of hydroelectric generation upon water supply and recreation.

A market survey performed indicates that the most feasible consumer of power generated will be the city of Waterviliet itself, using the power for street lighting and municipal buildings.

Excess power will be sold to the Niagara Mohawk Power Corporation.

Determination of optimum configuration has involved detailed technical analysis of eight siting options. Further definition of these options relating to intake type, penstock size, machine type, machine size, and switch gear resulted in analys is of a total of 78 distinct alternates. Of the economically ranked alternates, two were chosen for further analysis. The first, Project $A$, represents rehabilitation of existing facilities (penstock, powerhouse, etc.) to the extent possible. The second, Project $B$, represents new construction utilizing only the dam and surge pipe, but developing the power potential of the site to a greater degree than Project $A$. 
All facets of the potential environmental impacts were reviewed including possible effects of drawdown on wildlife and vegetation and reoxygenization effects upon stream fiow quality. In addition, a cultural assessment was performed including potential effects upon existing recreation patterns and known archaeological sites within the project area.

The pertinent review agencies and requirements for shortform licensing were determined after consultation with the Federal Energy Regulatory Commission. All agencies required to review the proposed project have been contacted and applicable review durations and agency requirements have been determined. The economic analysis of the selected projects has included detailed projections for all economic considerations including capital cost, lif̣e cycle labor. nperatino, maintonance, and replacement costs and benefits. While both projects are shown to be economically feasible, possible difficulties with licensing of the rehabilitation project has eliminated it from recommendation.

An investigation into appropriate mechanisms for implementation of the project have been considered with thc most feasible being city ownership and bonding as a water supply project. A preliminary PERT analysts has indicated an earliest on-line date of March 1982 .

III. CONCLUSIONS

The feasible project involves construction of a new intake at the existing reinforced concrete dam, installation of steel penstock beneath the existing rock streambed, terminating at a below-streambed powerhouse. Selected machinery includes a horizontal tubular type axial flow adjustable blade turbine and a 2400 volt synchronous generator. Anciliary equipment include.s automated control equipment. The facility will have a peak generating capacity of 850 kilowatts. The average annual power produced by the proposed project will be $70 \%$ of the potential power available at the site. The recommended project has a benefit-cost ratio of 2.36 and a rate of return of $16.2 \%$. The net present worth benefit to the city $(50$ years--8\%) is $\$ 3,300,000$. 


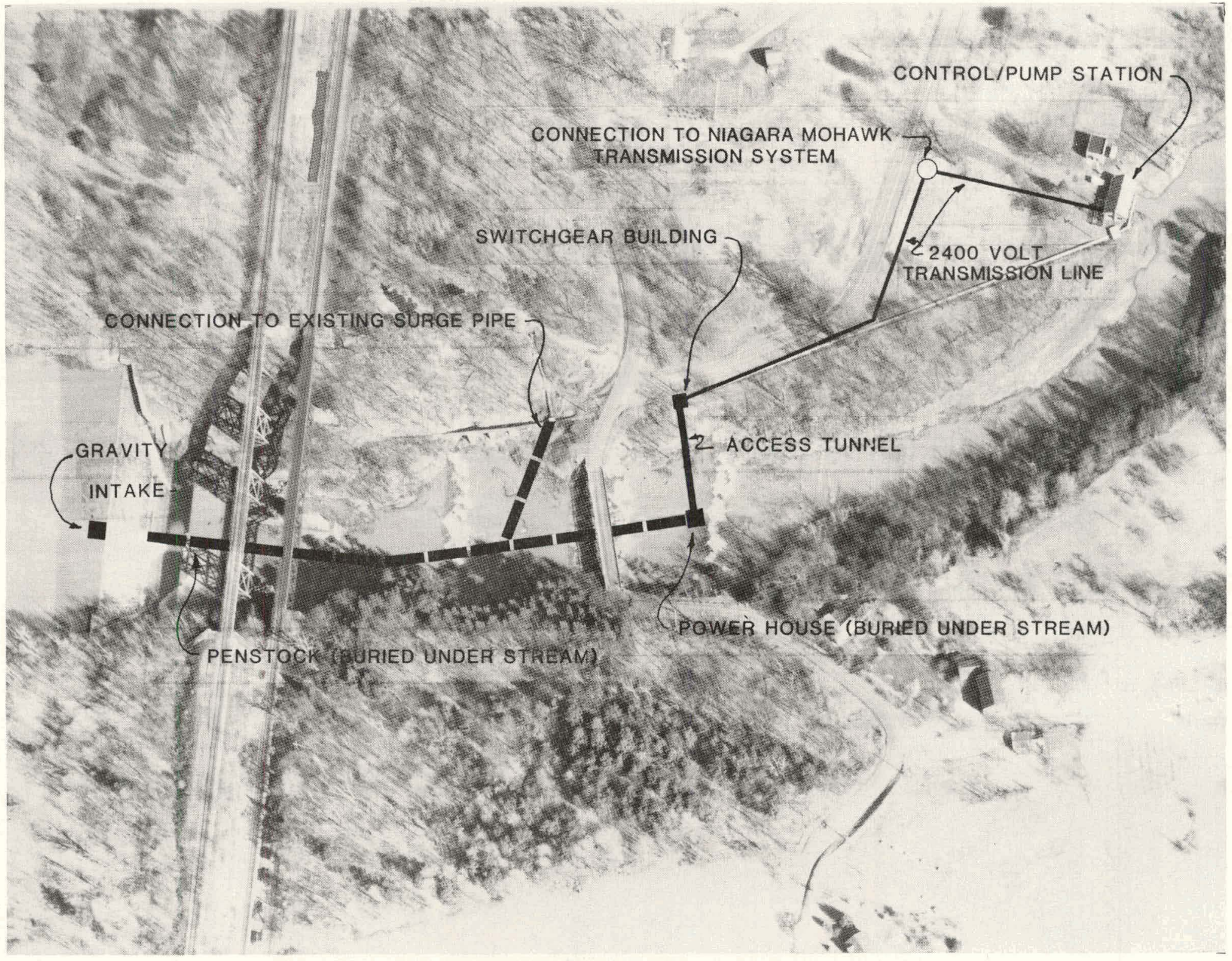




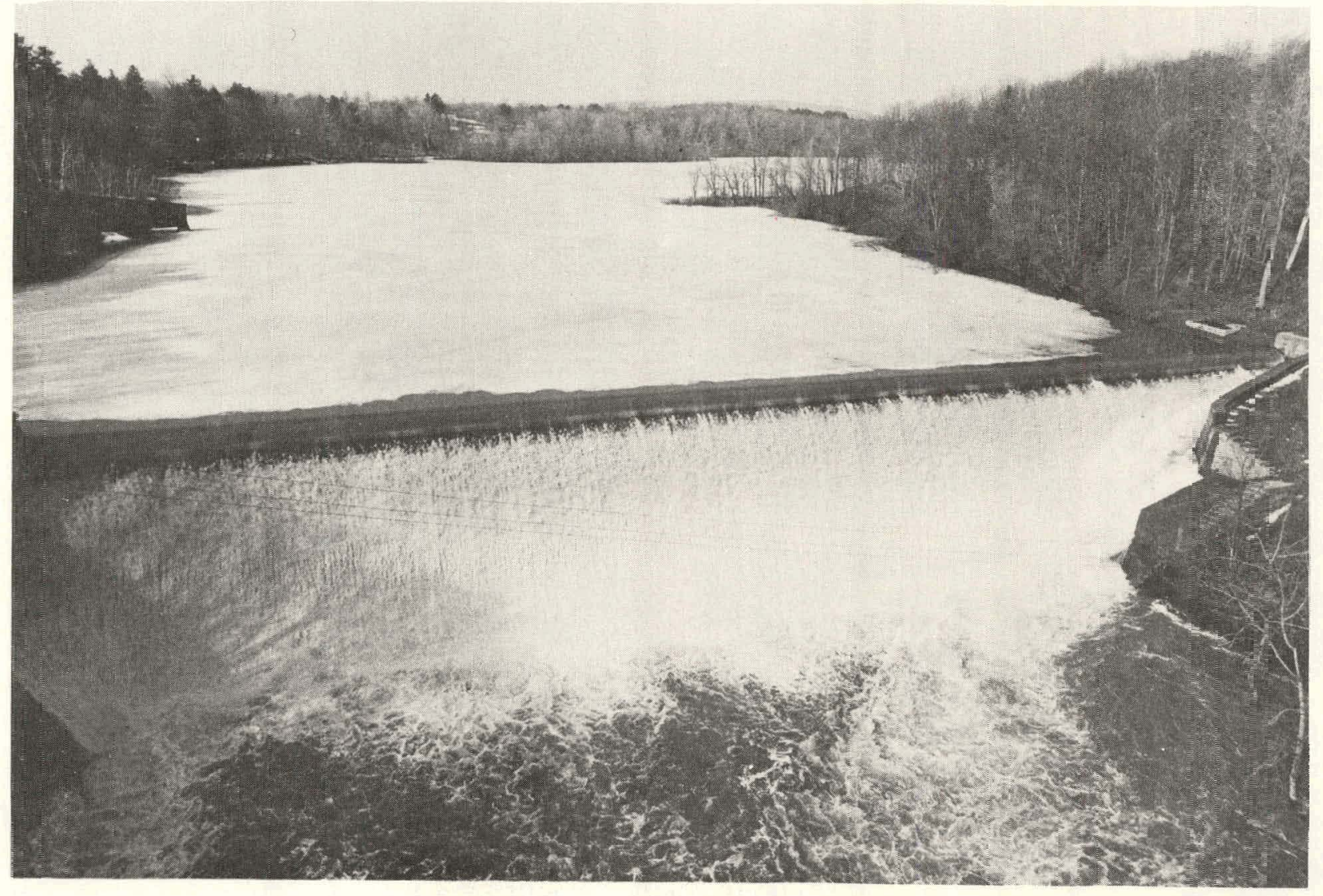




\title{
PENINSULAR PAPER COMPANY DAM ON THE HURON RIVER
}

\author{
Ypsilanti, MI
}

Ayres, Lewis, Norris \& May, Inc.

Principal Investigator: Donald W. Lystra, P.E.

PRDA Proposal Contract No. EW-78-F-07-1766

\section{INTRODUCTION}

The Peninsular Paper Company dam is located on the Huron River in Ypsilanti, Michigan, approximately twenty-five miles east of Detroit. The facility includes an abandoned hydroelectric powerhouse, a 240-foot wide weir dam and a I2-foot wide radial gate for the release of high flows. The average hydraulic head at the site is 13.0 feet.

Power was produced at the site beginning in the nineteenth century, however, the present powerhouse dates from 1918. It was originally equipped with two vertical Francis turbines directly connected to 4600 -volt slow-speed generators, rated 450 and 550 kilowatts full load. Annual production from the plant averaged about 2.6 million kilowatt-hours, ranging from a high of 3.7 million kilowatt-hours to a low of 1.3 million kilowatt-hours.

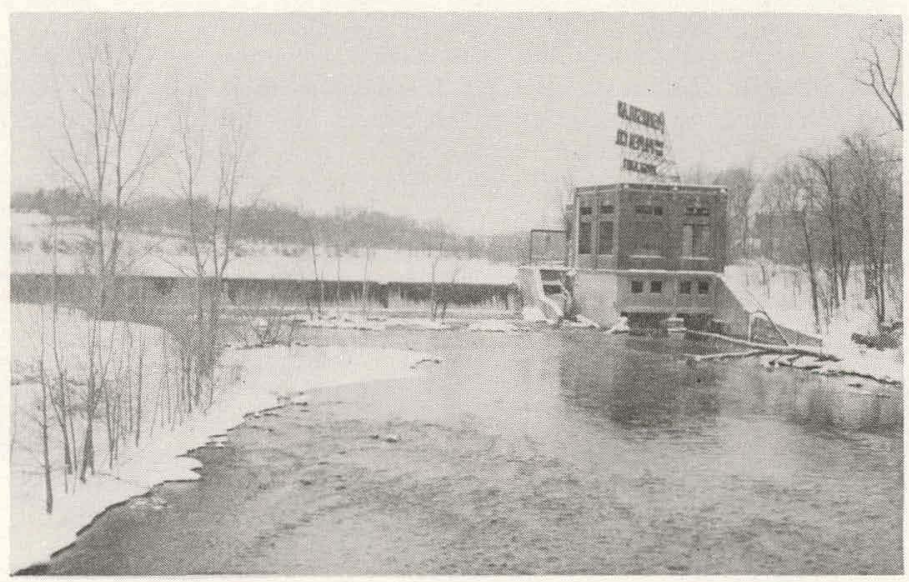

Upstream View of Peninsular Paper Company Dam Site

In 1971 electrical failures in the generators prompted the paper company to retire the plant. The power purchase agreement with the utility at that time was providing only about $\$ \mid 3,000$ annual gross revenue. In retiring the plant, the paper company removed and scrapped the generators and all related electrical equipment. In order to prevent the passage of water through the structure and to avoid a public hazard, the turbine pits were filled in with earth. It is not known at this time whether the turbines themselves were removed from the wheel pits. 


\section{HYDROLOGY}

Based on extrapolated data from a U.S.G.S. permanent gaging station approximately seven miles upstream of the Peninsular Paper Company dam, hydrological parameters at the site are estimated as follows:

$\begin{array}{lr}\text { mean discharge } & 498 \mathrm{cfs} \\ \text { mean annual flood peak } & 2441 \mathrm{cfs} \\ \text { mean annual 30-day low flow } & 264 \mathrm{cfs}\end{array}$

The flow-duration characteristics of the site are typical of those for sites in the midwestern United States. Average discharge during the wettest month of the year averages about five times that occurring during the driest month.

\section{USE OF ELECTRIC POWER}

The hydroelectric powerhouse is located directly across the river from the paper company's production facility. This close proximity makes a direct service connection possible, allowing the hydro plant to directly offset electric energy that would otherwise be purchased through the normal utility service.

Based on a comparison of the paper company's daily and monthly electric consumption pattern and the projected production from various sized hydroelectric facilities, it is estimated that virtually 100 percent of the hydro plant output could be consumed directly by the paper mill, for any hydro plant having an installed capacity of 700 kilowatts or less.

Presently, the paper company receives electricity under a primary rate agreement with the local utility, the Detroit Edison Company. Under the terms of this agreement energy charges (including current fuel adjustment) are $2.3 \xi$ per $\mathrm{kWh}$ onpeak and 1.7\& per kWh off-peak, monthly on-peak demand changes are $\$ 5.80$ per $\mathrm{kW}$, and maximum demand charges are $\$ 1.50$ per $\mathrm{kW}$ per month. Customers receiving primary service from Detroit Edison Company are permitted to receive power from an alternate and independent source of energy subject to a monthly surcharge of $\$ 1.75$ per kilowatt of alternate capacity.

\section{DESIGN STRATEGY}

An analysis of site hydrology established that the storage capacity in the upstream impoundment ( 445 acre-feet) was not sufficient to guarantee a firm demand capacity without experiencing unacceptable variations in lake level during draught conditions. It was determined, for example, that a differential of only $100 \mathrm{cfs}$ between natural runoff and dam discharge would, over 24 hours, cause a 34-inch change in headwater level. It was possible, however, to establish a limited amount of reliable monthly demand capacity based on natural stream flow.

The installed generating capacity of the facility in relation to stream flow characteristics was found to have an important influence on project cost-effectiveness. The benefits from increased capacity were found to diminish rapidly above a given point due to the flow-duration characteristics in the river. The table below shows the relationship between installed capacity and effective capacity (i.e., average utilized capacity) at the Peninsular Paper Company dam site. It can be seen that the proportional increment in effective capacity decreases with each increment in plant size.

$\begin{array}{lrrrrr}\text { Installed Capacity (kW) } & 100 & 300 & 500 & 700 & 900 \\ \text { Effective Capacity (kW) } & 96 & 228 & 287 & 326 & 351 \\ \text { Increment (kW) } & 96 & 132 & 59 & 39 & 25 \\ \text { Utilization } & 96 \% & 66 \% & 30 \% & 20 \% & 13 \%\end{array}$

\section{DESIGN ALTERNATIVES STUDIED}

A total of six project alternatives were examined in detail. The alternatives were distinguished by the type, number and size of hydraulic turbine units employed, as follows:

\begin{tabular}{|c|c|c|c|}
\hline $\begin{array}{c}\text { Turbine } \\
\text { Type }\end{array}$ & $\begin{array}{c}\text { Number of } \\
\text { Units }\end{array}$ & $\begin{array}{l}\text { Output Per } \\
\text { Unit }\end{array}$ & $\begin{array}{c}\text { Total Installed } \\
\text { Capacity }\end{array}$ \\
\hline Vertical & I & $340 \mathrm{~kW}$ & $340 \mathrm{~kW}$ \\
\hline Vertical & 2 & $340 \mathrm{~kW}$ & $680 \mathrm{~kW}$ \\
\hline Bulb & 2 & $126 \mathrm{~kW}$ & $252 \mathrm{~kW}$ \\
\hline Cross-flow & 1 & $195 \mathrm{~kW}$ & $195 \mathrm{~kW}$ \\
\hline Cross-flow & 2 & $195 \mathrm{~kW}$ & $390 \mathrm{~kW}$ \\
\hline Tubular & 1 & $400 \mathrm{~kW}$ & $400 \mathrm{~kW}$ \\
\hline
\end{tabular}

The vertical turbine designs were based on the re-use of the existing powerhouse; all other designs assumed the construction of a completely new and structurally independent powerhouse. All designs, except that employing the bulb turbines, were based on units having variable gates or blades to allow the output to be matched with stream flow. The bulb turbine design, on the recommendation of the manufacturer, was based on units having fixed blades and a single operating point. All designs were based on the use of synchronous generators, connected through speed increasers to the low-speed turbines. 
Table I below presents a cost summary of the six design alternatives studied.

TABLE I

COST SUMMARY OF DESIGN ALTERNATIVES

FOR DEVELOPING THE PENINSULAR PAPER COMPANY

DAM SITE FOR HYDROELECTRIC GENERATION

\begin{tabular}{|c|c|c|c|c|c|c|}
\hline & $\begin{array}{c}\text { One } 340 \mathrm{~kW} \\
\text { Vertical } \\
\text { Turbine }\end{array}$ & $\begin{array}{c}\text { Two } 340 \mathrm{~kW} \\
\text { Vertical } \\
\text { Turbines }\end{array}$ & $\begin{array}{c}\text { Two } 126 \mathrm{~kW} \\
\text { Bulb } \\
\text { Turbines }\end{array}$ & $\begin{array}{c}\text { One } 195 \mathrm{~kW} \\
\text { Cross-flow } \\
\text { Turbine }\end{array}$ & $\begin{array}{c}\text { Two } 195 \mathrm{~kW} \\
\text { Cross-flow } \\
\text { Turbines }\end{array}$ & $\begin{array}{c}\text { One } 400 \mathrm{~kW} \\
\text { Tubular } \\
\text { Turbine }\end{array}$ \\
\hline $\begin{array}{l}\text { Total Project Cost } \\
\text { Total Equipment Cost } \\
\text { Civil/Structural Cost } \\
\text { Project Cost } / \mathrm{kW} \\
\text { Equipment Cost/kW } \\
\text { C/S Cost } / \mathrm{kW}\end{array}$ & $\begin{array}{r}\$ 452,000 \\
205,000 \\
110,000 \\
1,329 \\
603 \\
324\end{array}$ & $\begin{array}{r}\$ 708,000 \\
380,000 \\
110,000 \\
1,041 \\
559 \\
162\end{array}$ & $\begin{array}{r}\$ 809,000 \\
396,000 \\
1136,000 \\
3,210 \\
1,571 \\
540\end{array}$ & $\begin{array}{r}\$ 493,000 \\
300,000 \\
76,000 \\
2,528 \\
1,538 \\
390\end{array}$ & $\begin{array}{r}\$ 756,000 \\
489,000 \\
96,000 \\
1,938 \\
1,254 \\
246\end{array}$ & $\begin{array}{r}\$ 795,000 \\
432,000 \\
116,000 \\
1,988 \\
1,080 \\
290\end{array}$ \\
\hline
\end{tabular}

\section{PROJECT FINANCIAL ANALYSIS}

Table 2 below presents a benefit/cost summary of the six project alternatives. After taking account of projected expenses for operation and maintenance, benefit/cost ratios were calculated ranging from $9.6 \%$ for the single vertical turbine alternative to $3.8 \%$ for the dual bulb turbine alternative.

TABLE 2

BENEFIT/COST SUMMARY OF VARIOUS
HYDROELECTRIC PLANT DESIGNS AT
PENINSULAR PAPER COMPANY DAM

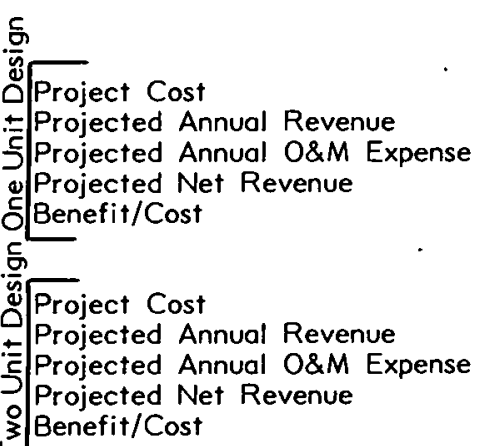

Vertical
$(340 \mathrm{~kW})$

$\$ 452,000$
58,900
15,600
43,300
$9.6 \%$

$\$ 708,000$

71,900

19,900

52,000

$7.3 \%$
Bulb

TYPE OF TURBINE
Cross-flow
$(193 \mathrm{~kW})$

$\$ 493,000$

40,100

18,100

22,000

$4.5 \%$.

$\$ 756,000$

63,900

22,900

41,000

$\begin{array}{cc}\$ 809,000 & \$ 756,000 \\ 51,600 & 63,900 \\ 20,900 & 22,900 \\ 30,700 & 41,000 \\ 3.8 \% & 5.4 \%\end{array}$

Tubular $(400 \mathrm{~kW})$

$\$ 795,000$ 65,000 21,100 43,900 - $5.5 \%$

VII. ENVIRONMENTAL IMPLICATIONS

A detailed environmental impact assessment was conducted using an impact matrix methodology of "nondevelopment" and "development" alternatives. The environmental assessment concluded that the development of the facility would have very slight environmental consequences due to the small scale of the facility and the fact that a "runof-the river" operating strategy would be followed. The main consequence which was identified was the enhancement of public safety due to the structural repairs to the dam and the projected high level of future dam maintenance. The vertical turbine design alternatives, which would involve the refurbishment of the existing powerhouse, would have additional positive consequences relating to site aesthetics, and the preservation of an historically significant structure.

\section{RECOMMENDED DESIGN}

If the Peninsular Paper Company dam-site is developed as a hydroelectric resource it is recommended that the design incorporate the features of the alternative showing greatest cost-effectiveness, as follows:

- type of hydraulic turbines:

- number of generating units:

- size of generating units:

- type of generators:

- generator speed:

- method of installation:

- use of power: vertical

one

approximately $340 \mathrm{~kW}$ output full load

synchronous

either low speed or standard speed through a gear drive

in existing powerhouse

feeding owner's production facility, in parallel with normal utility service. 
The following table gives a summary of project costs and operating characteristics of the recommended design.

$\begin{array}{lr}\text { Estimated Project Cost } & \$ 452,000 \\ \text { Installed Capacity (kW) } & 340 \\ \text { Effective Average Capacity (kW) } & 234 \\ \text { Utilization Factor } & 68 \% \\ \text { Cost/Installed kW } & 1,329 \\ \text { Projected Annual Production (MkWhr) } & 2.1 \\ \text { Average Monthly Demand Capacity (kW) } & 293 \\ \text { Projected Annual O\&M Expense } & \$ 15,600 \\ \text { O\&M Cost/kWhr Produced } & 0.74 \xi\end{array}$

The following figures give a projected financial summary of the recommended project, on a cash basis, for the first year of operation.

\section{Revenues}

\begin{tabular}{lr} 
Energy & $\$ 42,400$ \\
Monthly On-pcak Demand & $\$ 20,000$ \\
Mauximum Demand & 3,200 \\
Stand-by Surcharge & $(\$ 7,140)$ \\
\hline
\end{tabular}

Expenses

$\$ 58,500$

Operating Labor

Maintenance

Insurance

Interest on Construction Loan (10\%)

$$
\begin{aligned}
& \$ 7,300 \\
& \$ 6,300 \\
& \$ 2,000 \\
& \$ 45,200 \\
& \hline
\end{aligned}
$$

\section{$\$ 60,800$}

Net Profit (Loss)

\section{$\underline{(\$ 2,300)}$}

No property tax expense was included based on conversations with State and local government officials and the expectation that the project would qualify for a property tax exemption under the Michigan Industrial Redevelopment Act.

\section{CONCLUSION}

The development of the Peninsular Paper Company low-head dam site as a hydroelectric facility was determined by this study to be a feasible project in terms of engineering, environmental, and institutional factors. From an economic standpoint, however, it was determined to be non-cost-effective in terms of the economic factors pertinent to the owner, a private industrial concern. Conceivably, a combination of tax credits, low interest:loans, and/or construction grants reducing costs and expenses by approximately 25 percent would place this project within a financially feasible range. 
WOODRUFF NARROWS DAM ON THE BEAR RIVER

Uinta County, Wyoming

Utah Board of Water Resources

Utah Division of Water Resources, International Engineering Co. Inc., \& Utah Water Research Laboratory

Cooperative Agreement No. DE-FC07-78ID01767

\section{PURPOSE AND AUTHORITY}

The Utah Water and Power Board was created by the Utah Legislature in 1947 and charged with the responsibility of preparing and implementing plans which would bring about the full development and utilization and promotion of the very vital, but limited, water resources of the State. The Board was charged with the review and coordination of federally funded water programs, and in addition was given a Revolving Construction Fund for the development of water on a suall project basis.

In 1967, the Legislature changed the Board's name to the Board of Water Resources, retaining all of the assigned responsibilities, and named the Board's full-time staff the Division of Water Resources and placed it within a newly created Utah State Department of Natural Resources. Since then, as the need has grown and as the efficient use of water has become more critical, the legislatures have added new responsibilities. The latest was by the 1978 Legislature which created the "Water Conservation and Development Fund" at an initial funding of $\$ 25$ million and charged the Board and Division to develop larger water storage projects, including the construction of hydroelectric generating plants. It is under this responsibility and authority that the Utah Division of Water Resources initiated this study to assess the feasibility of hydroelectric power development at the existing Woodruff Narrows Dam and Reservoir. The results of this study will also provide some insight for potential hydroelectric power development at other existing and planned dam sites in the State of Utah.

To assist in the feasibility study of hydroelectric power generation at the Woodruff Narrows site, the Utah Division of Water Resources, with the cooperation of International Engineering Company of San Francisco and Utah Water Research Laboratory at Utah State University, responded to a U.S. Department of Energy Program Research and Development Announcement number ET-78-D-07-1706 which resulted in Cooperative Agreement Number DE-FC07-78ID01767 Woodruff Narrows Power Plant.

\section{SITE CHARACTERISTICS}

A. LOCATION AND GEOGRAPHIC SETTING. Woodruff Narrows Dam and Reservoir is located on the Bear River in Uinta County, Wyoming, near the Utah-Wyoming stateline approximately 20 miles north of Evanston, Wyoming.

The Bear River is an interstate stream which drains an area of 4,776,000 acres in the states of Idaho, Utah, and Wyoming. Its headwaters are but 90 miles from its mouth, yet it meanders 500 miles in a circuitous course in reaching Great Salt Lake. In its travels it makes five stateline crossings in three states. The Bear River is the largest tributary to the Great Salt Lake and the largest stream in the North American Continent that does not reach the ocean. The mean annual inflow to the Great Salt Lake from the Bear River is approximately $1,000,000$ acre-feet. The mean annual streamflow of the Bear River at Woodruff Narrows Reservoir is approximately 150,000 acre-feet.

Approximately 500 irrigation organizations own and operate separate irrigation systems in the Basin, supplying irrigation water for half a million acres of land. There are presently 5 hydroelectric power plants on the Bear River system with a total generating capacity of $125.5 \mathrm{MW}$ owned and operated by Utah Power and Light Company. The plants and generating capacity are as follows: Soda - $14 \mathrm{MW}$, Grace - $44 \mathrm{MW}$, Cove - 7.5 MW, Oneida - $30 \mathrm{MW}$, and Culter - $30 \mathrm{MW}$. Municipal and industrial withdrawals for a population of 100,000 (1970 census) are also made in the Basin. The National Bear River Migratory Bird Refuge is located at the mouth of the Bear River.

B. PRESENT CONDITION OF EXISTING FACILITIES. Woodruff Narrows Dam is a homogeneous compacted earthfill dam. The dam is 58 feet in height above the stream bed. The hydraulic head from the spillway crest to normal tailwater level is 32 feet. The dam has a crest length of 600 feet and a crest width of 20 feet with a front side slope of $2-1 / 2: 1$ and backside slope of $2: 1$. The dam embankment is in good condition. The spill.way was rnnstructed hy excavating through a rock abutment. The spillway was lined only at the upper end near the overflow crest. The unlined portion of the spillway has had some erosion from use over the 
years. The spillway is in fair condition, but will need to be lined or replaced sometime in the future, possibly in the next 5 to 10 years.

The outlet works consists of an intake structure and two rectangular reinforced concrete conduits. The intake structure was repaired in November 1977, which included replacing the existing trash racks and providing additional air vents to the intake gates from the gate house at the top of the dam. Th1s was done to alleviate a cavitation problem under the intake gate thimble. The outlet conduits are showing some signs of deterioration and will need to be repaired or replaced in the future.

C. HISTORY AND USE. The Woodruff Narrows Dam and Reservoir was constructed in 1961 by the Utah Board of Water Resources to provide supplemental irrigation water for approximately 36,000 acres of meadow hay in the Upper Bear River Valley primarily in Rich County, Utah. The total storage capacity of the reservolr is 28,000 acre-feet, of which 22,500 acre-feet is used for irrigation, 4,000 acre-feet is used for fish conservation for maintaining a minimum flow release from the reservoir of $10 \mathrm{cfs}$ to the main stem of the Bear River during the nonirrigation season, and 1,500 acre-feet is used for dead storage for fish conservation in the reservoir. Recreation facilities at the reservoir include a parking lot, rest rooms, and a boat ramp. The principal recreation uses are fishing and duck and goose hunting.

of the 22,500 acre-feet of storage for irrigation, 18,240 acre-feet is generally used as active storage each year, and 4,260 acre-feet is reserved for hold-over storage for use in drought years. The irrigation season generally begins about the first of May. Flows below the reservoir from spills and/or releases ranging from $500 \mathrm{cfs}$ to $700 \mathrm{cfs}$ are required to maintain the irrigation canals to their capacity depending upon tributary inflow and irrigation return flows. Irrigation of the meadow hay generally continues until approximately the loth of July, when the flow from the reservoir is reduced to approximately 30 cfs for stockwatering and fishery purposes. The reservoir releases remain low until approximately the 20 th of August when releases of 600 to $700 \mathrm{cfs}$ are made from 5 to 10 days to provide for an additional irrigation on the meadow hay and pasture to increase production for fall grazing. If sufficient water is not remaining in the reservoir above the hold-over storage for at least 5 days of irrigation, no late season releases are made. The late season water is available only about 50 percent of the time. The hold-over storage is generally not used for late season irrigation but is saved for low water years for use in June or early July.

The Division of Water Resources has designed an enlargement of the present dam and reservoir to increase the storage capacity from 28,000 acre-feet to 53,200 acre-feet. Application has been made to the Wyoming State Engineer for a construction permit to enlarge the reservoir. Acquisition of reservoir right-of-way for the proposed enlargement is approximately 90 percent completed. The 25,000 acre-feet of new storage will be used for supplemental irrigation of land in Rich County, Utah. Construction of this project is scheduled to begin as soon as water rights problems associated with the Bear River Compact can be resolved among the. states of Idaho, Utah, and Wyoming.

\section{HYDROELECTRIC POTENTIAL}

A. POWER AND ENERGY. The purpose of this study is to determine if it is feasible to add hydropower facilities when the reservoir is repaired and enlarged. An alternative dam site a short distance downstream from the present dam (lower site) utilizing the same reservoir basin would yield a higher power head. Runof-river hydropower alternatives were considered at both the present dam (upper site) and the lower site as well as a pumped storage alternative using the lower site as a holding pond.

The streamflow released from the reservoir during the fall and winter months of September through March generally ranges between 10 to $60 \mathrm{cfs}$. During this period, the reservoir level is generally low resulting in very little potential for power development. During the spring and summer months of April through August, the flow generally ranges between 300 and $1,000 \mathrm{cfs}$.

A computer simulation model based on mean monthly values, utilizing 26 years of recorded streamflow into the reservoir, was used to determine the mean annual energy potential for the following configurations: (1) present dam, (2) the proposed enlarged dam (alternative 1), (3) a new dam at the lower site with a maximum head of 65 feet which has approximately the same storage as the proposed enlarged dam (alternative 2), and (4) a new dam at the lower site which would store water to the same elevation as the proposed enlarged dam (alternative 3). Results of the simulation study show that the average annual energy potential of the above four configurations are respectively $3.4,5.0,7.1$, and 8.3 gigawatt hours. The corresponding maximum power capacities are respectively $2.1,3.0,4.0$, and 4.5 megawatts. The average annual energy production for the pumped storage alternative is $7.6 \mathrm{GWH}$ with a pumping requirement of 5.6 GWH resulting in a net average annual energy production of $2.0 \mathrm{GWH}$. The maximum power capacity for the pumped storage alternative is 3.0 megawatts.

B. TURBINE AVAILABILITY AND SUITABILITY. For alternative 1, with a maximum net head of $48 \mathrm{feet}$, a standardized pre-designed ready-made tube turbine was selected on the basis of cost, availability, simple installation and easy maintenance. For alternative 2, which has a maximum net head of 65 feet, a horizontal bulb type turbine was selected because the operating head of more than 60 feet is beyond the range of a 
standard tube turbine and also because a vertical Kaplan type turbine would be more costly. For alternative 3 , which has a maximum net head of 75 feet, a vertical Kaplan turbine was selected because the operating head is higher than the normal range for a bulb turbine. For the pumped storage alternative, a tube turbine similar to alternative 1 was selected which would be modified to serve also as a pump. It was concluded for the Woodruff Narrows site that as the maximum power head is increased the cost of the turbines that are suitable for the corresponding heads and the other power development costs rises faster than the value of the additional energy generated by the additional head.

\section{ECONOMIC ANALYSIS}

A. POWER MARKETING STUDY. Five potential users in the area were contacted to see what price they would be willing to pay for the energy that could be developed at the Woodruff Narrows site. The energy generated at the site would be available only on a seasonal basis in the spring and summer since the winter flow of the Bear River is small and would not justify keeping a power plant operating through the winter months. Under alternative 1, an enlarged reservoir at the existing site, the mean annual energy produced would be 5 GWH and would be available as shown in the table below.

\begin{tabular}{|c|c|c|c|c|c|c|}
\hline & April & May & June & July & August & Total \\
\hline Mean Energy Gen. (GWH) & $\overline{0.9}$ & $\overline{1.3}$ & 1.6 & 0.9 & 0.3 & $\overline{5.0}$ \\
\hline Mean Energy Gen. (\%) & 18 & 26 & 32 & 18 & 6 & 100 \\
\hline Max. Power Gen. (MW) & 2.7 & 2.8 & 2.9 & 2.6 & 1.8 & \\
\hline
\end{tabular}

This pattern of energy production is dictated by the irrigation releases from the reservoir. Unfortunately, all the energy is non-firm, since nothing is produced in the wintertime. Furthermore, the peak production does not coincide with the peak demands on the potential users' systems. Thus, the energy simply replaces the equivalent amount of fossil fuel and there is no reason for potential customers to pay a premium price.

An optimistic estimate of the current value of the energy that could be produced at the site is approximately $30 \mathrm{mills}$ per KWH. The power company in the area did not show much interest in purchasing the power but is willing to wheel the power at approximately 9 mills per KWH for a maximum plant capacity output of 3.0 megavatts based on a charge of $\$ 15$ per kW-yr and an annual generation of 5 GWH. Therefore, the estimated net value of the energy produced at the Woodruff Narrows site is approximately 21 mills per KWH.

B. COST OF PRODUCING ENERGY. The cost of repairing and enlarging the present dam is estimated to be $\$ 1.835$ million. The cost of repairing the dam without the enlargement would be approximately $\$ 1.6 \mathrm{million}$. The irrigation benefits from agriculture from the reservoir enlargement are estimated to be $\$ 214,000$ per year which when capitalized over a 50 year period at a discount rate of $47 / 8$ percent would amount to $\$ 4.0$ million. This is a benefit to cost ratio of 2.2 for repair and enlargement of the present reservoir. The discount rate of $47 / 8$ percent is used by the Utah Division of Water Resources in economic analyses of projects built by the Utah Water Conservation and Development Fund. The agriculture interests would pay all of the costs of the reservoir enlargement and repairs.

The estimated cost of providing a power facility on the enlarged reservoir (alternative 1) which would be capable of producing $5.0 \mathrm{GWH}$ per year is $\$ 2.625$ million. This cost estimate includes all the power features required for the project including a transmission line to the nearest area power company transmission lines. The estimated costs of a new dam for alternatives 2 and 3 respectively are $\$ 2.805$ and $\$ 3.275 \mathrm{million}$. The estimated costs of the power features for alternatives 2 and 3 respectively are $\$ 3.820$ and $\$ 4.550$ million. The net cost for the power development after subtracting the cost for enlarging and repairing the present dam for alternatives 2 and 3 respectively are $\$ 4.790$ and $\$ 5.990$ million. These costs result in a capital investment per installed kilowatt for alternatives 1,2 , and 3 respectively of $\$ 1,090, \$ 1,370$, and $\$ 1,500$.

The cost of producing energy for the three alternatives on a mills/kWH basis was computed using a 50 year repayment period for amortizing the power facilities for various interest rates and adding the annual operation and maintenance costs. The annual operation and maintenance costs of each alternative were estimated at 1.5 percent of the capital cost for the power development. The figure below shows these costs as a function of interest rate for the three alternatives. A shorter repayment period such as 35 years would increase the cost about 2 to $5 \mathrm{mills} / \mathrm{KWH}$ depending upon the interest rate. The wheeling costs are not included in the figure. The net value of energy ( $21 \mathrm{mills} / \mathrm{KWH}$ ) shown on the figure is the current value of the energy ( $30 \mathrm{mills} / \mathrm{KWH})$ less the wheeling cost ( $9 \mathrm{mills} / \mathrm{KWH})$. The cost of producing energy by alternatives 2 and 3 is greater than the net value of the energy produced even with no interest. The cost of energy produced by alternative 1 is 51 mills per KWH based on an 8 percent return on investment. If the wheeling charges are added, the total cost of producing the energy is $60 \mathrm{mills}$ per KWH. The rate of return on investment for alternative 1 is less than one percent based on the current net market value of $21 \mathrm{mills} / \mathrm{KWh}$ for the energy. Alternatives 2 and 3 are even less favorable than alternative 1 . The cost of producing power by alternatives 2 and 3 based on a rate of return on investment of 8 percent including wheeling charges is over $75 \mathrm{mills}$ per KWH. Based on a discount rate of $47 / 8$ percent used by the Utah Division of Water Resources for economic analyses of projects built by the Water Conservation and Development Fund the cost of producing 
power for alternative 1 would be 34 mills per KWH. This is more than 60 percent higher than the estimated net market value of the energy.

The cost of a reregulating reservoir at the lower site for allowing for peaking power production along with the additional cost of increased power plant capacity and increased wheeling charges would make power peaking an even less favorable alternative.

The pumped storage alternative would be similar to alternative 1 except that the unit would be a pump-turbine and a downstream reservoir would be required. No additional generating capacity would be provided, but firm power would be produced throughout the year. The net energy produced by this type of development would be less than by a run-of-river energy plant. For the pumped storage alternative the total capital cost is estimated to be $\$ 3.695$ million. This is a capital investment of $\$ 1,540$ per installed kilowatt. When the capital costs are amortized over a period of 50 years using an interest rate of 8 percent and added to the operation an maintenance costs including wheeling charges and energy purchases, the resulting cost of producing the energy is $60 \mathrm{mills} / \mathrm{KWH}$. This is identical to the cost of producinf energy by alternative 1 .

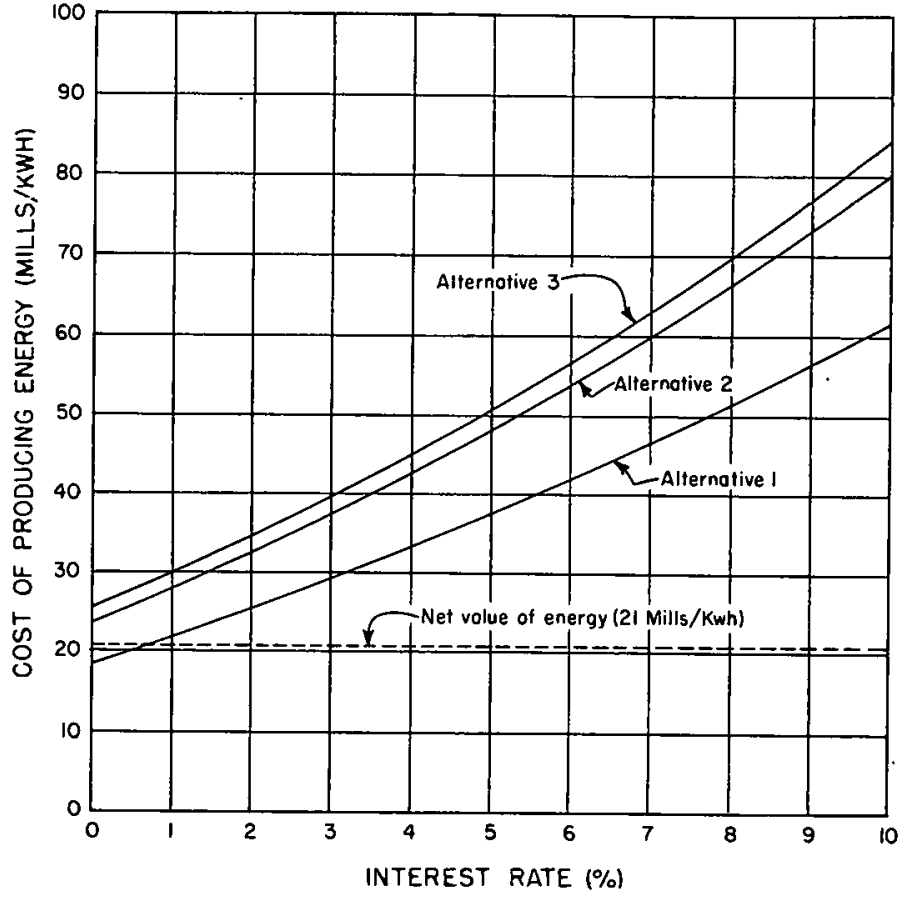

Cost of Producing Energy at Woodruff Narrows

\section{v. INSTITUTIONAL, SOCIAL, AND ENVIRONMENTAL ASSESSMENT}

The only institutional problem of any magnitude is the water right problems associated with the tristate Bear River Compact. The Bear River Commissioners of each state in December, 1978 signed an Amended Bear River Compact that would alleviate this problem. The Amended Compact has now been ratified by the legislatures of each of the three states. None of the alternatives under consideration would have significant negative social impacts. The proposed alternatives would result in little or no change in present patterns of water and land use, income, population, and employment. The very slight positive impacts from any of the alternatives would not result in any significant changes of the social structure or character of the area. Based on an assessment of ecological variables that would reflect stream ecosystem integrity, it is judged that hydropower development at the Woodruff Narrows site would have negligible impact on the Bear River ecosystem over and above existing structures and stream operations. Flow patterns, quality, and quantity would be essentially unchanged. Sensitive ecological factors appear nonexistent for that segment of the Bear River system.

\section{CONCLUSIONS AND RECOMMENDATIONS}

Both the upper site and lower site locations at the Woodruff Narrows Reservoir are geologically sound and acceptable from a geotechnical engineering viewpoint for hydroelectric power development. However, none of the three basic run-of-river or the pumped storage alternatives for hydroelectric power development are economically feasible at this time. Enlargement of the existing Woodruff Narrows Dam and Reservoir for agricultural purposes is economically feasible to construct. It is, therefore, recommended that enlargement of the existing dam and reservoir be pursued at this time without the addition of hydroelectric power development. If the market value of electric energy in the project area should rise at a rate much faster than inflation of construction costs, it may be feasible in future years to add hydroelectric power generation facilities at the. Woodruff Narrows Dam and Reservoir site. If the hydroelectric power development were economically feasible, funding most likely would be arranged by the State of Utah through the Utah Board of Water Resources from the Revolving Construction Fund and/or the Water Conservation and Development Fund. 


\author{
LOWELL CREEK \\ Seward, AK
}

\title{
CH2M HILL
}

Thomas S. Small, P.E.

Utilities Engineer, Anchorage Regional Office

PRDA Proposal Contract No. ET-78-D-07-1768

\section{INTRODUCTION}

The City of Seward, Alaska, is currently in a precarious position regarding its power supply. Since 1961 the city has purchased most of its power from the Chugach Electric Association (CEA); the city's only other power source is a city-owncd diesel plant with a capacity of 5,500 kilowatts for standby power. On 15 January 1979 CEA notified Seward that its power contract had terminated, under the terms of the contract itself, and that prices in any future wholesale power contract could increase by as much as 300 percent.

Consequently, the city is investigating other sources of electrical energy. CH2M HILL has assisted the city in its investigations by studying the feasibility of hydroelectric power development on Lowell Creek, a stream that passes through Seward. Lowell Creek was selected for study because of its steep gradient and resulting head potential as well as its proximity to the city. The study was conducted under Cooperative Agreement No. EW-78-F-07-1768 between the U.S. Department of Energy and the City of Seward.

The study began with compilation and research of maps, data, and other reports to develop concept designs and establish the available head. The hydrologic data were analyzed to estimate available energy throughout the year. Long-term temperature and rainfall data were examined to correlate the available streamflow data to the long-term average.

From the head and flow for alternative sites, the energy potential was computed for each site. Concepts and layouts were then developed for each site. The concept development included a study of dam safety, environmental impacts, and permit requirements. Project costs were approximated from cost quotations for major equipment items and general reconnaissance-level unit price cost data for the construction work. Finally, annual costs were estimated and applied to the project energy output.

\section{EXISTING FACILITIES ON LOWELL CREEK}

Lowell Creek has been the site of several dams and diversion projects, and the facilities that remain were assessed as part of the study to determine their potential for use in a hydroelectric project. One project consisted of a valve house, penstock, and powerplant built in 1905 by Seward Light and Power, a privately owned utility, to generate power for Seward. Another was a flood control diversion dam and tunnel that the U.S. Army Corps of Engineers began building in 1938. The sites of the facilities that still exist are shown in figure 1 along with the locations of the alternative project layouts developed during the study. It was determined by a physical inspection that the only abandoned hydroelectric facility that might be still usable is the valve house. However, the Corps of Engineers flood control project would be useful and has been incorporated into two of the alternatives developed during the study.

\section{POWER POT̈ENTTIAL OF CREEK}

Lowell Creek initially appeared suitable for hydroelectric power because it has a steep gradient (about 400 feet per mile), is fed from a large snowfield, and has two significant drops. One drop is formed by the Corps of Engineers diversion dam, and the second drop, of about 65 feet, is at the termination of the diversion tunnel. The canyon sides also are steep, and during high-water periods, vast quantities of rock debris are washed down the channel. Corps of Engineers feasibility reports on the diversion tunnel show estimates of 27,000 cubic yards per year of material moved downstream by the rampaging creek. No intake or diversion could be considered without a means to handle the bedload of rock, gravel, and sand. Generally, there is little bedload for flows of 60 cubic feet per second (cfs) or less, so that if the design flow for a new facility is $60 \mathrm{cfs}$, excess flows could be used to convey the bedload or to flush sediments from the sediment traps.

There is reasori to believe that a substantial percentage of the Lowell Creek runoff disappears into the alluvium and flows below the surface the remaining distance to Resurrection Bay. If a project proves feasible, a slurry trench or similar cutoff to maximize surface flow should be considered. 
Lowell Creek was gaged for 3-1/2 years, from May 1965 through September 1968, at the outlet of Lowell Creek near Resurrection Bay. The maximum flow was $1,200 \mathrm{cfs}$ on 21 August 1965, and the minimum flow was $1.0 \mathrm{cfs}$ for several days in January 1966. To extrapolate the 1966-68 flow records to a longer period, a correlation was made with long-term rainfall records. Daily streamflow data for 1966 through 1968 were used to compile a flow-duration curve, which was then corrected to represent a 30-year average. An examination of the 30-year-average curve showed that, during winter freezeup, flows are too low for operation of a plant. A plant would be shut down about 30 to 40 percent of the time, from about November to April each winter. In addition, about 10 percent of the time the flows are high enough (greater than 75 cfs) to carry a gravel and rock bedload that would be too large for a plant to be operated.

Using the flow-duration data, the potential power and energy production was computed for several sizes of powerplants. This information is plotted in figure 2 and shows that plants with rated flows larger than $60 \mathrm{cfs}$ would provide almost no gain in energy production. Data from this figure were used to arrive at the alternative plant sizes discussed below.

\section{ALTERNATIVE PLANTSITES AND DESIGNS}

Three alternative sites for hydroelectric plants were considered. All were limited to a low head, less than 66 feet, and all are run-of-river type projects. The locations of the alternatives are shown in figure 1. Basic components common to each alternative include an intake with rock separation and a sediment trap, a penstock pipeline, a turbine and generator, accessory equipment, buildings, a tailrace, and power transmission. A schematic of a typical induction generator is given in figure 3 . The plant characteristics are summarized in table 1 .

The powerplant in alternative $A$, which is farthest upstream of the three alternatives considered, is located at the site of the abandoned Seward Light and Power intake and valve structure about 1 mile upstream from the west edge of Seward. The design consists of rebuilding the old intake (only the old valve house is partly useful), constructing a 36 -inch pipeline running about 0.25 mile downstream, and building a new powerhouse close to the north side of the valley. This alternative has about 60 feet of head available.

For alternative $B$, the powerplant would be located at the diversion dam and entrance to the tunnel. Because of the restricted space around the tunnel entrance, the powerhouse would be sited on the south side. It would be a reinforced concrete structure with a vertical shaft casing, housing an axial flow or mixed flow turbine, and driving a vertical shaft induction generator at $720 \mathrm{rpm}$. The generator would be rated $100 \mathrm{~kW}$. This plan would use the head of about 30 feet between the stream level and tunnel invert.
Table 1. PLANT CHARACTERISTICS

Alt. A Alt. B Alt. C

Flow (cfs)

Design

Usable minimum

Head ( $\mathrm{ft}$ )

Maximum static

Net rated

Net minimum

Capacity (kW)

Rated (kW = $\mathrm{QH} / 14$ app.) $250 \quad 100 \quad 250$

Rated ( $\mathrm{HP}=4 / 3 \mathrm{~kW}) \quad 330 \quad 133 \quad 330$

Speed (rpm)

Specific Speed $\left(\mathrm{N}_{\mathrm{s}}\right)$

Power Conduit

Length ( $\mathrm{ft}$ )

Diameter (in.)

$\begin{array}{ll}133 & 330 \\ 720 & 720\end{array}$

$148 \quad 85$

78

1,300

42

Alternative $C$ would take water from the diversion tunnel exit through a bar screen, rock trap, and penstock to a powerhouse sited between the rock cliff and the road, for a total head of about 60 feet. The tailrace would then be through a culvert under the road to the beach. This alternative was considered in more detail than alternatives $A$ and $B$ because it has the best potential for eventual fedsibility. A schematic layout of this alternative is shown in figure 4.

For all the alternatives a fast-track schedule was prepared in which studies, designs, equipment manufacturing, and construction run concurrently to the greatest extent possible to expedite completion. The total elapsed time, from a decision to proceed with licensing to startup and testing, would be about 39 months. If the manufacture of small hydropower units is developed to standard designs allowing a 1-year delivery, the project schedule could be shortened to about 27 months. It was assumed that the Federal Energy Regulatory Commission (FERC) license process would take 8 months after an application is submitted.

\section{ENVIRONMENTAL IMPACTS AND REQUIRED PERMITS}

The development of a low-head hydroelectric generation facility would not adversely affect the natural or manmade elements of the environment in the Lowell Creek drainage or in the City of Seward. The creek has few existing human uses, and those that do occur, such as recreation, are infrequent and without accompanying support facilities. The creek supports no fisheries, and the State of Alaska has placed no restrictions on the creek to protect the wildlife habitat.

The safety of the existing Corps of Engineers diversion dam was recently verified by a Corps safety inspection. However, a hydroelectric dam built on the beach at Resurrection Bay, as in alternative $C$, would suffer damage during an earthquake similar to the 1964 event. 
The Corps diversion dam and tunnel are listed in the National Register of Historic Places, so that a permit would be required for construction of alternatives B and C. All three alternatives would depend on acquisition of a water use permit from the State of Alaska. An application for Diversion of Present National Stream would also need to be submitted for alternative $C$ and possibly for alternatives $A$ and $B$. Alternative $C$ would require a Corps of Engineers permit for construction occurring 10 feet below mean higher high water.

\section{COSTS AND VALUE OF POWER}

Reconnaissance-level cost estimates were prepared for the alternatives and are summarized in table 2. The capital costs are based on a single quotation for a package turbine-generator-control unit and unit prices for construction items such as excavation, reinforced concrete, structural steel, pipelines, buildings, road materials, electrical switchgear, and power transmission lines.

Table 2. COSTS AND VALUE OF ALTERNATIVE POWER SOURCES

\begin{tabular}{|c|c|c|c|c|c|c|c|}
\hline & Alternative & $\begin{array}{c}\text { Rated } \\
\text { Capacity } \\
(\mathrm{kW}) \\
\end{array}$ & $\begin{array}{c}\text { Annual } \\
\text { Energy } \\
\text { (MW) }\end{array}$ & $\begin{array}{c}\text { Capital } \\
\text { Cost } \\
\left(\$ \times 10^{3}\right) \\
\end{array}$ & $\begin{array}{c}\text { Unit } \\
\text { Cost } \\
(\$ / \mathrm{kW}) \\
\end{array}$ & $\begin{array}{c}\text { Annual } \\
\text { Cost } \\
\left(\$ \times 10^{3}\right) \\
\end{array}$ & $\begin{array}{c}\text { Energy } \\
\text { Cost } \\
\text { (Mills/ } \\
\text { kWh) } \\
\end{array}$ \\
\hline $\begin{array}{l}\text { A. } \\
\text { B. } \\
\text { C. } \\
\text { D. }\end{array}$ & $\begin{array}{l}\text { Upper Plant (Abandoned Valve House) } \\
\text { Middle Plant (Tunnel Inlet) } \\
\text { Lower Plant (Tunnel Outlet) } \\
\text { Other Sources } \\
\text { Present cost of energy from CEA } \\
\text { Grant Lake project } \\
\text { Incremental cost of direct fuel at pre }\end{array}$ & $\begin{array}{l}250 \\
100 \\
250\end{array}$ & $\begin{array}{l}800 \\
420 \\
800\end{array}$ & $\begin{array}{r}1,526 \\
828 \\
976\end{array}$ & $\begin{array}{l}6,104 \\
8,280 \\
3,904\end{array}$ & $\begin{array}{r}150 \\
98 \\
110\end{array}$ & $\begin{array}{r}188 \\
232 \\
137 \\
\\
34 \text { to } 40 \\
40\end{array}$ \\
\hline
\end{tabular}

The power production of a $250-\mathrm{kW}$ plant would be only about $800,000 \mathrm{kWh}$ per year, compared to the city's electric system purchases of about $5,000 \mathrm{~kW}$ peak and $20,000,000 \mathrm{kWh}$ per year. The average annual growth of Seward demand is probably about twice the amount of a $250-\mathrm{kW}$ plant. Thus, the city really needs a hydroelectric plant to supply the total present system plus allowance for future loads created by industry desiring to locate in Seward.

The value of the alternative plants developed for this study must be compared with the incremental cost of acquiring much larger blocks of power and energy. The values of alternatives $A, B$, and $C$ are compared in table 2 with the existing values of CEA power, power from a hydroelectric project recently studied for Seward at Grant Lake (about 30 miles north of Seward), and power from expanded generation at the city's diesel plant. The least costly new hydroelectric plant on Lowell Creek would have nearly 10 times the present cost of energy from the CEA, and about 4 times the cost of energy from the Grant Lake project.

\section{SUMMARY AND CONCLUSIONS}

None of the three alternatives approaches feasibility at this time. Major influencing factors are the high cost of energy at over 13 cents per $\mathrm{kWh}$, the winter freezeup resulting in plant shutdown from November to April, and a large amount of rock sediment carried by the stream and requiring expensive intake structures to skim of $f$ the rocks.

The most promising alternative (alternative $\mathrm{C}$ ), which would have a capacity of $250 \mathrm{~kW}$ and would produce about $800,000 \mathrm{kWh}$ per year, would fill less than 5 percent of the city's present energy needs. The plant would cost nearly $\$ 1$ million and produce energy at about 137 mills per $\mathrm{kWh}$. This alternative is the best of the three from the standpoint of lower cost, best access via existing all-weather road, least exposure to avalanche and rockslides, and proximity to existing powerlines.

The apparent nonfeasibility of a Lowell Creek project was recognized at the midpoint of the study and discussed with the city and the representative of the Department of Energy. The recommendation was made, and all agreed, to shorten the study, thereby avoiding further expenditure of the grant monies supporting this study. The study was then brought to a conclusion with the preparation of the report. 

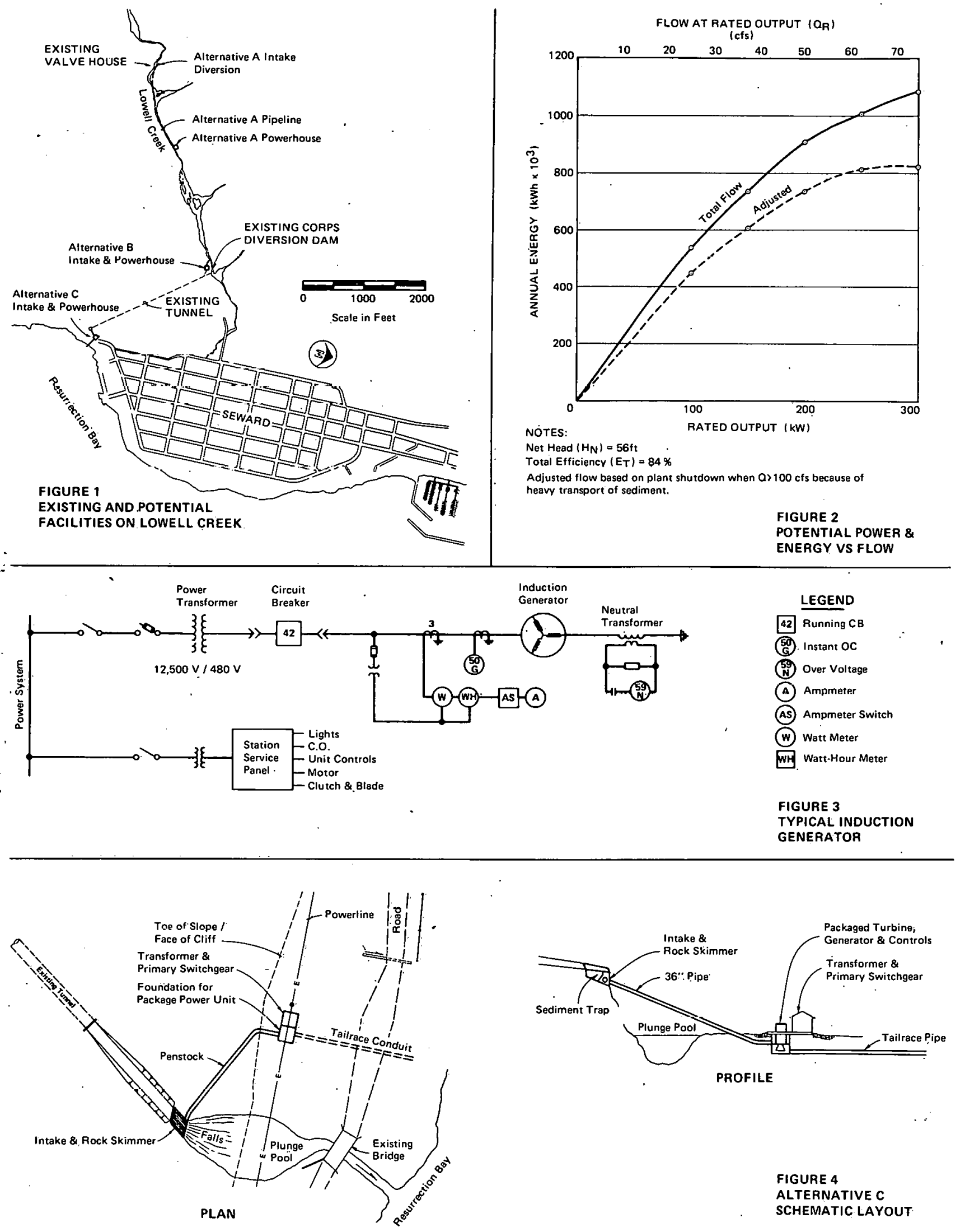

FIGURE 4

ALTERNATIVE C

SCHEMATIC LAYOUT 
THE CARLYLE RESERVOIR ON THE KASKASKIA RIVER

Carlyle, Illinois

City of Carlyle, Illinois Municipal Electric Utility Barnes, Henry, Meisenheimer and Gende, Inc.

PRDA Proposal Contract No. EW-78-F-07-1769

\section{INTRODUCTION}

This proposed project is located on Carlyle Reservoir in Clinton County, Illinois very near to the City of Carlyle, Illinois. The site is approximately river mile 107 of the Kaskaskia River and approximately 50 miles due east of the major metropolitan area of St. Louis, Missouri.

The proposed project would be owned and operated by the Carlyle, Illinois Municipal Electric Utility. The reservoir's operation is presently and will continue to be the responsibility of the St. Louis District Office of the U.S. Corps of Engineers. By the co-operation of these two organizations, the production of hydroelectric energy by Carlyle Reservoir will be added to the present functions of the Carlyle Reservoir. The City of Carlyle, Illinois has been granted a preliminary permit from the Federal Energy Regulatory Commission for the purposes of studying this proposed project.

Carlyle Reservoir has an earthen embankment whose length of crest is 6,610 $\mathrm{ft}$. with an elevation at the top of the dam of $472.0 \mathrm{ft}$. MSL. The reservair's operation calls for a maximum pool elevation for flood control of $462.5 \mathrm{ft}$. MSL. Normal pool elevation for the summer months is 445.0 compared to 443.0 for the period from December lst through April 30th of each year. The spillway for the reservoir is of the ogee crest type and has four (4) tainter gates, each with a $38 \mathrm{ft}$. width. The spillway crest elevation is 425.0 . The operation of these gates is determined by the St. Louis District Office of the U.S. Corps of Engineers in accordance with the Reservoir Regulation PIan VII and specificaliy Appendix B for Carlyle Reservoir. Under Plan VII, the range of gross heads available for generating equipment at the reservoir is between $10 \mathrm{ft}$. and $35 \mathrm{ft}$. with flows which range from a minimum of $50 \mathrm{cfs}$ to a maximum of $10,000 \mathrm{cfs}$. The weighted average of production under this range of gross operating conditions is a point of $23.9 \mathrm{ft}$. head and $3,492 \mathrm{cfs}$.

The site on the dam which was selected for development of the conceptual plant design is located immediately adjacent to and west of the spillway stilling basin for the reservoir. It will require two $13.5 \mathrm{ft}$. diameter holes to be bored through the non-overflow walls which are at that location. These holes would be approximately $33.5 \mathrm{ft}$. in length. On the upstream side of the nonoverflow wall would be a rectangular box type of basin inlet with the plant located downstream of the non-overflow wall. The discharge from the proposed plant would be an open channel and would require removal of a portion of the existing spillway west retaining wall.

The structural discussion of the study was the result of a thorough investigation of several sites at which to locate the hydroelectric plant. The selected location of the plant for development of the conceptual design was based on a site that was suitable both to hydraulic considerations and to structural considerations. 
The development of the final conceptual design for the plant, consisted of thorough but preliminary structural investigations pertaining to site conditions, subsurface soil and rock conditions, and the anticipated hydraulic and soil loadings. The structural development of the conceptual design discusses in detail many of the features that will be required to construct the hydro plant in the area of the west abutment of the gated spilliway of the reservoir. Hydraulic and soil loadings were developed to an extent that was sufficient to determine required sizes and physical details of the various types of structural elements and members.

The possibility of utilizing cast-in-place post tensioned concrete construction throughout the structure was investigated. The physical shapes and sizes of the structural members included in the conceptual design would be applicable to the post-tensioned method.

It is pointed out that the construction of the facility will be a difficult project. The construction and design difficulties are discussed in detail. None of the difficulties discussed, however, are considered to be insurmountable. The conceptual design is considered to be thorough enough to ensure that the facility can be constructed within the cost estimate provided.

Based on the results of our preliminary design, the plant facility including the various types of structures involved, is the optimum solution to providing hydroelectric generation at the Carlyle Reservoir.

The equipment which has been proposed to be utilized in this facility is of the horizontal shaft, fixed vane, adjustable blade propeller-type hydraulic turbine connected through a speed-increasing gear box to a 4,375 KW generator. There will be two (2) of these units required to take advantage of a range of net operating head between $14.5 \mathrm{ft}$. and $34 \mathrm{ft}$. The flow which will be utilized by this equipment ranges between 500 and $1,300 \mathrm{cfs}$ at a $14.5 \mathrm{ft}$. of net head, and at the higher head condition utilizes between 750 and $i, 900 \mathrm{cfs}$. The elevation for the turbine centerline of $418.5 \mathrm{ft}$. MSL is believed to give cavitation-free operation over the entire range of operating conditions.

This project as conceptually designed is expected to require forty-five (45) months for development from the initial authorization to the ultimate production of electricity. The early phases of the project will require an extensive engineering design period which will be followed by a detailed review of that design by the U.S. Corps of Engineers. The estimated project cost including the extensive development phase is approximately $\$ 7,550,000$, or an average of $\$ 863.00$ per installed kilowatt.

The anticipated annual production by this proposed project is an average $21,500,000$ kilowatt hours per year with a maximum anticipated hourly output of $7,400 \mathrm{KW}$. Operation of the proposed facility will be by the present personnel of the Carlyle Municipal Electric Utility. The plant would be started up manually, but then its operation will be monitored and controlled remotely at the existing control center for the Carlyle Municipal Electric Utility located at the Carlyle Power Plant, approximately 3,000 ft. from the site for the proposed hydroelectric plant. The water used for generating electricity will be determined by the St. Louis District Office of the U.S. Corps of Engineers in accordance with their Reservoir Regulation Plan VII. No additional water storage will be requested for the purpose of power generation. By operating under this premise, it is believed that the proposed project can be compatible with the present functions of Carlyle Reservoir. The production from the facility would be utilized in three (3) seperate distribution systems as follows; first, the City of Carlyle, then the City of Breese, Illinois and finally excess power would be transmitted to the large private utility in the area, Illinois Power Company. Any excess production during years of high water can easily be utilized in this network and all utilities involved have expressed an interest in receiving such power if it could be justified on an economic basis and loading conditions will permit its usage. 
The operation of this proposed facility under the present regulation plan already in effect will assure that any impact on the environment will be in accordance with that already being experienced as a result of reservoir operation. Also development in the area of proposed highway FAP 409 should be compatible with this proposed project. The new centerline for the proposed highway is to be parallel to and $401 \mathrm{ft}$. south of the access of the dam for the reservoir. If there should be any conflict between the tailrace of the proposed power plant and the bridge over the spillway exit channel for the highway, this conflict is believed to be minimal and can be worked out during final design of both projects.

\section{FEASIBILITY}

The average cost of fuel and purchased power for the Carlyle Municipal Electric Utility has increased approximately $14.8 \%$ since the fiscal year ending April 30, 1975. This trend of increasing cost is expected to continue, although probably at a lower rate. For the purposes of the feasibility study, a combined fuel and purchased power cost increase averaging $6.4 \%$ per year was used. When combined with the remaining cost projections, an annual increase in total operating expenses of $5 \%$ per year resulted. The study was developed on the basis that the proposed project would produce at its average annual level without any fluctuation. For the twelve months ended Apri1 30, 1985, an estimated $18,466,600$ kilowatt hours from the proposed project could be used by Carlyle, and approximately 2,284,800 kilowatt hours could be used by Breese, as well as 748,600 kilowatt hours could be used by the Illinois Power Company. By utilizing $18,466,600$ kilowatt hours of hydroelectric generation in 1985 , the Carlyle Municipal Electric Utility would experience an estimated reduction in total operating expenses of $\$ 531,328$ from $\$ 1,526,598$ projected under present operations to $\$ 995,270$ of total operating expenses projected based on utilizing hydroelectric energy as much as possible. The additional energy which would be transmitted to the Breese Municipal Electric Utility has been estimated to produce another $\$ 51,600$ in revenue for the proposed project, and the energy transmitted to the Illinois Power Company should produce additional revenue of $\$ 9,900$ for fiscal year 1985. Combining the revenues from excess hydroelectric energy, the reduced expenses which would be experienced by Carlyle by utilizing hydroelectric energy and the Net operating Income which the Carlyle Municipal Electric Utility should probably experience for that year, approximately $\$ 798,700$ would be available for retiring debt service of this proposed project for the fiscal year 1985 . These projections were continued through the year 1990 and held constant after that year. For the purposes of the study, debt service requirements were based on a 35 year serial maturity at $7 \frac{1}{2} \%$ interest for $\$ 8,495,000$. This total debt is based on $\$ 7,550,000$ in project costs, $\$ 1,095,000$ for refunding present debt less $\$ 150,000$ of existing funds. Assuming a serial maturity, the total funds avai1able for debt service over the 35 year life of the bonds were $\$ 36,200,000$ compared to a total principal and interest requirement of $\$ 24,200,000$. This is an estimated coverage ratio of 1.49 . This assumes maintained production at the average annual rate.

\section{U.S. CORPS OF ENGINEER'S APPROVAL}

This proposed project will require a thorough review by the U.S. Corps of Engineers. This review is believed to fall in four (4) phases. Initially, the Corps of Engineers would be approached to approve the proposed project based on the conceptual design presented in the feasibility study. This is an interim approval and is believed to be acceptable to the corps on the basis that that agency will reserve the right of ultimate approval of any final design for the project. This interim approval would be necessary for the Federal Energy Regulatory Commission license application and also for any contracts needed in the development phase of the project such as for funding or for co-ordination between utilities and between the City of Carlyle and the Corps of Engineers. The second phase of approval by the Corps of Engineers if for a complete engineering design to be submitted for the project which would specifically define all of the engineering details of the proposed project. The Corps of Engineer's term for such a design, is a Feature Design Memorandum. This 
memorandum would be reviewed at the District Office level, the Division Office level and the Office of the Chief of the Corps of Engineers. Once each of these levels of authority has reviewed the memorandum, revisions will probably be required and a re-submittal through the three levels of Corps authority will be necessary. The third phase of Corps of Engineer approval will be the construction plans and specifications which are necessary for contractor's proposals on the construction of the project. This third phase approval will require review at the same three levels of authority for the Corps of Engineers. This review should be somewhat quicker, since it will coincide with the approvals under the previous phase. During construction, the Corps' final phase approval will be experienced as they will monitor and approve construction in progress.

\section{FEDERAL ENERGY REGULATORY COMMISSION LICENSE APPLICATION}

The proposed project. will require approvals from numerous federal, state and local agencies, however these will be summarized as all being part of the ultimate license which would be granted by the Federal Energy Regulatory Commission. This license is a two-phase procedure of which the City of Carlyle has already accomplished the first phase. A preliminary permit has been granted to the City of Carlyle to study this proposed project. This permit was issued November 1 , 1978 for a period of eighteen (18) months. The next phase would be to apply for a license for this project. Such application would require gathering the review comments of such agencies as the Illinois Department of Conservation, the interim. approval mentioned previously of the U.S. Corps of Engineers, the Illinois Department of Transportation and the Ili inois Historic Preservation Officer to name a few. Approvals from these agencies will require some time, and therefore they should be contacted as soon as the project receives authorization from the City of Carlyle. It is probably to the project's advantage to obtain its license prior to the expiration of the preliminary permit, however, this is not believed to be critical to the project's ultimate development.

\section{PROBLEMS}

As a result of the feasibility study of this proposed hydroelectric power plant on Carlyle Reservoir, several problem areas havc been indicated. While the project appears to be able to retire its anticipated debt requirements based on $i$ ts average annual production, there is no guaranty that the project will produce at this level. Therefore, some provision must be made in order to assure debt service requirements are met during years of low production. Another area of difficulty for this proposed project is the extensive reviews which will be required by the U.S. Corps of Engineers. That agency's review will probably require the single greatest length of time in the project's development, but there does appear to be an arrangement whereby the lack of final approval from that agency would not hinder the issuance of a license for this proposed license. None of these problems are believed to prevent this project from being developed. 


\section{RESTORATION OF FROG HOLLOW MILL}

HYDROELECTRIC PLANT

Middlebury, Vermont

Central Vermont Public Service Corporation

Townscape, Inc.

Tippetts-Abbet $t-M c C a r t h y-S t r a t t o n$

PRDA Cooperative Agreement No. EW-78-F-07-1770

\section{INTRODUCTION}

Central Vermont Public Service Corporation (CVPS), a private utility company providing electricity to approximately $50 \%$ of Vermont's population and Townscape, Inc.., a private development company located in Middlebury, Vermont, have agreed jointly to pursue the feasibility of developing a small hydroelectric generating site known as frog Hollow, located on Otter Creek in the Town of Middlebury, Vermont. Electric power generation was first developed here in 1917 and terminated in 1964 due to major breakdowns in equipment. At that time, there were alternative sources of electrical power available at a cost lower: than that of continued operation of rehabilitated equipment. The site was first developed to produce mechanical power in the late $1700^{\prime} s$. The site is not presently producing any electric power.

With the advent of the Arab Oil Embargo and the resulting dramatic increase in the costs of fossil fuels, our interests have returned to the possible development or redevelopment of hydro sites in our area. We have taken advantage of the opportunity as presented by the Department of Energy (DOE) to study the low-head hydro feasibility in Middlebury. On February 24, 1978, we filed an application with the DoE for a grant to examine the feasibility of Frog Hollow. On. April 2l, 1978, we were notified of the acceptance of our application and the issuance of a grant.

CVPS and Townscape Inc. engaged a consulting engineering firm, Tippetts-Abbett-McCarthy -Stratton (TAMS) of New York City to examine the hydrology, civil facility layout, environmental impact, and cost of the project. CVPS and Townscape went forward with the economic analysis and the architectural rendering of the project.

\section{I . SUMMARY}

Work performed during this feasibility study has included studies of alternative project arrangements and related cost estimates, analysis of hydrology and power outputs for the alcernative project arrangements, a topographic survey, collection of riverflow data, the drilling of a test hole to ascertain foundation conditions, an assessment of environmental conditions pertinent to this site, and the analysis of loads and alternative power supply sources. Together these elements should determine the economic feasibility of developing the frog Hollow site.

Of the alternatives studied, the one which appears at this time to have the greatest promise is the one with the greatest installed capacity. This arrangement includes the installation of two $750 \mathrm{KW}$ tube type turbines with an average annul energy production of $8,625,000$ KWH's (annual plant capacity factor $65.6 \%$ ).

The total investment cost for the project is estimated to be $\$ 3,409,000$ which amounts to $\$ 2273 / \mathrm{kW}$ assuming construction to be completed to meet an in-service date of November 1983 .

The economic feasibility of the project was analyzed by comparing the annual cost of supporting the $1,500 \mathrm{KW}$ of the Frog Hollow capacity with the annual cost of an equivalent amount of capacity from (1) an oil fired gas turbine, (2) a base incermediate coal plant, and (3) a nuclear plant over a period of twenty one years. 
The annual differences in dollars and the cumulative difference from the Frog Hollow alternative were then compared over the study period by present worthing these dollars back to the anticipated first full year of plant operation, 1984.

In all cases, the results show that during the early years of the project's life, the costs of developing Frog Hollow are greater than the alternatives.

On a present worth basis when comparing Frog Hollow against the coal alternative, it takes about 16 years to break even and at the end of the 21 year study period ( 2004 ), Frog Hollow shows an approximate $\$ 500,000$ advantage. When compared with a Gas Turbine alternative, the break even point falls slightly beyond the study period. After that point in time, the advantage for Frog Hollow should grow rapidly as the cost of fuel for the Gas Turbines increases substantially.

When compared with a 1983 nuclear unit, the advantages of Frog hollow are not nearly as apparent as in the cases where fossil fuels were used. Based on the assumpions used in this study, we estimate that the break even point for Frog Hollow vs Nuclear would be approximately 25 - 27 years after the unit goes into service. In our opinion, this represents marginal economics. However, over the normal life time of 50 years for a hydro plant, it should show long-term advantages.

We believe the project shows good technical and engineering feasibility; however, a segment of the citizenry of the Town of Middlebury has expressed concern about the diversion of water from the natural falls area to the water conduit of the hydroelectric generating equipment. Obviously, any commitment for continuous discharge of water over the falls for aesthetic reasons will further lessen the ecinomic advantage of the project, as now foreseen.

Based on conventional private utility financing, we conclude that the project is marginally economic during its early life; however, over its full lifetime, we are convinced that it will prove to be a viable alternative.

We are deeply concerned with the energy situation and are anxious to explore ways by which a marginal project such as this could be made to become more economically attractive. As far as financing the project is concerned, a second alternative to conventional utility financing would be to develop a program with interim construction needs to be financed through a project financing agreement with a commerical bank which later on, and upon completion of construction, will be financed through a lease arrangement or a private placement. financing.

It is possible that any type of private financing will not improve the economics of a hydro project. Under these circumstances, it may be necessary to seek governmental loans or grants if it is the country's goal to develop power from renewable resources and lessen our dependence on foreign oil. In this 1 ight, it is our company's intent to actively pursue any grant or loan programs that may be available for developing hydro projects.

\section{CONOLLUSIONS}

A. From an engineering and technical standpoint, the project appears to be feasible.

B. In our opinion, the environmental impact to the river should be minimal, however, we do recognize that a segment of the citizens of Middlebury is concerned with the aesthetic impact. In this regard, we will certainly work cooperatively with the Town of Middlebury to resolve this concern. If the visual impact of this project on the area is unacceptable and it is necessary to reduce project size, a further economic evaluation will be required.

c. We believe this project to be marginally economic when compared to the best alternative, i.e. a 1983 nuclear plant. When compared with fossil fuel alternatives, the project is more attractive. However, over the full lifetime cycle of the project, it should be a viable one as compared to allalternatives. 
D. Due to marginal economics of this project, further investigation should be made of alternative financing methods.

Central Vermont Public Service and Townscape, based upon the results of the feasibility study to date, are encouraged to proceed with the further investigation of this project.

IV. PROPOSED PROJECT

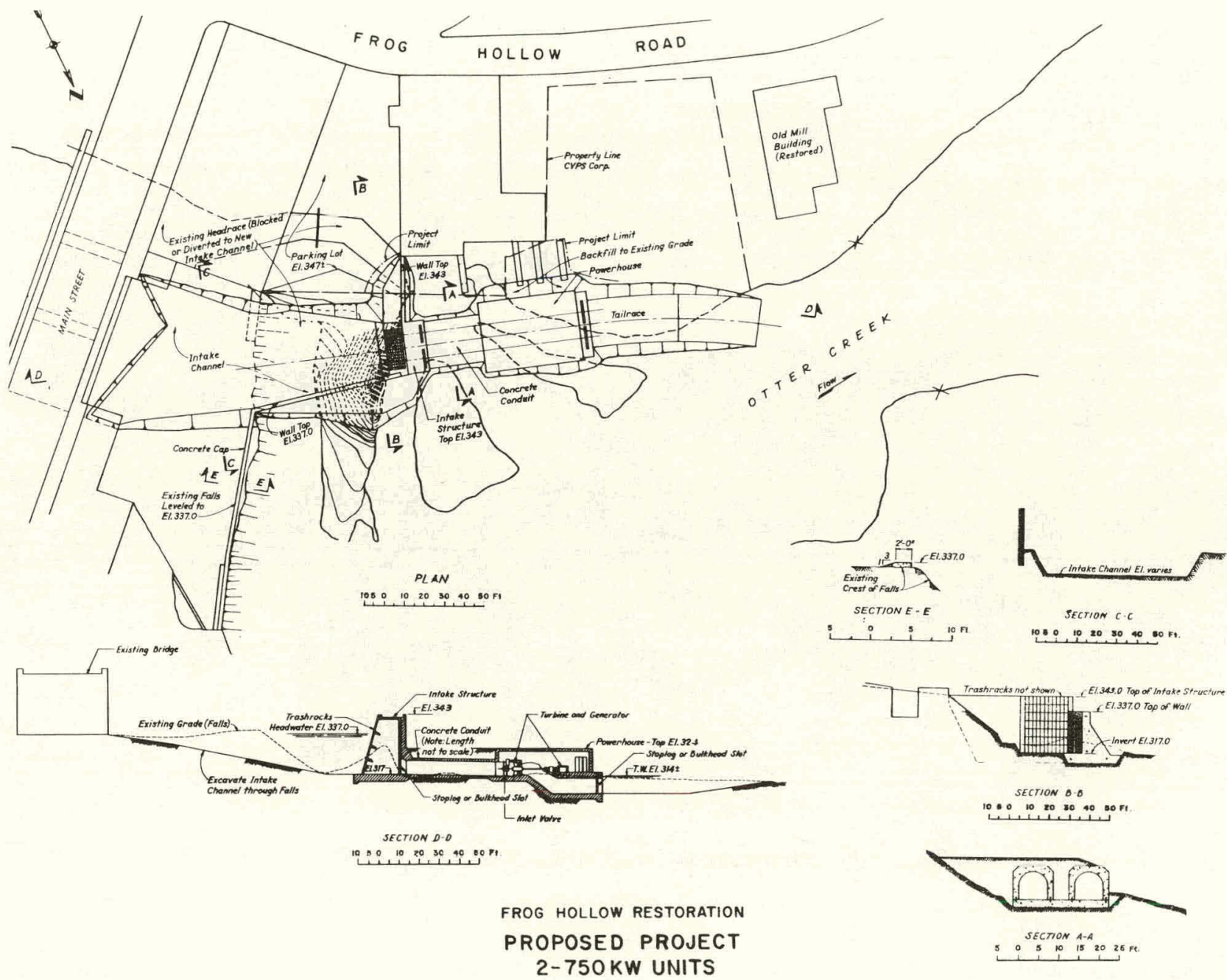




\section{FRENCH LANDING DAM ON THE HURON RIVER}

Van Buren Township, MI

Ayres, Lewis, Norris \& May, Inc.

Principal Investigator: Donald W. Lystra, P.E.

PRDA Proposal Contract No. EW-78-F-07-1772

\section{INTRODUCTION}

The French Landing dam is located on the Huron River in southeastern Michigan, approximately ten miles east of Detroit. The facility was constructed in 1925, the last in a series of five dams on the Huron River developed for hydroelectric generation by the Detroit Edison Company.

The facility includes a powerhouse, two adjustable sector gates for the release of high flows, and a 181 -foot-long reinforced-concrete multiple-arch dam for control of the impoundment (see Figure 1). The height of the dam from the bottom of the footings to the arch crest is 35 feet. The powerhouse was originally equipped with two vertical Francis turbines, directly connected to 4600 volt slow-speed generators, rated 1200 and $2400 \mathrm{kVa}$. Annual production from the plant averaged about 7.5 million kilowatt-hours, ranging from a high of 12.7 million kilowatt-hours in 1950, to a low of 7.2 million kilowatthours in 1931.

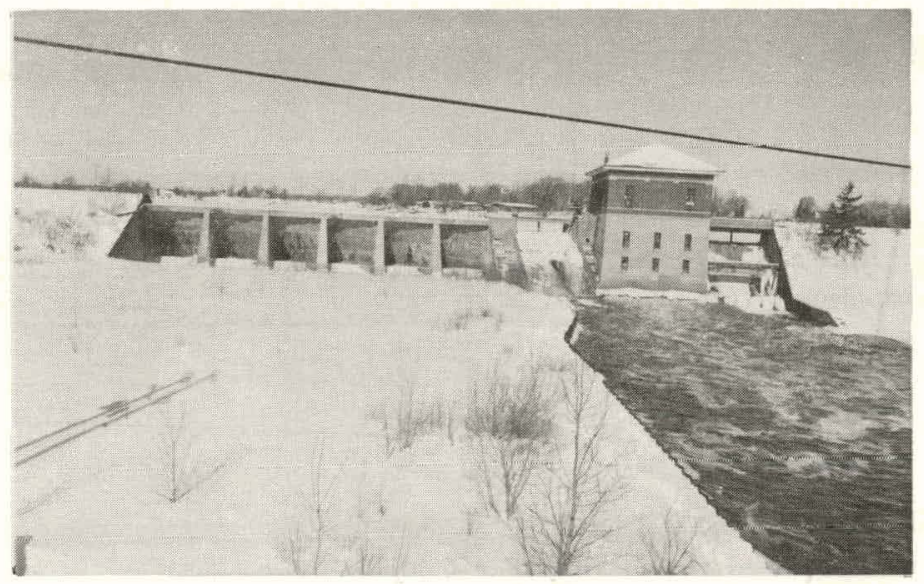

Figure I

Upstream View of French Landing

Durn Site

In 1962 the facility was taken out of service. The generators and all related electric equipment were removed from the powerhouse. The turbine units were left in place in the wheel pits, however to prevent rotation, the shafts were welded to the guide bearing housings and the runner buckets were burned off. The gate casings, guide vanes, and gate operating mechanisms were left in an operational condition so that they could be used to control the discharge of water through the structure.

In 1973 the French Landing facility was turned over to Van Buren Township. The transfer agreement included a provision which prohibited use of the dam site "for the generation of electric power for resale at any time." Since 1973 the Township has owned and operated the facility with its own funds. 


\section{HYDROLOGY}

Based on data from a U.S.G.S. permanent gaging station twenty-two miles upstream of the French Landing facility, hydrological parameters at the site are estimnted ns follows:

$\begin{array}{lr}\text { mean discharge } & 518 \mathrm{cfs} \\ \text { mean annual flood peak } & 2530 \mathrm{cfs} \\ \text { mean annual 30-day low flow } & 275 \mathrm{cfs}\end{array}$

The flow-duration characteristics of the site are typical of those for sites in the midwestern and eastern United States. Average discharge during the wettest month averages about five times that occurring in the driest month.

The impoundment reservoir above the dam site is seven-mile-long Belleville Lake, covering an area of 1425 acres. Downstream of the dam the Huron River Valley broadens out into a wide shallow floodplain which is largely undeveloped.

\section{MARKETS}

Two feasible markets for the sale of power were identified: 1) the local electric utility, Detroit Edison Company, and 2) a group of manufacturing concerns located in a nearby industrial park. (NOTE: In view of the current energy situation, the Detroit Edison Company readily agreed to waive the provision in the 1973 agreement which prohibited the use of the site to generate power.) A substantial difference was found to exist in the potential revenues from each market, based on the fact that the utility would only agree to purchase power based on gross energy (average 16 mills per $\mathrm{kWhr}$ ), whereas the industrial concerns could purchase power based on both energy and demand charges ( 19.3 mills per kilowatt-hour, $\$ 5.80$ per kilowatt peak monthly demand, based on offsetting the utility's primary supply rate). In general the projected revenues from the industrial markets for any given fncility design averaged about 50 percent higher than the projected revenues from the utility market.

\section{DESIGN STRATEGY}

An anolysis of site hydrology established that the storage capacity in the upstream impoundment was not sufficient to guarantee a firm demand capacity without experiencing unacceptable variations in lake level during draught conditions. It was possible, however, to establish a limited amount of reliable monthly demand capocity based on natural stream flow. Figure 2 on the following page is a conceptualization of a proposed operating strategy for the facility in relation to the flow duration curve.

It was found that the installed generating capacity of the facility in relation to stream flow characteristics has an important influence on project cost-effectiveness. The benefits from increased capacity were found to deminish rapidly above o given point due to the flow-duration characteristics in the river. The table below shows the relationship between installed capacity and effective capacity (i.e., average utilized capacity) at the French Landing dam site. It can be seen that the proportional increment in effective capacity decreases with each increment in plant size.

$\begin{array}{lllll}\text { Installed Capacity (kW) } & 500 & 750 & 1000 & 1500 \\ \text { Effective Capacity (kW) } & 448 & 596 & 703 & 844 \\ \text { Increment (kW) } & 448 & 148 & 107 & 141 \\ \text { Utilization } & 90 \% & 59 \% & 43 \% & 28 \%\end{array}$

A detailed benefit/cost onalysis was conducted to identify the optimum facility size in terms of incremental costs and revenues. It was found that the most cost-effective design contained a relatively small amount of production capacity, in relation to available water power, with a correspondingly high utilization factor. Figure 3 illustrates the conceptual model upon which the benefit/cost analysis was based. It can be seen that the civil and structural costs were found to be relatively stable whereas the equipments costs were found to be highly variable with facility size.

\section{DESIGN ALTERNATIVES STUDIED}

A total of seven project alternatives were examined in detail. The alternatives included different production capacities, different hydraulic turbine designs, and equipment by different manufacturers. One alternative involved refurbishment of the existing vertical turbines.

From an engineering standpoint it was found that items of equipment needed to recommission the site are readily available from both U.S. and foreign manufacturers. The one possible exception is slow-speed vertical generators which, although still available, require special fabrication. A satisfactory alternative to the slow-speed units is available, however, through the use of standard speed generators operated through speed increasers.

The project alternatives which were examined included vertical, bulb, and tubular turbine designs. Equipment costs were found to be relatively independent of turbine design; estimated costs for two $750 \mathrm{KW}$, units, including generators and governors, averaged about $\$ 430$ per $\mathrm{KW}$. One exception was the James E. Leffel Company of Springfield, Ohio, whose equipment was significantly less expensive than that of other manufocturers. 


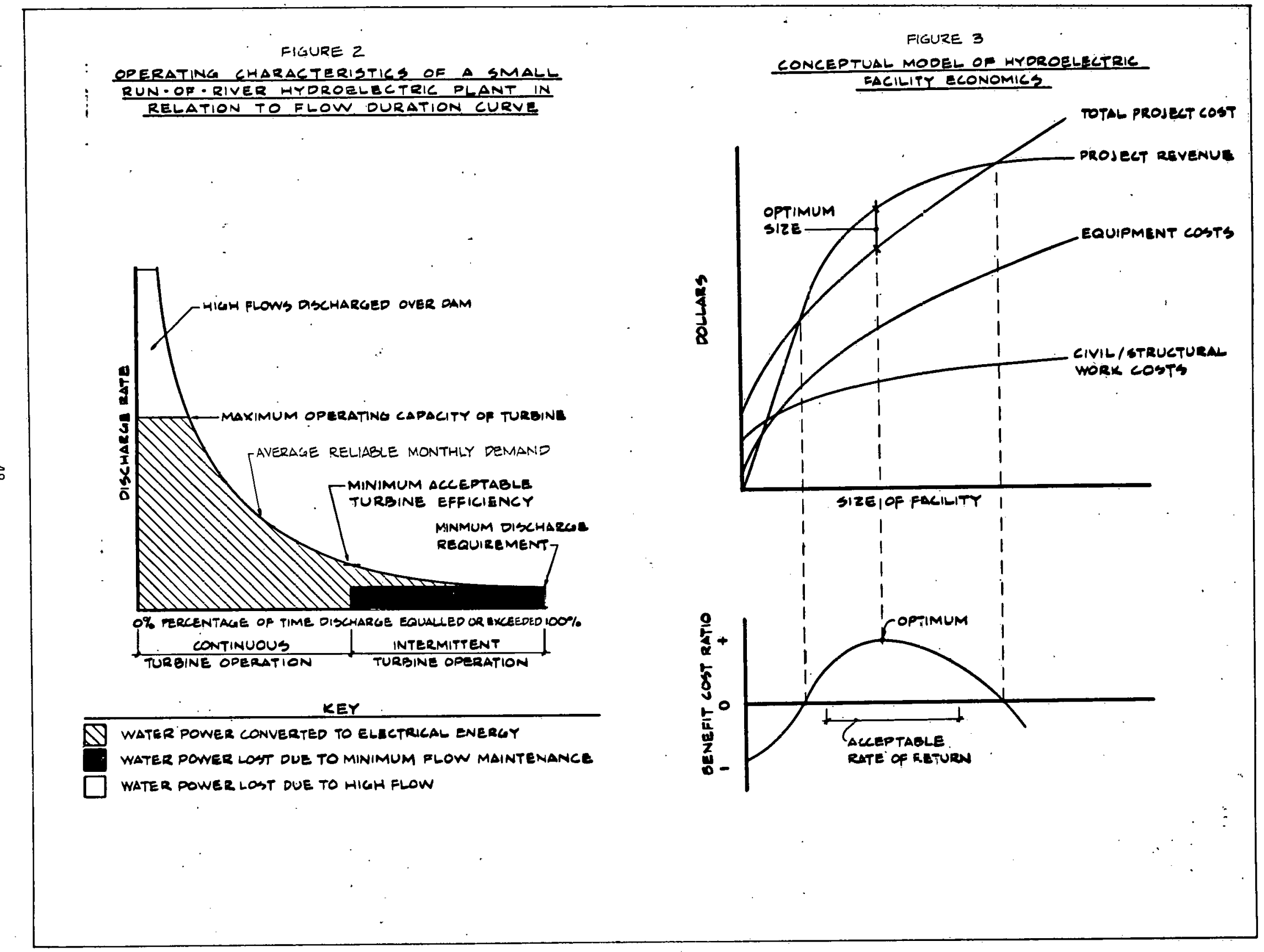


ZUMBRO DAM ON THE SOUTH FORK ZUMBRO RIVER

Roshester, Minnesota

City of Rochester, Minnesota

K. W. Beck and Assoctates

PRDA Cooperative Agreement No. EW-78-F -1773

\section{T. I.NTRODUCTION}

This report summarizes the results of the feasibility assessment study under a DOE grant for the C1ty of Rochester, Minnesota to determine if it is economical to add the third generating unit in the empty stall at the existing powerhouse at Zumbro Dam on the South Fork Zumbro River. The studies and investigations have included site reconnaissance, system loads, growth rate, site hydrology, conceptual profect arrangements and layouts, power output, estimates of construction costs and annual costs, economic analyses, development of a design and construction schedule and a preliminary environinental review of the proposed Project alternatives.

\section{EXISTING DEVELOPMENT}

The existing Zumbro Hydroelectric Project is located in southeast Minnesota on the South Fork Zumbro River approximately 15 miles north of the City of Rochester and approximately 70 miles southeast of the Minneapolis-St. Paul metropolitan area. The location of the Project is shown in Exhibit 1 . The South Fork Zumbro River has a drainage area of 811 square miles above the dam site and over the 48-year pertod of 19311978 the flow at the site has averaged $361 \mathrm{cfs}$.

This existing hydroelectric power plant is owned and operated by the City of Rochester. The plant was completed in 1919 and has been in continuous operation by the City since that time. The extsting Project consists of a concrete gravity weir section, 440-feet long, with an uncontrolled crest and short non-overflow sections at each abutment. An intake and powerhouse section is located near the left abutment and is an integral part of the water barrier. Two turbine-generator sets are installed at present and an empty stall is available for installation of a third generating unit.

The existing turbines are 12-vaned, Francis-type wheels and are each rated at 1,350 hp under a net head of 44 feet and were designed to operate at a synchronous speed of $225 \mathrm{rpm}$. The existing generators are each rated at $1,150 \mathrm{kVA}$ which, with a 0.80 power factor, results in a rated output of $920 \mathrm{~kW}$. Over the past 18 years the existing plant has produced, on an average basis, about $7,400,000 \mathrm{kWh}$ annually.

\section{PROPOSED PROJECT ARRANGEMENT}

The proposed development will consist of adding the third unit at the existing powerhouse at the $\mathrm{Zumbro}$ Hydroelectric Project; installing two feet of flashboards to the spillway; installing a new 3-phase transformer at the plant; and the installation of a new step-down transformer at the Zumbro River Substation in Rochester.

The new Francis turbine will be rated at $2,350 \mathrm{hp}$ under a net head of 52.3 feet, and operating at a synchronous speed of $200 \mathrm{rpm}$. Discharge at full gate output would be about $461 \mathrm{cfs}$, and at best gate operation a discharge of $392 \mathrm{cfs}$ would produce about $2, \mathrm{l} 60 \mathrm{hp}$. The maximum diameter of the runner (at discharge ring) would be slightly less than 66 inches which corresponds to the existing scroll case and draft tube design. Some portion of concrete was omitted during the original construction to enable conventent installation of embedded parts for the proposed new unit. Small amounts of existing concrete might require removal and scartfication of some surfaces will be required, but it is anticipated that the new units can be installed with little additional work. Proposed modifications to the powerhouse are shown in Exhibit 2 .

The new generator will be rated at $2,000 \mathrm{kVA}$ with a 0.9 power factor, which corresponds to a rated output of $1,800 \mathrm{~kW}$. Voltage of the new generator will be the same as the two existing units so that all three units can be connected into a $2.4-\mathrm{kV}$ bus. Power at the existing plant is transformed from generator voltage to 13,8$\mathrm{kV}$ for transmission to the City's distribution system. The transmission line is insulated for 34.5-kV and it is proposed to install a new three-phase, $34.5-\mathrm{kV}$ transformer rated at $4,500 \mathrm{kVA}$ to reduce transmission $10 s s e s$. A second transformer will be required at the Zumbro River Substation in Rochester to step-down the 34.5-kV trars mission "to distribution voltage." 
In the past as much as a two-foot height of the flashboards on the spillway has been used to increase output from the plant. Howeyer since about 1951 this practice has been discontinued, It is proposed to increase the reservoir level during peak load months at E1 922 by means of Installing two feet high flashboards on the spillway crest. The flashboards will be designed so that by manual removal of one pin connection, progressive failure will occur in event of a flood occurring while the flashboards are in place,

The three-unit plant will therefore have an installed capacity of $3,640 \mathrm{~kW}$, consisting of two existing units, each of which is rated at $920 \mathrm{~kW}$, and a new unit rated at $1,800 \mathrm{~kW}$. The dependable capacity from the plant, delivered at the City's load center, will be $3,227 \mathrm{~kW}$. The average annual energy from the plant, delivered at the City's load center will be $10,661,000 \mathrm{kWh}$, of which 3,652,000 kWh will be firm (prime).

\section{IV。 PROJECT OPERATION}

The Zumbro Hydroelectric Plant is currently operated as a run-of-the-river installation with pondage available for daily and weekly operation. Historically, the reservoir has been subjected to wide vartations in surface elevations with the reservoir being drawn down to as low as El 910. The proposed development would continue to operate as a run-of-the-river installation. However, the reservoir level would generally be malntained within a two-foot operating range for any month to increase the average annual energy and capacity from the development. During periods of extreme low flow, the Project alternative would operate for limited periods from streamflow and pondage and increased drawdown would occur.

\section{ECONOMIC ANALYSIS}

Four alternatives of development at the existing Zumbro Plant were compared. The first three of these involve various modifications to the existing two-unit installations, together with the additional power from thermal generation, to match the output of the proposed third unit installation (Alternative IV). The costs of the additional firm energy and dependable capacity needed for the first three alternatives is based on the most economical substitute of part of a new simple-cycle combustion turbine installation. The cost of the additional secondary energy needed is equated to those of fuel replacement of currently operated ofl and coalfired plants.

For the scheduled on-line date of October 1983, considered to be the earliest practical date, the Total Investment Cost of installing the third unit and other work for Alternative IV is estimated to be $\$ 1,718,400$, equal to $\$ 954 / \mathrm{kW}$ installed at that time frame. The annual cost for the first full year (October 1983 - September 1984) of operation of the three-unit plant is $\$ 238,800$ using 40 -year, $7 \%$ interest revenue bond financing.

The proposed Alternative IV shows about the same first year cost as the next least costly alternative (III). Over the first ten years of operation the proposed alternative shows a present worth savings of $\$ 129,800$ indicating economic feasibility of the Project.

\section{ENVIRONMENTAL CONDITIONS}

An initial assessment has been made of the environmental impacts expected to occur as a result of the proposed development. There is no apparent evidence to indicate that the project will affect current land uses, fish and wildlife, water quality, archaeological historic resources or socio-economic conditions in the project area. The relatively stabilized reservoir operation is considered to be a beneficial impact to the recreational use of Zumbro Lake. A minimum release during non-generating periods has been scheduled to support the modest tailwater fishery and to maintain water quality downstream.

\section{CONCLUSION}

The proposed development poses no unusual technical problems and no significant adverse environmental effects are anticipated. It shows sufficient promise of technical, economic and financial feasibility, to justify the City entering into the next phase of work, the FERC License Application, as soon as possible so that the installation can be completed by October 1983. Concurrently with this, the City should make application to the DOE for a demonstration project grant under the second Project Opportunity Notice, responses to which will be solicited shortly.

Installation of the new transformers as soon as possible will provide additional economic benefit to the City which could be realized in advance of the scheduled on-line date of October 1983. 


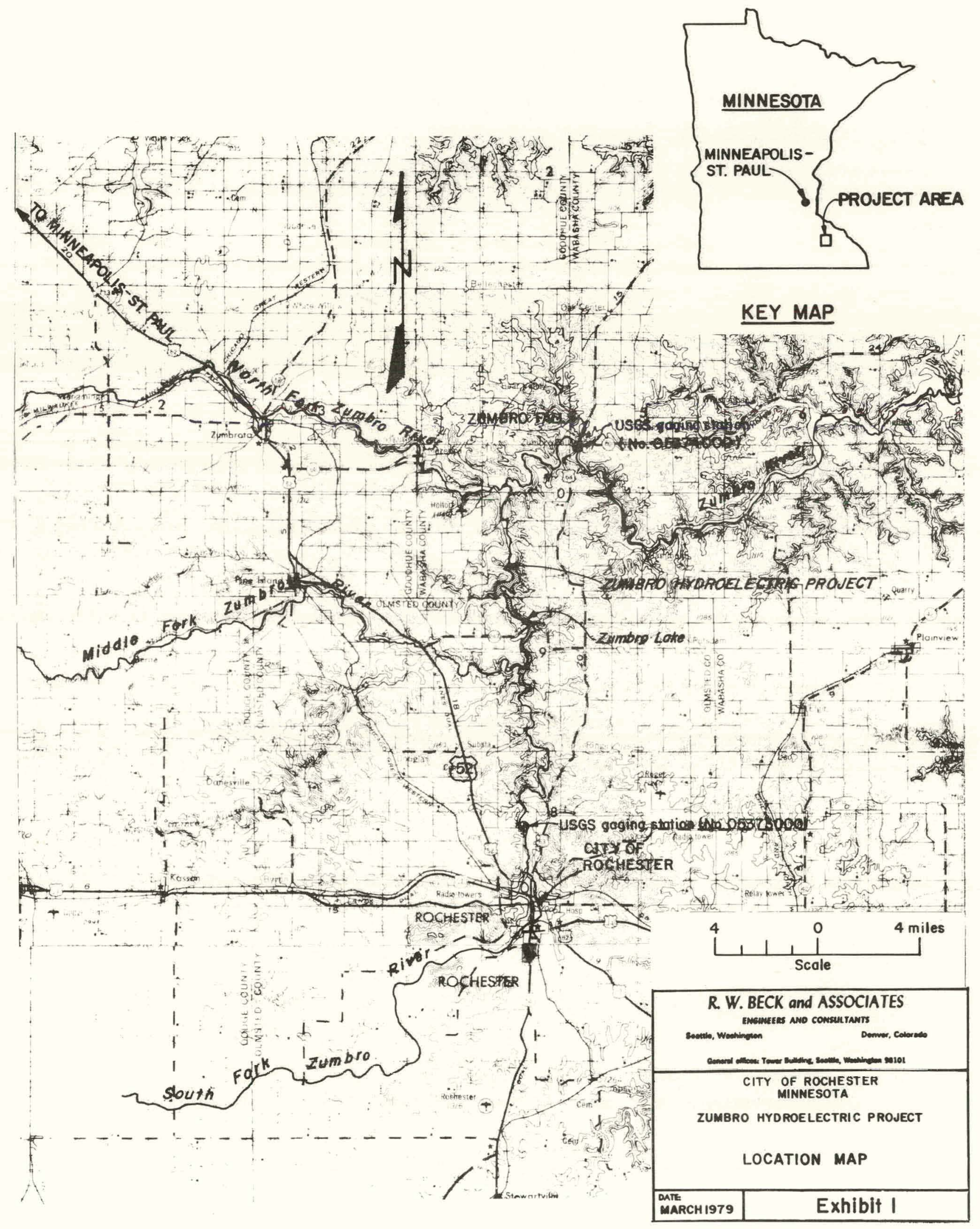



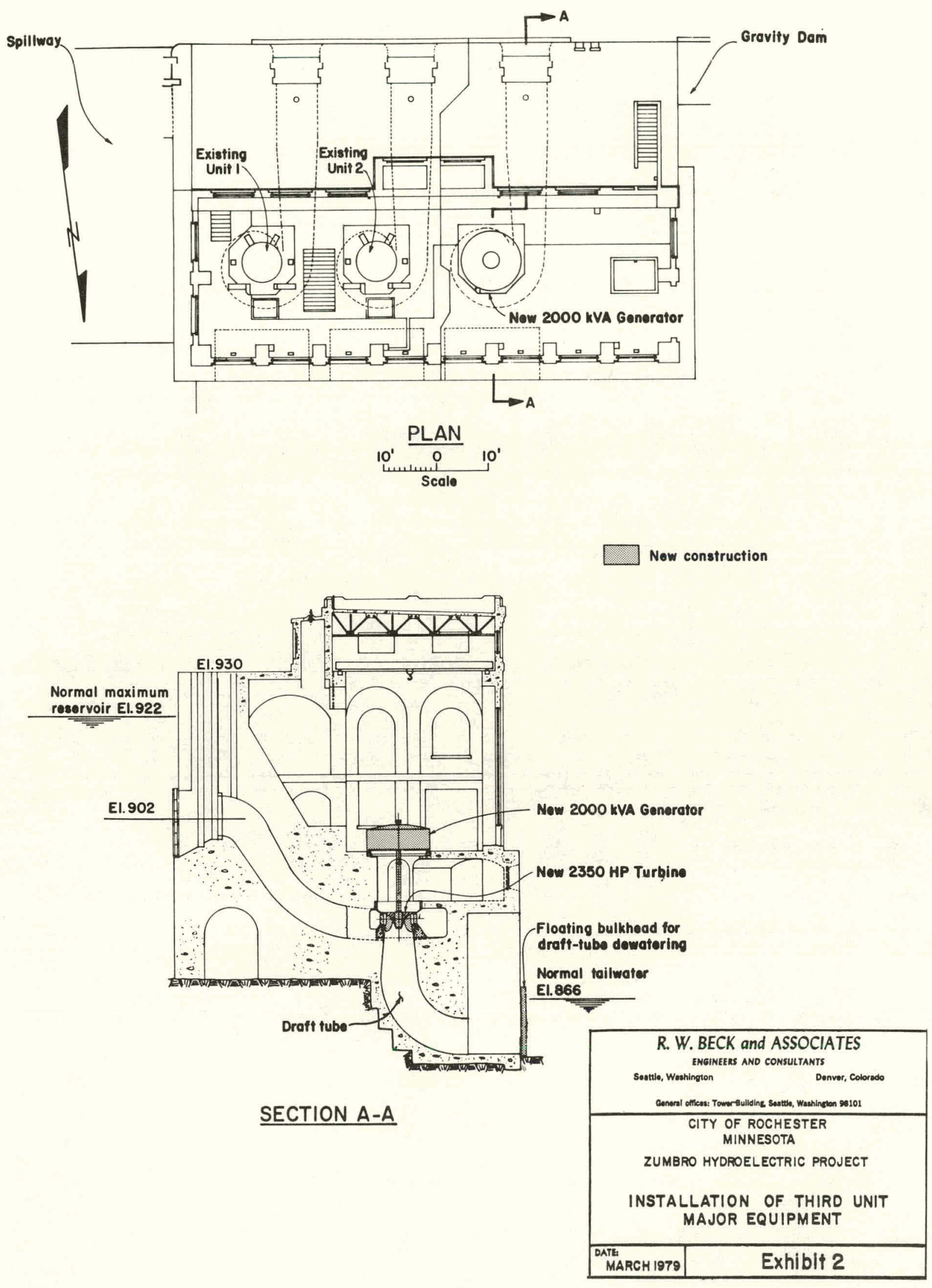
BIG BLUE RIVER HYDROELECTRIC DEVELOPMENT

Big Blue River, NE

Nebraska Municipal Power Pool

Acres American Inc.

PRDA Proposal Contract No. 1774

\section{INTRODUCTION}

The Big Blue River Co-Dependent Hydroelectric Development feasibility study has been underlaken by Acres American Incorporated under the terms of a contract with Nebraska Municipal Power Pool (NMPP) dated August 17, 1978. The study has been jointly funded by the Department of Energy (DOE) and NMPP under Cooperative Agreement No. EW-78-F-07-1774. The development comprises a series of seven existing dams on a 65 -mile stretch of the Big Blue River in Nebraska. The objective of the study was to establish the technical and economic feasibility of developing the hydroelectric power potential at the seven sites.

This paper presents the results of the feasibility study for the development and deals with the conceptual design alternatives, construction cost estimates and schedules, preliminary environmental and safety assessments and power marketing studies for the proposed installations. The project will involve construction and/or rehabilitation of hydroelectric generating facilities at each of the seven selected sites on the Big Blue River. Totaling up to $3900 \mathrm{~kW}$ in capacity, these sites are located to the south and southwest of Lincoln, Nebraska and control a total of 4,444 square miles of drainage area. The power plants will utilize gross heads at the existing dam sites ranging from 10 to 20 feet. Existing facilities include overflow dams and power houses at each site in various states of repair.

The NMPP Project Manager for this study was Mr. H. Steve Wacker, assisted by Mr. Stan Feuerberg. The Principal Investigator for Acres was Mr. John D. Lawrence, P.E., assisted by Mr. Parimal S. Pal.

Assistance in the study in the compilation of local site and environmental data, surveys and mapping was provided by 01ssen Associates of Lincoln, Nebraska, and is gratefully acknowledged. Dr. William T. Trick, Consulting Engineer, carried out on behalf of Acres the necessary inspections of existing power generating facilities at all seven sites. The assistance of Dr. Trick in formulating the project design alternatives is also gratefully acknowledged.

Geotechnical exploration work and testing of materials was undertaken by Western Laboratories, also of Lincoln, Nebraska.

The cooperation and assistance of the following current owners of the sites are also acknowledged:

- ABC Electric Company, Inc.

- Nebraska State Game and Parks Commission

- City of Crete

- John D. Zwonechek

- Robert L. Cunning

- Nebraska Public Power District

- Norris Public Power District

\section{CONCEPTUAL PROJECT DESIGNS}

The Big Blue River Co-Dependent Hydroelectric Development has been found to be a technically feasible concept, for both redevelopment and in some cases rehabilitation of seven existing sites. The proposed redevelopment project will include seven installations with a recommended nominally rated redeveloped capacity of $3,920 \mathrm{~kW}$ ranging from $120 \mathrm{~kW}$ at the northernmost site in Seward County to $1500 \mathrm{~kW}$ at Barneston. The average annual gross generation expected from the seven redeveloped sites totals $11,555,000 \mathrm{kWh}$. It is estimated that the total cost of redevelopment of these seven sites will be $\$ 14,090,000$ at 1979 price levels, providing power at an average levelized cost of about 5.3 cents per kWh based on 7 percent cost of money, a mid-1983 commissioning date, and allowing for funds durin construction and cost escalation over a 30-year period. 
Rehabilitation of original installations at Crete, Dewitt, Blue Springs and Barneston is technically feasible for a total installed capacity of $1,415 \mathrm{~kW}$ with annual average gross generation of $6,675,000 \mathrm{kWh}$. The total cost of this rehabilitation is estimated as $\$ 3,372,000$ at 1979 price levels, or about 2.4 cents per kWh, levelized on a similar basis.

Rehabilitation of the Barneston site alone for an installed capacity of $760 \mathrm{~kW}$ and annual generation of $3,581,000 \mathrm{kWh}$ is both technically and economically feasible. The total estimated cost of this alternative is $\$ 668,000$ providing power at a cost of about 1.9 cents per kwh at 1979 price levels. The benefit/cost ratio for Barneston rehabilitation is estimated as 1.23 .

2.1 Description of Proposed Facilities: The proposed hydroelectric redevelopments will be $10 \mathrm{cated}$ on a 65 mile continuous stretch of the Big Blue and West Fork Rivers in Nebraska, west and south of the City of Lincoln.

The seven sites are currently in varying states of repair and are owned by various private and public entities, as follows:

- Plant Site No. 2, Seward Co.; ABC Electric Co., Inc.

- Shady Trail, Saline Co.; Nebraska State Games and Parks Commission

- City of Crete, Saline Co.; City of Crete

- Dewitt, Gage Co.; John D. Zwonechek

- Holmesville, Gage Co.; Robert L. Cunning

- Blue Springs, Gage Co.; Nebraska Public Power District

- Barneston, Gage Co.; Norris Public Power District

Dams at the above sites have been breached or are beyond repair, with the exception of Crete, Holmesville and Barneston. The Big Blue River at Crete has been diverted around the existing structure. Of the above sites, only Dewitt, Blue Springs and Barneston power plants are or have relatively recently been in operation. The plants at the other sites are non-existent or beyond repair. The existing power plants at Dewitt, Blue Springs and Barneston are amenable to rehabilitation. The original powerhouse structure at Crete is in good enough condition to be redeveloped with units of similar size.

The proposed redevelopment and rehabilitation schemes at each site and preliminary cost estimates are summarized in Tables 1 and 2. New overflow dams are proposed at five sites. On other than rock foundations, these dams will consist of high-strength, weather-resistant, steel sheet pile structures with rockfill upstream slopes and rockfill gabion aprons downstream.

On rock foundations the dams will be constructed of rockfill gabions with concrete facing and provided with effective drainage systems. All dams will be restored to the original crest level and will be capable of being safely overtopped.

2.2 Alternatives Considered: The four basic options considered for development of hydroelectric potential at each of the sites were:

- rehabilitation of the existing powerhouse and generating equipment;

- rehabilitation of the existing powerhouse and replacement of the generating equipment at a similar capacity;

- rehabilitation of the existing powerhouse structure and installation of generating equipment of a different type and/or size;

- complete redevelopment of the powerhouse and generating equipment.

In the interests of economy, equipment selection was confined essentially to the available standard manufactured units. Four basic types of unit were found to be suitable for use at the sites:

- vertical, open-flume propeller;

- horizontal, single-regulated Kaplan (tube);

- mini-hydel, Francis;

- vertical, open-flume Francis.

A variation of the vertical, open-flume propeller unit, with adjustable blades and axial intake, was - also considered. In equipment selection, emphasis was placed on achieving maximum economy through commonality of designs and units.

No specific facilities exist in the existing structures for passage of fish. Consequently, no provision has been made in the proposed development for such facilities other than in the installation of appropriately sized trashracks at intakes and tailraces to prevent passage of fish through the power plants.

2.3 Plant and Unit Size Selection: The plant and unit sizes have been selected on the basis of availability and condition of the existing facilities, original pond water levels, the hydraulic characteristics of the 
existing and proposed water passages, intakes and tailrace channels, the availability and variation of river flows, and comparative power values. The selected installations at each site are considered to provide optimum usage of the available hydroelectric potential. Initial plant size optimization and comparison of alternatives was based on preliminary power values published by the FERC for alternative combustion turbine, combined cycle and coal-fired sources in the Mid-Continent Area Reliability Coordination Agreement (MARCA) region.

Initial assessments of firm capacity and average annual generation were based on run-of-river operation of plants with no use of pondage for flow augmentation. The additional energy to be gained with flow augmentation from daily pond drawdown was subsequently estimated. A summary of the results of these evaluations for the selected schemes is presented in Table 1. The preliminary evaluations were made for purposes of selection of number and size of units at each site. In general it was found that there was little overall economic difference between the two or three most favorable options at each site. Unit selection was therefore made with a view to achieving greatest commonality of designs.

The selected plant capacities were limited to a significant extent by the dimensional constraints and hydraulic characteristics of the existing structures and the availability of appropriately sized turbinegenerator equipment. Attempts were made in the study to select as representative a variety of types of units as possible. Generators were generally assumed to be standard design high speed machines, coupled to turbines through appropriate speed increasers. The selection of plant size and configuration will not be significantiy influenced by any likley differences in power values. Nevertheless, further scrutiny of optimized plant size may be warranted in later phases of project evaluation when power values are more sperifically defined.

A typical example of a plant conceptual design is shown on Plates 14 and 15.

3. DEVELOPMENT OF CONSTRUCTION COST ESTIMATES AND SCHEDULES

3.1 General: Detailed construction cost estimates have been prepared for all seven sites, together with typical schedule data on four selected sites for the Big Blue Development. These costs and schedules were developed to a degree of detail such that further detailed economic evaluation as well as finance and schedule planning may proceed with an acceptable level of confidence.

3.2 Cost Estimates: Summary cost estimates for redevelopment alternatives considered for all seven sites and for rehabilitation alternatives considered for four sites are presented in Table 2 . Detailed cost estiriates for each alternative have been prepared for a generally consistent level of development in each case relative to plant facilities, access, provision of maintenance facilities and automated operation. Construction costs were based on cost levels applicable to the type of work involved and local conditions in the Nebraska area and reflect first quarter 1979 costs.

3.3 Schedules: Typical project schedules are shown in their two principal phases on Plate 23, Engineering Schedule, and Plate 27, Construction Schedule (Barneston). The Engineering Schedule is essentially based on concurrent licensing and engineering design and equipment procurement activities to result in the shortest construction lead time. The Engineering Schedule is applicatile generaliy to each site and is contingent upon receipt of a Federal Energy Regulatory Commission (FERC) license no later than week 88 of the concurrent case.

The licensing phase of the schedule includes a 15-week preparation period in parallel with the initial engineering design activities. The initial design activities will include finalizing the project arrangement and preparing turbine-generator procurement documents. It is estimated that the current time required for issuance of licenses for projects of this size is 12 to 15 months. Receipt of license by week 88 is therefore a reasonable expectation.

Consecutive licensing and engineering activities would lengthen the schedule considerably. However, the FERC recently introduced a new short-form license application procedure for small hydro projects (1500 kW or less). The requirements for this application are intended to simplify and shorten the period necessary for preparation and approval of hydropower project licenses. With this new legislation FERC hopes to reduce the licensing period to three months. On this basis the overall schedule, assuming consecutive licensing and engineering activities following the initial 15-week preparation period, will be lengthened by an estimated 18 weeks.

The critical portion of the Construction Schedule at each site is the demolition and reconstruction or rehabilitation of the existing powerhouse and dam which have been typically scheduled for the relatively dry period of October through December. It is planned that river flows will be diverted for these construction activities by temporary cofferdams.

Timely delivery of turbines and generators and associated equipment are all crucial to the realization of the schedules shown. Procurement of these items has therefore been scheduled during the licensing period: and sufficiently in advance of the civil construction contract to al low appropriate manufacturing lead time in each case. 
3.4 Project Cash Flows: With a conservative assumption of consecutive licensing and engineering activities, mid-1983 commercial service dates are reasonably attainable for all developments considered.

Typical cash flow requirements were developed for the four locations for which construction schedules have been prepared. The calculated allowance for funds during construction (AFDC) has been estimated assuming a 7 percent annual cost of money and end of period payment. The cost basis is for prices ruling at the end of March 1979, appropriately escalated to 1983 levels assuming 6 percent annual inflation.

\section{PRELIMINARY ENVIRONMENTAL AND SAFETY ASSESSMENTS}

4.1 Existing Conditions: The proposed hydroelectric redevelopment and/or rehabilitation projects will all be located at previously developed sites on the Big Blue and West Fork Rivers in Nebraska (Plate 1). The seven sites are currently in varying states of repair and are owned by various private and public entities.

Dams at four of the sites have been breached or are beyond repair and at a fourth site the river has been diverted around the existing structure. Power plants which were originally installed at all seven sites have been abandoned at all but three and of these only one is currently operative.

4.2 Preliminary Environmental Assessment: The proposed redevelopment and/or rehabilitation of hydroelectric potential at the seven sites will have negligible impact on the present terrestrial and aquatic systems both during construction and operation of the facilities.

The proposed developments are all relatively small in capacity, the largest at Barneston being $1500 \mathrm{~kW}$. Licensing for all sites may therefore be undertaken using recently introduced FERC short-form procedures. A detailed environmental impact report will therefore not be required as part of the 1 icensing process. The current study has been brief and preliminary and has been adapted to the level of feasibility assessment .. appropriate at this time. The study consisted of a preliminary review of pertinent environmental reports, a site reconnaissance and contacts with individuals from local, state and federal agencies having expertise on the terrestrial and aquatic ecosystems found within the project area.

4.3 Preliminary Safety Assessment: Construction of the proposed hydroelectric facilities will potentially impact on the safety of the public as well as construction workers in the immediate vicinity of the power plant to a minor degree. Appropriate precautions will therefore be necessary to minimize these risks. Design and opeiating procedures wi 71 be formulated to erisure that no significant change, and in several iristances a, reduction in risks to public safety, will arise during operation of the hydroelectric installations.

\section{MARKETING STUDIES}

The essential role of the Nebraska Municipal Power Pool (NMPP) is to pool the resources of participant municipalities in the state that run and operate their own electric utilities. Studies authorized by NMPP in 1977 and 1978* have determined that pooling of resources of 25 participants in the pool will prove to be economically advantageous. The relatively small sizes of the seven proposed Big Blue Hydroelectric Developments are such that the optimum use of the power will be in participant systems which are physically close, thus limiting transmission losses. No firm commitments have been made for purchase of the power produced by the proposed projects at this time. The marketing potential has, therefore, been assessed by comparison with the alternative power sources available to potential NMPP participants in the vicinity of each site.

The three northernmost sites are closest to the City of Crete, a NMPP participant. The four remaining sites are closest to Beatrice, also a participant. The NMPP Power Study indicated that the future power requirements of each of these participants will include significant power purchases from the Nebraska Public Power District (NPPD). The economic viability of all seven proposed projects has therefore been assessed on the basis of a comparison with the future costs of NPPD power purchases. For NMPP to support any of these developments a significant cost benefit should be realized by substitution of the power output from the proposed plant for an equivalent amount of purchased power.

5.1 Projected Power Costs: The life of a completely redeveloped hydro site is conservatively estimated as 40 years. Considerably longer periods are likely. For rehabilitation alternatives some deterioration of existing structure may take place in this period, but 40 years is still considered a reasonable life expectancy for financial planning purposes. However, a maximum 30 year period from 1983 has been adopted for developed life-cycle cost comparisons with purchased power alternatives. Annual fixed costs and operation and maintenance expenses for 1983 have been assumed from data pubiished in the FERC Final Draft Hydroelectric Power Evaluation Report dated August 1978. These costs were considered for comparison purposes as wholesale power costs exclusive of payments in lieu of taxes or any administrative and general costs which may be added

* Power Supply Study, Phase I (July 1, 1977) and Phase II (January 15, 1979) for NMPP, by Burns and McDonnell 
to consumers' bills. Operation and maintenance costs for subsequent years were assumed to escalate at 5.3 percent per annum. (Similar to NPPD capacity charge escalation for 1983 to 1993). Accumulated present worth values for 1983 were estimated on the basis of a 7 percent per annum interest rate.

The wholesale municipal power rates of NPPD were assumed to be based on average system costs and to continue to be so for the period of the study. The power sources of NPPD are fuel-dependent, predominantly oil or coal-fired. For study purposes, capacity and energy costs from 1983 through 2013 were assumed to escalate at average annual rates of 5.3 and 7.5 percent respectively, as indicated in the Power Study. The NPPD demand charges are based on monthly peaks. For study purposes the value of hydroelectric power for each site was conservatively based on estimated annual firm capacity and total annual generation. Levelized power values were again estimated for the 30 year period. 1983 through 2013 assuming a 7 percent annual interest rate.

5.2 Comparison of Alternatives: It is evident from the results of the analysis that oniy the Barneston Project will prove to be more economic than NPPD purchased power on the basis of the assumptions made with regard to future power cost and value escalations. It should be noted however that the future availability of NPPD power at the costs assumed, and of the fuels necessary to produce that power, has not been considered at this time. Fuel scarcities and cost increases beyond those assumed may well render more of the projects viable over a 30 year period.

Annual power costs for the Blue Springs Project Rehabilitation alternative will be favorable compared with NPPD power purchases by the early 2000 's and also probably economic on a life cycle basis over the 40 to 50 year life of the project which may be anticipated. This project may therefore be considered marginally economic.

Although favorable on a net annual cost basis by about the year 2010, the Blue Springs Redevelopment alternative is less attractive than rehabilitation from an economic standpoint. However, future consideration of other lower cost alternatives for turbine-generators may be warranted.

\section{RECOMMENDATIONS}

It is recommended that NMPP initiate discussions with the Norris PPD and Beatrice at an early date with'a view to licensing and development of the Barneston Project. It is also recommended that further studies be undertaken to optimize the development at Barneston and to consider further the potential development at Blue Springs.

TABLE - 1

BIG BLUE HYDROELECTRIC DEVELOPMENT PRELIMINARY ECONOMIC COMPARISONS (1979 DOLLARS IST QUARTER)

\begin{tabular}{|c|c|c|c|c|c|c|c|c|}
\hline \multirow[t]{2}{*}{ site } & \multirow[t]{2}{*}{ Optlon } & Installed & \multirow{2}{*}{$\begin{array}{l}\text { Firm } \\
\text { Capaclty } \\
\text { (KW) }\end{array}$} & \multirow{2}{*}{$\begin{array}{l}\text { Annual } \\
\text { Generation } \\
\left(\mathrm{K} W \times 10^{3}\right)\end{array}$} & \multirow{2}{*}{$\begin{array}{l}\text { Capacity } \\
\text { Factor } \\
\text { (\$) }\end{array}$} & \multirow{2}{*}{$\begin{array}{l}\text { Levellized } \\
\text { Annual } \\
\text { (cfsst/KWn) } \\
\end{array}$} & \multirow{2}{*}{$\begin{array}{l}\text { Level I zed } \\
\text { Annual } \\
\text { valye (3) } \\
\text { (cts/kwh) }\end{array}$} & \multirow{2}{*}{$\begin{array}{c}\text { Benefit } \\
\text { Cost } \\
\text { Ratio }\end{array}$} \\
\hline & & $\begin{array}{l}\text { Capacity } \\
\text { (KW) }\end{array}$ & & & & & & \\
\hline Seward & Redev. & 280 & 261 & 619 & 25 & 9.1 & 3.5 & 0.38 \\
\hline Shady Trall & Redev. & 310 & 233 & 639 & 24 & 10.2 & 3.1 & 0.30 \\
\hline City of Crote & Redev. & 315 & 315 & 1,016 & 37 & 7.8 & 2.8 & 0.36 \\
\hline & Rehab. & 125 & 119 & 767 & 70 & 5.5 & 1.9 & 0.35 \\
\hline Dewitt & Redev. & 375 & 375 & 935 & 28 & 7.9 & 3.4 & 0.43 \\
\hline & Rehab. & 190 & 190 & 661 & 40 & 4.2 & 2.7 & 0.64 \\
\hline Holmesville & Redev. & 520 & 520 & 2,193 & 48 & 4.5 & 2.4 & 0.53 \\
\hline Blue Springs & Redev. & 620 & 620 & 2,260 & 42 & 5.8 & 2.6 & 0.45 \\
\hline & Rehab. & 340 & 340 & 1,666 & 56 & 3.0 & 2.2 & 0.73 \\
\hline Barneston & Redev. & 1,500 & 1,259 & 3,893 & 30 & 2.8 & 2.9 & 1.04 \\
\hline & Rehab. & 760 & 739 & 3,581 & 54 & 1.1 & 2.2 & 2.00 \\
\hline Iotals & Redev. & 3,920 & 3.583 & 11,555 & 33.6 & 5.3 & 2.8 & 0.53 \\
\hline & Rehab. & 1,415 & 1,082 & 6,675 & 53.9 & 2.4 & 2.2 & 0.92 \\
\hline
\end{tabular}

NOTES:

(1) Adjusted for flow augmentation from pondage.

(2) Mld-1979 P.W. costs, based on mid-1983 comnissioning, 30 year period, asM costs escalated at $5.3 \not$ per annum, 1979 ist quarter cost levels, 78 interest.

(3) Based on NPPD power purchases, 1979 P.W. levels, capaclty charge (1983) $\$ 8.58 / K W$-month escalated $5.3 \%$ per annum, energy charge (1983) $12.14 \mathrm{mlll} / \mathrm{s} / \mathrm{KWh}$ escalated $7.5 \%$ per annum, 30 year perlo, $7 \%$ interest. 


\begin{tabular}{|c|c|c|c|c|c|c|c|c|c|c|c|c|}
\hline \multirow[b]{2}{*}{$\begin{array}{l}\text { Account } \\
\text { Number }\end{array}$} & & \multirow{2}{*}{$\begin{array}{l}\text { SENARE NO. } 2 \\
\text { Redev. }\end{array}$} & \multicolumn{3}{|c|}{ 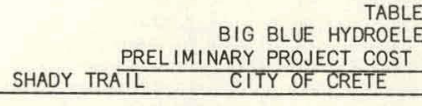 } & \multicolumn{2}{|c|}{$\begin{array}{l}2 \\
\text { CTRIC DEVELOPNENT } \\
\text { COMPARISONS (THOUSANDS } \\
\text { DEWITT }\end{array}$} & \$) & \multicolumn{2}{|c|}{ BLUE SPRINGS } & \multicolumn{2}{|c|}{ BARNESTON } \\
\hline & $\underline{1+e m}$ & & Redev. & Redev. & Rehab. & Redev. & Rehab. & Redev. & Redev. & Rehab. & 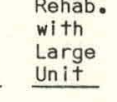 & Rehab. \\
\hline 330 & $\begin{array}{l}\text { Land and Land } \\
\text { Rights }\end{array}$ & --- & -- & -- & -- & --- & -- & -- & -- & --- & --- & --- \\
\hline 331 & $\begin{array}{l}\text { Structures \& } \\
\text { Improvements }\end{array}$ & 225.9 & 247.2 & 282.3 & 24.4 & 357.6 & 10.2 & 343.9 & 266.8 & 31.6 & 116.8 & 14.6 \\
\hline 332 & $\begin{array}{l}\text { Reservoirs, } \\
\text { Dams \& } \\
\text { Waterways }\end{array}$ & 24.2 .9 & 379.9 & 424.3 & 320.9 & 177.2 & 182.1 & 165.3 & 416.9 & 364.6 & 229.3 & 82.8 \\
\hline 333 & $\begin{array}{l}\text { Turbines \& } \\
\text { Generators }\end{array}$ & 260.4 & 260.4 & 393.0 & 131.0 & 462.0 & 154.0 & 864.0 & $1,260.0$ & 264.0 & 972.0 & 266.0 \\
\hline 334 & $\begin{array}{l}\text { Accessory } \\
\text { Electrical } \\
\text { Equi pment }\end{array}$ & 149.0 & 149.0 & 177.0 & 177.0 & 177.0 & 60.0 & 152.0 & 150.0 & 90.0 & 177.0 & 90.0 \\
\hline 335 & $\begin{array}{l}\text { Misc. Power } \\
\text { Plant } \\
\text { Equipment }\end{array}$ & 3.0 & 3.0 & 3.0 & 3.0 & 3.0 & 3.0 & 10.0 & --- & 15.0 & 8.0 & 15.0 \\
\hline 336 & Access Roads & 10.0 & 10.0 & 10.0 & 10.0 & 10.0 & 7.3 & 6.0 & 2.0 & 2.0 & 1.0 & 2.0 \\
\hline 353 & $\begin{array}{l}\text { Sub-station } \\
\text { Equi ipment }\end{array}$ & 21.0 & 21.0 & 21.0 & $\underline{21.0}$ & 21.0 & 10.0 & 40.0 & 50.0 & --- & 70.0 & -- \\
\hline & Sub-Total & 912.2 & $1,070.5$ & $1,310.6$ & 687.3 & $1,207.8$ & 426.6 & $1,581.2$ & $2,145.7$ & 767.2 & $1,574.1$ & 470.4 \\
\hline & $\begin{array}{l}\text { Contingencies } \\
(15 \%)\end{array}$ & 136.8 & 160.6 & 196.6 & 103.1 & 181.2 & 64.0 & 237.2 & 321.8 & 115.1 & 236.1 & 70.6 \\
\hline & Direct Cost & $1,049.0$ & $1,231.1$ & $1,507.2$ & 790.4 & $1,389.0$ & 490.6 & $1,818.4$ & $2,467.5$ & 882.3 & $1,810.2$ & 541.0 \\
\hline & $\begin{array}{l}\text { Engineering } \\
\& \text { Administra- } \\
\text { tion (25\%) }\end{array}$ & $\underline{262.3}$ & $\underline{307.8}$ & 376.8 & 197.6 & $\underline{347.3}$ & 122.7 & 454.6 & $\underline{616.9}$ & 220.6 & 452.6 & 135.3 \\
\hline & $\begin{array}{l}\text { Total Project } \\
\text { Capital Cost }\end{array}$ & $1,311.3$ & $1,538.9$ & $1,884.0$ & 988.0 & $1,736.3$ & 613.3 & $2,273.0$ & $3,084.4$ & $1,102.9$ & $2,262.8$ & 676.3 \\
\hline
\end{tabular}




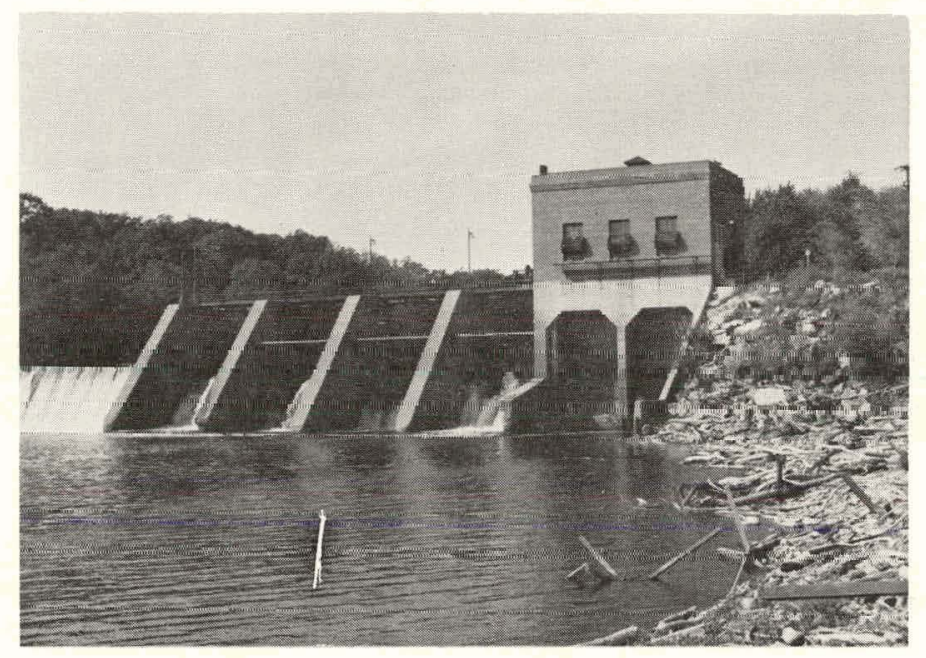

DAM, SPILLWAY AND POWERHOUSE LOOKING UPSTREAM

BARNESTON DAM SITE. BIG BLUE RIVER 


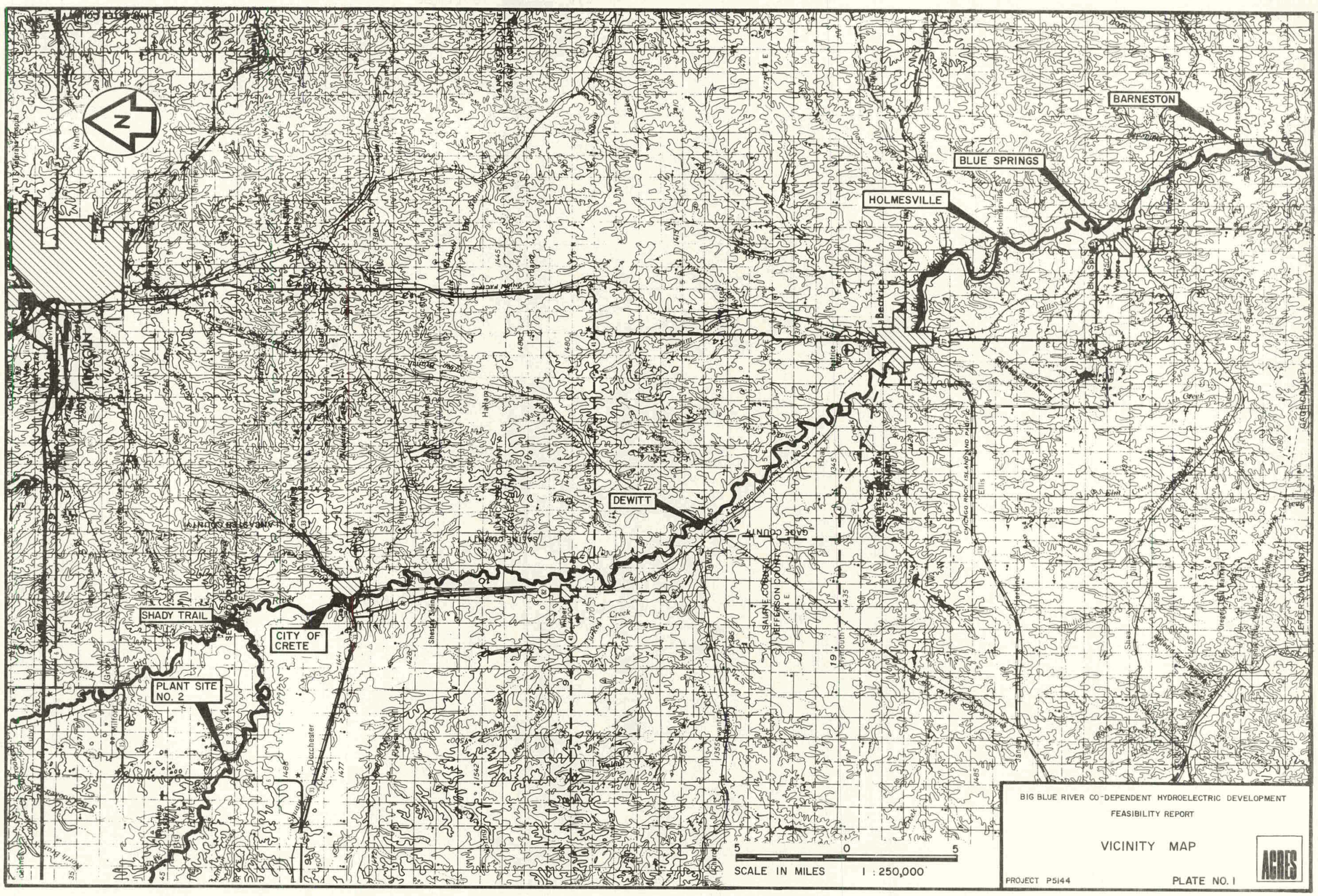




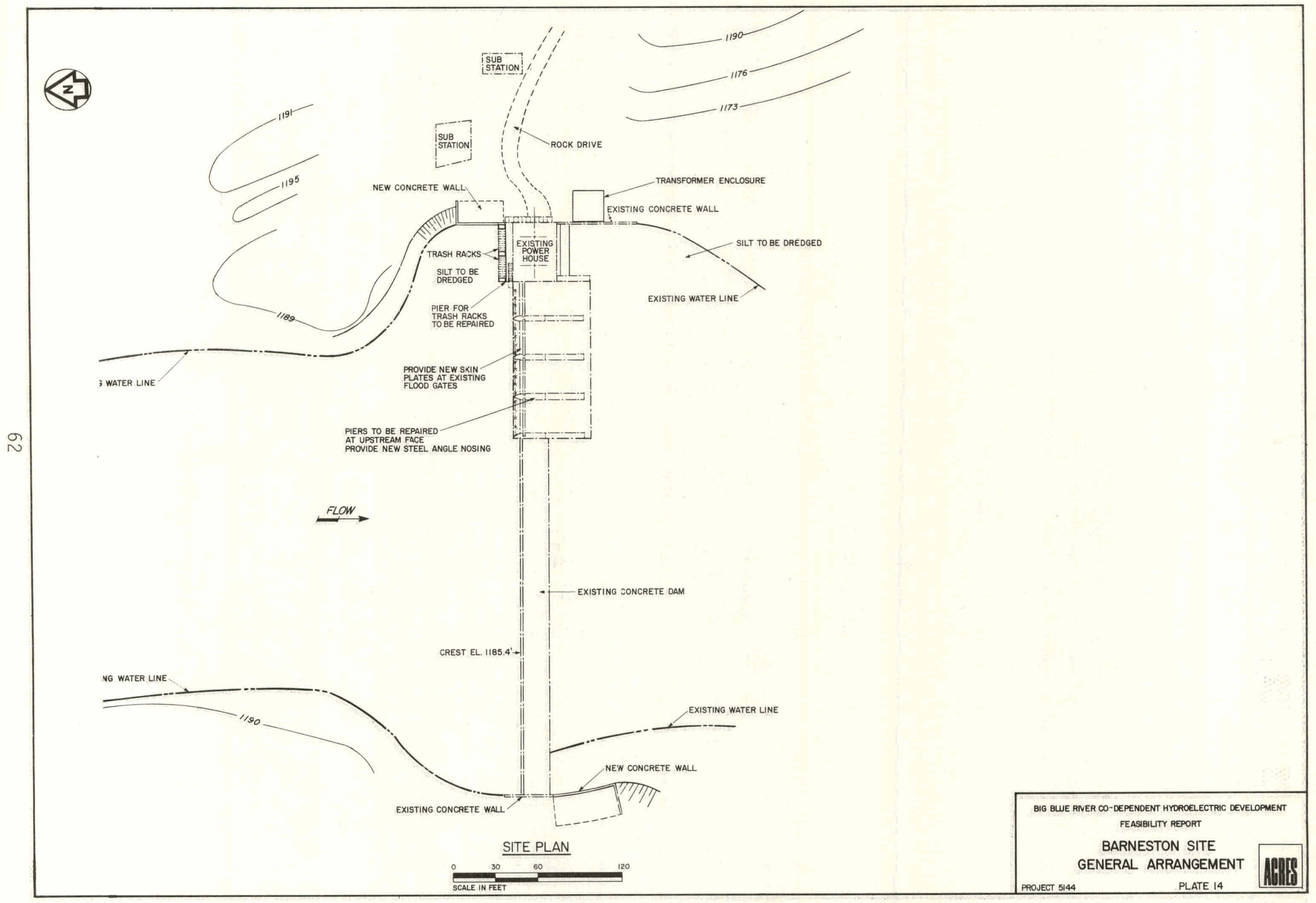



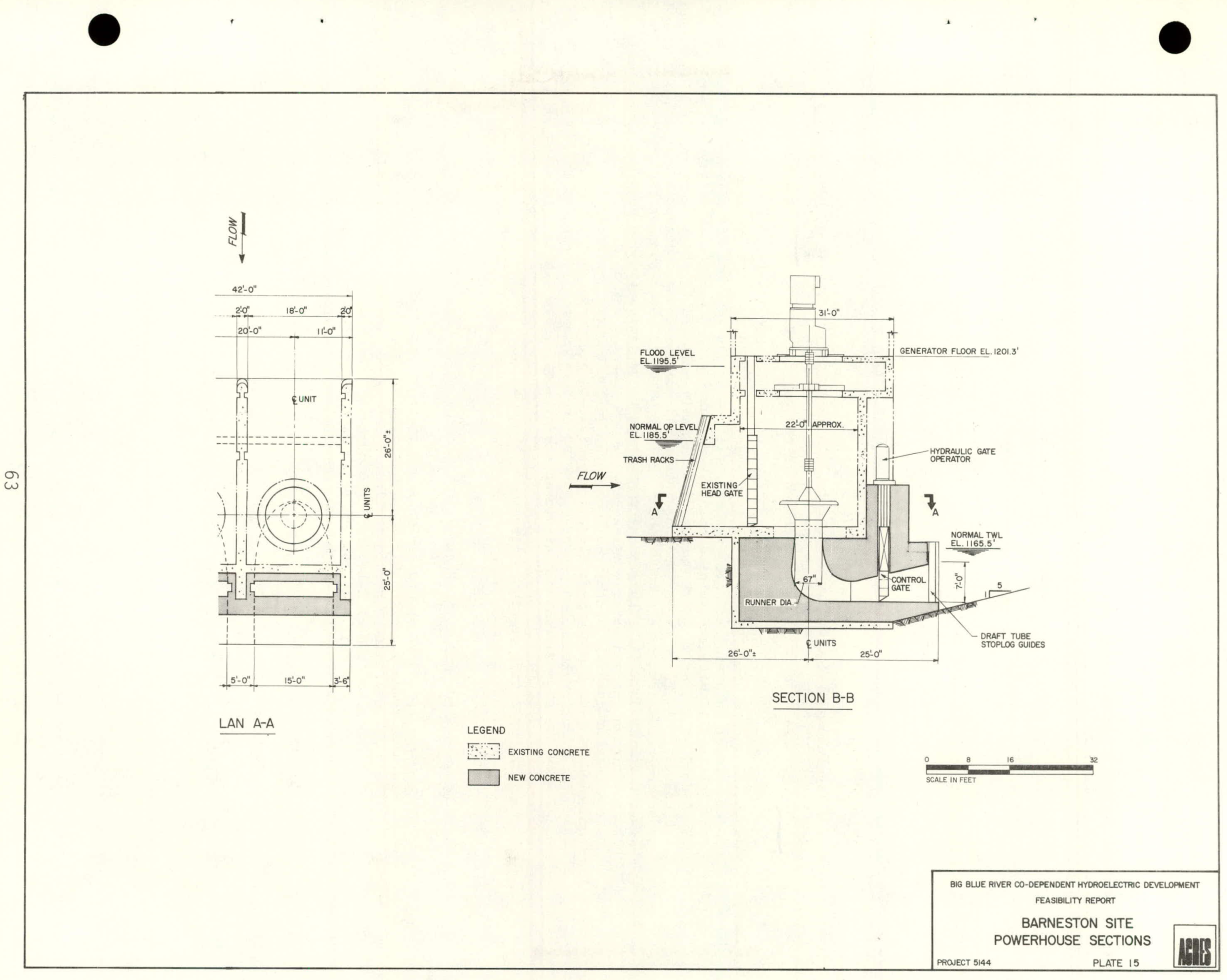
VULCAN POWER FACILITY ON THE FOX RIVER

Appleton, Wisconsin

Kimberly-Clark Corporation

Kimberly-Clark Corporation \& Mead and Hunt, Inc.

PRDA Proposal Contract No. EW 78-7-07-1775

\section{INTRODUCTION}

The Vulcan Hydroelectric project is located on the north side of the Fox River in Appleton, Wisconsin, and is within 500 feet of the world's first hydroelectric facility - installed in the year 1882 .

Operation of the Vulcan Hydroelectric plant began in 1909 with an expansion in the year 1916 bringing its capacity to $1350 \mathrm{KW}$ of 25 cycle power. Power generated at this site was utilized by the adjacent KimberlyClark Atlas Mill with the surplus being transmitted to a downstream KimberlyClark Mill at Kimberly. Both operations initially utilized 25 cycle power exclusively. As major expansions, equipment and process changes occurred, it became necessary to rely upon public utility 60 cycle power to meet the growing energy demands. The gradual conversion to 60 cycle, reduced power plant efficiencies and deteriorating civil works prompted a 1956 feasibility assessment for possible reconstruction of the Vulcan plant. The study, conducted by Mead \& Hunt, hydroelectric specialists and consultants, deemed any major reconstruction and conversion to 60 cycle economically not feasible based upon the then current and predicted energy costs. The plant's operation was terminated in 1974 after 65 years of service. The equipment and buildings housing the operation remain in place.

\section{ASSESSMENT}

\section{A. DRAINAGE AREA AND RIVER FLOW}

The upper Fox and Wolf Rivers and their tributaries comprise a drainage area of about 6,027 square miles above the Vulcan power site. The U.S. government controls the levels throughout the watercourse and with the exception of Lake Winnebago no major impoundments exist. Industries and utilities operate their water power driven facilities on a run-of-the-river basis. Average water flows at the Army Corps of Engineers gaging station are recorded as 4,156 cfs for the period of 1918 through 1972.

\section{B. HEADWATERS}

The headwater level is maintained by the U.S. Upper Dam, operated by the Army Corps of Engineers and normally regulated between elevations 737.6 feet and 738.1 feet. 


\section{c.}

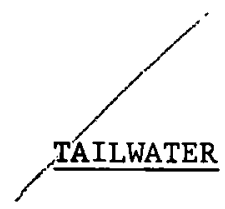

The level of the tailwater is controlled by a privately owned middle dam with the top of gate elevation at 721.37 feet. The pool level for this study has been assumed to be at a constant elevation of 721.4 feet for normal river flows.

\section{NET HEAD AND USEABLE FLOW}

Based on study and historical data, head curves show that net heads will vary between 15.9 feet for low river flows and 13.8 feet with river flows of 5,000 cfs and canal discharge of $2,300 \mathrm{cfs}$.

\section{E. PROPOSED REDEVELOPMENT}

Having determined that it would not be feasible to attempt to salvage any of the equipment or the powerhouse structure, and in order to maximize the use of the potential water power, modern high-efficiency generating equipment should be installed in a new structure situated to minimize head losses.

Based upon head, size of unit, availability of service and parts, civil work required and total costs, it has been determined that a horizontal tube unit would be most feasible. Bulb units do not compete in cost with other units for the particular size of units required. Vertical units were not selected because of the excessive civil works required for the draft tube construction.

Recommended equipment includes the installation of two horizontal, hydraulic, adjustable blade, fixed vane, standard $2,750 \mathrm{~mm}$ tube turbines, each rated to develop $1100 \mathrm{KW}$ under a net head of 13.5 feet. Unit discharge at rated output would be approximately $1,0.80 \mathrm{cfs}$.

Adjustable blade turbines were selected so that the units will operate over a wide range of flows with favorable efficiencies. The installation of two $2750 \mathrm{~mm}$ units will provide a maximum generating capacity of $2200 \mathrm{KW}$ and will have a hydraulic capacity of 2,300 cfs at 13.5 feet head. Considering efficiencies, the annual generation would be about $14,000,000 \mathrm{KW}$ in an average water year.

Since this would be a run-of-the-river plant, firm capacity will be limited to power that can be generated during low-flow periods. Firm capacity, normally defined as the maximum power that can be supplied on demand for a three-hour period, could be increased if some draw-down could be made on the pool above the upper dam. Discussions with the Corps of Engineers indicate they may recommend approval of an application to install flashboards so the pool would always be above the minimum legal level, which is the crest of the dam.

The new powerhouse construction will improve water flow at both the intake and discharge ends. 


\section{F. MARKET POTENTIAL}

The Atlas Paper Mill, located adjacent to the Vulcan site, is also. owned by Kimberly-Clark Corporation. The mill has a load requirement of about $450 \mathrm{KW}$ and uses approximately 3,000,000 KWHR per year. Generation from the redeveloped Vulcan plant will be used to supply these needs. Surplus power will be marketed.

\section{G. OPERATION AND MAINTENANCE}

It is proposed that the Vulcan plant be automated, thereby eliminating the need for a full-time operator. A part-time operator will be required to maintain oil levels, read meters, maintain a daily operating $10 \mathrm{~g}$, make routine switchgear inspections, clean racks and perform daily housekeeping duties. The duty will require approximately four hours per day, five days per week and be provided by the personnel from the adjacent Atlas Mill. Operation and maintenance costs are estimated at three mils per KWHR. This is equal to $\$ 42,000$ per year beginning with 1981 .

H. PROJECT LIFE

The depreciable life of the project is to be 28 years with normal maintenance.

\section{COST ESTIMATE AND RETURN ON INVESTMENT}

The estimated cost to construct a new powerhouse and install new operating equipment adjusted to the fourth quarter of 1979 is $\$ 3,360,000$, which is $\$ 1,527 / \mathrm{KW}$.

The discounted cash flow return on investment is estimated at 10.9 percent with a probable low of 6.1 percent and a probable high of 15.1 percent. The payback for the project, which is an expression of the number of annual cash flows required to equal the original investment, is 11.2 years. Paybacks range from 9.4 years for the most favorable projection to 14.1 years for the least favorable.. The most likely financial returns are based on the prediction that electricity prices in the Fox Valley of Wisconsin are likely to increase at an average annual. compound rate of 10 percent.

\section{J. IMPACT ON RIVER AND RESERVOIR}

The construction and operation of a $2200 \mathrm{KW}$ hydroelectric plant at the Vulcan site will have no impact on other perceived water resource needs of the area or on the current use of the reservoir or on the use of the area downstream from the proposed plant. The proposed plant will have no effect on the operation of other hydroelectric plants located either upstream or downstream. Recreational use of the river will not be affected.

K. ENVIRONMENTAL ASSESSMEN'L

The environmental assessment, part of the feasibility assessment initially submitted, shows that the short- term use of the environment 
through reactivation of the facility will have no detrimental effects; long-term productivity and self-sufficiency in energy resources is enhanced by the utilization of hydropower.

L. REQUIREMENTS OF REGULATORY AGENCIES

Regulatory bodies with jurisdiction and concerns for the proposed project redevelopment have been appraised of the study plans. Normal submission of the details developed upon project approval will meet requirements currently known and anticipated.

M. ACCEPTABILITY OF THE SITE

As the proposed redevelopment will be accomplished with only minor modifications to head and tail race canals of an existing facility which has served for 65 years, we anticipate no problems.

N. SCHEDULE

The redeveloped Vulcan facility could be on line 18 months after design commences.

\section{BASIC CONSTRAINTS}

\section{A. RETURN ON INVESTMENT}

Estimated rates used in this study and as offered for "on-peak" and "off-peak" surplus energy purchased by the utility are significantly lower than comparable rates charged by said utility for purchased power. The most favorable projected return on investment based on current proposed surplus power credit results in a payback in excess of nine years. This payback is not within current Corporate acceptable guidelines.

\section{B. SALE OF POWER}

Under provisions of the recently enacted Public Utilities Regulatory Policies Act, the Federal Energy Regulatory Commission is now in the process of drafting regulations exempting qualified "small power production facilities" which market part or all of the power they produce from otherwise applicable federal and state public utility regulatory requirements. As we read this new act, the Vulcan project should qualify for these exemptions. In any case, Kimberly-Clark will assure that all necessary public utility restrictions and regulatory requirements are appropriately fulfilled.

\section{UNIQUE SITUATIONS}

The proposed reconstruction will be accomplished on a proven watercourse with historically documented flow and level controls on a site which has served successfully for over 65 years. No new environmental constraints can logically be applied. The return of this proven and valuable renewal resource to active energy production is most critical in terms of our current national energy emergency. 
. MAX STARCKE PARK DAM

Seguin, Texas

City of Seguin

Alfred H. Koebig

PRDA Proposal Contract No. EW-78-F-07-1776

\section{INTẼODODCTIION}

The Max Starcke Park Dam is located on Guadalupe River in Seguin, Texas. The low-head dam made of rock and concrete forms an impoundment with a water level approximately 10 feet above the normal tailwater level. The existing dam has an existing hydroelectric unit in operation, along with a small additional power house structure not readily suitable for additional units. The flows in the river are regulated to a large extent by other hydroelectric facilities on the river. The feasibility assessment evaluated the addition of one or more hydro units to the existing dam.

\section{RIVER FLOWS}

The reservoir formed by the dam has no storage capacity available to influence rates at which water can be passed through new turbine units. The impoundment is for all practical purposes a constant level lake. Flow rates available to pass through the turbine are the discharges that now exist in the river.

Daily stream flow records have been maintained on the Guadalupe River upstream from Seguin. These records show that the average discharge has been approximately 700 cubic feet per second (cfs) for the 44 year period of record.

Kiver flow patterns at Seguin have been greatiy altered by the construction of the Canyon Reservoir a short distance upstream. Flow regulation at Canyon Reservoir began on July 21,1963 . The minimum conservation pool level was first reached in April 1968. The reservoir has a top of conservation capacity of 382,000 acre-feet and a capacity at the flood spillway crest of 736,700 acre-feet. The average river flow rate since the closing of Canyon Reservoir has been some $13.5 \%$ greater than the total period of record.

Flow-duration curves were developed for the Guadalupe River at Seguin and are shown on Plate 2. The 1965-1977 curve was adjusted down to reflect the lower river flows that have been experienced over the total period of record.

Daily river flow patterns are modified by the operation of hydroelectric units at a dam immediately upstream from the Max Starcke Park Dam reservoir. The operation of the upstream hydroelectric units results in a regulated flow-duration curve as shown on Plate 2.

The Max Starcke Park Dam presently has in operation a $250 \mathrm{KW}$ hydro turbine. The flow rate through the turbine is approximately $300 \mathrm{cfs}$ and the unit operates almost continuously. New units would operate when flows greater than $300 \mathrm{cfs}$ occur. An automatic start and stop operation would be employed and would be governed by the water level in the upstream impoundment.

\section{PLANT LAYOUT}

\section{A. Plant Location}

The most advantageous location for new hydro units was determined to be south of the existing turbine unit and adjacent to the south abutment. An overali plan view of the dam and the power plant's location near the south abutment is shown on Plate 1. 


\section{B. Unit Selection}

The selection of the type of generating units was based on several factors including operating conditions and economic considerations. Two types of units meeting the operating requirements were considered: a horizontal shaft tube type machine with adjustable blades and a vertical machine with adjustable gates. High flood water levels in the river would necessitate extensive civil works to protect the horizontal tube type unit. The vertical type machine can be so arranged that the generator and governor can easily be placed above the high water level. The costs of required civil works, machinery costs, and operating performance indicated that the vertical open flume type units were more suitable.

\section{Number of Units and Capacity}

Flow variations indicated that flows up to $800 \mathrm{cfs}$ are practical for hydropower development. Two units, each with a full gate flow rate of approximately $400 \mathrm{cfs}$, were determined to be more suited for the conditions at the site than one single large unit. The units would each have the ability to operate over a head range from 8.5 feet to 10.5 feet and over a flow range from approximately 200 cfs to $400 \mathrm{cfs}$. The capacity of each unit would be $250 \mathrm{~kW}$ with flows of up to $400 \mathrm{cfs}$. The layout for the plant is shown on Plate 3.

\section{POWER GENERATION POTENTIAL}

\section{A. General}

Projected power plant operation studies were made to determine the amount of power that could be generated and the capacity that could be supplied by the two additional $250 \mathrm{KW}$ units. The studies covered a projected 50 year period from 1982 to 2031 .

\section{B. Power Generated}

The power generated by the new units was based on the flow duration curves shown on Plate 2 . The difference between the lake water surface and tailwater level was used as being 10.5 feet at $300 \mathrm{cfs}$ and 8.4 feet at $1,100 \mathrm{cfs}$. It was assumed in the calculation of power generated that $70 \mathrm{cfs}$ would be permitted to flow over the dam during 12 daylight hours daily. The $70 \mathrm{cfs}$ will result in a depth of flow over the dam crest of about .2 feet. The 70 cfs was assumed to flow over the dam so as not to eliminate the beauty of the existing dam.

Passing water through the new turbines will reduce the head water level in the lake and therefore the head on the existing unit and the power generated by the existing unit.

The reductions in head on the existing unit will reduce the power generated by approximately $4.5 \%$ or 63,000 KWH annually.

The average annual increase in power generated by the new units is 1,700,000 KWH for the 1982 through 2000 period. This value is projected to decrease to $1,575,000 \mathrm{KWH}$ per year in year 2010 because of anticipated diversions from the river upstream, but then remains constant through the life of the plant. The plant factor is. 39 for the new $500 \mathrm{KW}$ installation during year 1982 but reduces to . 36 in year 2032 .

\section{Dependable Capacity}

An examination of the historical flow patterns and frequencies revealed that on the average, the two now $250 \mathrm{KW}$ units should supply a dependahle capacity of $200 \mathrm{KW}$.

\section{ESTIMATED COSTS}

Estimated costs were developed for the required installation. Costs were increased $8 \%$ annually from present day costs to account for inflation that is expected before construction can be accomplished.

The total order of magnitude installed cost for the facility is $\$ 1,320,000$. The total cost equals $\$ 2,640$ per KW of capacity. The initial capital cost per KWH produced annually is $\$ 0.78$. The costs are based on field construction during 1981. 


\section{ECONOMIC ANALYSIS}

A. General

The economic analysis for the generating facility includes the costs related to the initial cost of the installation, the continuing operating and maintenance cost, and the value of the power generated. Economic comparisons were developed that take into account the costs (debt retirement and operating and maintenance costs) and the benefits (income from sale of power). The economic life of the facility was assumed in the economic comparisons to be 50 years. Economic comparisons were made on the basis of present value of annual costs.

\section{B. Cost of the Facility}

The total cost of the facility includes costs for construction, engineering services, debt service during construction, and in-house expenses to be incurred by the City before the plant is put into operation. The debt service costs were based on an interest rate of $6-1 / 2 \%$ and 25 equal and annual pdyllenls.

\section{Operating and Maintenance Cost}

The $0 \& M$ costs were increased $6 \%$ annually to account for expected increases in cost.s resulting from inflation.

\section{Income from Sale of Power}

The generation of power was projected to produce continued income through the life of the plant. The value of the power generated was based on the price currently paid by the City for power purchased from the Lower Colorado River Authority (LCRA) and projected increases anticipated by LCRA.

The City currently pays LCRA approximately 3 mills per KWH for energy purchased, approximately 20 mills per KWH as a fuel charge and $\$ 2.75$ per kilowatt per month for a demand charge. The monthly demand charge is based on peak demand realized during a month.

LCRA's projected annual increase in fuel cost is approximately $6-1 / 2 \%$ for the four year period from June 1981 to June 1985. Based on the present costs to the City and the projected increases by LCRA, the January 1, 1982 charge for energy will be approximately $5.2 \mathrm{mills}$ per KWH, the capacity charge will be $\$ 57.50$ per KW per year, and the fuel charge will be $21.9 \mathrm{mills}$ per $\mathrm{KWH}$. (The 1982 value is cited because that year is projected as the first year of operation for the new plant.)

\section{E. Economic Comparison}

The economic comparison for the new units considered annual costs (costs for retirement of the debt and annual costs. for operation and maintenance). The economic comparison also considered annual benefits for the value of power produced and the value of the reduction in peak power demand resulting from plant operation.

The present values of annual costs were projected to exceed the annual values of the benefit for the first twelve years of operation. The present value of the cumulative net benefit at the end of 50 years of operation was determined to be $\$ 982,363$. The benefit-cost ratio was calculated to be 1.60 at the end of 50 years of operation.

\section{CONCLUSION}

The results of the feasibility assessment show that an additional $500 \mathrm{KW}$ of generating capacity at the Max Starcke Park Dam is economically justified. However, the annual costs are projected to exceed the annual benefits for the first twelve years of operation. The benefit-cost ratio over the projected 50 year life is 1.60 . 


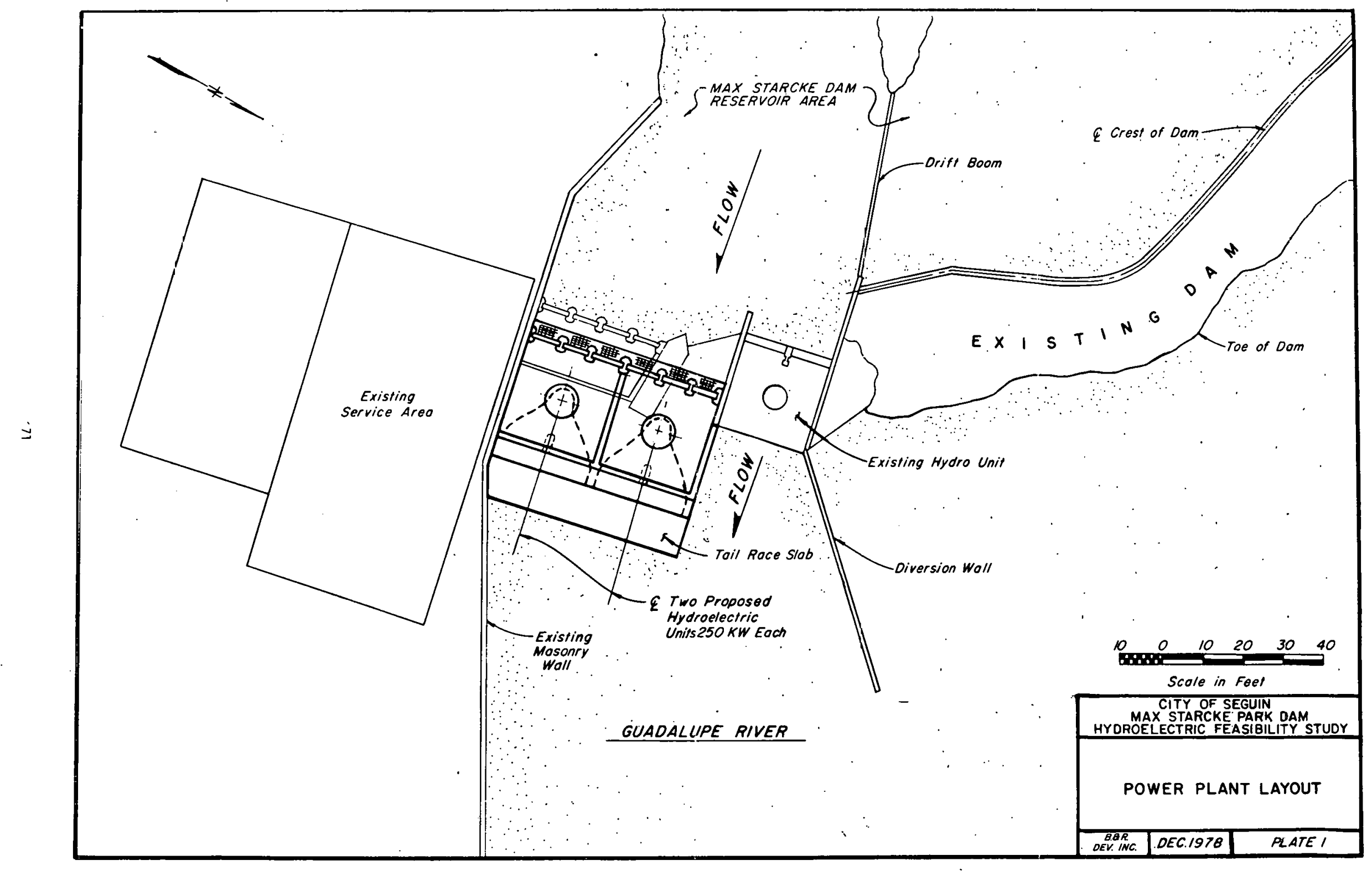




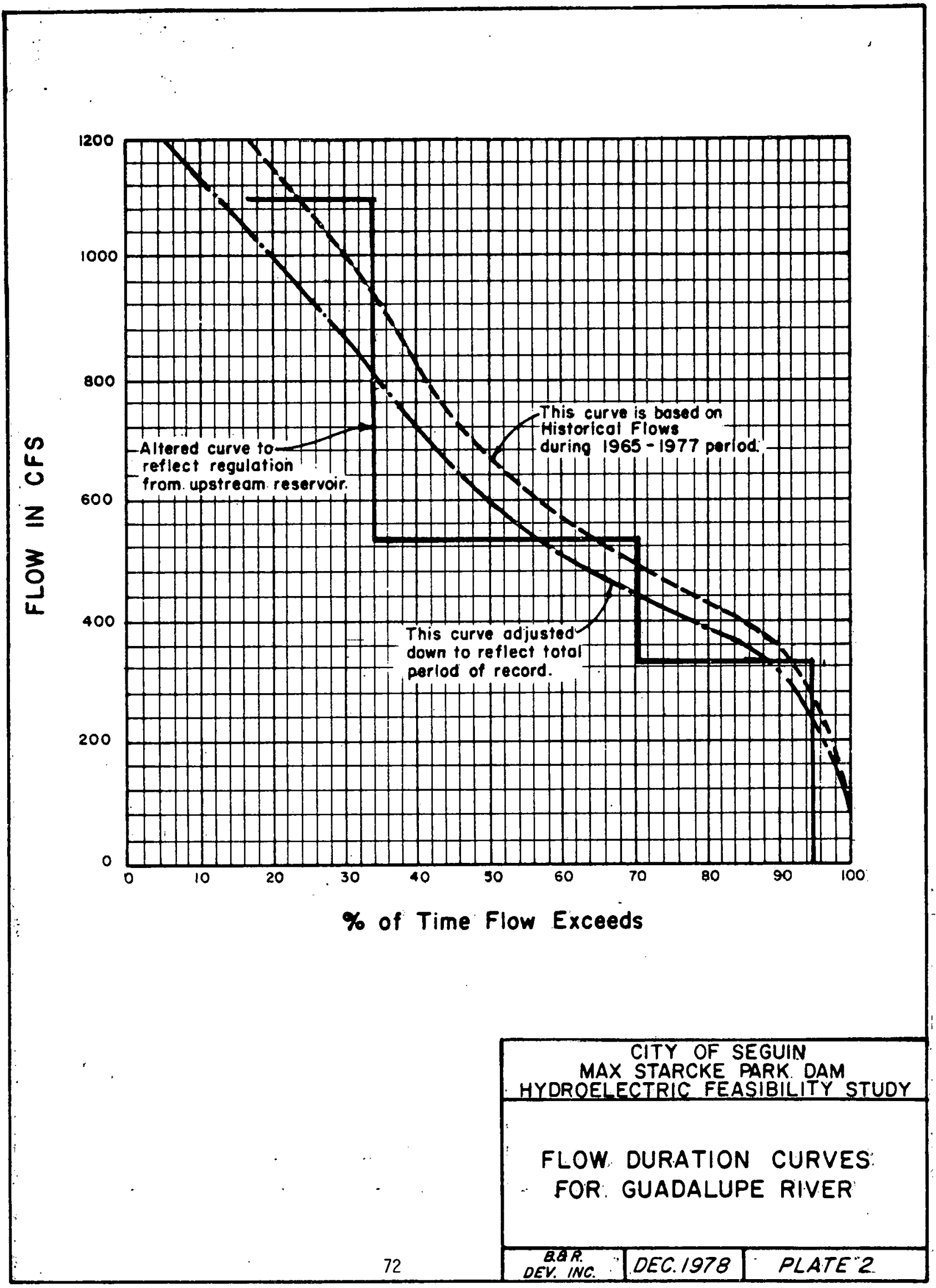




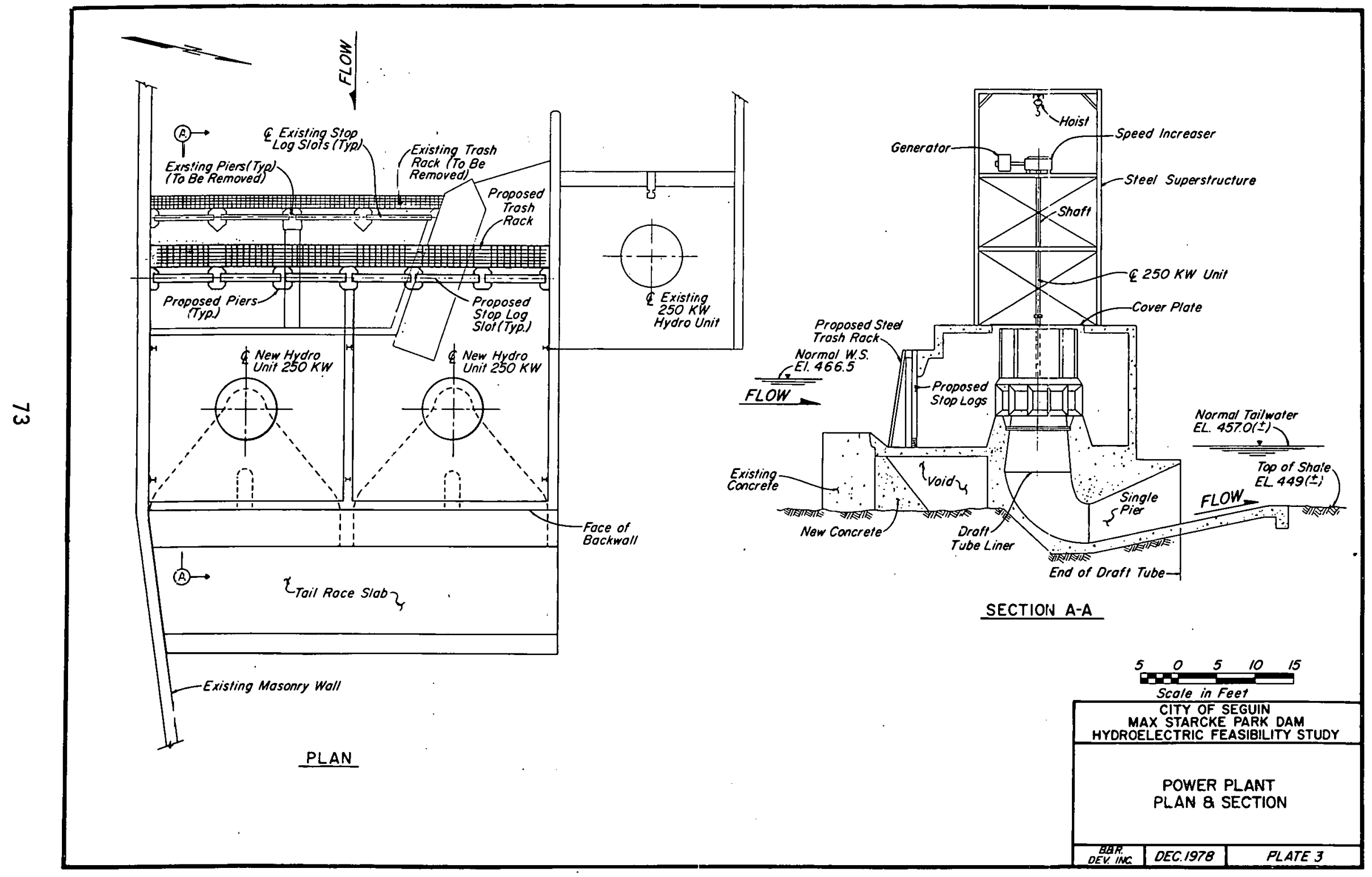


FOUR SITES ON THE MOUSAM RIVER

Kènnēbünk, $M \ddot{E}$

Kennebunk Light and Power District

Foster-Miller Associates, Inc.

PRDA- 1706

Cooperative Agreement No. ET-78-F-07-17777

\section{INTRODUCTION}

This study is reviewing the possibility of redevelopment of the hydroelectric power potential of four dams on the lower Mousam River in or near the town of Kennebunk, ME, and was: undertaken on behalff of the Kennebunk Light and Power District, the municipally-owned electric utility supplying the town and certain adjoining communities.

The study is principalily funded' by the Department of Energy and the Principal Investigator on behalf of the Kennebunk Light and Power District is Foster-Mililer Associates, Inc:, of Waitham, MA:. The Pirincipal: Investigator subcontracted: portions of the study as: follows:

a) Metcalf, andi Eddy, Inc:, Boston, MA.

b) J.E:. Edinger Associates, Inc., Wayne, PA:

c) Mike Harper, P'.E., Peterborough, $\mathrm{NH}$
Geotechnical Assessment, Civiil! Construction Requirements: and Geologic: As sessment for Twine Mị17: Dam and Rogers Mi1:1 Dam.

Environmentali Assessments for Twine Mi 1its. Dami andi Rogers: Mitil Dam:

Determination of available: Energy, Development of: Restoration: Concepts, Assessment of Turbine, Alternatives, Assessment of Generator and Utility Interface Concepts', Economic Assessment of a:1]? sites: and: production: of preliminary drawings'.

In addition to the contribution of the Principal Investigator and the subcontractors, the: owner, Kennebunk. Light. and Power District, also is. contri-. buting local historical research, economic data, and has: carried out physicall investigation of conditions. at certain sites. 
II. SCOPE OF STUDY

The present KL\&PD system has a peak load of about $10 \mathrm{~mW}$, and growth appears to have stabilized at approximately 5 percent per annum. Apart from the output of the existing $130 \mathrm{~kW}$ hydro unit at Kesslen Mi1l, all energy is purchased from either Central Maine Power Company or from the $700 \mathrm{~kW}$ (total) privately owned hydro plants at New Dam and 01d Falls.

The potential sites covered by the study are as follows:

\begin{tabular}{|c|c|c|c|c|}
\hline \multirow[b]{2}{*}{ No. } & \multirow[b]{2}{*}{ Name } & \multicolumn{2}{|c|}{ Net Head } & \multirow{2}{*}{$\begin{array}{c}\text { Present } \\
\mathrm{kW} \text { Operable }\end{array}$} \\
\hline & & Meters & Feet & \\
\hline 1. & Dane Perkins & 2.43 & 8 & 0 \\
\hline 2. & Twine Mill & 5.48 & 18 & 0 \\
\hline & Twine Mill & 8.53 & 28 & 0 (Note 1$)$ \\
\hline 3. & Kesslen Mill & 3.96 & 13 & 130 \\
\hline 4. & Rogers Mi11 & 6.09 & 22 & 0 (Note 2$)$ \\
\hline
\end{tabular}

Note 1: The present dam structure at Twine Mi1l, if rebuilt to its original height, would restore the operating head to $5.48 \mathrm{M}$ ( 18 feet). However, if this dam was so raised as to flood back over the abandoned Dane Perkins site, the head would be raised to $8.53 \mathrm{M}$ ( $28 \mathrm{feet}$ ).

Note 2: The listed head at Rogers Mill of $6.09 \mathrm{M}$ (22 feet) is to tail water level at Mean High Spring Tide. The normal tidal range at this site does not exceed 1.2M ( 4 feet), so that the maximum design head will range from $6.09 \mathrm{M}$ (22 feet) to $7.29 \mathrm{M}$ ( $26 \mathrm{feet}$ ). The 1 isted head also assumes that Rogers Mill dam would be so rebuilt as not to raise tailwater level at Kesslen Mill.

\section{SITE DESCRIPTIONS}

The various sites may be briefly described as follows:

a) Dane Perkins

This is an old sawmill site and the wood crib spillway section of the dam has failed although the masonary and concrete wings remain in good condition. The useful head here is only 8 feet.

b) Twine Mil1

The wood crib dam here is again, breached but the wing walls require only repair of spalled areas to restore them to service. The head is 18 feet and brief consideration was given to raising the dam to give a 28 foot head by flooding back the Dane Perkins site; however, this approach proved economically unattractive. 
The existing powerhouse still contains the old Rodney Hunt twinwheel turbine and casing, in sufficiently good condition that restoration is considered possible, although the governor, generator, and switchgear have all gone for scrap in the 18 years since the unit was last operated.

\section{c) Kesslen Mill}

This plant comprises a vertical shaft unit rated at $130 \mathrm{~kW}$ at 13 feet and had been out of service for some 7 years until it was successfully restated through the initiative of KL\&PD's General Manager in 1977. New switchgear and certain minor overhaul items are required.

d) Rogers Mill

This site is completely abandoned and the wood crib dam is nonexistent. Rebuilding would entail the re-escavation of almost 1500 feet of headrace, the construction of a new power house and the cleanout of the tai]race channel to tidewater.

IV. STUDY RESULTS

The results of the study and the consequent recommendations are summarized in the following table: 


\begin{tabular}{|c|c|c|c|c|c|}
\hline & & $\begin{array}{l}\text { Dane } \\
\text { Perkins } \\
\end{array}$ & $\begin{array}{l}\text { Twine } \\
\text { Mill }\end{array}$ & $\begin{array}{l}\text { Kesslen } \\
\text { Mill } \\
\end{array}$ & $\begin{array}{l}\text { Rogers } \\
\text { Mill } \\
\end{array}$ \\
\hline & Head, ft & 8 & 18 & 13 & 22 \\
\hline & Present kW & 0 & 0 & 130 & 0 \\
\hline & Present kWh/yr & 0 & 0 & 778,100 & 0 \\
\hline (A) & Maximum kWh/yr & 785,300 & $1,742,400$ & $1,274,000$ & $2,160,400$ \\
\hline & Recommended 'kW & 80 & 375 & 130 & 200 \\
\hline & Increase $\mathrm{kW}$ & 80 & 375 & 0 & 200 \\
\hline & Possible kWh/yr & 479,100 & $1,685,100$ & 778,100 & $1,231,500$ \\
\hline (B) & Value of Increase & $\$ 14,420$ & $\$ 50,700$ & 0 & $\$ 37,000$ \\
\hline (c) & Capital Cost & $\$ 186,570$ & $\$ 426,411$ & $\$ 31,000(F)$ & $\$ 799,420$ \\
\hline (D) & Cost of Increase & $\$ 19,682$ & $\$ 44,986$ & $\$ 3,270$ & $\$ 84,338$ \\
\hline$(E)$ & Cost of Energy & $\$ 0.0412$ & $\$ 0.0267$ & $\$ 0.0042$ & $\$ 0.0683$ \\
\hline & Best value & 3 & 2 & 1. & 4 \\
\hline & Proposed Program & Future & $79 / 80$ & 79 & Future \\
\hline $\begin{array}{l}\text { NOTE } \\
\text { (A) } \\
\text { (B) } \\
\text { (C) } \\
\text { (D) } \\
\text { (E) } \\
\text { (F) }\end{array}$ & $\begin{array}{l}\text { ES: } \\
\text { Based on } 39 \text { year } \\
\text { At projected } 1980 \\
\text { In } 1979 \text { dollars } \\
\text { Based on } 30 \text { year } \\
\text { Cost of the increa } \\
\text { Cost of necessary }\end{array}$ & $\begin{array}{l}\text { Ns } \\
\text { ine Power } \\
\text { at } 7 \text { per } \\
\text { in } \$ / \text { kWh } \\
\text { rovements }\end{array}$ & $\begin{array}{l}\text { ort of } \$ 0.0 \\
\text { est (per ye } \\
\text { increase. }\end{array}$ & & \\
\hline
\end{tabular}


TREMONT DAM ON THE WEWEANTIC RIVER

Wareham, Massachusetts

R. F. Packard, Principal Investigator

Town of Wareham, Massachusetts

\&

E. S. Wright, Hydro Program Manager

United Technologies Research Center

PRDA Proposal Contract No. DE-FC07-78IDO1778

I.

\section{INTRODUCTION}

The site proposed for this project is the Tremont Mill Pond Dam located on the Wewewantic River in Wareham, Plymouth County, Massachusetts. This site is approximately five miles upstream from the river outlet at tidewater on Buzzards Bay and is located within two miles of the intersection of Routes 25 and 195.

The Weweantic River drains portions of Plymouth County in the towns of Middleboro, Carver, and Plymouth before reaching wareham. Its direction is primarily southerly into the sea. The drainage area totals 53 square miles and is relatively low and level. It consists of farms and woods with considerable swampy and boggy areas. Normally, large areas of swamps and bogs act as runoff reservoixs, moderating the flow of rivers during both the high and low rainfall extremes, and this factor strongly affects the flow of the Weweantic in a manner favorable to the generation of power. However, numerous areas of natural bogs have been converted to cranberry bogs and the artificial water flows in and out of these bogs at various times of the year tend to produce an uneven river flow.

The dam structure is 800 feet long, with a width across the top of 20 feet. The elevation is 62 feet above sea level. The dam is of earthen construction with granite block facing on the downstream side. The pond level is maintained at approximately 58 feet elevation by Town of Wareham municipal workers by manually adjusting two wooden gates at the spillways. The 39-acre Tremont Mill Pond is shallow and has very limited storage potential. A maximum of 24 feet is available, and the nominal operating head is 22 feet. There are 4 gates, controlling two overflow spillways each 14 -feet wide and two underground water tunnels each 10 feet wide. All four lift gates are heavy timber construction with timber rubbing surfaces set in massive vertical concrete foundation work. The gates are operated by ancient cast iron machinery which may be turned by hand or by . electric motors through a clutch.

The eaxthen dam was originally. built in 1845. The concrete spillways and wooden gate structure were moved in 1918 from their original position to the present location. A concrete and brick powerhouse with two turbine wells was then built and Leffel turbines installed in 1923. The work was under the direction of the Charles T. Main Company, Engineers, of Boston. The powerhouse sits on a massive foundation below the damface at elevation 36.0 feet and is 45 feet high. The earthen dam, all the concrete work on the spillways and powerhouse foundation, and the wooden gates and gate operating machinery were all repaired or restored in a project that was completed in 1977. No hydroelectric generating equipment or water turbines are presently installed.

This study included an extensive survey of potentially applicable hydroelectric generating equipment, an intensive examination of the potential value of the power produced, and a determination of the environmental, social, institutional, and regulatory constraints and impacts. A comprehensive computer analysis was conducted and an optimized installation recommended for the site. The bulk of this feasibility study project was carried out by the United Technologies Research Center (UTRC) in East Hartford, Conn. Some sections of the work were done by Engineering Department Staff Members of the Massachusetts Maritime Academy, by James Bell of Bell Hydropower, and Town. of Wareham staff. 
Traditionally, small hydroelectric projects have been evaluated by rule of thumb analysis. Stream flow duration curves were established from actual or extrapolated U. S. Geological Survey Data, the working head determined, and a plant capacity factor assumed. Average values of efficiency, value of power, etc. were used to establish estimated feasbility and the evaluation of variations which might occur were limited to those which were hand calculable. Obviously, such procedures have little value in today's energy market where a high premium must be placed on cost effective electricity generation from indigenous, renewable resources.

Modern day energy systems analysis incorporates many powerful tools to insure system optimization in a wide variety of applications, and UTRC has conducted this type of systems analysis in a wide variety of potential applications for many years. As a result, it was believed that a comprehensive computer program could be developed for accurate analysis of small hydro sites. Consequently, an UTRC Corporate-sponsored program was developed during 1978. This computer program has been applied to the Tremont Mill pond Dam Hydroelectric Feasibility project and the results form the basis for all the economic feasibility conclusions reached in this report.

In brief, the program attempts to match a customer's demand with the water resources available, and, using real utility energy and demand rate schedules, and real efficiences, measures the cost savings (if any) compared to the costs to meet that demand solely from utility power.

\section{CONCLUSIONS}

(1) The expected configuration of the Tremont Dam Project is two hydroturbines installed in the present forebays, one of which is to be a reconditioned vertical Francis unit and one of which is to be a new crossflow turbine. Each unit will drive a separate generator. The total capacity is to be between 200 and $250 \mathrm{~kW}$ divided approximately equally between the two units.

(2) For an estimated mean flow, this installation will deliver between 965,000 and $1,027,000 \mathrm{kWhrs}$ annually depending on the actual capacity installed. Actual production will depend on the actual stream flow in any given year. The project will operate essentially run-of-river, but has a limited capacity for peaking relative to a 4 foot permissible variation in the level of the 39-acre pond.

(3) The proposed hydropower installation will have a minimum impact on other perceived water resource needs of the area and on the current use of the pond.

(4) All pwer produced is expected to be marketed directly to. New Bedford Gas and Edison Light Company under an agreement with the Town of Wareham which recognizes both the tangible and intangible benefits from the Project to both the Town and the Utility.

(5) The Town should immediately file an application for a minor license with the Federal Energy Regulatory Commission. Other local, State, and Federal agency requirements can be met without undue difficulty.

(6) The total capital investment is expected to range between $\$ 150,000$ and $\$ 175$, 000 which would equate to $\$ 600$ to $\$ 800$ per kilowatt. It is hoped that the Town will qualify for State or Federal grants which would reduce the Town's share of capital investment to below $\$ 500$ per $\mathrm{kW}$.

(7) For a $250 \mathrm{~kW}$ installation at $\$ 500 / \mathrm{kW}$, the internal rate of return to the Town is 19 percent for a 30 year period and the payback time is 7 years, when all power is sold to the utility at $30 \mathrm{mills}$ (using reasonable financial assumptions, inflation rates, and 78 financing). These figures decrease to 15 percent rate of return and 10 years payback period when the selling rate is 26 mills per kWhr. Unit costs are 24.1 mills per kWhr in the first year of operation, including capital, depreciation, operation, and maintenance.

(8) For the same installation, the net present value of the savings which the Town should realize from the project are $\$ 6,651, \$ 47,765$, and $\$ 311,368$ at the end of the first, sixth and 30 th year, respectively, for an initial selling rate of 26 mills per kWhr and, 
similarly, $\$ 11,707, \quad \$ 77,204$, and $\$ 439,374$ at 30 mills per $k$ whr. Total 30 year savings are projected at $\$ 1,431,593$ for the $26 \mathrm{mill}$ case and $\$ 1,948,803$ for the 30 mill case.

(9) The anticipated annual operation and maintenaance costs are estimated at 4 mills per kWhr initially. This estimate assumes that the time of Town workers currently employed in regulating the pond level will not be charged to the project, that project startup costs are separately accounted for, that supervisory personnel will be on Town overhead charges, and only those costs directly associated with the production of electricity will be charged to the project.

(10) The anticipated project life is assumed to be 30 .years in all economic calculations, with a 15 percent salvage value. In actuality, the Project life is expected to be indefinite since the dam has existed for over 130 years and gives no siqn of failing.

(1i) Minimal environmental damage and socio-inst.titional impact is expected. The dam and pond have existed for years without conflict and pond regulation will not exceed present practice. Cooperative interaction will be required with cranberry growers nearby.

(12) There is not expected to be a safety hazard associated with the rehabilitation of the hydroelectric power plant or with the day to day operation of it.

(13) The Project site is acceptable from an engineering standpoint for hydroelectric power development.

(14) Suitable hydroturbine, generators, and accessories are presently available for the recommended installation, but the availability of a suitable used vertical Francis unit may change by the time it can be ordered and purchased by the Town. In the event that a similar new unit is required, the project will still be feasible, although its financial attractiveness will decrease, unless the utility electricity purchase contract is adjusted accordingly.

(15) The development plan for placing the Project on-line involves immediate approval by the Town to proceea, inciuding the filing for a FERC minor license. An appl.ication should be submitted to the state of Massachusetts for a $\$ 25,000$ grant. This grant, if approved, could permit a start by July 1st, 1979, for the purchase and installation of a good used rehabilitated vertical Francis turbine unit, provided the FERC license can be issued by then. This unit could be placed on line during the Fall of 1979 . In addition, funding from the U. S. Department of Energy for 258 of the total project cost should be sought. Approval of such a DOE grant would then permit purchase of the crossflow unit which would be manufactured and installed no later than the lst quarter of 1980 . Thus, it appears that it is feasible to place the facility in full operation within one year provided the FERC license application involves no unforeseen delays.

(16) It is concluded that since no environmental or other barriers seem to exist to the restoration of hydroelectric capability at the Tremont Dam site, this Project should move forward as quickly as practicable because of the demonstrated significant financial benefits to the Town and because of the favorable possibilities as part of state and Federal demonstration programs that would promote the cost-effective. utilization of indigenous, renewable energy pr-grams. 


\section{JOHNSON LAKE INLET}

Elwood, Nebraska

The Central Nebraska Public Power and Irrigation District

E. L. Hamilton

Cooperative Agreement No. EW-78-F-07-1779

\section{INTRODUCTION}

The Central Nebraska Public Power and Irrigation District (Central District) reviewed several possible low-head hydroelectric sites on their canal system. Of three which showed promise, the Johnson Lake Inlet was chosen for a feasibility study.

Centra1 District owns and operates a water-storage reservoir, Lake McConaughy; a 75-mile supply canal commencing at a diversion dam on the Platte River near North Platte, Nebraska; three hydroelectric plants, Jeffrey, Johnson No. 1 and Johnson No. 2 ; a fossil fueled steam electric plant, Canaday; and a system of canals and laterals to deliver irrigation water to farms in South-central Nebraska. Each of the existing hydroelectric plants has a capacity of $18 \mathrm{MW}$, while the Canaday plant has a capacity of $100 \mathrm{MW}$. A 50-MW, single-unit hydroelectric power plant is being designed for installation at Kingsley Dam.

Johns on Lake is a regulating reservoir for the Johnson No. 1 plant. The inlet to the lake is from the supply canal through a single taintor gate structure, (Figures 1, 2 \& 3). Water level in the canal is maintained nearly constant, as there is a irrigation canal headgate at one side. Flow through the structure will vary with upstream conditions, such as Jeffrey Plant load.

\section{FEASIBILITY STUDY}

The study was made by CH2M HILL consulting engineers in conjunction with Central District's staff. The sequence of tasks to be undertaken was as follows:

1. Site Inspection

2. Data Collection

3. Performance Characteristics

4. Equipment Survey

5. Plant Size and Configuration

6.* Safety

7. Engineering Acceptability

8.* Environmental and Social Impacts

9.* Impacts on Other Water Use

10. Capital Cost Estimate and Financing

11. Operation, Maintenance, and Project Life

12. Economic Feasibility

13. Marketing Plan

14.* Permits and Licensing

15.* Schedule (for implementation)

16. Feasibility Report

It was determined midway in the study that economic feasibility was not possible. The study was terminated and a report prepared.

* Project was proven infeasible before this task was undertaken and is not discussed in this report. 


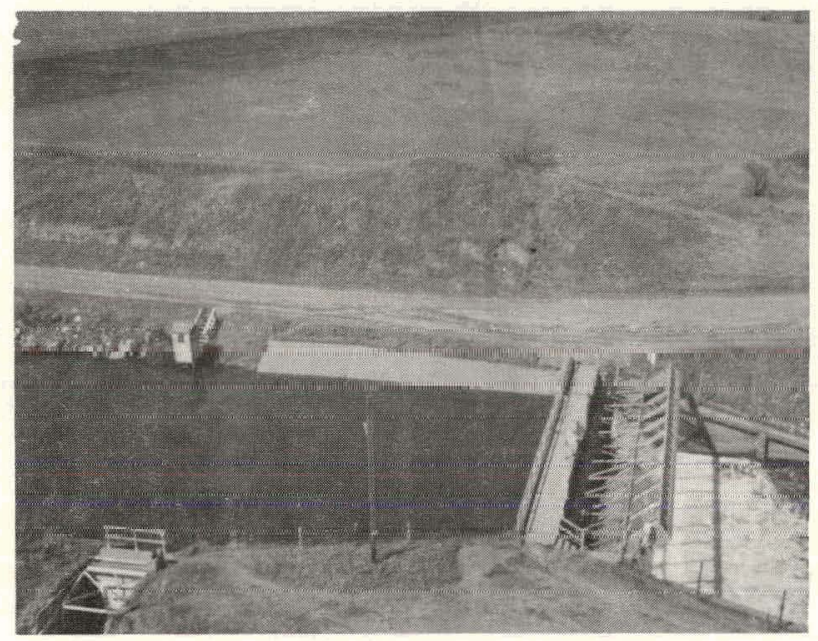

Johnson Lake Inlet Looking North across the Inlet Gate, Supply Canal Left, to Johnson Lake Right, E65 Irrigation Lateral Head Gate Lower Left, Location for Hydro Unit beyond Inlet Gate.

\section{Figure 1.}

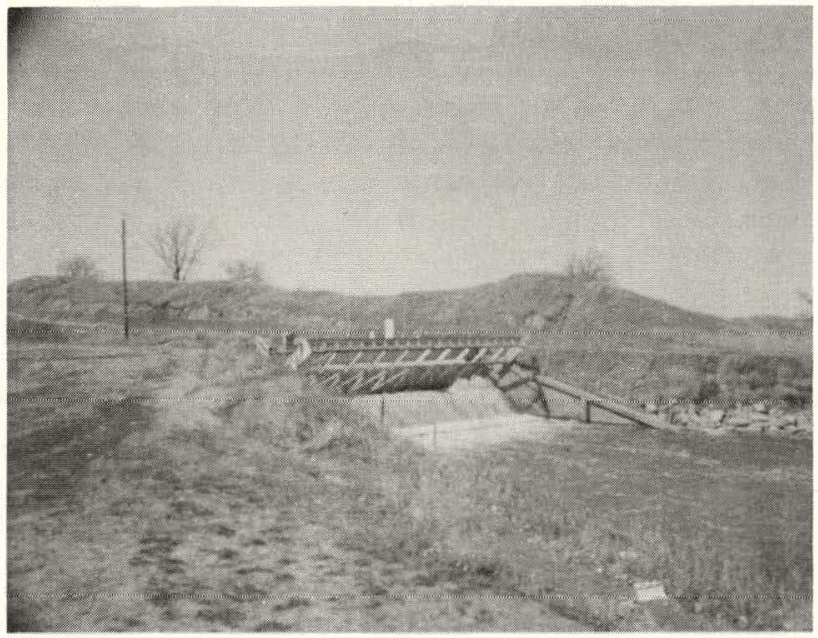

Johnson Lake Inlet Gate Looking Upstream, Location for Hydro Unit to Right of Inlet Gate.

\section{Figure 2.}




\section{a. HYDRAULIC CONDITIONS}

The gross head would vary from 8.5 to 12.5 feet and average about 10 foot. Net head would be approximately a foot less.

Canal flow varies from zero to about $2000 \mathrm{cfs}$ with an average of about $1000 \mathrm{cfs}$. A flow of $700 \mathrm{cfs}$ was available about 78 percent of the time.

\section{b. GENERATING CAPACITY}

Several hydraulic turbine-generator sizes were studied and their relative economics compared. A 450-KW single unit at a $700 \mathrm{cfs}$ flow was selected as the best of the alternates. This machine would generate down to $250 \mathrm{cfs}$ with fair efficiency.

\section{c. POWER GENERATION POTENTIAL}

Based on the turbine-generator as described, the average annual energy production would be $3,600,000 \mathrm{Kwh}$. Table 1 , below, shows the generation and average flow by the month.

TABLE 1. Average Canal Flow and Power Generation Potential

\begin{tabular}{lccc} 
Month & $\begin{array}{c}\text { Average Flow } \\
\text { 25-Year Monthly Mean } \\
\text { cfs }\end{array}$ & $\begin{array}{c}\text { Average Power } \\
\text { Output } \\
\text { KW }\end{array}$ & $\begin{array}{c}\text { Average Energy } \\
\text { Outeput } \\
\text { JWH }\end{array}$ \\
\cline { 2 - 3 } February & 990 & 450 & 277,000 \\
March & 1,165 & 450 & 327,000 \\
Apri1 & 1,189 & 450 & 334,000 \\
May & 1,129 & 450 & 317,000 \\
June & 1,018 & 450 & 284,000 \\
July & 1,035 & 450 & 292,000 \\
August & 1,153 & 450 & 323,000 \\
September & 1,066 & 450 & 299,000 \\
October & 915 & 450 & 256,000 \\
November & 1,023 & 450 & 288,000 \\
December & 1,076 & 450 & 301,000 \\
& 1,079 & 450 & 302,000
\end{tabular}

The estimated annual capacity factor would be 0.68 . Flows fall below the minimum $250 \mathrm{cfs}$ about three percent of the time. Therefore, no firm capacity can be claimed.

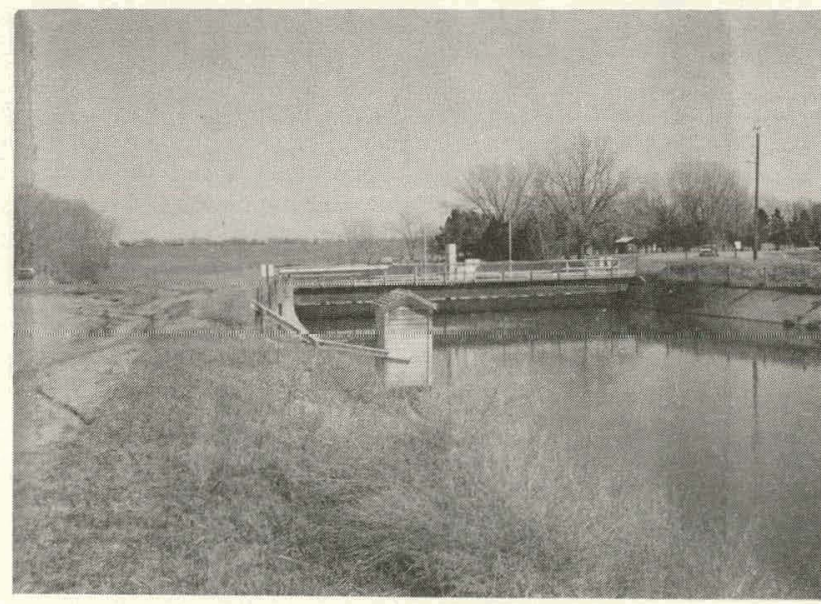

Julısun Lake Inlet Gate from Upstrcam, Supply Canal Right Foreground, Lake in Background, Location for Hydro Unit to Left of Inlet Gate.

\section{Figure 3.}




\section{d. TURBINE}

Vertical and horizontal shaft machines were comsidered. Francis type and propeller, fixed and adjustable, were checked. The tube type, horizontal shaft with adjustable blades was selected as the most reasonable. This 4-blade, 2,500 millimeter diameter turbine would fit the head and flow conditions. A butterfly valve would be used to shut off flow completely, for normal shutdowns, and for maintenance.

e. GENERATOR

The generator, a $600-\mathrm{KW}$ induction unit operating at 4,160 volt, connected to the turbine through a speed increase, would seem to fit the conditions. This could be connected to the local rural electric distribution system.

\section{f. GONTROL}

The turbine-generator unit would normally be on automatic control with remote monitoring and manual control possible. The automatic control would maintain the upstream water level essentially constant. Flows beyond the 250 to $700 \mathrm{cfs}$ limits of the turbine would be bypassed through the existing gate structure.

\section{g. ESTIMATED CONSTRUCTION COSTS}

Table 2, below, is a summary of the construction costs including contingency, engineering and financial costs totaling $\$ 3,380,000$.

\section{TABLE 2. Construction Costs}

$\begin{array}{lr}\text { On-Site Construction } & \$ 1,400,000 \\ \text { Equipment } & 1,980,000 \\ \text { Tota1 } & \$ 3,380,000 \\ \text { Tota1 Annual Cost } & \$ 296,000\end{array}$

\section{h. FEASIBILITY ANALYSIS}

Energy and Capacity Benefits are estimated at 24 mills per Kwh for the first $300,000 \mathrm{Kwh}$, and $20 \mathrm{mills}$ per Kwh for all additional energy and $\$ 5.60$ per Kw Month for capacity. The total annual benefits (1982) would be $\$ 116,600$ for a Benefit-toCost Ratio of 0.39 .

Present worth benefits were computed for a 40-year period as $\$ 3,334,000$ and Present Worth costs at $\$ 3,978,000$. This represents a Benefit-to-Cost Ratio of 0.84 .

\section{CONCLUSION}

The economic feasibility of the project was not shown on a time-of-construction basis or a present-worth basis.

Reasons for lack of feasibility is high construction cost. This includes: high machine costs per $\mathrm{KW}$, significant coffer dam and dewatering cost, and high civil construction costs since the water flow for generation must by-pass a major gate structure.

Continued project study was terminated, since economic feasibility was not shown. 


\title{
PIQUA HYDROELECTRIC PROJECT ON THE GREAT MIAMI RIVER \\ P1qua, Oh10
}

\author{
City of Piqua \\ R. W. Beck and Assoclates
}

PRDA Proposal Contract No. EW-78-F-07-1780

\section{INTRODUCTION}

In response to a Program and Research Development Announcement by the Department of Energy (DOE), the City of Piqua, Ohio (C1ty) submitted a proposal in February 1978 to study the feasibility of instalilng hydroelectric generating facilities at the existing City of Plqua Dam with financial assistance from the DOE.

The City's proposal was approved by the DOE and the grant was awarded to the City with the feasibility study work to be performed pursuant to Cooperative Agreement No. EW78-F-07-1780 between the City and the DOE.

The studies and investigations have included site reconnaissance, system loads, growth rate, site hydrology, conceptual project arrangements and layouts, power studies, estimates of construction costs, development of capital costs, economic feasibility, development of a design and construction schedule, and a preliminary environmental review of the proposed development.

\section{EXISTING DEVELOPMENT}

Plqua Dam is an existing dam owned by the City and is located on the Great Miami River in Miami County, Oh1o, approximately 30 miles north of Dayton, Ohio. The dam lies about 116 miles upstream from the mouth of the Great Miami River where it empties into the onlo River. The drainage area above the dam is 885 square miles and the average annual flow at the dam site is $759 \mathrm{cfs}$. The general location of Plqua Dam is shown in Exhibit A.

Plqua Dam was constructed in 1937 to provide a stable pool to supply condenser cooling water for the adjacent thermal electric generating station which is owned and operated by the city. The dam is an overflow type concrete gravity structure about 211 feet in length consisting of two uncontrolled overflow sections and three gated splilway bays. The reservoir Impounded by Piqua Dam extends upstream approximately 2.2 miles north from the dam site 1nto the City. The surface area of the reservolr at the normal pool level of El 844.0 is approximately 40 acres and has a gross volume at this elevation of about 155 acre-feet.

\section{DESCRIPTION OF PROPOSED PROJECT}

The Piqua Hydroelectric Project, as shown in Exhibit B, would consist of a new power installation on the left (east) bank downstream from the existing dam, incluaing a power intake, power conduit, powerhouse, tallrace channel, access road, and transmission line which would interconnect directly to the City's existing distribution system. The Project. would pose no unusual technical or environmental problems.

The intake structure would be founded on rock and will be equipped with a rectangular trashrack structure and a stoplog slot which would be used for dewatering the power conduit. The power conduit would consist of 10-foot diameter pre-cast concrete pipe which would be about 130 feet in length. Near the powerhouse the condult would bifurcate into two 7.5-foot diameter steel sections which would connect to the turbines. The powerhouse would be an above-ground Indoor-type reinforced concrete structure which would be founded on rock and would be watertight so as to eliminate damage to the equipment inside the powerhouse during periods of high riverflow. A short tailrace channel would be excavated from the powerhouse back out into the streambed to allow for a smooth return of powerhouse discharges to the natural stream channel. 
The Project would have an installed capacity of $400 \mathrm{~kW}$, consisting of two $200-\mathrm{kW}$ horizontal shaft tubular-type propeller turbines, operating under a rated net head of 8 feet. The average annual energy delivered to the City's distribution from the Project would be $1,462,000 \mathrm{kWh}$. Because of the wide varlation in streamflows and the lack of avallable pondage no firm (prime) energy or dependable capacity is obtainable from the Project operation.

\section{ECONOMIC ANALYSIS}

It is estimated that the Piqua Hydroelectric Project, for a January 1984 on-11ne date, would have a total investment cost of $\$ 2,828,000$, which is equivalent to about $\$ 7,000 / \mathrm{kW}$ installed at that time frame. The estimated total annual cost of the Project for the first year of operation is $\$ 289,000$. An economic analys is of the Project based on 40-year, $6.50 \%$ financing, shows intial year benefits from savings in fuel cost at the City's generating plant, as being substantialiy less than the first-year Project costs. over the f1rst 10 years of Project operation, a similar comparison shows a total 10-year present worth defic1t (January 1984 level) from Project operation of $\$ 1,807,000$, as shown in Table A. The unfavorable economics for this Project can be attributed primarily to the relatively high cost of generating equipment for this site (resulting from the very low avallable head), the wlde range of natural streamflow fluctuations at the site, and the lack of avallable pondage to allow daily peaking operations on a dependable basis during low flow periods.

\section{CONCLUSIONS}

The Profect is techinically and environmentally feasible and would present no unusual problems in construction. Based on the economic feasibility analysis, the Piqua Hyaroelectric Project does not show economic feasibility to the City during the first 10 years of operation and development of the Project cannot be justified. It is therefore recommended that the City abandon further consideration of the Project. 


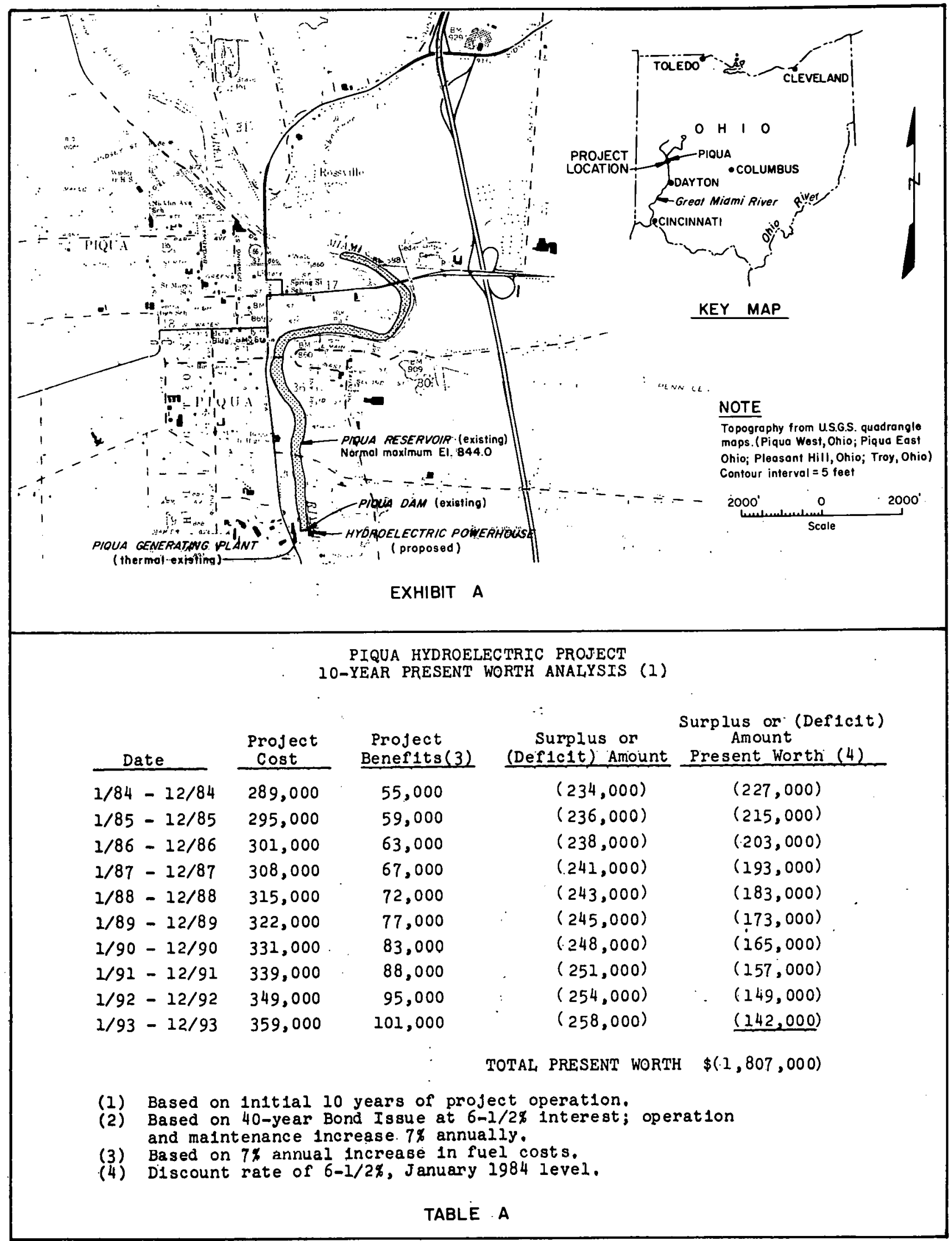




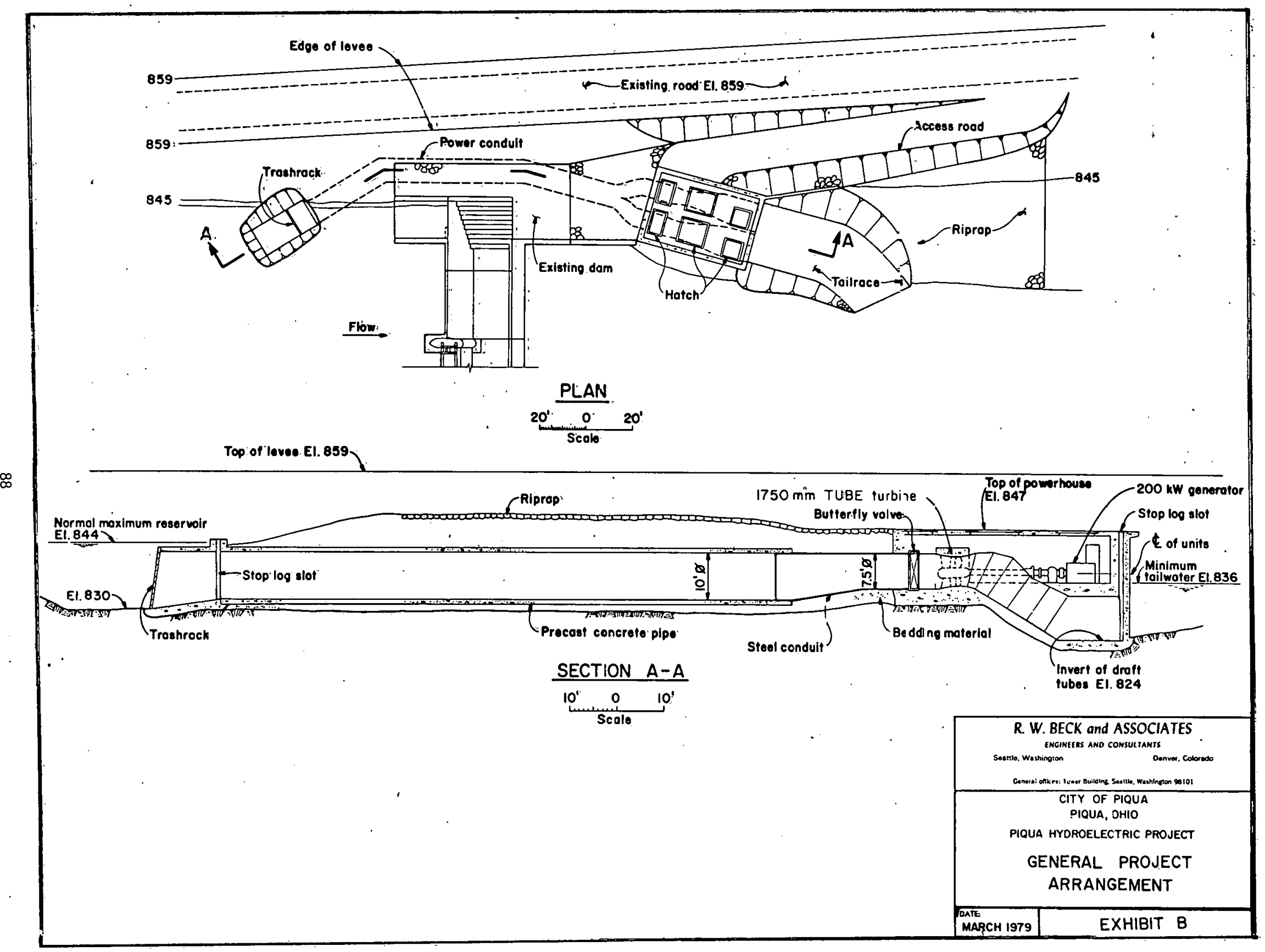




\section{PHILLIPS HYDROELECTRIC PROJECT}

Croton Falls, New York

New York State Energy Research and Development Authority Development and Resources Corporation

PRDA Proposal Contract No. EW 78-F-07-1782

\section{THE SITUATION}

Location and description. The Phillips site is located in Putnam County, New York. The town of Brewster is to the north and the town of Croton Falls is just south of the property. The property and the buildings form the Croton Falls Executive Park. Figure 1 shows a general plan of the Executive Park. The four buildings that are located in the Executive Park date back to the mid-1800's. These have been renovated; three have been converted into office space, and the fourth now houses the Diversified Insulation Products Limited.

History and present usage. The Phillips site has a great deal of historical significance. The North Salem Historical Society has recently designated the site a historical landmark. The local Chamber of Commerce has presented an awaxd for the quality of the site restoration.

The recorded history of the site dates back to 1754. It was then part of the Philip Philipse family holdings, which once encompassed nearly all of what is now Putnam County, New York. In 1884, the George Juengst family bought the property and water rights to the flow of the East Branch of the Croton River. The family firm, George Juengst \& Sons, generated electrical power at the site beginning in the late 1800's. This facility supplied the power needs not only of adjacent industry but also of nearby communities in northern Westchester and southern Putnam counties. On February 25, 1911, Justice Martin J. Keogh rendered a decision granting New York City "the right to divert or take from the East Branch of the Croton River all the waters of said East Branch of the Croton River and all tributaries thereof in excess of thirty million gallons per day." Walter T. Phillips, Jr., bought the property and water rights of the site on October 28, 1969. The site is leased to the Salem Energy Corporation.

Croton River System. The East Branch of the Croton River is a part of the Croton System of the New York water supply network. There are storage reservoirs both above and below the site. Natural flows above 30 million gallons per day are subject to diversion (at the Diverting Reservoir) into the Croton Falls Keservoir on the West Branch of the Croton River.

Diversion Dam. The diversion dam is an overflow gravity structure of cyclopean construction completed in the $1880^{\prime} \mathrm{s}$. The dam is $22 \mathrm{feet}$ in height. The dam will require remedial work to insure the dam's continued safety.

Forebay, intake and penstocks. When the site was operated for the production of hydroelectric power, water was conveyed from the forebay via penstocks 48 inches in diameter to two powerhouses located further downstream.

Powerhouse. Two power plants were originally in operation at the site. The plants operated to produce hydroelectric power from the late $1800^{\prime}$ 's to 1956 . 


\section{REDEVELOPMENT ALTERNATIVES}

A full rarge of potential redevelopment alternatives for the Phillips Hydroelectric Project were assessed. Reuse of the buildings where hydroelectric power was once generated was not considered in any of the redevelopment alternatives. The reason for this is that the buildings have been converted to other uses. Therefore, locations immediately downstream of the existing diversion dam and adjacent to the lower powerhouse.were investigated. A total of six different alternatives inyolving three turbine manufacturers were evaluated. Table 1 displays the pertinent technical and related information for the six alternatives studied. The six alternatives studied are as follows:

Alternative 1 (Upper site) - Allis-Chalmers: The unit is referred to by Allis-Chalmers as their Standardized Hydroelectric Generating Unit because it comes as a complete package which includes the turbine, intake butterfly valve, speed increaser, generator, blade positioner, hydraulic power unit, flexible coupling, indoor generator protection and control panel, outdoor high voltage module which contains a cubicle for revenue metering equipment, utility interface, high voltage switch and fuse, generator power circuit breaker, and the power transformer. This unit will operate over a flow range of 39 to 88 cubic feet per second with a net head of 19.7 feet. Its corresponding turbine efficiencies would be 79 percent at around 40 percent load to 85.5 percent at full load. The turbine is of the propeller type with adjustable blades for flow control installed in a horizontal position in a steel shell. A gear box is provided to increase the turbine runner speed from 525 to $900 \mathrm{rpms}$ so as to be able to utilize a standard type generator. Speed control is accomplished by use of a Woodward UG type governor. Delivery time for this complete standardized hydroelectric generating set would be six to nine months. Complete shutdown would be accomplished with the upstream bulkhead.

Alternative 2 (Lower site) - Allis-Chalmers: Alternatives 1 and 2 are identical except that for alternative 2 a larger unit is required due to the greater head that would be available ( 40 versus 20 feet).

Alternative 3 (Upper site) - Leffel Turbine: The turbine for this location will operate over a flow range of 97 to 161 cubic feet per second with a net head of approximately 21 feet. Its corresponding turbine efficiency would vary from 70 percent at one-half load to 85 percent at full load. This turbine is of the vertical propeller type installed in an open flume setting. The wicket gate operating mechanism will be connected to a gate shaft which will in turn extend up to the generator floor for connection to the governor which would be of the Woodward type. Complete shutoff would be accomplished with the upstream headgate.

Alternative 4 (Lower site) - Leffel Turbine: The turbine is basically the same as for alternative 3 with the exception that it will operate with a higher head ( 40 versus 21 feet) and be encased in a concrete pressure flume setting. Positive closure would be accomplished with the upstream headgate.

Alternative 5 (Upper site) - Ossberger: The unit is referred to by Ossberger as their Hydroelectric Generating Set.. It comes as a package complete with intake transition piece, cross-flow turbine, oil bath speed increaser, synchronous generator, governor, high and low speed coupling, foundation frame for the turbine, draft tube, flywheel, generator control panel and miscellaneous piping, bolts, etc. The generating set will operate over a flow range of 25 to 150 cubic feet per second with a net head of 21 feet. Its correspondingturbine efficiencies would be 80 percent at about one-sixth load to 83 percent at full load. The Ossberger unit is of West Germany manufacture and is a radial, modified impulse type turbine with cylindrical runners. The flow to the units is controlled by adjustable guide vanes that can be closed, thereby providing the function of upstream valves or gates. The units are provided with draft tubes for full head recovery. The generating sets include a flywheel to aid in control of speed during load changes. The turbines are low speed $(136 \mathrm{rpm})$, therefore, speed increasers are provided to permit the use of high speed ( $1200 \mathrm{rpm})$ standard generators. To prevent water column separation and loss of head the manufacturer recommends a maximum draft head of 12 feet. The manufacturer indicates that around 12 - 14 months will be required for delivery and that about 65 percent of equipment and materials will be of North American origin.

Alternative 6 (Lower site) - Ossberger: This alternative is the same as for alternative 5 with the exception that it will operate under a higher head ( 40 versus 21 feet). Positive closures would be accomplished with the upstream headgate. 


\section{PROJECT OPERATION}

Energy Production. Flows on the East Branch at the Phillips site are influenced by upstream regulation and the release pattern policy carried out by the New York City Department of Water Resources. At the present time the release policy governing flow down the East Branch of the Croton River below Diverting Reservoir is generally as follows:

"Pass 5 mgd through the blowoff into the East Branch of the Croton River from Diverting Reservoir and allow the remainder of the inflow to pass into Croton Falls Reservoir through the unregulated weir located on the west side of the reservoir. In addition, if the inflow is sufficient, the remainder will pass over the unregulated spillway at Diverting Reservoir into the East Branch of the Croton River. "

By court action in 1911 , a decision was rendered which granted New York City 'the right to divert or take from the. East Branch of the Croton River all the waters of said East Branch of the Croton River and all tributaries thereof in excess of thirty million gallons per day."

For purposes of this study, simulated flows below Diverting Reservoir for the period $1927-1976$ were adopted for use in developing monthly and annual flow duration curves. Flow duration curves were used to determine the amount of energy that can be developed on an annual or monthly basis for the six alternatives studied. Table 1 shows the annual energy potential of the six alternatives studied. All alternatives studied would be capable of producing some power in any given month. There will be periods when no power or energy can be produced due to the flows being insufficient to meet the minimum requirements of any of the turbines studied. Therefore, no firm power or energy under the classical definition will be available.

If pending action to implement Part 672 - Sub Part 672-3 of New York State's Reservoir Releases Regulation is adopted, a minimum flow of $30 \mathrm{mgd}$ would be assured at the Phillips site. This would provide for developing 60 to 110 kilowatts of firm capacity capable of producing firm energy in the range of 500,000 to $1,000,000$ kilowatt hours annually.

\section{PROJECT ECONOMICS}

Energy market evaluation. The value of electricity generation from the Phillips Hydroelectric Project depends on both the nature of generation from the plant and the economics of the power purchaser. A discussion of the production characteristics, power purchaser economics and value of energy follows:

Production Characteristics. The project as envisioned has no capability for short term ponding. Therefore, the project is a run-of-the-river hydro development where electricity must be generated when flow is available or the energy is lost. There may be periods of no generation, particularly in the summer months of July through October. There is pending action to implement the Reservoir Release Regulations Part 672. If implementation is in accordance with the recommendations, a minimum flow of 46 cubic feet per second would be assured on the East Branch of the Croton River below Diverting Reservoir. This magnitude of flow would make it possible to develop firm capacity at the Phillips Hydroelectric Project.

Power Purchaser Economics. The Phillips site is located in the service area of New York State Electric \& Gas Corporation (NYSE\&G). The NYSE\&G is a part of a larger utility pool known as the New York Power Pool (NYPP). NYSE\&G's generation sources differ significantly from the NYPP as a whole. Whereas the NYPP has $59 \%$ of total generating capacity oil fired, NYSE\&G has none. A full $25 \%$ of NYSE\&G energy is received from Power Authority of the State of New York (PASNY) at extremely low energy rates. The sources of this energy are primarily the Niagara and St. Lawrence hydro developments with some energy from the Fitzpatrick Nuclear Station. Another $67 \%$ comes from their own coal fired plants and the remaining $8 \%$ is coming from other utilities and the NYPP.

Value of Phillips Power and Energy. The project will have energy displacement value to NYSE\&G and some capacity value due to the particulars of the project and NYSE\&G's load. For energy value calculations, a combined escalation rate of $8 \%$ was adopted to account for general inflation plus increases in general electric rate. Therefore, the 1978 non-firm energy value in NYSE\&G's system is $17.5 \mathrm{mills}$ escalating at $8 \%$ per year. The project may also have capacity value even if no firm capacity can be 
developed since NYSE\&G is a winter peaking utility. The company is required to maintain more capacity in the winter than the summer and does so by purchasing additional winter capacity from other systems. The winter months, November through April, are also the months of sustained higher flow in the East Branch of the Croton River below Diverting Reservoir. Energy calculations show that most of the options have average plant factors over 70 percent in these months. This high plant factor and the system's winter peak load indicate a capacity credit may be warranted. Since the Phillips power plant would be displacing energy from the oil and coal fired sources, any capacity value of the plant would be associated with the cost of coal and oil fired capacity. A figure of $\$ 3.00$ per kilowatt credit was adopted for use in the study for a capacity value. The value of the plant's output to the site owner can take a number of forms. This is because (1) Diversified Insulation Products Limited is located on the site and is a ready market for the plant's output and (2) the characteristics of the plant's output make it such that there will be periods when either insufficient or surplus energy will result. The apparent options the site owner has are:

Option 1 -- The owner keeps his existing service at the insulation factory-and sells his entire output from the generating plant to NYSE\&G.

Option 2 -- The owner serves the insulation factory from the hydroelectric plant and provides standby power with service from NYSE\&G.

Option 3 -- The owner serves the insulation factory direct from the hydroelectric plant and provides standby power with a diesel engine driven generator set and sells surplus power to NYSE\&G.

Option 4 -. The owner serves the insulation factory direct from the hydroelectric plant with standby service from NYSE\&G and sells surplus power to NYSE\&G.

Figures 2, 3, and 4 show a graphical display of the benefit to cost ratio over the project life of 40 years for alternatives 2,4 , and 6 . 'l'he criteria that was applied in evaluating the economic and financial feasibility follows:

- The project was analyzed as a stand alone venture receiving the full economic value for the energy produced. This perspective results in the true economic merits of the project being established.

-Inflation in both the cost and revenue streams has been explicitly incorporated. A $6 \%$ general inflation and a $8 \%$ escalation rate for energy was assumed.

- The project has been assumed to be both owned and financed by the site owner. For financial feasibility, 40 year, $10 \%$ funds were assumed.

- Average annual energy production has been assumed.

- Three year construction period with escalation in capital costs at the general inflation rate has been used. Capital expenditures have been split $20 \%$ in the first year and $40 \%$ in each of the following two years.

- A sinking fund has been calculated which will provide sufficient funds in future dollars to perform major repairs and replacements.

Economic analysis compares the time value of the cost stream with the benefit stream. Evaluation criteria such as the internal rate of return (IRR), net present value and benefit-cost analysis are used. Both the IRR and benefit-to-cost criteria were used. The IRR is defined as the interest rate at which the present value of the discounted cost and benefit streams, excluding capital recovery, are zero. Table 2 displays the results of the economic and financial analysis for the six alternatives studied based on selling all of the plant's output to NYSE\&G. 
TABLE 1

GENERATING UNITS - - ALTERNATIVES INVESTIGATED

\begin{tabular}{|c|c|c|c|c|c|c|c|}
\hline $\begin{array}{l}\text { Alternative } \\
\text { and Turbine } \\
\text { Manufacturer }\end{array}$ & $\begin{array}{c}\text { No. of } \\
\text { Units }\end{array}$ & $\begin{array}{c}\text { Generator } \\
\text { Output } \\
(\mathrm{KW})\end{array}$ & Orientation & $\begin{array}{l}\text { Turbine } \\
\text { Type }\end{array}$ & \multicolumn{2}{|c|}{ Speeds - RPM } & $\begin{array}{c}\text { Annual Energy } \\
\text { Production }\end{array}$ \\
\hline 1-Allis-Chalmers & 1 & 130 & $\mathrm{H}$ & AP & 525 & 900 & $785,000 \mathrm{KWH}$ \\
\hline 2 - Allis-Chalmers & 1 & 300 & $\mathrm{H}$ & $\mathrm{AP}$ & 586 & 900 & $1,822,500 \mathrm{KWH}$ \\
\hline $4-$ Leffel & 1 & 439 & $\mathrm{~V}$ & $P$ & 514 & 514 & $1,693,100 \mathrm{KWH}$ \\
\hline 5 - Ossberger & 1 & 202 & $\mathrm{H}$ & $C F$ & 98 & 1,200 & $1,110,700 \mathrm{KWH}$ \\
\hline 6 - Ossberger & 1 & 386 & $\mathrm{H}$ & CF & 135 & 1,200 & $2,096,000 \mathrm{KWH}$ \\
\hline
\end{tabular}

LEGEND:

$\mathrm{H}$ - Horizontal

$\mathrm{V}$ - Vertical

AP - Adjustable Blade Propeller

CF - Cross Flow

P - Propeller 


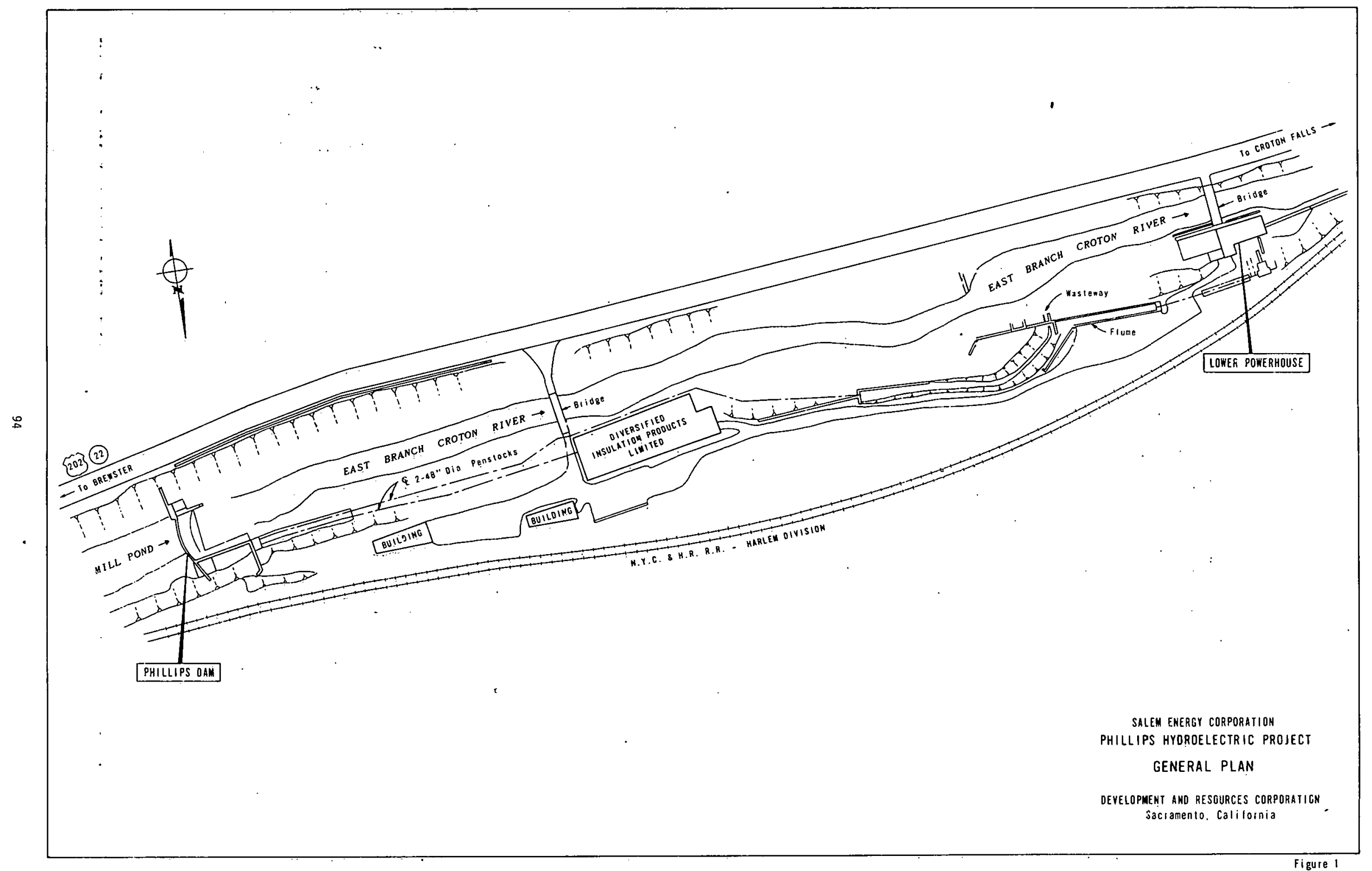

Figure 1 


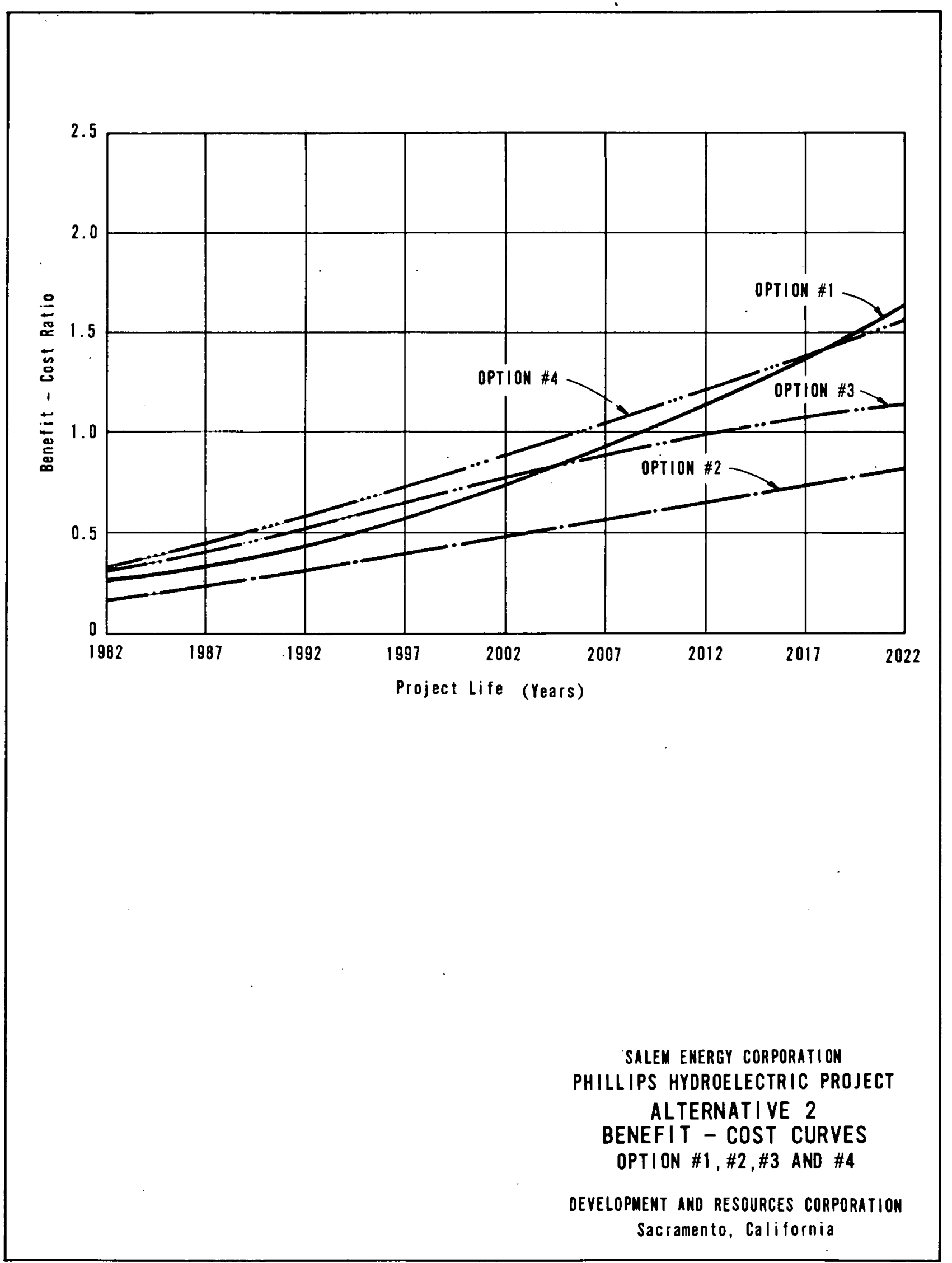

Figure 2 


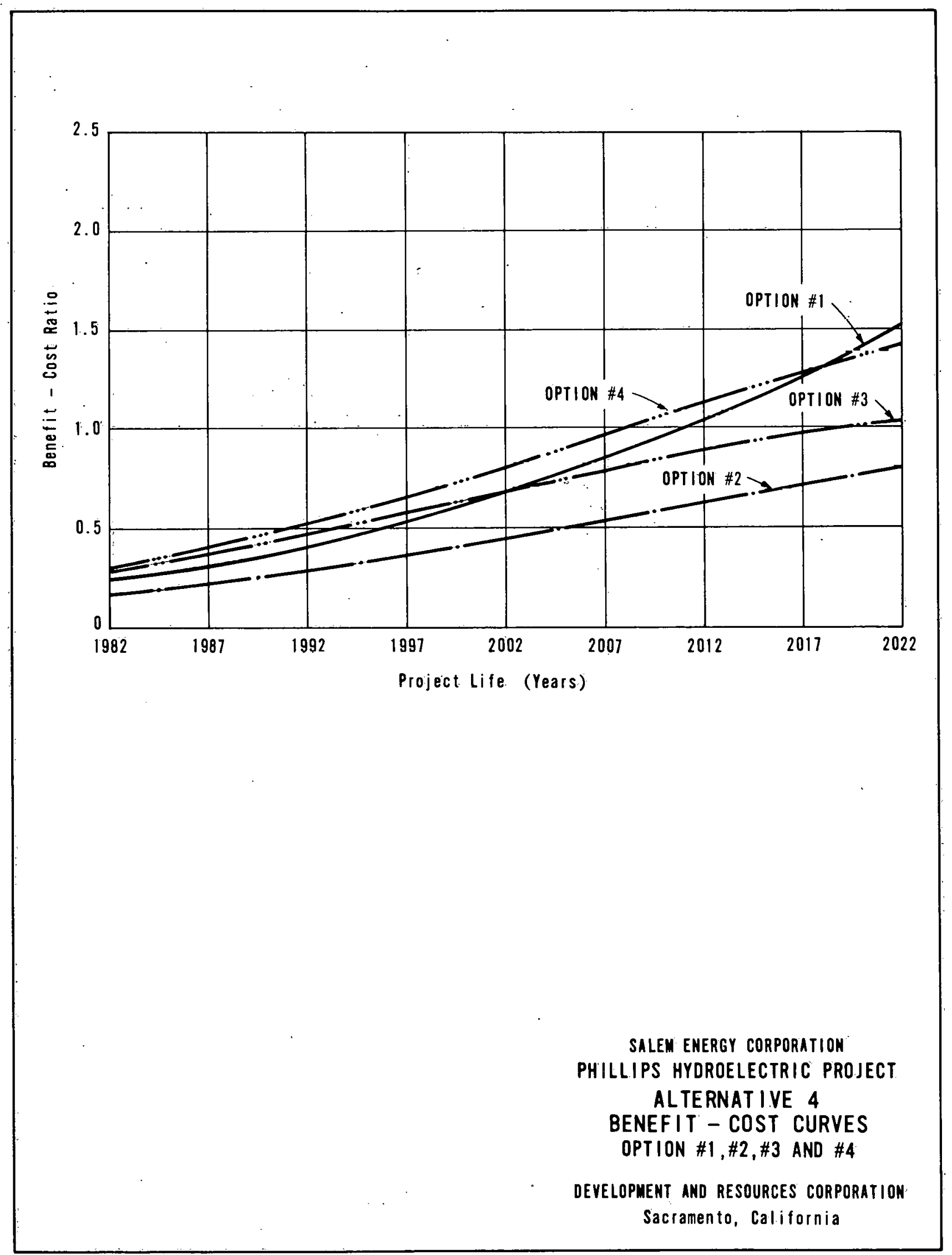

Figure 3 


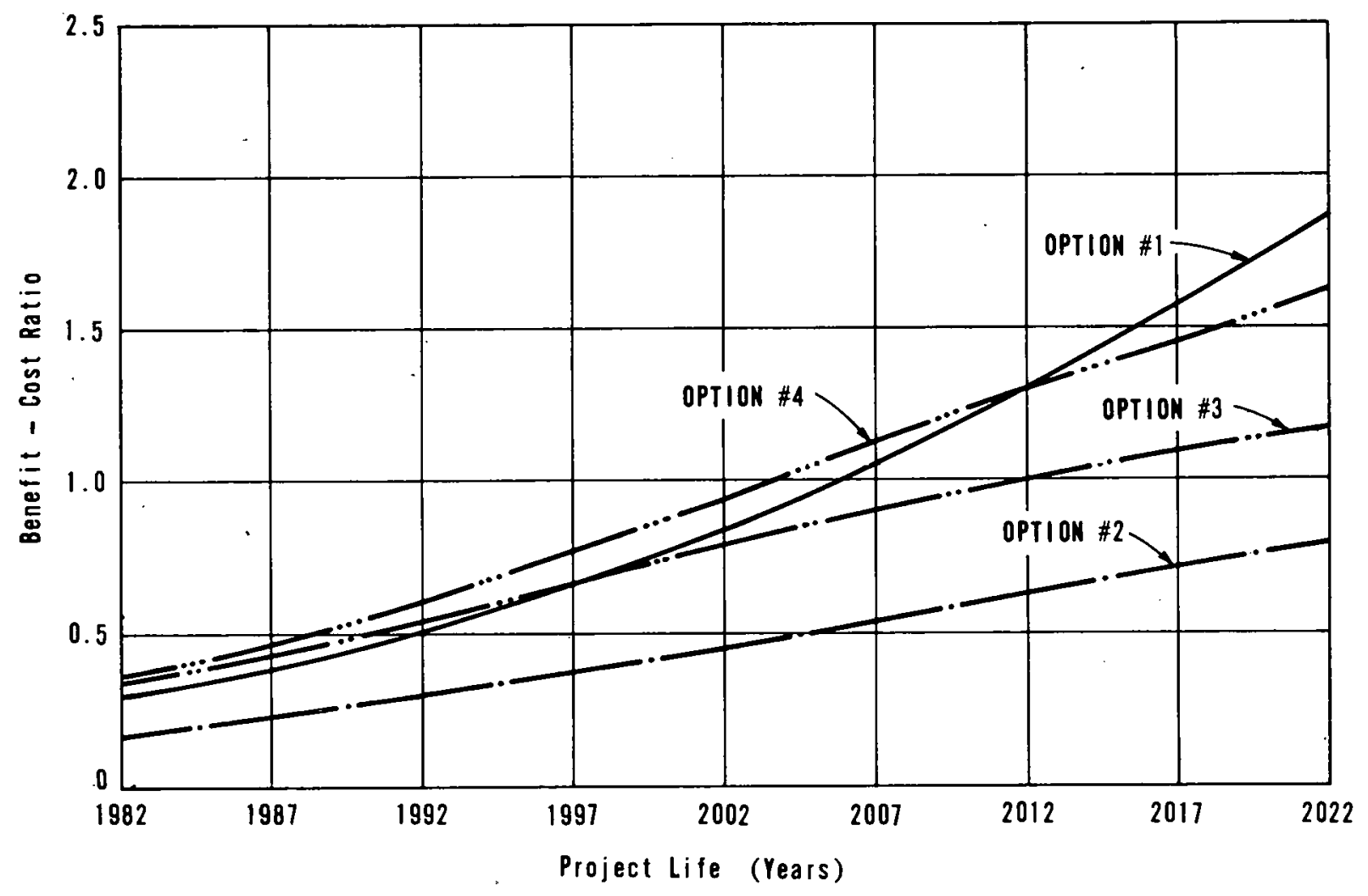

SALEM ENERGY CORPORATION PHILLIPS HYDROELECTRIC PROJECT

ALTERNAT IVE 6 BENEFIT - COST CURVES OPTION \#1,\#2,\#3 AND \#4 DEVELOPMENT AND RESOURCES CORPORATION Sac ramento, California 
TABLE 2

SUMMARY OF ECONOMIC AND FINANCIAL ANALYSIS

\begin{tabular}{|c|c|c|c|c|c|c|}
\hline \multirow[b]{2}{*}{ ITEM } & \multicolumn{6}{|c|}{ ALTERNATIVE } \\
\hline & 1 & 2 & 3 & 4 & 5 & 6 \\
\hline Capital Costs & $\$ 819,265$ & $\$ 1,068,217$ & $\$ 855,789$ & $\$ 1,155.000$ & $\$ 824,170$ & $\$ 1,087,900$ \\
\hline Bonds Required & $\$ 949,400$ & $\$ 1,236,600$ & $\$ 990,000$ & $\$ 1,337,300$ & $\$ 955,200$ & $\$ 1,259,800$ \\
\hline $\begin{array}{l}\text { Repairs \& Replacement } \\
\text { PV of R\&R thru } 30 \text { years } \frac{1}{1} \\
\text { Annual S.F. ( } 30 \text { years }) \text { I/ }\end{array}$ & 4,000 & 3,900 & 3,300 & 3,500 & 4,400 & 4,400 \\
\hline $\begin{array}{l}\text { Annual Costs } \\
\text { Debt Amortization }(10 \%\end{array}$ & & & & & & \\
\hline $\begin{array}{l}\text { Interest) } 40 \text { years } \\
\text { O\&M } 3 \text { - } \\
\text { Administration }(20 \% \text { of } 0 \& M) \\
\text { Insurance }(0.2 \% \text { of Capital }\end{array}$ & $\begin{array}{rr}\$ 97,100 \\
\$ 29,800 \\
\$ \quad 6,000\end{array}$ & $\begin{array}{rr}\$ & 126,500 \\
\$ & 29,800 \\
\$ & 6,000\end{array}$ & $\begin{array}{l}\$ 101,200 \\
\$ 29,800 \\
\$ \quad 6,000\end{array}$ & $\begin{array}{rr}\$ & 136,800 \\
\$ & 29,800 \\
\$ & 6,000\end{array}$ & $\begin{array}{l}\$ 97,700 \\
\$ 29,800 \\
\$ \quad 6,000\end{array}$ & $\begin{array}{lr}\$ & 128,800 \\
\$ & 29,800 \\
\$ & 6,000\end{array}$ \\
\hline $\begin{array}{l}\text { Costs) } \\
\text { License Fee } \underline{4} /\end{array}$ & $\begin{array}{ll}\$ & 1,800 \\
\$ & 2,400\end{array}$ & $\begin{array}{ll}\$ & 2,400 \\
\$ & 2,400\end{array}$ & $\begin{array}{ll}\$ & 1,800 \\
\$ & 2 ; \\
\$ & 400\end{array}$ & $\begin{array}{l}2,400 \\
2,400\end{array}$ & $\begin{array}{ll}\$ & 1,900 \\
\$ & 2,400\end{array}$ & $\begin{array}{ll}\$ & 2,400 \\
\$ & 2,400\end{array}$ \\
\hline $\begin{array}{l}\text { Plant Data } \\
\text { Installed kw } \\
\text { Average Annual Energy( kwh) }\end{array}$ & $\begin{array}{c}130 \\
785,000\end{array}$ & $\begin{array}{l}300 \\
1,822,500\end{array}$ & $\begin{array}{c}242 \\
900,000\end{array}$ & $\begin{array}{c}46.2 \\
1,693,100\end{array}$ & $\begin{array}{c}221 \\
1,110,700\end{array}$ & $\begin{array}{r}418 \\
2,096,000\end{array}$ \\
\hline$\$ / \mathrm{kw}$ Installed & $\$ 6,302$ & $\$ 3,560$ & $\$ 3,536$ & $\$ \quad 2,500$ & $\$ 3,729$ & $\$ \quad 2,602$ \\
\hline 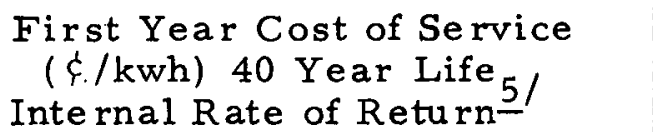 & 17.95 & 9.38 & 16.05 & 10.57 & 12.79 & 8.29 \\
\hline $\begin{array}{l}40 \text { Year Life } \\
\text { Net Funds in First Year }\end{array}$ & $\begin{array}{r}-6.0 \% \\
-\$ 121,700\end{array}$ & $\begin{array}{c}6.6 \% \\
-\$ 125,900\end{array}$ & $\begin{array}{c}-0.8 \% \\
-\$ 121,500\end{array}$ & $\begin{array}{c}5.9 \% \\
-\$ 137,300\end{array}$ & $\begin{array}{r}2.4 \% \\
-\$ 114,500\end{array}$ & $\begin{array}{l}7.8 \% \\
-\$ 121,700\end{array}$ \\
\hline
\end{tabular}

1/Present Value of Repairs \& Replacements at Start of Operations

2/Annual Sinking Fund Starting in First Year of Operation

3/ 4/ Annual Costs Starting in First Year of Operation

5/Energy Value of 22.0 mils/kwh in First Year of Operation 
LOWER MAIN CANAL HYDRO STATIONS

\author{
Modesto, California \\ Modesto Irrigation District \\ CH2M Hill \\ PRDA Proposal Contract No. EW-78-F-07-1783
}

\title{
I. INTRODUCTION
}

The Modesto Irrigation District is located in central California and is a publicly owned Irrigation District supplying both agricultural water to the farm land within its District and electrical power to its residential, commercial, industrial and agricultural customers. Water for irrigation is distributed by gravity in open concrete lined canals from a regulation storage facility known as Modesto Reservoir. For some distance below the reservoir the water is transmitted in a single canal known as the Main Canal before fanning off into distribution laterals. Two sites, one at the outlet of Modesto Reservoir and one at a drop in the Main Canal known as "Stone Drop" are the subject of this study, since these two sites represent the greatest potential for hydroelectric power development on Modesto's canal system.

Since the District is in the power transmission and distribution business, any power generated at the project could readily be utilized by the existing electrical system.

\section{PROJECT}

The study considered the alternative layouts and turbine generator units for each of the two sites. Characteristics of the proposed plants are:

\begin{tabular}{|c|c|c|c|c|}
\hline & $\begin{array}{l}\text { Rated } \\
\text { F1ow } \\
\end{array}$ & $\begin{array}{l}\text { Gross } \\
\text { Head } \\
\end{array}$ & $\begin{array}{l}\text { Installed } \\
\text { Capacity } \\
\end{array}$ & $\begin{array}{c}\text { Average Annual } \\
\text { Energy Production }\end{array}$ \\
\hline Modesto Reservoir & $750-800 \mathrm{CFS}$ & 18 feet & $1000 \mathrm{KW}$ & $3,370,000 \mathrm{KWH}$ \\
\hline Stone Drop & $750-800 \mathrm{CFS}$ & 19 feet & $1000 \mathrm{KW}$ & $4,020,000 \mathrm{KWH}$ \\
\hline
\end{tabular}

The estimated c̀apital investment is $\$ 3,166,000$ for development of both sites.

III. SUMMARY

Feasibility analysis of the power. plants involved comparing the value of the output of the proposed project with the alternative of continuing to buy the equivalent amount of power at wholesale rates from the present neighboring power supplier. While some sensitivity studies were conducted, the most probable cost of power from the project was estimated to be $40.4 \mathrm{mills} / \mathrm{KWH}$ in 1979 . An analysis on an annual basis indicated a Benefit-Cost ratio of $.71: 1$ for the project. Additionally, a 30 year discounted cash flow analysis was conducted using anticipated escalation rates for maintenance and operation costs and energy and capacity values. This study indicated that the Benefit-Cost ratio on a 30 year present worth basis was $1.41: 1$. On this basis the project cuuld be considered feasible.

Since the project is small and located on sites already owned by the Modesto Irrigation District, few constraints, other than financial, appear to developing the project. Since the Benefit-Cost ratio ranges from less than $1: 1$ to greater than $1: 1$ the project could be considered somewhat marginal. The availability of grant funds could be a determining factor in proceeding with the project.

The development of these and similar projects should be encouraged, so as to improve the available technology and the availability of equipment for this size plant. Developing agencies could then proceed with greater confidence that their projects would be truly financially feasible. 


\title{
CHICOPEE FALLS DAM
}

\author{
Chicopee, MA \\ Chicopee Municipal Lighting Plant and Raytheon Service Co. \\ Raytheon Service Co. \& Acres American Inc. \\ PRDA Proposal Contract No, 1784
}

\section{INTRODUCTION}

This project is located at the Chicopee Falls Dam in Chicopee, Massachusetts: The Chicopee Falls Dam is on the Chicopee River a few miles upstream from its confluence with the Connecticut River. The dam and the land which would be required for the project is owned by the City of Chicopee.

The projected facility controls a 714 square mile drainage area and would utilize 16 feet of gross head developed by the Chicopee Falls Dam and an additional 10 feet of head at the site of a former dam 580 feet downstream. The plant would generate 9,000,000 kilowatt hours of electricity annually with an installed capacity of $1,600 \mathrm{~kW}$. Project cost is estimated to be $\$ 4,053,750$ at 1978 price levels. This yields a capital cost per kilowatt of $\$ 2,534$.

The selected design utilizes an 11 foot diameter penstock beginning at the existing gatehouse at the dam and running parallel to the river bed along an existing flood control wall. For most of its length the penstock would be partly or wholly buried. The powerhouse location is between the existing flood control wall and the river. The type of turbine chosen is a single tube unit.

The projected hydroelectric facility would be owned and operated by the Chicopee Municipal Lighting Plant (CMLP). All power received would be distributed by CMLP to existing residential, commercial and industrial customers within its service area. The hydropower site is only a few hundred feet from a connection to the CMLP-maintained grid. CMLP is a public utility owned by the City of Chicopee.

The site is typical of many in New England. The dam is soundly constructed and there are no factors to indicate that installation of hydropower at the dam would increase flood risk or cause other changes that would place insurance costs in a special category. The city has placed no value upon property or water rights so that the projected costs reflect only improvements to the site. Environmental impacts of the proposed development have been judged to be minor, and negative impacts seem to be balanced by several favorable effects.

\section{ECONOMICS}

The feasibility of the project at Chicopee is essentially dependent upon its economic attractiveness, since no important regulatory or environmental obstacles exist. Economic feasibility has been measured principally in terms of net present value (NPV). CMLP's main alternative to investing in the hydroelectric project is to continue buying power under existing power purchase contracts that provide it with relatively low cost power (presently under 30 mills per $\mathrm{kWh}$ ). NPV was calculated with revenue valued at 30.7 mills in 1979, escalated at 6 percent, and alternatively at 9 percent, for 10 years. Costs were escalated at 6 percent, also for 10 years. Project life is taken as 40 years and the interest rate used is $81 / 3$ percent. NPV is highly negative, indicating the project is not feasible for CMLP: 
Costs and revenues both escalate at $6 \%$ annually for 10 years Costs escalate at $6 \%$ for 10 years and revenues at $9 \%$, also for 10 years
NPV $\left(\$ 1,000^{\prime} s\right)$

$-\$ 5,392$

$-\$ 4,053$

The poor showing is accounted for on the cost side by the high capital cost of the project, $\$ 4,053,750$ (only coincidentally similar to the minus $\$ 4,053,000 \mathrm{NPV}$ above), and the high level of payments in lieu of taxes. The high capital cost leads to a high cost for repayment of bond principal and interest, equal during the first year of project operation to 43 percent of total annual costs. Payments in lieu of taxes equal 46 percent of total annual costs the first year.

\section{ENGINEERING CONCE PT DESIGN}

In arriving at the recommended installation, major design decisions were made concerning location of the power plant, equipment type, and capacity of the generating facility.

Two locations were considered initially, one at the dam, the other at the downstream location ultimately selected for the powerhouse. The $\mathrm{kWh}$ generation available from using the increased head at the downstream site was more than 50 percent greater than that available at the dam, and easily justified the additional cost. Having selected the downstream site, analysis concentrated on evaluating equipment types and powerhouse designs at that location.

Equipment alternatives evaluated for the downstream site included a single tube unit, a two-unit double horizontal Francis turbine installation and a three-unit, cross-flow Ossberger installation. Total project cost comparisons favor the tube turbine:

One $1,600 \mathrm{~kW}$ tube unit

Two $800 \mathrm{~kW}$ double Francis units

Three $500 \mathrm{~kW}$ Ossberger units
Total Project Cost $\left(\$ 1,000^{\prime} s\right)$

$$
\begin{aligned}
& \$ 4,054 \\
& \$ 5,189 \\
& \$ 5,207
\end{aligned}
$$

In addition to the cost advantage, technical considerations such as the compact size of the civil works required also favored the tube turbine.

To analyze optimal size capacity of the installation, four tube turbines having capacities of $1,300 \mathrm{~kW}, 1,600 \mathrm{~kW}, 1,900 \mathrm{~kW}$, and $2,200 \mathrm{~kW}$ were compared. The benefit-cost ratios for the smallest and largest of these were less than those for the two in the middle. Benefit-cost ratios of the 1,600 and $1,900 \mathrm{~kW}$ units were found to be nearly identical, and the $1,600 \mathrm{~kW}$ unit was therefore recommended as the more conservative choice. This decision would be reviewed if the project goes forward to detailed engineering.

The facilities plan and the powerhouse design are shown on the following pages. 


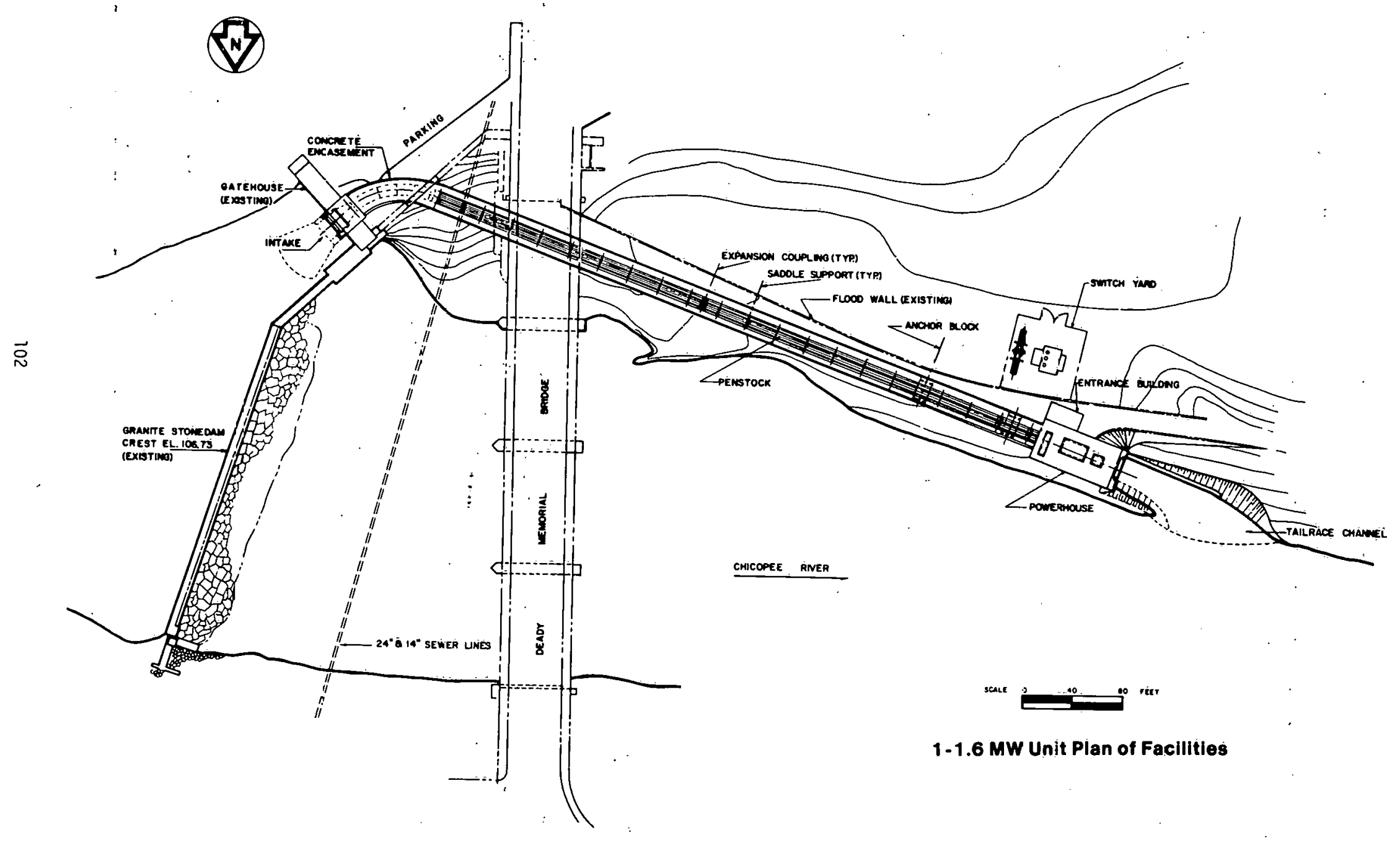




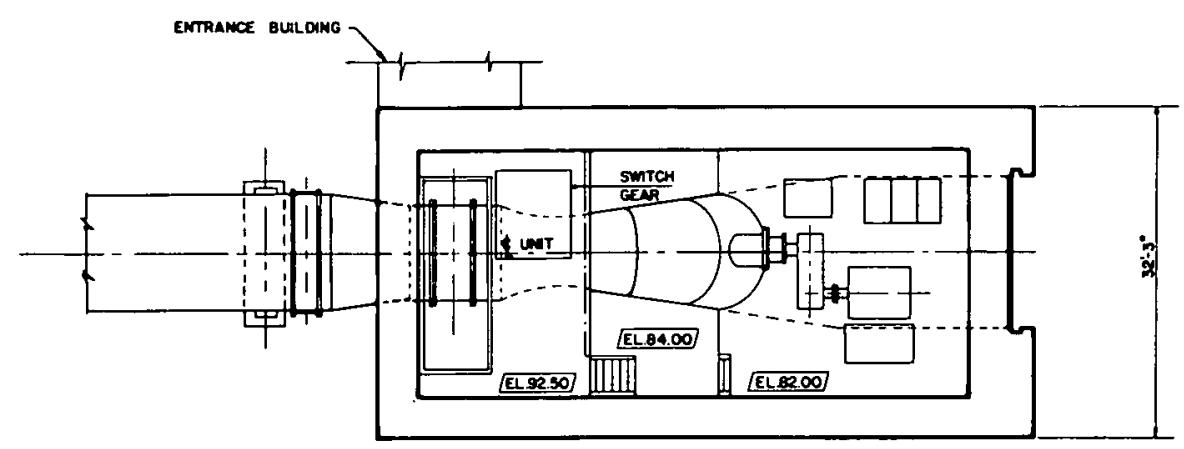

SECTIONAL PLAN ABOVE TURBINE FLOOR

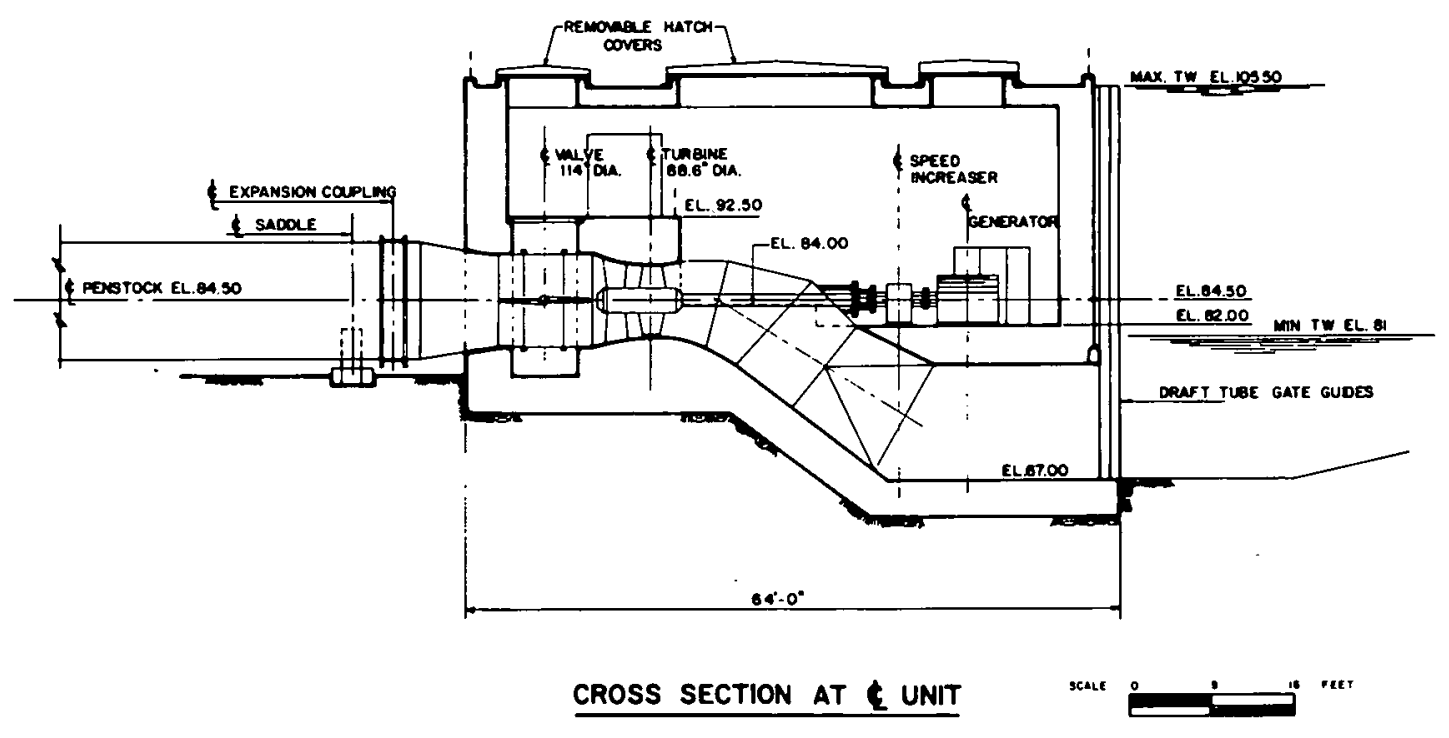

1-1.6 MW Unit Tube Turbine 


\title{
LEWISTON CANAL DEVELOPMENT
}

Lewiston, Maine

\author{
Central Maine Power Company \\ Kleinschmidt and Dutting Consulting Engineers
}

PRDA Proposal Contract No. EW-78-F-07-1785

The feasibility assessment of the hydroelectric potential of the Red Shop site on the Lewiston Canal System in Lewistun, Maine, involved two separate but related studies. The evaluation of the current and potential hydroelectric capability of the entire Lewiston Canal System and an indepth evaluation of the hydroelectric development potential of the Red shop site, In order to select the most practical development alternative for the Red Shop site, it was essential to ascertain the future capability of the canal system and the ability of the canal system to deliver usable water to the Red Shop site.

The existing canal system was designed and constructed to handle a flow of approximately 4,000 cfs. At the time of our study, several units were out of service for short term repairs so that only half of this flow was being utilized. These repairs are expected to be completed during 1979, at which time the canal system will be operating at approximately $85 \%$ of its original design capacity. Our evaluation of the canal system indicated that it is possible to operate the canal system at a peak flow rate of $4500 \mathrm{cfs}$. Central Maine Power Company (CMP) concluded that the canal system has ample hydraulic capability to permit the redevelopment of the Red shop Station with a flow capacity of approximately $1600 \mathrm{cfs}$. Our study of the canal system concluded that when it is operated with the proposed Red Shop development on line, it would be advisable to install more sophisticated, automatic water level monitoring equipment to protect adjoining land owners from overflows and flooding. Our review of the structural condition of the canal system concluded that no significant structural repairs need be made to implement the proposed Red Shop project.

The study found that some of the existing hydroelectric equipment in use on the canal was inefficient and showed signs of significant deterioration. The majority of the units on the canal system are currently owned by CMP and operated by Bates Fabric Incorporated under a 14 year lease arrangement. If existing hydroelectric units are abandoned by Bates Fabric for a period of 12 months, the operating rights automatically revert to CMP. As the useful life of the existing units continues to deteriorate and Bates Fabric abandons them, CMP is committed to rebuilding them to a reasonable level of efficiency and continuing.to operate them for the long term. The efficiency of the individual units on the canal ranges from $32 \%$ to $75 \%$. Improvement of the canal's total hydropower output would require rehabilitation of some salvageable units and reallocation of canal flows from the less efficient units to the more efficient one proposed for the Red shop site.

Central Maine Power Company evaluated six separate redevelopment al.ternatives as part of this study. These involve two powerhouse sites one the present Red shop building location and the other a site at the end of Cross Canal No. 1 on the shore of the Androscoggin River. Three of the alternatives considered continued operation of the existing inefficient units on the lower canal system with a resultant developable flow to the Red shop site of $1000 \mathrm{cfs}$. The other three alternatives considered diverting flow from some inefficient units on the lower canal to a project at Red Shop which could utilize $1600 \mathrm{cfs}$. Head levels of 16 feet and 22 feet were considered at both flow rates. Because of the 
low efficiency of some existing units, it became apparent that the best alternative would require that maximum flow be diverted to the Red Shop site. Accordingly the $1000 \mathrm{cfs}$ flow project alternatives were eliminated in a preliminary evaluation and the study focused on the three $1600 \mathrm{cfs}$ alternatives. The economic analysis of these three favored the greater head development of 22 feet.

The two 1600 cfs, 22 foot head alternatives came out equal in economic analysis; the major difference between the two was the location - of the powerhouse. The ultimate decision favoring the new powerhouse location at the end of the canal was based on the engineering consideration that construction of a new powerhouse and the raising of the canal walls to accommodate a 22 foot head appeared to present fewer unknown variables than the existing site which would involve a deep ledge excavation inside the existing canal walls. Although this is physicalily póssible to accomplish, the risks appeared to.be considerably greater.

Comparison of the hydro and fossil alternatives was made on the basis of lowest total levelized annual cost. This is a technique normally used in evaluating generation alternatives with different lines. Return on Investment andissis is not really applicable since Central Maine Power's return on equity is regulated by the Maine Public Utilities Commission.

All three of the final alternatives analyzed compared favorably with fossil fuel plants of similar size and capacity in the economic evaluation. The alternative selected will have a gross plant investment of $\$ 2,804,000$ and an installed capacity of $2500 \mathrm{KW}$. Fixed annual costs for the project were estimated at $20 \%$ of gross plant investment and the increased Union Water Power Company head and flow regulation assessment will be approximately $\$ 53,200$ per year. The total annual cost for the Red Shop project will be approximately $\$ 614,000$ which on a levelized basis would be $\$ 290,000$ lower than providing the same energy and capacity with the fossil fuel alternative. The total average additional energy output for the proposed development will be 15,140 megawatt hours per year and will result in a cost per kilowatt hour over the assumed 50 year life of the project of 40.5 mills.

The current FERC license for the Lewiston Canal system expires in 1993. The time period between commercial operation of a unit at Red shop and expiration of the license is too short to permit recovery of the necessary investment, therefore, a renewal of the existing license will be required to justify the development. Provided this renewal is obtained, the addition of generation on the canal is justifiable and Central Maine Power Company should proceed.

No significant structural safety or environmental problems are anticipated as part of the Red shop project. The report contains a general development plan providing for completion of the project by late 1983 provided licensing and permits will begin by mid 1979 and current delivery schedules for turbine equipment are maintained.

This feasibility study has provided Central Maine Power Company with the opportunity to study a highly complex and interrelated hydropower network and canal system. Hopefully the detailed study of the Lewiston Canal system presented in this report will be a guide to the increased use of the canal's untapped hydropower potential. 
HIGH FALLS HYDROELECTRIC PLANT

High Falls, N. Y.

Central Hudson Gas \& Electric Corp.

Chas. T. Main of New York, Inc.

PRDA Proposal Contract No. 1786

\section{INTRODUCTION}

The purpose of this study is to determine if it is feasible to re-activate the presently-retired High Falls Hydroelectric station by either the rehabilitation of existing unit(s) or the construction of new unit(s). The study includes the environmental aspects of re-activation, as well as the economics of the size of the installation best suited to the resources available.

In this study, the cost of obtaining additional electrical energy by re-activating the High Falls station is compared with the cost of displaced oil. Optimization of installed capacity is achieved by comparing the value of incremental energy generated with the incremental cost of the required generating facilities.

II. DESCRIPTION OF THE EXISTING FACILITIES

The present High Falls Hydroelectric Station was constructed in about 1910. The third and last generating unit was installed in 1926. The plant is located on Rondout Creek near the Village of High Falls, New York, and is owned by Central Hudson Gas \& Electric Corp. The project takes advantage of a natural falls, about twenty feet high, and a series of lesser falls totaling about thirty feet. A low concrete weir exists along the top of the main fall. Joining the fall to the intake structure is a concrete masonry dam having a maximum height of thirty feet. The gated intake structure is located in the right abutment and leads to a ten-foot diameter, riveted steel penstock about 450 feet long and a surge tank. The three horizontal shaft Francis turbine and generator units are rated at $1000 \mathrm{KW}, 560 \mathrm{KW}$ and $560 \mathrm{KW}$ and are housed in a concrete and stone structure. The penstock and surge tank are extensively rusted and beyond repair. The generating units, in addition to being well-used, have been severly vandalized. 
Rehabilitation of Existing Plant

In this approach, the dam, spillway and intake structure will be repaired and made completely serviceable. A new wood-stave penstock and steel surge tank will be constructed and the existing powerhouse structure repaired and remodeled.

Turbine runners and draft tubes will be replaced while the balance of the turbines will be repaired. Generators will be replaced with new ones having a voltage rating of $13.8 \mathrm{KV}$, thus saving the cost of a step-up transformer. The existing open type switchboard will be replaced by modern metalclad switchgear and a metal enclosed switchboard.

Three options were selected for comparison: rehabilitate 1) only the $1000 \mathrm{KW}$ unit, 2) the $1000 \mathrm{KW}$ unit plus one of the $560 \mathrm{KW}$ units, and 3) the $1000 \mathrm{KW}$ unit plus both of the $560 \mathrm{KW}$ units.

\section{Building of New Station}

In this approach, the work described above will be done from the forebay down to the lower portion of the penstock. There will be no surge tank for this arrangement, and the old powerhouse will be left in its existing decommissioned state. A new excavation will be opened on the low rock ledge between the existing powerhouse and the normal river channel. In this excavation, a new structure proportioned to provide the most efficient and compact housing for the turbinegenerating unit and all of its electrical and mechanical accessories will be constructed.

Several alternative capacities, ranging from $970 \mathrm{KW}$ to $3735 \mathrm{KW}$, were examined and compared.

IV. POWER POTENTIALITY

As a basis for design, flow records at Rosendale since 1952 were analyzed. By plotting monthly flow-duration curves the average annual amount of energy generated by each alternative was determined. High Falls would operate as a run-of-the-river plant utilizing all water available up to the capacity of the unit(s) installed, and delivering this energy into the system immediately.

\section{ECONOMIC ANALYSIS}

The usual approach of identifying load plus reserves and satisfying these demands through the most economical form of capacity addition cannot, for various reasons, be used in the case of High Falls. Due to reduced load growth, Central Hudson, as well as the electric utility industry generally, is presently in a state of "excess capacity". The generating 
capacity Central Hudson already owns (or is contractually committed to purchase) exceeds its load plus reserve requirement, and Central Hudson does not require any additional generating capacity for load plus reserve requirements until the 1990's. Therefore, the High Falls project could not yield any savings under its present contractural arrangements and forecasted loads in terms of a reduction in investment in some other capacity additions to the system until at least that time.

It can be seen that the economic feasibility of High Falls cannot be judged in the normal manner of comparison of alternative generating additions. Instead, since over 95\% of Central Hudson's present generating capacity is oil-fired, its reactivation must be justified on the basis of fuel savings. "The economic value of the High Falls project can be judged by comparing the cost of producing a comparable amount of energy from the oil-fired units with the total cost (the annual carrying charges on the required investment plus the O\&M costs) af High Falls. If the total annual cost of the project is less than the value of the displaced oil, then a savings would accrue and the reactivation would be economically viable.

To be able to perform this analysis quantitatively, both the total cost of the High Falls energy and the value of the displaced oil must be calculated. The total cost of the High Falls energy can be calculated based upon the cost estimates. The capacity cost portion of the total cost is actually determined by taking the total installed cost (or total investment) and multiplying by the levelized annual fixed charge rate, as determined by Central Hudson, of $14 \%$ for the High Falls project. The levelized annual components of this fixed charge rate are based on an assumed 50-year plant life and include: return on investment, depreciation, income tax, property tax, insurance, and an allowance for replacement of equipment that wears out in less than the assumed 50-year plant life. The only other cost associated with High Falls energy would be O\&M.

The calculation of the value of the displaced oil-fired energy is much more complex. In reality the value of the energy produced at High Falls each hour would be equal to the value of the energy produced from the most expensive oil-fired generator being dispatched for that particular hour. However, even if the cost of the oil fired generation for every hour could be calculated, the output of High Falls for every hour could not.

As an approximation, the unit that is generally the last to be dispatched on an economic basis to serve load for the majority of time during the year was selected for comparison, and the price of oil for this unit and its average heat rate was used to determine the average cost of generating a kilowatt hour of energy. 
VI. CONCLUSION

The accompanying table summarizes the various costs and shows the economics of reactivating the High Falls project with oil at $\$ 13.85$ per barrel, the November, 1978 cost to the utility.

The figures indicate that while all alternatives show an annual deficit, the construction of a new plant is more economical than rehabilitating the old and that installation of approximately $2400 \mathrm{KW}$ is the least unattractive. As the price of oil increases, the unatractiveness would be reduced and a larger capacity would begin to be favored. Once the plant is constructed, and most of the annual charges thus fixed, a continued rise in the price of oil would probably show an eventual net saving resulting from the reactivation of the plant. 
HIGH FALLS HYDRO STATION - ECONOMIC ANALYSIS (NOV. 78 OIL PRICE)

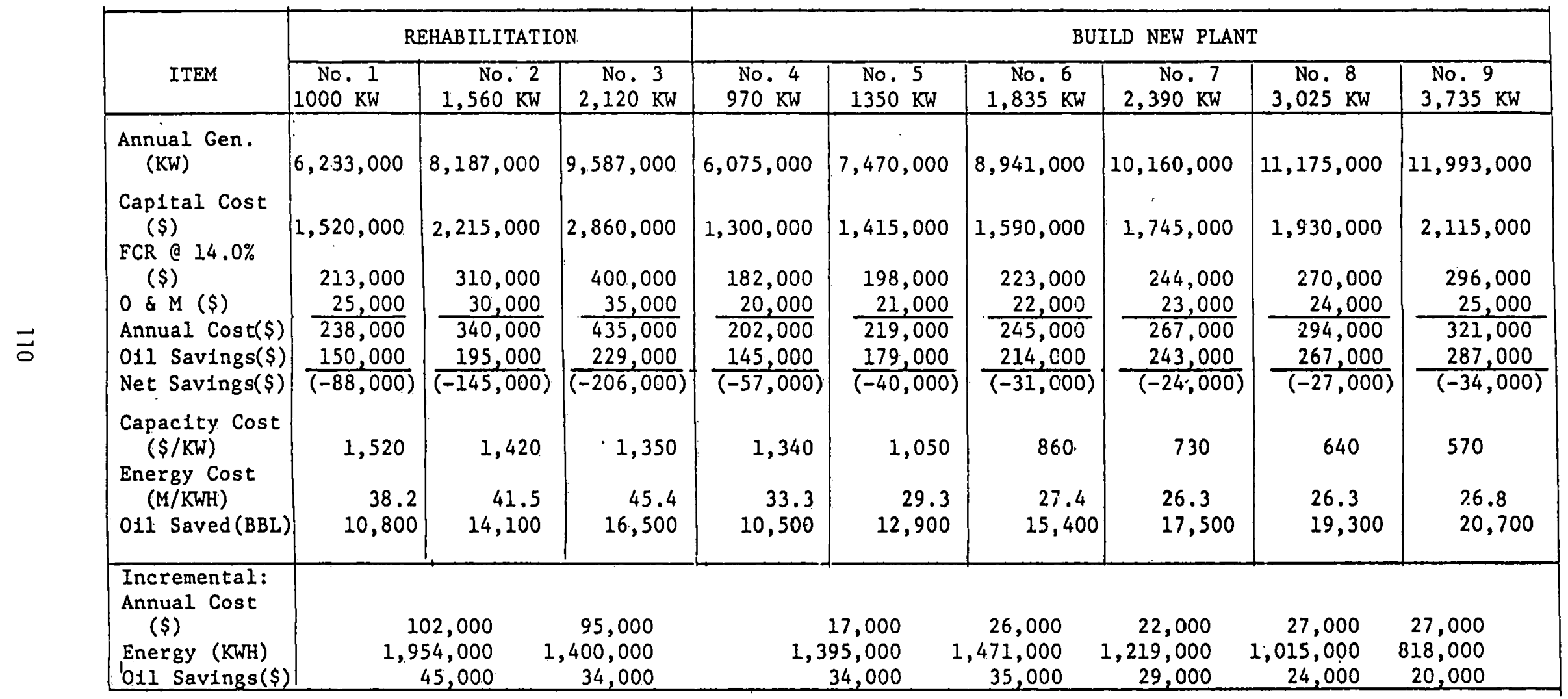

Notes 1) Nov 78 oll price $\$ 13.85 /$ bhl. 2) Annual Generation from App. C. 3) Capital Cost from Table 1. 4) FCR= fixed carrying charge, and Includes amortization, interest, and replacement reserves. 5) Operation and Maintenance charges are based on CHG\&E experience.

6) 011 saved ( $\$$ and b.bl) 1s based on operation of CHG\&E Danskammer Unit No. 3 in Nov. 78. 7) Negative Net Savings indicates cost of new hydro exceedg value of ofl saved. 8) Incremental values are the differences between adjacent schemes. 
BRIGHTON DAM HYOROELECTRIC REDEVELOPMENT

\author{
BRIGHTON, MARYLAND \\ 1 \\ WASHINGTON SUBURBAN SANITARY COMMISSION \\ ACRES AMERICAN INCORPORATED
}

PRDA Proposal Contract No. 1787

\title{
I. INTRODUCTION
}

The Brighton Dam Hydroelectric Redevelopment Feasibility Study has been undertaken by Acres American Incorporated (Acres) under the terms of a contract with Washington Suburban Sanitary Commission (WSSC) dated December 6, 1978. It is a candidate project under the nepartment of Energy (DOE) PRDA Program No. PRDA-ET-78-D-07-1706, "Feasibility of Determination of Low Head Hydroelectric Power Development at Existing Sites." The study has been jointly funded by the DOE and WSSC under Cooperative Agreement No. EN-78-F-07-1787, entered into December 13, 1978. The objective of the study was to investigate the technical and economic feasibility of redeveloping the disused hydroelectric facility at the Brighton Dam and to prepare a Feasibility Report on the findings.

The Brighton Dam is on the Patuxent River about 15 miles upstream of Laurel in Maryland. It impounds the waters of the Triadelphia Reservoir which covers an area of 800 acres. The drainage area is 78.4 square miles. The average flow over a 12 -month period is 87 cubic feet per second, and the gross head Detween the normal maximum reservoir level and the tailwater level is 61 feet. The old generating plant, disused since 1969, consisted of two turbines and generators and had a total output of $150 \mathrm{~kW}$.

The Report presents the conceptual design for the installation of a $500 \mathrm{~kW}$ generating plant in the existing powerhouse which is built into the dam structure. This represents a 233 percent increase in the original installed capacity. Section 2 of the Report forms a summary of the investigations and findings of the study. It is set out in full in this symposium presentation.

The other sections of the Report, not reproduced in this presentation, are as follows. Section 3 contains a description of the existing facilities and basic data and assumptions used in the study. Section 4 deals with the alternatives considered in developing conceptual designs for the project and selecting the recommended scheme. Section 5 presents further details of the selected design, together with cost estimates and financial and power marketing studies. The schedule for engineering, licensing and construction of the project, together with the cash flow estimate, is included in Section 6 . Sections 7 and 8 deal with environmental and safety assessments. Background data and other related information are included as appendices to the Report.

The WSSC Project Manager for the study was Mr. Alan L. Will. 'The Principal Investigator for Acres was Mr. Charles A. Debelius, assisted by Mr. Hubert F. Allman. The assistance of Baltimore Gas \& Electric Company and various state and environmental agencies who have provided information and guidance during the study is gratefully acknowledged.

\section{SUMMARY}

The redevelopment of the hydroelectric facility at Brighton Dam has been found to be both technically and financially feasible, the benefit to cost ratio being 1.53:1 compared with an equivalent coal-based generation source. Environmental impacts have been assessed as relatively slight, but some problems, due to possibly poor water quality at the bottom of the reservoir are anticipated and solutions for these will have to be worked out. The benefit to cost ratio could thus be marginally decreased, but the relative costs of one alternative scheme compared to another would not be affected. There is no apparent impediment to proceeding with the work of redevelopment.

The selected redevelopment plan would have a single hydroelectric generating unit of $500 \mathrm{~kW}$ rated capacity. The gross energy generation from the project would be $2,840,000 \mathrm{kWh}$ in a year with average rainfall. It is estimated that the total project cost would be $\$ 734,000$ (at third quarter 1978 price levels), with no allowance for funds during construction (AFDC). Based on 6.25 percent cost of money, the project would provide energy at a levelized cost over the plant lifetime of approximately $23.3 \mathrm{mills}$ per klwh with no AFDC or $24.6 \mathrm{mills} / \mathrm{kWh}$ with AFDC. 
At present, WSSC electrical power demands at Brighton Dam amount to 147,000 kWh per year which is met by a supply from Baltimore Gas \& Electric Company (BG\&E). This represents only 5 percent of the potential generation at the site and BG\&E have agreed in principal to purchase the surplus output.

\section{1 - DESCRIPTION OF RECOMMENDED FACILITY}

The selected scheme would have a 4 feet diameter penstock with a butterfly shut-off valve connecting one half of the existing intake tower to the turbine. The turbine would be of the vertical shaft, axial flow, propeller type placed centrally in the existing powerhouse. It would be rated at $500 \mathrm{~kW}$ under a net head of 50 feet and a discharge of $130 \mathrm{cfs}$. The draft tube would be of the standard elbow type installed in the existing tailrace tunnel under the powerhouse after some additional excavation of concrete and rock. Some modification of the tunnel will also be necessary to remove the severe constriction where it emerges into the tailrace channel.

The $500 \mathrm{~kW}, 480 \mathrm{~V}$ generator would be mounted vertically on top of the turbine casing.

The powerhouse has a history of flooding and funds have been included in the project costs to carry out essential modifications to prevent a recurrence.

The switchboard could be installed on the floor of the powerhouse or on the mezzanine floor.

A power transformer located in one of the downstream bays of the dam would step-up the station output to $13.2 \mathrm{kV}$ for connection to the existing BG\&E Company distribution line which terminates on the site.

Plates 1 and 2 show the location of the project and the general plan and elevation of the site.

\section{2 - ALTERNATIVES CONSIDERED}

Recognizing that the most economically rewarding scheme was likely to be that with a minimum of civil work within the existing powerhouse structure, a number of possible alternative turbine-generator arrangements were identified. These involved the utilization of the two existing penstocks to greater or lesser degrees.

The arrangements of the plant which were studied came under two main headings:

Alternative $A$ : With two identical units each utilizing flows in the range 50 to $70 \mathrm{cfs}$.

Alternative B: With one larger unit utilizing a flow in the range 90 to $130 \mathrm{cfs}$ with, or without, a small unit to handle the regulatory minimum flow of $7.5 \mathrm{cfs}$.

The existing penstocks were designed to give "straight-through" flows of 125 cfs to each of the discharge regulating valves and $20 \mathrm{cfs}$ via branch connections to each of the original $75 \mathrm{~kW}$ turbines. With this magnitude of flow, the head losses in the pipes were not significant, but with the proposed higher output units, the head losses would be a considerable proportion of the total head available, thus seriously reducing the potential output from the project. Hence, alternative approaches of modifying the existing penstocks, or of installing a new one, were considered. For each of the alternatives, it was evident that modification of the tailrace tunnel outlet would be necessary to remove the constriction.

Full consideration has been given to the number and types of units. Alternatives evaluated comprised one- and two-unit installations, utilizing Francis turbines with horizontal shafts, single-regulated Kaplan and fixed-blade propeller turbines in both horizontal and vertical shaft configurations. sludy.

The cooperation of major U.S. and European manufacturers of small hydraulic turbines was sought for the

The alternative which included a very small unit to generate solely from the regulatory minimum flow of $7.5 \mathrm{cfs}$ was rejected when this proved uneconomic, due to very low capacity factor and high cost per kW of the unit.

\section{3 - PLANT SIZE SELECTION}

The plant capacity and unit sizes were selected following an analysis of the existing facility condition and layout, the hydraulic characteristics of the intake tower, penstocks, tailrace tunnel and tailrace channel, variation of available flow, comparative power values, the preferred load requirements of BG\&E, and the established WSSC rules for the operation of the reservoir for water storage and flood control. 
The selected $500 \mathrm{~kW}$ installation is considered to provide optimum usage of the available hydroelectric potential at the site. Initial plant size optimization and comparison of alternatives was based on preliminary power values published by FERC for an alternative coal fired generating unit source in the PennsylvaniaNew Jersey-Maryland interconnected system (PJM). The selection of plant capacity and configuration will not be significantly influenced by any likely differences in power values from these published levels.

Project cost evaluations for one- and two-unit alternatives are summarized in Table 1. The total project costs of the alternatives range from $\$ 734,000$ to $\$ 880,000$. On the basis of the estimating costs provided by manufacturers for this study, the single $500 \mathrm{~kW}$ vertical shaft propeller turbine with an asynchronous generator appears to be the most cost effective alternative with the nearest contender costing 9 percent more with no improvement in performance.

\section{4 - ECONOMIC EVALUATION}

Construction costs are based on unit costs applicable to the type of work involved, on conditions similar to those prevaling in the Brighton Dam area and on pricing levels effective in the third quarter of 1978 .

A single comparison of the project cost of energy to that from an alternative coal fired source, is presented in Table 2. The cost of money for the hydroelectric plant was determined on the basis that WSSC, being a public utility is able to obtain capital funds at 6 to 6.25 percent interest. BG\&E is dependent on private financing, therefore, the equivalent cost of money for the "coal fired" alternative was taken as 10 percent. Furthermore, WSSC is self insured and pays no taxes on Brighton Dam. Thus, the annual costs of the total fixed charges for the WSSC hydroelectric and the BG\&E coal fired thermal power alternative; are 9 percent and 19.56 percent of capital cost, respectively.

The FERC power values, referred to in 2.3, suggest a capacity value of $\$ 136 / \mathrm{kW}$ and an energy value of $\$ 11.6 / \mathrm{MWh}$ which, for the selected Brighton Dam scheme, results in a total power value of $35.5 \mathrm{mill} \mathrm{s} / \mathrm{kWh}$. Thus, the hydroelectric energy cost level estimated at $23.3 \mathrm{mills} / \mathrm{kWh}$ provides a benefit to cost ratio of 1.53 on 1978 costs without any provision for escalation of fuel costs in future years. Therefore, the project is economically feasible and may be expected to become an increasingly beneficial investment in years to come.

\section{5 - DEVELOPMENT OF CONSTRUCTION COST ESTIMATES AND SCHEDULES}

\section{(a) General}

Detailed construction cost and schedule data were developed for the recommended hydropower redevelopment under consideration for the Brighton Dam Project. The data is presented to a degree of detail such that further detailed economic evaluations as well as financial and schedule planning may proceed with an acceptable level of confidence.

\section{(b) Cost Estimates}

Summary cost estimates, for four alternative project design concepts considered, are presented in Table 1. Detailed cost estimates were prepared for the $500 \mathrm{~kW}$ vertical shaft propeller unit, the $420 \mathrm{~kW}$ horizontal shaft tube unit and the two arrangements of twin $243 \mathrm{~kW}$ or $240 \mathrm{~kW}$ Francis units installed on the existing penstocks, with and without modification, respectively.

Cost estimates for each alternative were based on similar plant facilities, type of generator, electrical auxiliaries, controls and modifications to tailrace. Estimated construction costs were based on current (third quarter 1978) price levels applicable to the type of work involved and the local conditions at Brighton Dam. Additionally, unit costs for the major civil construction activities were estimated to allow for the environmentally sensitive location of the project and the resulting construction restrictions pertaining to dust, preservation of water quality and for limitations due to the flood control requirements at the existing structures.

\section{(c) Schedules}

The Report projectschedule will show the two principal phases of engineering and construction for the recommended scheme. The engineering schedule has essentially been based on concurrent licensing and engineering design and equipment procurement activities to provide the shortest construction lead time. Consecutive licensing and engineering activities would lengthen the schedule by at least 12 months.

The FERC licensing phase of the schedule will include a 3 month preparation period in parallel with initial engineering design activities. These activities will include finalizing the project arrangement and the preparation of turbine-generator procurement documents. The earliest scheduled date for receipt of 
the FERC license will be in month twelve. Shortly after this date, the civil construction contract document will be ready for issue to prospective bidders. If schedule delays are to be avoided, the latest date for receipt of the license will be the end of the fifteenth month.

The total scheduled period from authorization to completion of the project will be 32 months.

\section{(d) Project Cash Flow}

The project cash flow shown in the Feasibility Report is based on present day estimated costs with no allow ance for future escalation. AFDC has been estimated, assuming a 6.25 percent annual cost of money and end of period payments, at an amount of $\$ 42,300$ or $53 / 4$ percent of the estimated capital cost $(\$ 734,000)$. The total project cost, including AFDC, is thus $\$ 776,300$.

\section{6 - PRELIMINARY ENVIRONMENTAL AND SAFETY ASSESSMENTS}

\section{(a) Existing Conditions}

The proposed hydroelectric redevelopment at Brighton Dam lies within WSSC owned structures and 1 ands. The development will be integrated with the existing Triadelphia Reservoir which is currently being.operated for water-storage and flood control purposes. The existing reservoir and adjacent areas are scenically attractive, provide significant wildlife habitats and are used for recreational activities on a relatively small scale during the summer months only.

\section{(b) Preliminary Environmental Assessment}

The proposed development of hydroelectric potential will have negligible impact on the present terrestrial and aquatic systems both during construction and operation of the facilities, provided adequate precautions are taken. This applies particularly to the initial start-up of the plant if this occurs at a time of low flows, as the release of poor quality water from the bottom of the reservoir could be harmful.

To assist in the selection of the most favorable alternative, preliminary environmental and safety assessments have been conducted. These assessments identified the major impacts anticipated from construction and operation of the proposed hydroelectric facility.

Detailed environmental/safety assessments will be required as part of the licensing process. The current study on the other hand, has been brief and preliminary, and has been adapted to the level of feasibility assessment appropriate at this time. The study consisted of a preliminary review of pertinent environmental reports, a site reconnaisance and contacts with individuals from state and federal agencies having expertise on the terrestrial and aquatic ecosystems found within the project area.

\section{(c) Preliminary Safety Assessment}

Construction of the proposed hydroelectric facility will have a potential impact on the safety of the public as well as on that of construction workers in the immediate vicinity of the power plant. Appropriate precautions will be necessary to minimize these risks. Design and operating procedures will have to be formulated to ensure that no significant increase in risks to public safety will arise during operation of the reactivated hydroelectric installation.

\section{7 - MARKETING STUDIES}

WSSC is a water utility and, apart from standby diesel generators, has no operational electricity generating plant of its own. At the present rate of demand, only 5 percent of the potential hydroelectric output at Brighton Dam could be used at that location. The present supply of electricity to WSSC at Brighton Dam is provided by BG\&E who operate and maintain the $13.2 \mathrm{kV}$ line to the facilities there. It therefore follows that the power surplus to WSSC's needs should be sold to BG\&E. The only alternative to this would be for WSSC to construct their own power distribution lines to their other water pumping and sewage treatment plants. This is not considered feasible for cost and operational reasons.

Preliminary discussions with BG\&E have resulted in agreement in principal. As Brighton Dam hydroelectric redevelopment could be used primarily for peaking generation, reasonably high energy values may be expected to apply. Furthermore, consideration of more rapid escalation in energy costs from fuel-dependent sources in the future indicated that hydroelectric peaking generation will be more economic on a present worth basis, over a 30 year period. ISSC could, therefore, derive significant economic benefit from a hydroelectric power plant of the particular capacity envisaged. 


\section{8 - RECOMMENDATION}

Based on the findings of this report, it is recommended that a FERC license application be filed for the Brighton Dam redevelopment project at an early date.

TABLE 1 - PROJECT COSTS AND BENEFIT:COST RATIOS FOR ALTERNATIVE SCHEMES

\begin{tabular}{|c|c|c|c|c|}
\hline Account Item & $\frac{\stackrel{\mathrm{Al}}{2-240 \mathrm{~kW} \text { Francis }}}{\text { existing penstocks }}$ & $\frac{\frac{\mathrm{A} 2}{2-243 \mathrm{~kW} \text { Francis }}}{\text { modified penstocks }}$ & $\frac{\frac{\mathrm{Bla}}{\mathrm{1-500} \mathrm{kW} \text { Vert. }}}{\text { prope1ler }}$ & $\frac{\frac{B l b}{1-420 \mathrm{~kW}}}{\text { Horiz. Tube }}$ \\
\hline 331 Structure \& Improvements & $\$ 26,920$ & $\$ 36,000$ & $\$ 43,000$ & $\$ 44,000$ \\
\hline 332 Reservoirs, Dams \& Waterways & 6,600 & 24,730 & 11,700 & 9,100 \\
\hline 333 Turbines \& Generators & 327,000 & 327,000 & 292,300 & 414,100 \\
\hline 334 Accessory Electrical & 50,000 & 50,000 & 40,000 & 0 \\
\hline 335 Misc. Power Plant Equipment & 2,000 & 2,000 & 2,000 & 2,000 \\
\hline 353 Substation Electrical & 15,000 & 15,000 & 2,000 & $\underline{0}$ \\
\hline Subtotal & 427,520 & 454,730 & 391,000 & 469,200 \\
\hline Contingencies (25\%) & 106,980 & 113,770 & 98,000 & 117,300 \\
\hline Engineering \& Administration & 267,500 & 284,500 & 245,000 & 293,500 \\
\hline TOTAL PROJECT COST & $\$ 802,000$ & $\$ 853,000$ & $\$ 734,000$ & $\$ 880,000$ \\
\hline $\begin{array}{l}\text { Expected Annual Generation Revenue } \\
\text { (See Table 2) }\end{array}$ & $\$ 97,520$ & $\$ 98,750$ & $\$ 101,000$ & $\$ 84,100$ \\
\hline Expected Annual Cost of Project & $\$ 72,180$ & $\$ 76,770$ & $\$ 66,060$ & $\$ 79,200$ \\
\hline Benefit/Cost Ratio & 1.35 & 1.29 & $\underline{\underline{1.53}}$ & 1.06 \\
\hline
\end{tabular}

TABLE 2. - COMPARATIVE PROJECT COSTS AND BENEFIT:COST RATIO

PROJECT DATA

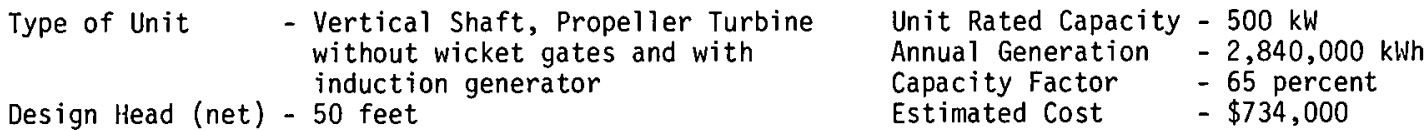

COST COMPARISON

Annual Cost

Cost of Money

Depreciation

Insurance (WSSC Self Insured)

Tax (in lieu)

Fuel Inventory

$G \& A$

$0 \& M$

Total Fixed Charges

Hydro Charges (\%)

6.25 (Public)
0.45 (40 yr)
0.00
0.00
0.00
1.20
$\frac{1.10}{9.00}$

Typical Coal Fired Charges (\%)

10.00 (Private)

$0.61(30 \mathrm{yr})$

0.25

5.00

0.70

1.20

$\frac{1.80}{9.56}$

Total Cost of Hydroelectric Supply $=\$ 734,000 \times 0.09=\$ 66,060 /$ year or $23.3 \mathrm{mills} / \mathrm{kWh}$

Total Cost of Alternative Coal Fired Generation

From FERC "Prel iminary Generalized Power Values for National Hydropower Study" June 23, 1978, for PJM Interconnection (Page 24), for hydro capacity factor of $65 \%$ :

Capacity Cost $=\$ 136 / \mathrm{kW}$ yr and Energy Cost $=11.6 \mathrm{mi} 1 \mathrm{~s} / \mathrm{kWh}$

Thus for the selected facility rated at $500 \mathrm{~kW}$ producing 2,840 MWh/yr:

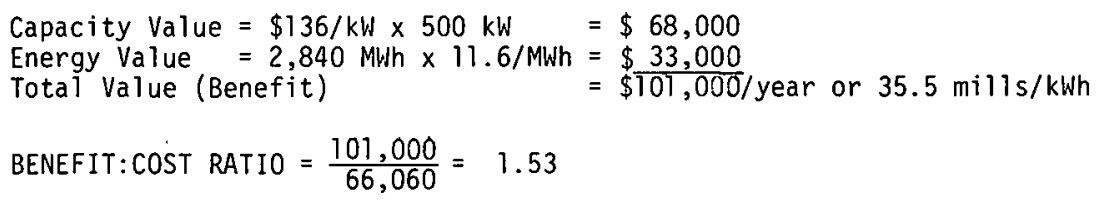


,

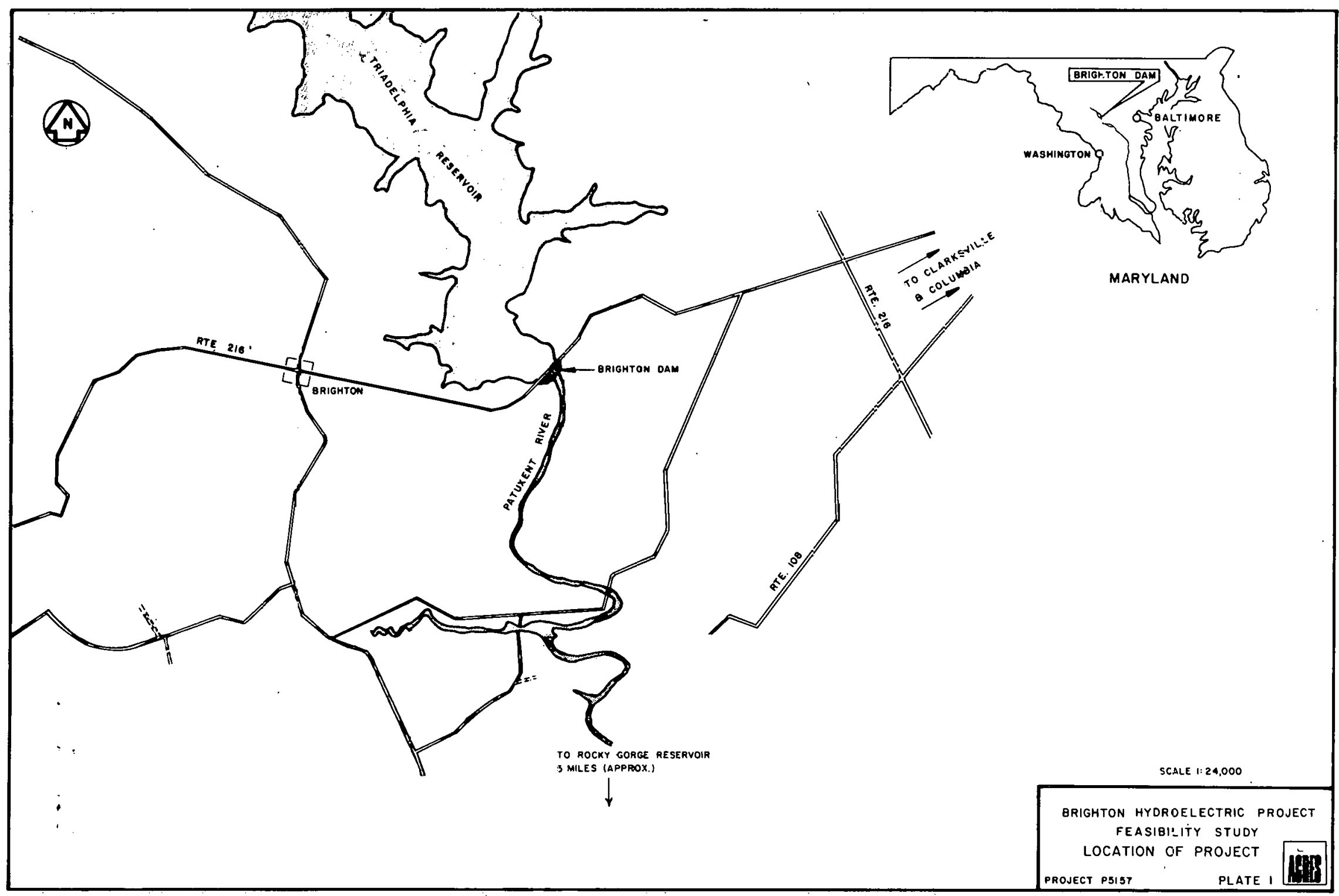




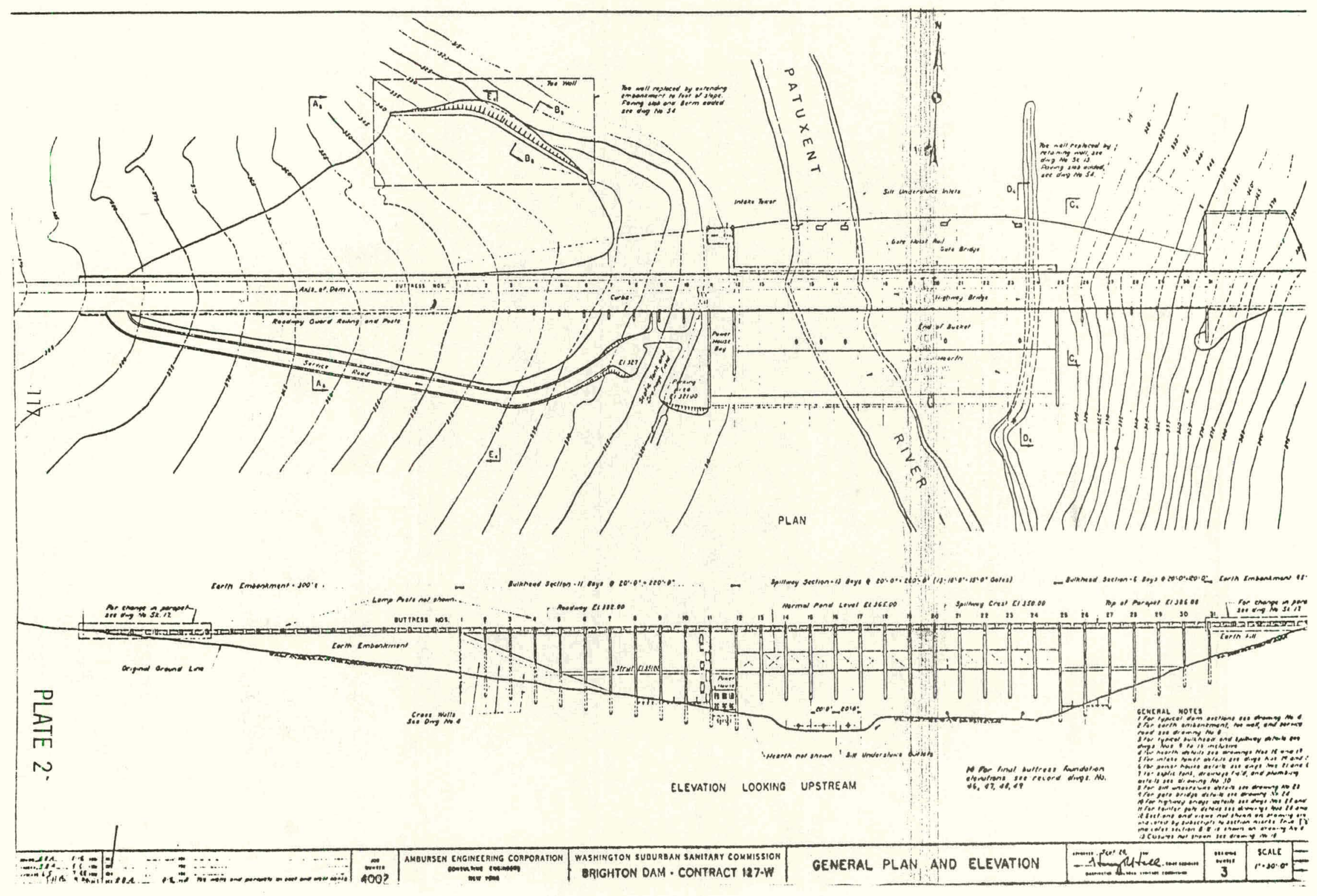




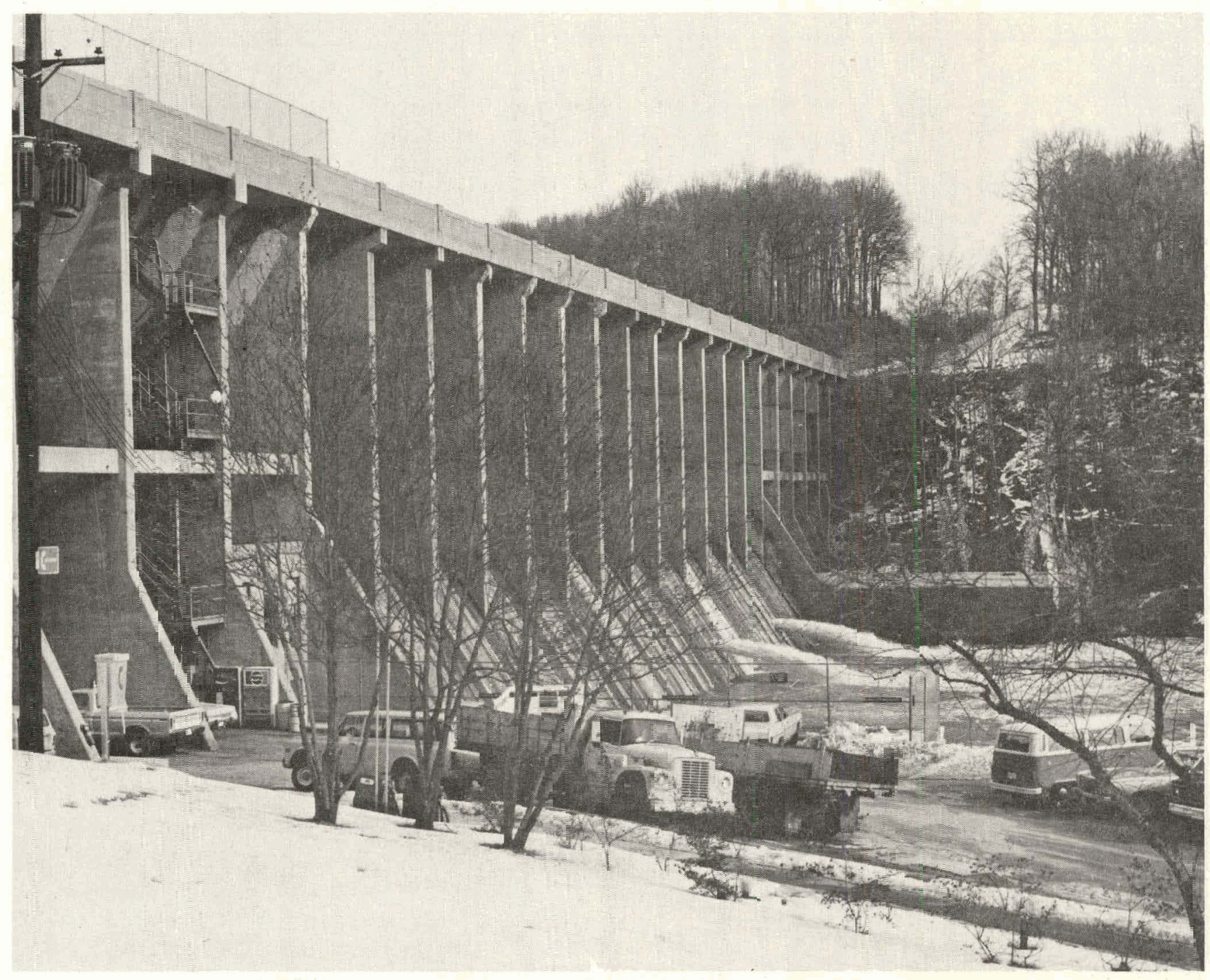

BRIGHTCN DAM 


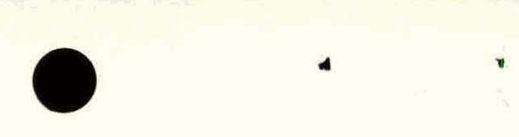

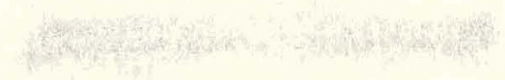

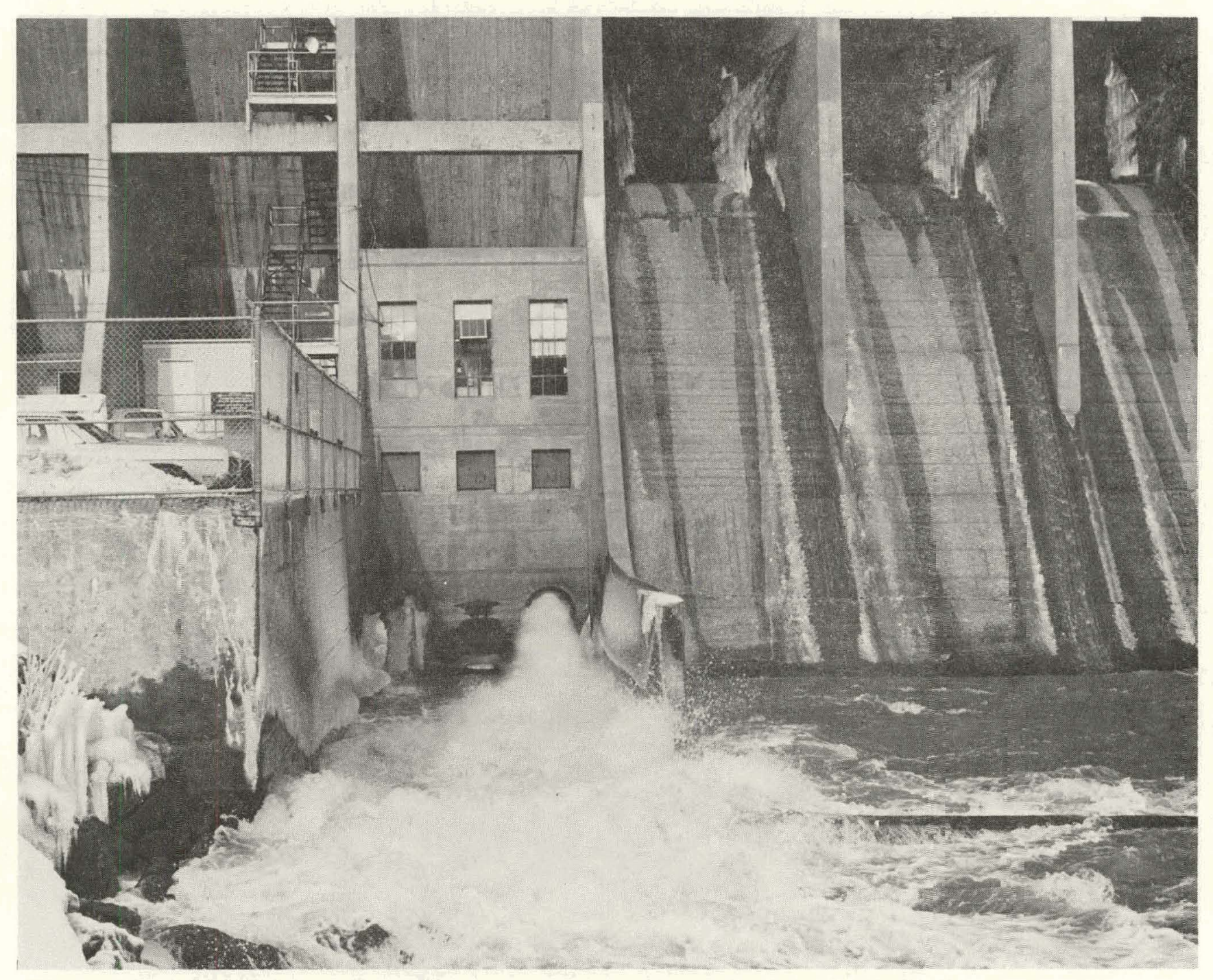

BRIGHTON DAM - POWERHOUSE 


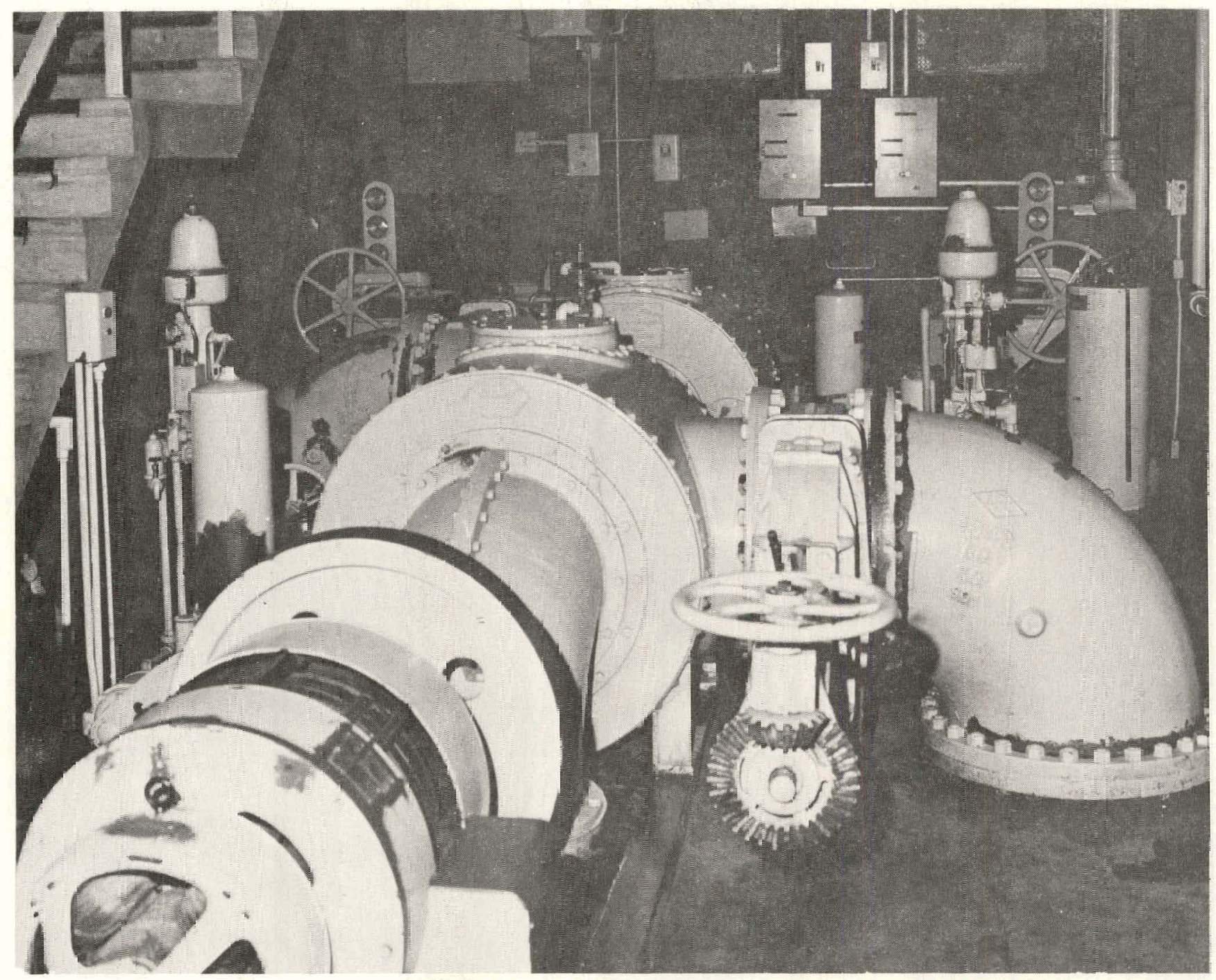

BRIGHTON DAM - EXISTING HYCFOELECTRIC PLANT 
HYDROELECTRIC POWER POTENTIAL

Woonsocket Falls Dam

University of Rhode Island

Rhode Island State Energy Office

PRDA Proposal Contract No. 1788

\section{INTRODUCTION}

A relatively new flood control dam, located in the City of Woonsocket, has been studied to determine the potential for hydroelectric generation. The dam is municipally owned by the City of Woonsocket, under supervision of the Corps of Engineers. It is inspected by them on a semiannual basis as to operability and structural stability.

The original Woonsocket Falls dam was a fixed-crest masonry structure dating back into the $1800^{\prime} \mathrm{s}$ and was located 100 feet upstream of the South Main Street Bridge. This was replaced after the flood of August 1955. The dam is a 266 foot $10 n g$ concrete flood control dam equipped with four tainter gates, each 50 feet long and approximately 10 feet high.

\section{SITE LOCATIONS}

Three sites for the location of the power plant were looked at in detail. These sites are designated $\mathrm{A}, \mathrm{B}$, and $\mathrm{C}$ and are illustrated in Figure 1.

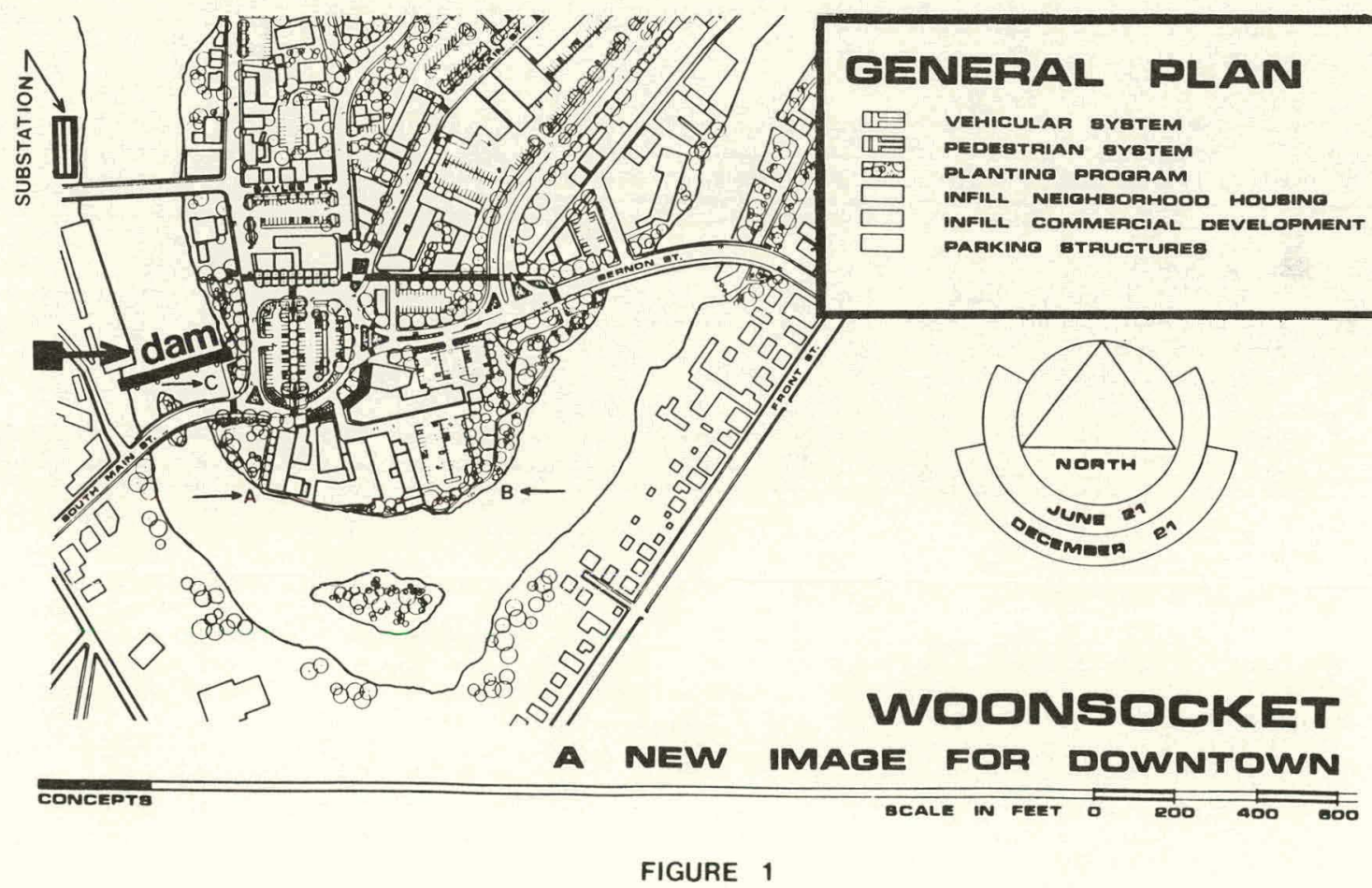

Site A is located approximately 300 feet downstream f'rom the dam and takes advantage of an increase in available head at the expense of a buried penstock ( 8 foot pipe for water flow). This site does entail the acquisition of a vacant private parcel of land. 
Site B is across the bend in the river and approximately 1200 feet downstream from the dam and takes advantage of a further increase in head at the expense of an increased length for the penstock. This site has the highest cost for development.

Site C is in the river channel opposite the tainter gate on the dam's east side. This would eliminate the need for a penstock and its associated costs; but will require evaluation and approval of its effects on flood control operations and the dam's structure by the Corps of Engineers. This site has the lowest cost for development.

\section{III. "WHEELING" OF ENERGY}

The proposed hydro station should be operated in parallel with the existing utility system. Use of local distribution lines for "wheeling" of energy from the hydro generator to sites where it can be best utilized has been investigated, as wel1 as, selling all of the energy to the utility company. A fee is charged by the utility for this distribution service. The fee is based on expenses involved plus a fair return on the capital value of the distribution equipment. Consideration is given to the fact that only a fraction of the load on the distribution facilities is the energy being wheeled. The municipal sewer and water works are good sites where the energy can be wheeled. Wheeling of the energy does give a significant improvement to the project's financial feasibility.

Utility power rate structures were not designed for cogeneration and may need changes that take into account the unique capability of a hydroelectric plant. For example, although there are many different power rate structures, they can in most cases he broken down into three generic classifications: industrial, commercial, and residential. The industrial rate, for which the sewer qualifies, is approximately .034 dollars per KWH in New England and the customer buys a relatively large amount of energy. The commercial rate is approximately .051 dollars per $\mathrm{KWH}$ and the customer buys less under this structure. Under the industrial rate, a facility that has energy "wheeled" to it, decreases energy purchased and may find that it does not qualify anymore for the lower industrial rate for energy brought from the utility company. Under these circumstances, there could be a detrimental change in financial feasibility for a hydro cogenerator.

\section{ENGINEERING ASPECTS}

The civil, electrical, and mechanical elements have been studied. To reduce costs and to improve financial feasibility, the plant should be fully automated and this has been assumed during the study. For safety purposes, control and monitoring circuits should be available for use by the Blackstone Valley Electric Company.

It is proposed that the hydro station be tied through a transformer and a short overhead line to the $13.8 \mathrm{kV}$ bus of the utility's Sayles Street substation. Synchronous generating units should be used with protective relaying. The units should be able to run under automatic control, be brought from standstill to synchronism without an operator, and be disconnected from the system if necessary by remote tripping.

Semi-automatic mechanical raking equipment for the trash racks is included in the design concept. It is assumed that collected debris will be manually removed from the intake site by Woonsocket Public Works personnel utilized in a dual capacity.

\section{FINANCING}

Woonsocket may utilize one or a combination of several alternatives to finance this project. External financing could consist of sales of bonds, general or revenue; financing through federal government aid, either a direct grant or loan associated with the National Energy act; or a leasing arrangement. Woonsocket could consider the possibility of internal financing out of any reserves or out of current revenues through taxes.

During construction, the project experiences a net cash outflow consisting of the payment for construction and for bond interest. Woonsocket may decrease net interest costs during construction if part of the borrowing funds are placed in Treasury securities. This has been assumed during the study.

\section{OPERATING AND MAINTENANCE COSTS}

Estimates of operating and maintenance costs were based on conversations with operating personnel of four hydro units in Norwich, Connecticut, and the experiences of a utility 
company in Canada that owns a large number of small hydro plants. Operating and maintenance costs for the machines in Canada were approximately $\$ 8,000$ per unit. For the Woonsocket hydro station, these costs have been estimated as $\$ 17,400$ per year.

\section{PLANNING PERMITS AND LEGAL FACTORS}

Contacts and discussions about the project have been held with the:

State Energy Office,

Public Utilities Commission,

Department of Environmental Management,

City of Woonsocket,

Rhode Island Water Resources Board,

Corps of Engineers,
Federal Energy Regulatory Commission, Blackstone Valley Electric Company, Eastern Utilities Associates, Water Resources Board, State-wide Planning Program, Department of Economic Development.

Preliminary review has indicated that the hydro facility will have a minimal impact on the environment, although site $C$ will have to be carefully investigated as to effect on flood control operation of the dam. Good communication with regulatory agencies in the planning stage will assist in the development of the hydroelectric facility.

There appears to be no legal impediments to the development of hydroelectric power at Woonsocket Falls. The City has clear title to the dam, and therefore, according to the Rhode Island Mill Act, has a right to maintain the dam without "molestations".

\section{VIIT.COMPUTER MODEL}

A comprehensive computer model, that takes into account engineering, environmental, economic, and financial factors, was utilized to estimate financial feasibility of each of the three sites for various options. Output from the model is the cash flow, which is the city revenue after operating, maintenance, and loan payments have been removed from the income of the proposed hydro plant.

A performance index that is based on the sum of the cash flows js used for the optimization studies. Two indices are available - the first is the sum of the cash flows over the loan period and the second is the sum of the cash flows over the operating life.

\section{SUMMARY OF FINANCIAL FEASIBILITY ASSESSMENTS}

Summary of the feasibility assessments are tabulated in Figure 2 . Conservative installed plant costs and best available data and information, with due consideration of time and monetary constraints, were used in the model. For some of these results, a nominal generator size of $1000 \mathrm{KW}$ provided a basis for comparison during each of the case studies. Power plant size that optimizes financial feasibility and their associated monetary values are indicated in the last four columns of this table. The configurations that give the best cash flow return over the short term and operating life of the power plant are:

$$
\begin{array}{ll}
\text { SITE A with } & \text { SITE C with } \\
\text { energy wheeled } & \text { energy wheeled }
\end{array}
$$

Both of these have comparable financial returns and should be considered prime configurations. Site A entails the acquisition of a vacant private parcel of land and Site C is subject to detailed evaluation and approval by the Army Corps of Engineers.

\section{$X$. RECOMMENDATIONS}

It is recommended that:

(1) The City of Woonsocket proceed with plans to develop one of the prime sites - Site $A$ or Site $C$ - with the energy being wheeled to the sewer and water works and excess sold to the utility company.

Reasons and Comments: By decreasing electrical energy brought from, and selling excess to the utility company, the proposed hydro facility has the capability of providing a net increase in disposable funds to the city over the short and long term life of the project.

(2) The City of Woonsocket proceed immediately to obtain the necessary permits and licenses for the project.

Reasons and Comments: The money required to satisfy the regulatory requirements appears as if it is relatively low; however, time required is relatively long. Because of potential problems regulatory aspects can cause, satisfaction of these 
requirements should precede a commitment to actual construction.

(3) The Rhode Island State Energy office explore the possibility of obtaining a demonstration grant for the project.

Reasons and Comments: The concept of wheeling, as used in the project, and its implications are somewhat unique and should provide a basis for a demonstration grant.

(4) Funding be provided so that the computer model and, information and data input, be further refined to incorporate more details of the system. Some of these include better modelling of the demand features of the power rate structure, and inclusion of random variation in the river flow data.

Reasons and Comments: The sensitivity of optimal plant sizing, due to the effects of actual non-smooth, daily random river flow, needs to be determined. It was assumed that changes in demand charges - due to wheeling - for utility brought. energy at the sewer works would not significantly change the financial feasibility of the hydro plant. This qualitative assessment could be further tested by a more detailed quantitative simulation. The impact of recent energy legislation on power rate structures is unknown at this time:

(5) The power rate structures be studied to determine if they are applicable to nonutility owned, cogeneration facilities.

Reasons and Comments: Utility power rate structures were not designed for cogeneration and may need changes that take into account the unique capability of a cogeneration facility.

\begin{tabular}{|c|c|c|c|c|c|c|c|c|c|c|c|c|}
\hline & $\begin{array}{l}\text { UTILIZATION } \\
\text { OF } \\
\text { ENERGY }\end{array}$ & $\begin{array}{l}\text { HEAD } \\
\text { FEET }\end{array}$ & $\begin{array}{l}\text { NOMINAL } \\
\text { INSTALLED } \\
\text { COST FOR } \\
1000 K W \text { UNIT } \\
\$ / K W\end{array}$ & $\mathrm{M}$ WH $/ \mathrm{YR}$ & $\begin{array}{c}\text { OVERALL } \\
\text { AVERAGE } \\
\text { EFF. } \\
\text { O\% }\end{array}$ & $\begin{array}{c}U_{1}(\phi) \\
\left.(\$ 1,00)_{s}\right)\end{array}$ & $\begin{array}{c}v_{2}(\delta) \\
(\$ 1,000 s)\end{array}$ & $\begin{array}{c}\text { INITIAL } \\
\text { FIVE } \\
\text { VEAR } \\
\text { CASH } \\
\text { FLOW } \\
(\$ 1,000 s)\end{array}$ & \begin{tabular}{|} 
OPTIY \\
PLAN \\
SIZE \\
$\mathrm{v}_{1}{ }^{\text {FOF }}$
\end{tabular} & $\begin{array}{l}\text { YAL } \\
\text { vT } \\
(\mathrm{KW}) \\
\mathrm{v}_{2}\end{array}$ & $\begin{array}{c}\mathbf{U}_{1}(8) \\
(\$ 1,000 s)\end{array}$ & $\begin{array}{c}v_{2}(\phi) \\
(\phi 1,000 s)\end{array}$ \\
\hline \multirow{6}{*}{$\underset{5}{+\infty}$} & So $1 d(1)$ & 18 & 2022. & 5926.0 & 71. & 2153. & 1.80. & -274 . & 1150. & 700 & 2247. & 249. \\
\hline & A.C. & & & & & & & & & & & \\
\hline & theoled ${ }^{(2)}$ & 18 & 2022 . & 5926.0 & 71. & -4952. & 1694. & 233. & 1150. & 1000. & 5100. & 1694. \\
\hline & Sold (1) & 18 & 1800. & 5782.5 & $70 .(3)$ & 2268 . & 350. & -193. & (4) & (4) & (4) & (4) \\
\hline & N.W.P. & & & & & & & & & & & \\
\hline & Wheeled (2) & 18 & 1800 & 5782.5 & $70 .(3)$ & 5098. & 1881. & 219 & (4) & (4) & (4) & (4) \\
\hline \multirow{4}{*}{ 吕 } & Sold (1) & 20 & 2520 . & 6199.1 & 75. & 1854 . & -225 & -462. & 1300 & 500. & 1969. & -33 \\
\hline & Wheoled $(2)$ & 20 & 2520. & $6199: 1$ & 75. & 4780 & 1358. & -36 & 1200. & 800 . & 4956. & 1429. \\
\hline & Sold (1) & 20 & 2298. & 6108.5 & $70 .(3)$ & 2014. & -31. & -374. & (4) & (4) & (4) & (4) \\
\hline & Wheolod $(2)$ & 20 & 2298. & 6108.5 & $70 .(3)$ & 4965. & 1567. & 55. & (4) & (4) & (4) & (4) \\
\hline \multirow{3}{*}{ 品 } & Sold (1) & 16 & 1643. & 5567.3 & 67. & 2254. & 418 & -149. & 1050 & 900. & 2309 . & 441. \\
\hline & A.C. & & & & & & & & & & & \\
\hline & Wheeled (2) & 16 & 1643. & 5567.3 & 67. & 4884. & 1842. & 233. & 1050. & 1050. & 4975. & 1860. \\
\hline
\end{tabular}

\begin{tabular}{|c|c|c|}
\hline (1) & $\begin{array}{l}\text { All of the hydro genorated energy is gold to } \\
\text { utility company. }\end{array}$ & $\begin{aligned} v_{1}= & \text { Discounted cash flow sum ovor } \\
& 35 \text { year operating life. }\end{aligned}$ \\
\hline (2) & $\begin{array}{l}\text { Hydro generated enerey is wheelod to the sewer } \\
\text { and water works with oxcess sold to the utilitity } \\
\text { company. }\end{array}$ & $\begin{aligned} U_{2}= & \text { Discounted cash rlow sum over } \\
& 20 \text { year loan period. }\end{aligned}$ \\
\hline (3) & $\begin{array}{l}\text { No information was provided by manufacturer to } \\
\text { obtain this valuo, this is an estimated data point. }\end{array}$ & $\begin{aligned} & \text { A.C. }= \text { Allis-Chalmers hydroelectric } \\
& \text { unit. }\end{aligned}$ \\
\hline (4) & Insurficient data available to determine this value. & $\begin{aligned} \text { N.W.P. = Northern Water Power hydroelectric } \\
\text { unit. }\end{aligned}$ \\
\hline
\end{tabular}




\section{LOW-HEAD HYDROPOWER ON THE MILL RIVER}

Northampton, Massachusetts

Northampton Planning Department and Curran Associates, Inc.

PRDA Proposal Contract No. 1789

\section{INTRODUCTION}

Five existing dams along a 6.5-mile reach of the Mill River in the City of Northampton, Massachusetts were studied to assess the feasibility of developing the sitcs for low-head hydroelectric power generation.

\section{SUMMARY OF FINDINGS}

The summary of findings resulting from the present feasibility assessment of potential hydro projects on the Mill River is presented below.

\section{A. CONFIGURATIONS AND CAPACITIES.}

For three of the projects--Chartpak, Pro Brush, and Smith College-each powerhouse would be constructed adjacent to the existing dam and would oontain one horizontal-shaft turbine-generator unit. The fourth project, Cookes Intermediate, would involve diversion of water from the pond formed by the Button Shop dams through a penstock to a powerhouse below Cookes Dam, thereby combining the heads available at both projects.

The estimated capital costs are in mid-1978 dollars and include all facilities required to tie the plants into the existing distribution system. They also include allowances for engineering and Owner's administration but exclude interest during construction. The installed capacities and estimated capital costs corresponding to the four plants selected for study throughout this report are as follows:

Project Installed Capacity

$\begin{array}{lr} & \text { kW } \\ \text { Chartpak } & 235 \\ \text { Cookes Intermediate } & 265 \\ \text { Pro Brush } & 200 \\ \text { Smith College } & \underline{120}\end{array}$

Total 820
Estimated Capital Cost

$$
\text { mid-1978\$ }
$$

880,000

$1,160,000$

800,000

770,000

$3,610,000$

B. PEAK POWER AND ENERGY.

The table below summarizes the power potentials at the four selected projects: 


\begin{tabular}{|c|c|c|c|}
\hline \multirow[b]{2}{*}{ Chartpak } & \multirow{2}{*}{$\begin{array}{r}\mathrm{kW} \\
204\end{array}$} & \multicolumn{2}{|c|}{ (Equivalent } \\
\hline & & 850. & $(1,420)$ \\
\hline Cookes Intermediate & 0 & 1,140 & $(1,900)$ \\
\hline Pro Brush & 171 & 845 & $(1,410)$ \\
\hline Smith College & 106 & 570 & $(950)$ \\
\hline & & 3,405 & $(5,680)$ \\
\hline
\end{tabular}

C. IMPACTS ON WATER RESOURCES.

Principal uses of the Mill River in Northampton are water supply and disposal of wastewater discharges. Pro Brush withdraws small quantities of water for cooling from its pond and returns somewhat more water to the river in the form of uncontaminated cooling water discharges. River water is also for irrigation of a golf course downstream from Cookes dam. None of these uses of the water resource would be measurably altered or affected by installation and operation of hydropower facilities. Besides Pro Brush, the only other impoundment in current use is Paradise Pond formed by the Smith College dam. This pond provides for summer and winter recreation as well as aesthetic enhancement of the campus. Major concerns expressed by. Smith College officials are the need to minimize water level fluctuations in the pond, the need to maintain a small amount of flow passing over the dam for aesthetic reasons, and the need to make hydroelectric structures compatible with the existing visual character of the area. All of these needs could be met by the proposed project although only with some loss of energy generation due to intentional spillake.

\section{MARKETING POTENTIAL.}

Part of the output of the Chartpak project would be used by the Chartpak company and the local utility, Massachusetts Electric Company, would buy the residual at the prevailing fuel displacement rate which is currently $2.2 \$ / \mathrm{kWh}$.

Massachusetts Electric Company would purchase all of the output from the Cookes Intermediate Project at the prevailing fuel displacement rate.

All of the output from both the Pro Brush and Smith College projects would be used by the current dam owners.

\section{E. REGULATORY REQUIREMENTS.}

Regulatory requirements applicable to hydro development of the existing Mill River dams are both formal and informal. Upon decision to proceed with any of the projects, frequent and close coordination with all agencies involved would be important in expediting project approvals. Essential requirements would include:

- Short-form license-from Federal Energy Regulatory Commission;

- Section 10 and Section 404 permits frum U.S. Army Corps of Engineers;

- Waterways permit and wetlands permit from Massachusetts Department of Environmental Quality Engineering (the latter after approval by Northampton. Conservation Commission); 
- Consultation with and review by U.S. Fish and Wildlife Service, U.S. Environmental Protection Agency, Massachusetts Division of Fisheries \& Wildlife and others.

\section{F. CAPITAL INVESTMENTS.}

Capital investments per installed kilowatt, total costs per kilowatthour and return on investment are summarized as follows:

\begin{tabular}{|c|c|c|c|}
\hline Project & $\begin{array}{c}\text { Capital } \\
\text { Investment } \\
(\$ / \mathrm{kW}) \\
\end{array}$ & $\begin{array}{l}\text { Present Value } \\
\text { Cost for } \\
\text { Hydro Energy* } \\
(\$ / \mathrm{kWh}) \\
\end{array}$ & $\begin{array}{c}\text { Present Value } \\
\text { Cost for } \\
\text { Purchased Energy } \\
(\$ / \mathrm{kWh}) \\
\end{array}$ \\
\hline Chartpak & 3,400 & 2.89 & 2.32 \\
\hline Cookes Intermediate & 4,110 & 2.64 & --- \\
\hline Pro Brush & 3,600 & 2.72 & 1.96 \\
\hline Smith College & 5,750 & 4.03 & 1.93 \\
\hline All projects together & 4,020 & 2.59 & --- \\
\hline
\end{tabular}

* Based on total costs over 50-year life cycle

**Based on costs to user for purchasing electricity in amounts equal to hydro project production over 50-year life cycle, allowing for utility rate inflation $4 \%$ greater than general inflation.

The return on investment assuming concurrent development of the four projects was calculated to be 4.1 percent per annum based on a project payout period of 50 years.

\section{G. OPERATIION AND MAINTENANCE COSTS.}

If the four plants were operated and maintained as a single system the estimated cost would be $\$ 55,000 /$ annum. The corresponding figure for the operation and maintenance of a single plant would be in the order of $\$ 20,000 /$ annum.

\section{H. PROJECT LIFE.}

On the basis of a site inspection of the dams on the Mill River it was concluded that the remaining life of the existing structures is unlimited. The economic life of all the hydro projects was assumed to be 50 years which is a figure often used for this purpose.

\section{ENVIRONMENTAL AND SOCIO-INSTITUTIONAL IMPACTS.}

Environmental impacts of hydro developments on the Mill River would be associated with construction as well as operation of the projects. Excavation and other land-disturbing activities necessary for powerhouse, tailrace, and penstock construction would generate some sediment which might be washed into the river. Because much of the required excavation would be in rock, sediment quantities would likely be small. Construction phase impacts would be minimized by scheduling work in and near the river to avoid the season of greatest recreational fishing pressure and by requiring sediment and other pollution control measures to be taken as necessary, during construction.

Operational impacts relate basically to modification of natural river flows. While ponding water at Chartpak, flows in the river could be reduced to near zero, except for seepage and local inflows, frequently for periods of a few hours and infrequently for up to 18 hours. During the summer, reduc tion of already low flows during part of the day could adversely affect trout 
and other stream biota, although augmentation of fiows during the generation period could be beneficial for the stream fishery. These issues would need to be addressed further by the agencies responsible, should the projects proceed. Water flows between Button Shop south dam and Cookes dam would be substantially reduced if the Cookes Intermediate project were developed. "Increased sedimentation, stagnation, and encroachment of marsh and terrestrial vegetation would be possible in the Cookes pond area due to the decreased flows.

Nulte of the proposed Mill River projects is expected to have major social or institutional consequences locally, However, the projects would contribute to the national policy of lessening dependence on foreign oil, even if only in a small way, and would set a precedent for cogeneration projects in the Massachusetts Electric Company service area.

Alternative institutional arrangements for implementing the projects would include: Individual development and operation of parh prnjert byr the prosont ow er; individual development by owmers and operation by the City; development and operation of all projects by the City; or development of all projects by the City and operation. by a single private contractor.

\section{J. SAFFTY}

It was concluded that the addition of a hydropower facility at any of the dams under study would not affect the safety of the existing structures. A possible safety hazard would be introduced in the course of operating the plants in periods of low flows when generation would not be continuous. At the start of generation the water level downstream of each dam would rise causing a potential problem to individuals who might have strayed into the riverbed. The magnitude of this rise should not be more than a foot or two.

K. ENGINEERING ACCEPTABILITYY.

On the basis of a visual inspection of the sites and the subsequent engineering work which was carried out, that the construction of a hydropower facility at each site considered is technically feasible.

L. AVAILABILITY OF SUITABLE EQUIPMENT.

On the basis of the availability of flow and head it was concluded that the smallest-size standardized tube turbine-generator unit now available commercially from the Allis-Chalmers company would be a suitable machine for installation at all sites under study. This type and size of unit was used to obtain equipment costs and to size the divil works at each site. Comparison with hydro-generating equipment available from other manufacturers would be necessary at the design stage lo ensure final selection of the most suitable unit.

M. SCHEDULE.

A preliminary schedule for the design and construction of power facilities for the Chartpak, Cookes Intermediate, Pro Brush and Smith College projects includes nine. months of detailed design, advertisement for bids, and bid preparation and analysis prior to the award of contracts. Civil construction, and equipment fabrication, delivery, installation and testing would take a further fourteen months. This gives a total elapsed time, from the decision to proceed until all four plants are commissioned, of 23 months.

\section{CONCLUSIONS}

Development of the existing Mill River dams for hydroelectric power production is considered technically feasible and would present no ummanageable engineering, legal, or environmental problemș. However, none of these projects, either individually or jointly, would be financially feasible without substantial assistance in the form of capital grants. 


\section{NORTH HARTLAND DAM PROJECT}

North Hartland, VT

Vermont Electric Cooperative

Vermont Electric Cooperative \& Acres American Inc.

PRDA Proposal Contract No. 1790

\section{INTRODUCTION}

The North Hartland Dam Project feasibility study has been undertaken by Acres American Incorporated under the terms of a contract with Vermont Electric Cooperative Inc. (VEC) dated August 7 , 1978. The study has been jointly funded by the .Department of Energy (DOE) and VEC under Cooperative Agreement No. ET-78-D-07-1706. The North Hartland Dam and Reservoir is a federally owned flood control facility operated and maintained by the Corps of Engineers. The objective of the study was to establish the technical and economic feasibility of developing the hydroelectric power potential at the dam.

A preliminary permit (No. P2816) was granted to VEC for the project, by the Federal Energy Regulatory Commission (FERC) on February 19, 1979. This paper presents the results of the feasibility study for the proposed $6 \mathrm{MW}$ hydroelectric installation and deals with the conceptual design alternatives, construction cost estimates and schedules, preliminary environmental and safety assessments and power marketing studies for the project.

The existing North Hartland Dam is located on the Ottauquechee River, about 1.5 miles above the 0ttauquechee River/Connecticut River confluence, in Windsor County, Vermont. The reservoir controls a 220-square mile drainage area, and has a capacity of 71,400 acre-feet. The proposed generating plant will be located near the toe of the dam and will develop a gross head of 65 feet between the current permanent pool elevation of 425 feet and the estimated tailwater elevation, 360 feet.

The VEC Project Manager for this study was Mr. Walter N. Cook and subsequently Mr. William J. Gallagher. The Principal Investigator for Acres was Mr. John D. Lawrence, P.E., assisted by Mr. Richard E. Mayer, P.E. The assistance of the Corps of Engineers, New England Division, in the preparation of this report, is gratefuliy acknowledged, as is the guidance provided by the various other state and federal environmental agencies contaited.

\section{CONCEPTUAL PROJECT DESIGN}

The North Hartland Hydroelectric Project has been found to be a technically feasible concept. The proposed project will have a recommended $6000 \mathrm{~kW}$ nominally rated capacity at a 52 feet turbine design head and $1680 \mathrm{cfs}$ demand flow. The gross generation expected from the project is $11,980,000 \mathrm{kWh}$ per year. It is estimated that the project will cost $\$ 8,997,000$ at 1978 price levels, with no allowance for funds during construction.

The project will provide peaking power at a levelized cost of about $41 \mathrm{mills}$ per kWh at 1979 price levels based on 7 percent cost of money, a 1985 commissioning date, and allowing for funds during construction and cost escalation over a 30 -year period. The benefit-cost ratio compared with an equivalent oil-based generation source over a similar period is estimated as 1.06 .

2.1 Description of Proposed Facilities: The proposed hydroelectric development will be located downstream of the existing North Hartland Dam, as shown on Plates 1 and 2, and will make use of the existing dam outlet facilities as an intake and penstock. The conduit will be steel lined and extended approximately 680 feet downstream. A separate bypass will be installed with a flow control gate discharging into a concrete-lined channel. The proposed powerhouse will be constructed at the downstream end of the existing outlet channel. The tailrace of approximately 250 -feet length will be excavated in the existing Ottauquechee River bed.

Power from the project will be transmitted via a new $46 \mathrm{kV}$ transmission line approximately six miles to an existing Vermont Electric Power Company transmission line of similar voltage.

The North Hartland reservoir is presently being operated for flood control purposes as a unit of the comprehensive plan of flood protection for the Connecticut River Basin. ATl existing structures are operated, 
maintained and monitored by the Corps of Engineers and are in excellent condition. The spillway crest structure and overflow channel show minor signs of frost damage to concrete, which can be repaired at minimal cost. This structure has never, in fact, been used. There is also evidence of minor leakage in the intake tower gate chamber, which is not considered serious.

2.2 Alternatives Considered: Two alternative powerhouse locations were considered together with the associated dam and spillway modifications, and a range of sizes and numbers of units. In order to develop a gross head of 65 feet at the upstream powerhouse location, it will be necessary to raise the reservoir permanent pool elevation by 25 feet. In such a case, major modifications to the existing dam or spillway will be required. On the other hand, extension of the penstock to a downstream powerhouse location will allow development of a similar 65 feet of gross head without raising the present permanent pool level or requiring modifications to the dam or spillway. Adoption of the downstream powerhouse location, wi th two tube-type turbine-generator units was found to be the most acceptable and cost effective alternative.

No specific facilities exist in the North hartland dam and outlet conduit for passage of fish. Consequently, no provision has been made in the proposed development for such facilities other than in the installation of appropriately sized trashracks at the intake and tailrace to prevent passage of fish through the power plant.

2.3 Plant and Unit Size Selection: The plant and unit sizes have been selected on the basis of the availability and condition of the existing facilities, reservoir water levels, the hydraulic characteristics of the existing and modified intake, conduit and outlet channel, the availability and variation of reservoir outflows, and comparative power values. The selected $6 \mathrm{MW}$ installation at the downstream location is considered to provide optimum usage of the available hydroelectric potential at the site. Initial plant size optimization and comparison of alternatives was based on preliminary power values published by the FERC for an alternative combustion turbine source in New England. The selection of plant size and configuration will not be significantly influenced by any likely differences in power values. Nevertheless, further scrutiny of optimized plant size may be warranted in later phases of project evaluation when power values are more specifically defined. The plant capacity is limited to a significant extent by the dimensional constraints and hydraulic characteristics of the proposed intake and penstock structures.

Full consideration has been given to the number and type of units for the power facility. Alternatives evaluated comprised one-, two- and three-unit installations, utilizing double- and single-regulated Kaplan and fixed-blade propeller turbines in both horizontal (tube, buib or Strafio) and vertical configurations., and installed capacities ranging from 4500 to $6800 \mathrm{~kW}$. Although smaller installations providing mid-range power may result in lower net costs per kWh of generation, the project would not be considered an economic alternative to other mid-range generating sources already available to VEC. In the case of the single-regulated Kaplan (or tube) turbines, plant sizes were limited to standard manufactured units with 2000,2250 , and $2500 \mathrm{~mm}$ runner diameters. Three-unit alternatives were found to provide no significant economic benefit in terms of increased generation and were therefore rejected in favor of the one- or two-unit installations.

Project evaluations for one- and two-unit aiternatives are summarized in Table 1 . On the basis of the costs provided by manufacturers for this study, the tube unit alternative appears to provide a significant potential for cost reduction of approximately $\$ 1,761,000$ relative to $i$ ts nearest competitor. This alternative was therefore selected for more detailed cost determinations at the upstream and downstream sites.

\section{DEVELOPMENT CONSTRUCTION COST ESTIMATES AND SCHEDULES}

3.1 General: Detailed construction cost and schedule data were developed for two principal alternative hydro developments under consideration for the North Hartland Dam Project. The data is presented to a degree of detail such that further detailed economic evaluations as well as finance and schedule planning may proceed with an acceptable level of confidence.

3.2 Cost Estimates: Summary cost estimates for six alternative project design concepts considered are presented in Table 1. Detailed cost estimates were prepared for the proposed installations with two standardized $3000 \mathrm{~kW}$ tube turbines, at each of the upstream and downstream power plant locations considered. As indicated for Alternatives 1 and 6 in Table 1 , the two-tube unit installation at the downstream location, at a total estimated cost of $\$ 8,997,000$ is $\$ 1,388,000$ less in construction cost than the upstream location.

Cost estimates for each alternative were based on equivalent plant facilities at each location, relative to access, provision of powerhouse maintenance and dewatering services and automatic operation. Estimated construction costs were based on current (1978-79) cost levels applicable to the type of work involved and local conditions in Vermont and effective through the third quarter of 1979. Additionally, unit costs for the major civil construction activities were estimated to allow for the environmentally sensitive location of the project and associated construction restrictions pertaining to noise, dust, preservation of water quality and limitations due to the flood control requirements of the existing structures. 
3.3 Schedules: Engineering and construction scheduling for the project will require a total period of 162 weeks from initiation of design to commissioning of two units, as shown on Plates 12 and 14 . This Engineering Schedule is essentially based on concurrent licensing and engineering design and equipment procurement activities to result in the shortest construction lead time. Consecutive licensing and engineering activities would lengthen the schedule by at least 90 weeks.

The FERC licensing phase of the schedule will include a 15-week preparation period in parallel with initial engineering design activities. The initial engineering design activities will include finalizing the project arrangement and preparing turbine/generator procurement documents. The earliest date scheduled for receipt of the FERC 1 icense will be week 95 , shortly after which time the civil construction contract document will be ready for bidding. This license lead time of 80 weeks is somewhat longer than the processing time required for the recently issued Lawrence Hydro Project (FERC No. 2800) on the Merrimack River in Massachusetts. To avoid schedule delays, the latest date for receipt of license will be week 108.

The critical portion of the Construction Schedule will be the closure of the outlet conduit through the dam to allow penstock and bypass installation and power plant construction to take place. This has been optimistically scheduled to take place during the relatively dry four-month period of July through October, weeks 132 through 150 of the schedule. The reservoir will be kept drawn down during this period by means of pumps. Timely delivery of penstocks, bypass control gate, turbines and generators and associated equipment will all be crucial to realization of the schedules. Procurement of these items has therefore been scheduled during the licensing period and sufficiently in advance of the civil construction contract to allow appropriate manufacturing lead times in each case. Licensing and contract award by week 108 will be essential.

Several potentially adverse circumstances will present themselves if construction were to start at other times of the year or if high flows were to occur during the summer season. Potential. problems will include loss of partially completed tunnel and power plant installation, winter concreting operations, overtime and extra shift operations, and many other possibilities for which contingency planning will be required. The construction schedule for plant commissioning at the downstream site on Plate 14 will require 54 weeks. from week 108. Each schedule has been based on separate Electrical and Mechanical Installation Contracts awarded 8 weeks after the Civil Construction Contract.

3.4 Project Cash Flow: With a conservative assumption of consecutive licensing and engineering activities, a commercial service date of January 1985 is reasonably attainable. Assuming 6 percent annual escalation of estimated 1978 cosis, the cash flow requirenent for the recommended downstream site only, by quarter (i3 week period), is presented in Table 2. The calculated allowance for funds during construction (AFDC) has been estimated assuming a 7 percent annual cost of money and an end of period payment. The total project cost, including AFDC, escalated to the commercial service date, is thus $\$ 13,931,000$.

\section{PRELIMINARY ENVIRONMENTAL AND SAFETY ASSESSMENTS}

4.1 Existing Conditions: The proposed hydroelectric facilities at North Hartland lie within and on federally owned lands. The development will be integrated with the existing North Hartland Reservoir which is currently being operated for flood control purposes as a unit of the comprehensive plan of flood protection for the Connecticut River Basin. The existing reservoir and adjacent areas are scenically attractive, provide significant wildlife habitats and are used for recreational activities on a relatively small scale.

4.2 Preliminary Environmental Assessment: The proposed development of hydroelectric potential will have negligible impact on the present terrestrial and aquatic systems both during construction and operation of the facilities.

Current evaluations of alternatives for hydroelectric installations have identified essentially three principal development concepts. Two of these involve raising the existing reservoir conservation pool level by 25 feet and construction of a power plant immediately downstream of the dam. The third alternative will make use of the present reservoir operating level in conjunction with a power plant located about 700 feet downstream from the dam. To assist in the selection of the most favorable alternative, preliminary environmental and safety assessments have been conducted. These assessments identified the major impacts anticipated from construction and operation of the proposed hydroelectric facilities.

Detailed environmental/safety assessments will be required as part of the licensing process. The current study, on the other hand, has been brief and preliminary and has been adapted to the level of feasibility assessment appropriate at this time. The study consisted of a preliminary review of pertinent environmental reports, a site reconnaissance and contacts with individuals from state and federal agencies having expertise on the terrestrial and aquatic ecosystems found within the project area.

4.3 Preliminary Safety Assessment: Construction of the proposed hydroelectric facilities will potentially impact the safety of the public as well as construction workers in the immediate vicinity of the powerplant. 
Appropriate precautions will be necessary to minimize these risks: Design and operating procedures will be formulated to insure that no significant change in risks to public safety will arise during operation of the hydroelectric installations.

\section{MARKETING STUDIES}

Current VEC plans for future peaking generation requirements are based on purchases of gas turbine capacity until 1989. Alternatives available to VEC beyond that date are confined to further purchases or investment in oil-based generation sources. Commissioning of North Hartland in 1985 is a reasonably attainable objective which would result in displacement of $5700 \mathrm{~kW}$ of gas turbine capacity and a total of $11,980,000$ kWh of generation per year, of which at least 5,133,000 kWh are oil-based.

Consideration of the future scarcity and more rapid escalation in costs of fuel-dependent sources, indicates hydroelectric peaking generation to be more economic on a present worth basis over a 30-year period. VEC could derive maximum hydro potential from a hydro site of the particular capacity envisaged. The proposed project will closely conform to and coordinate with the utility power requirement of the Cooperative. Additional generation capacity presently available to VEC may be used to back up the North Hartland plant during periods of seasonally low flows. Reserve requirements for the proposed project also presently available to VEC will additionally allow full use of the hydro potential for firm power requirements rather thall so-called "dump power" sales for energy not carefully fitted to the system's daily and monthly load curves.

TABLE 2

NORTH HARTLAND DAM PROJECT ESCALATED CASH FLOW REQUIREMENTS

\begin{tabular}{|c|c|c|c|c|c|c|c|}
\hline Year & Period & $\begin{array}{l}\text { Payments } \\
(\$ 1000)\end{array}$ & $\begin{array}{c}\text { Escalation } \\
\text { Factor } \\
\end{array}$ & $\begin{array}{l}\text { Escalated } \\
\text { Payments } \\
\end{array}$ & $\begin{array}{l}\text { Cumulative } \\
\text { Payments }\end{array}$ & $\begin{array}{l}\text { AFDC } \\
(\$ 1000)\end{array}$ & $\begin{array}{c}\text { Cumulative } \\
\text { AFDC } \\
\end{array}$ \\
\hline 1981 & OND & 70 & 1.26 & 88 & 88 & 0 & 0 \\
\hline \multirow[t]{4}{*}{1982} & JFM & 70 & 1.34 & 94 & 182 & 1.5 & 1.5 \\
\hline & $\Lambda \mathrm{MJ}$ & 70 & & 94 & 276 & 3.3 & 4.8 \\
\hline & JAS & 70 & & 94 & 370 & 4.9 & 9.7 \\
\hline & OND & 100 & & 142 & 512 & 6.6 & 16.3 \\
\hline \multirow[t]{4}{*}{1983} & JFM & 115 & 1.42 & 163 & 675 & 9.2 & 25.5 \\
\hline & AMJ & 127 & & 180 & 855 & 12.3 & 37.8 \\
\hline & JAS & 148 & & 210 & 1065 & 15.6 & 53.4 \\
\hline & OND & 266 & & 378 & 1443 & 19.4 & 72.8 \\
\hline \multirow[t]{4}{*}{1984} & JFM & 552 & 1.50 & 828 & 2271 & 26.5 & 99.3 \\
\hline & AMJ & 5000 & & 7500 & 9771 & 41.5 & 140.8 \\
\hline & JAS & 2109 & & 3164 & 12935 & 173.5 & 314.3 \\
\hline & OND & 300 & & 450 & 13385 & 231.9 & 546.2 \\
\hline
\end{tabular}

NOTES: (1) Based on commercial service date (2 units) Jan. 1, 1985

(2) For $6000 \mathrm{KW}$ installation, downstream powerhouse location.

(3) Escalation of 1978 costs at $6 \%$ per annum

(4) Al lowance for Funds During Construction (AFDC) at 7 percent annual interest, end of period payments, accumulated through comenercial service date. 
$\underline{\text { TABLE } 1}$

NORTH HARTLAND DAM PROJECT

PRELIMINARY PROJECT COST COMPARISONS (THOUSANDS \$)

TOTAL INSTALLED CAPACITY - $6.0 \mathrm{MW}$

\section{Account Item}

30 Land \& Land Rights

Structures \& Improvements

Reservoirs, Dams \& Waterways

Turbines \& Generators

Accessory Electrical Equipment

Misc. Power Plant Equipment

Roads \& Recreation Facilities

Substation Equipment

355/6 Transmission

\section{Sub-Tota}

Contingencies (15\%)

Direct Cost

Engineering \& Administration $(20 \%)$

TOTAL PROJECT CAPITAL COST

$\underline{2-T_{u b e}^{(1)}} \quad \begin{gathered}2 \\ \text { 2-Propeller }\end{gathered}$

\begin{tabular}{cc}
3 & 4 \\
2-Bulb (3) & 2-Straflo \\
\hline
\end{tabular}

$\underline{1-K a p l a n}^{(4)}$

$38=38$

$\begin{array}{r}38 \\ 555 \\ 3,897 \\ 2,160 \\ 160 \\ 25 \\ 97 \\ 87 \\ 506 \\ \hline\end{array}$

555
897

160

25
97
87

506

7,525

1,129

8,654

$\begin{array}{r}542 \\ 4,137 \\ 3,970 \\ 275 \\ 30 \\ 97 \\ 87 \\ 506 \\ \hline 9,682 \\ 1,452 \\ \hline 11,134 \\ \\ 2,227 \\ \hline 13,361 \\ \hline \hline\end{array}$

$\begin{array}{ll}1,731 & 2,227 \\ \underline{\underline{10,385}} & \underline{\underline{13,361}}\end{array}$

$\begin{array}{r}38 \\ 564 \\ 4,137 \\ 3,600 \\ 275 \\ 30 \\ 97 \\ 87 \\ 506 \\ \hline 9,334 \\ 1,400 \\ \hline 10,734 \\ \\ 2,147 \\ \hline 12,881 \\ \hline \hline\end{array}$

$\begin{array}{r}38 \\ 432 \\ 4,137 \\ 3,200 \\ 275 \\ 30 \\ 97 \\ 87 \\ 506 \\ \hline 8,802 \\ 1,320 \\ \hline 10,122 \\ \\ 2,024 \\ \hline 12,146 \\ \hline \hline\end{array}$

$\begin{array}{r}38 \\ 713 \\ \hline\end{array}$

4, 127

4,370

275
118
97

$\begin{array}{r}87 \\ 506 \\ \hline\end{array}$

10,331

1,549

11,880

2-Tube ${ }^{(5)}$

NOTES: (1)Horizontal, single-regulated units

(2) Vertical, fixed-blade units

(3) Horizontal, fixed-blade units

(4) Vertical, double-regulated unit

(5) Downstream location (al1 others upstream) 


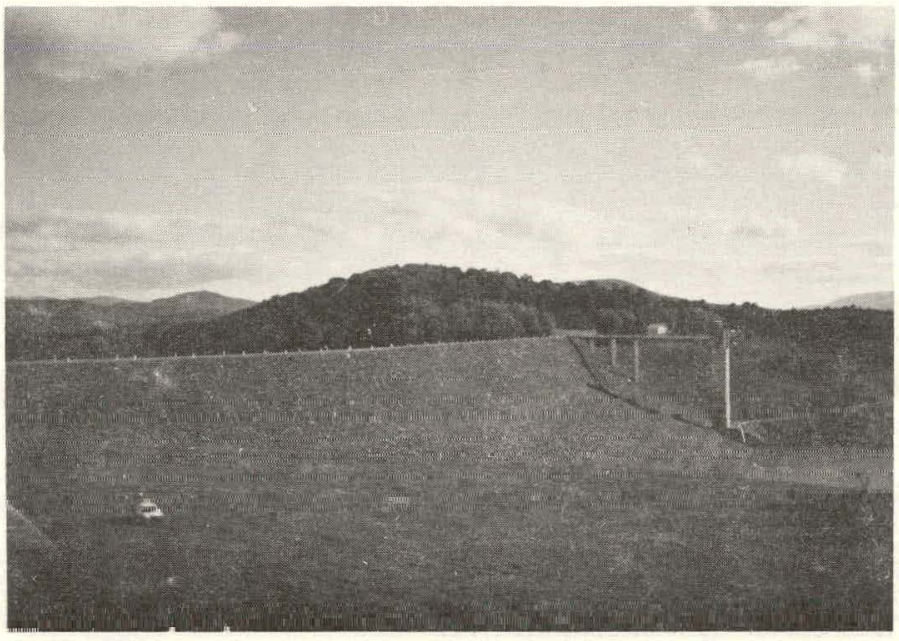

NORTH HARTLAND DAM

OTTAUQUECHEE RIVER WINDSOR COUNTY, VERMONT 



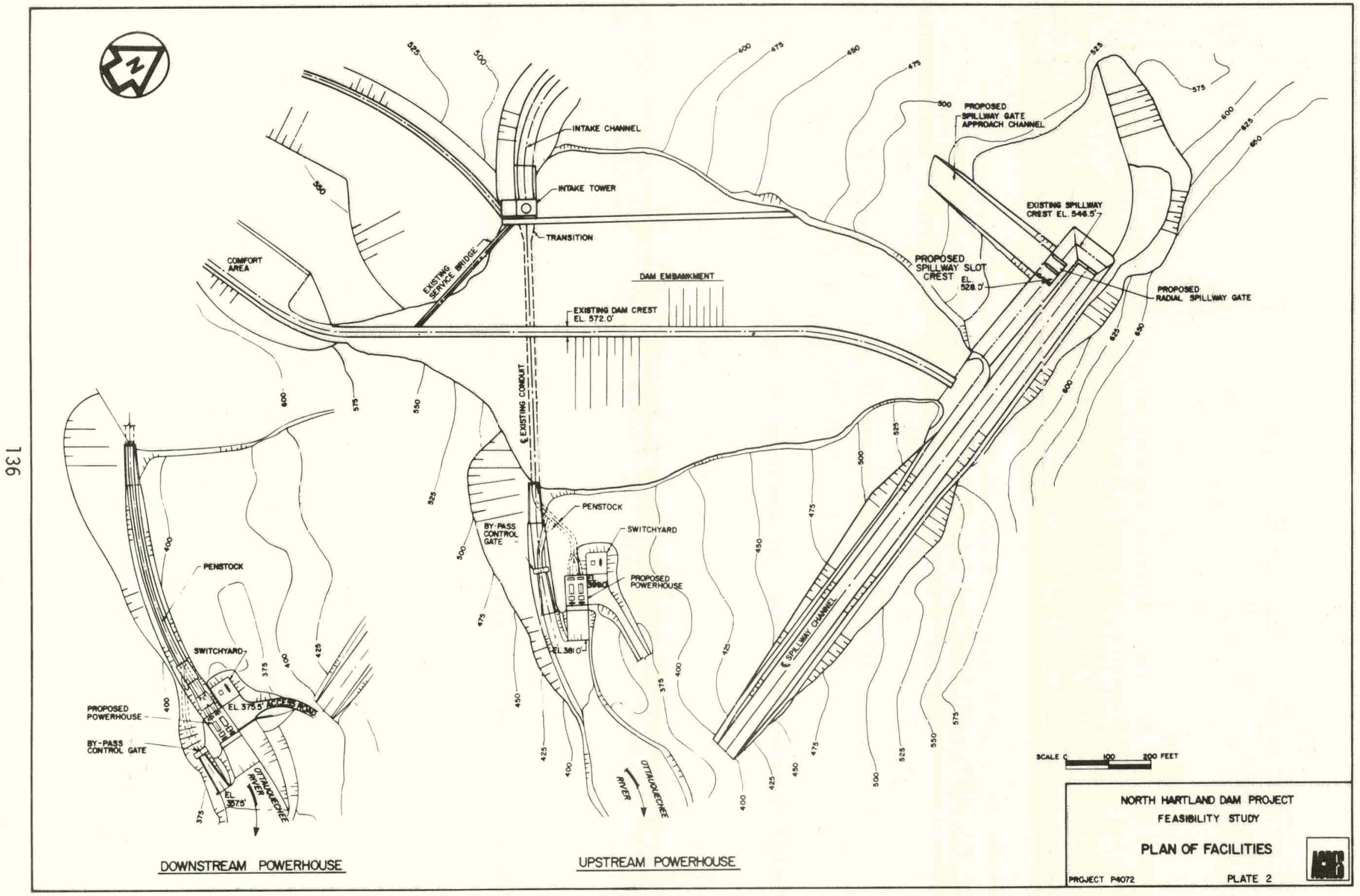


ENLOE DAM ON THE SIMILKAMEEN RIVER

OROVILLE, WASHINGTON

OKANOGAN COUNTY PUBLIC UTILITY DISTRICT NO. 1

PRDA Proposal Contract No. EW-78-F-07-1791

\section{INTRODUCTION}

Enloe Dam and powerhouse are located on the Similkameen River 3.5 to 4 miles northwest of Oroville, Washington (see figure 1). The dam and powerhouse were constructed in the early 1920 's and operated as a "run of the river" generation facility until 1959. Power generation ceased in 1959 due to increasing operation cost and the availability of less expensive power from the Bonneville Power Administration (BPA).

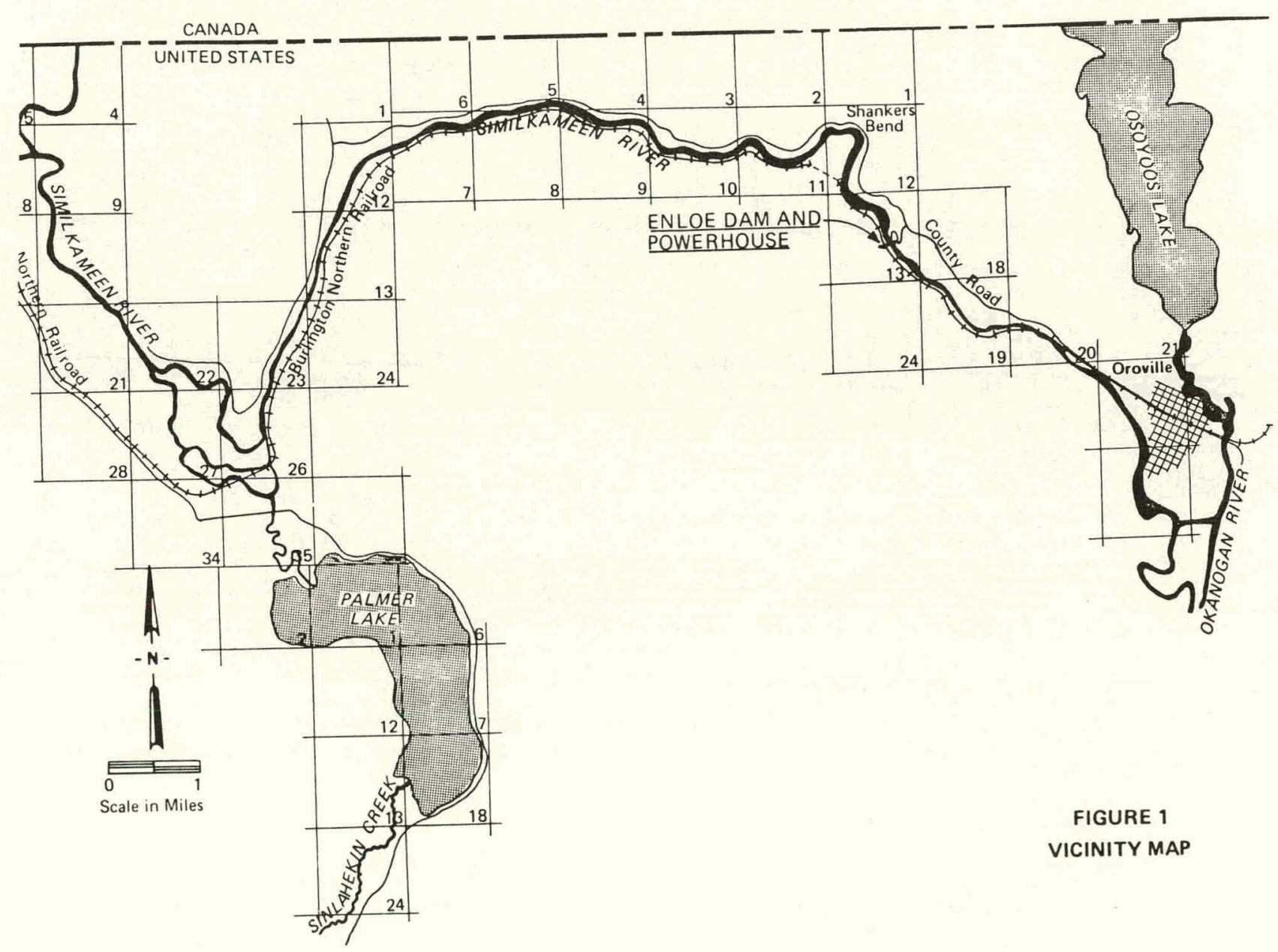




\section{EXISTING FACILITIES}

Enloe Dam is a concrete arch-gravity structure about 54 feet above streambed. It is about 6 feet wide at the top and over 41 feet wide at the base; the upstream face of the structure is vertical. Over 9,700 cubic yards of concrete were used in the structure. The spillway is an unregulated flow type with a crest width of 276 feet. The approximate elevation of the spillway crest is 1,044 feet above mean sea level. When the structure was operational, flashboards were installed along the top of the spillway during low-flow periods, which raised the reservoir surface 4 feet during low-flow periods. Flashboard supports consist of 6-inch diameter pipes and steel rails embedded 1-foot deep on 5-foot centers.

The penstock intake works are on the right side of the dam and consist of two steel pipes 7 feet in diameter with vertical slide gates and wooden trashracks. Hoist facilities for the slide gates are on the top of the dam. Two wood-stave pipes 7-feet in diameter go from the dam along the right side of the canyon for 743 feet to two elevated surge tanks. The taller of the tanks is over 32-feet high and 17-feet in diameter while the other is over 25-feet high and 24-1/2-feet in diameter. From the surge tanks, two 7-foot-diameter riveted steel penstocks lead down to two $1,600 \mathrm{~kW}$ horizontal turbine-generator units housed inside the machine room of the powerhouse. These units each have two 31-inch diameter Francis runners mounted on a common horizontal shaft.

The powerhouse is 83 -feet long and 40 -feet wide. Its foundation is concrete; the wal1s are red brick; and the roof is corrugated steel. The machine room section occupies about half the floor area of the building and has a high overhead area (41-feet in height). Adjacent to the machine room at a floor level 5-feet higher are the control room and transformer room. The switchyard is located adjacent to the powerhouse structure.

The facility was abandoned in 1959 because of the availability of less expensive power from BPA. Since that time, the plant has been badly vandalized because it has been impractical to provide complete security.

The most durable component, the dam, is in good condition. The Seattle District of the U.S. Army Corps of Engineers is currently working on a Phase I Dam Inspection Report of Enloe Dam. To minimize any duplication of effort, only the effects of the proposed rehabilitation on the safety of the dam were evaluated for this feasibility report. The Corps' finding on the overall safety of Enloe Dam will be made public in March of 1979.

The proposed remedial works and powerhouse operations will not affect the overall safety of the dam. The intake structure was in operation for 35 years, and the structure as a whole has been safe for 58 years. The proposed cosmetic concrete repair should enhance the life of the dam. These findings will be checked when the Corps' Phase I Dam Inspection Report becomes available.

\section{REHABILITATION}

The rehabilitation of the existing powerhouse below Enloe Dam has been found to be the most economical alternative for power development at the site. The existing turbines were designed to utilize a maximum combined flow of 650 cubic feet per second (cfs) of river flow, which is somewhat lower than desirable considering the flow that is available in the Similkameen River at the site. However, the cost for complete demolition of the existing facilities to make room for new equipment with significantly higher flow capacity cannot be recovered with the added power benefits that would accrue.

The remaining wood stave penstock will be removed and two new steel penstocks installed. To reduce head losses and to aid in construction, the new steel penstocks will have a 5/16-inch wall thickness and an 88.6-inch outside diameter. The outside diameter was chosen to fit the existing concrete cradles which supported the wood stave penstocks.

\section{FEASIBILITY/POWER COST}

The feasibility assessment shows that rebuilding the existing powerhouse and appurtenant facilities is technically feasible. Rebuilding the existing turbines and generators proved to be the most desirable. 
The characteristics of the proposed rebuilt powerplant are as follows:

$\begin{array}{ll}\text { No. of Units } & 2 \\ \text { Full Gate Flow } & 375 \mathrm{cfs} \text { per unit } \\ \text { Gross Head } & 83-72 \mathrm{feet} \\ \text { Installed Capacity } & 3,720 \mathrm{kw} \\ \text { Average Energy Production } & 22.5 \mathrm{mi} 11 \text { ion kWh }\end{array}$

The plant will be operated as a "run of the river" type with no potential for storage or peak power production.

The total estimated capital investment is $\$ 6.3 \mathrm{million}$, which gives a unit cost for installed capacity of approximately $\$ 1,700$ per $\mathrm{kW}$. The total annual costs for operation, maintenance, interim equipment replacement, insurance, and administration are estimated to be $\$ 135,000$. By using 6.5 percent bonds to retire the inital capital investment in 25 years, a total annual cost of $\$ 724,206$ would be incurred. The unit cost of energy would be 32.2 mills per KWh based on the estimated 22.5 million $\mathrm{kWh}$ expected to be produced in an average year.

It is important to note that project economics in an inflationary environment is very sensitive to time delays. The projected busbar costs presume aggressive pursuit of the project and prompt Federal action on licensing.

The marketing analysis shows that the District is clearly the operating entity that could ultimately utilize the output of the Enloe project. Three marketing options are proposed which will provide an interim sale of the output until needed by the district. We believe it possible to devise a suitable power marketing plan that will support early construction and result in a longterm economical power supply for the District. 
BROWN BRIDGE, KEYSTONE, BOARDMAN, SABIN

AND UNION STREET DAMS ON BOARDMAN RIVER

Traverse City and Grand Traverse County, Michigan

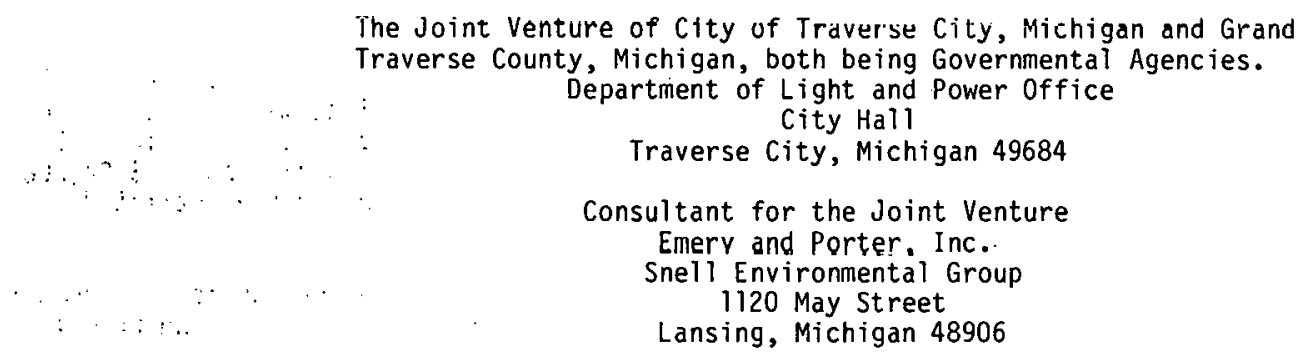

Cooperative Agreement No. EW-78-F-07-179?

SUMMARY

This report presents the results of a study conducted in 1978 to determine the feasibility of rehabilitating one or more of the five existing dam sites located on the 19-mile portion of the Boardman River upstream from the mouth of the river in Traverse City, Michigan.

Detailed data gathered during the study is presented and includes a description and evaluation of facilities at the sites; hydrologic analysis of the river basin, evaluation of the potential market for power which would be produced, and an appraisal of equipment that would be suitable for installation and economic and financial factors related to the potential development. Water resource needs, safety hazards, environmental concerns, and socio-institutional factors are also identified and evaluated. Federal, State of Michigan, and local government regulations were reviewed and permit requirements were identified and evaluated.

Evaluation of economic and non-economic factors indicates that hydroelectric generation at four of the sites is economically beneficial and has no significant effect on the quality of life in the Boardman River area. Rehabilitation of Keystone Dam, the fifth site, is economically beneficial but since it involves re-establishing an impoundment, significant environmental changes will occur, some of which are detrimental.

A potential major obstacle to early utilization of the power exists. Since Michigan law requires fish passages at dams, the Department of Natural Resources intends to require the installation as a condition of any permit issued. Additional costs and impacts of fish passage installation are presented but the issue could not be resolved in the report. If the Natural Resources Commission waives the requirement for fish passages, economic benefits will accrue without significant environmental impact.

The report includes management and development recommendations. Continuation of present ownership is recommended with easements to the City of Traverse City for development and operation of all dams for hydroelectric generation. Development of hydroelectric potential is recommended in three phases. Rehabilitation of Brown Bridge, Boardman and Sabin Dams with a combined potential of $2290 \mathrm{KW}$ by 1981 in the first phase. Rehabilitation of Union Street Dam with an additional $220 \mathrm{KW}$ by 1982 is the second phase. Reconstruction and rehabilitation of Keystone Dam with an additional $470 \mathrm{KW}$ after 1982 for a total capacity of $2980 \mathrm{KW}$.

Details of facility rehabilitation, time schedule and cost estimates are presented. The estimated cost of redevelopment is $\$ 5,950,000$. In 1978 dollars, the cost per installed $\mathrm{KW}$ is $\$ 2,010$, and the cost per KWH is $4.32 t$. If the cost of fish passages is charged to hydroelectric generation, the initial cost increases $\$ 3,250,000$. to $\$ 9,200,000$. 1978 dollar cost per installed KW would be $\$ 3,274$, and the cost per KWH is increased $43 \%$ to $6.2 \%$. The return on investment without fish passages is $111 / 4 \%$, with fish passages it is less than $5 \%$. 


\title{
OTTER CREEK HYDROELECTRIC FEASIBILITY REPORT
}

\author{
Proctor, VT
}

\author{
Vermont Marble Company \\ International Engineering Company, Incorporated
}

PRDA Proposal Contract No. 1793

\section{INTRODUCTION}

Vermont Marble Company (VMCO) and its subsidiaries produce a wide variety of products, including block marble for construction and memorials and finely ground marble for use as industrial fillers and extenders in the paper, paint, and plastic industries. VMCO also owns and operates four hydroelectric projects located on a 50-mile reach of 0tter Creek in west central Vermont. This investigation included three of these installations - Center Rutland, Beldens, and Huntington Falls. The fourth installation, Proctor, is the largest, but is not included in this study. All plants on Otter Creek operate as run-ofriver stations, and the limited reservoir storage capacities impose severe limitations on any other type of operation.

VMCO operates its hydroelectric projects as a public utility to satisfy its mill requirements and the demands of other customers in its service area. VMCO has recently expanded its mill capacity and will continue expanding until the mill is about four times its original size. This expansion plus normal economic growth in the area have increased electrical demand beyond the capabilities of VMCO's existing hydroelectric installations. Therefore, VMCO desires to improve its facilities to satisfy as much of the increased demand as is economically feasible. VMCO presently must purchase power and energy from a public utility to satisfy demand and will have to continue these purchases even after its projects have been improved.

This study has been performed in three phases:

- Appraisal of existing facilities.

- Evaluation of improvements and selection of the most feasible.

- Assessment of selected improvements.

The results show that, under the assumptions made in this study, Beldens and Huntington Falls can be economically improved. Center Rutland will become economically attractive only if the cost of energy escalates at a rate of around 10 percent per year.

\section{APPRAISAL OF EXISTING FACILITIES}

The condition of the existing facilities was based on field observations made during several field inspection trips; discussions with operating and 
supervisory personnel; and study of available files, reports, and other records. These appraisals included the structures, generating equipment, geological and hydraulic conditions, and environmental impacts.

The generating equipment is old, obsolete, and difficult and expensive to operate and maintain. The units are inefficient and markedly undersized for economical exploitation of the available hydraulic resources. Modification of the units for increased head or discharge is not economically feasible. The turbine centerlines are well above tailwater level, and draft head is only partially recovered. The transformers at Center Rutland and Huntington Falls are old, and core losses may be abnormally high.

No geological conditions were found during surface inspections that preclude site improvements, including increasing the dam heights.

Two hydraulic conditions were evaluated during the appraisal. These included using more discharge for electrical generation than is presently done and reducing the severity of floods. These conditions were studied further in the evaluation of improvement possibilities.

The environmental impacts were evaluated and found to be mostly favorable. The few impacts that were not require only simple measures to rectify. No environmental impact was found that precludes proceeding with the contemplated improvements.

The existing structures are not in danger of impending failure, and the generating equipment can continue to operate for a while. However, the time has arrived when improvements and rehabilitation are necessary for full exploitation of the Otter Creek energy resources.

\section{EVALUATION OF IMPROVEMENTS}

Three basic philosophies were used to formulate development alternatives. The first made maximum use of existing facilities and resulted in the least capital investment and energy generation. The second fully exploited the hydraulic resources and produced the most energy, but required the highest capital investment. The third philosophy was intermediate between these two and resulted in intermediate capital investment and energy production. Four development alternatives, including all three sites and embodying these philosophies, were formulated.

Technical evaluations were made of the components of each alternative to eliminate the least feasible and reduce them to a more manageable number. The unit size and upstream urbanization limited the Center Rutland site to one improvement possibility. Technical evaluations of Beldens reduced improvement possibilities to a single reservoir level and two or three units. These evaluations resulted in investigating the nine project improvements shown in Table $A$.

Quantity and cost estimates were prepared and the average annual energy was computed for the nine projects. Table B contains a summary of the resulting data.

Economic evaluations were made for the nine eligible projects, using the present worth method of analysis. The evaluations used 3, 5, and 7 percent 
TABLE A

PROJECT SELECTION

ELIGIBLE PROJECTS

CENTER R.UTLAND

Reservoir E1. 509.0; 2 1,200-kW units. Identification Symbol CR/202.4-509.

BELDENS

Reservoir E1. 284.0; $32,100-\mathrm{kW}$ units. Identification Symbol BEL/3-6.3-284. Reservoir El. 284.0; 2 2,100-kW units. Identification Symbol BEL/2-4.2-284.

HUNTINGTON FALLS

Reservoir El. 241.0;3 3,700-kW units. Identification Symbol HF/3-11.1-241. Reservoir El. 241.0; $23,700-\mathrm{kN}$ units. Identification Symbol HF/2-7.4-241. Reservoir El. 230.0; 3 3,100-kW units. Identification Symbol HF/3-9.3-230. Reservoir El. 230.0; $23,100-k$. units. Identification Symbol HF/2-6.2-230. Reservoir El. 218.0;3 2,300-kW units. Identification Symbol. HF/3-6.9-21.8. Reservoir E1. 218.0;2 2,300-k. units. Identification Symbol HF/2-4.6-218.

TABLE B

PROJECT SELECTION

SUMMARY OF PROJECT COSTS AND ENERGY

Item

Total Capital Investment (\$) Average Annual. Energy (kw!h) Installed Capacity (kW) Cost Per Installed kW (\$)

Total Capital Investment (\$) Average Annual Energy (kWh) Installed Capacity (kN) Cost Per Installed kW (\$)

BEL/3-6.3-284 BEL/2-4.2-284

$$
\begin{array}{r}
6,259,400 \\
20,855,000 \\
6,300 \\
994
\end{array}
$$

$\underline{H F / 2-7.4-241} \quad \underline{H F / 3-9.3-230}$

$\mathrm{HF} / 3-11.1-241$

$$
\begin{array}{r}
14,298,400 \\
37,525,000 \\
17,100 \\
1,288
\end{array}
$$

$\mathrm{HF} / 2-6.2-230$

$$
\begin{array}{r}
8,760,800 \\
26,740,000 \\
6,200 \\
1,508
\end{array}
$$

$$
\begin{array}{r}
11,340,500 \\
32,631,000 \\
7,400 \\
1,533
\end{array}
$$

$\mathrm{HF} / 3-6.9-218$

$$
\begin{array}{r}
9,079,700 \\
23,275,000 \\
6,900 \\
1,316
\end{array}
$$

$$
\begin{array}{r}
4,803,600 \\
18,152,000 \\
4,200 \\
1,144
\end{array}
$$

$11,396,900$

$30,878,000$

9,300

1,225

$\mathrm{HF} / 2-4.6-218$

$$
\begin{array}{r}
6,936,000 \\
20,225,000 \\
4,600 \\
1,508
\end{array}
$$


escalation; 35-, 40-, and 50-year analysis periods; and discount rates from 6 through 11 percent. These evaluations were used only to select a recommended development, which was further analyzed by other methods.

No analysis was made for zero escalation, because it is considered to be unrealistic. Escalation was uniformly applied to all costs and benefits for the first half of the analysis periods, and no further escalation was applied for the second half. The minimum analysis period corresponds to the useful life of some major project parts, especially the generating equipment and the transmission line conductors. The longest period represents a usually acceptable standard for hydroelectric evaluation. The discount rates are considered to be applicable to this type of development.

Benefits are the value of energy that does not have to be purchased from an outside source and, accordingly, are based on the price recently paid. The demand charge, transmission charge, and energy mill rate were combined on a weighted average basis and resulted in 25 mills per kilowatt-hour. The rate was escalated after the first year on the same basis as costs. System energy losses were subtracted from gross generation in computing total annual benefits, or revenue. The ranges of benefit/cost ratios and internal rates of return are shown in Table $C$.

TABLE $C$

RANGE OF BENEFIT/COST RATIOS

AND INTERNAL RATES OF RETURN

SELECTION OF RECOMMENDED DEVELOPMENT

$\frac{3 \% \text { Escalation }}{\text { B/C Ratio IRR }}$

$\frac{5 \% \text { Escalation }}{\text { B/C Ratio IRR }}$

$\frac{7 \% \text { Escalation }}{\text { B/C Ratio }}$

Center Rutland

$$
\text { 0.44-0.67 }
$$

1. $38-1.78$

$0.76-1.31$

7.08-9.21

Huntington Falls

$0.58-1.06$

4.26-6.62

$0.50-0.77$

$0.86-1.52$

$2.67-3.10$

8.76-11.12

$0.66-1.24$

$5.57-8.38$

$0.56-0.89$

$0.97-1.74$

$0.74-1.42$

3.98- 4.47

$10.46-12.56$. :

Under the above assumptions, no benefit/cost ratio greater than 1.00 was obtained for Center Rutland; and consequently, it was eliminated. Relatively low benefit/cost ratios were also obtained for Huntington Falls with the reservoir level at EI. 241.0 and with three units. The remaining possibilities were Beldens and Huntington Falls with two or three units. A study of the benefit/ cost ratios and internal rates of return for these possibilities resulted in selecting two 2,100-kW units at Beldens and two 3,100-kW units at Huntington Falls with reservoir El. 230.0 .

\section{SELECTED IMPROVEMENTS}

The installed capacity of the selected plants is 4,200 $\mathrm{kW}$ at Beldens, which will produce 18,152,000 kilowatt-hours, and 6,200 kW at Huntington Falls, which will produce $26,740,000$ kilowatt-hours, during an average year. The combined output of 44,892,000 kilowatt-hours will save a total of about 75,000 barrels of oil annualiy.

The market for the power and energy generated already exists within VMCO's service area, and electricity that cannot be produced by their hydroelectric plants is presently being purchased from a local public utility. Purchases 
from this source will still be necessary when the proposed improvements are completed; therefore, no question exists regarding the marketability of the increased output.

Further economic analyses and financial evaluations were made for the two selected projects using 5 percent escalation and a 50-year period. The benefit/cost ratios obtained from these analyses are shown in Table $D$.

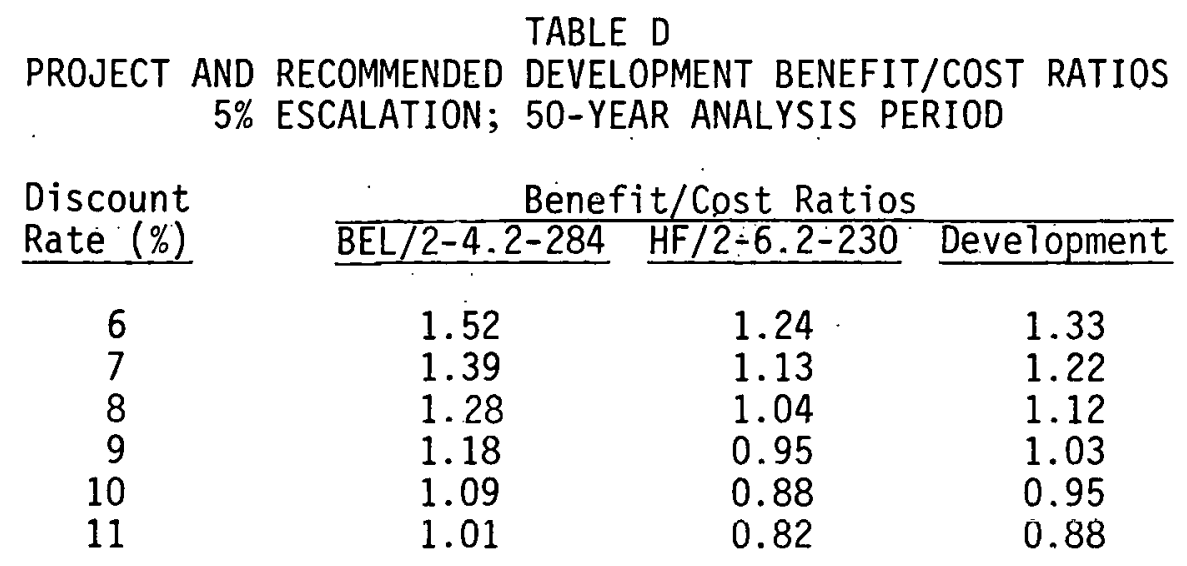

Net present value analyses were made for the Beldens two- and three-unit installations and for the Beldens two-unit installation combined with Huntington Falls two-unit installation, using all three reservoir levels. The internal rate of return is 9.37 percent based on 5 percent escalation and a 50-year analysis period. These analyses confirmed the selection of the recommended development.

The foregoing selection was made assuming base load operation, because of the limited reservoir storage capacity and the effects that peak load operation would have on other plants on Otter Creek. Environmental constraints and the discharge lag time between plants were also considered in making base load operation selection. Nevertheless, the reservoir capacities are sufficient to warrant consideration of daily peak load operation; and consequently, Huntington Falls was analyzed to determine the peak load output, if the foregoing technical difficulties can be overcome. The study assumed a 12-hour minimum operating period, as we 11 as longer periods up to 24 hours per day when the discharge permitted. The presently proposed minimum release was discharged at any time the plant was inoperative. The study showed that about 95 percent of the base load energy could be generated, including that produced during both daily peak load and base load hours. The energy produced during the 12 peak load hours would be about 71 percent of that produced by base load operations. It is suggested that field trials be made to determine more precisely the effects of peak load operation.

\section{CONCLUSIONS}

The proposed improvements are simple and can be provided easily. A total of 43 months is estimated to be required before power can be commercially generated. Eighteen months are allowed for amending the existing FERC 1 icense. Final design and bidding documents would be prepared during 16 months of this same period. Another four months are required for bidding, bid evaluation, contract award, and mobilization of the selected construction contractor. The construction contract should be awarded in time for construction to start 
by April, so that the two non-freezing seasons can be used to complete the work as scheduled. The proposed construction schedule envisions award of the construction contract in March 1981, with actual construction starting the following month, and completion occuring during october 1982 . Two months are allowed for startup and test.

VI. RECOMMENDATIONS

The selected development has been found to be technically feasible and economically viable. Therefore, it is recommended that Vermont Marble Company proceed immediately with the measures necessary to implement improvement of Beldens and Huntington Falls. The required measures include the following major items:

- Initiate procedures for amending the existing FERC Ticense.

- Initiate project financing.

- Proceed with final design, drawings, contract documents, and specifications required for construction.

- Obtain the necessary permits and licenses required by local, state, regional, and federal agencies.

- Begin land acquisition activities for any land required that is not presentiy owned.

It is also recommended that the Central Rutland feasibility study be reactivated if new data forecasts an energy cost increase rate higher than the one assumed in this study. 
LAKE FRANCES POWER GENERATING FACILITIES

Si loam Springs, Arkansas

City of Siloam Springs, Arkansas

McGoodwin, Williams and Yates, Inc.

PRDA Proposal Contract No. 1794

\section{INTRODUCTION}

The Lake Frances Dam is located on the 111 inois River approximately three miles southwest of Siloam Springs, Arkansas. The dam and most of the 517 acre lake are located in the extreme northwest corner of Adair County, Oklahoma.

The dam was originally planned, designed and constructed during a period of three years, from 1929 through 1931. The structure included a powerhouse with an open-flume vertical turbine and a direct coupled vertical synchronous generator. The generator failed because of an overload that occurred in 1935.

In 1943, approximately 700 feet of the earth embankment washed out due to high flows that exceeded the capacity of the spillway.

The ${ }^{\prime}$ city of Siloam Springs purchased the dam and the adjacent 1 and in 1954 . To reduce the possibility of the failure occurring again, the dam was rehabilitated with a 200 foot section of sheet piling. The earth embankment was also raised two and one-half feet. The turbine was encased in concrete to plug the hole in the powerhouse.

The structure has been operated as rebuilt since 1954.

\section{I1. SERVICEABILITY OF THE STRUCTURE}

Since the powerhouse and the concrete section of the dam are forty-eight years old, the serviceability of the structure is very important.

The Oklahoma Water Resources Board and the Tulsa District, Corps of Engineers, have classified the Lake Frances Dam as an intermediate size dam with a high hazard potential. The classification is a result of the Phase I Inspection Report of the National Dam Safety Program.

The Corps of Engineers estimates the Probable Maximum Flood (PMF) to be approximately 555,000 cubic feet per second, and at this flow the dam would overtop 8.1 feet which would cause a failure of the earth embankment. The Corps of Engi neers also estimates the spillway can safely pass approximately 20 percent of the PMF without overtopping the earth embankment. The maximum flood recorded at the damsite occurred in 1892 and was estimated at 84,000 cubic feet per second.

The reported safety hazards associated with the dam are present whether or not the dam is utilized for the generation of electric power. Therefore, the power project does not include provisions for a major renovation of the entire structure.

For the hydro-power project to be feasible, any remedial measures necessary to insure dam safety during flooding conditions would have to be funded from alternate sources.

The powerhouse appears to be structurally-sound. There is no evidence of any foundation failure which would be caused by differential settlement. However, there is extensive surface deterioration of the concrete powerhouse structure. The building that once housed the generator and equipment has deteriorated beyond repair. There are several holes in the construction joints within the concrete arch section of the dam immediately adjacent to the powerhouse. Since the arch section of the dam and the existing powerhouse are so closely related to the hydro-power project, the costs for rehabilitating the arch section and the powerhouse have been included in the cost estimates. 


\section{STREAM FLOW AND POWER 'POTENTIAL}

The flow data utilized in calculating the power potential of the Lake frances site were taken from the U.S.G.S. Water-Data Reports. The period from October 1955 through September 1975 was used in all calculations.

The 111 inois River is in the Arkansas River Basin. The data used were gathered at gaging station 07195500 , which is at the U. S. Highway 59 bridge near Watts, Oklahoma. This gaging station is $0.8 \mathrm{mile}$ downstream from the Lake Frances Dam. The Lake Frances reservoir has a drainage area of 635 square miles.

For the twenty years of record from Water Year 1956 through Water Year 1975, the average flow is 622 cubic feet per second. With the average flow condition of 622 cubic feet per second and a constant head of twenty feet, the stream has an average power potential of 1,200 horsepower, or 894 kilowatts.

Because the capital investment is substantially less, the open flume-generating arrangement is the most feasible. A sketch indicates how the equipment would be incorporated into the existing structure. A differential level in the headwater elevation is the typical method of controlling an open-flume generating system. If the control differential is expanded to use the top six inches of the lake storage while maintaining a constant minimum downstream flow of 100 cubic feet per second through the low flow conduit, the stream-lake combination has an average annual capability of producing 177 equivalent days of power at a sustained flow of 590 cubic feet per second.

The flow of 590 cubic feet per second can support an 850 kilowatt generator which will have a twenty year average annual utilization factor of 48 percent.

As can be seen from the following table, the most economical size is the 850 kilowatt generator with an annual cost of production of $18 \mathrm{mills}$ per kilowatt-hour.

GENERATOR COMPARISON TABLE

\begin{tabular}{|c|c|c|c|c|c|}
\hline SIZE OF GENERATOR (KILOWATTS) & 500 & 650 & 750 & 850 & 1000 \\
\hline REQUIRED FLOW (CUBIC FEET/SECOND) & 347 & 451 & 520 & 590 & 690 \\
\hline 20 YEAR AVG. ANNUAL EQUIVALENT CFS-DAYS & 211 & 191 & 189 & 177 & 158 \\
\hline 20 YEAR AVG. ANNUAL UTILIIZATION FACTORS & $58 \%$ & $52 \%$ & $51 \%$ & $48 \%$ & $43 \%$ \\
\hline 20 YEAR AVG. ANNUAL PRODUCTION (KWH) & $2,528,809$ & $2,962,734$ & $3,375,957$ & $3,596,680$ & $3,216,880$ \\
\hline TOTAL PROJECT COSTS (MARCH, 1979) & $\$ 515,653$ & $\$ 591,553$ & $\$ 602,553$ & $\$ 608,053$ & $\$ 646,776$ \\
\hline COST PER INSTALLED KW & $\$ 1,031$ & $\$ 910$ & $\$ 803$ & $\$ 715$ & $\$ \quad 646$ \\
\hline ANNUAL COST (LOAN PLUS $0 \& \mathrm{M}$ ) & $\$ 56,748$ & $\$ 63,261$ & $\$ 64,205$ & $\$ 64,677$ & $\$ 68,000$ \\
\hline COST OF PRODUCTION (MILLS/KWH) & 22.4 & .21 .4 & 19.0 & 18.0 & 21.1 \\
\hline
\end{tabular}

\section{MARKET ANALYSIS}

The city of Siloam Springs can be characterized as a public utility in that the city owns and operates the electrical distribution system. Since the most economical generator (i.e., 850 kilowatts) can produce only approximately 5 percent of the city's power needs, any time there is sufficient stream flow all of the power that the generator can produce will be used immediately.

Because the power would be utilized in lieu of purchased power, the city would actually have a marketing arrangement best described as savings per kilowatt hour.

The marketing aspect of the hydro-power project is one of its best benefits. This benefit is ease of utilization of the power produced. 


\section{ECONOMIC ANALYSIS}

As is the case with many low-head hydro-power installations, the Lake Frances hydro-power facility's benefits are limited to savings of other nonrenewable energy sources and to possible future cost savings caused by the escalation of future energy prices.

The city has a contract with Southwestern Electric Power Company for wholesale power. The present rate the city pays for power under this contract is approximately 14 mills per kilowatt-hour (i.e., energy charge plus fuel adjustment charge). The rate actually varies because the fuel adjustment charge varies.

The city will have to be able to generate power at a rate lower than the rate paid other suppliers for the project to be a viable alternative energy source. As the price for power increases and if the capital investment could be fixed at some point in time, the hydro-power alternative will have a better chance of being feasible.

For example, assuming the generating facilities were constructed and were put on line in three years and an annual inflation rate of 7 percent is applied to the total project costs, the facility would cost approximately $\$ 744,892$, Since at the same time the electrical energy costs will have the same or a higher rate of inflation, at the time the facility would be put on line the electrical rate would be at least $17.2 \mathrm{mills}$ per ki lowatt-hour. It would take an additional four years for the cost of producing hydropower to equal the price of power supplied by others.

Provided there is an adequate maintenance program, the typical expected life of a.hydro-power facility such as the one that would be installed in the Lake Frances Dam is 50 years.

Since all of the loan calculations are based on a 25 year amortization cost, the final 25 years of 1 ife would give the city a very low production cost per ki lowatt-hour.

The hydro-power facilities project is not economically feasible at the city's present day wholesale power rate. On the other hand, if the capital investment can be fixed, then, with the cost of power increasing every year, the facility indicates a future profit.

\section{FINANCIAL. FEASIBILITY}

As the city owns and operates its electrical distribution system, the city could issue 25 year revenue bonds to construct the facility. As shown in the economic analysis, however, the project is not self-liquidating at present day energy costs. Consequently, for the project to be constructed, the project would have to be subsidized for a period of time.

VII. SUMMARY

The purpose of this study is to analyze the feasibility of developing the power potential of the lllinois River at the Lake Frances Dam. Our study finds that:

A. The actual average power potential of the river is 1,200 horsepower or 894 kilowatts, with an average annual power production of $3.6 \mathrm{million}$ kilowatt-hours.

B. The power can be easily utilized on the city of Siloam Springs' distribution system.

c. The cost of an 850 kilowatt hydro-generating facility is estimated to be $\$ 608,053$.

D. The annual total per k.ilowatt-hour cost to produce the power available at the dam varies from $17.1 \mathrm{mills}$ per $\mathrm{ki}$ lowatt-hour to $19.4 \mathrm{mills}$ per kilowatt-hour, depending on the type of financing secured.

E. The project is not self-liquidating at the present wholesale rate that the city pays for power.

F. The installation would save nonrenewal types of energy, and, if the capital cost can be fixed at present day prices, the unit will become economically feasible as electric rates increase.

G. The hydro-power project will not support any remedial rehabilitation of the entire dam structure.

VIII. CONCLUSIONS

A. Construction, operation, and maintenance of the Lake Frances hydro-power generating facility could be feasible if the following conditions are met. 
1. If guidelines are published and the city is able to acquire the needed funds for the dam safety improvements. Cost estimates would be based on the published guidelines.

2. If financing arrangements can be made using either subsidies, grants, bonds, or a combination. of all three so that the capital costs can be fixed to assure an adequate future financial return.

B. The hydro-power facilities should be constructed, owned, and operated by the city of siloam Springs, which has an immediate use for the power generated and means to finance at least a portion of the project.

C. There will be no significant adverse environmental impact resulting from either the construction or operation of the hydro-power facilities.

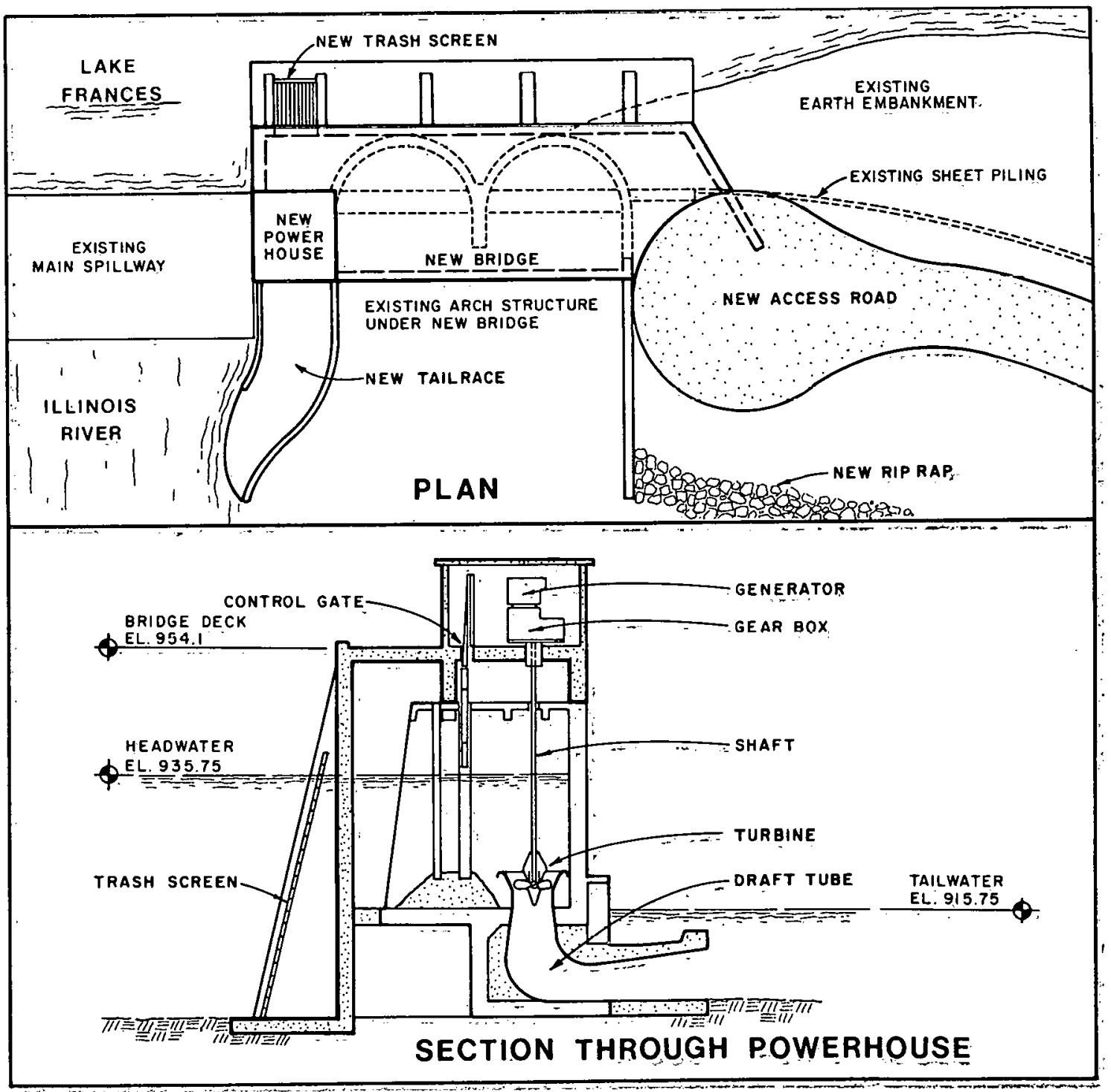




\section{ST. JOSEPH RIVER HYDROELECTRIC PLANTS}

Five Locations, Indiana and Michigan

American Electric Power Service Corporation

W. W. Stelle, Asst. Chief Civil Engineer

PRDA Proposal Contract No. 1795

\section{INTRODUCTION}

This report presents the current status and preliminary results of a feasibilitiy assessment study for upgrading five existing hydroelectric plants on the St. Joseph River in Michigan and Indiana. These plants are, in downstream order, the Mottville, Elkhart, Twin Branch, Buchanan, and Berrien Springs plants. The plants are owned and operated by two subsidiaries of American Electric Power Company (AEP). The assessment is being carried out under the provisions of $D O E$ Cooperative Agreement No.EW-78-F-07-1795 between the Department of Energy and the AEP Service Corporation (AEPSC).

\section{RESULTS OF STUDIES TO DATE}

Studies completed to date have involved assessing the generating capability of the existing plants, determining the production potentials at each site, defining alternatives for reconditioning or upgrading each plant to increase generating capability, and assessing the environmental and regulatory aspects of implementing the alternatives.

\section{CAPABILITY OF EXISTING PLANTS}

Recent operating records were analyzed to assess the generating capability of the five existing plants. The units at each plant are over 50 years old and, as shown on Table 1 , their generating capabilities are less than would be expected from new plants of the same installed capacity. Lost capability is considered to result from the age and condition of equipment and from unattended operating procedures which sometimes cause inefficient use of available water. The remaining useful life of existing equipment is uncertain. In the absence of reconditioning, it would seem reasonable to assume a useful life of 10 years.

\section{TV. OPERATING MODES AND POTENTIAL PRODUCTION}

The five plants are currently operated as mun-of-river installations. With limited drawdown from storage, it would be possible to concentrate more of the energy production during the daily 12 - to 15 - hour peak load periods in the AEP system.

Operation studies were performed at each plant to determine capacity and energy potentials for a range of installed capacities and four operating modes as follows: run-of-river and $12-, 8$-, and 4-hour peaking. Installed capacities up to about 1.5 times those currently provided were consldered. In the peaking modes, drawdown during the peaking hours was limited to $1.0 \mathrm{ft}$ at Mottville and Twin Branch and $2.0 \mathrm{ft}$ elsewhere.

The results of the study (Table 2) show that a 50 percent increase in capacity would provide from 3 percent (Twin Branch) to 10 percent (Elkhart) increases in average annual generation and from 10 percent (Twin Branch) to 34 percent (Elkhart) increases in average peaking capacity for the 4-hour peaking mode. Lesser increases In average peaking capacity occur with the Ionger peaking modes; however, the 8 and 12-hour modes do permit greater concentration of energy production during the 12 to 15 hour dally peak-luad period of the AIF system. 


\section{V.. ALTERNATIVE SCHEMES FOR UPGRADING}

Alternative schemes for upgrading the plants include: (a) reconditioning of existing units; (b) replacing existing units with new units, requiring minimal structural changes; (c) provision of new units in new powerhouse structures; and (d) headwater control at Buchanan Dam, the only ungated dam of the five. In all schemes, remote control would be provided to improve the efficiency of operation and permit limited use for peaking and reserve capacity.

Alternatives at each plant are presented in Table 3. Reconditioning generally includes new runners, bearings, wicket gates, shafts, and governors. Existing generators would be retained. For alternatives involving new units, two types of standardized units were considered. These are the horizontal-shaft tube-turbine units offered by Allis-chalmers and the vertical-shaft open-flume units offered by Bofors-Nohab. Selection of new unit sizes was made so that the units would fit within the present unit bays without the need for excavation below existing structures to avold disturbance of the existing wood plle foundations. This constraint affects unit selection because of limitations of setting with respect to tailwater for horizontal-shaft tube units and inlet submergence for vertical-shaft open flume units. Headwater control alternatives at Buchanan Dam (Table 4) involve replacing. the existing flashboards with gates.

\section{VI. $\underline{\text { COSTS }}$}

Estimated construction costs for upgrading at each plant are presented in Tables 5, 6, and 7. The construction costs are estimated at January 1979 price level and include contingency, engineering, and administrative costs. The costs for installing new units include the necessary civil works. Civil construction cost estimates were prepared from detailed layouts and quantity estimates.

\section{BENEFITS}

The estimates of benefits and economic evaluation are still in progress as of the date of this summary:

\section{VIII.PRELIMINARY CONCLUSIONS}

The following preliminary conclusions can be drawn based on studies made to date:

1. The existing plants are economical producers of energy.

2. At present, the plants are not capable of generating the power that would be expected from new plants. of the same installed cenacity.

3. The nominal installed capacities provided at each plant are fairly well matched to the existing head and available flow conditions, and increased installed capacity will not provide substantial increases in average annual generation.

4. Potentials exist for using a small amount of available pondage to concentrate energy production during system peak load periods. This type of operation could provide higher capacity and energy benefits than continued run-ofrive operation but is subject to the objections of local residents and recreational users of the impoundments.

5. Reconditioning of the existing units is possible and would permit recovery of a substantial portion of the energy and capacity currently lost because of equipment age and construction.

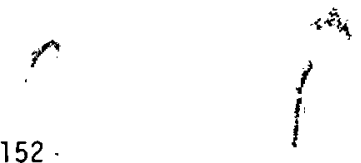


6. Provision of remote-control equipment will provide for better utilization of available streamflow and is preferable to continuing with unattended operations.

7. New standardized units can be accommodated at most of the plants within the existing unit bays without the need for major structural modification or disruption of existing foundations. In some cases new generator buildings would be required. At Berrien Springs, the standardized units cannot be accommodated in the existing unit bays but can be placed in new structures downstream from the existing draft tubes. At Buchanan, space exists to accommodate new units outside of the existing powerhouse in a new structure.

8. A comparison of construction costs indicates that reconditioning and provision of remote control is substantially less costly than providing new units in terms of cost per $\mathrm{kW}$ of installed capacity and cost per $\mathrm{kW}$ of average output. New equipment would, however, have the advantage of longer expected service life and improved maintainability in comparison with the reconditioned units of much older design. Since the incremental gain in generation is relatively smaIl with increases in capacity above that which could be provided with reconditioning, substantial capacity enlargements probably will not be attractive. Benefit estimates and economic evaluation are being performed at this time to define the most-attractive alternatives.

9. The high cost of providing gates at Buchanan Dam probably cannot be offset by increased production and reduced operating costs at Buchanan. However, the improved control at Buchanan also will benefit the Berrien Springs plant, and therefore, further study of this matter is planned.

10. Significant environmental problems are not expected to be encountered during the construction phase. The environmental effects of limited peaking operations are still under study.

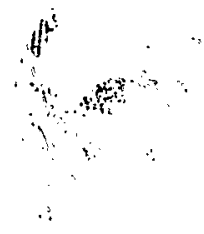


Table 1

CAPABILITY OF EXISTING PLANTS

\begin{tabular}{|c|c|c|c|c|c|c|}
\hline & & Mottville & Elkhart & $\begin{array}{c}\text { Twin } \\
\text { Branch }\end{array}$ & Buchanan & $\begin{array}{l}\text { Berrien } \\
\text { Springs }\end{array}$ \\
\hline Installed Capacity & $\mathrm{kW}$ & 1600 & 3440 . & 7260 & 4104 & 7200 \\
\hline Rated Head & ft & 11 & $18^{\circ}$ & $19 \underline{1}$ & 13 & 21 \\
\hline Age of Newest Units & yrs & 56 & 56 & 57 & 52 & 51 \\
\hline Age of oldest Units & yrs & 56 & 58 & 75 & 59 & 71 \\
\hline Expected Avg. Annual Generation $2 /$ & MWh & 8500 & 16500 & 33600 & 20300 & 41100 \\
\hline Actual Avg. Annual Generatio̧ & MWh & 6500 & 12800 & 21200 & 12200 & 25700 \\
\hline Ratio of Actual to Expected & - & .76 & .78 & .68 & .60 & .63 \\
\hline Estimatcd Plant Efficiency & Pct & 61 & 62 & 50 & 48 & 50 \\
\hline \multicolumn{7}{|l|}{ Maximum Monthly Generation } \\
\hline - Recorded Maximum & Avg $k W$ & 1440 & 2760 & .5650 & 2470 & 5650 \\
\hline - Corresponding Net Head & ft & 10.1 & 15.8 & 19.3 & 11.9 & 21.6 \\
\hline - Expected Maximum A & Avg $\mathrm{kW}$ & 1410 & 2830 & 7740 & 3590 & 7510 \\
\hline - Ratio of Actual to Expected & - & 1.02 & 0.98 & 0.76 & 0.69 & 0.75 \\
\hline \multicolumn{7}{|l|}{ Maximum Plant Output } \\
\hline - Expected with Like-New Units & $\mathrm{kW}$ & 1790 & 3030 & 7440 & 3590 & 7780 \\
\hline - Corresponding Head & ft & 11.9 & 16.5 & 19.3 & 11.9 & 22.1 \\
\hline - Estimated with Existing Units & $\mathrm{kW}$ & 1790 & 2970 & 5650 & 2470 & 5850 \\
\hline $\begin{array}{l}\text { Average River Flow } \\
\text { Ratio of Rated Discharge }\end{array}$ & $f t^{3} / s$ & 1530 & 2100 & 3180 & 3450 & 3470 \\
\hline to Average Flow & - & 1.4 & 1.3 & 1.8 & 1.35 & 1.5 \\
\hline
\end{tabular}

I/ Assumed average; units are rated at 18 and $22.5 \mathrm{ft}$.

2/ Run-of-river operation with plant efficiency of 80 percent.

3/ Based on a comparison of monthly generation with expected generation.

4/ Plant discharge at rated head. 
Table 2 (Sheet 2 of 2)

SUMMARY OF PRODUCTION OF ALTERNATIVE PLANTS OPERATING MODES 3 AND 4

\begin{tabular}{|c|c|c|c|c|c|c|c|c|c|c|c|c|c|}
\hline \multirow[b]{3}{*}{ Plant } & \multirow[b]{3}{*}{ Condition } & \multirow[b]{3}{*}{$\begin{array}{c}\text { Service } \\
\text { Ii fe } \\
\text { Years } \\
\end{array}$} & \multirow[b]{3}{*}{$\begin{array}{l}\text { Ra }=\text { ed } \\
\text { Head } \\
f=- \\
\end{array}$} & \multirow[b]{3}{*}{$\begin{array}{c}\text { Rated } \\
\text { Capacity } \\
\mathrm{kW} \\
\end{array}$} & \multirow{2}{*}{\multicolumn{4}{|c|}{$\begin{array}{l}\text { Mode } 3-8 \text { Hour Peaking } \\
\text { Avarage Annual Generation }\end{array}$}} & \multirow{2}{*}{\multicolumn{5}{|c|}{$\begin{array}{l}\text { Mode } 4-4 \text { Hour Peaking } \\
\text { Average Annual Generation }\end{array}$}} \\
\hline & & & & & & & & & & & & & \\
\hline & & & & & $\begin{array}{c}\text { Avg. Peaking } \\
\text { capacity } \\
\mathrm{kW}\end{array}$ & $\begin{array}{c}\text { Peak Hours } \\
\text { MWh } \\
\end{array}$ & $\begin{array}{c}\text { of f-peak } \\
\text { MWh } \\
\end{array}$ & $\begin{array}{c}\text { Total } \\
\text { MWh } \\
\end{array}$ & $\begin{array}{c}\text { Avy. peaking } \\
\text { capacity } \\
\mathrm{kW} \\
\end{array}$ & $\begin{array}{l}\text { Peak Hours } \\
\text { EWh }^{1 /} \\
\end{array}$ & $\begin{array}{c}\text { Of f-Peak } \\
\text { MWh } \\
\end{array}$ & \multicolumn{2}{|r|}{$\begin{array}{c}\text { Total } \\
\text { Mwh }\end{array}$} \\
\hline \multirow{5}{*}{ Mottville } & Existing & 10 to 15 & 11 & 1600 & 960 & 2620 & 3710 & 6330 & 1060 & 2460 & 3890 & & 6350 \\
\hline & Reconditioned & 40 & 11 & 1600 & 1260 & 3450 & 4880 & 8330 & 1390 & 3240 & 5120 & & 8360 \\
\hline & New & 50 & 11 & 1600 & 1260 & 3450 & 4880 & 8330 & 1390 & 3240 & 5120 & & 8360 \\
\hline & $n$ & 50 & 11 & 2000 & 1370 & 3660 & 4960 & 8620 & 1600 & 3460 & 5270 & & 8730 \\
\hline & $"$ & 50 & 11 & 2400 & 1410 & 3740 & 5040 & 8780 & 1720 & 3570 & 5310 & & 8880 \\
\hline \multirow{2}{*}{ Elkhärt } & Existing & 10 to 15 & 18 & 3440 & 1800 & 5050 & 7520 & 12570 & 1930 & 4820 & 7870 & & 12690 \\
\hline & Reconditioned & 40 & $i 8$ & 3440 & 2330 & 6510 & 9710 & 16220 & 2490 & 5220 & 10160 & & 16380 \\
\hline \multirow{3}{*}{ : } & New & 50 & 18 & 3440 & 2330 & 6510 & 9710 & 16220 & 2490 & 6220 & 10160 & & 16380 \\
\hline & $n$ & $5 \dot{0}$ & 18 & 4500 & 2670 & 7160 & 9790 & 16950 & 3020 & 6810 & 10520 & & 17330 \\
\hline & $"$ & 50 & 18 & 5500 & 2900 & 7560 & 9750 & 17310 & 3330 & $? 070$ & 10600 & . & 17670 \\
\hline \multirow{4}{*}{ Twin Branch } & Existing & 10 to 15 & $19^{-2}$ & 7260 & 3030 & 8370 & 12220 & 20590 & 3690 & 8130 & 12490 & & 20620 \\
\hline & Recondttioned & 40 & 19 & 7260 & 4810 & 13290 & 19390 & 32680 & 5850 & 12900 & 19830 & $\therefore$ & 32730 \\
\hline & New & 50 & 19 & 7260 & 4810 & 13290 & 19390 & 32680 & 5850 & 12900 & 19830 & & 32730 \\
\hline & $=$ & $5 \dot{0}$ & 19 & 8500 & 4950 & 13560 & 19480 & 33040 & 6190 & 13140 & 19840 & & 32980 \\
\hline & $=$ & 50 & 19 & 10000 & 5050 & 13770 & 19610 & 33380 & 6460 & 13400 & 19940 & & 33340 \\
\hline \multirow[t]{5}{*}{ Buchanan (Res. E1. 637.0) } & Existing & 10 to 15 & 13 & 4104 & 1510 & 4400 & 7290 & 1.690 & 1660 & 4360 & 7420 & $\therefore:$ & 11780 \\
\hline & Recoñditioned & so & 13 & 4100 & 2510 & 7340 & 12140 & 19480 & 2770 & $: 260$ & 12370 & F: & 19630 \\
\hline & New & so & 13 & 4100 & 2510 & 7340 & 12140 & 19480 & 2770 & $i 260$ & 12370 & . & 19630 \\
\hline & $"$ & 50 & 13 & 5000 & 2660 & 7750 & 12680 & 20430 & 3000 & .620 & 12880 & & 20500 \\
\hline & n & 50 & 13 & 6000 & 2770 & 8030 & 13120 & $2: 150$ & 3140 & $: 890$ & 13310 & . & 21200 \\
\hline \multirow{5}{*}{ Buchanan (Res. E1. 639.1) } & & 10 to 15 & 13 & 4104 & 1820 & 5310 & 8720 & 14030 & 2030 & 5.280 & 8930 & $\cdot$ & 14210 \\
\hline & Reconditioned & 40 & 13 & 4100 & 3040 & 8850 & 14540 & 23390 & 3390 & 8800 & 14880 & . & 23680 \\
\hline & New. & 50 & 13 & 4100 & 3040 & 8850 & 14540 & 23390 & 3390 & 8800 & 14880 & $\cdots$ & 23680 \\
\hline & " & & 13 & 5000 & 3180 & 9230 & 15030 & 24260 & 3620 & $\$ 070$ & 15230 & & 24300 \\
\hline & " & 50 & 13 & 6000 & 3290 & 9480 & 15430 & 24910 & 3770 & $\$ 320$ & 15630 & & 24950 \\
\hline \multirow{5}{*}{ Berrien Springs } & Existing & 10 to 15 & $2 i$ & 7200 & 3540 & 9930 & 14980 & 24910 & 3910 & $\$ 520$ & 15520 & 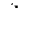 & 25040 \\
\hline & Reconditioned & 40 & $2:$ & 7200 & 5660 & 15880 & 23980 & 39860 & 6250 & 15.230 & 24830 & & 40060 \\
\hline & New & 50 & 2: & 7200 & 5660 & 15880 & 23980 & 35860 & 6250 & 15230 & 24830 - & & 40060 \\
\hline & $n$ & 50 & 2: & 9000 & 6090 & 16870 & 24860 & 41730 & 7110 & $1 \in 240$ & 25630 & & 41870 \\
\hline & " & 50 & $2:$ & 11000 & 6320 & 17270 & 25030 & 42300 & 7660 & $1 \in 640$ & 25720 & & 42360 \\
\hline
\end{tabular}


Table 3

MAXIMUM UNIT SIZES AND POTENTIAL CAPACITIES WITH NEW UNITS

\section{Existing Installed $\frac{\text { Capacity }}{\mathrm{kW}}$ \\ kh}

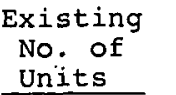

Factor(s) Affecting
Selection of Max.

Selection of Max.

Runner
Diameter

Head

Discharge

Unit Potential Units $\mathrm{mm}-\mathrm{ft}$

\section{Increase \\ Over}

HORIZONTAL SHAFT (TUBE-TYPE) UNITS

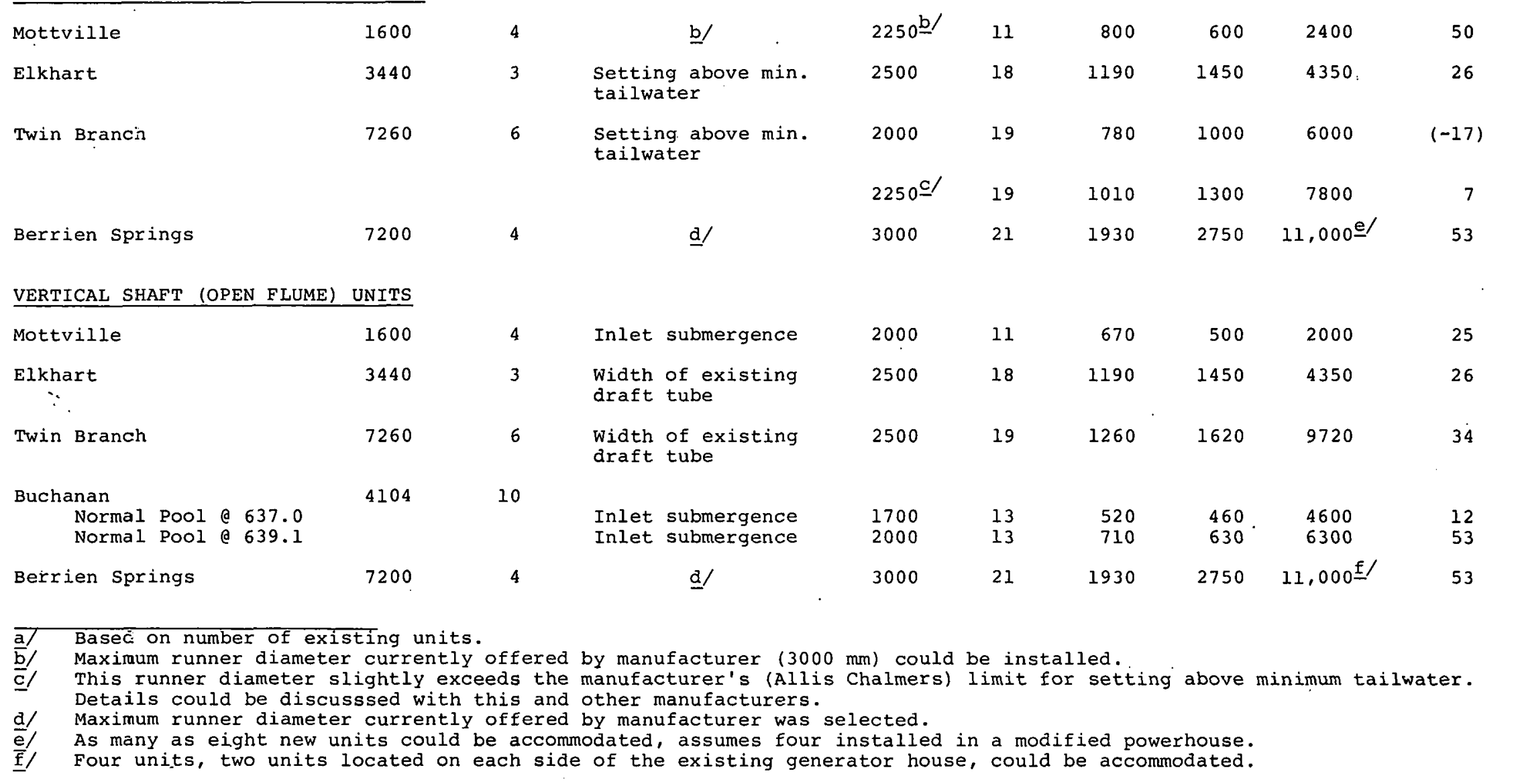

Note: Overall plant efficiencies assumed to be 80 percent. 
Table 4

ALTERNATIVES FOR GATES AT BUCHANAN DAM

\begin{tabular}{|c|c|c|c|c|c|c|}
\hline $\begin{array}{c}\text { Normal } \\
\text { Reservoir } \\
\text { Elevation } \\
\text { Et,msl }\end{array}$ & $\begin{array}{l}\text { Length } \\
\text { of Gated } \\
\text { Crest } \\
\text { ft }\end{array}$ & $\begin{array}{l}\text { No. of } \\
\text { Gates } \\
\end{array}$ & $\frac{\text { Widt }}{\mathrm{ft}}$ & $\frac{\frac{z e}{H e i g h t}}{\mathrm{ft}}$ & $\begin{array}{l}\text { Length of } \\
\text { Flashboards } \\
\frac{\text { Remaining }}{\mathrm{ft}}\end{array}$ & $\begin{array}{l}\text { Estimated } \\
\text { Construc- } \\
\frac{\text { tion Cost }}{\$}\end{array}$ \\
\hline 637.0 & 387 & 6 & 61 & 2.9 & 0 & $1,350,000$ \\
\hline 639.1 & 387 & 6 & 61 & 5.0 & 0 & $1,420,000$ \\
\hline
\end{tabular}


Table 5

ESTIMATED COSTS FOR RECONDITIONING EXISTING UNITS (REPLACEMENT EQUIPMENT; JANUARY 1979 PRICE LEVEL)

Capacity with Refurbishing, $\mathrm{kW}$ No. of units

Replacement Runners, Shafts, Gate casings Wicket Gates, and Bearings

Rewind Generators

New Draft Tubes

Replace Grease Systems and Piping

Governors

Replacement Servomotor Gate shaft and Connecting Links

Dismantle Units, Refurbish Draft Tubes

and Supports

Installation

Shipping

Contingency b/
Cost in Dollars

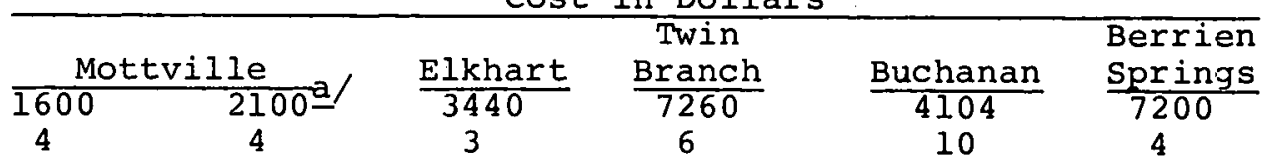

$\begin{array}{cc}700,000 & 700,000 \\ - & 500,000 \\ - & - \\ - & -\end{array}$

\section{0,000}

$$
\text { - }
$$

10,000

66,000

66,000

$.210,000$

20,000

20,000

120,000

40,000

40,000

90,000

152,000

152,000

190,000

24,000

24,000

30,000

$80,000-29,000-100,000$

$1,042,0001,631,0001,410,000$

249,000

$198,000 \quad 210,000$

$1,200,0001,880,0001,620,000$

Total

750

895

471
541

$3,420,000$

510,000

$3,930,000$

100,000

490,000

76,000

100,000

200,000

30,000

100,000

$1,540,000$

230,000

$1,770,000$

431 
Table 6

ESTIMÁTED COSTS FOR REMOTE CONTROL

(January 1979 Price Level)

\section{$\underline{\text { Item }}$}

Water Level Gaging Equipment

Automatic Start-stop Equipment

Supervisory Equipment

Microwave Equipment

Governor Potentiometers
Automatic Gate Control
gates at each Dam.)

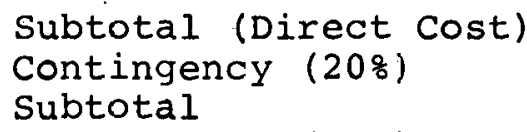

Subtotal

Eng. \& Adm. (15\%)

Total Construction cost

Central computer and console

Total Construction cost (Five Plants)

(Five Plants plus Buchanan Gates)

$$
49,000
$$

118,000

24,000

142,000
21,000
Cost in Dollars

\begin{tabular}{|c|c|c|c|c|c|}
\hline Mottville & Elkhart & $\begin{array}{c}\text { Twin } \\
\text { Branch }\end{array}$ & Buchanan & $\begin{array}{l}\text { Eerrien } \\
\text { Springs }\end{array}$ & Total \\
\hline 5,000 & 5,000 & 5,000 & 5,000 & 5,000 & $\cdots 25,000$ \\
\hline 43,000 & 51,000 & 102,000 & 165,000 & 63,000 & $: 424,000$ \\
\hline 10,000 & 5,000 & 5,000 & 5,000 & 5,000 & $, 30,000$ \\
\hline 10,000 & - & - & - & - & $10 ; 000$ \\
\hline 1,000 & 1,000 & 2,000 & 3,000 & 1,000 & 3,000 \\
\hline
\end{tabular}

45,000

47,000

a)

44,000

- 185,000

107,000

21,000

161,000

32,000

178,000

$.36,000$

128,000

193,000

214,000

118,000

24,000

$682,0.00$

19,000

29,000

32,000

142,000

137,000

122,000

$147,000 \quad 222,000$

246,000

163,000

941,000

$\frac{138,000}{1,079,000}$

$1,141,000$

a/ If spillway gates are provided at Buchanan cost would be about $\$ 45,000$ at direct cost level or $\$ 62,000$ at construction cost level.

b) Located at Twin Branch Generating Station; new building not required. 
Table 7

ESTIMATED COSTS FOR NEW UNITS .(JANUARY 1979 PRICE LEVEL)

\begin{tabular}{|c|c|c|c|c|c|c|c|c|c|c|c|c|}
\hline \multirow[b]{2}{*}{ Plant } & \multirow{2}{*}{$\begin{array}{c}\begin{array}{c}\text { Present } \\
\text { Installed } \\
\text { Capacity }\end{array} \\
\mathrm{kW}\end{array}$} & \multirow{2}{*}{$\begin{array}{l}\text { No. of } \\
\text { Existing } \\
\text { Units } \\
\end{array}$} & \multirow[b]{2}{*}{ Type of New Units } & \multirow[b]{2}{*}{$\begin{array}{c}\begin{array}{c}\text { Runner } \\
\text { Diameter }\end{array} \\
\mathrm{mm}\end{array}$} & \multirow{2}{*}{$\begin{array}{l}\text { No. of } \\
\text { New } \\
\text { Units }\end{array}$} & \multirow{2}{*}{$\begin{array}{c}\text { New } \\
\text { Installed } \\
\frac{\text { Capacity }}{\mathrm{kW}}\end{array}$} & \multicolumn{5}{|c|}{ Cost in Thousands of Dollars } & \multirow[b]{2}{*}{$\begin{array}{c}\text { Cost } \\
\mathrm{kW} \text { per } \\
\text { Installed }\end{array}$} \\
\hline & & & & & & & $\begin{array}{l}\text { Civil } \\
\text { Works }\end{array}$ & $\begin{array}{l}\text { Equip- } \\
\text { ment }\end{array}$ & $\begin{array}{l}\text { Contin } \bar{b} / \\
\text { gency }\end{array}$ & other & Total & \\
\hline \multirow[t]{2}{*}{ Mottville } & 1600 & 4 & $\begin{array}{l}\text { Vertical-shät, open } \\
\text { flume type }\end{array}$ & 2000 & 4 & 2000 & 503 & 1909 & 412 & 424 & 3248 & 1,624 \\
\hline & & . & $\begin{array}{l}\text { Horizontal-shaft, } \\
\text { tube-type }\end{array}$ & 2250 & 4 & 2400 & 1381 & 3607 & 886 & 881 & 6755 & 2,815 \\
\hline \multirow[t]{2}{*}{ Elkhart } & 3400 & 3 & $\begin{array}{l}\text { Horizontal-shaft, } \\
\text { tube-type }\end{array}$ & 2500 & 3 & 4350 & 454 & 3496 & 638 & 688 & 5276 & 1,213 \\
\hline & & & $\begin{array}{l}\text { Vertical-shaft, open } \\
\text { flume type }\end{array}$ & 2500 & 3 & 4350 & 190 & 1934 & 338 & 369 & 2831 & 651 \\
\hline \multirow[t]{3}{*}{ Twin Branch } & 7260 & 6 & $\begin{array}{l}\text { Horizontal-shaft, } \\
\text { tube-type }\end{array}$ & 2000 & 6 & 6000 & 915 & 4680 & 931 & 979 & 7505 & 1,251 \\
\hline & & & Same & 2250 & 6 & 7800 & 870 & 6084 & 1131 & 1213 & 9298 & 1,192 \\
\hline & & & $\begin{array}{l}\text { Vertical-shaft, } \\
\text { open flume }\end{array}$ & 2500 & 6 & 9720 & 729 & 4620 & 875 & 934 & 7158 & 736 \\
\hline \multirow[t]{3}{*}{ Buchanan } & 4104 & 10 & $\begin{array}{l}\text { Vertical-shaft, open } \\
\text { flume; Pool @ } 637.0\end{array}$ & 1700 & 10 & 4600 & $1258 *$ & 3483 & 837 & 837 & 6415 & 1,395 \\
\hline & & & $\begin{array}{l}\text { Vertical-shaft; Pool } \\
\text { (a } 639.1\end{array}$ & 2000 & 10 & 6300 & $1258 *$ & 4233 & 950 & 966 & 7407 & 1,176 \\
\hline & & & $\begin{array}{l}\text { Horizontal-shaft units } \\
\text { Outside of Present } \\
\text { Powerplant }\end{array}$ & 2250 & 3 & 2250 & 682 & 2871 & 602 & 623 & 4778 & 2,124 \\
\hline Berrien Springs & 7200 & 4 & $\begin{array}{l}\text { Horizontal-shaft, tube } \\
\text { type }\end{array}$ & 3000 & 3 & 8250 & 1048 & 4922 & 1000 & 1046 & 8016 & 972 \\
\hline \multirow[t]{2}{*}{$\cdot$} & & & & & 4 & 11000 & 1376 & 6509 & 1320 & 1381 & 10586 & 962 \\
\hline & & & $\begin{array}{l}\text { Vertical-shaft, open } \\
\text { flume type }\end{array}$ & 3000 & 4 & 11000 & 1602 & 4248 & 1037 & 1033 & 7920 & 720 \\
\hline
\end{tabular}

a/ Plan output at rated head.

b/ Allowance of 258 on civil works estimate and 158 an equipment estimate.

c/ Allowance of $15 \%$ on civil works, equipment, and contingency for engineering, administrative, and other costs.

*Based on Mottville estimate. 
CATARACT POWER PLANT EXPANSION ON THE SACO RIVER

\author{
Saco, ME \\ Centra1 Maine Power Company \\ Tippetts-Abbett-McCarthy-stratton
}

PRDA Proposal Contract No. EW-78-F-07-1796

\title{
I. INTRODUCTION
}

The existing Cataract Project (FERC 1icensed project no. 2528) is 1ocated in Southern Maine in the City of Saco, on the Saco River about three miles from its mouth in the east channel of the river and abutting Factory Island.

This site was originally developed to provide power in 1653 and its utilization as a source of energy has been almost continuous to the present day. The present development was constructed in 1937-38 and the $6650 \mathrm{KW}$ vertical Kaplan unit is still operating as a reliable source of energy with an average annual output of approximately $45,000,000 \mathrm{~kW}$ hours per year.

The drainage area at the site is 1703 square miles which provides: a median flow of 2200 cubic feet per second (cfs) and a calculated average flow, based on 60 years of record, of $3497 \mathrm{cfs}$. Not all of this water is available to the Company for generation purposes as factories which line both river banks have certain water rights. These water rights together with fish ladder releases, and gate and flashboard leakage were estimated to require an average continuous flow of $300 \mathrm{cf}$ s.

After a preliminary review of the available drawings and data it was concluded that three different cases of plant expansion would require study 1.e.,

a) Examine the technical feasibility of increasing the power of the existing turbine by installing new rotating parts.

b) Increase the power of the existing turbine and construct a new power plant.

c) Construct a new power plant without altering the existing unit.

\section{PREFERRED PROJECT}

Figures 8 and 9 of the full report (copies attached) show the location of the proposed power plant in relation to the other project structures, and the new power plant plan, elevations and sections respectively.

The preferred expansion project would consist of the construction of a new power plant housing two 2.5 meter horizontal shaft, standardized design, adjustable blade, tube type turbines having a design head of $39 \mathrm{feet}$. The turbines would be connected through speed increasing gearboxes to synchronous generators with a total rated capacity of $6240 \mathrm{KW}$. At maximum head and maximum turbine power generator capacity would rise to $7900 \mathrm{KW}$. Generation would be at $4160 \mathrm{~V}$ and a s.tep-up transformer would be provided to enable connection into the existing distribution system at $34,000 \mathrm{~V}$. Operation would.be performed remotely from the existing powerhouse control room with surveillance and maintenance being performed by the present project staff. 
The headworks would utilize the existing West Channel Dam, a portion of which would be removed. Due to the relatively shallow depth of water upstream of the dam an open flume headrace channel would be used to convey water to the powerhouse, while an open cut excavation in rock would form the tailrace channel. The relative length of these two channels was determined by access requirements for maintenance and trash removal past existing buildings together with the need to install flashboards in the flume wall with a discharge capacity equal to those lost when the portion of dam is removed so as not to raise upstream water levels during a flood.

Gross Plant Investment at present day costs was estimated to be $\$ 5,230,000$ with an anticipated design and construction time of 30 months after receipt of a license from FERC.

Average annual energy recovered from the new plant was estimated to be $15,900,000 \mathrm{~kW}$ hours per year, however, in excess of $70 \%$ of this energy is recovered in the four months during the snowmelt runoff season.

\section{TECHNICAL PROBLEMS ENCOUNTERED}

Establishing the design head for the new power plant entailed considerably more work effort than originally estimated. This was due to a combination of many factors. The existing plant has a design head of 44 feet which is derived from tailwater at elevation 0.0 feet above mean sea level and a headwater at Elevation 44.0 feet in the forebay pond. Headwater is maintained at E1. 44.0 feet by regulation of releases from the 750 acre feet storage behind Bradbury and Springs Dam. The outlet gate is remotely controlled from the existing. control room. However, it was found that the water passage under the combined road-rail bridge immediately upstream of the existing powerhouse formed a hydraulic restriction which would create head losses should the flow be increased. Due to the deepening of the channel to the fullest extent practical for the existing unit the problem of rapid headwater drawdown could not be overcome if the flow is substantially increased.

Tailwater is effected by tide, thus, fluctuates on a predictable basis. However, hydraulic controls in the river between the sea and the powerhouse also cause the tailwater elevations to vary with flow in the river. Examination of gage records of headwater and tailwater elevation kept at the powerhouse revealed that even at zero flow tailwater elevations of 0.0 were rarely achieved whereas elevations of +13.0 feet in a major flood are on record.

Due to the upstream hydraulic restraints in the East Channel it was decided to investigate use of the West Channel for a new power plant despite the disadvantage of remoteness from the existing control room and substation. In this channel tailwater elevations still remained a problem which was further complicated at times of low tide by a shallow section of riverbed near the downstream Main Street Bridge. Removal of this shallow section by excavation proved economically nonviable especially as benefits were only derived during the low tide period.

The outcome of this review led to the selection of a design head of 39 feet with the tailrace channel excavated so that tailwater will normally vary approximately \pm 1 foot depending on tide and river flow stage.

In considering the optimum plant installed capacity many variations were studied. The use of a standardized design tube unit was reviewed but it was found that the largest available machine gave less power than appeared to be optimum. Therefore the use of two smaller units was studied. This required that a review of the cost of one custom designed unit be compared to the cost of the same capacity in two standardized units. This led to the conclusion that two standardized units would prove cheapest.

Due to the relatively small variation in head a review was also made of the possibility of using fixed blade turbines with induction generators. The adjustable blade machine with synchronous generator proved to be the most economic. 
This feasibility study indicates that redevelopment of the Cataract site as described above is a marginally economic proposition which might offer some savings, over the life of the unit; however, two significant questions remain unanswered. First, will a fishway be required as part of the redevelopment? second, can a new or renewed fifty year FERC license be obtained for the Cataract site?

Central Maine Power Company intends to make more detailed studies to refine specific aspects of the plant, explore the question of the fishway with the appropriate state and federal agencies and persue the possibility of acquiring the Saco Tanning water rights. If the above mentioned items can be satisfactorily resolved the Company would expect to proceed with the application for a new fifty year license from the Federal Energy Regulatory Commission. 


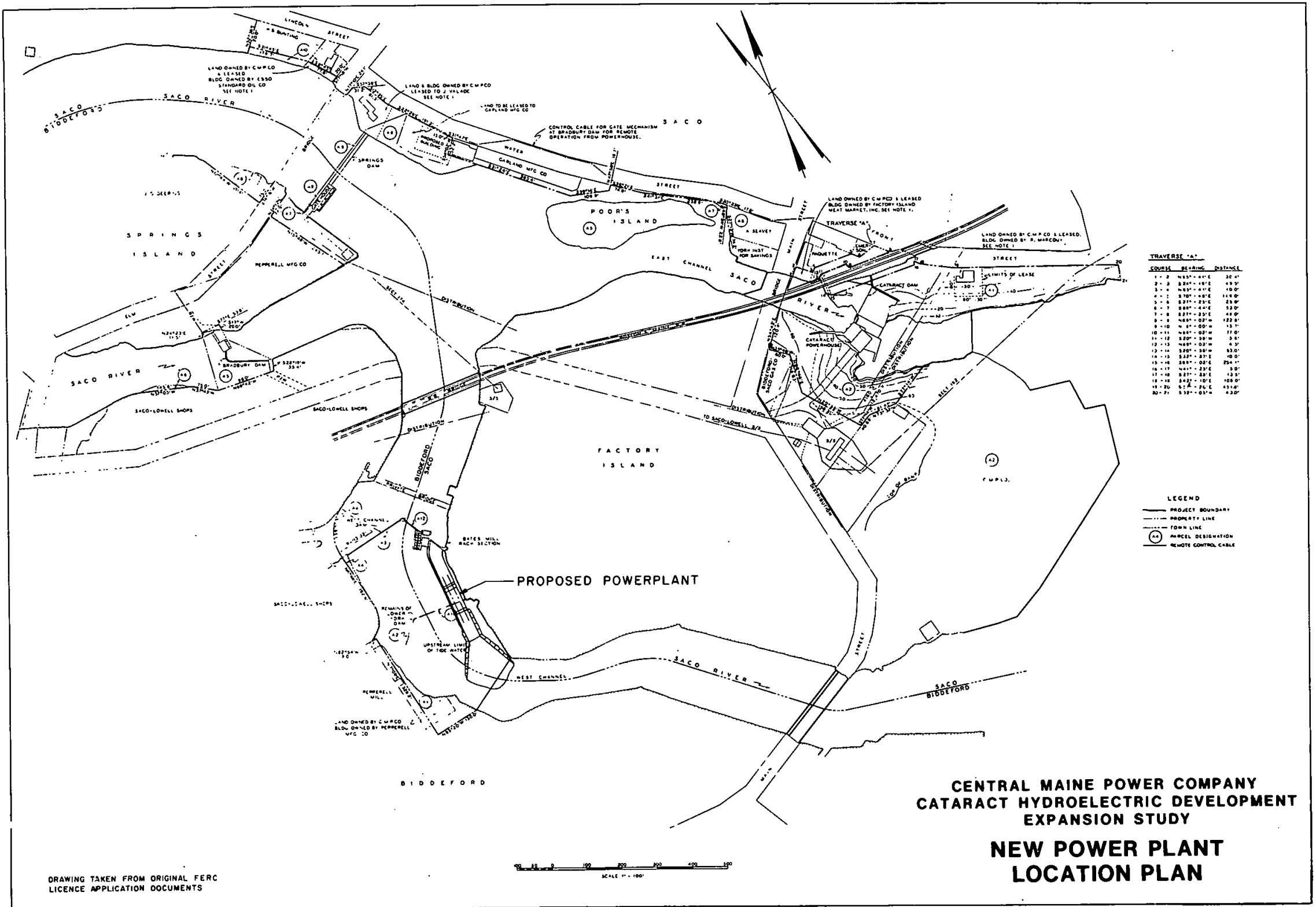




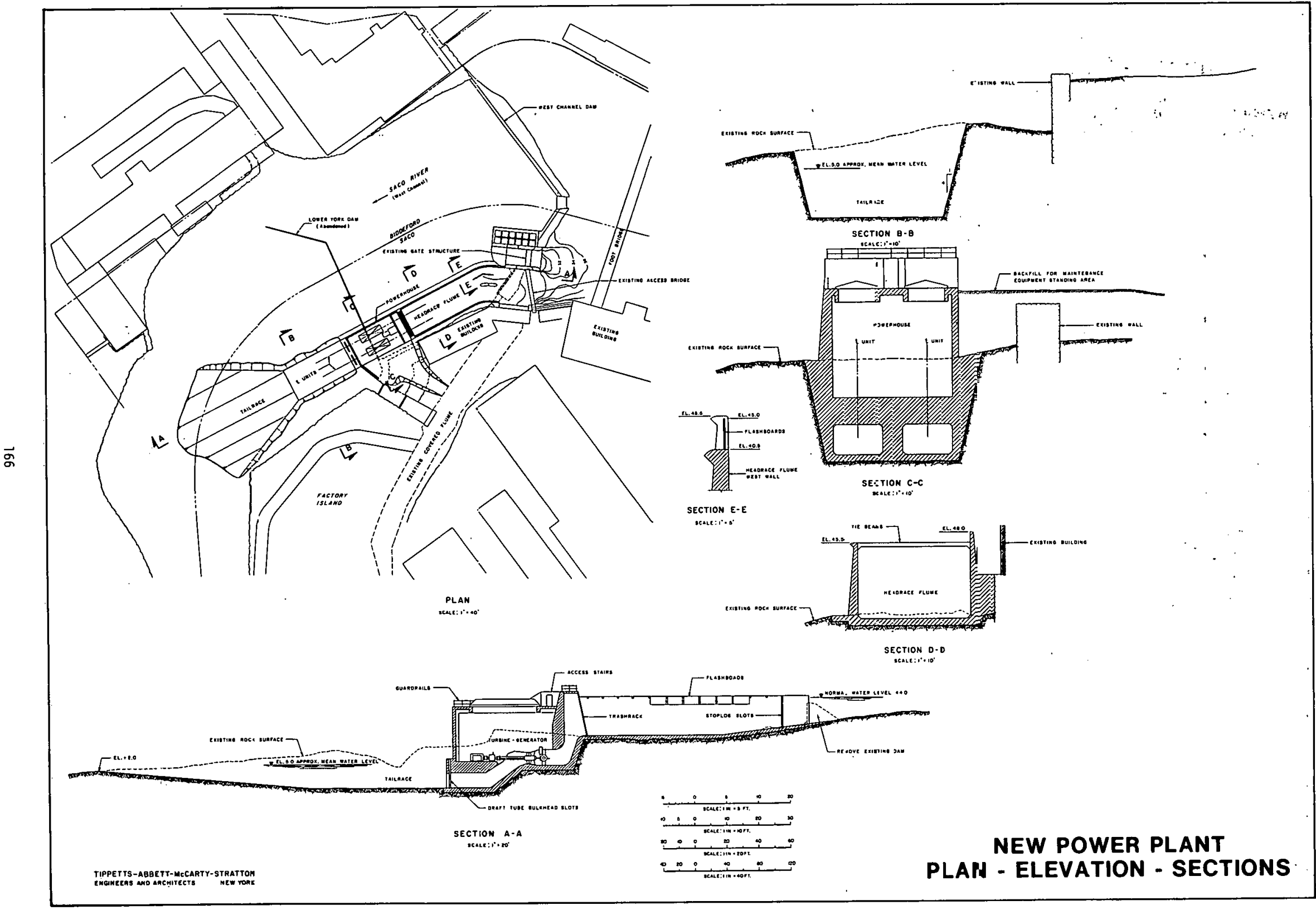

FIGURE 9 
TUTTLE CREEK DAM ON THE BIG BLUE RIVER

Manhattan, Kansas

Kansas Electric Power Cooperative, Inc. R. W. Beck and Associates

PRDA Proposal Contract No. EW-78-F-07-1798

\section{INTRODUCTION}

In response to a Program and Research Development Announcement by the Department of Energy (DoE), the Kansas Electric Power Cooperative, Inc. (KEPCo) submitted a proposal dated February 18 , 1978 to study the feasibility of installing hydroelectric generating facilities at the Army Corps of Engineers' (Corps) existing Tuttle Creek Dam, with financial assistance from the DOE. The studies and investigations performed for this feasibility assessment have included site reconnaissance, review of system load characteristics and site hydrology, development of conceptual project arrangements and layouts, power studies, estimation of construction costs, development of capital costs, determination of economic feasibility, development of a design and construction schedule and a preliminary environmental review of the proposed Project.

\section{EXISTING DEVELOPMENT}

Tuttle Creek Dam is located on the Big Blue River 10 miles upstream from the mouth at the Kansas River as shown in Exhibit A. The dam and reservolr (Tuttle Creek Lake) are owned and operated by the Corps for purposes of flood control, recreation, enhancement of fish and wildlife habitat and downstream water quality. Construction of the dam was completed 1n 1962, and hydroelectric generating facilities have never existed at the site.

As shown in Exhibit A., the existing development consists primarily of a zoned earthfill embankment, a gated spillway, a twin-barrel concrete conduit outlet works with intake tower and stilling basin, and a $2,346,000$ ac.-ft reservolr. The dam has a maximum height above streambed of $137 \mathrm{feet}$, a crest length of 7,487 feet and a volume of about $21,000,000$ cubic yards. The spillway is located in the left abutment and consists of an approach channel, a gated concrete weir structure, a concrete chute and an excavated outlet channel. The outlet works include an approach channel, an intake tower with service and emergency gates, two 20-foot diameter horseshoe conduits passing beneath the dam, a divided stiling basin and an outlet channel. The reservoir is normally held around the top of the multipurpose pool, E1 1075.0; currently the reservoir 1s annually fluctuated between EI 1073.0 to El 1079.0 to support some recreation and fish and wildlife functions.

\section{PROPOSED PROJECT ARRANGEMENT}

Two alternative project layouts were developed and compared. One alternative is to construct a tunnel through the left abutment of the dam with a powerhouse discharging through a long concrete outlet channel into the pond below the dam. The second alternative is to place a steel liner in one of the existing outlet works conduițs with a powerhouse discharging into the stilling basin. The tunnel alternative proved to be very costly because of the long waterway required and is not economically feasible. Hence the outlet works alternative was selected as the Project concept for cconomic analysis.

The existing outlet conduits are not designed for pressure flows, and thus a primary emphasis of the design of the power condult must be the prevention of pressurizing and cracking the existing conduit. This can best be accomplished by installing a steel liner from the existing service gates in the intake tower all the way through the conduit. The proposed power facilities would use the right (westerly) conduit. The required modifications would begin with a trashrack fastened to the front of the existing tower. The steel 11ner would begin 1mediately downstream of the tower service gates, and would include a 40-foot long twin rectangular section, a 60-foot long transition and an 800-foot long, 18-foot diameter penstock section. At the entrance to the stilling basin, the power condult would branch through a wye section. A shutoff gate (18' $D$ butterfly valve) would be located fust downstream, which would be closed during power operation and fully opened during flood discharges through the conduit. The other arm of the wye would connect to the powerhouse by a $90-f \circ o t$ long 18-font dlameter steel penstock and a 50-foot long mantfold. 
The powerhouse would discharge into the existing stlling basin as shown in Exhibit A. The powerhouse would contaln three Allis-Chalmers standardized 4,750 kW TUBE units and one Allis-Chalmers $500 \mathrm{~kW}$ TUBE unit for a total installed plant capacity of $14,750 \mathrm{~kW}$. The small unit would be included to allow generation with mininum flow releases. The generating units would operate under a rated net head of $60 \mathrm{feet}$.

The dependable capacity of the Project as delivered into the existing transmission and distribution network is $12,290 \mathrm{~kW}$ and the average annual energy is $56,690 \mathrm{MWh}$. This generation would serve to displace energy in the peak and intermediate load range which is now purchased from Kansas Power and L1ght Co. (KPL).

\section{PROJECT COST AND ECONOMIC FEASIBILITY}

The earliest practical date for the Project to come on-11ne 1s considered to be July 1984, which assumes 18 months for FERC license processing and a 21-month construction period. The Direct Construction Cost 1s estimated to be $\$ 10,376,000$. The Total Investment Cost, exc.luding any charges for use of the Foderal facilities, is estimated at $\$ 19,662,000$ for financing at a $9.5 \%$ interest rate.

Economic feasibility was studied by comparison of the Project estimated cost with the projected cost of continued power purchases equal to the power output of the Project, for the following three alternative methods of financing:

(1) An REA loan with a $9.5 \%$ interest rate and 35 year repayment period. For the first 7 years of the loan, only interest is paid. The following 28 years, both interest and principal are paid.

(2) An REA loan with a $7 \%$ interest rate and the same repayment schedule outlined abnve. The low 1nterest rate is assumed to display the benefits of low interest financing which may become available under the current Federal policy of accelerated small hydro development.

(3) A composite loan from the DOE and REA. The DOE portion of the loan would be for $75 \%$ of the Project cost and would be a 30-year conventional loan at $7-1 / 8 \%$ interest rate, based on provisions of Title IV, Small Hydroelectric Power Project section of the Public Utilities Regulatory Act (part of the National Energy Regulatory Act). The remalning $25 \%$ of the Project cost would be financed by a 30 -year $9.5 \%$ Interest rate $10 a n$.

Estimated costs and benefits for the Project with the three types of financing are shown in the table in Exhibit B. As can be seen, a large portion of the operating costs for the Project are taxes, which are very high on ut1lities in Kansas. The Project benefits are based on projected costs of purchased power from KPL and the Project average annual generation of $56,690 \mathrm{MWh}$ and a dependable capacity of $10,450 \mathrm{~kW}$ (1ncluding a $15 \%$ reserve allowance). As shown, the Project benefits in the first year are less than the Project costs for each of the three methods of financing. It should be noted that it is now generally accepted by FERC and others that a hydroelectric project can show a deficit in the first year of operation and yet still be considered feastble because 1 ts costs are essentially fixed with time as compared to alternatives. As shown graphically in Exhibit $B$, the benefits begin to exceed the costs during the fourth year of operation with $7 \%$ REA financing, during the sixth year with the $7-1 / 8 \%$ DOE financing and during the eighth year with $9.5 \%$ REA financing. Over a 10-year perfod on a present worth basis, the Project shows a surplus with the $7 \%$ REA financing but deficlts with the other two methods of financing. Therefore, by accepted methods of determining project viability, the Project is feasible only if low interest loans can be secured, such as the $7 \%$ REA $10 a n$ assumed here.

During the course of the feasibility investigation, 1nquiry was made of the Kansas C1ty District, Corps of Engineers as to possible charges to the Project for use of storage in the reservolr. In response, the Corps tentatively proposed charges of $\$ 150$ per ac.-ft. capital cost and $\$ 0.36$ per ac.-ft. operation and maintenance (assumed to be 1979 costs), subject to change in subsequent studies. The addition of the charges changes the $\$ 1,166,000$ benefit with the $7 \%$ REA financing to a $\$ 7,988,000$ defic1t for the 10-year period (July 1984 dollars). Obviously, such charges would render hydro generation at Tuttle Creek Dam totally infeasible. It is recognized that such dam use fees have sometimes been assessed on the 11censes of hydroelectric developments at some other Federal dams. However, for low head projects the concept of Federal dam-user fees is inconsistent with the current concentrated Federal program for development of small hydro, and here, as in most cases, imposition of such fees would inevitably preclude development.

\section{CONCLUSIONS}

The Project is considered technically feasible and without any major environmental issues. It shows economic feasibility providing satisfactory low-interest financing terms are available and providing satisfactory agreements with the Corps regarding reservolr use charges can be reached. 

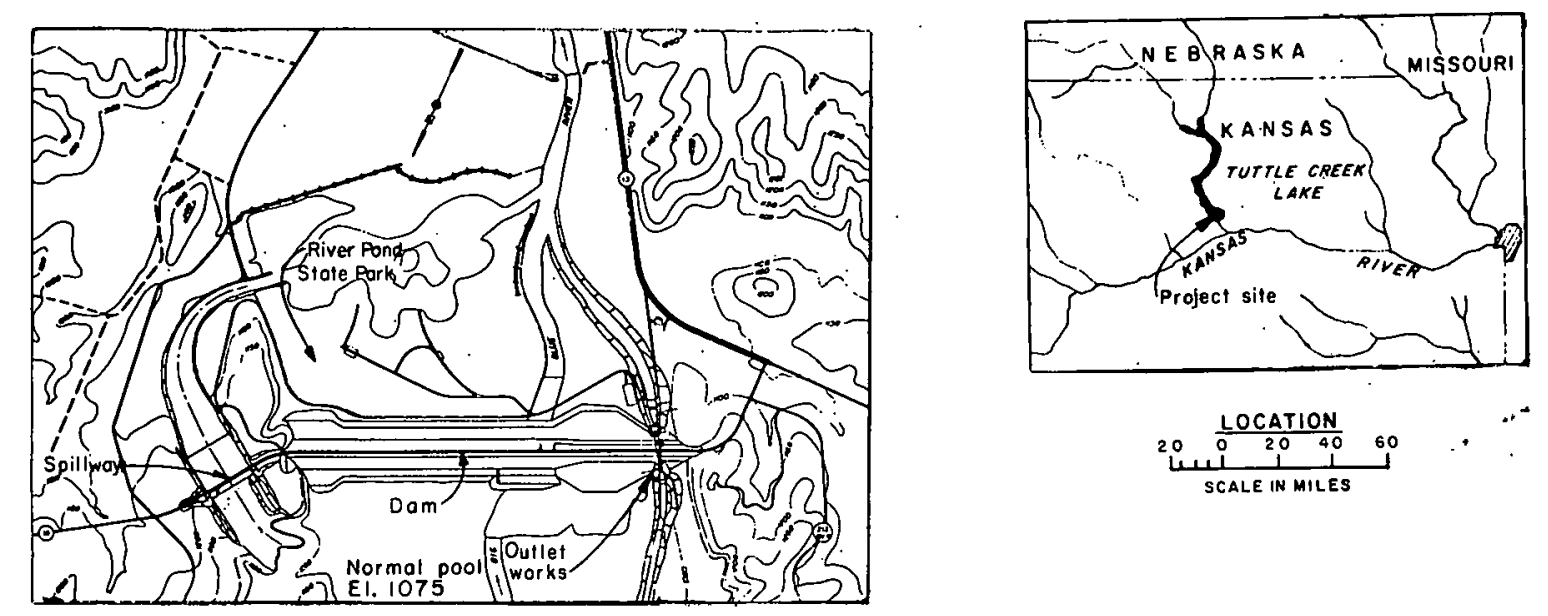

EXISTING PROJECT-PLAN

$\underbrace{1000 \text { i } 10002000}_{\text {SCALE IN FEET }}$
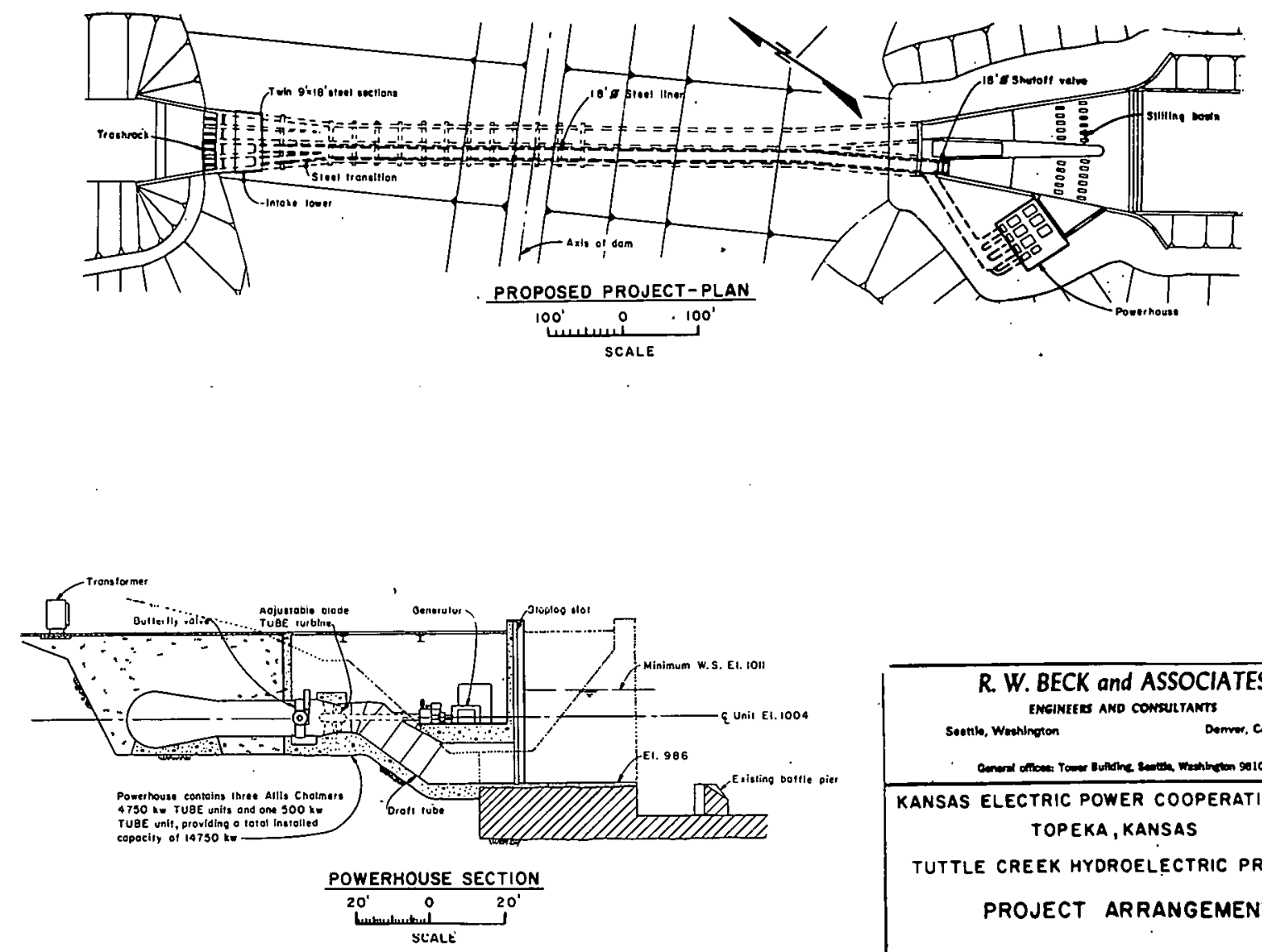

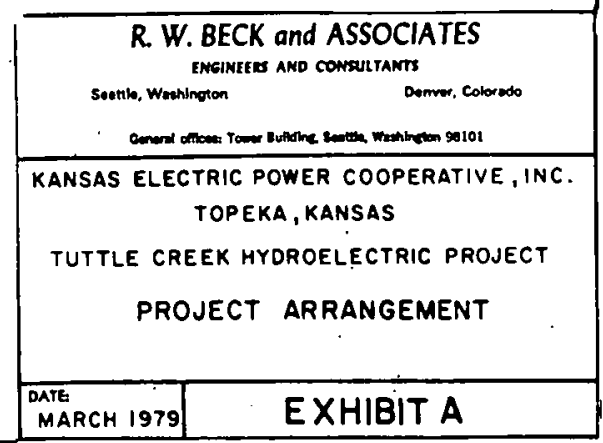




\section{ANNUAL PROJECT BENEFITS AND COSTS (I)}

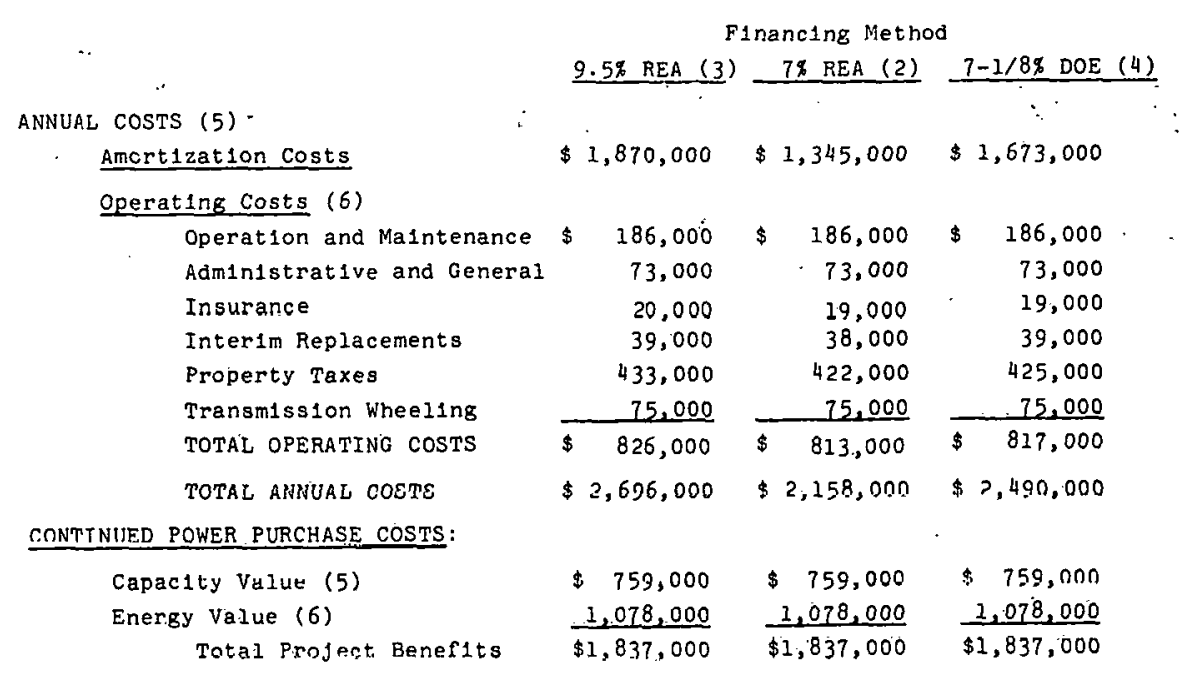

\section{YEAR ANALYSIS}

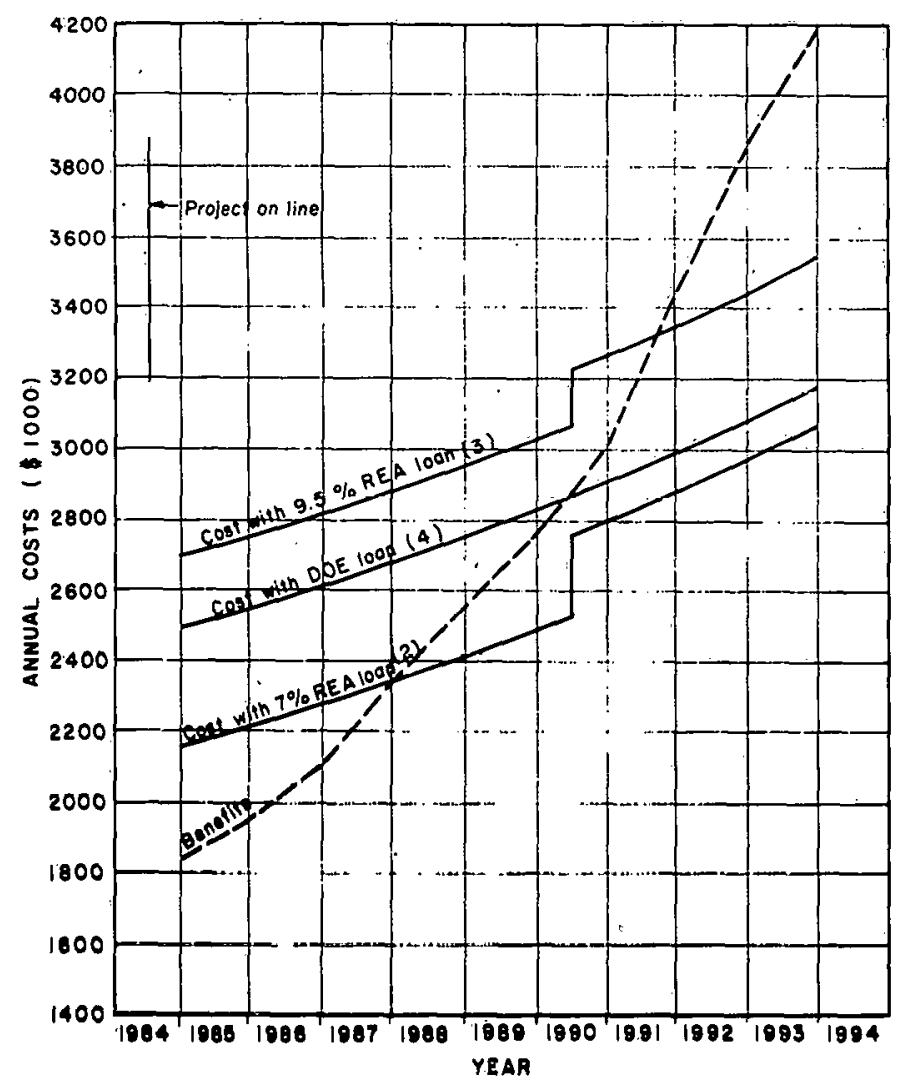

(1) Values shown are for first year of operation, July 1984 through June 1985.

(2) Pinancing at $7 \%$ interest rate, 35-year term, with principal paywents deferred for 7 years after completion.

(3) Financing at 9.52 interest rote, 35-year term, with principal paywents deferred for 7 years after completion.

(4) Financing at $7.125 z$ Interest rate, 30-year term for $75 \pi$ of Profect cost and 95 interest rate, 30-year term for the remaining $25 \%$.

(5) Dependable capac1ty is $10,450 \mathrm{~kW}$ after 157 allowance for reserves. Capacity valued at and $\$ 96.13 / \mathrm{kW}$ for the second half of the and $\$$ year.

(6) Average annual energy 1s 56,690 wh, valued at $18.79 \mathrm{millo} / \mathrm{kWh}$ for the firat half of the year and $19.25 \mathrm{mills} / \mathrm{k}$ h for the second half of the year.

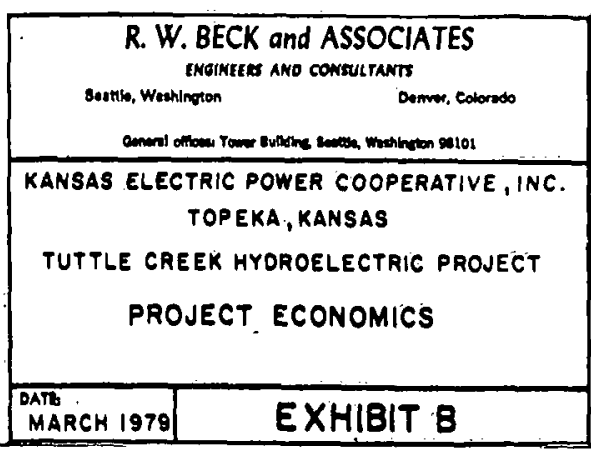




\section{JOINT IRRIGATION DISTRICTS HYDROPOWER ASSESSMENT STUDY}

Turlock, CA

Turlock Irrigation District and Fluid Energy Systems, Inc.

PRDA Proposal Contract No. EN-78-F-07-1799

\section{INTRODUCTION}

In August, 1978, the Department of Energy and Turlock Irrigation District entered into a cooperative agreement for a "Joint Districts Low-Head Hydropower Assessment Study". The purpose of the agreement was to carry out a study of the hydropower potential at nineteen sites within. the borders of the Turlock, Merced, South San Joaquin and Jakdale Irrigation Districts.

Under a sub-contract agreement with Turlock Irrigation District, Fluid Energy Systems, Inc. of Los Angeles, California, gathered and analyzed the required data and prepared a final report for. DOF.

The results of the report indicate the total potential small hydropower capacity for the Joint Districts is 19,560 kilowatts installed with an annual energy generation of 68,561,800 kilowatthours. This is equivalent to oil-savings of 118,616 barrels per year.

This assessment study represents a unique innovation. It involves three irrigation districts in the codependent development of a system of sites in each district. This approach is unique on two levels;

a. A system of sites rather than a single site studied; and

b. three irrigation districts approaching the project in a cooperative fashion.

These innovations can multiply the project potential, increase overall benefits-to-costs, reduce project system development element costs and provide overall project development management efficiency.

\section{STUDY OBJECTIVES}

DOE entered into an agreement with Turlock Irrigation District (TID), the lead agency of the Joint Districts, to undertake the assessment study of twelve of the identified sites. The study - conducted by the Joint Districts and Fluid Energy Systems, Inc. (FES) - assessed sites ranging from 50 kilowatts to 4,700 kilowatts capacity to determine the economic feasibility of developing the sites within the co-dependent snow pack, rivers and canat systems.

The specific objectives of the hydro assessment study were to determine in detail the total undeveloped small hydropower potential at the identified sites in each of the four irrigation districts' canal systems; to develop unified data gathering and evaluation systems within the Joint Districts to provide a common language for small hydropower systems development; to document an estimate of total usable small hydropower capacity of each of the systems that can be developed with a balanced framework of technical, demographic and economic factors; and to analyze various financing and marketing options for small hydropower systems development.

The Joint Districts eolleetive approach has several advantagee:

a. Application of the small hydropower systems development methodology.

b. Avoidance of unnecessary duplication of efforts.

c. A large number of combinations of head and flow variations within the systems for evaluation. This maximized the use of in-house computer system development programs.

d. A single DOE contact for assessing the feasibility of a significant sample of system sites within one area.

e. The specialized small hydropower systems knowledge and expertise within the Joint District assessment team, multiplying the analytic power of the study.

f. Opening the possibility for the Joint Districts to become a single small hydropower system developer, financing entity, developer of the overall project, power purchaser, and operating and maintenance entity.

The results of the Joint Districts study are presented in the Final Assessment Report to D0E. The report is divided into two volumes. Volume One contains a project overview meant to be accessible to lay-people and 
professionals alike, and the detailed technical analyses of the assessment. Volume Two contains Phases A, B, and $C$ which are detailed site reports.

\section{CONCLUSIONS AND RECOMMENDATIONS}

After six months of system development assessment study, FES offered the following conclusions and recommendations:

\section{Conclusions;}

a. Installation of small hydropower system facilities is economically and technically feasible at twelve of the nineteen identified sites within the jurisdiction of the Joint Districts.

b. The total installed capacity of the Turlock. Merced and South San Joaquin systems is $19,560 \mathrm{~kW}$.

c. Development of the sites within each of the three smali hydropower systems would produce over 68.5 million kilowatthours per year.

d. This electrical power is enough to replace 118,616 barrels of oil per year.

e. Development of the three systems would make a significant contribution to meeting the economic development needs of the Joint Districts' service areas.

f. No significant adverse environmental effects are foreseen in construction and operation of the systems assessed during the study.

Recommendations;

a. That the Districts proceed to develop the sites within the three systems judged to be economically feasible during the study.

b. That the three system, twelve site small hydropower development program of the Joint Districts be implemented.

c. That the Districts leave open the possibility of developing other sites should technological or financial developments make them feasible.

\section{HYDROPOWER CAPACITY}

Table I is a breakdown by site and by District of the total small hydropower system capacity, the estimated annual energy, oil savings, and the approximate costs to develop the identified sites.

Tabie I

Joint Districts Small Hydropower Capacity

\begin{tabular}{|crrrr|}
\hline Site & $\begin{array}{c}\text { Installed } \\
\text { Capacity (kW) }\end{array}$ & $\begin{array}{r}\text { Annua } \\
\text { Energy }(\mathrm{kWh})\end{array}$ & $\begin{array}{r}\text { Oil Savings } \\
\text { (bbls/year) }\end{array}$ & $\begin{array}{r}\text { Deveiopment } \\
\text { Cost }(\$)\end{array}$ \\
\hline IID System & & & & \\
\hline Drop One & 3,260 & $12,200,000$ & 21,107 & $3,560,493$ \\
Drop Two & 660 & $2,073,400$ & 3,587 & $1,048,247$ \\
Drop Six & 920 & $2,902,000$ & 5,020 & $1,313,712$ \\
Drop Seven & 700 & $2,101,400$ & 3,635 & $1,089,088$ \\
Drop N1ne & 1,070 & $4,700,000$ & 8,131 & $1,786,400$ \\
Merced System & & & & \\
\hline Main Canal & 2,800 & $9,169,000$ & 15,863 & $3,660,690$ \\
Canal Creek & 940 & $3,262,000$ & 5,643 & $1,274,232$ \\
Fairfield & 970 & $2,809,000$ & 4,860 & $1,183,702$ \\
Escaladian & 270 & 822,000 & 1,422 & 459,967 \\
SSJID System & & & & \\
\hline Woodward & 2,300 & $6,906,000$ & 11,948 & $2,537,193$ \\
Frankenheimer & 4,700 & $16,962,000$ & 29,346 & $6,006,110$ \\
Goodwin Dam & 970 & $4,655,000$ & 8,054 & $1,507,262$ \\
\hline Totals & & & & \\
\hline
\end{tabular}




\section{JOINT DISTRICTS SERVICE AREA SOCIO-ENVIRONMENTAL FACTORS}

The Northern San Joaquin Valley in Central California is considered one of the nation's prime "breadbasket" areas. The 494,631 acres covered by the Joint Districts reach from Stockton, in central inland California, to a point some sixty miles south through the center of the 200-mile long valley. There are approximately 250,000 people living within the boundaries of the combined districts which falls within three counties.

\section{POWER MARKETING ANALYSIS}

Of the three cooperative agencies, only Turlock Irrigation District distributes electrical energy. In the past, TID has used far more electrical energy than it has been capable of generating even during those years when there have been heavy or record rainfalls. The area is classified as a "demand" area with a substantial, but not excessive, peak-loading. All of the energy generated at various sites proposed can be locally used for residential, commercial or agricultural purposes. Five of the twelve sites are within TID's electrical service areas and the generated electricity at these sites can be fed directly into the TID power grid.

TID's generated power will be integrated into $i$ ts own system, but 'Ylerced and South San Joaquin Irrigation Districts have the following options for the most economically advantageous sale of their generated power: offsetting power presently purchased from Pacific Gas and Electric Company (PG\&E); wheeling the power over $P G \& E$ lines for sale to other buyers; direct sale to PG\&E.

\section{ECONOMIC ANALYSIS}

The economic viability of developing the identified sites depends on the terms and availability of financing. FES has analyzed two major types of financing, i.e., municipal tax-exempt versus investor-owned utility financing.

Municipal tax-exempt financing substantially raises the benefit-to-cost ratio of site development due to lower interest rates, longer terms and tax exemptions for public agencies. Municipal financing indicates a pay-back for each of the three systems as seven years for the Turlock and Merced systems and six and one-half years for the South San Joaquin system.

\section{DEVELOPMENT PLANS AND SLHEDULES}

As a result of the efforts of the study, an overall Joint Districts Hydropower Development Plan was prepared. The Development Plan includes four additional sites that were not part of the D0E funded effort. The overall Plan includes twelve sites; five in the.Turlock system; four in the Merced system; and three in the South San Joaquin system. The on-line power development schedule is based on estimated equipment and materials delivery schedules; weather contingencies; irrigation water operations and dry (no water delivery) seasons. It is estimated that all of the selected sites could be engineered, constructed, equipment installed and on1 ine by March 1982, Even with contingencies accounted for, all sites could be operational not later than March 1983.

\section{UNIQUE EQUIPMENT CONFIGURATION SELECTION}

The turbine-generators chosen for two of the sites are two bulbturbine units each mounted on a vertical gate. Figure 1 shows this arrangement, which would allow the turbine-generator to be removed from the canal and repaired or replaced without disruption of irrigation water delivery. The gates may be raised and lowered by means of winches or counter-weight. A by-pass around the turbine installation is also provided to allow for turbine shut-down conditions and for excesss demand conditions.

The outer casing of the bulb turbine is fixed with the gate along with four stay vanes used to support the turbine and direct the flow. The generator is completely submerged and contained within the inner casing. This generator is of the synchronous type. All auxiliary equipment such as synchronizer, oil pressure supply system, lubricating oil system, feed water and drainage system, etc. are built in the gate and/or the bulb unit. All other equipment, i.e., switchgear, controls, etc. would be installed in the power plant structure above the canal as shown.

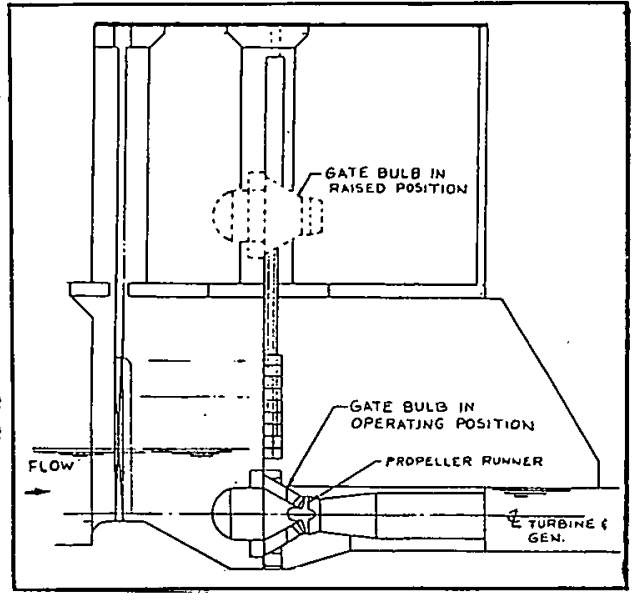

Fuji Gate-Type Bulb Turbine Figure 1 


\section{DAN RIVER}

Danville, Virginia

Dan River Incorporated \& Acres American Incorporated

PRDA Proposal Contract No. 1800

\section{INTRODUCTION}

Dan River Incorporated, an industrial corporation with textile manufacturing facilities át Dariville, Virginia, owns and operates a low-head hydroelectric plant at its Schoolfield Dam on the Dan River in the City of Danville, Virginia. In addition, Dan River Inc. Owns the property and water rights for two dams on the Dan River downstream from the Schoolfield Dam. The power generating facilities at the two downstream sites (Union Street and Main Street) were abandoned a number of years ago, but the dam structures remain in operable condition.

The Schoolfield plant went into operation in 1904 and the generating equipment is in need of extensive rehabilitation or complete replacement. As mentioned above, the generating facilities at the Union Street and Main Street Dams were removed and abandoned several years ago. Dan River Inc., in its continuing interest in developing electrical power, undertook a feasibility study for two basic hydroelectric sites.

(i) Redevelopment of the 20 feet of head using the existing Union Street Dam and intake channel on the right bank; and

(ii) Rehabilitation and/or replacement of the hydraulic turbine-generator units at the Schoolfield Dam.

The Schoolfield site develops 28 feet of head with the use of 3 foot high flashboards. The existing Schoolfield site has a total installed capacity of about $6200 \mathrm{~kW}$ in 9 units utilizing a plant flow in the order of $4000 \mathrm{cfs}$. With all units in operation there is a potential average annual energy production of about 25 million $\mathrm{kW} \mathrm{hr}$ from the site. Records from the 15 year period between 1962 and 1976 indicate the average annual energy production from the Schoolfield plant has been only about 11 million kWhr; the reliability factor of the station, therefore, is very low, from $40 \%$ to $50 \%$. The existing plant at Schoolfield generates power at $25 \mathrm{Hertz}$ with the majority of its units. Units No. 8 and No. 9, which are rated at a total of $950 \mathrm{~kW}$, generate power at 60 Hertz. The power from the Schoolfield plant is used totally in the textile mills owned by Dan River Inc. The demand for 25 Hertz power is being gradually phased out by replacement of existing electrical equipment operating on that frequency.

\section{ALTERNATIVES}

Several alternative schemes were identified and investigated for both sites. Preliminary drawings were prepared for each scheme involving new equipment and structures. These drawings were used for quantity take-off measurements; this together with information and prices from equipment suppliers formed the basis of the capital cost estimates. The anticipated annual average revenue was calculated from the expected annual average energy production obtained from the average flow duration curve for the Dan River. Energy production was derated by a reliability factor in the calculations. The value of replacement energy for revenue calculations was based on Dan River Incorporated's current billings in January 1979 of 25 mills per kWhr. This rate was escalated and levelized for 10-year and 40-year periods and found to be 33 and $54 \mathrm{mill}$ is per kWhr respectively. From the capital costs, annual costs were established. A Benefit/Cost ratio was derived from the annual costs and annual benefits or revenue. The Benefit/Cost ratios for the alternatives were compared and a most favorable alternative was established.

The following is a tabulation of the alternative schemes investigated in the feasibility study:

S-I - Schoolfield site. Rehabilitate the nine existing units retaining the 25 Hertz and 60 Heritz generation mix. 
S-IA - Schoolfield site. Rehabilitate the nine existing units converting all generation to 60 Hertz.

S-II - Schoolfield site. Rehabilitate seven existing units retaining the 25 Hertz and 60 Hertz generation mix.

S-IIA - Schoolfield site. Rehabilitate seven existing units converting all generation to 60 Hertz.

S-III - Schoolfield site. Install 2 new horizontal tube units and rehabilitate units No. 8 and No. 9.

S-IIIA - Schoolfield site. Install 3 new horizontal tube units and rehabilitate units No. 8 and No. 9.

S-IV - Schoolfield site. Install 2 new vertical units and rehabilitate units No. 8 and No. 9.

S-IVA - Schoolfield site. Install 3 new vertical units and rehabilitate units No. 8 and No. 9.

UL-I - Union Street site. Construct new powerhouse with 2 new horizontal tube units included.

UL-II - Union Street site. Construct new powerhouse with 2 new horizontal tube units included further downstream of alternate UL-I.

The total estimated capital cost of the schemes is provided in Table 1.

\section{RECOMMENDED SCHEME}

Schoolfield schemes S-I and S-II are based on rehabilitation of existing old equipment which, at best, would have an extended life of 10 years. These two schemes would continue to generate power at 25 Hertz for which the demand is being phased out; accordingly, these schemes are inconsistant with future demand and plant planning. Alternates S-III and S-IV have a slight advantage over alternates S-IA and S-IIA when comparing benefit cost ratios for appropriate lives. Alternates S-IA and S-IIA have been assigned life of 10 years while alternates S-III and S-IV have been assigned a life of 40 years. It was also concluded that any substantial capital investment would best be made in new, rather than rehabilitated equipment. Schemes S-III and S-IV have the advantage over S-IIIA and S-IVA in that the plant capacity is developed to an optimum economic degree.

The redevelopment of the Union Street site is not recommended because of the relatively high cost and the low benefit/cost ratio.

The two new units at Schoolfield under Schemes III and IV will operate as base units whereas the rehabilitated Units 8 and 9 will be used for standby service and to supply peaking power during high flow periods. All units will have full automatic local controls and remote supervisory controls can be added as an option. The units will produce power at a frequency of $60 \mathrm{Hertz}$. The new units will include turbines, either vertical propeller type or horizontal tube type, governors, $1500 \mathrm{~kW}$ rated synchronous generators and rotating brushless exciters. The horizontal units will be equipped with adjustable blade runners, controlled by hydraulic governors. They will also include speed increasers and intake butterfly valves. In the vertical arrangement, adjustable wicket gates and new head gates with operating hoists will be installed rather than butterfly valves.

The recommended scheme for development of the Schoolfield site will have a capacity factor of $68 \%$. The potential average energy production of $21 \mathrm{million} \mathrm{kW} / \mathrm{hr}$ is an increase of approximately $14 \mathrm{million} \mathrm{kWhr}$ annually over the last two years average production.

Although the redevelopment of the Schoolfield Dam has been shown to be technically feasible, it is considered marginal economically. It must be recognized that Dan River Inc. is a textile manufacturing concern in private industry. Private manufacturing companies evaluate capital expenditure projects in a manner different than what has been presented. The rate of return on investment (ROI), which has been carried out for the Schoolfield scheme S-III and S-IV, is the method which Dan River Inc. and other similar industries evaluate their projects.

Dan River Inc. uses a discounted cash flow method for computing the ROI. The ROI assigned a 12 year life for the project, 2 years construction, and 10 years revenue income. The recommended alternative has an ROI of $6.8 \%$ pre-tax and $3.4 \%$ after tax. These figures have discounted 7 million kWhr of annual anticipated production from 21 million $\mathrm{kWhr}$. The $7 \mathrm{million} \mathrm{kWhr}$ is the last two years average production of the plant as it is. The Benefit/Cost ratios presented in Table 1 have not included the 7 million kWhr discount. If the 7 milition kWhr is discounted from the expected average energy production for Scheme S-III and S-IV the Benefit/Cost ratios for the present, 10 year, and 40 year lives are $0.3,0.4$, and 0.7 respectively. From 
the foregoing the project is not considered feasible to Dan River Inc.

There are a number of ways in which the cost of redevelopment of a site such as the Schoolfield site might be made attractive to a private concern. These are listed as follows:

(i) Significant construction grants.

(ii) Increased investment tax credit which is presentiy at $10 \%$, whereas heat recovery and energy saving devices have a credit of $20 \%$.

(iii) Low interest loans such as these anticipated by the new Energy Act.

No adverse environmental impacts are anticipated except during construction. However, the construction related impacts are minor and will only be of a temporary nature and short lived. Perhaps the most significant positive impact is the long term benefits derived from increased power production using a non-depletive energy source.

Drawings of the recommended schemes and photographs of the site are also attached for reference. 
TABLE 1

DAN RIVER INCORPORATED

ALTERNATIVES - CAPITAL COSTS \& EVALUATION

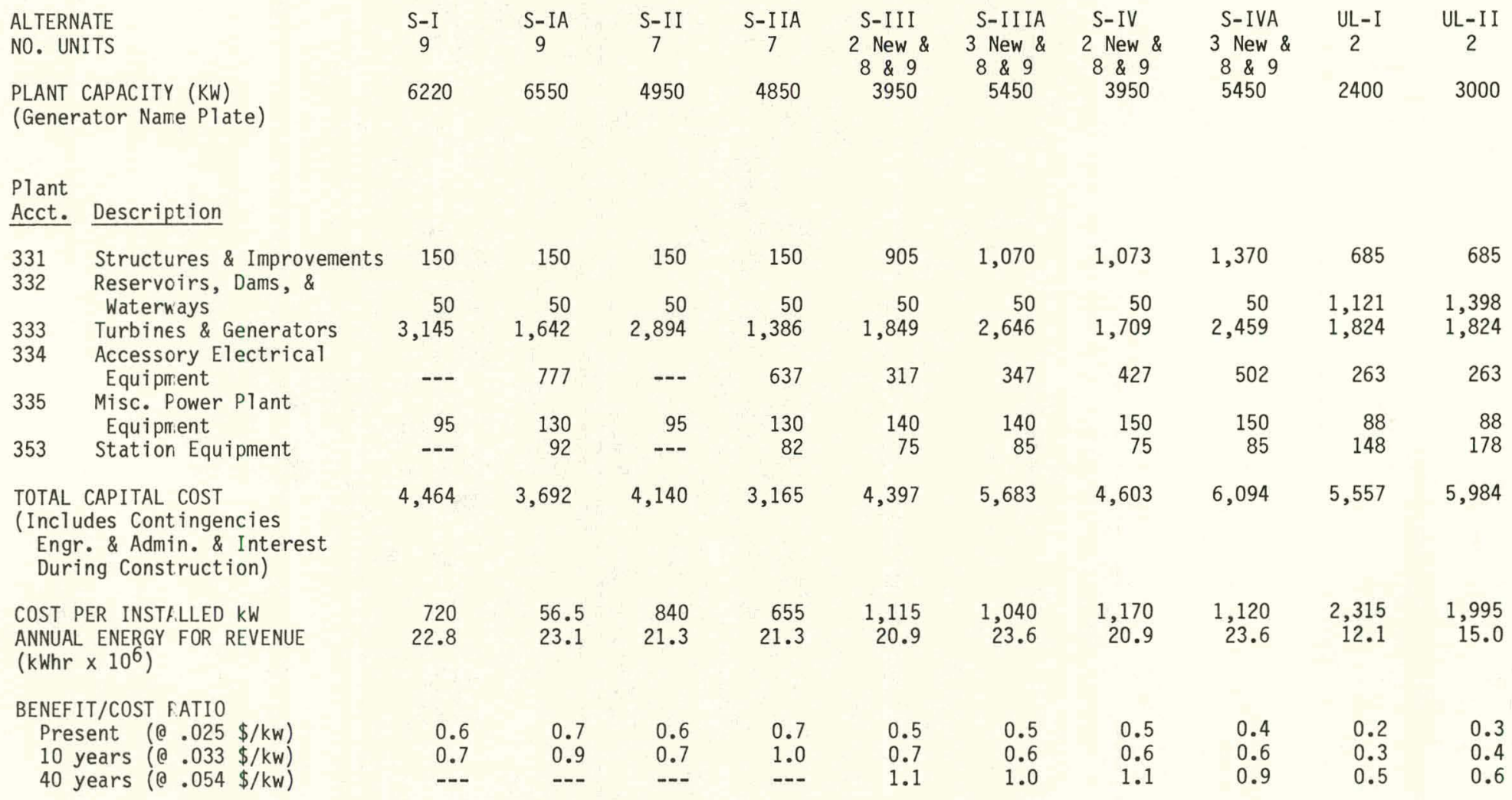

NOTE: All Capital Costs presented are in Thousands $(\$ 1,000)$ 


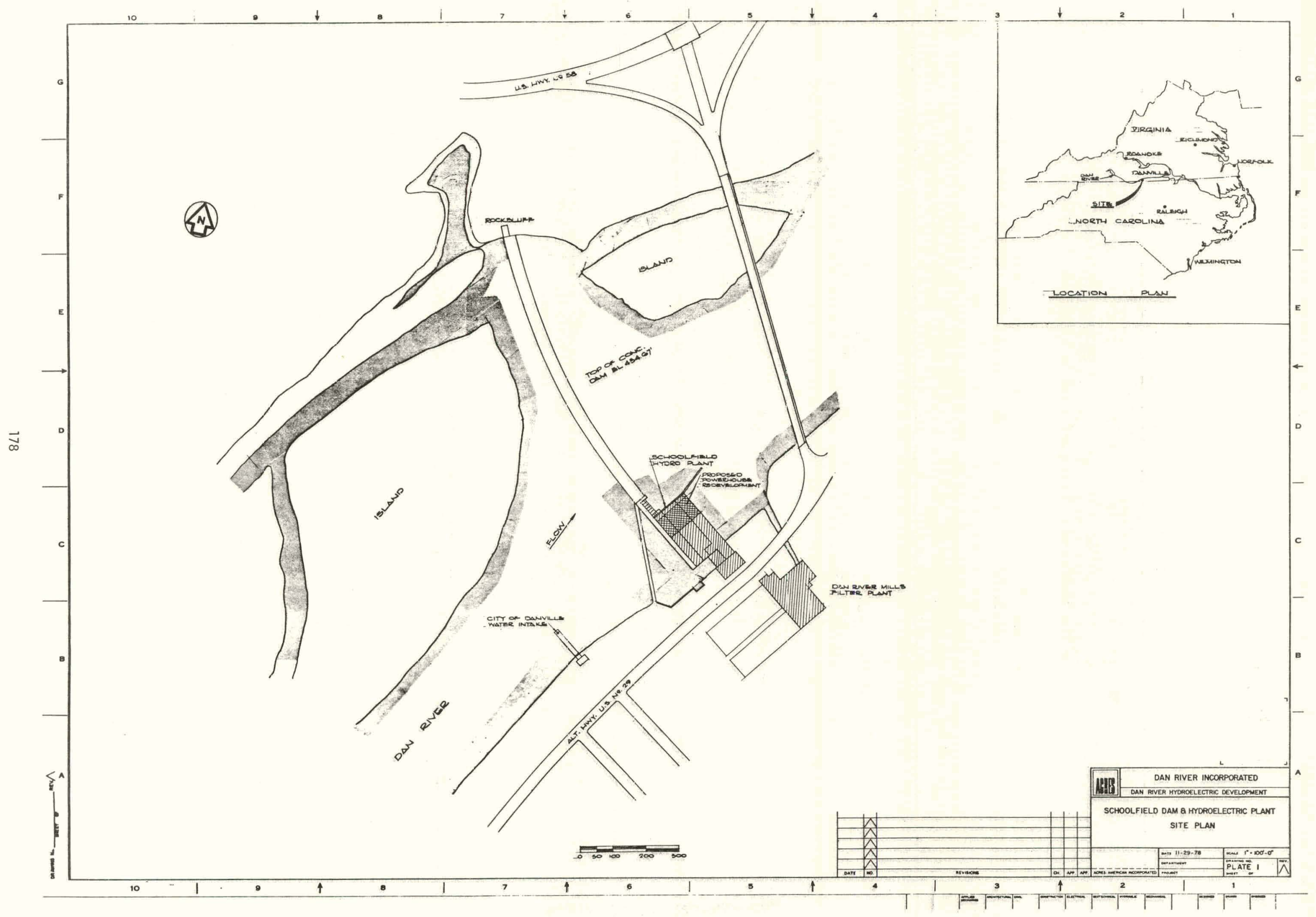




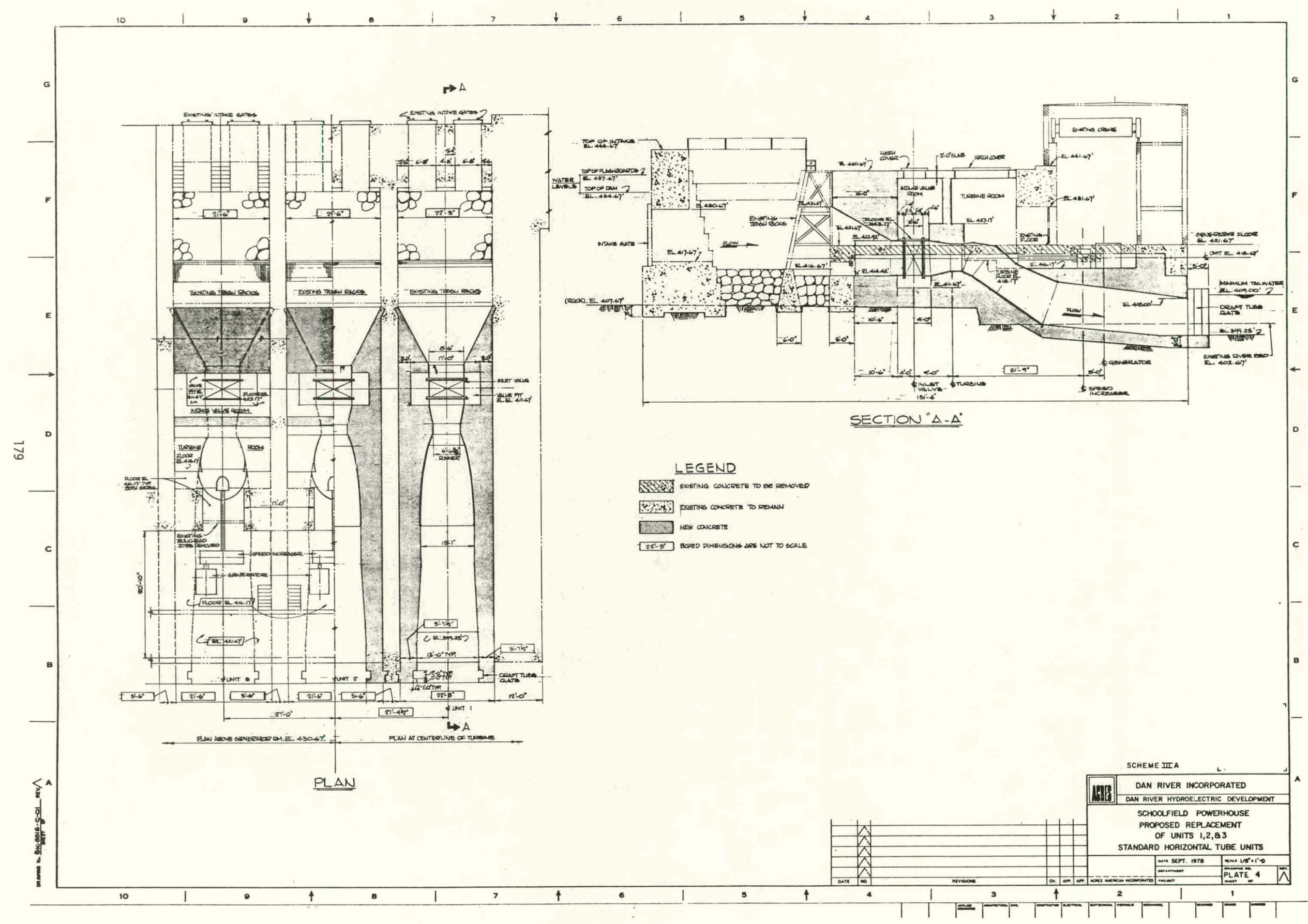




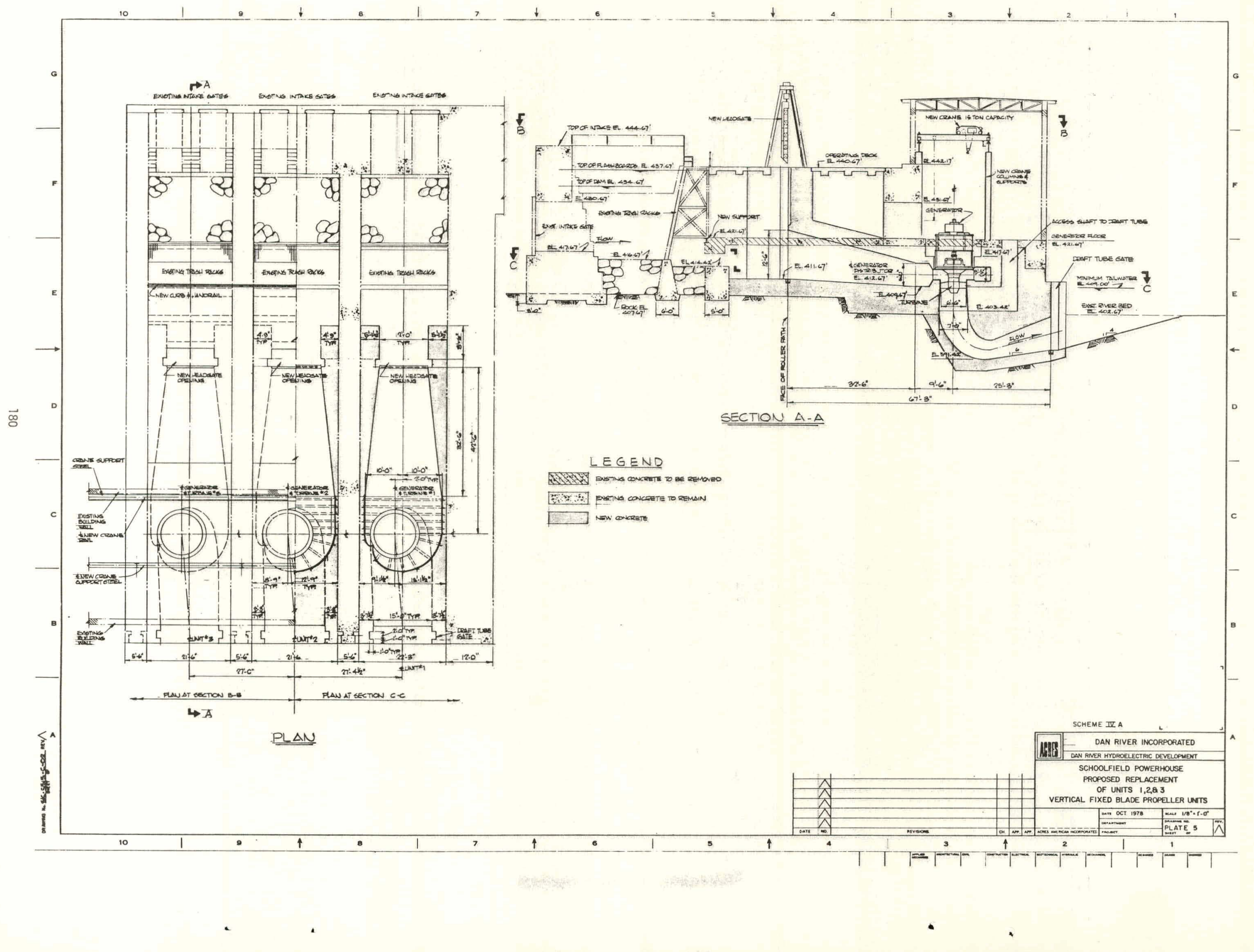


DAN RIVER HYDROELECTRIC JEVELOPMENT

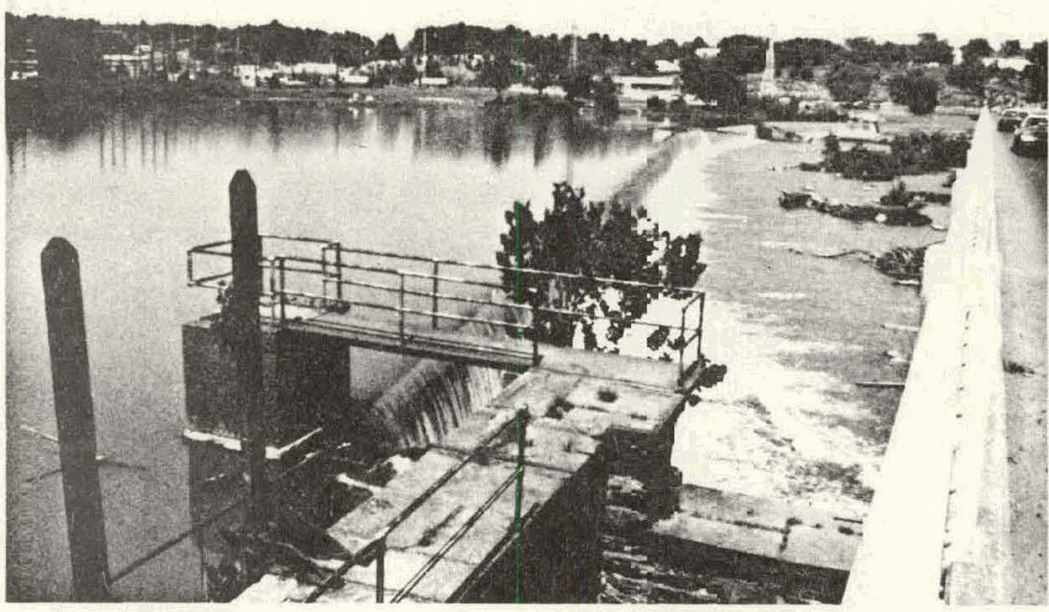

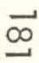

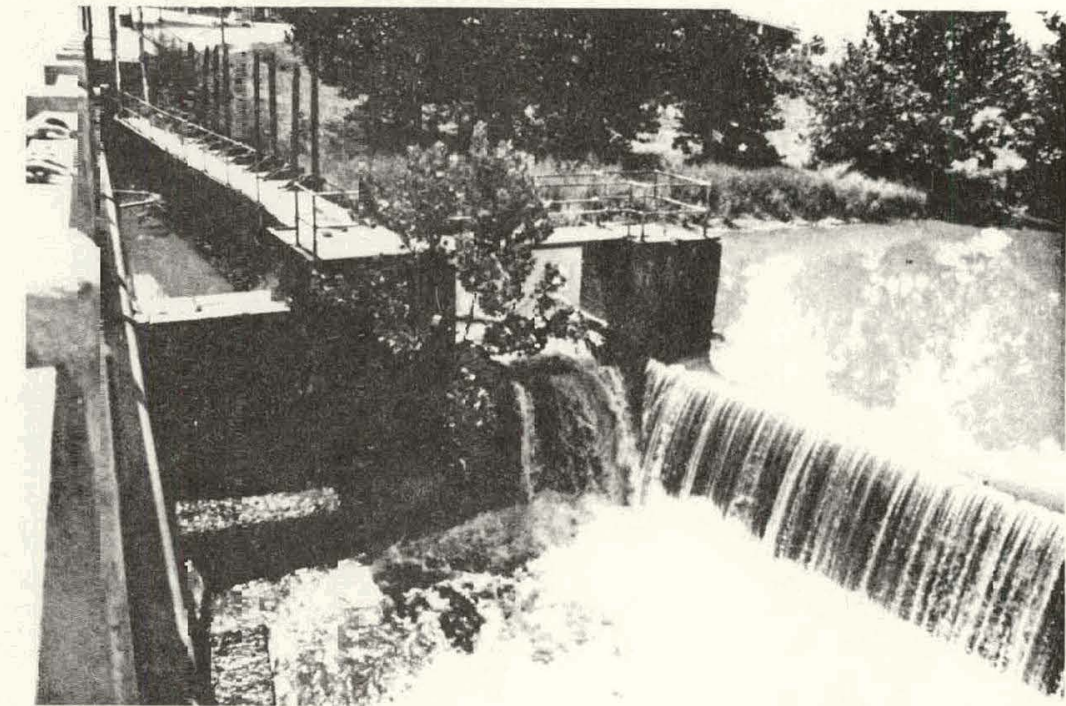

JNIOV STREET DAM - VIEW OF INTAKE TO CANAL

UNION STREET DAM - RIGHT ABUTMENT

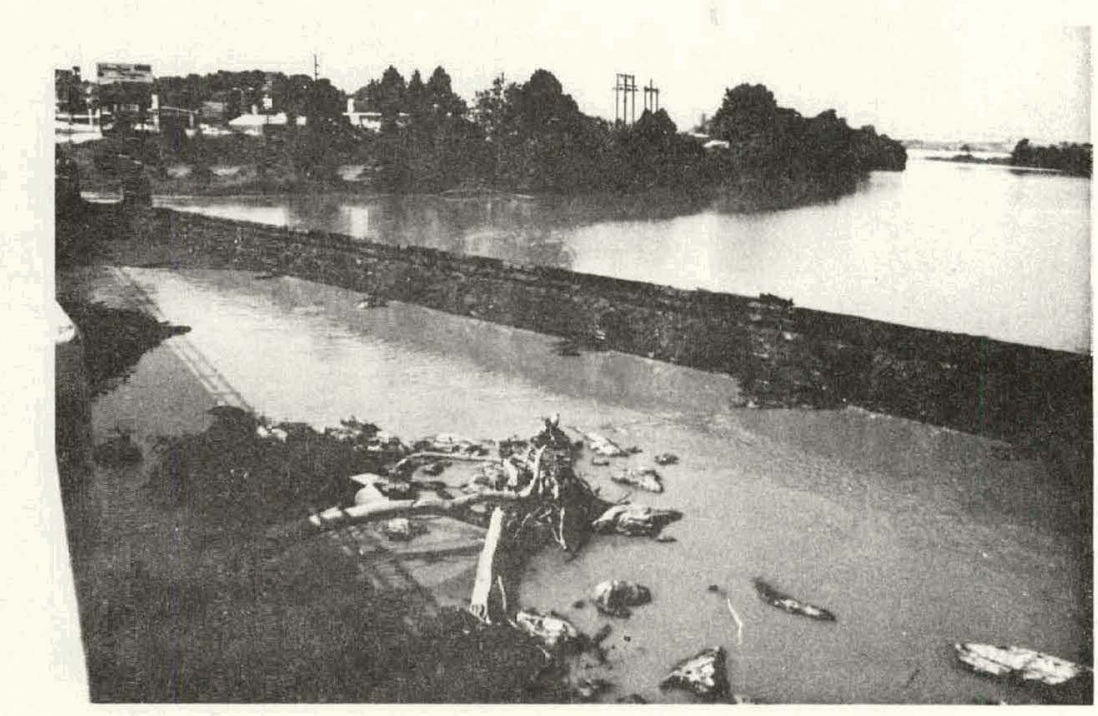

UNION STREET DAM - LFFT ABUTMENT

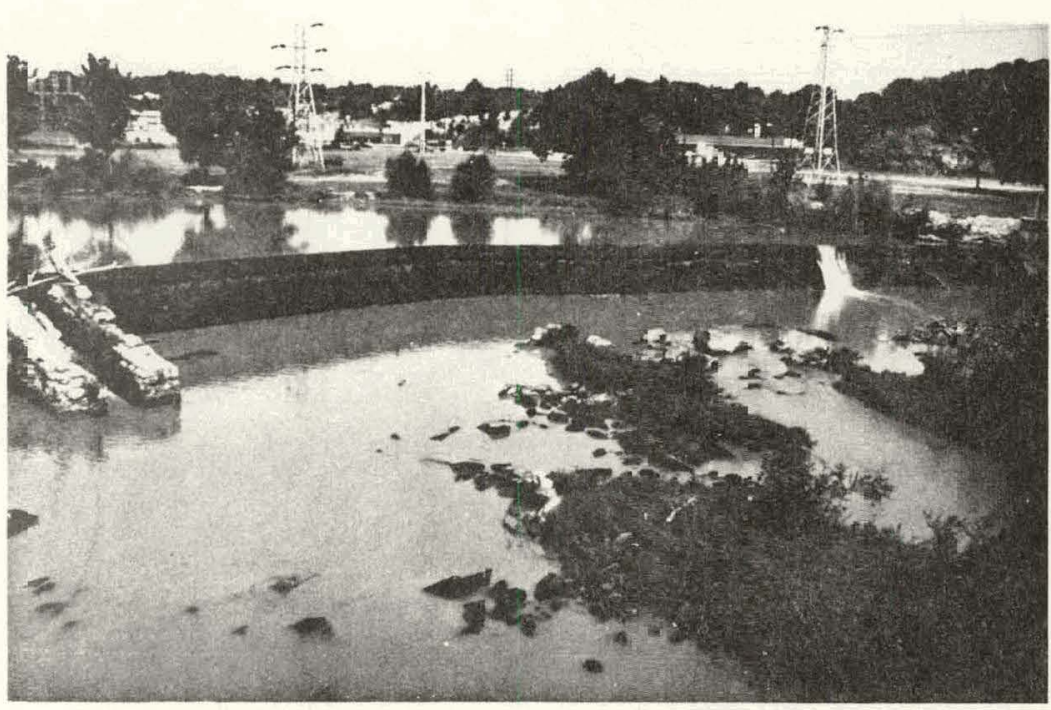



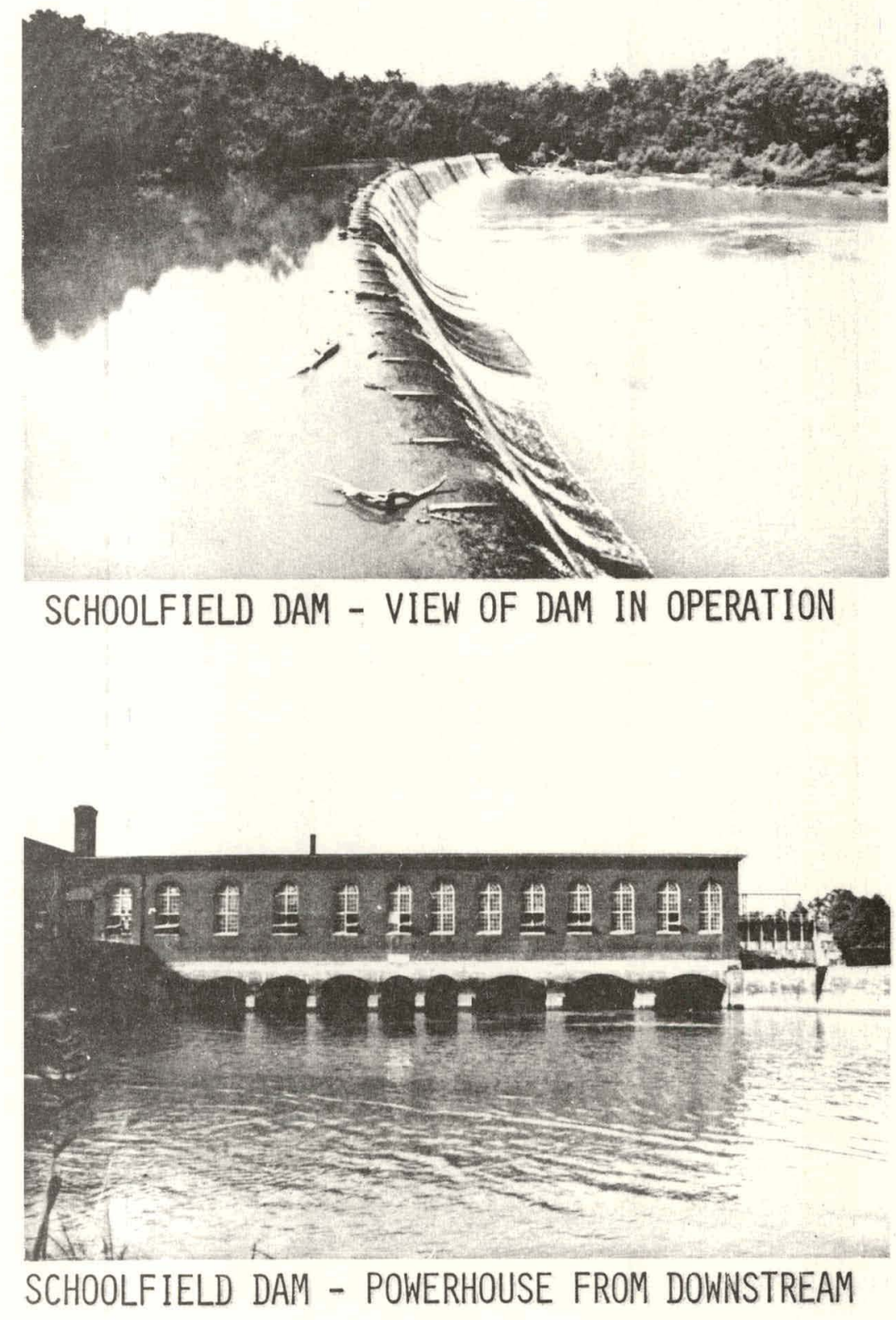

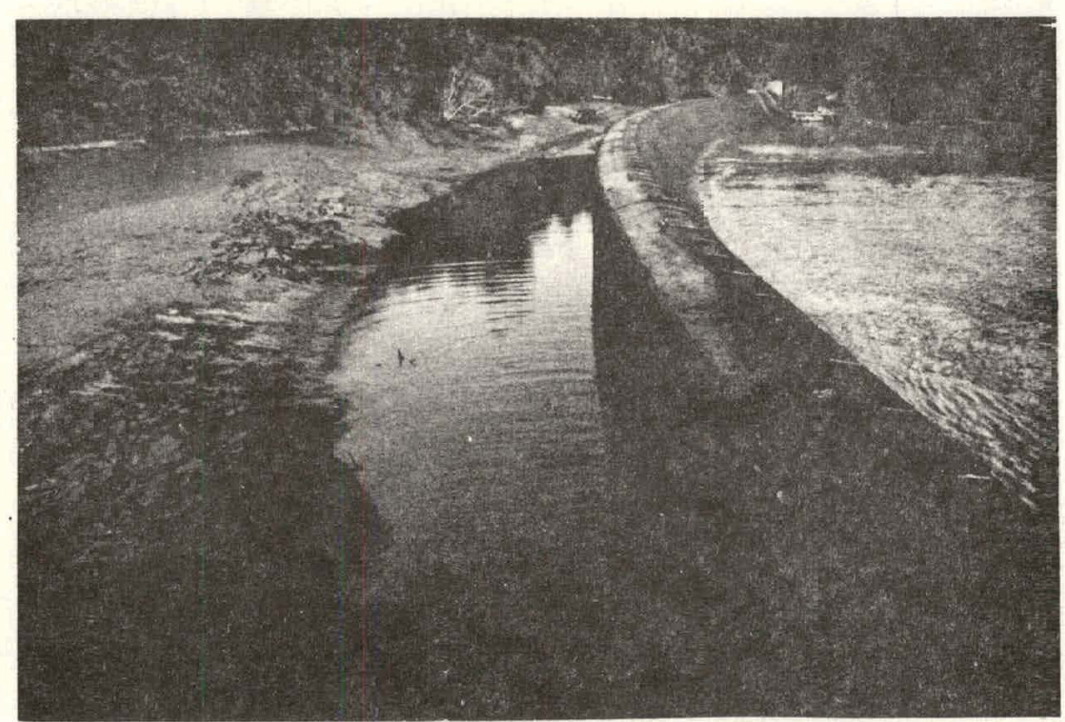

SCHOOLFIELD DAM - VIEW OF DAM DEWATERED

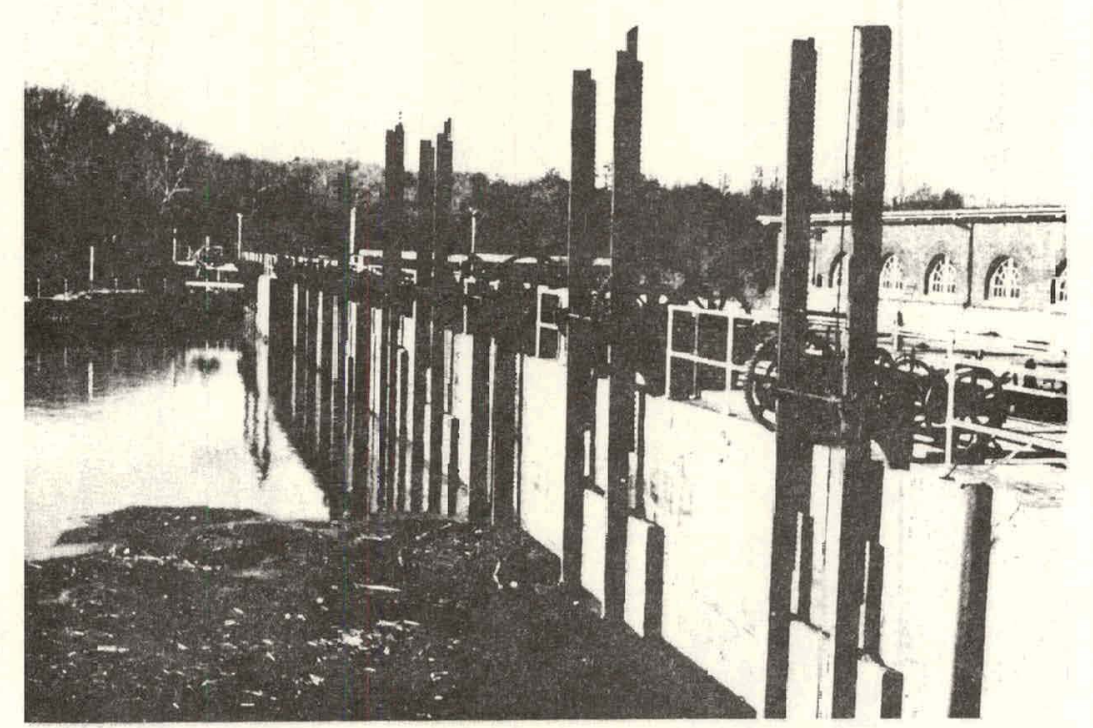

SCHOOLFIELD DAM - INTAKE STRUCTURE 


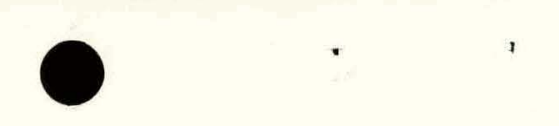

DAN RIVER HYLROELECTRIC DEVELOPMENT

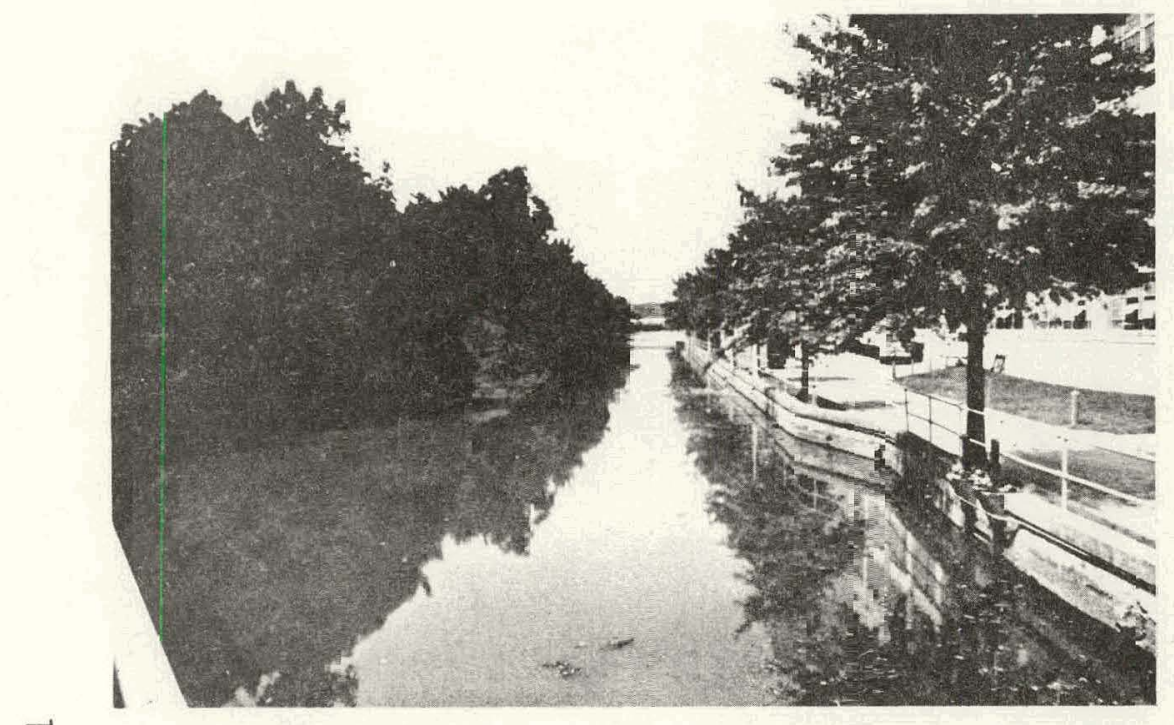

$\vec{\infty}$

UN:ON STREET DF.M - INTAKE CANAL

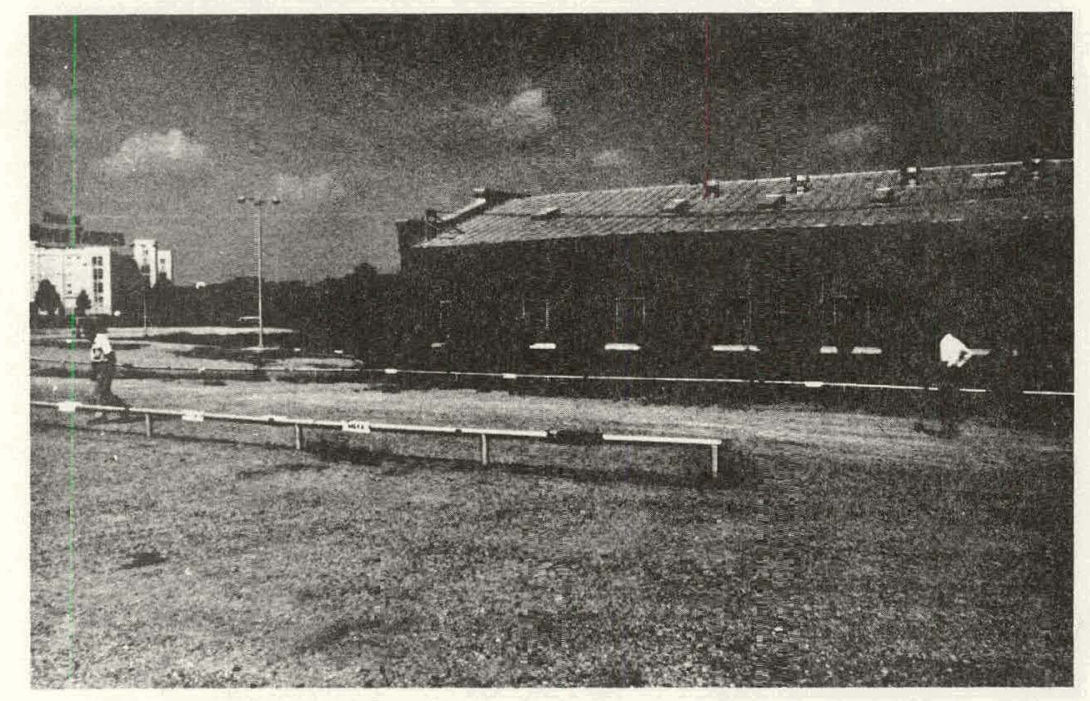

UNION STREET DAM - VIEW OF POWERHOUSE LOCATION

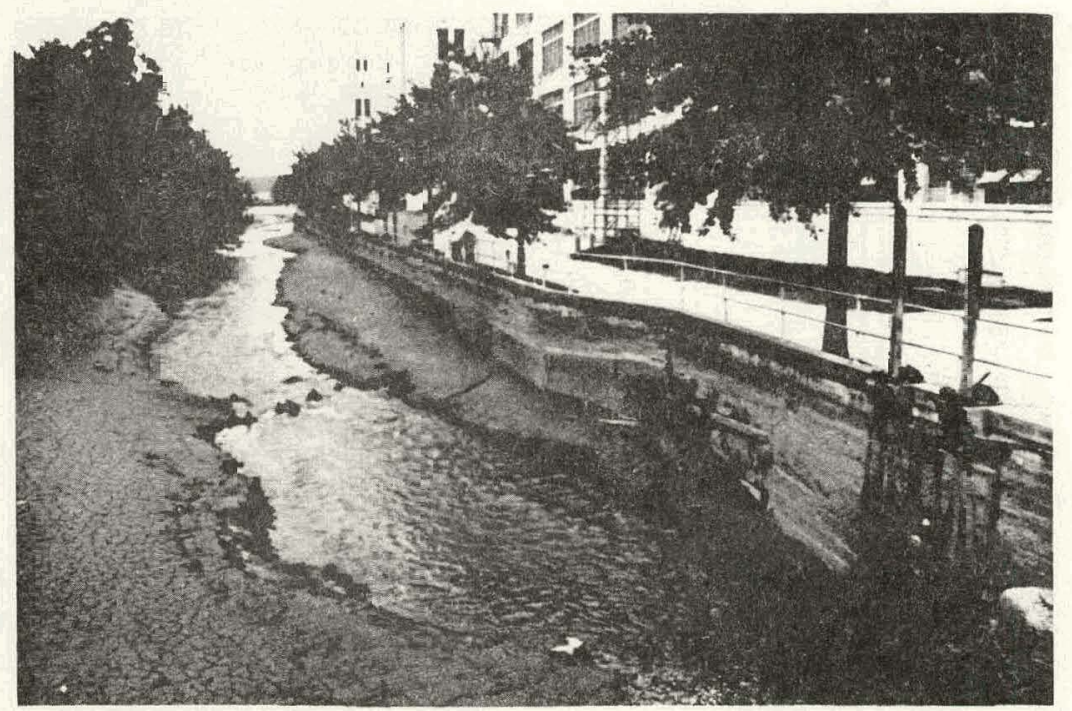

UNION STREET DAM - INTAKE CANAL DEWATERED

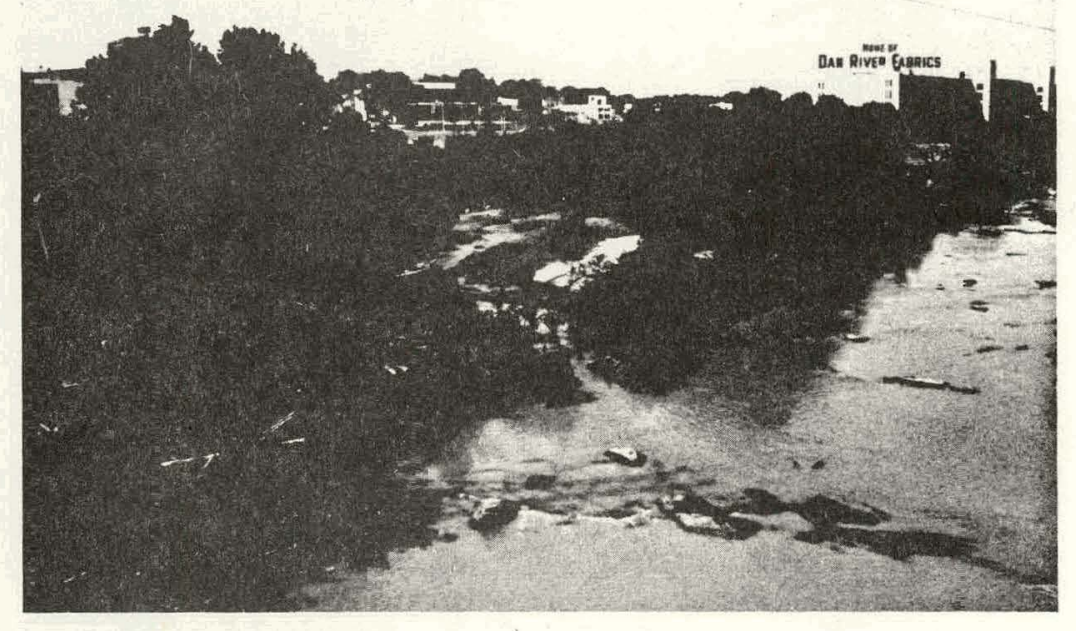

UNION STREET DAM - VIEW OF TAILRACE LOCATION 
DAN RIVER HYDROELECTRIC DEVELOPMENT

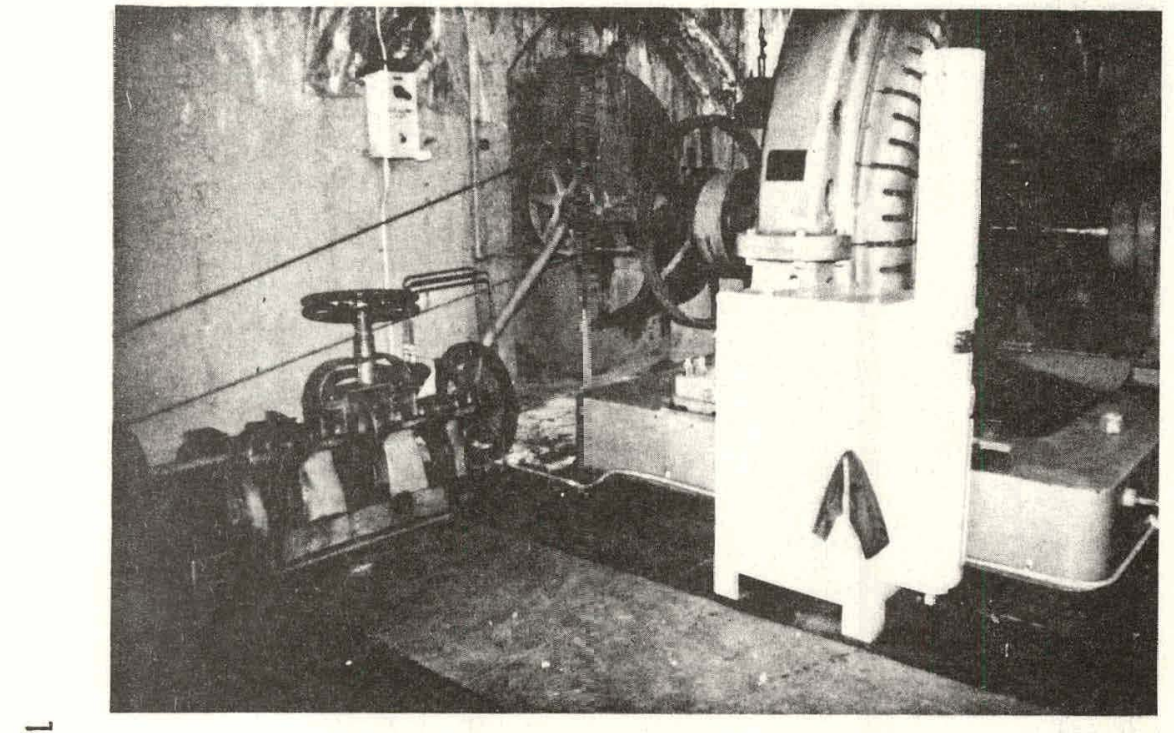

$\vec{\infty}$

SCHOOLFIELD DAM - MODIFIED GOVERNOR

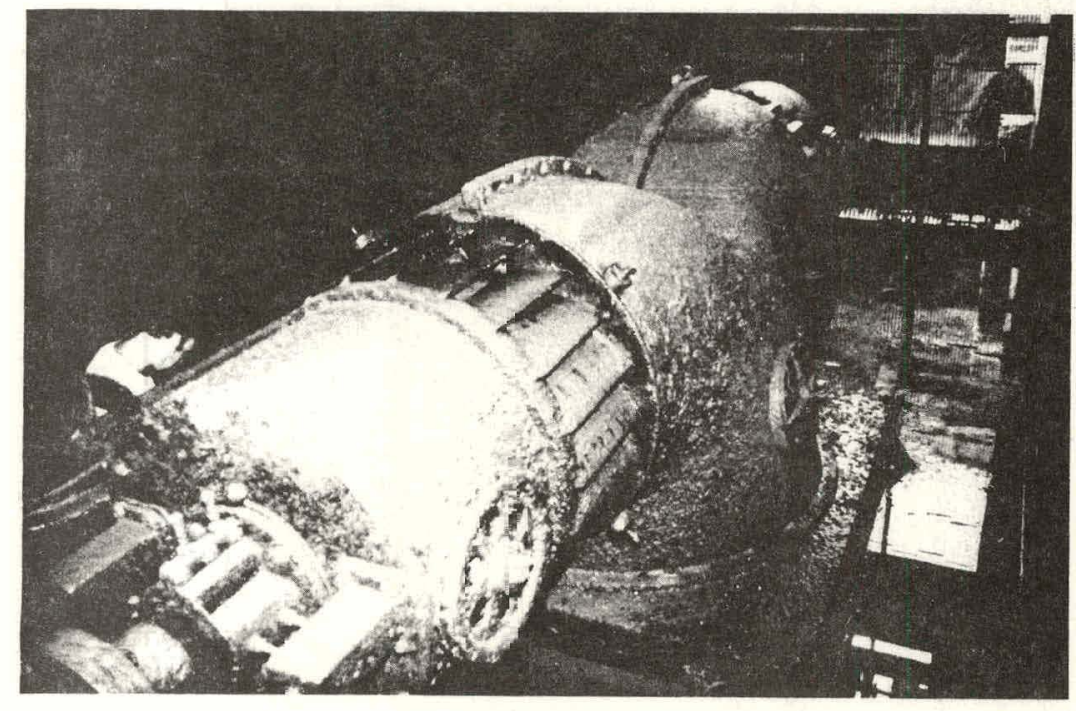

SCHOOLFIELD DAM - TURBINE

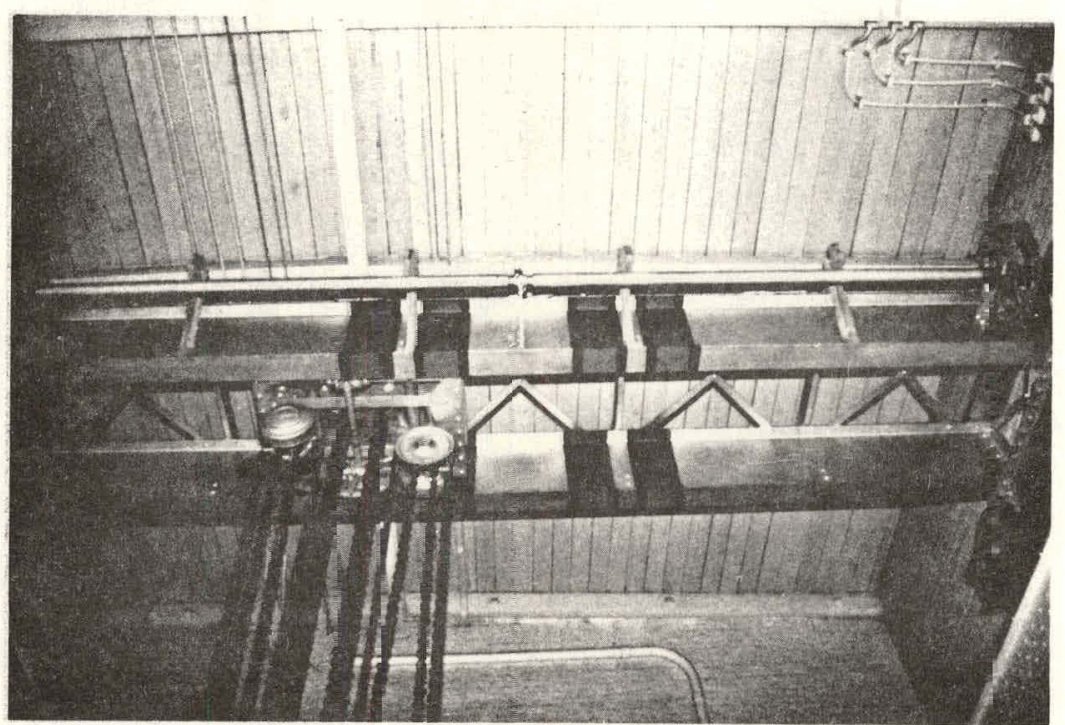

SCHOOLFIELD DAM - POWERHOUSE CRANE

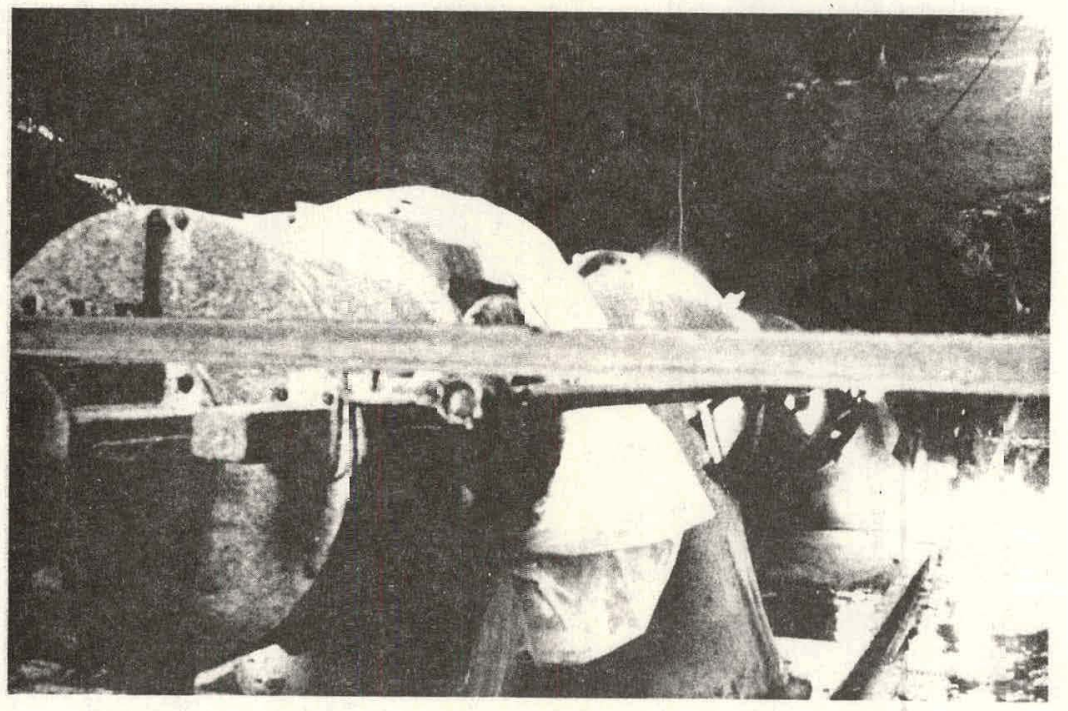

SCHOOLFIELD DAM - TURBINE 


\section{○}

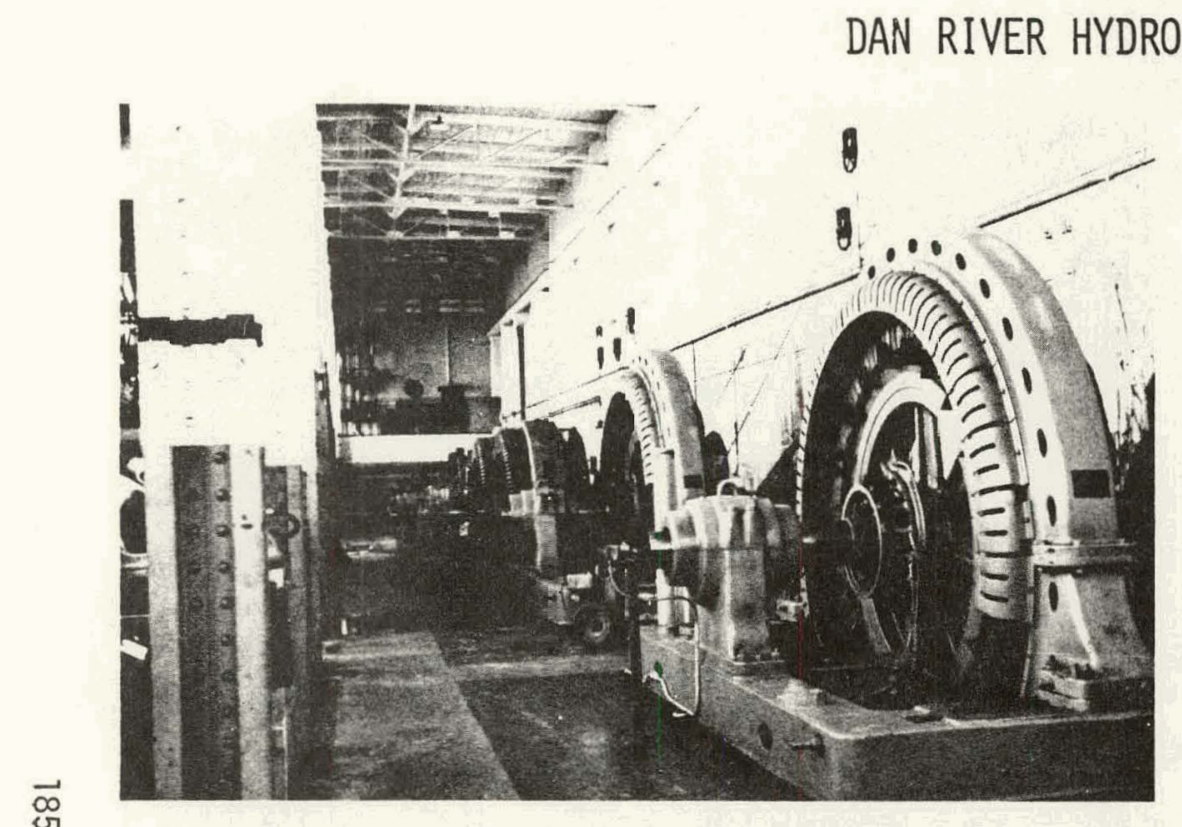

SCHOOLFIELD DAM - GENERATOR ROOM

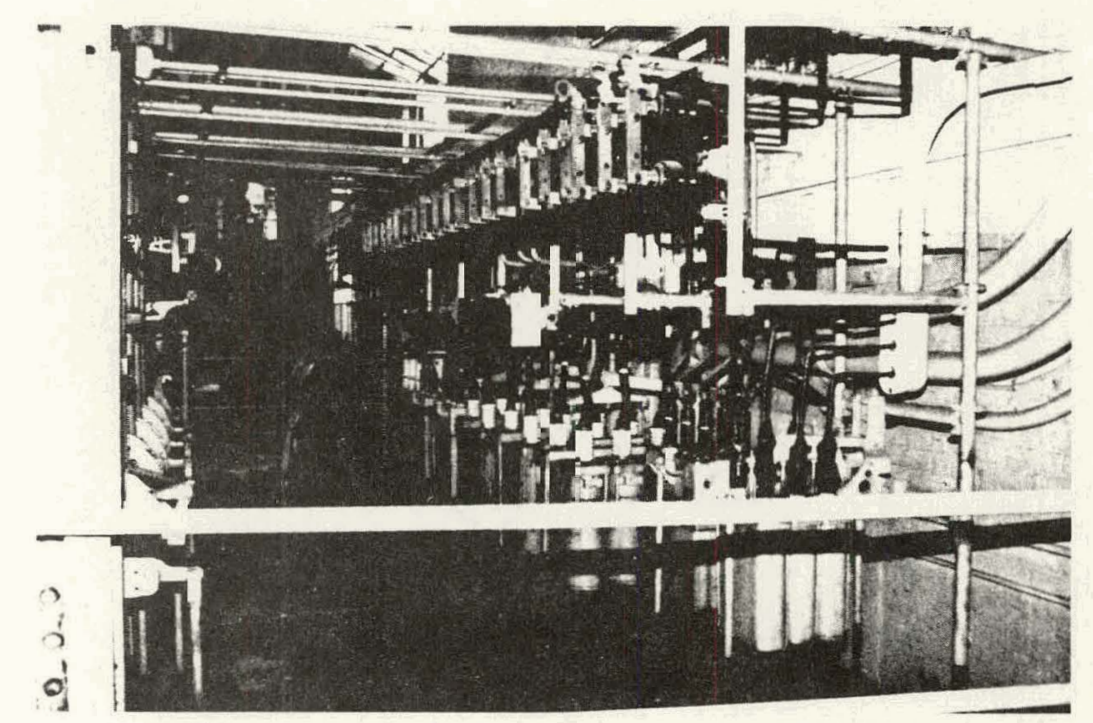

SCHOOLFIELD DAM - ISOLATING SWITCHES

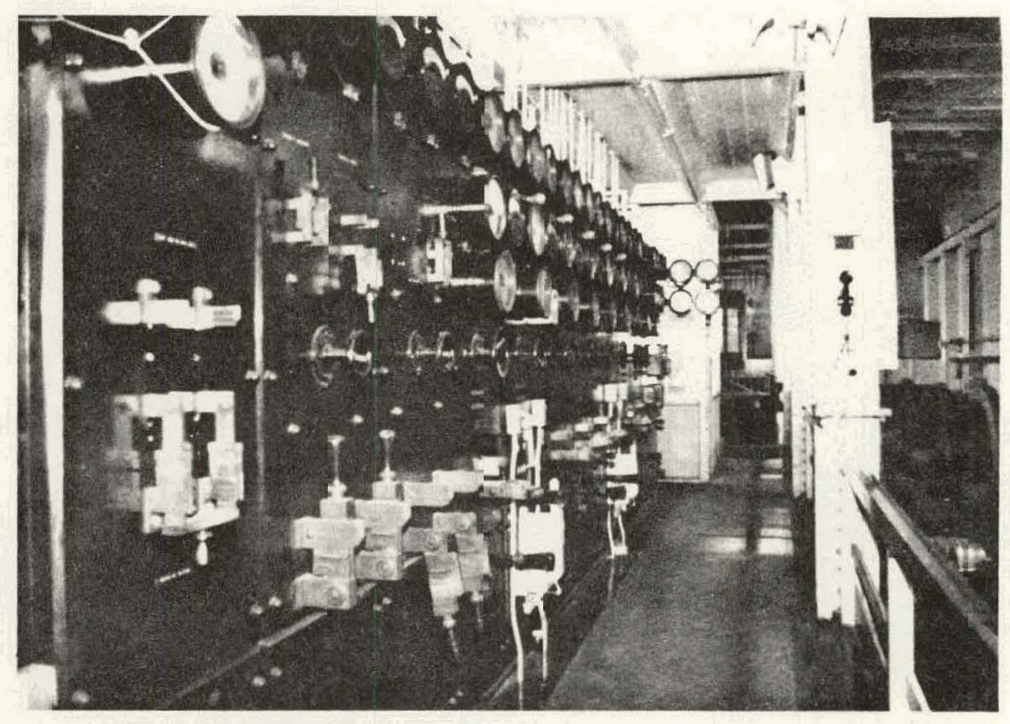

SCHOOLFIELD DAM - CONTRIL PANEL

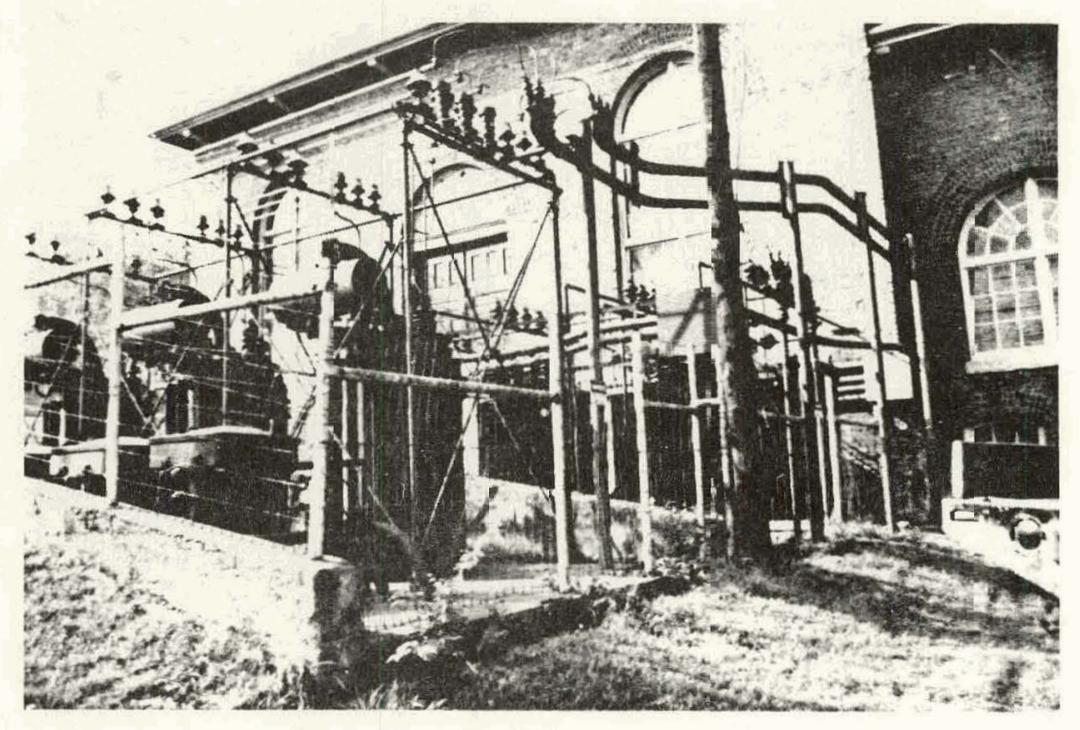

SCHOOLFIELD DAM - SWITCHYARD 

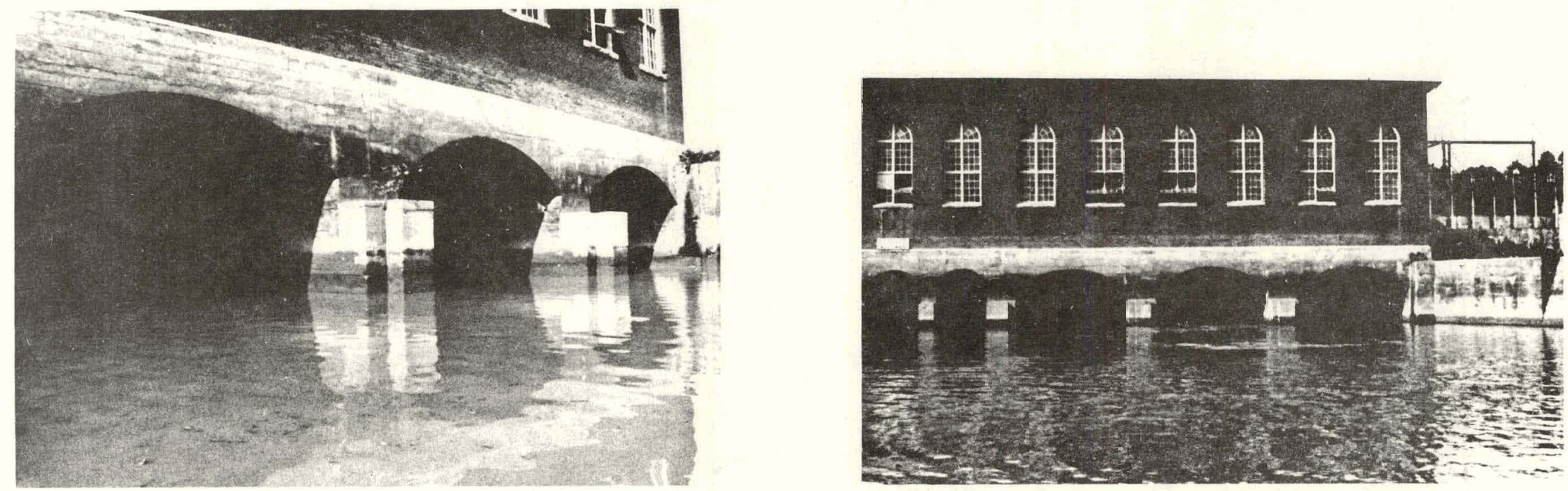

ळ્SCHOOLFIELD DAM - POWERHOUSE D/S VIEW BAYS $1,2 \& 3$

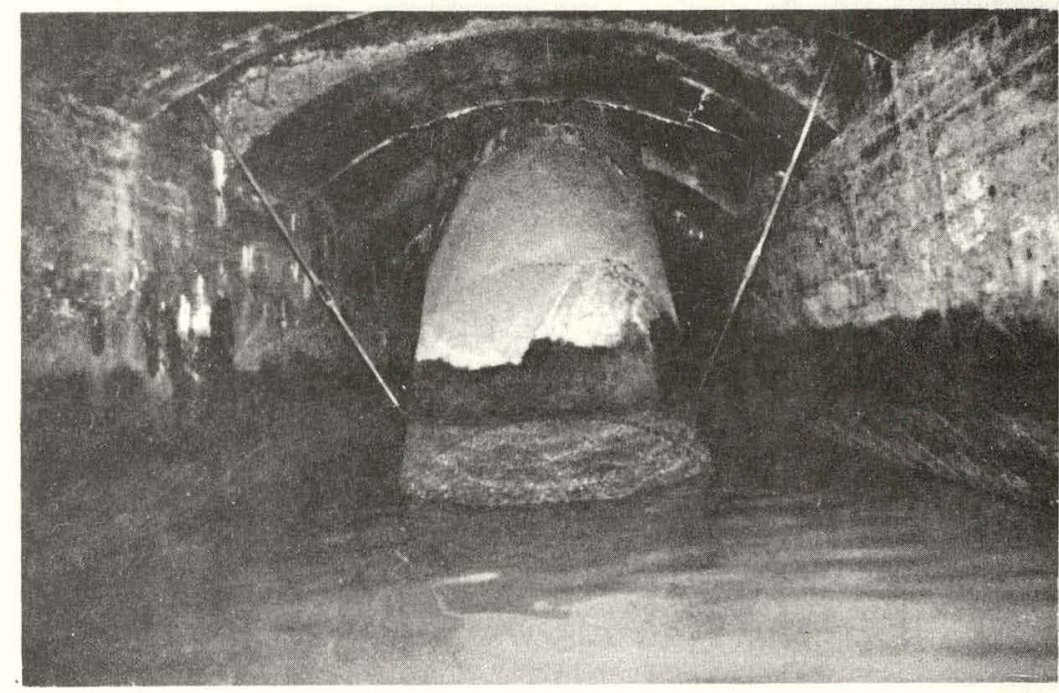

SCHOOLFIELD DAM - POWERHOUSE DOWNSTREAM VIEW

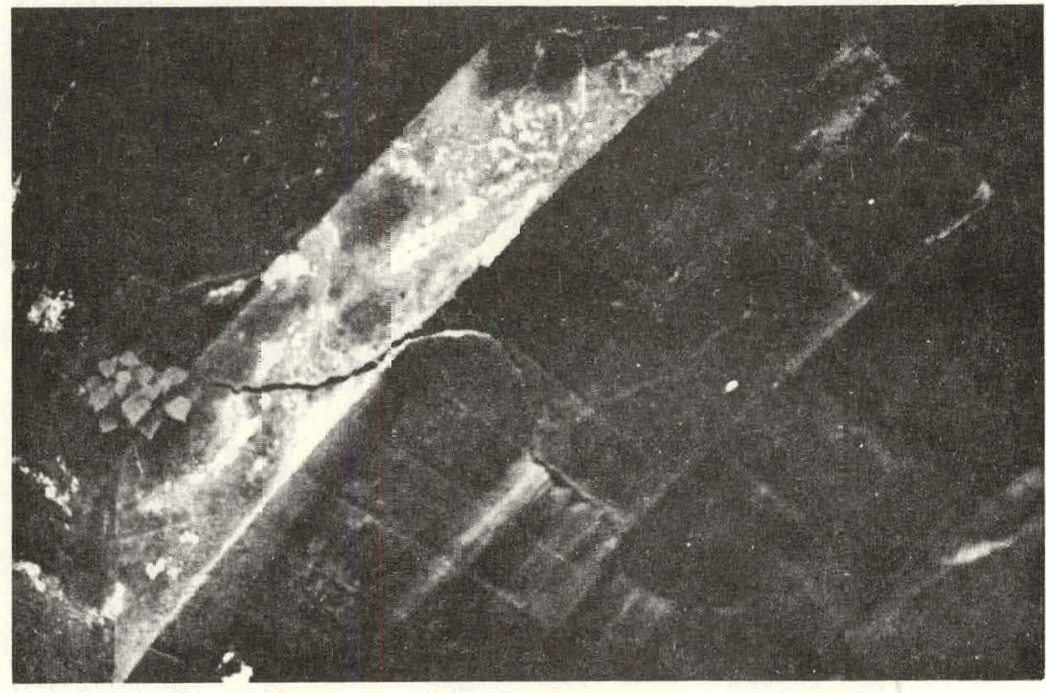

SCHOOLFIELD DAM - POWERHOUSE DRAFT TUBE CONE

SCHOOLFIELD DAM - POWERHCUSE DRAFT TUBE ROOF 


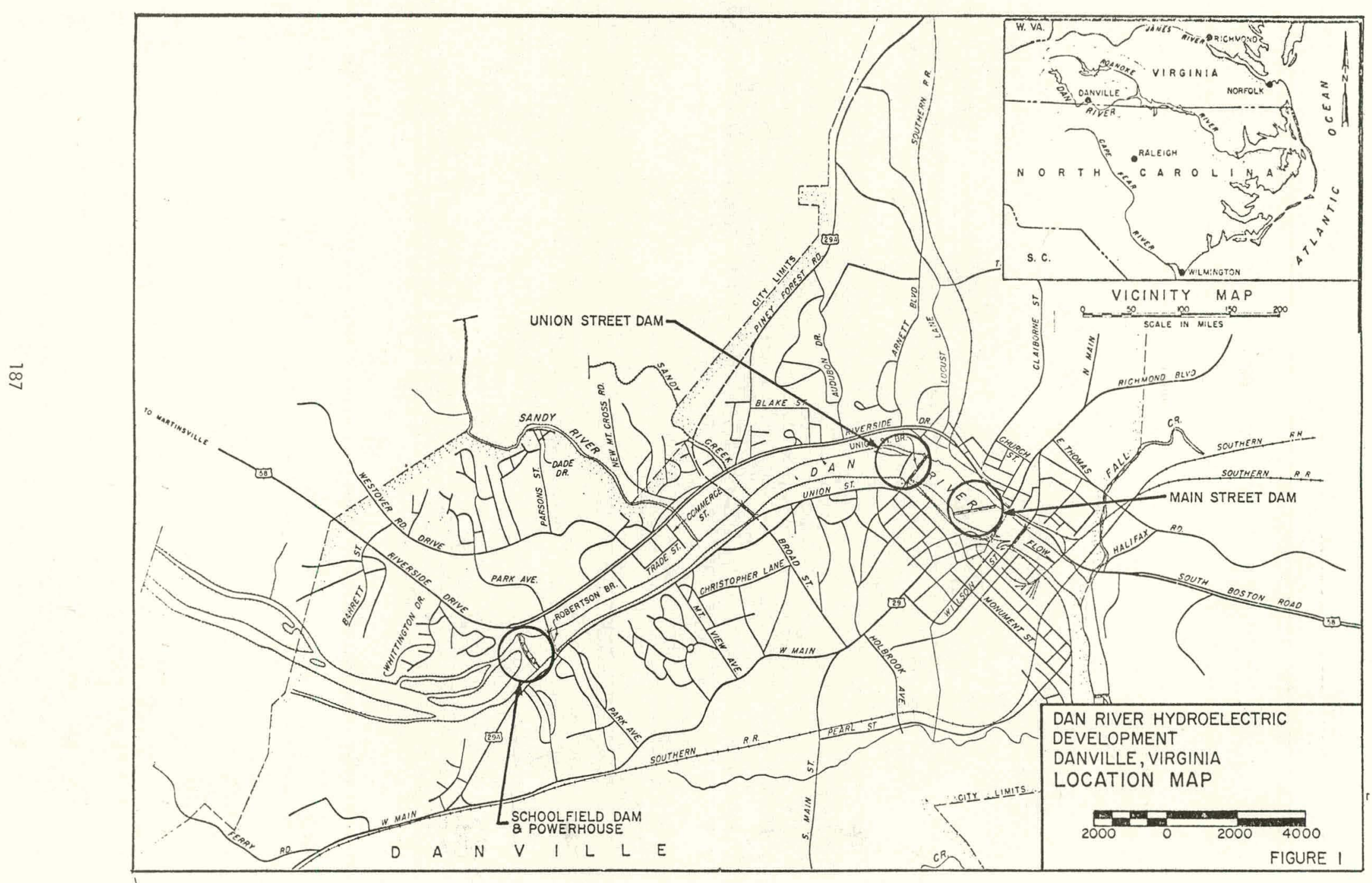


ADDITIONAL POWER GENERATION AT UPRIVER DAM ON THE SPOKANE RIVER

Spokane, Washington

City of Spokane

PRDA Proposal Contract No. EW-78-F-07-1801

\section{INTRODUCTION}

National Energy Act, H.R. 8444, Section 586, emphasized the need for reviva1 of the oldest and often neglected energy resources -- the hydroelectric power of small rivers and streams. Rightly Department of Energy (DOE) announced, as a first step, a grant scheme for feasibility study for low head hydro-generation. In the meantime, the City of Spokane was conducting preliminary studies for additional power generation at Upriver Dam on the Spokane River. The City of Spokane was successful in getting the DOE grant and Tudor Engineering Company, Seattle, was subcontracted by the City to conduct a detailed analysis.

The Water Division of the City of Spokane maintains and operates the existing hydroelectric plant at the Upriver Dam site on the Spokane River. The plant has three adjustable blade, vertical Kaplan turbines; each has a capacity of $1800 \mathrm{hp}$ at a design head of $33 \mathrm{ft}$, with a variation in the range 27-33 ft. Each turbine is coupled directly to a synchronous alternator rated at $1300 \mathrm{~kW}, 2300$ Volts, $60 \mathrm{~Hz}, 0.8 \mathrm{pf}$. The dam is a concrete gravity structure, constructed in 1937, replacing a timber-crib dam. The turbines were installed in 1938. Preliminary studies indicated a slight loss in efficiency of generation and thus, the feasibility assessment was contemplated to address:

(i) Uprating the existing system and improving efficiency.

(ii) Installing additional generation.

\section{SITE AND FLOW CHARACTERISTICS}

The Upriver Dam complex is located in the Northeast quarter of Section 11, Township 25, North Range 43 East. At this site, the Spokane River flows in a generally South-Westerly direction. There is not much storage capacity behind the dam and the site is characterized as a run-of-the-river type. Although the primary purpose of the dam is to give the generation head, the water, due to elevation difference along the river, backs up giving a storing capacity of about 1.8 mi11ion cubic meters (1500 acre $\mathrm{ft}$ approximately). A diversion canal about $600 \mathrm{~m}$. in length commences approximately $35 \mathrm{~m}$. upstream from the dam and runs to the headworks of the existing powerhouse about $500 \mathrm{~m}$. downstream. A visual inspection of the dam, as a phase I investigation, indicated it to be in sound condition.

The Spokane River has its origin at the Coeur d'Alene Lake and is a tributary of the Columbia. The Washington Water Power Company, a private utility, has five hydroelectric plants along the river and has the right to control the lake elevation. Depending on their requirement the flow in the river is also controlled. On an average, during winter months when their power demand is the highest, around 175 cubic meters per second (c.m.s.) is allowed. This flow is the maximum flow that can be usefully utilized in the hydroelectric plants owned by them. In summer months, flows are minimum and draw-down from the Lake is also 1 imited due to recreational purposes. During this period the flow at Upriver dam is augmented up to $15 \mathrm{c} . \mathrm{m} . \mathrm{s}$. due to the flow from the underground aquifer.

The flow-duration curve, shown in Figure 1, indicates how much percentage of time a particular flow or excess thereof will be maintained. This curve has been drived by

Paper prepared by M.R. Nandagopal, P.E., Ph.D., Engineer, City of Spokane, and scheduled for presentation at the "Smal1 Hydropower PRDA-1706 Contractor's Symposium" sponsored by Department of Energy 
considering the 40 years of flow. The flow that is maintained for a least $50 \%$ of time is considered the average flow and for the Upriver Dam site, it is about $100 \mathrm{c} . \mathrm{m} . \mathrm{s}$. Presently, the existing generators use up to about $70 \mathrm{~cm} . \mathrm{s}$. Surplus flow spilled through the gates floods the tail-race and thus there is considerable variation in the head from about $5 \mathrm{~m}$ (under heavy flows) to $11 \mathrm{~m}$ (under low flows).

\section{UPRATING EXISTING FACILITIES}

The existing plant total name-plate capacity. is $3900 \mathrm{~kW}$. On an average, in a year, the plant produces 34 million $k W h$. The forty-year old plant is well maintained and produces this energy at an operating cost of $3 \mathrm{mills} / \mathrm{kWh}$. Uprating this facility by replacing turbine blades and rewinding the generators is a highly economical proposition. It will increase the life and efficiency of the power plant. Considering the cost involved in the modification and the availability of tax-free revenue bond loan, the energy cost will be $6 \mathrm{mills} / \mathrm{kWh}$.

\section{ADDITIONAL POWER POTENTIAL}

Feasibility assessment of any additional power generation must consider the region in which the site is located, return for investments towards additional power generation, the economical alternatives available for the extra power needed for future expansions. Upriver Dam is located in a regional area where hydroelectric power constitutes a large percentage. Further all the electric utilities in the Pacific Northwest are under a coordination agreement which divides the total hydroelectric energy into Critical period energy and secondary energy. The Critical period energy of a system is the average energy which can be produced under a coordinated operation during that multi-month period determined for the coordinated system under adverse stream flows of historical record. The Critical period for the Spokane River is a twelve month period of low flow in the year 1932-1933. The energy that could be generated in this period is the critical energy. Due to the run-of-the-river type of operation at the Upriver Dam and also due to the limited capacity of all the other plants downstream, owned by the Washington Water Power. Company, the additional generators will have no peaking capability. The secondary energy is the surplus energy produced in an average year compared to that in the critical year. The rate of return expected for the additional power generated, as accepted by the regional utilities, is $25 \mathrm{mills} / \mathrm{kWh}$ for Critical period energy and $10 \mathrm{mills} / \mathrm{kWh}$ for secondary energy.

Cost - benefit analysis is done considering two scenarios:

(i) Additional power generation without uprating the existing generators.

(ii) Additional power generation including uprating the existing generators.

Table 1 and Table 2 summarize the computer results and cost - benefit calculations. From Table 1 , if uprating the existing generators is not considered, 6 MW additional capacity gives the maximum benefit to cost ratio. Also it can be noted that the change in the ratio is not very significant up to $9 \mathrm{MW}$ capacity. If the existing turbine generators are revamped and uprated, Table 2 indicates that there is no economically feasible size. But if the loan available carries less interest or if some federal grant money is available, additional capacity around 6 MW to $9 \mathrm{MW}$ can be justified. Flow conditions are such that a 9 MW additional capacity may produce up to $55 \mathrm{million} k$ Wh annually, which is equivalent to nearly 100,000 barrels of imported oil saving the nation nearly $\$ 1.5$ million. The computer results indicate maximum utilization of the flow with unit sizes of 3 MW to $4 \mathrm{MW}$.

\section{CONSTRAINTS AND ALTERNATIVES}

The Upriver hydroelectric plant was installed in 1938 with the primary purpose of providing power for pumping well-water for distribution in the city. The demand for water is the heaviest during summer months and the flow in the river is the least, limiting the generation. During winter and early spring, the river has good flow and the generation keeps up at the maximum. But the demand for water is the least.

The Washington Water Power Company is an investor owned private electric utility in spokane. Its electric power demands peak in winter and are lowest in summer. This demand pattern, which is just opposite to that of the water utility, created a situation for a mutually beneficial power exchange contract. Accordingly, the City delivers all 
the surplus power to the utility distribution grid and a credit, earned at the agreed rate of exchange, is utilized during peak demands of the City water distribution. This contract which is good until 1986 aiso stipulates a rate of $8.55 \mathrm{mills} / \mathrm{kWh}$ for any excess power received. The company officials feel that there is no problent to cuntinue the agreement, if not improve the rate for the benefit of the City.

At present the power exchange contract covers only the energy utilized in water pumping stations and on an average the exchange is working out even. Uprating the present plant and increasing the efficiency creates enough extra energy for all the projected power needs for pumping water. This alternative results in an increase in the cost of generation from $3 \mathrm{mills} / \mathrm{kWh}$ (presently) to 6 mills/kWh, but is still below the exchange rate. Any additional power generation by putting new turbines will increase the cost of generation to nearly $15 \mathrm{mills} / \mathrm{kWh}$ and is economically justified only if $7 \%$ bond money is available. Unless there is'a dire need for the extra.power, which is considerable if a $6 \mathrm{MW}$ to $9 \mathrm{MW}$ generation capacity. is planned, it is very hard to justify for the city to go into debt. Thus any additional generation by putting new turbines could only be justified if encouraged by some federal grant and the City doing its share to help the nation conserve the energy now spilled over the dam. All the additional energy produced will be used for augmenting public facilities through suitably modified power exchange contract. The City of Spokane Sewage Treatment facilities use up to 25 million kWh annually at a cost of nearly $\$ 250,000$. Some other avenues for the generated power could be for part of parking lot lighting, City owned building heating and lighting, etc.

\section{CONCLUSION}

The feasibility assessment for uprating the existing plant and installation of additional turbines at Upriver Dam site, owned and operated by the Water Division of the City of Spokane, indicates the uprating of the existing system as the most economica? proposition. Further a $9 \mathrm{MW}$ additional capacity will produce an additional 50 million $\mathrm{kWh}$ annualiy which is equivalent to nearly 75,000 barrels of imported oil, saving the nation more than one million dollars. Financial consideration seems to be the only constraint for the city not to undertake the installation of additional power generation. The Department of Energy would do well to help the nation conserve the energy by encouraging the City of Spokane through some form of federal grant or interest free loan. 
Table 1.

Cost - Benefit Analysis of Additional Power Generation

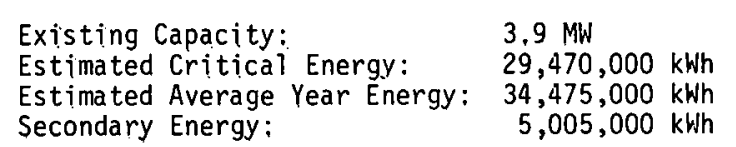

Estimated Average Year Energy: $34,475,000 \mathrm{kWh}$

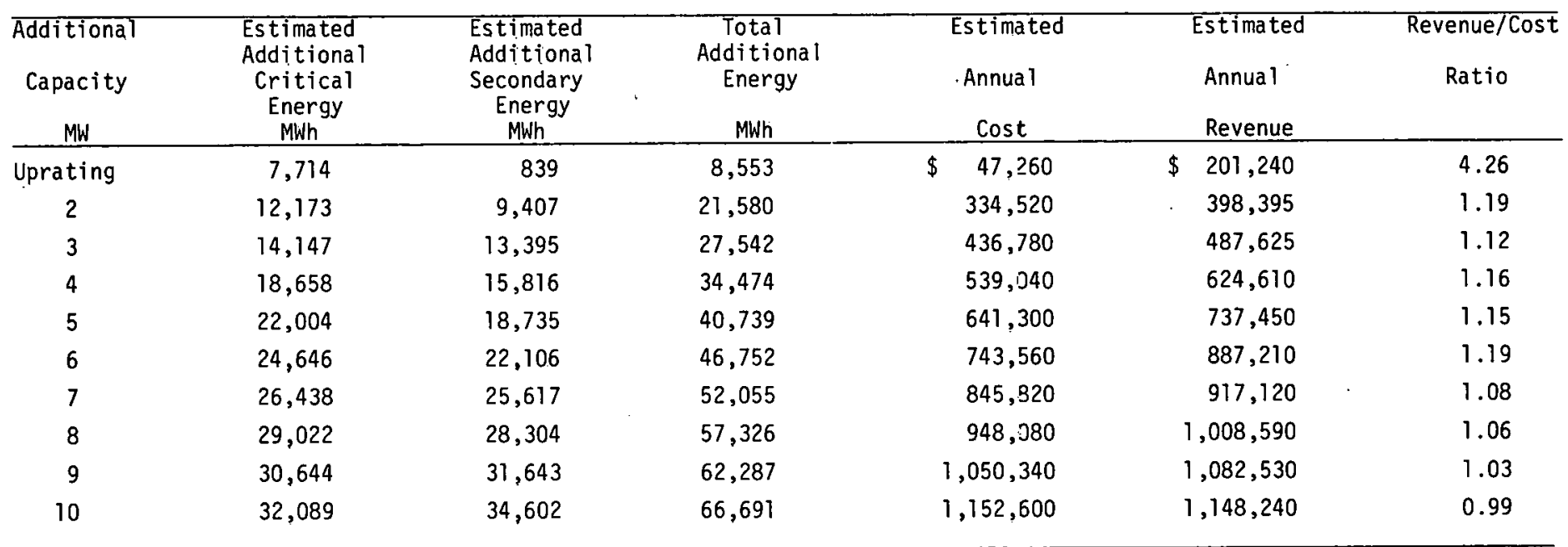

Notes: 1. Estimated annual cost is calculated for amortization of the plant cost estimated at $\$ 1000 / \mathrm{kW}$, assuming $10 \%$, 40 yr loan, plus $\$ 130,000$ annually for operation, maintenance and insurance cost.

2. Estimated annual revenue is calculated by assuming $\$ 25 /$ MWh for critical period energy and $\$ 10 /$ MWh for secondary energy. 
Table 2

Cost - Benefit Analysis of Additional Fower Generation With Uprating of the "Existing Generators

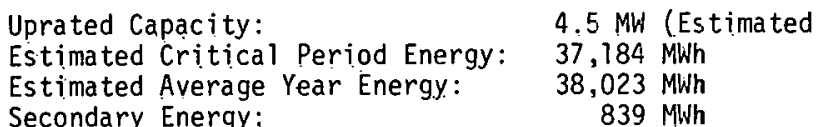

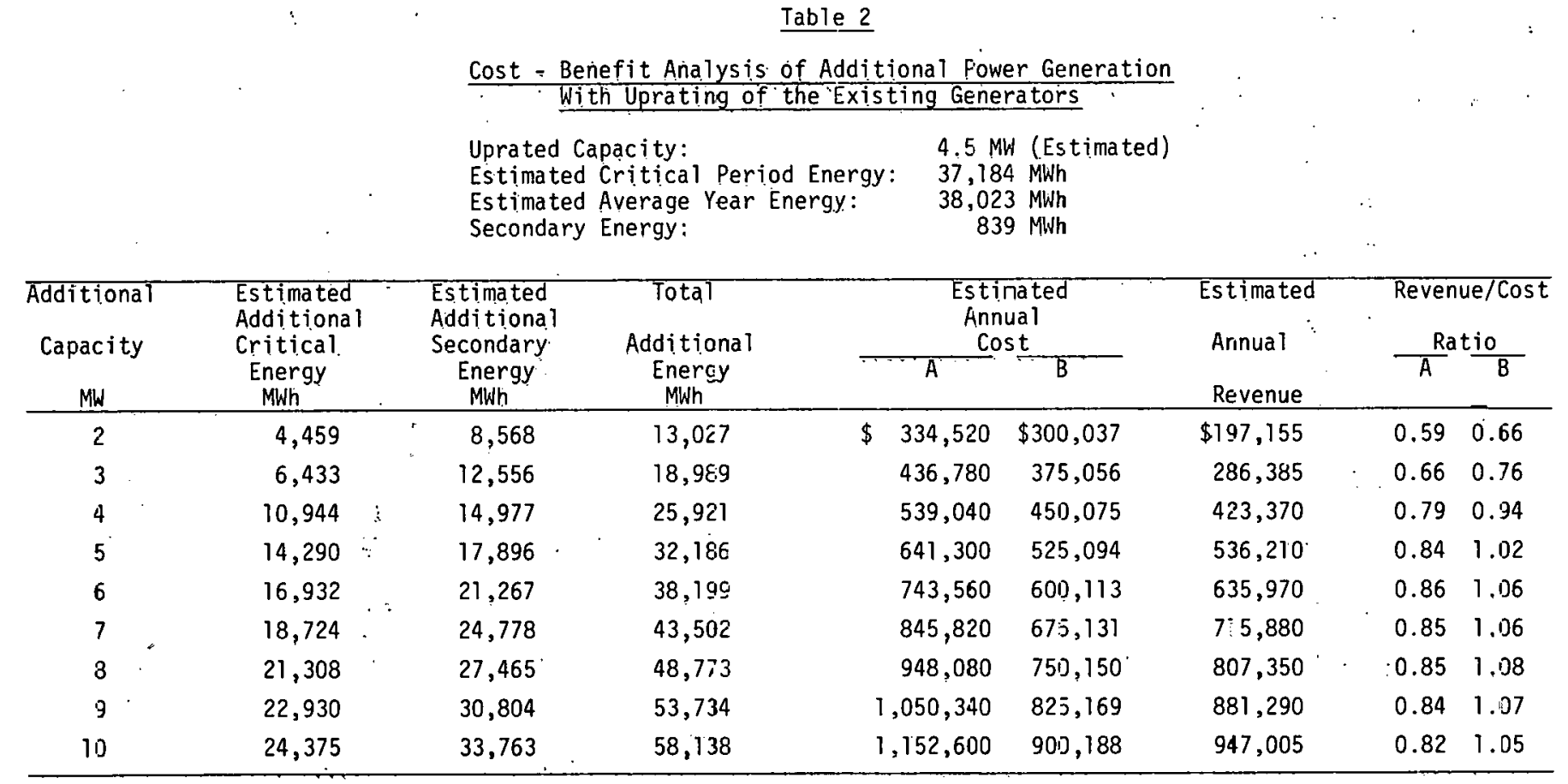

Notes: 1. Estimated annual cost is calculated for amortization of the plant cast estime ted at $\$ 1000 / \mathrm{kW}$

(A) Assuming $13 \%, 40$ yr loan, plus $\$ 130,000$ annually for operation, maintencince and insurance cost.

(B) Assuming 7\%, 40 yr, tax exempt loan, plus $\$ 150,000$ annually for Operaticin and Maintenance.

2. Estimated annual revenue is calculated by assuming $\$ 25 /$ MWh for critical periad energy and $\$ 10 /$ MWh for secondary energy. 


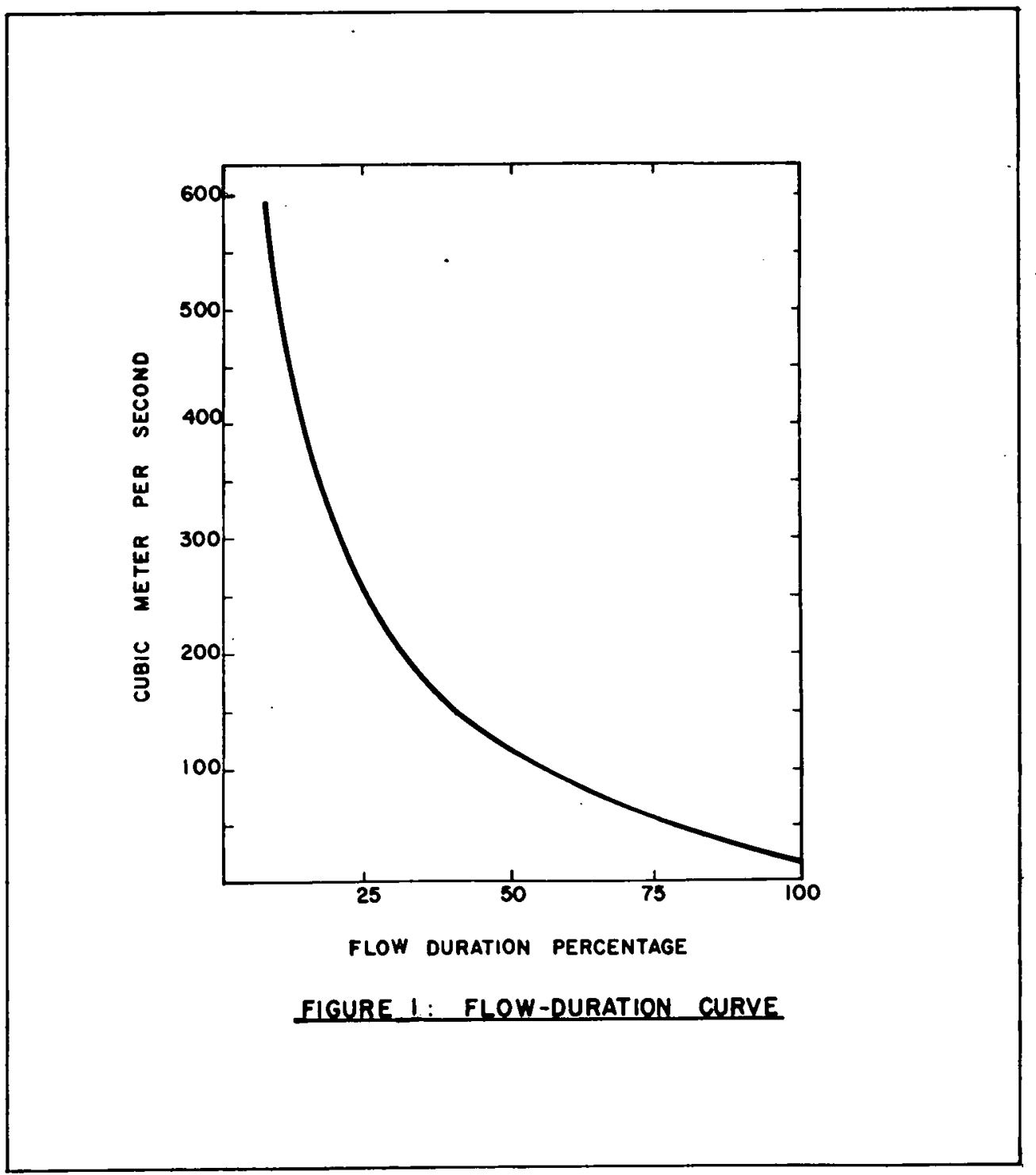

Additional Power Generation at Upriver Dam on the Spokane River 


\author{
PATILLAS RESERVOIR \\ PATILLAS, PUERTO RICO \\ Energy Research \& Applications, Inc. \\ John J. Huetter, Jr.
}

PRODA Proposal Cunlracl Nu. EW-78-F-07-1804

\title{
I. INTRODUCTION
}

In accomplishment of a feasibility determination for the retrofit of hydroelectric generating equipment at Patillas Reservoir, Puerto Rico, ENERGY RESEARCH $\&$ APPLICATIONS, INC. has identified an extremely favorable application for hydropower technology and, accordingly has developed a three phase potential implementation plan.

Though the methodology (and its specific analytic tools) were developed to establish site-specific acceptance/non-acceptance criteria for hydropower generation at Patillas Reservoir, it has been ERGA's intent that this system be applicable for hydropower feasibility determination at any existing dam/reservoir in Puerto Rico.

\section{II. $\quad$ HYDROLOGIC ANALYSIS}

Initial hydrologic study, based on a 59 year record of reservoir behavior, established the potential for significant recovery of energy through hydropower retrofit. Statistical variability of reservoir surface elevation and irrigation demand (the Patillas Dam's primary function) were subjected to computer analysis with respect to either a l2ihour peak demand generating cycle or a 24 hour/base load generating cycle.

A purely hydrologic estimate of generating capacity from a single installation is $800 \mathrm{KW}$ peaking or $400 \mathrm{KW}$ base power. Implementation of a second phase system based on a seven (7) month 'wet' season surplus of water would augment this estimate.

\section{ENGINEERING FEASIBILITY AND DESIGN CONCEPT}

Three(3) potential locations for hydropower equipment retrofit were identified in the engineering analysis of the Patillas site. These locations in turn become the three(3) potential phases of development according to their respective economic benefits. Suitable equipment options and the trade-offs involved with each are included in the analysis of each location/phase.

lhe first location/phase is at the site of the existing irrigation outlct structure on the earth dam. Development at this site affords both the lowest installed cost for equipment and assured availability of water flow, based on irrigation demand. At this location engineers preferred a vertical turbine arrangement due to the availability of standard equipment suitable to design parameters, greater efficiency because of maximum head utilization, and the minimization of mechanically destructive cavitation. The rated installed capacity is $665 \mathrm{KW}$.

Location/phase II incorporates the construction of a penstock and powerhouse adjacent to an existing concrete spillway built in 1976 . A vertical turbine (for reasons similar to Phase I) would exploit necessary spillage of surplus water during the rainy season (May - November). Installed capacity is estimated at $650 \mathrm{KW}$ peaking power for up to eight(8) months each year, with actual usage dependent on reservoir surplus over current commitments.

Location/phase III proposes a power plant roughly 1.4 miles below the Phase I installation on the irrigation canal. The 42 foot head would produce roughly $315 \mathrm{k}$ installed capacity from a horizontal turbine. While the cost of penstock pipe to enclose the now open canal prevents Phase III from being economically attractive at current energy cost levels, it is a straightforward engineering exercise and is identified as a future possibility. 
Fully automatic operation is feasible (and the appropriate hardware readily available) for all three(3) phases, and therefore has been costed, assumed in design and recommended.

\section{IV. $\quad$ ECONOMIC FEASIBILITY}

Due to the particular role of the Puerto Rico Water Resources Authority(especially their current $97 \%$ dependency on \$14/Bb1. oil for power production), the viewpoint selected for determination of economic feasibility of the Patillas hydropower project is that of Puerto Rico. A detailed rationale for this approach is developed in the Final Report.

A model structured on critical or impact factors, with an output consisting of costs and benefits as well as return on investment, was developed for use in the Puerto Rico environment. (Appropriate tax assumptions, etc. are constant and imbedded in the analytic too1.) This approach provides an independent assessment of economic viability. The responsible entity can operate the model and determine if resulting RoI, cost/kw, oil savings, or other decision factors meet required thresholds.

The calculated ROIs of the different installation phases range from $8.3 \%$ to $21.8 \%$. The most attractive operating strategies focus on displacing the maximum amount of opeC oil.

\section{ENVIKONMENTAL IMPACT}

A primary directive for the engineering assessment was to minimize environmental impact. Consequently, both the ERGA staff ecologist and the Puerto Rico Center for Energy and Environment Research (under sub-contract) have determined that operation of the proposed retrofit creates no ecological impact over and above current reservoir use and irrigation demand. and identifiable in detail.

Transient environmental disruption during construction is expected to be minimal

In addition, personal interviews with responsible Puerto Rico agencies (including the Environmental Quality Board) further reinforce the scientific findings that no environmental prohibition to the project will be encountered.

\section{LEGAL AND REGULATORY FEASIBILITY}

No legal impediments to the implementation of hydroelectric generation at Patillas Reservoir are anticipated. Not only are dedicated irrigation flows and downstream water rights unaffected, but precedent is established in the specific mandate for hydropower development in the South Coast Irrigation District (of which Patillas Reservoir is a part) according to Puerto Rican law (22 Laws of Puerto Rico $228(\mathrm{~b})$ and 258 ). The PRWRA has legal authority for both the irrigation district and the potential for hydropower development in the district as well as the entire island of Puerto Rico.

The Phase I and III aspects of the Patillas Hydropower Project are specifically exempt from FERC licensing under Section 30 of the Federal Power Act. Phase II could easily be licensed by short form method in the event that it is required.

Again, based on personal contact with agencies which would issue formal approval of the project (Puerto Rico Planning Board, Environmental Quality Board, and Regulation and Permits Administration), prompt approval is expected.

V 11

\section{EQUIPMENT AVAILABILITY AND EVALUATION}

Of the 20 turbogenerator hardware manufacturers from which quotes were solicited, four(4) vendors were identified as responsive with appropriately detailed equipment lists, cost quotes and delivery schedules. Engineering design allows for the use of the services of any of these suppliers.

Basic equipment costs range from approximately $\$ 190,000$ to $\$ 335,000$, including automatic control, interfacing and switching hardware.

VIII. INSTITUTIONAL AND SOCIAL FEASIBILITY

Though thc specific legal mandate along with approximately $1000 \%$ increase in fuel cost to the PRWRA over the past 15 years appear to firmly establish institutional justification for the patillas hydropower development, several factors demanded a more in-depth justification. 
Between 1960 and 1974 several small hydropower.sites on the island were classified as uneconomic and shut down. High operation and maintenance costs were the justification. Puerto Rican decision makers therefore required the specific technical justification for. the minimal O\&M costs plotted in ER\&A's economic analysis.

In addition, though the hydroelectric installation at patillas can be expected to deliver a 15-20\% ROI, the addition of a half megawatt to a. $4000 \mathrm{MW}$ grid may better be justified by more elusive political, economic and social factors. Not least.among these is the displacement of cost and supply uncertainty of imported crude from an opeC source.

Political and social benefits include not only the initiation of attempts to supply puerto Rican consumers with a reduced power rate, but also a"temporary local employment gain during construction.

IX.

\section{CONCLUSION}

All external factors are in concordance with the feasibility of hydroelectric equipment retrofit at Patillas Reservoir. A feasible operating capacity of between $665 \mathrm{~kW}$ and $1470 \mathrm{KW}$ peaking power or $400 \mathrm{KW}$ to $700 \mathrm{KW}$ base load power (depending on extent of development) cán be delivered at a cost below current PRWRA bus bar costs. No significant environmental, social, or legal barriers exist.

Further, responsible Puerto Rican decision makers are enthusiastic. In a hriefing requested by Puerto Rico Energy Office Director, Dr. Frank Castellón, and delivered to PRWRA Executive Director, Alberto Bruno Vega, by the ER\&A project manager on March 14, 1979, Puerto Rico's commitment to the development of renewable energy sources in a mixed energy futures strategy and the specific example of the patillas hydropower project were emphasized.

FEASIBLE OPERATING PROFILES PATILLAS RESERVOIR

\begin{tabular}{|c|c|c|c|c|c|}
\hline \multirow[b]{2}{*}{ vo. } & \multirow{2}{*}{$\begin{array}{r}\text { Hydropower } \\
\text { Installation }\end{array}$} & \multicolumn{2}{|c|}{ Generating Insta11. Capacity $(K W)$} & \multicolumn{2}{|c|}{ Annual Energy $\quad(K W H / Y R)$} \\
\hline & & $24 \mathrm{hr} /$ day ' $\mathrm{yr}$ round & $\begin{array}{l}\text { Pegk Hour } \\
12 \mathrm{hr} \text { dày } 5 \text { day wk }\end{array}$ & $24 \cdot \mathrm{hr} /$ day year' 'round & Peak hrs-12hr/dy $5 \mathrm{dy} / \mathrm{wk}$ \\
\hline 1 & at earth dam & 400 & 490 & $3,504,000$ & $1,528,800$ \\
\hline 2 & at Spillway* & $\therefore$ & 650 & --- & $2,028,000$ \\
\hline 3 & at Syphon & 300 & 330 & $2,628,000$ & $1,029,600$ \\
\hline \multicolumn{2}{|c|}{ Total Phase 1 (1) } & 400 & 490 & $3,504,000$ & $1,528,800$ \\
\hline \multicolumn{2}{|c|}{ Total Phase $2(1+2)$} & 400 & 1140 & $3,504,000$ & $3,556,900^{* *}$ \\
\hline \multicolumn{2}{|c|}{ Total Phase $3(1+2+3)$} & 700 & 1470 & $6,132,000$ & $4,586,400$ \\
\hline
\end{tabular}

* Operates only for Peak Power Generation

** Probability of failure to deliver stated energy levels: $1.98 \%$ 


\title{
O'SHAUGHNESSY AND GRIGGS DAMS ON THE SCIOTO RIVER
}

\author{
Columbus, Ohio
}

City of Columbus, Division of Water

Burgess \& Niple, Limited

Cooperative Agreement

EW-78-F-07-1805

\section{STUDY PROCESS}

The study considers the feasibility of developing hydroelectric plants at two water supply dams, Griggs and 0 'Shaughnessy, both located on the Scioto River in the vicinity of Columbus, Ohio. The work is being performed in accordance with the U.S. Department of Energy Requirements. In order to gain maximum benefits from available expertise, work on the project was subdivided among four concerned organizations as follows:

City of Columbus, Division of Water - Data on water and electricity usage; funding plan; partial responsibility for engineering/environmental data.

City of Columbus, Division of Electricity - Marketing analysis; partial responsibility for power transmission engineering, particularly electrical.

State of Ohio, Department of Energy - Responsibility for assessing legal and regulatory factors and for communication with interested agencies and parties.

Burgess \& Niple, Limited - Primary responsibilities for engineering; environmental review, and project coordination.

Other agencies which, while not contractural participants in the project, did contribute significantly, were the U.S. Geological Survey, the Corps of Engineers, and the Columbus and Southern Ohio Electric Company.

Early in the study, it became evident that several factors combined to enhance the feasibility of the project; throughout the course of the study effort was directed at taking the greatest advantage of these factors:

- The agency owning the dams, the Division of Water, could utilize all of the energy generated.

- The local utility and the City Division of Electricity were willing to transmit power.

- The reservoirs' storage could be used to allow flexible operating programs.

- Substantial discharges, in addition to water supply usage, were available for energy generation.

An important criterion adopted for the study was that water supply yields of the reservoirs remain undiminished. Thus, during low flow periods only the (daily) volume of water supply use would be available for generation. The timing of this release would be a matter of study.

\section{ENGINEERING CONSIDERATIONS}

O'Shaughnessy Dam, about 16 miles north of Columbus, is approximately 65 feet high, impounds 16,900 acre-feet of water when full, and controls a drainage area of 980 square miles. Griggs Dam, about $9 \mathrm{miles}$ downstream from 0 'Shaughnessy Dam, is about 35 feet high, impounding 4,200 acre-feet of water. It controls a drainage area of 1,044 square miles. Both reservoirs are primarily for water supply, and are heavily used for recreation by area residents. About seven miles downstream from Griggs Dam are the Dublin Road water treatment plant and a small intake pool which stores about 200 acre-feet of water. Taken together, the three dams impound a relatively small proportion of basin runoff--about four percent.

For the hydrologic analysis, duration curves of annual and monthly discharge and headwater elevation were developed based on records from 1921 through 1978. Tailwater elevations were defined by dischargeelevation rating curves, which were in turn developed by numerical modeling of hydraulic stream profiles: Flood levels were determined primarily from flood water surface profiles by others. The duration curves indicated discharge in excess of water supply needs during 85 percent of the time, and 20 times water supply about 20 percent of the time. 
Based on the above described hydrologic relationships, the annual energy dissipated over the dams is estimated at 39.5 million kilowatts at 0 'Shaughnessy Dam and 20 million kilowatts at Griggs Dam. For the purposes of the study, the range of facility sizes was defined widely in order to include all feasible sizes. At both sites the study included discharges ranging from 400 to 1,500 cubic feet per second, corresponding to durations ranging from 13 percent to 34 percent of the time. At 0'Shaughnessy Dam the resultant power output ranged from 6.4 to 1.9 megawatts, yielding 8.7 to 15.6 million kilowatt-hours per year. At Griggs Dam the corresponding power output ranged from 0.9 to 2.5 megawatts, yielding 4.4 lo 6.8 million kilowatt-hours per year. Figure 1 shows the resultant curves for various types of equipment over the range considered.

Evaluation of sites for different turbine sizes, number of units, types, and locations presented a major task. Early in the study, it was determined that a daily peaking type of operation would be beneficial both in terms of providing power at the needed time of day and in terms of extending the range of economical operation. The extension of operating range by peaking is significant and readily accomplished because of the ability of the three reservoir pools to store the volumes required without major fluctuations in water levels. For a typical turbine unit with a design discharge of 1,000 cubic feet per second, and without peaking operation, efficiency would fall off severely at discharges less than about 250 cubic feet per second; however, by operating only part of the time, water can be stored in the reservoir and released at 250 cubic feet per second. This mode of operation contributes about 15 percent of energy generation. Figure 2 shows the resulting power and operating time duration curves.

Because of the relative complexity of this analysis, a numerical model (a computer program) was developed to represent the system. This model utilizes the hydrologic data noted above (discharge and headwater duration curves and tailwater rating curves) along with data on equipment (turbine capacities, efficiency curves, head losses, and operating criterion) to calculate energy generated, power, efficiency, hours per day of operation, and discharge through the turbine for each month using ten increments per month. The monthly results allow computation of the value of energy generated, wheeling charges, and dependability.

\section{MARKETING AND INTERCONNECTION/TRANSMISSION}

The City of Columbus presently operates both electrical and water supply facilities under the Department of Public Service. The Division of Water operates the Dublin Road treatment plant in Columbus, supplied by the Scioto River and the Morse Road plant. A third, the Parsons Avenue plant, is now in early construction stages and will be located about ten miles south of the Dublin Road plant. The Division of Electricity has, in the past, generated electricity at a coal fired plant. This plant has been shut down and is to be replaced by a new plant at another location. In the interim, the city is purchasing power wholesale, from Columbus and Southern Ohio Electric Company, to meet its 7,000 customers demands. The city proposes to serve the new Parsons Avenue plant from the Division of Electricity system, but not the Morse Road plant.

Because of these on-going transactions among the Division of Water, the Division of Electricity, and Columbus and Southern Ohio Electric Company, the city has available the organizational and technical ability to operate an electric power generator and transmission system.

Because the distances between the dam sites and the proposed points of use of Dublin Road and Parsons Avenue water plants are substantial, about $25 \mathrm{miles}$, an arrangement for transferring power through existing lines or construction of an independent transmission line is necessary. The Division of Electricity has tentatively agreed on connection arrangements and wheeling charges with the Columbus and Southern Ohio Electric Company. (An independent line is, however, considered technically and economically feasible). The points of connection to the Columbus and Southern Onio Electric Company system require only short segments of connecting power lines; 1,600 feet of 13.2 kilovolt overhead at Griggs Dam and 1,000 feet of 34 kilovolt underground at 0 'Shaughnessy Dam.

The wheeling charges for transfer of electric energy from the sites to the Division of Electricity substation would be $\$ 18.00$ per kilowatt annually, based on maximum power output, which results in approximately 5.5 mills per kilowatt-hour on an average energy basis. This relatively high charge is due in part to the wide range in variation of output of the proposed facilities. The present average wholesale rate to the Division of Electricity by Columbus and Southern Ohio Electric is $\$ 0.028$ per kilowatt-hour, expected to increase to $\$ 0.0305$ by 1980 . This is the rate adopted for the financial analysis.

\section{LEGAL AND REGULATORY, INSTITUTIONAL, AND SOCIAL FACTORS}

The necessary license from the Federal Energy Regulatory Commission will require a complete environmental impact assessment, and may cause delays while licensing is under consideration. Because the developer, the City of Columbus, is the owner of the existing dams, there should be no question as to their having primary authority to develop. Also, construction work in the stream channel and in the reservoirs will require a permit from the U.S. Army Corps of Engineers (a 404 permit). The requirements for these permits have been taken into consideration in project planning and no unusual problems are expected. 
Institutional and social factors have been considered throughout the study because of the numerous agencies and groups with interests in the project, the affected stream, and the adjacent land. The Institutional Advisory Task Force is made up of representatives of state agencies (Department of Natural Resources, Environmental Protection Agency, Department of Energy, and Public Utilities Commission), City of Columbus agencies (Divisions of Water and Electricity and Department of Parks and Recreation), and the local electric utility (the Columbus and Southern Ohio Electric Company). Contact with private groups such as boating clubs is through these agencies. Concerns brought forth by this group include water flow and level fluctuations and resultant effects on boating and fishing; possible releases of low quality water from the reservoir; and timing of power production in relation to system needs. Comments in the above areas of concern have been answered in the project plan by adopting development and operating procedures based on such comments. The concept of hydroelectric development at these sites has been publicized in the local news media throughout the proposal and study phases, and has received favorable comments, because of the environmental acceptability, and because of the potential for monetary savings in municipal operations.

\section{ENVIRONMENTAL REVIEW}

The environmental task force has acquired pertinent ecological data for the project area. A hydraulic analysis of the affected $16 \mathrm{mile}$ strean reach has been completed for existing and proposed discharge conditions, and the resultant information on velocity, depth, and profile at 97 sections used to evaluate environmental effects and to plan tentative operating programs. The environmental effects of project implementation are generally considered in qualitative terms for this feasibility study. The environmental impact statement required for licensing by the Federal Energy Regulatory Commission will be of greater detail, enabling, where possible, the expression of project impacts in quantitative terms. Environmental concerns evidenced to date have been taken into consideration in developing design and operating criteria without significant effect on project feasibility.

\section{ALTERNATIVE DEVELOPMENT PLANS}

At both Griggs and 0 'Shaughnessy Dams, variable level intakes and valved water supply conduits were included in the original structures and are presently in use. Because these water supply conduits included intake, trash racks, and valves which could be used with hydroelectric facilites, their potential as turbine-feed conduits was reviewed. Both were, however, found unsuitable due to their small capacity, and the cost of integrating them into other structures. Therefore, the study concentrated on the feasibility of sites at the original hydroelectric conduits.

At 0 'Shaughnessy Dam, development of a site at the existing hydropower conduit, a 15 foot by 19 foot opening, is the preferred alternative. A plan for this site involves construction of a powerhouse, penstock, tailrace channel, construction access road, and improvements to the existing intake structure. The potential output at this site, 14.5 million kilowatt-hours per year, is greater than at the center of dam, by about 17 percent. Maximum power output would be about five megawatts, with a load factor of 0.32 . A limitation with this site is that, when the reservoir is drawn down during a severe drought, inadequate depth of water at the intake will force equipment shutdown; however, this condition comprises only about one percent of operating time and is not of economic consequence.

At Griggs Dam the preferred plan is to use the existing (plugged) nine foot diameter original hydroelectric conduit through the west abutment section of the dam. Major features of the modification include construction of a powerhouse and penstock below the dam and tailrace channel. Construction access would be via the stream channel and maintenance access would be by foot only via a stairway from the existing roadway at the top of the high bank. As no intake structure exists at this site, a substantial structure is also needed. The potential capacity of this site is estimated to be two megawatts, producing 6,500 million kilowatt-hours per year with a load factor of 0.36 . This is about double the capacity of the east bank site.

\section{COST AND FINANCIAL ANALYSIS}

Project costs were estimated from equipment manufacturers quotes (nine in all) and, for civil works, from facility cost estimates based on quantities taken from preliminary plans. Costs were adjusted to a January 1, 1980 date, and allowances were made for contingencies, contractor profit, design costs, and interest during construction.

The financial analysis for the proposed facilities was conducted on an annual net income basis, summing the present value of net gain over the project life to arrive at a figure for the net value of the project. The actual calculations have been carried out via a numerical computer model (University of Rhode Island, Hydroelectric Power Generation and Financial Analysis program per "Hydroelectric Power Potential, Woonsocket Falls Dam", January, 1979) acquired and modified for the conditions at the Columbus sites. The above noted program has been designed to estimate power generation from available head, flow and equipment parameters, and to evaluate the financial feasibility of a facility using estimated costs for project development, operation and maintenance, wheeling, and related financial parameters. The sequence of computation used in the model is: 
1. Annually, calculate the value of electrical energy produced.

2. For the same year, calculate cost for bond repayment for specified term and rate; operating and maintenance costs; and wheeling charges.

3. Calculate the net cash flow as (1) above, less (2), and calculate the present value of the net.

4. Accumulate item 3 and update all time dependent parameters.

5. Summarize results, totals for power produced, net gain (cash flow), present value, and benefit ? cost ratio.

The sites at Columbus required a more intricate analysis of power and energy output than did the site for which the URI Program was developed. A separate program as noted earlier was developed to estimate peak power and energy production and appropriate operating periods.

The use of a model or program of this type was considered essential in order to properly account for the effect of inflation on the project's feasibility in terms of costs and value of energy generated. The current high interest rates reflect anticipation of future inflation on the part of the lender. The borrower is paying for inflation in advance, and must, therefore, consider the future, inflated value of his product. The major parameters required. for the financial analysis were:

- Bond Term and Interest - 25 years; six percent, the current rate for City of Columbus bonds.

- Inflation Rate - Overall economy, seven percent per current federal t.arget.; for energy, nine percent through 1983, and six percent thereafter, based on the marketing study.

- Starting Date for Financial Analysis - January 1, 1980; not necessarily the start-up date.

- Project Life - Taken as 35 years for the financial analysis.

- Value of Energy Produced - An average of $\$ .0305$ per kilowatt-hour in 1980.

- Wheeling Charge - $\$ 18.00$ per year per kilowatt, equal to $\$ .00549$ per kilowatt-hour (1980).

The results of the financial analysis are presented in the table below:

\begin{tabular}{|c|c|c|c|c|c|c|c|}
\hline & Capacity & Project Cost & Unit Cost & Net Gain (PV) ${ }^{(1)}$ & $\mathrm{ROI}(2)$ & $\begin{array}{l}\text { Benefit Cost } \\
\quad \text { Ratio } \\
\end{array}$ & $\begin{array}{c}\text { Current }^{(3)} \\
\text { Energy } \\
\text { Cost } \\
\end{array}$ \\
\hline $\begin{array}{l}\text { 0'Shaughnessy Dam } \\
\text { Griggs Dam } \\
\text { Combined }\end{array}$ & $\begin{array}{l}5 \mathrm{mw} \\
2 \mathrm{mw} \\
7 \mathrm{mw}\end{array}$ & $\begin{array}{r}\$ 4,069,000 \\
3,588,000 \\
7,657,000\end{array}$ & $\begin{array}{l}\$ 800 / \mathrm{kw} \\
\$ 1,800 / \mathrm{kw} \\
\$ 1,100 / \mathrm{kw}\end{array}$ & $\begin{array}{r}\$ 6,748,000 \\
319,000 \\
7,067,000\end{array}$ & $\begin{array}{r}13 \% \\
6 \% \\
10 \%\end{array}$ & $\begin{array}{l}1.73 \\
1.05 \\
1.44\end{array}$ & $\begin{array}{l}\$ 0.031 / \mathrm{kw}-\mathrm{hr} \\
\$ 0.056 / \mathrm{kw}-\mathrm{hr} \\
\$ 0.038 / \mathrm{kw}-\mathrm{hr}\end{array}$ \\
\hline
\end{tabular}

(1) PV - The sum of the present values of annual income; ${ }^{(2)}$ Return on investment; (3) Includes financing

These values indicate project feasibility for both sites and for each site independently. The 0 'Shaughnessy Dam site does generate a greater income and a higher benefit cost ratio than Griggs Dam. This occurs because, while the development costs are nearly identical, the higher head at 0'Shaughnessy Dam allows generation of about double the energy of Griggs Dam. The cash flow of the project was found to be negative for the first five years, by 165,000 in the first year and declining thereafter. This can be covered by Division of Water revenues, short-term borrowing or by deferred payment on the primary bonds.
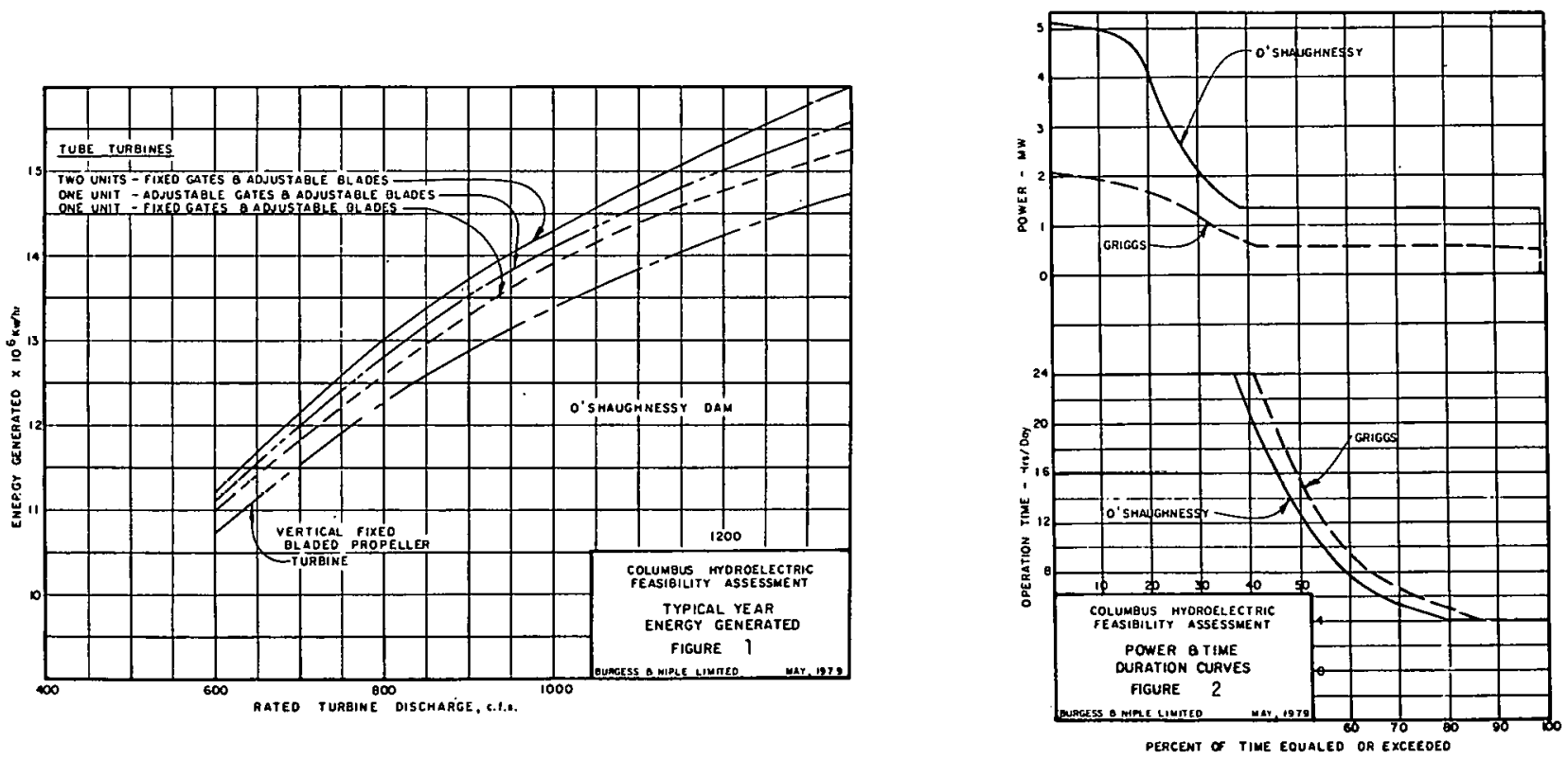


\title{
PAWT UCKET DAM AND NORTHERN CANAL
}

\author{
Lowell, MA
}

Boott Mills and Raytheon Service Co. Raytheon Service Co. \& Acres American Inc.

PRDA Proposal Contract No. 1807

The projected hydroelectric site is on the Merrimack River at Lowell, Massachusetts. The facility would utilize the existing Pawtucket Dam and a portion of the existing Northern Canal. It has a 4,020 square mile drainage area and 34.5 feet of gross head developed by the $\mathrm{dam}$, the canial, and additional excavation at the tailrace. The plant would generate 74,250,000 net kilowatt hours of electricity annually with an installed capacity of $15,000 \mathrm{~kW}$.

The feasibility assessment was performed for Boott Mills by the Raytheon Service Company with oversight and extensive participation by Boott Mills and the active cooperation of the Massachusetts Municipal Wholesale Electric Company.

Two ownership options are possible and both were found to be feasible. In the first, the new hydroelectric facility would be developed jointly by Boott Mills and Massachusetts Municipal Wholesale Electric Company (MMWEC), with rights to the power to be generated.being.sharad by entitlemeit in a (tentative) 60/40 (MMWEC/Boott Mills) ratio. MMWEC's larger entitlement is based on its supplying all project financing. Under this arrangement, .MMWEC would purchase approximately $10 \%$ of Boott Mills entitlement bringing its total to $70 \%$ of the annual kwh generated. Its costs per kw based upon receiving $70 \%$ of the power output would be $\$ 1497$.

As an alternative, Boott Mills might develop the site itself with the New England Power Company (NEPCO) being the principal power purchaser. In either case, it appears that the market for the power generated is adequate to support development of the project.

Project cost is estimated to be $\$ 15,720,000$ at 1978 price levels. This includes an allowance of $\$ 1,000,000$ for fish passage facilities and excludes any allowance for the cost of land, water rights, or existing facilities. The capital cost per kilowatt is $\$ 1,048$.

The site is owned by the Proprietors of Locks and Canals on the Merrimack River, a sister corporation of Boott Mills. Boott Mills currently supplies power to its industrial tenants, using a number of small, older turbines at several locations on the canal system. It would continue as a supplier to these tenants if the new facility were built.

The recommended design will bring water through approximately 2,000 feet of the existing canal; the canal will be modified with a control structure and a new canal retaining wall diverting the canal flow to the new powerhouse. The powerhouse will be located close to the existing canal, 
on the south bank of the river. Power will be fed to the local $23 \mathrm{kV}$ electrical system through a tap running one mile via cable and overhead line to an existing substation.

The site is shown in the first photograph, which is taken looking down across the canal. The powerhouse and intake structure will be located directly below the wood frame structure which sits on the canal wall. The tailrace of approximately 1,000 feet will be excavated in the rapids of the river bed leading towards the right in the photograph and along the near shore.

The projected facility would be located within the recently established Lowell National Historical Park. Results of preliminary assessment are that the hydroelectric plant and its associated facilities can accommodate to Park needs and, in addition, make a contribution to the educational objectives of the Park by permitting a comparison of nineteenth and twentieth century methods of utilizing water power.

Other important environmental considerations include provisions regarding an historic wastegate structure that must be removed, design of a fully adequate fish passage facility and provision for minimum flow requirements in the river below the dam.

Raising the height of the dam, shown in the second photograph, either with a permanent concrete cap or bascule gates, was considered as a means of gaining increased head. Continuing the present system of using four feet of flashboards proved to be the most cost-effective alternative.

Turbine alternatives considered included two-unit bulb, Straflo, and vertical fixed blade propeller installations, and a four-unit installation using the largest standardized tube turbines. Single unit installations were rejected because there was no cost advantage and the site owner preferred the operating flexibility of multiple units. Estimated costs were lowest for the tube turbine installation, but final equipment selection is reserved until the equipment procurement stage, at which time firm bids can assure the best project price resulting from any of the multiple unit alternatives considered. 

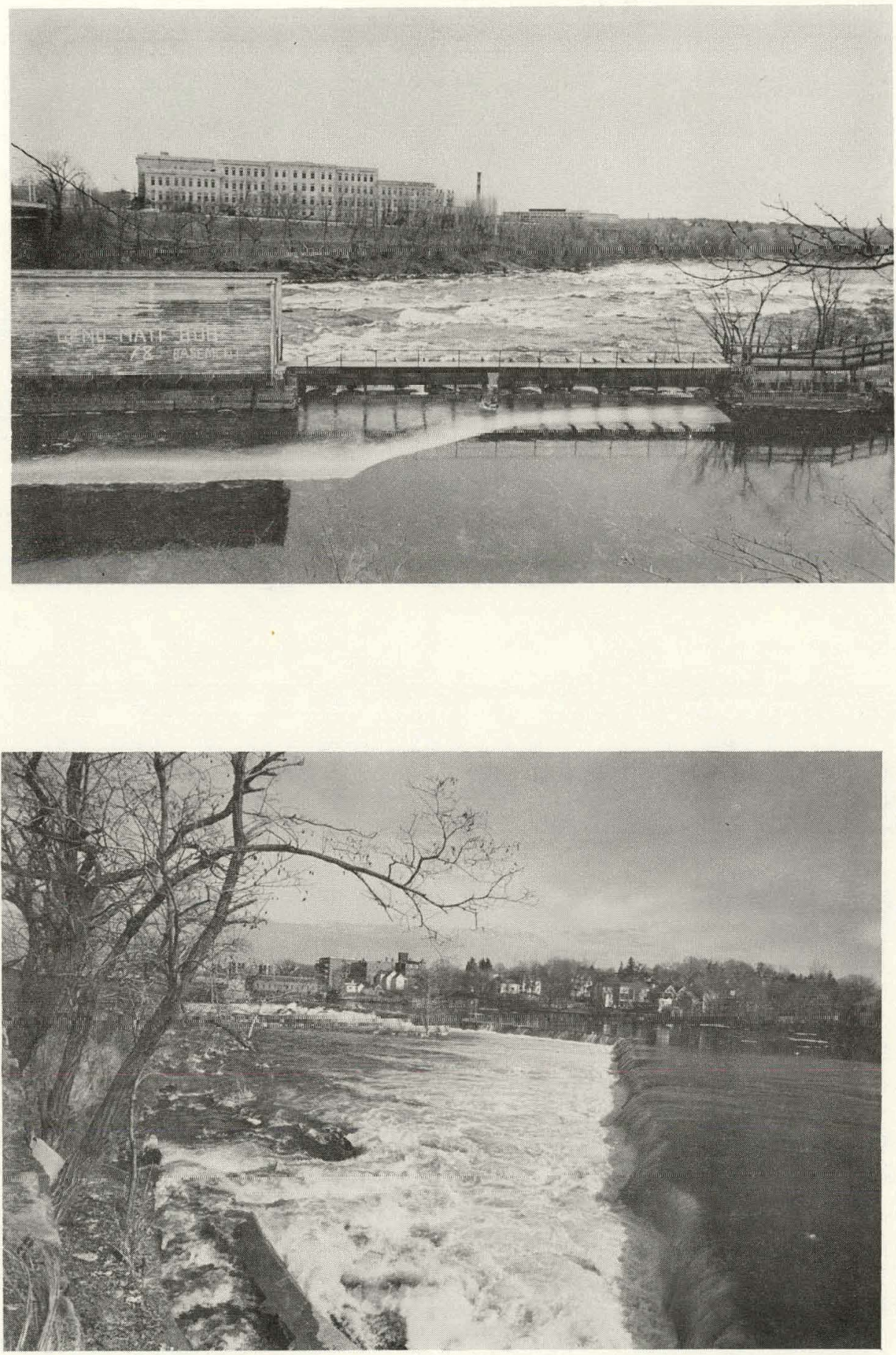
DAM AND POWER FACILITIES ON THE MERRIMACK RIVER

Sewall's Falls, Concord, N. H.

New Hampshire Water Resources Board

Hoyle, Tanner \& Associates, Inc.

PRDA Proposal Contract No. EW-78-F-02-1808

BACKGROUND

The Sewall's Falls power facilities consists of a dam across the Merrimack River, a powerhouse, and a canal between the two components. The site is located within the boundary of the City of Concord, New Hampshire. Figure 3 is a site plan of existing facilities.

The dam was constructed in 1893 by Concord Electric Service. The canal and powerhouse were completed in 1894, and hydroelectric power was generated starting in late 1894.

An economic study by Concord Electric Company in the early 1960's showed that it was cheaper for Concord Electric Company to purchase power from the Public Service Company of New Hampshire than to generate it themselves from hydropower. Consequently, the power station was deactivated in 1966. The equipment was removed, and the dam, buildings, flowage rights, and entire site was deeded to the New Hampshire Water Resources Board.

EXISTING

The existing dam is stone filled, timber crib construction. The top of the cribbing is at three separate levels, as three steps. The spillway (top step) is 495 feet long. The dam measured 67.5 feet between upstream and downstream faces. Most of the above water timbers are missing from the middle step. The dam will require renovation.

The canal, including headworks, and wasteweir, will require only minor renovation. Discharge to the powerhouse is limited by the capacity of the canal.

The old powerhouse, consisting of two power stations, originally housed five horizontal shaft and two vertical 
shaft Francis runner units, with an installed capacity of $2000 \mathrm{kw}$. The powerhouse is structurally sound. All turbines, generators, governors, etc. have been removed.

Net head at median flow averages over 15 feet. Net head at 10 year frequency flood $(19,300$ cfs) is about 10 feet.

\section{HYDROLOGY}

The drainage area of the Merrimack River at Sewall's Falls dam is about 2,360 square miles. A flow-duration curve of the Merrimack River, adjusted to the site location, shows the capacity of the unlined canal of $2,160 \mathrm{cfs}$ is exceeded 60 percent of the time. Median river flow is $2600 \mathrm{cfs}$, and the capacity of a lined canal of 3,600 cfs is exceeded 35 percent of the time.

A renovated plant would be protected against a 100 year flood, and would be operable at a 10 year flood level. Present flood levels are mitigated by the Corps of Engineers flood control reservoir upstream at Franklin Falls.

\section{RENOVATION AND DEVELOPMENT}

Development alternatives included retrofitting one of the existing power stations with 5 tube type turbines; or constructing a new power station with 3 larger tube type turbines. The installed capacity of each alternative was predicated on a cost-benefit analysis of lining the canal. It was determined to be cost effective to line the canal and construct a new "low profile" power station utilizing $3600 \mathrm{cfs}$, with installed capacity of about $4,100 \mathrm{kw}$. The average annual power at the installed capacity is about 24 million kwh.

The estimated 1979 project cost of the selected alternate, including renovating the dam, is $\$ 7,225,000$. The amount includes a 10 percent contingency allowance. The resultant project cost is about $\$ 1,760 /$ installed $\mathrm{kw}$.

Figure 15 is a conceptual plan of the recommended alternate. 


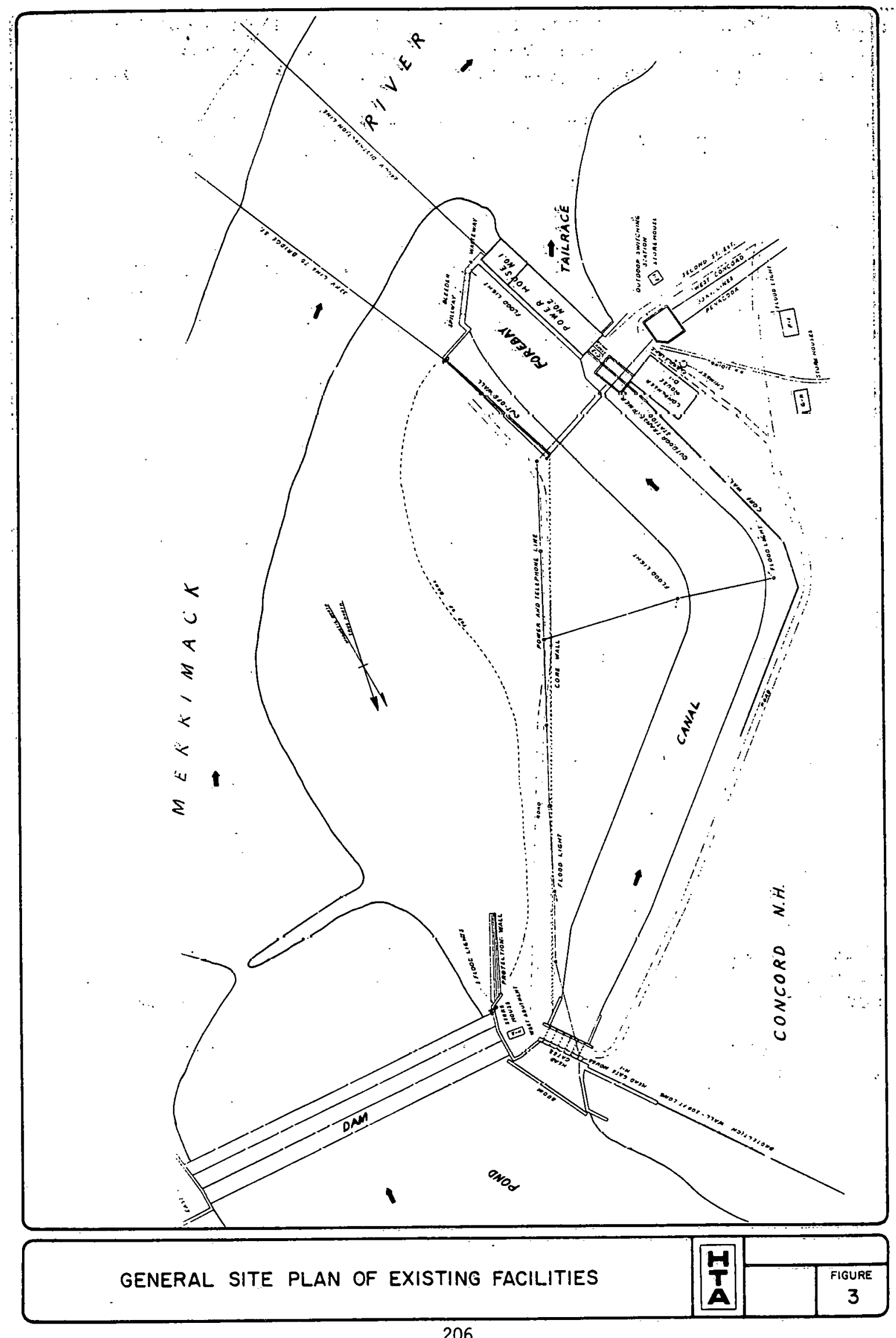




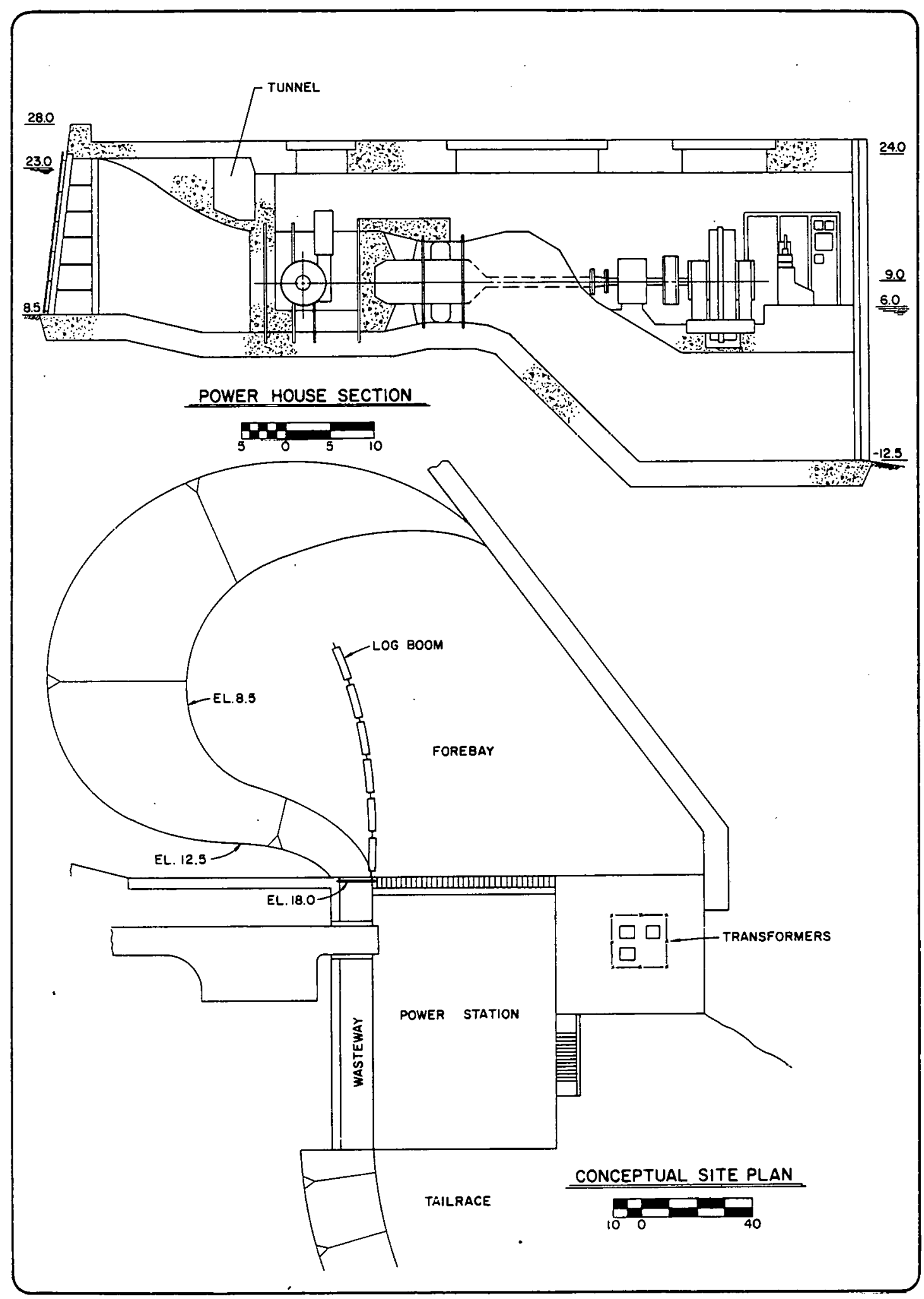

\section{CONCEPTUAL, PLAN OF RECOMMENDED ALTERNATE}

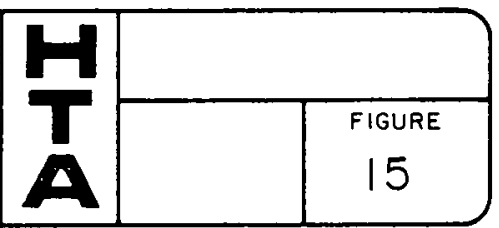


BARGE - CANAL ON THE MOHAWK RIVER

'Little Falls, New York

N1agara Muhawk Power Colporation and Acres American Inc.

PRDA Proposal Contract No. 1803

\section{INIKÜUULTIONH}

Niagara Mohawk Power Corporation, an electric and gas utility operating in New York State and providing electric service in the vicinity of the City of Little Falls, New York; the City of Little Falls, a municipality located in Herkimer County, New York; and Burrows Paper Company, a private corporation doing business in the City of Little Falls, have jointly undertaken a feasibility study for the development of hydrnelectric power on the Mohawk River in the City of Little Falls, New York.

Three dam sites are located in a one-mile reach of the Mohawk River at Little Falls. At the upstream site, two dams at Hansen Island are operated by the New York State Department of Transportation to control the Erie Barge Canal, which flows parallel to the river at this location. Middle Dam and Gilbert Dam are located respectively 1500 and 4000 feet downstream of the state dams. A total head of 40 feet is available for power generation in the reach of river proposed for study.

The only significant hydroelectric generation in this reach of river in the past was from a plant developing 18 feet of head at the Middle Dam. The plant was decommissioned in 1962 at which time the dam was breached, the intake control gates were closed off, the intake canal was partially filled, and the turbinegenerators and related equipment were dismantled and removed. All that remains is the concrete substructure and masonry superstructure.

The facilities at Gilbert Dam include a partially demolished mill on the right bank which at one time included three small hydraulic turbines for mechanical mill drives and electrical power. The dam is a masonry structure approximately 12 feet high.

The installation of the Middle Dam site had a rated capacity of $1150 \mathrm{~kW}$ and operating records from 1946 to 1960 showed the average annual energy production was 8 million kWh.

The City of Little Falls owns the site of the abandoned powerhouse at the Middle Dam, while Niagara Mohawk owns other properties and various water rights in the vicinity of the abandoned station. The Burrows Paper Company owns certain property which might be affected by a hydroelectric development in the reach of river being investigated. Accordingly, the parties jointly undertook a feasibility study. The basic objectives of the study are as follows:

(i) The feasibility of rehabilitation of the abandoned facility at the Middle Dam site;

(ii) The feasibility of development or redevelopment at the State Dam site, the Middle Dam site, the Gilbert Dam site and the Barge Canal site.

\section{ALTERNATIVES}

Several alternatives for a development of hydroelectric power were identified and investigated. Preliminary drawings were prepared for each alternative involving new equipment and structures. These drawings were used for quantity take-off measurements; this together with information and prices from equipment suppliers formed the basis of capital cost estimates. The anticipated annual average energy production obtained from the average flow duration curve for the Mohawk River energy production was derated by a reliability factor in the calculations. From the capital costs, annual costs were estimated. From the annual costs and average annual energy production, a cost per kWhr was established. The costs per kWhr for the alternatives were compared and the most favorable alternative was established.

The following is a listing and brief description of the alternative schemes investigated; the State Dam site was eliminated from consideration early in the study. The site examination and evaluation revealed the site has only a 3 or 4 foot gross head.available at the State Dam and this was not sufficient to warrant serious consideration. 
Middle Dam Site - The site would be redeveloped by demolishing the existing powerhouse and rebuilding a new facility. Two facilities, one with 2 units and one with 3 units were investigated.

Gilbert Dam Site - The partially demolished mill on the right bank would be fully demolished and a new facility built. Two facilities, one with 2 units and one with 3 units were investigated.

Barge Canal Site - The Barge Canal site is located downstream of the Gilbert Dam site :and utilizes the barge canal as an intake channel. Two facilities, one with 2 units and one with 3 units were investigated.

Rehabilitate Middle Dam Powerhouse - The existing powerhouse at Middle Dam was investigated for rehabilitation.

\section{RECOMMENDED SCHEME}

The evaluation indicated the barge canal site to be the most favorable alternative; it has the lowest cost per kWhr. For the Barge Canal site, as well as the other sites, the $3000 \mathrm{cfs}$ flow is shown to have the advantage over the $4000 \mathrm{cfs}$ flow or 3 unit alternatives. This is to say the estimated benefits expected from the additional capacity does not justify the additional expenditure required for the increased capacity.

The Barge Canal site will use the canal as an intake channel. This dictates multiple usage of the Barge Canal which is owned by the State of New York and operated by the New York State Department of Iransportation (NYSDOT). Hydraulic studies on the joint use of the Barge Canal have been completed for a design flow of $3500 \mathrm{cfs}$, which includes $500 \mathrm{cfs}$ for lock filling. These studies indicate maximum velocities in the cianal of $2.2 \mathrm{fps}$, and a surface energy loss of $0.1 \mathrm{ft}$, between the upstream control dam and Lock 17 , a distance of about 1 mile. The studies show from hydraulic design, there are no apparent engineering reasons which may preclude the joint use of the Barge Canal for navigation and power purposes.

The historical sole use of the Barge Canal for navigation, however, poses certain aspects which must be addressed and considered. Previously, the Barge Canal was dewatered from December through May annualiy for preventive maintenance purposes. Dewatering the Canal would not be a normal annual occurrence if a power facility were to use the Canal as an intake channel and any maintenance requiring complete shut down of the Canal would be of an emergency nature. Preliminary indications confirm that the complete shut down would be required for emergency repairs only, and should not present a serious obstacle to the development of the Barge Canal as a power facility site. An agreement, between the owners of the power facility and the NYSDOT, establishing responsibilities for operation and maintenance of the Canal would have to be reached before the project could proceed. All of the aforementioned aspects appear favorable to the development of a power facility at this time and no insurmountable obstacles to the joint usage of the Barge Canal are envisioned.

The power facility using the Barge Canal would produce an annual 32 million kWhr of energy. The 32 million kWhr has included a $200 \mathrm{cfs}$ discount from the flow duration curve as an allowance for minimum flow to be maintained in the section of the Mohawk River which would be bypassed by the Barge/power Canal. The facility would have a plant capacity factor of $53 \%$.

Several drawings presenting the recommended alternative are attached for reference. The plan view drawings show the three-unit option; the recommended alternative for the two-unit option would have the same intake and powerhouse arrangement but for two units. Several photographs of the site are also attached. 
TABBLE' 1

LITTLE FALLS HYDROELECTRIC DEVELOFMENT

ALTERNATIVES - CAPITAL COSTS \& EVALLATION

SITE

GROSS HEAD (F $\vec{i})$

PLANT FLOW (CFS)

NO. UNITS

PLANT CAPACITY (KW)

(Generator Name Plate)

Plant

Accit. Descriotion

331 Structures \& Improvements

332 Reseryoirs, Dams, \& Waterways

Accessory Electrical

Equipment

Misc. Power Plant

Equi pment

Roads, Railroads, and

353 Station Equipment

TOTAL CAPITAL COST

(Includes Cont ingencies

Engr. \& Admin. \& Interest

During Construction)

COST PER INSTALLED KW

ANNUAL ENERGY FOR REVENUE (kWhr $\times 10^{E}$ )

COST $-\$ / k W h r$
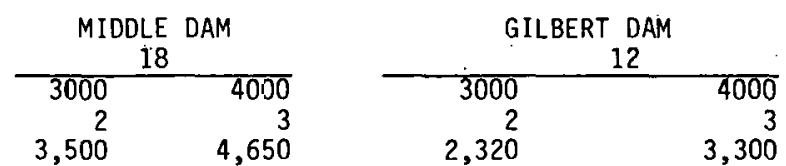

$857,000 \cdot 1,203,000$

355,000

$2,448,000$

325,000

100,000

$---$

77,000

$5,491,000$.

377,000

390,000

150,000

82,000

$7,096,000$

1570

1530

15.5

18.1

0.081

0.090

420

11.0

12.8

0.120

0.146

\begin{tabular}{rr}
\multicolumn{2}{c}{ BARGE CANAL } \\
\hline 3000 & 40 \\
8,600 & 4000 \\
8,60 & 11,600
\end{tabular}

REHABILITATION

MIDDLE DAM

18 .

3

2,100

$\begin{array}{rrrrr}876,000 & 1,250,000 & 892,000 & 1,295,000 & 170,000 \\ 580,000 & 654,000 & 70 \mathrm{C}, 000 & 1,011,000 & 310,000 \\ 2,294,000 & 3,428,000 & 2,91 \epsilon, 000 & 3,845,000 & 1,460,000 \\ 320,000 & 385,000 & 33 E, 000 & 405 ; 000 & 380,000 \\ 100,000 & 150,000 & 10 C, 000 & 150,000 & 150,000 \\ 50,000 & 50,000 & 7 C, 000 & 70,000 & :-1 \\ 117,000 & 127,000 & 16 \%, 000 & 177,000 & 70,000 \\ 5,744,000 & 7,990,000 & 6,84 \%, 000 & 9,080,000 & 3,317,000\end{array}$

803

785

1580

32.8

37.4

11.4

0.048

0.056

0.067 


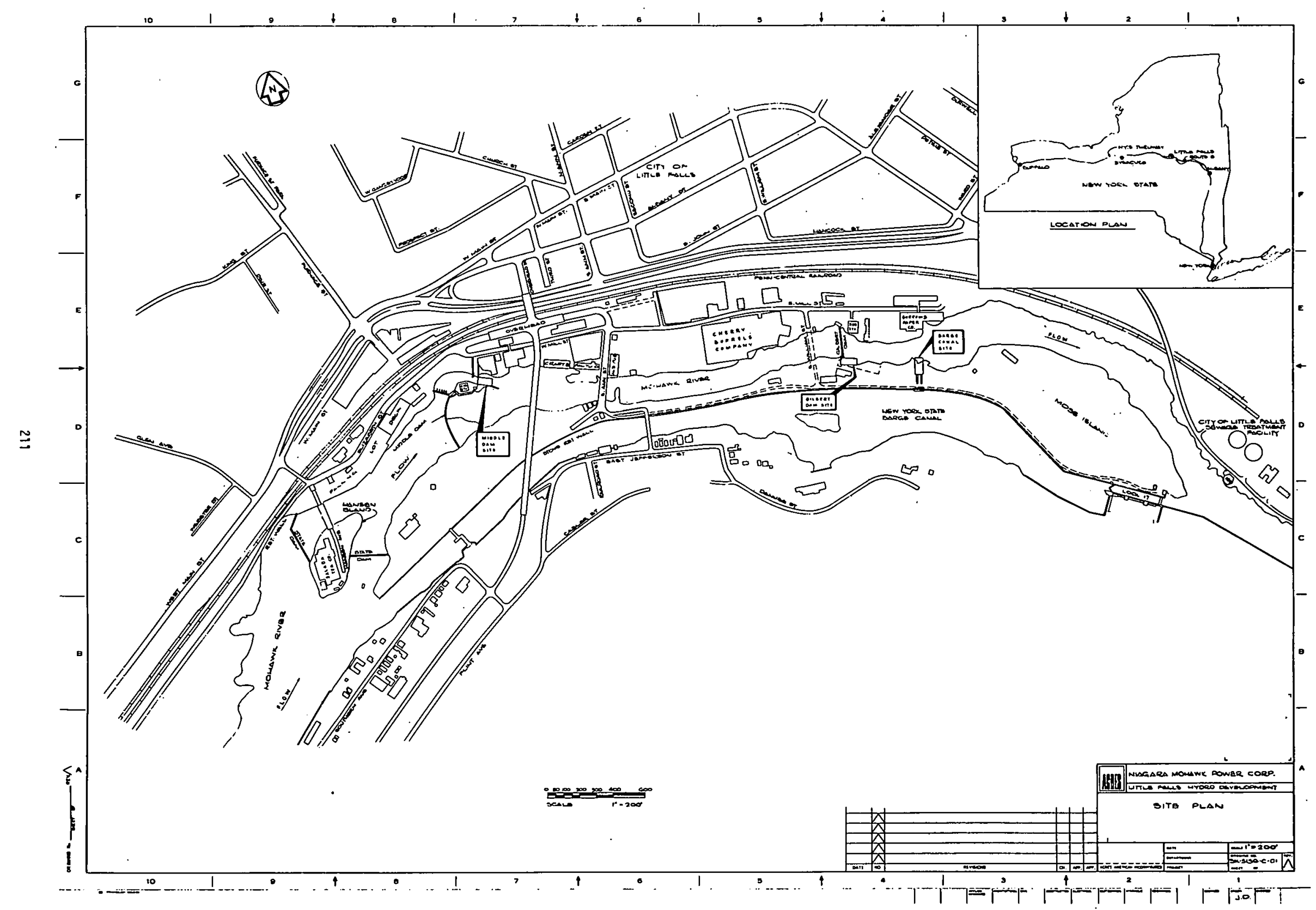




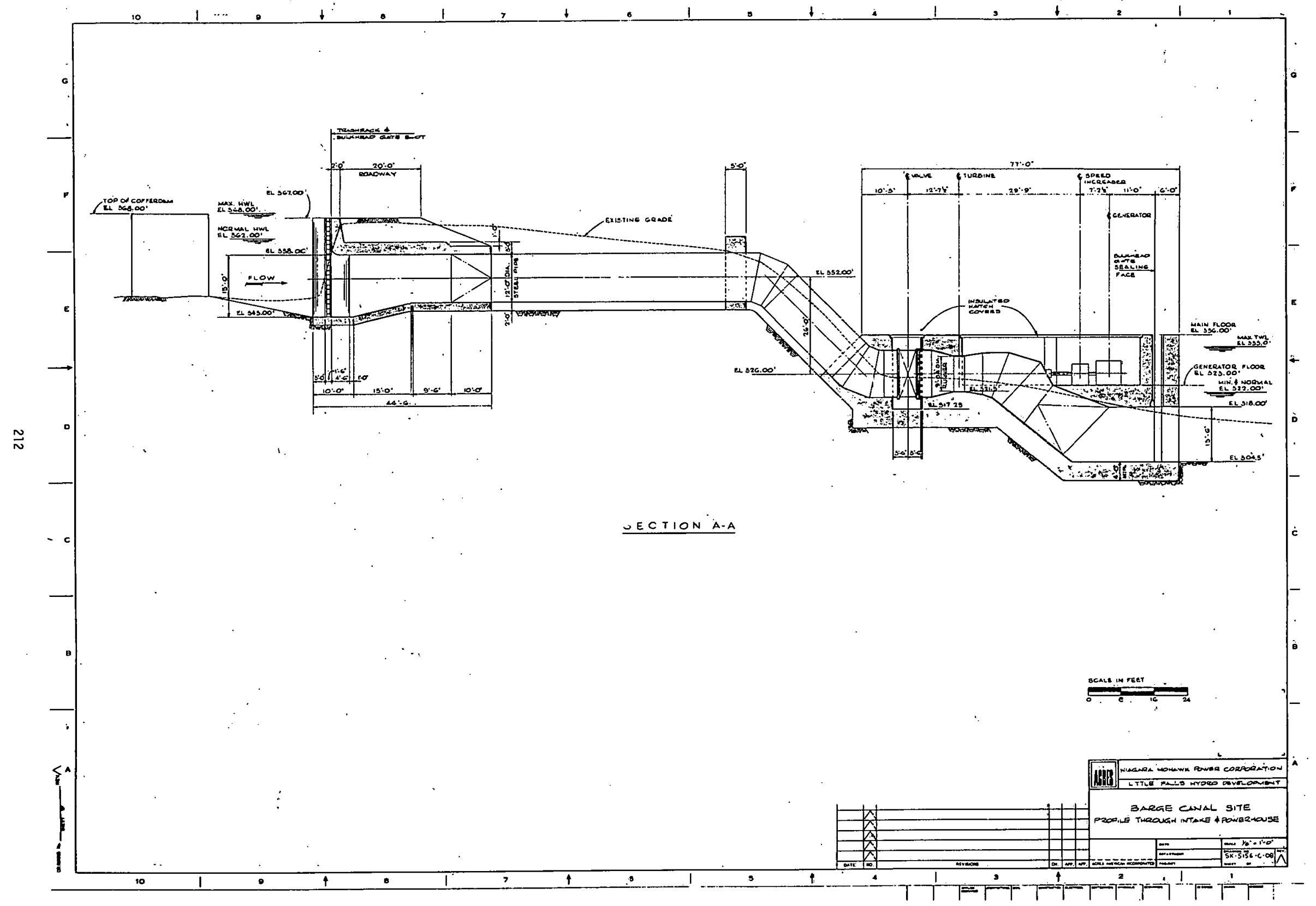




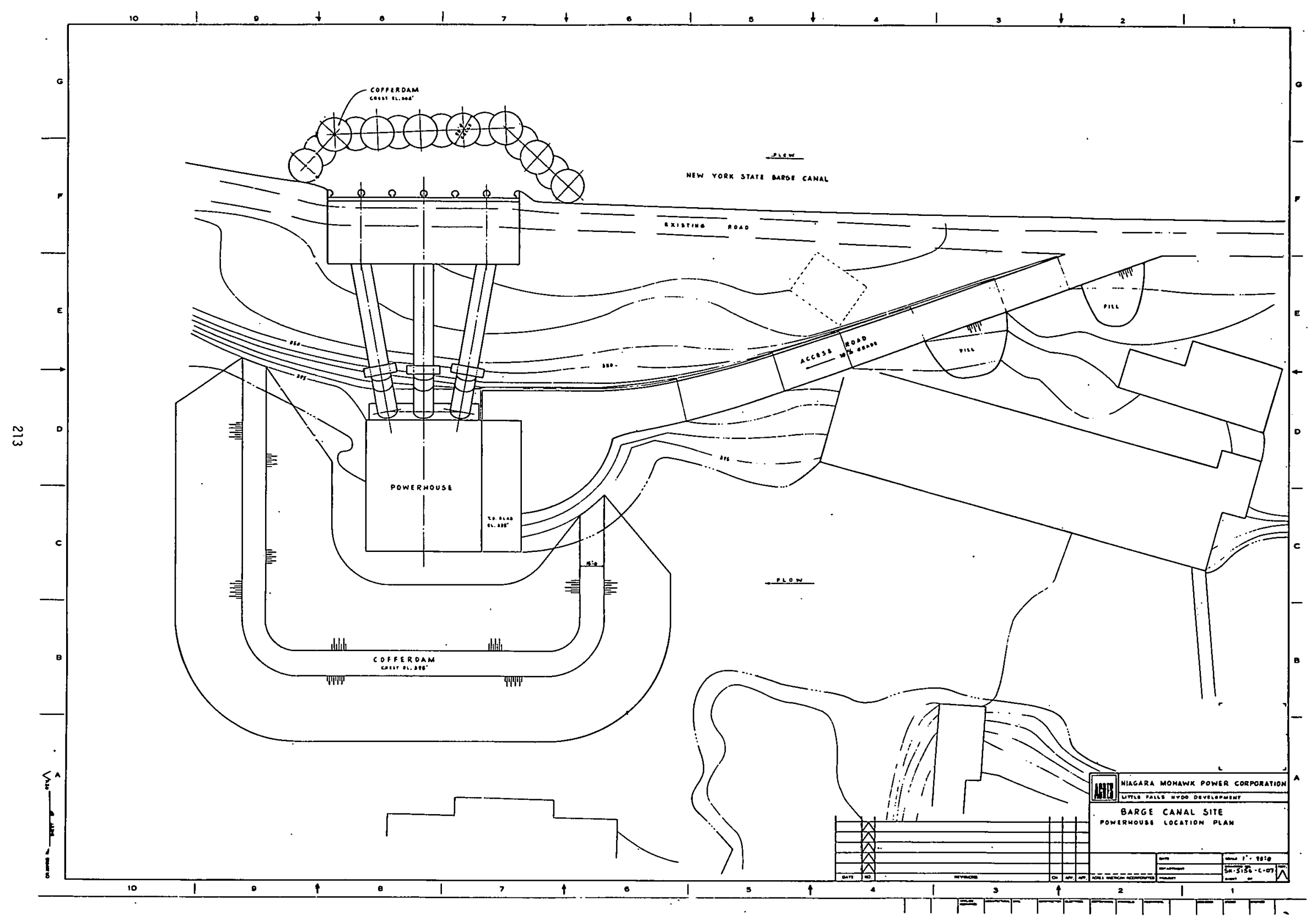




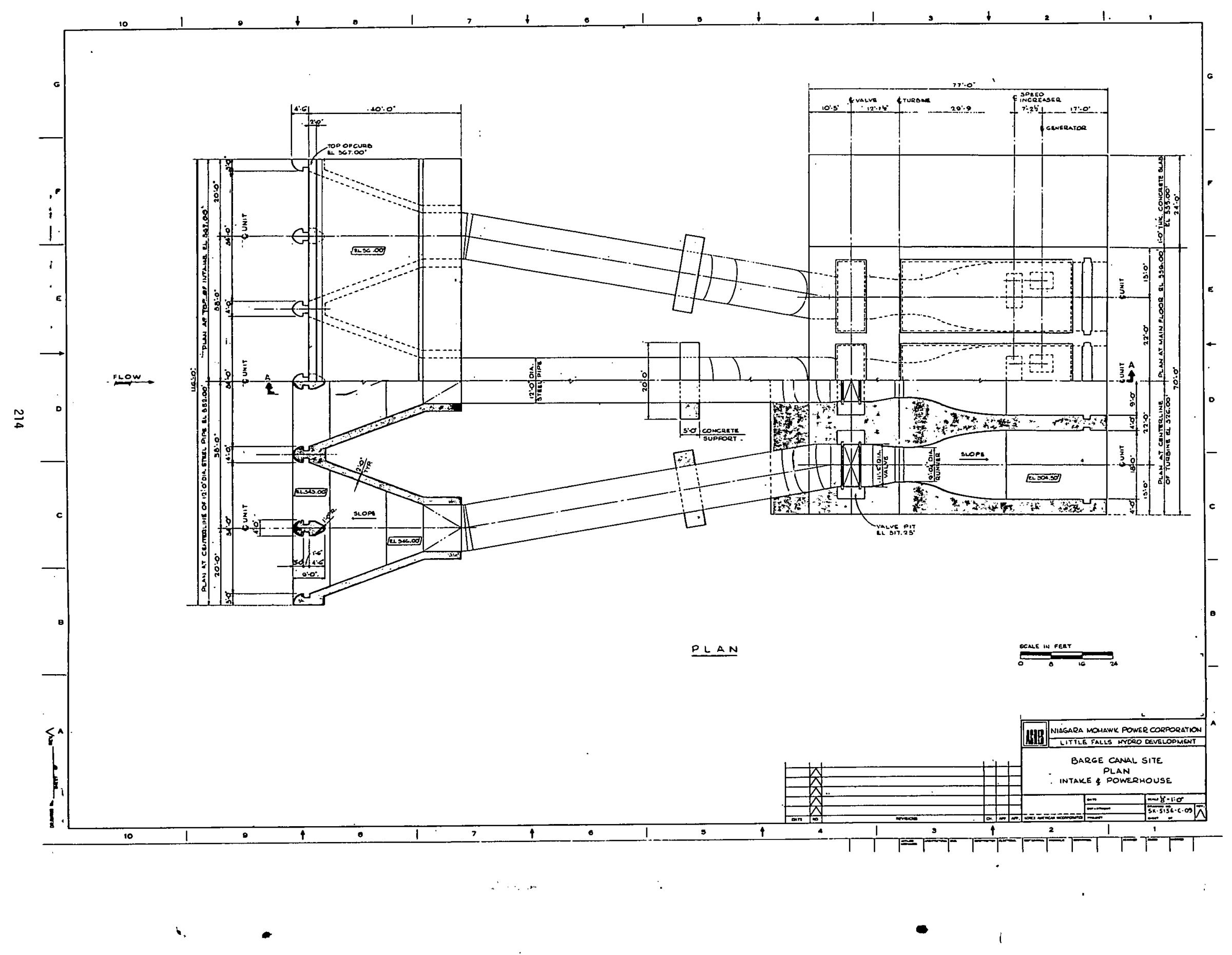


LITTLE FALLS HYDROELECTRIC DEVELOPMENT

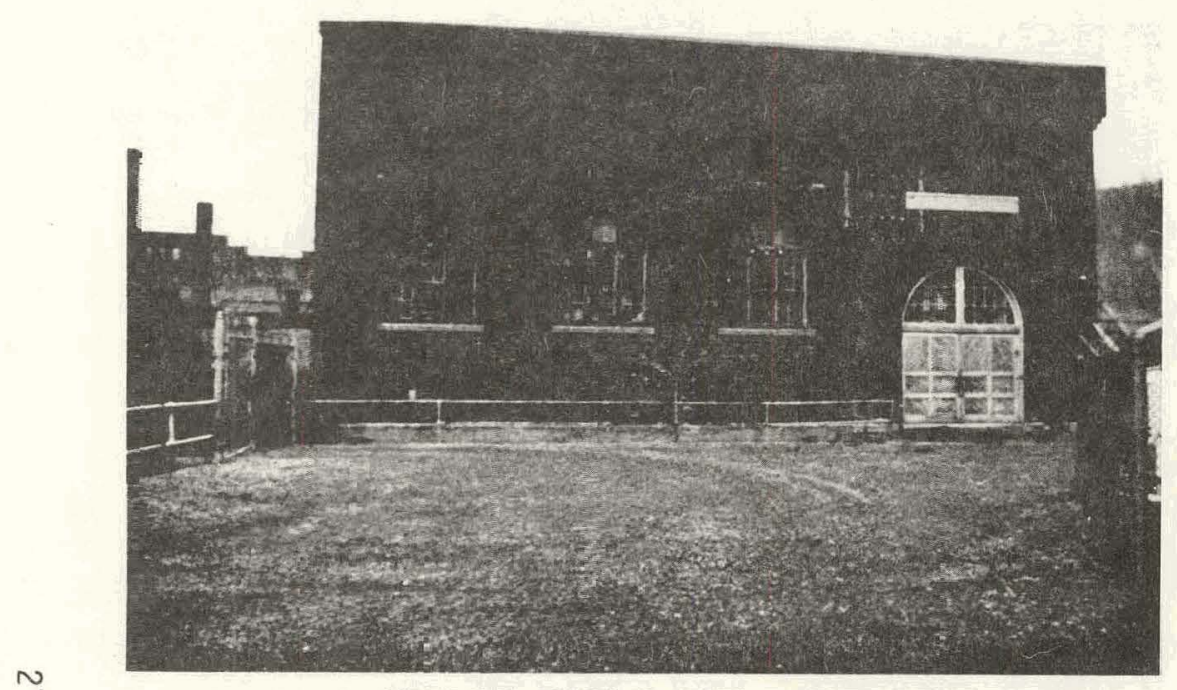

MIDDLE FALLS DAM - POWERLOUSE

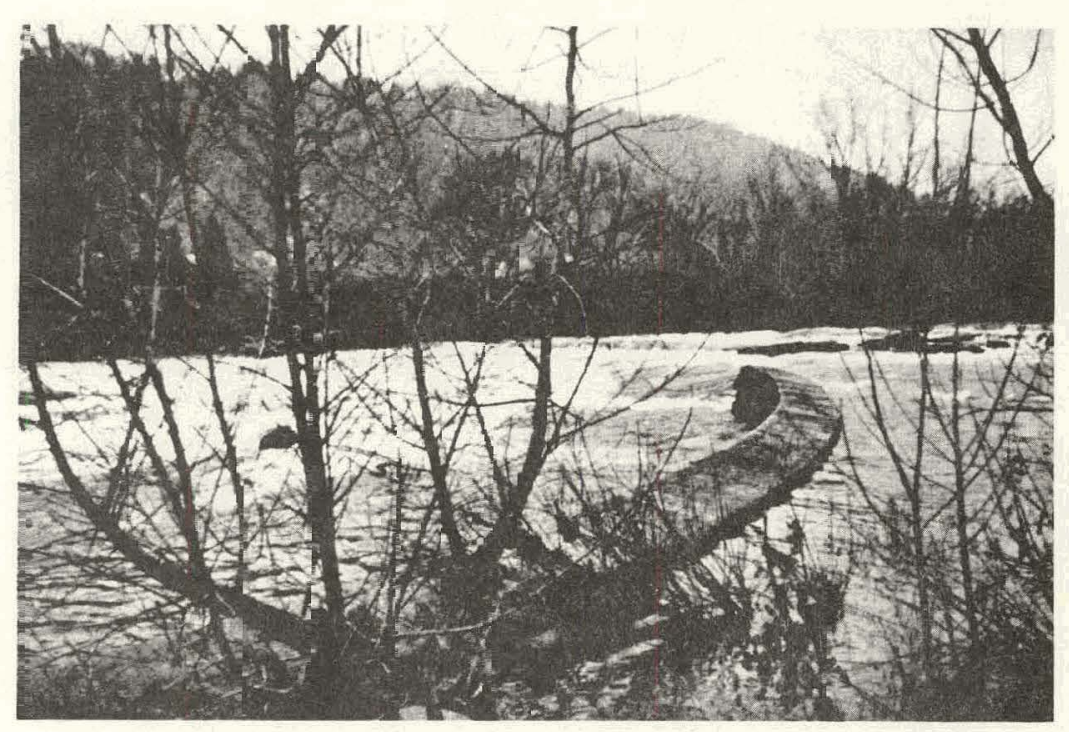

MIDILE FALLS DAN - BREACHED CONTROL DAM

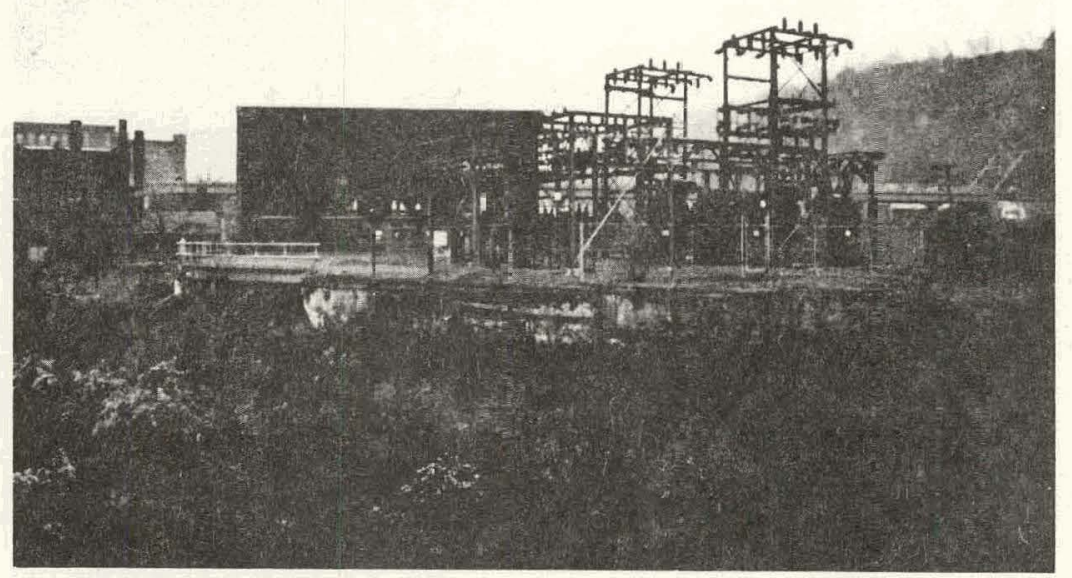

MIDDLE FALLS DAM - POWERHOUSE AND SWITCHYARD

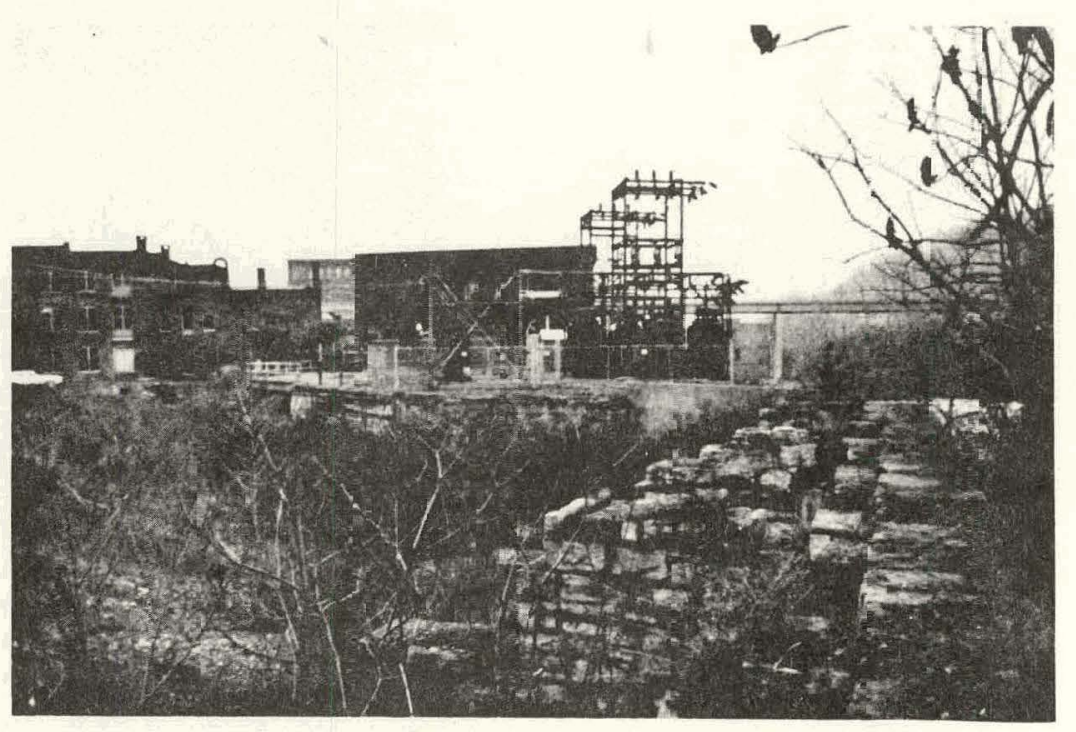

MIDDLE FALLS DAM - INTAKE CHANNEL 


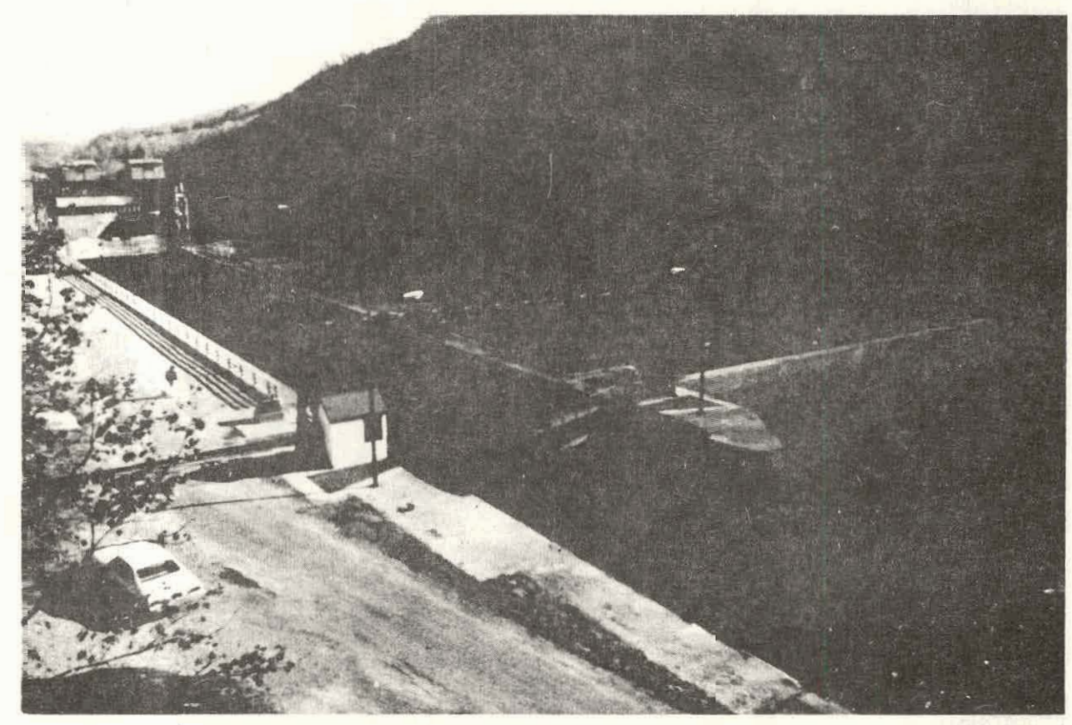

NAVIGATION LOCK NO. 17 - GENERAL VIEW

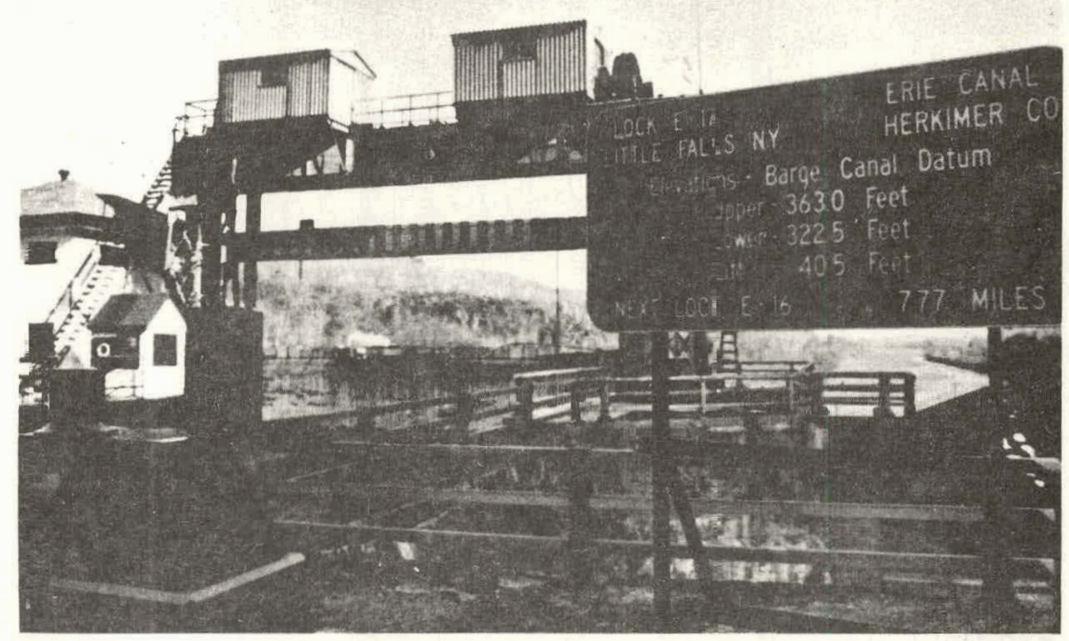

NAVIGATION LOCK NO, 17 - DOWNSTREAM GATE

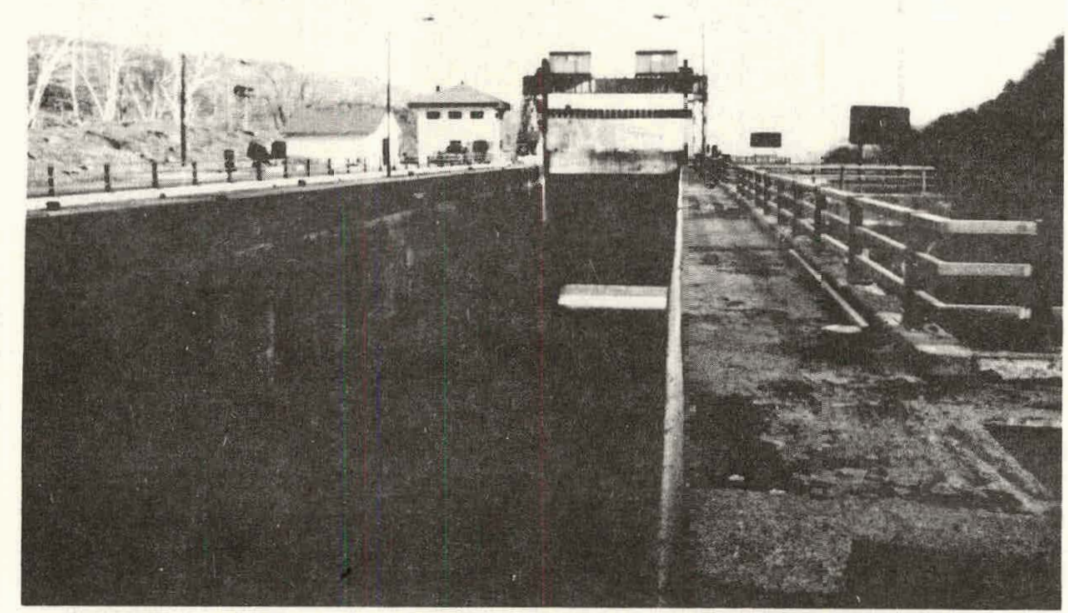

NAVIGATION LOCK NO, 17 - DOWNSTREAM GATE

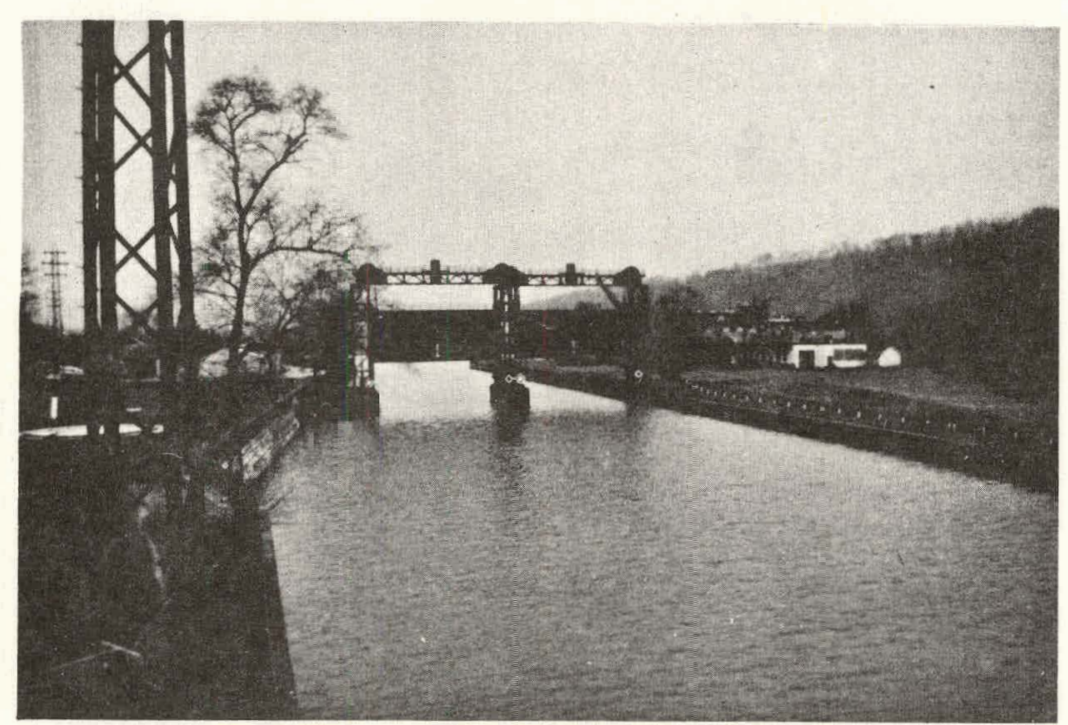

NAVIGATION LOCK HO, 17 - BARGE CANAL CONTROL GATES 
LITTLE FALLS HYDROELECTRIC DEVELOPMENT

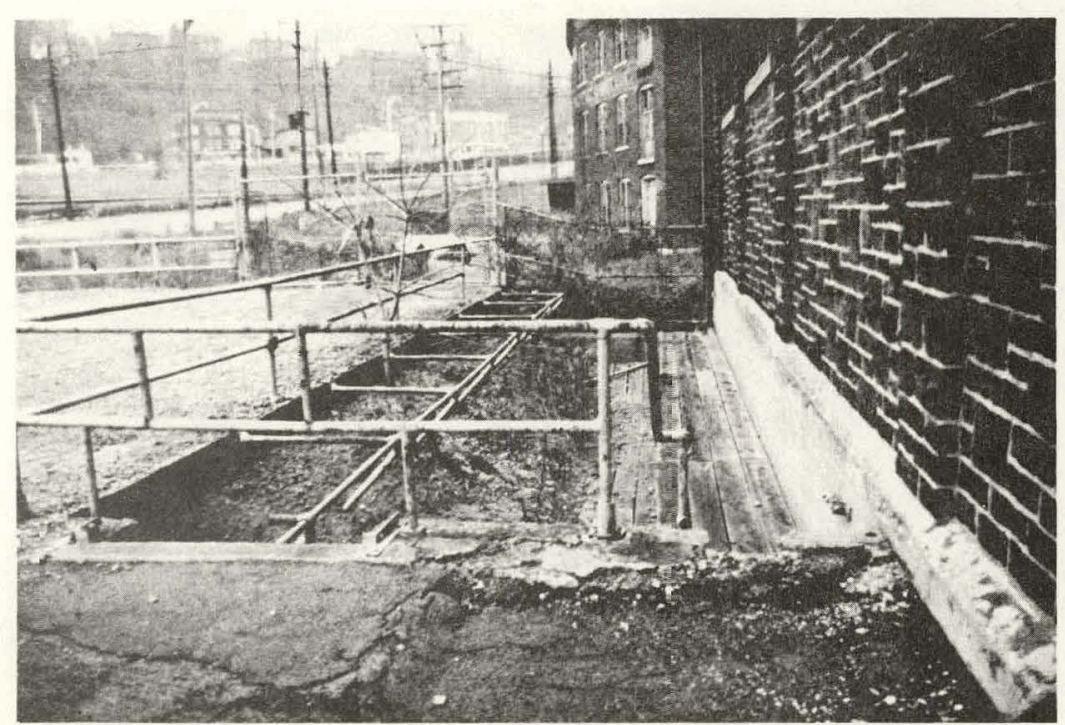

$\stackrel{N}{*}$

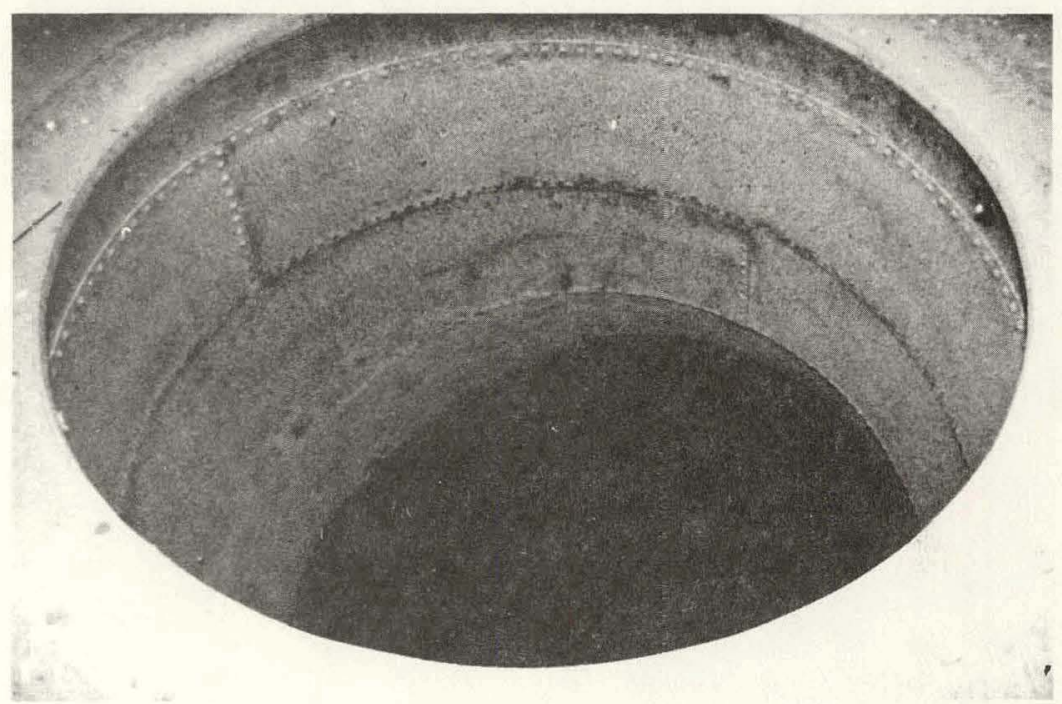

MIDDLE FALLS DAM - DRAFT TUBE FROM FLUME

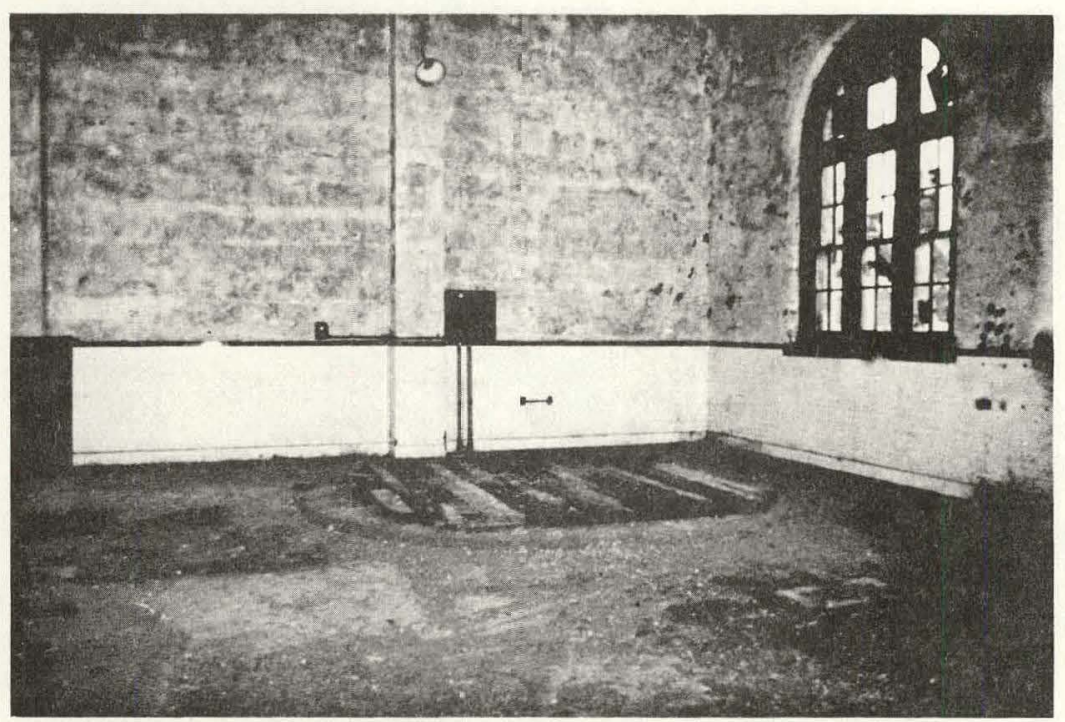

MIDDLE FALLS DAM - POWERHOUSE INTERIOR

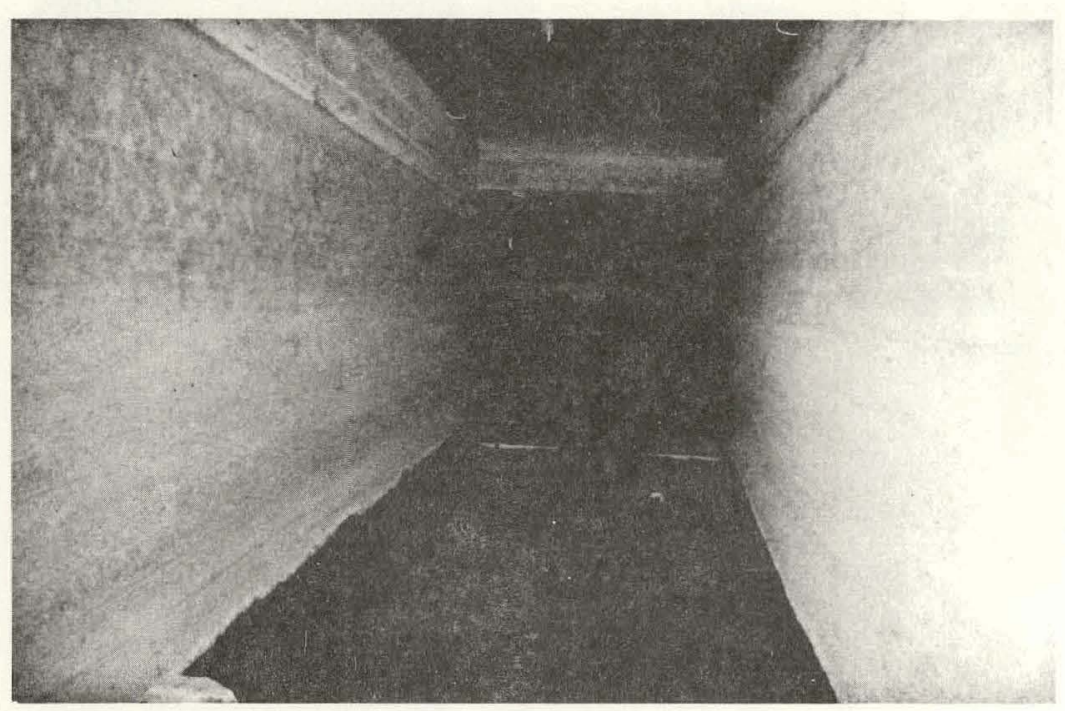

MIDDLE FALLS DAM - OPEN FLUME AND INTAKE GATE 
LITTLE FALLS HYDROELECTRIC DEVELOPMENT

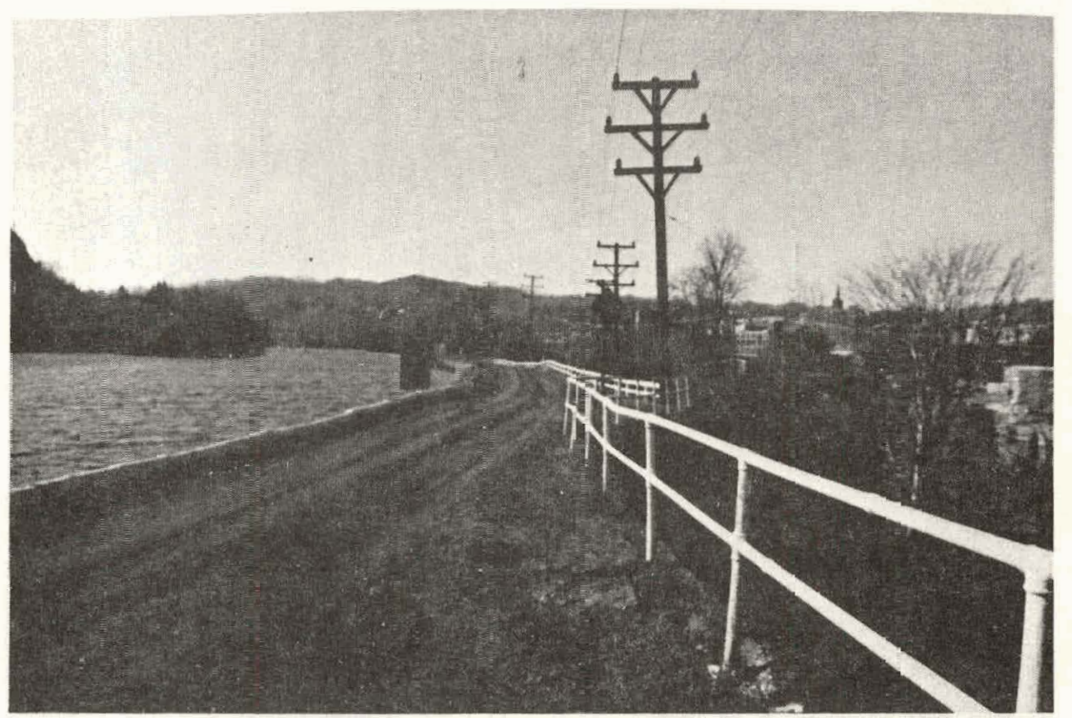

$\stackrel{\sim}{\infty}$

BARÍE CANAL HYDRO SITE - GENERAL VIEW OF CANAL

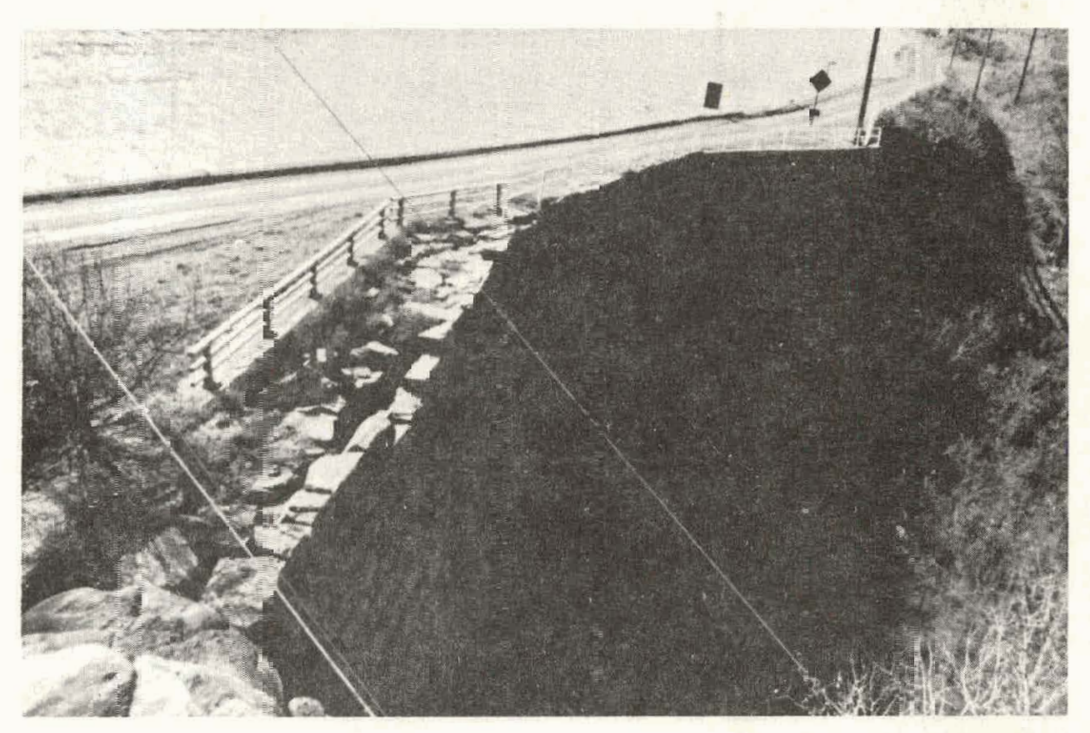

BARGE CANAL HYDRO SITE - PROPOSED INTAKE SITE

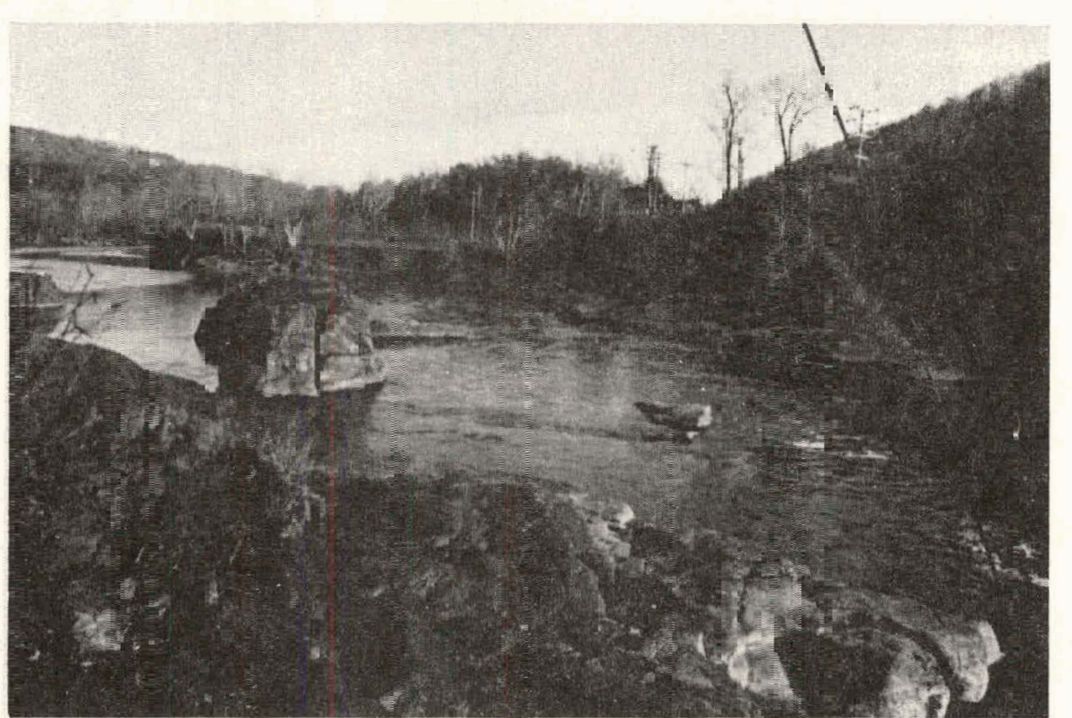

BARGE CANAL HYDRO SITE - PROPOSED PCWERHOUSE SITE

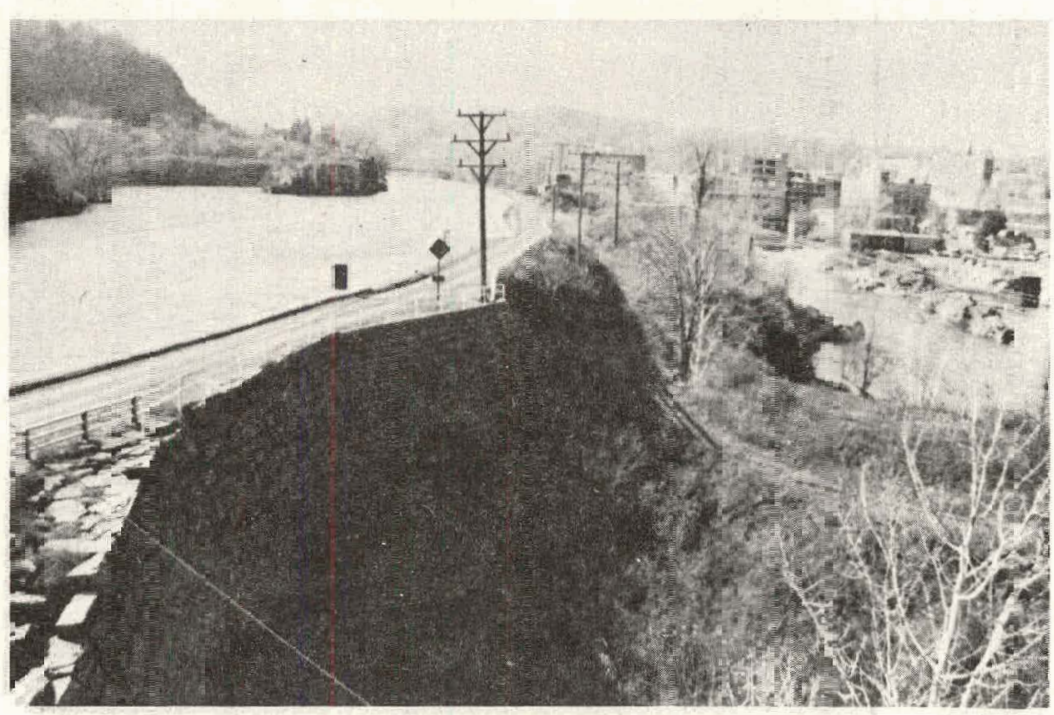

BARGE CANAL HYDRO SITE - PROPOSED INTAKE SITE 


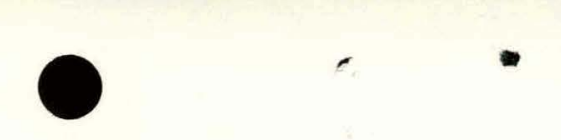

\section{LITTLE FALLS HYDROELECTRIC DEVELOPMENT}

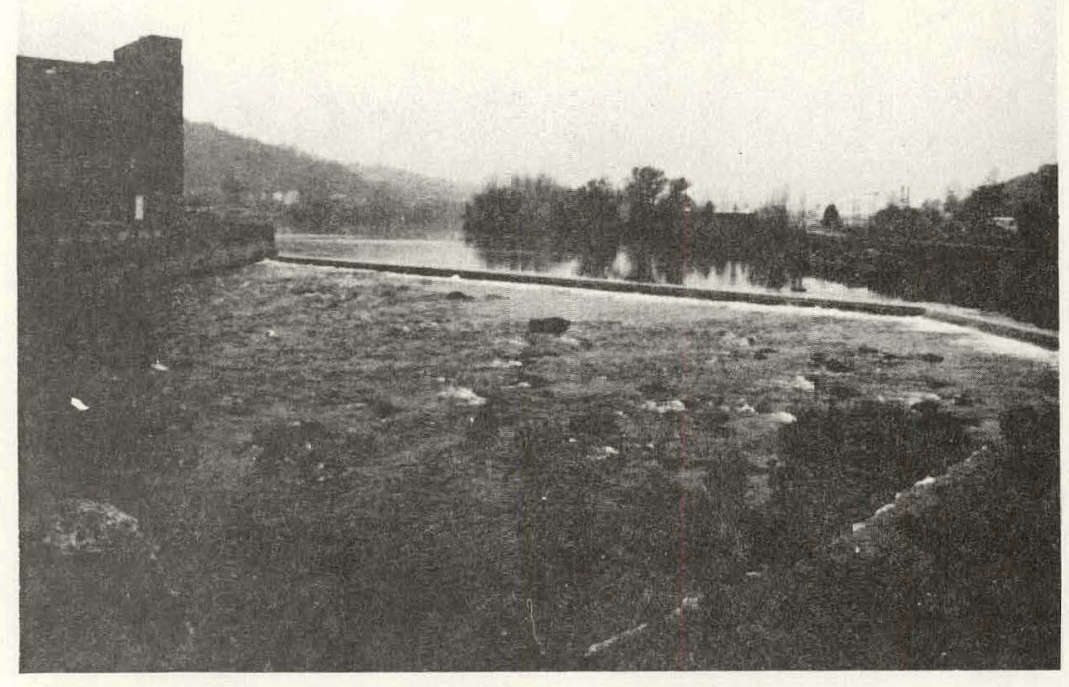

STATE DAM - LEFT DAM

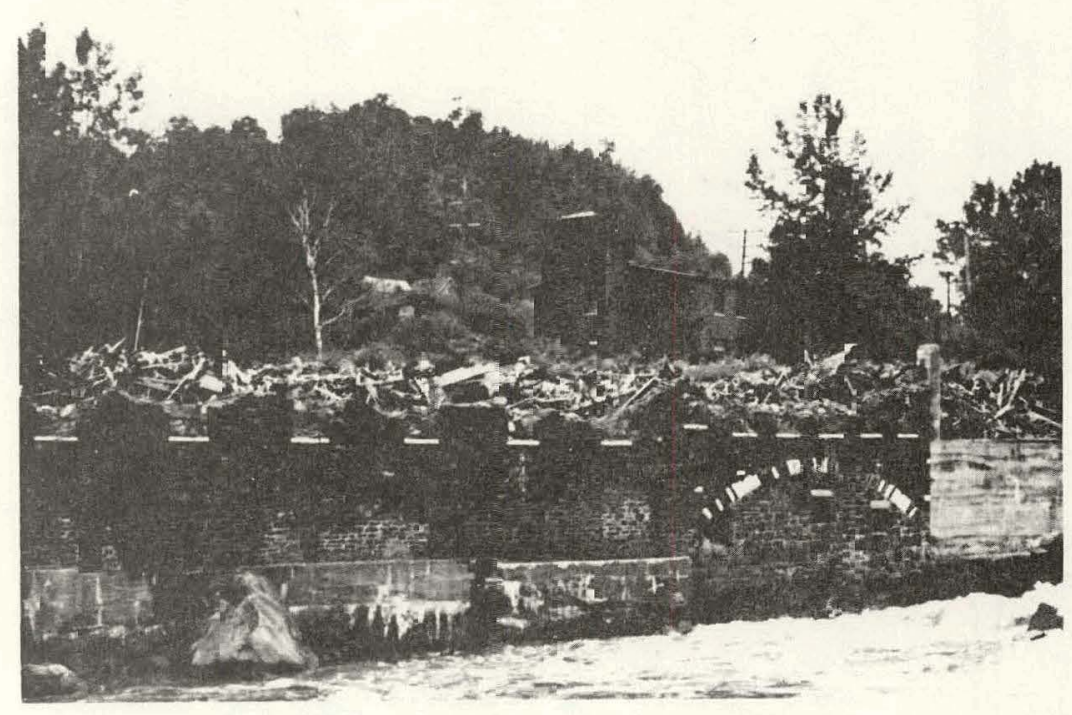

GILBERT DFM - RIGHT BANK

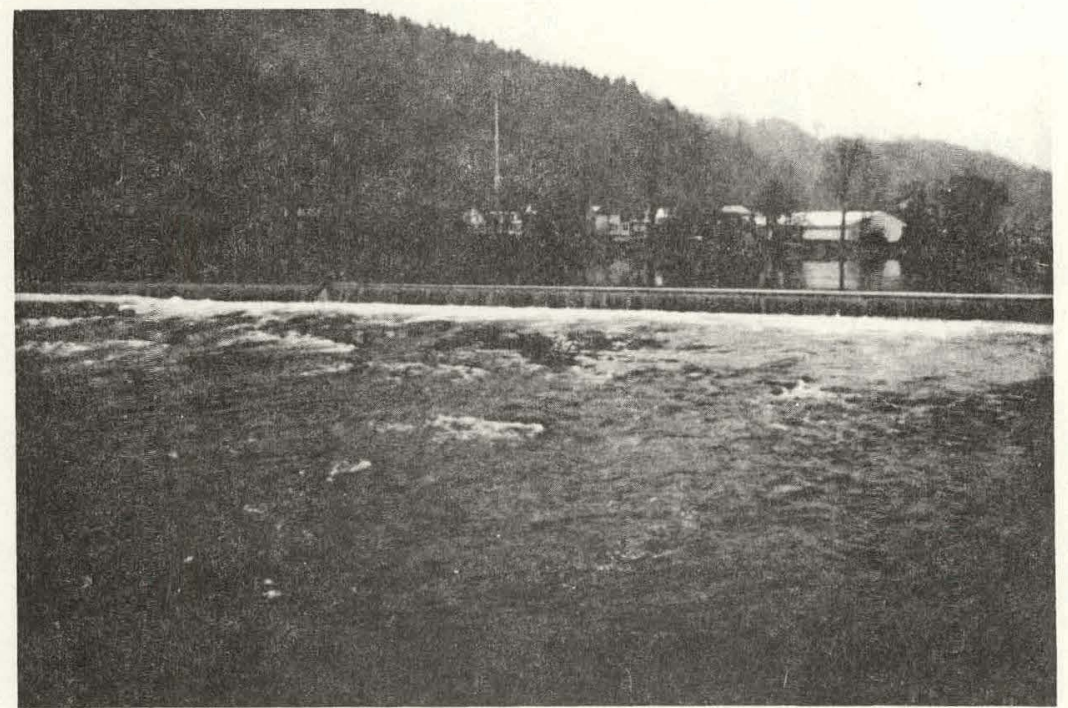

STATE DAM - RIGHT DAM

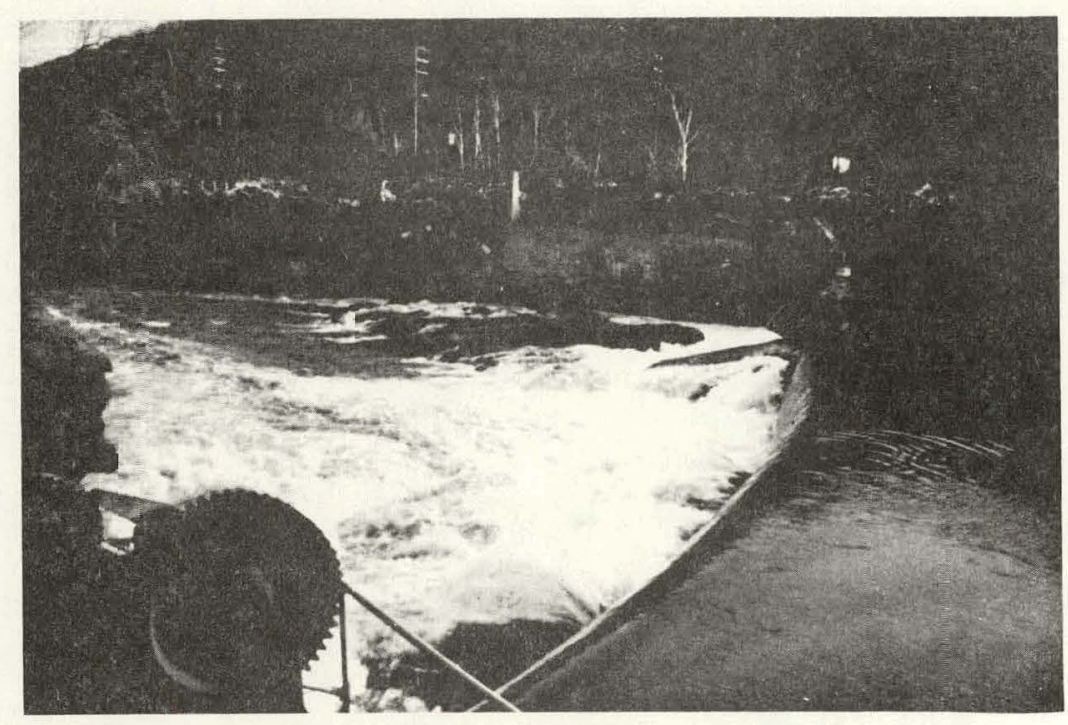

GILBERT DAM - VIEW FROM INTAKE 


\section{DRY FALLS DAM POTENTIAL HYDROELECTRIC POWER}

Columbia Basin Project, Washington

South Columbia Basin Irrigation District

Tudor Engineering Company

PRDA Proposal Contract No. EW-78-F-07-1811

\section{INTRODUCTION}

The Columbia Basin Project is a multi-purpose development constructed by the U.S. Department of the Interior, Bureau of Reclamation (USBR). The source of water is Franklin D. Roosevelt Lake, formed by the impoundment of the Columbia River at Grand Coulee Dam. Project irrigation facilities are designed to deliver water to 1,095,000 acres of irrigable land in the central area of the State of Washington. Altogether, there are 333 miles of main canals, 1,936 miles of laterals and 2,223 miles of drains and waterways. In 1977 irrigation water service was available to 543,230 acres. Water supply, agricultural economy, and environmental investigations and engineering design and cost estimate studies are in progress relating to the facilities necessary to serve an additional area of approximately 550,000 acres.

Within the Columbia Basin Project, water users are represented by irrigation districts, which entities are responsible for payments to the USBR in accordance with repayment contracts, and for operation and maintenance of designated distribution facilities. Three irrigation districts have been formed for this purpose: Quincy Columbia Basin Irrigation District; East Columbia Basin Irrigation District; and South Columbia Basin Irrigation District.

Within the Columbia Basin Project, there are several facilities which provide service to two or more of the Districts. Those which are common to al1 three Districts are known as Project Reserved Works. The Dry Falls Dam and Main Canal are in this group. Control is exercised by the Districts through a Reserved Works Committee comprised of representatives of each of the Districts. As the Reserved Works Committee is not yet a legal entity, the Committee and the respective districts have duly resolved to delegate, for the time being, the authority for contracting for, managing, administering and reviewing the feasibility assessments for contemplated hydropower developments at Project Reserved Works, to the South Columbia Basin Irrigation District.

The District's replacement repayment contract with the United States provides, for the project reserved works, that the Districts "may build plants for the production of power and energy and structures and facilities necessary for the operation of such plants and all such plants shall remain in exclusive control, possession and ownership of the districts".

Various facilities throughout the project - dams, checks, chutes and drops - offer the potential of hydroelectric energy generation. Preliminary investigation of six potential sites indicates that more than $100 \mathrm{MW}$ of installed capacity are economically and technically feasible at this time. Also many additional small hydro sites will become available when the proposed expansion in irrigable acreage takes place. The Districts are currently pursuing development of all these sites.

\section{EXISTING FACILITIES}

Dry Falls Dam is located at the South end of Banks Lake, the primary equalizing reservoir for the Columbia Basin Project. Also known as South Coulee Dam, the dam is an earthfill structure 115 feet high at its highest point, 9,880 feet long at crest elevation 1580 . The active storage of the reservoir is 696,000 acre-feet, between elevations 1540 and 1570 .

The Main Canal headworks is located at the left abutment of Dry Falls Dam. It consists of a rectanqular six-cell barrel conduit, with warped inlet and outlet transitions. Each cell is controlled by a 12-foot by 18 -foot top seal radial gate located slightly upstream of the dam axis. The structure was designed to pass a flow of $13,200 \mathrm{cfs}$ with a water surface elevation of 1540 in Banks Lake. Upstream of the headworks is the approach channe1, with a bottom width of 120 feet and 1-1/2 to 1 side slopes, excavated up to 40 feet into the lake bed. Downstream of the headworks, the main canal consists of unlined rock and concrete- 7 ined reaches. 
Irrigation releases are made during the period of mid-March through late October. In a typical season, daily flows are increased gradually over a two to three-month period; maintained at or near a maximum in June or July; and diminish thereafter until the end of the season. Due to the variations in head and tailwater surface elevations, discharges through the headworks have historically undergone a head loss in the range of 15-50 feet. The energy corresponding to this head loss is dissipated in the hydraulic jump downstream of the radial gates.

Headwater and tailwater variations will change with anticipated future increase in discharae and development of new facilities. These changes have been projected and the power plant sizing and design selections have been checked against the future conditions.

\section{CAPACITY AND ENERGY}

The optimum installed capacity of the Dry Falls site was defined as that plant size which would produce the greatest amount of energy at a cost which was marketable under a power purchase agreement currently being considered by the South District. The calculation of energy for various installed capacities is directly dependent on the available discharge, forebay elevation, tailwater elevation and plant efficiency. Each of these factors is variable at the Dry Falls site. A computer model was developed to incorporate these variables and simulate a wide range of potential hydraulic and design characteristics. The model also incorporated an economics subroutine so that costs and economic returns for various assumptions could be readily evaluated.

The computer runs derived the power and annual energy output from the power development, given the number, rating, and design head for the turbines installed. Power output under varying head conditions was calculated using values for turbine efficiency obtained from a variety of published texts and information received from manufacturers. For each case considered, the computer produces a graphical display of the power output, and a numerical total for the annual energy production in the. year for which the flow conditions apply.

Computer runs were made to determine the effect of varying the number of units installed in a plant of given total capacity. These demonstrated that there was a significant increase in the total annual energy when the plant design included two turbines as compared to one. However, a design using three turbines did not increase the annual energy or plant efficiency sufficiently to compensate for the additional construction costs.

A series of runs was made to compare the energy output of 2-unit plants of varying capacity. The runs were made for 1982 , assumed as the first year of full operation of the power project. Projections were also made, using the computer, of annual energy production over a 40-year period of plant operation for 2-unit installations of various capacities.

From the annual costs and the estimate of annual energy production in 1982, the estimated unit cost of energy can be calculated for each size of installation considered. The results demonstrated that cost would be a minimum for a plant in the capacity range 9 to $13 \mathrm{MW}$. Based upon this finding, if 40-year financing is employed, a $12 \mathrm{MW}$ plant will produce annually 56 million kWh of energy at 21.2 mills in 1982 dollars, a cost which is likely to be readily marketable. It was also apparent that, as irrigation releases increase from year to year, and if current economic trends continue, additional units will become feasible in the future. The development recommended in the report, therefore, consists of an initial installation of two $6 \mathrm{MW}$ units, with provision for the construction of further units in later years.

\section{PROJECT DEVELOPMENT}

Alternative locations for the power plant, penstock and tailrace were considered. The alternative arrangements differed primarily in the use of existing and new water passages through the dam. Based on operational, economic and impact considerations the alternative considering a new conduit penetrating the existing dam was chosen for detailed study.

In order to preserve the integrity of the dam's earth core, the penstocks will be placed in a tunnel excavated through the foundation rock. Individual, 14-foot diameter penstocks are proposed for each unit in order to keep tunnel excavation as far beneath the dam foundation contact surface as possible. The powerhouse will be located immediately downstream of the toe of the existing dam embankment. The powerhouse will be a rectangular concrete structure with plan dimensions approximately 117 feet by 48 feet. Downstream of the powerhouse, the tailrace will consist of a concretelined transition section, and an unlined channel excavated in rock to join the existing Main Canal. The switchyard will be located adjacent to the powerhouse. Concrete foundations will be provided for the step-up transformer, takeoff towers and related equipment. 
Selection of the type of turbine most suitable for the project conditions requires the consideration of power output over the expected. range of operating conditions. Generating plants operating under a head in the range of 10 to 80 feet are considered "low head" installations, and call for the selection of a hydraulic turbine which can be designed to have a high specific speed. The most suitable turbine runner to meet these conditions is the propeller type, which can be incorporated in a variety of configurations. The efficiency of a turbine varies with the head and flow under which it operates. In order to obtain acceptable performance throughout the wide range of operating conditions at Dry Falls, a propeller with adjustable blades would be required. For the purpose of comparing alternative power plant locations, and as a basis for the financial analysis of the project, the use of conventional vertical-shaft, Kaplan turbines, has been assumed. Selection of the most suitable type will be reviewed in the course of final design, based upon firm quotations to be obtained from equipment suppliers.

\section{FINANCIAL ANALYSIS}

The estimated construction costs representing contractors' bid prices in September 1978 dollars is approximately $\$ 8.47$ million. The total represents a cost per kilowatt of installed capacity of $\$ 706$.

The total construction investment required was determined by adding the cost of engineering, design, supervision, and contract administration to the estimated construction cost, and allowing for escalation to the date of construction. Escalation was calculated at 8 percent annually, for a 31month period, on the assumption that bids would be submitted in the spring of 1981 . The total construction investment, reflecting these allowances, is estimated as $\$ 11.54$ million.

To obtain the total capital cost of the project, such costs as interest during construction, fees for legal services and bond counsel, and various miscellaneous costs related to project implementation should be added to the investment cost. In addition, the financing of the development must provide for the payment of interest on borrowed funds during construction. The actual requirements will be dependent upon the selection of a power purchaser, and advice by the District's financial consultant and bond counsel concerning the method of financing. Including allowance for these costs, the project could be financed by means of a $\$ 13.7$ million bond issue. Annual debt service for a $7 \%$ bond issue with a 40 -year maturity will be approximately $\$ 1,030,000$. Estimated annual operating expenditures in the first year of operation are calculated at $\$ 150,000$. On this basis, total annual costs are estimated as $\$ 1,180,000$ and the cost per $\mathrm{kWh}$ is 21.2 miles.

The value of electrical energy in the Pacific Northwest is heavily influenced by the availability of resources, and the role of the Federal government as a major marketing agent for power in the region. Hydroelectric developments have provided a major share of the region's energy needs to date. These resources have been developed by privately- and publicly-owned utilities, as well as the Federal government. Development of the region's major resources of low-cost hydropower is approaching saturation, and it follows that future expansion of generating capacity will involve higher-cost thermal, small hydro, and nuclear plants. Until recently, BPA has been meeting the full requirements of all the public utilities. For the first time in history, BPA has informed such utilities that its resources will not be sufficient to meet their growth needs after 1983. BPA has notified the aluminum, chemical, nickel and other basic industries which it serves directly that it cannot renew their power contracts when they expire in the mid-1980's. As of January 1979, the South Columbia Basin Irrigation District is in the process of .negotiating a contract with the cities of Seattle and Tacoma for the purchase of power from a $5 \mathrm{MW}$ installation known as P.E.C. 22.7, near 0thello, Washington. The contract records the intent of the three Irrigation Districts and the cities to. enter into purchase agreements covering power from subsequent developments within the Columbia Basin Project. Such purchase would be contingent upon the developments conforming with agreed cost criteria.

\section{PROJECT IMPLEMENTATION}

Authority for the Districts to undertake development is subject to the terms of the repayment contracts with the U.S. Department of Interior, Bureau of Reclamation (USBR). Under these contracts, water rights within the Columbia Basin Project are vested in the United States, subject to the right of the Districts to the unimpaired use of the project water supply. Construction of the power facilities on federally-controlled land, and use of the water supply for power generation purposes, is subject to the prior approval of the Secretary of the Interior. Approval to proceed with development at Check 22.7 on the Potholes East Canal has been given to the South Columbia Basin Irrigation District. Development would be governed by an agreement with the USBR, containing provisions whereby the integrity of the irrigation system, the water rights of the United States, and its responsibilities for operation and maintenance of project reserved works are protected. In addition, the Bureau has requested that the financial returns from the proposed development be carefully evaluated to:

(1) ensure that the District's contractual obligations are not impaired, and (2) establish water. supply criteria to avoid any prejudice to the development of new project lands. Similar provisions would apply at Dry Falls. 
Preparation of the FERC license application and design and construction activities will start immediately after the conclusion of the power negotiations. One year has been allowed for the FERC license application approval process. The process to obtain all other necessary permits and agreements will also be initiated following the completion of the power negotiations. Throughout the process of negotiating agreements, obtaining permits, and in connection with financing requirements, legal services and professional advice regarding financing would be obtained.

Major construction activity is scheduled for the period between irrigation seasons to minimize the risk of interruption to irrigation system operations. Based upon contact with manufacturers of hydraulic and heavy electrical machinery, a period of 15 months has been allowed for delivery of the major equipment. The schedule indicates that the development will produce power in mid-1982.

Based upon a preliminary environmental assessment of the project, the South Columbia Basin Irrigation District has filed a declaration of non-significant environmental impact. Since no negative responses were received from the agencies notified and no opposition or objections to the published and advertised declarations were entered within the period of time allowed by law, the declaration of non-significant environmental impact has become final.

A more detailed environmental assessment will be conducted as part of the FERC license application procedure; however, it is our expcrience that negative environmental impacts would not resilt from construction of the proposed plant. On the other hand, several positive impacts can be expected. Since five nuclear power plants are in various stages of design and construction in Washington State, and since other coal-fired plants are being considered in the region, the construction of the Dry Falls Dam power plant would be a pollution-free source of energy which would help reduce the future use of these alternative polluting fuels.

Construction and operation of a power plant at Dry Falls Dam should have a slightly beneficial impact on the regional and national economy. The power cost will be cheaper than most other options for future power that regional electric utilities are considerating. In the long run, construction and successful operation of a hydropower development at Dry Falls Dam is 1ikely to spark greater interest in construction of hydroelectric plants at similar sites throughout the region. Future construction projects of this type will directly benefit the local cons truction economy, and indirectly benefit the regional economy by helping to hold down the power rates. 
EXPANSION OF SHAWMUT HYDROELECTRIC PROJECT

Fairfield, Maine

Central Maine Power Company

stone \& Webster Engineering Corporation

PRDA Proposal Contract No. EW-78-F-07-1812

\section{I : INTRODUCTION}

The Shawmut Hydroelectric Project is located on the Kennebec River, 67 miles above its mouth, in the community of Shawmut, Maine. Most of the existing facilities were built in 1912. They include a 1,135 ft. long concrete gravity dam and a separate powerhouse structure containing six hydro units having a total combined capacity of 5,800 $\mathrm{KW}$. Each existing unit consists of a horizontal shaft, four runner Francis turbines, with a direct connected generator located in a gallery downstream of the turbine assembly. With $4 \mathrm{ft}$. flashboards on the dam, the gross operating head is about $23 \mathrm{ft}$. The average annual plant output is presently $41,300,000 \mathrm{KWh}$.

The purpose of the feasibility study was to determine the most practical method of installing additional generating capacity at this site, and the preferred size and type of new units.

\section{ALTERNATIVES STUDIED}

The alternatives studied for the Expansion of Shawmut Hydroelectric Project are as follows:

A. Two fixed blades, $1720 \mathrm{KW}, 2500 \mathrm{MM}$ standardized TUBE units, in a new powerhouse at the downstream end of the existing powerhouse forebay on the west side of the river.

B. Two fixed blades, $2500 \mathrm{KW}, 3000 \mathrm{MM}$ standardized TUBE units with a new powerhouse and forebay at the east abutment of shawmut Dam which is situated in the Town of Benton.

C. Removal of one or more of the existing four runner Francis turbines in the existing powerhouse and replacement with modern turbogenerating equipment.

D. Two fixed blade STRAFLO units, rated $2500 \mathrm{KW}$ each, in a new powerhouse at the east side of the river (similar to Alternate B).

\section{FINDINGS AND CONCLUSIONS}

The results of the study indicate that Alternative $A$, two $1,700 \mathrm{KW}$ TUBE units on the west side of the river, is the most viable alternative for increasing the capacity of the shawmut Project. The powerhouse layout developed for this scheme, which is referred to as the west Side Layout, is shown in Figure 1. Due to the fairly simple nature of the standardized unit installation, construction of Alternative $A$ could be completed in one construction season.

Alternatives $A$ and $B$ were developed in sufficient detail to determine their power output and estimated construction costs, which are shown as follows: 
A.

West Side

Layout

New Installed Capacity, KW

Average Additional Annual Output, KWh

Direct Construction Cost, $\$$

Gross Plant Investment, \$

Annual Energy Costs, Mills/KWh

$$
3,440
$$$$
18,000,000
$$$$
3,000,000
$$$$
4,490,000
$$

198,000
B.

East Side Layout

$$
5,000
$$

$21,000,000$

$4,900,000$

$7,060,000$

67.2

$(88,000)$

The flow duration curve used in this study is shown in Figure 2 . It is based on 11 years of record at the Weston station of Central Maine Power Company (CMP) which is just above Shawmut. As shown on the Flow Duration Curve, the new units would be "first-on, last-off" running essentially continuously with the old units, which have wicket gates, running as flow permits.

Alternative $C$, the use of the existing powerhouse by replacing some or all of the existing units, was investigated briefly and found to be impractical for various reasons.

Alternative D, the use of STRAFLO turbogeneration units rather than TUBE units was found to be uneconomical. While some savings in powerhouse civil cost can be achieved by the use of STRAFLO units, the savings do not offset the higher capital cost for this type of equipment.

The anticipated ecological and socioeconomic impacts from any of the alternatives considered for this study would be minimal. They would be primarily related to construction activities which are of relatively short duration. No potential safety hazards are anticipated as a result of the proposed Shawmut Expansion.

Based on, the above Central Maine Power Company plans to proceed with the initial planning for the recommended expansion. However, because the existing license expires in 1993 a request for revision and extension of the existing license will be filed with FERC as part of our application procedure. 


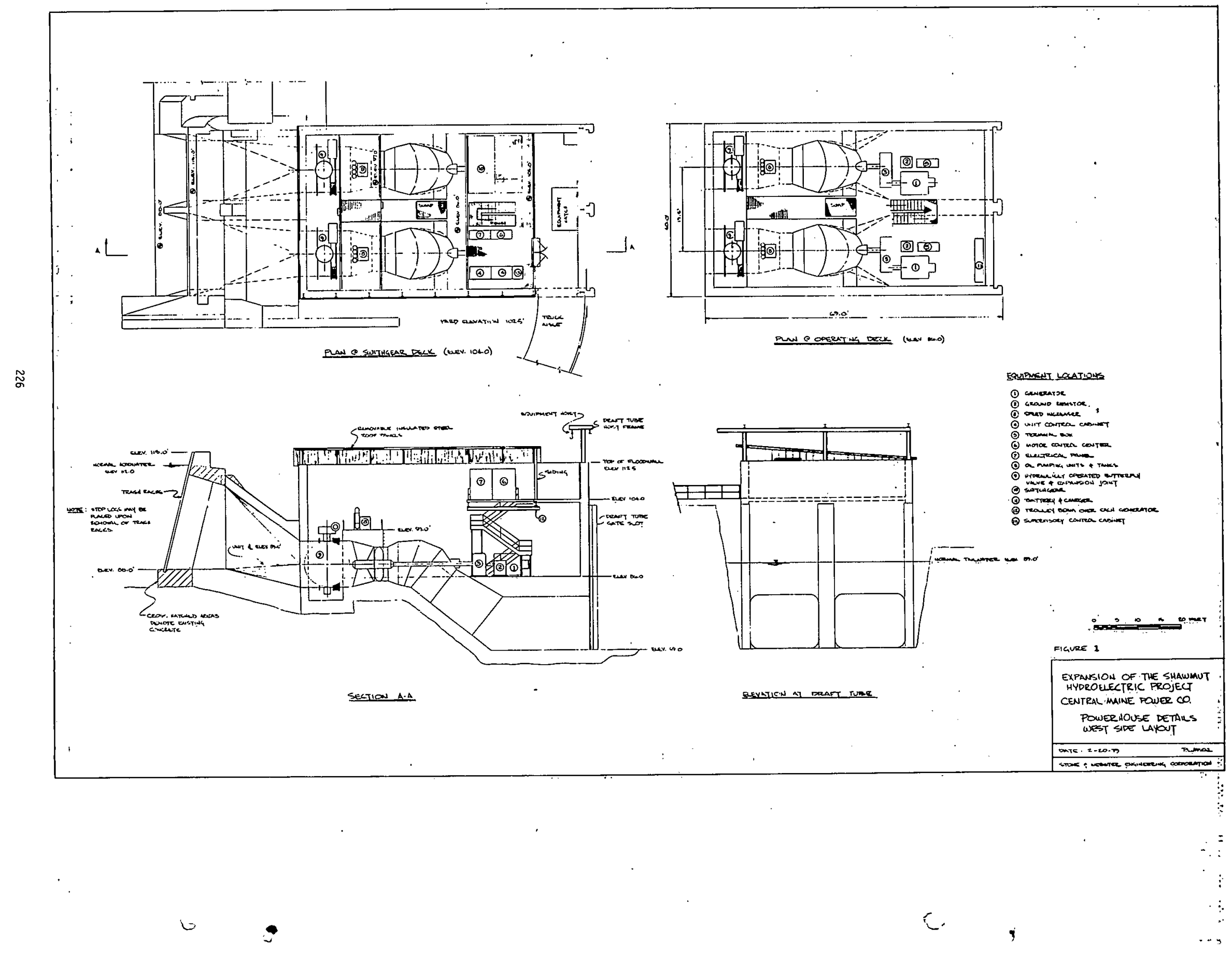




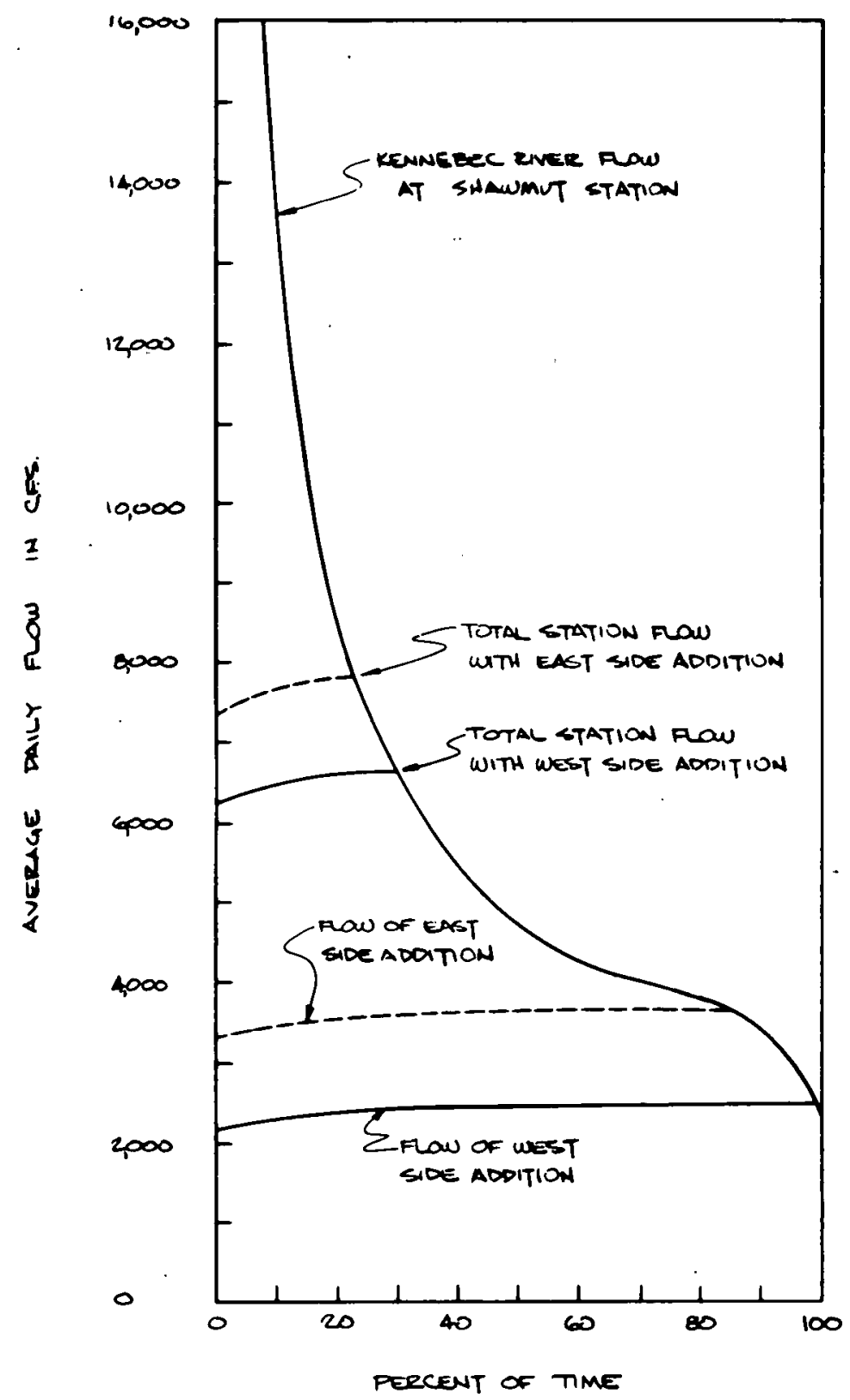

DRAINAGE AREA - 4200 SQ. MI.

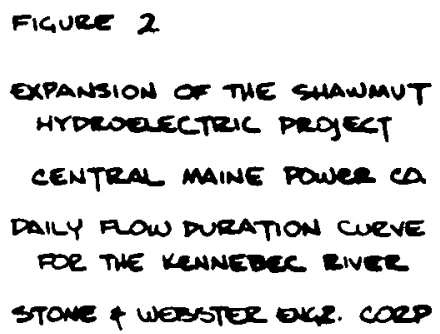


MAXWELL LOCKS. AND DAM

Southwestern, Pennsylvania

Allegheny Electric Cooperative Inc.

R. W. Beck and Associates

PRDA Proposal Contract No. 1813

\section{INTRODUCTION}

The proposed Maxwell Hydroelectric Project on the Monongahela River in southwestern Pennsylvania will utilize the 19.5-foot differential head of the existing Maxwell Locks and Dam to develop an annual energy of about 36 million kWh. From this feasibility assessment study for the Allegheny Electric Cooperative Inc. of Harrisburg, Pennsylvania the preliminary indications are that an 8-MW plant may be installed without significantly affecting the operation of the existing locks. In addition to site reconnaiseance and analysis of existing conditions, this study included alternative project arrangements and equipment, power output, cost estimates, economic analysis, and a preliminary environmental review.

At the Project about 30 miles south of Pittsburgh, the Monongahela River is about 600 feet wide in a well defined valley up to 1,500 feet wide with rather precipitious banks of weathered sedimentary rocks rising about 300 feet above the valley floor. The 4,990 square-mile drainage basin lying along the northwest side of the Allegheny Mountains has a humid continental climate with the average annual precipiation varying from about 40 inches at the Project up to about 50 inches including 100 inches of snowfali in the upper basin at elevations up to 4,842 feet. With an average of about $8,770 \mathrm{cfs}$, the streamflow at the site varies seasonally from an average of 2,760 cfs during September up to $18,530 \mathrm{cfs}$ during March. Two reservoirs in the upper basin provide regulation by peaking power from Lake Lynn and low-flow augmentation from Tygart Lake in addition to flood control.

\section{EXISTING DEVELOPMENT}

The existing Maxwell Locks and Dam is one of nine such navigational facilities of the Corps of Engineers on the main stem of the Monongahela which has an annual traffic of about 40 million tons, predominantly coal barges going down river. The existing facility provides a 19.5-foot lift through the two 84-foot wide locks along the right bank of the river by a dam composed of five radial gates each 84 feet long on a broad crested concrete weir founded on rock. At the left bank the powerhouse site is severely constricted in the 90 feet between the dam abutment and the railroad on the cut bench of the river bank about 60 feet above the streambed. In addition to the extensive anchorage system required to stabilize the excavated slopes in weathered rock, other unique site conditions include rather difficult access, limited construction area and the dramatic rise of the tailwater in the lower navigation pool while the upper pool level is held constant by raising the spillway gates to pass flood flows.

\section{PROJECT ARRANGEMENT}

After considering alternative arrangements, units and sizes, the preliminary investigation indicates that the most economical arrangement of the powerhouse would include four vertical units of 2-MW each. As shown in Exhibit A, a conventional intake with hydraulicly operated slide gates would convey up to 6,500 cfs through a covered power conduit over and behind the existing abutment structure to a 4-unit powerhouse situated along the bank below the dam. The powerhouse and water conduit are situated to minimize the excavation on the steep slope below the railroad.

Alternative arrangements considered include bulb and straflo units as..well as a. single tube unit and four small standardized tube units. The single tube unit appears.to be the 
most practical alternative but the estimated cost is in excess of the proposed vert1cal units. The cost of an arrangement with four standard tube units of 2-MW each appears to be competitive with the vertical unit arrangement but the powerhouse would extend into the river below the dam spillway exposing the powerhouse to flood flows. With all alternatives construction would be accomplished in two stages with dewatering by a cellular cofferdam.

\section{POWER OUTPUT}

After deducting the water required for lock operations and gate leakage, the power operation studies indicate that the $8,000-\mathrm{kW}$ project can develop an average annual energy of 35.9 million $\mathrm{kWh}$ and an average annual capacity of $4,914 \mathrm{~kW}$, delivered at the load center. The Project would be tied into the local 25-kV distribution system of West Penn Power Company with line losses deducted to deliver power into the nearest Allegheny service area about 40 miles east of the Project.

\section{ECONOMIC ANALYSIS}

The earliest practical schedule for the Project is an on-line date of January 1985. At that time the Total Investment cost is estimated to be from $\$ 17,800,000$ to $\$ 18,100,000$, depending on the interest rate assumed for interest during construction.

As shown in Exhibit $B$ economic feasibility was studied by comparison of the estimated annual cost of the Project with the projected costs of continued wholesale power purchases equal to the power output of the Project, with financing loans from three alternative sources. These alternatives are $7 \%$ and $9 \%$ interest rate REA loans, and financing under the National Energy Act at $7-1 / 8 \%$ interest on $75 \%$ of the Project cost, and additional financing at $9 \%$ on the balance. Current REA financing would be at about $9 \%$ whereas the $7 \%$ rate is considered a possibility for the future. With costs based on REA financing at $7 \%$, and benefits based on the projected power costs of West Penn Power Company, benefits begin to exceed the costs during the fifth year of operation with a cumulative net benefit in the ninth year, and the accumulated present worth (1985 level) becomes positive during the tenth year of operation. With the alternatives of $9 \%$ REA and 7-1/8\%-9\% DOE financing, the accumulated present worth values show that the project benefits are less than the costs for the first 10 years of operation.

\section{CONCLUSIONS}

The Project is considered technically feasible and without any major environmental issues. It shows economic feasibility providing satisfactory financing terms are attainable. Such satisfactory financing alternatives include a 7\% REA loan, which might consist of a combination of $5 \%$ and $9 \%$ REA loans, or DOE financing under the new National Energy Act with the $25 \%$ portion of the loan not covered being financed with $7 \%$ or lower interest loans (possibly through REA).

If significant Federal dam-user fees were charged for the use of the Maxwell Locks and Dam it is generally apparent that the Project would not be feasible. Such fees have been assessed on the licenses of hydroelectric developments at some Federal dams in the past but for low-head projects the concept of such fees appears to be in opposition to the current Federal program to promote low-head development. 


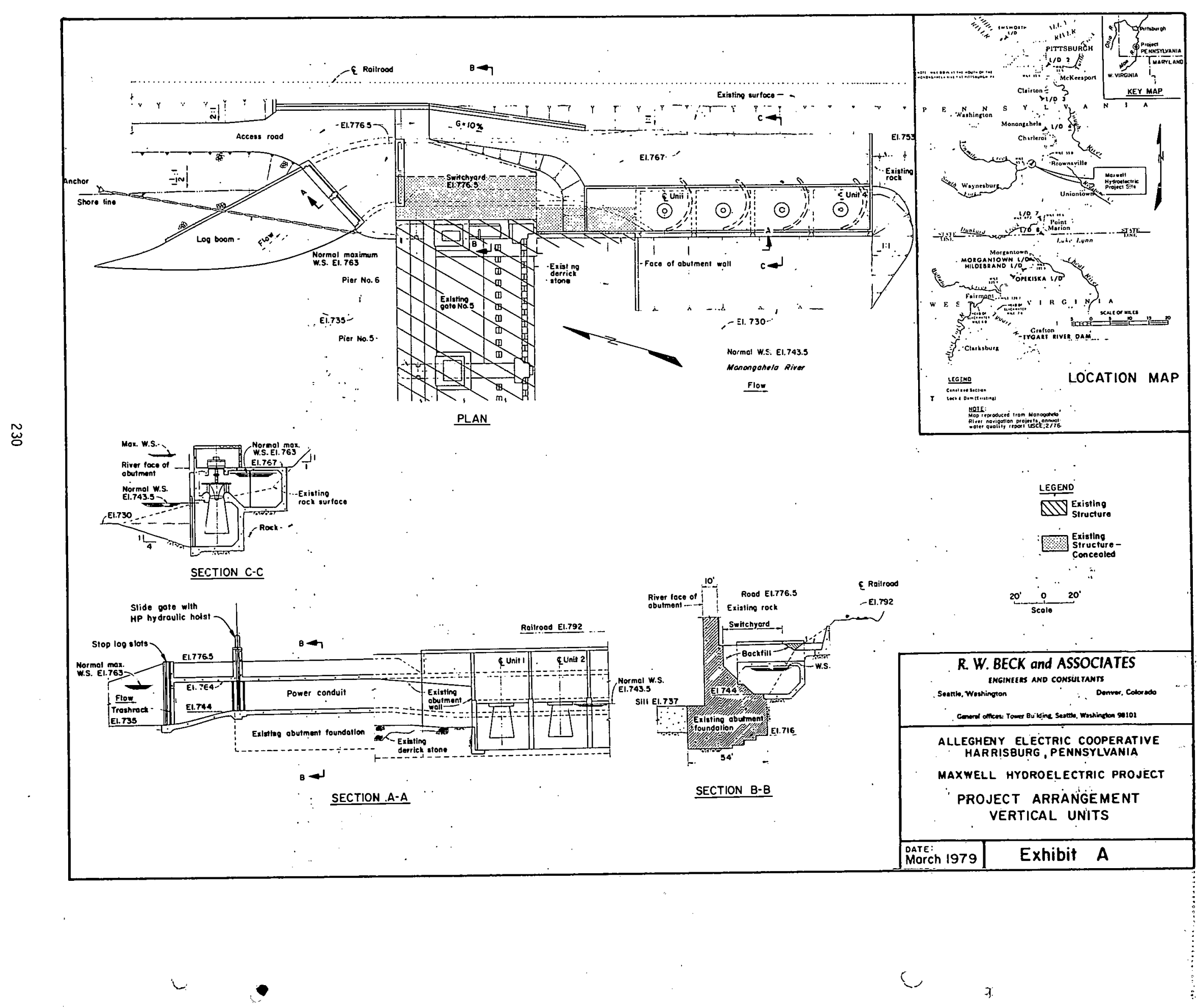




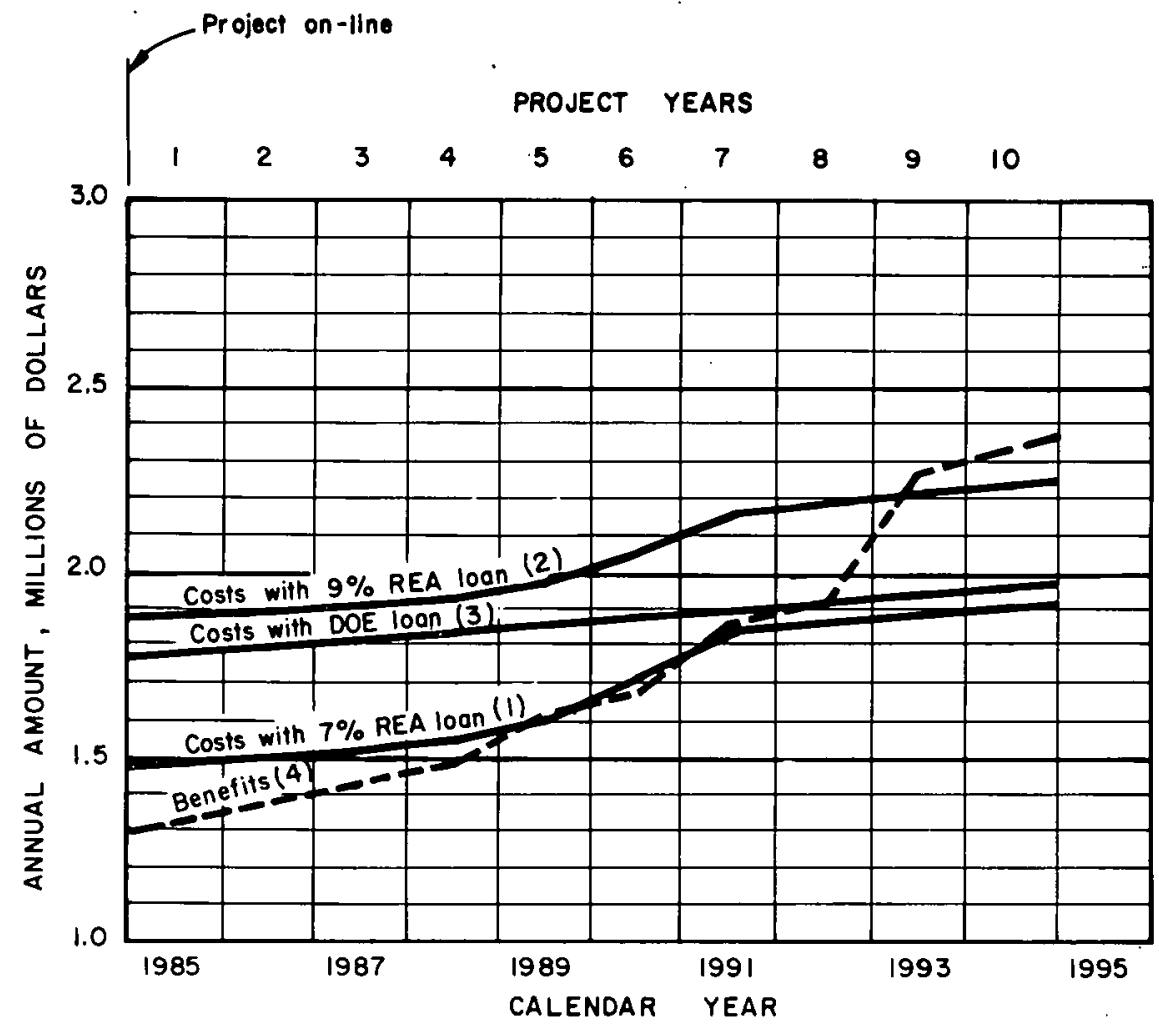

NOTES

I. Project annual cost with a 35 year REA loan at $7 \%$, or half af $5 \%$ and half of $9 \%$.

2. Project annual cost with a 35 yeor REA loan at $9 \%$

3. Project annual cost with a 30 year DOE loan at $7-1 / 8 \%$ for $75 \%$ of the total loon, and the balance of $9 \%$ with a 30 year conventional loan.

4. Project benefits based on West Penn Power Company wholesale power costs as projected by Southern Engineering Compony.

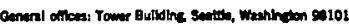

ALLEGHENY ELECTRIC COOPERATIVE HARRISBURG, PENNSYLVANIA

MAXWELL HYDROELECTRIC PROJECT

ECONOMIC COMPARISON PROJECT COSTS AND BENEFITS 


\section{BROADWATER HYDROELECTRIC PROJECT}

Toston, $\mathrm{MT}^{*}$

Tudor Engineering Company

PRDA Proposal Contract No. EW-78-F-07-1822

\section{INTRODUCTION}

The Montana Department of Natural Resources and Conservation entered into a cooperative agreement with the United States Department of Energy to conduct a study to investigate the feasibility of developing the Broadwater Hydroelectric Project. The Department, in turn, issued a subcontract to Tudor Engineering Company to perform a malor portion of the study. Also, subcontracts were issued by the Department to the Lowell c. Hansen Company of Helena, Montana for surveying and by Tudor to Hydro-Research Sclence of Santa Clara Californta for a hydraulic model study.

The Broadwater Hydroelectric Project would be located at Toston Dam, which was bullt in 1940, is a concrete gravity overflow dam which diverts irrigation water to the agricultural land around Toston.

Two alternate conflgurations were evaluated for the Broadwater site. One, known as the conventional alternative, would consist of a powerhouse structure contiguous to the left abutment of the existing structure. This configuration would be typical of the arrangement commonly used at similar sites. The other configuration, known as the apronmounted alternative, would consist of four turbine-generator units mounted on the downstream apron of the existing spillway. This configuration would be unique and could have significant implications for the development of many low-head hydroelectric sites in the nation.

To assess the economic feasibility of the project, and to determine the better alternative, both alternatives were thoroughly evaluated. The evaluations included the preparation of site layouts, an estimate of the potential generation, a determination of the project cost, an assessment of the project economics and a brief overview of the environmental aspects. Additionally, a model study was performed for the apron-mounted alternative because of the unusual flow conditions of the configuration.

The result of the evaluations was the determination that the apron-mounted alternative was the best option for development of the Broadwater site. Additionally, the Bureau of Reclamation PL-984 loan program, previously considered inapplicable to small hydroelectric projects, was determined to be viable and economically superior to. the other financlal options commonly used. Using these two options, the cost per kilowatt for the Broadwater site was determined to be $\$ 1,180$ and the cost per kilowat-hour in the first year of operation was calculated to be 17.4 mills/kWh. The latter value is considerably less than the value of energy of $26.6 \mathrm{mills} / \mathrm{kWh}$ estimated for western Montana, thus indicating a feastble project.

\section{PROJECT DESCRIPTION}

Plates showing the proposed layouts of the two alternate configurations are attached to this summary. The conventional conflguration would utilize four tube turbines, totaling ten-megawatts, in a powerhouse structure to be built on the left abutment of the existing dam. The powerhouse would be attached to the dam and would become an integral part of the 1mpoundment faclitiy. The tube turbines would be mounted in the manner typically used for tube turbines. The turbine runner would be located in the water passageway directly downstream of the trashracks. Downstream of the runner, the passageway would bend slightly and the turbine shaft would pass through the passageway wall to the speed increaser and generator. Considerable excavation would be required to provide approach and taflrace channels for this alternative. 
The apron-mounted configuration would utilize four vertical shaft propeller turbines, with a total capacity of 9.8 megawats. The turbine cases would be encased in a mass concrete addition to the downstream face of the dam. The speed increasers and generators would be located in a superstructure to be bullt above the spillway. The configuration would be what is commonly known as a flume-type configuration. Flow to the turbine runner would not pass through a closed conduit. Instead, an impoundment, formed by the powerhouse structure, would be created on the downstream face of the spillway. Water would be withdrawn directly from this impoundment, through the turbine runner and out the draft tube. The turbine shaft would pass directly through the lmpounded water to the speed increaser and generator located on a floor above.

Each of the alternatives would include the replacement of the existing flashboard system, which increases storage capacity during the summer months, with radial arm gates. The gates would provide increased operational flexibility and would allow a constant water surfce elevation to be maintained on the turbines.

The two alternatives would operate similarly through the range of normal operation. All of the reservolr release would be routed through the power plant. During periods of high flood flows, however, the two alternatives would operate differently. Both would shut down as the increased tallwater made power generation impossible. Additionally, however, the apron-mounted alternative, which would occupy a section of the existing spiliway, would have to be reconverted to a spillway function. To accomplish this, the back wall of the powerhouse would consist of fixed wheel gates, which could be raised to allow the passing of spill. It was determined that the construction of this configuration would not significantly reduce this spillway capacity. The flood that would require operation of the fixed wheel gates would be an infrequent event with an estimated recurrence interval of twenty years. In addition to the function of the fixed wheel gates during periods of spill, the gates would also serve as stop logs during routine plant maintenance.

A model study was prepared of the apron-mounted configuration because of the unusual flow conditions involved. The model contractor, Hydro-Research Science of Santa Clara, California, prepared a model of a single turbine bay. The model as evaluated during both the normal operation and the spill modes. No serious flow problems were discovered in elther mode. A minor vortex problem in the normal operation mode was solved by the installation of a vortex breaker.

Both alternatives would include the replacement of the existing diversion intake structure with a new structure, located at a higher elevation, to accomodate the higher reservolr water surface elevation created by the radial gates.

\section{PROJECT ECONOMICS}

As a preliminary step to the calculation of project feasibility, the potential power generation and project cost was estimated for each alternative. The generation from each alternative, based upon. an operation study using fifty years of hydrologic data, was determined to be approximately fifty-five million kilowatthours per year. The project costs, including contingencies and indirect costs, were determined to be $\$ 11,500,000$ for the apron-mounted alternative and $\$ 13,200,000$ for the conventional alternative.

Three possible sources of financing were considered in evaluating the Broadwater project; the potential Department of Energy loan program, the Bureau of Rec1amation PL-984 loan program and conventional financing through revenue bonds. The PL-984 loan program hs been previously considered to be inapplicable to small hydroelectric projects. Conversation with Bureau officials, however, established that the Bureau is willing and anxious to make these funds avallable to small hydroelectric developers. Using the interest rates and repayment periods pertinent to each funding source, the unit energy production cost was calculated for each of the possible configurations and financial options. These were as follows:

Energy Production Cost

Apron-Mounted

DOE Luan

PL -984

Revenue Bonds
$19.3 \mathrm{mills} / \mathrm{kWh}$

$17.4 \mathrm{mills} / \mathrm{kWh}$

$22.7 \mathrm{mills} / \mathrm{hWh}$

\section{Conventional}

$22.3 \mathrm{mflls} / \mathrm{kWh}$

$20.1 \mathrm{~m} 111 \mathrm{~s} / \mathrm{kWh}$

$26.4 \mathrm{mills} / \mathrm{kWh}$ 
From data gathered and published by the Federal Energy Regulatory Commssion, the value of energy in western Montana.was determined to be 2.6 .6 m1lls/kwh. Thus the Broadwater project is feasible regardless of the alternatives used. However; $1 \mathrm{t}$ 1s clear that the. PL-984 $10 a n$ option and the apron mounted configuration are the better alternatives.

One possible disadvantage of the PL-984 financing is the long processing time: required by the Bureau. The profects schedule developed during the study indicated that the profect could be expected to go on-line no earlier than october 1983. using these funds. This is approximately one year later than could be achieved using efther of the other funding sources.

The effect of inflation was also evaluated. It was shown that greater future power values from inflation greatly enhance the project feasibility. For example, when the assumed inflation rate is increased from zero percent to three percent, the benefit/cost ratio of the conventional configuration financed with revenue bonds assuming a ten percent discount rate, Increases from 1.02 to 1.37 .

\section{SUMMARY}

The apron-mounted configuration was shown. to be a viable and economically superior alternative for the Broadwater site. This configuration could have wide use at other, similar sites throughout the nation. The Bureau of Reclamation PL-984 loans were also shown to be a viable and economically sound option for project financing. 


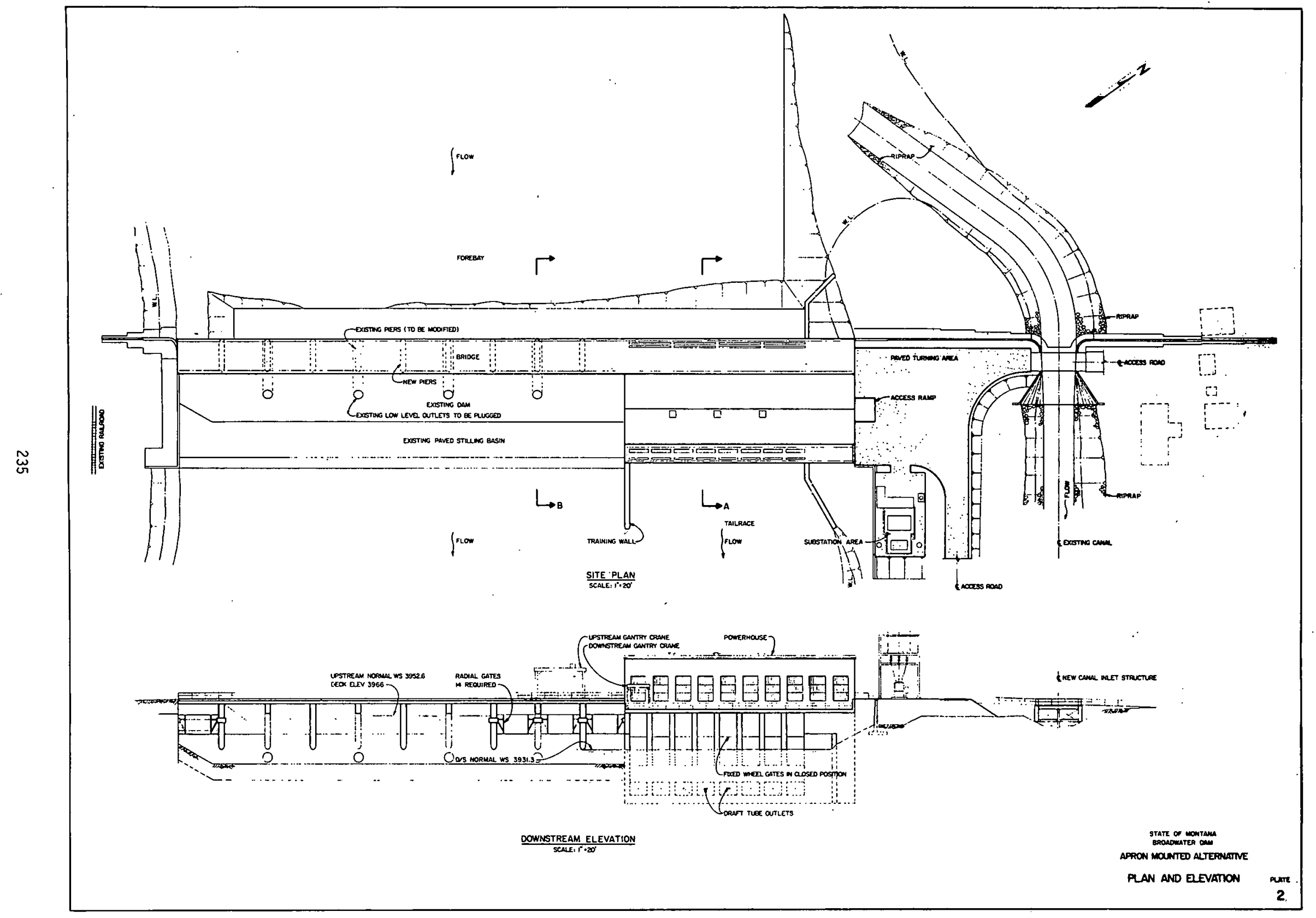




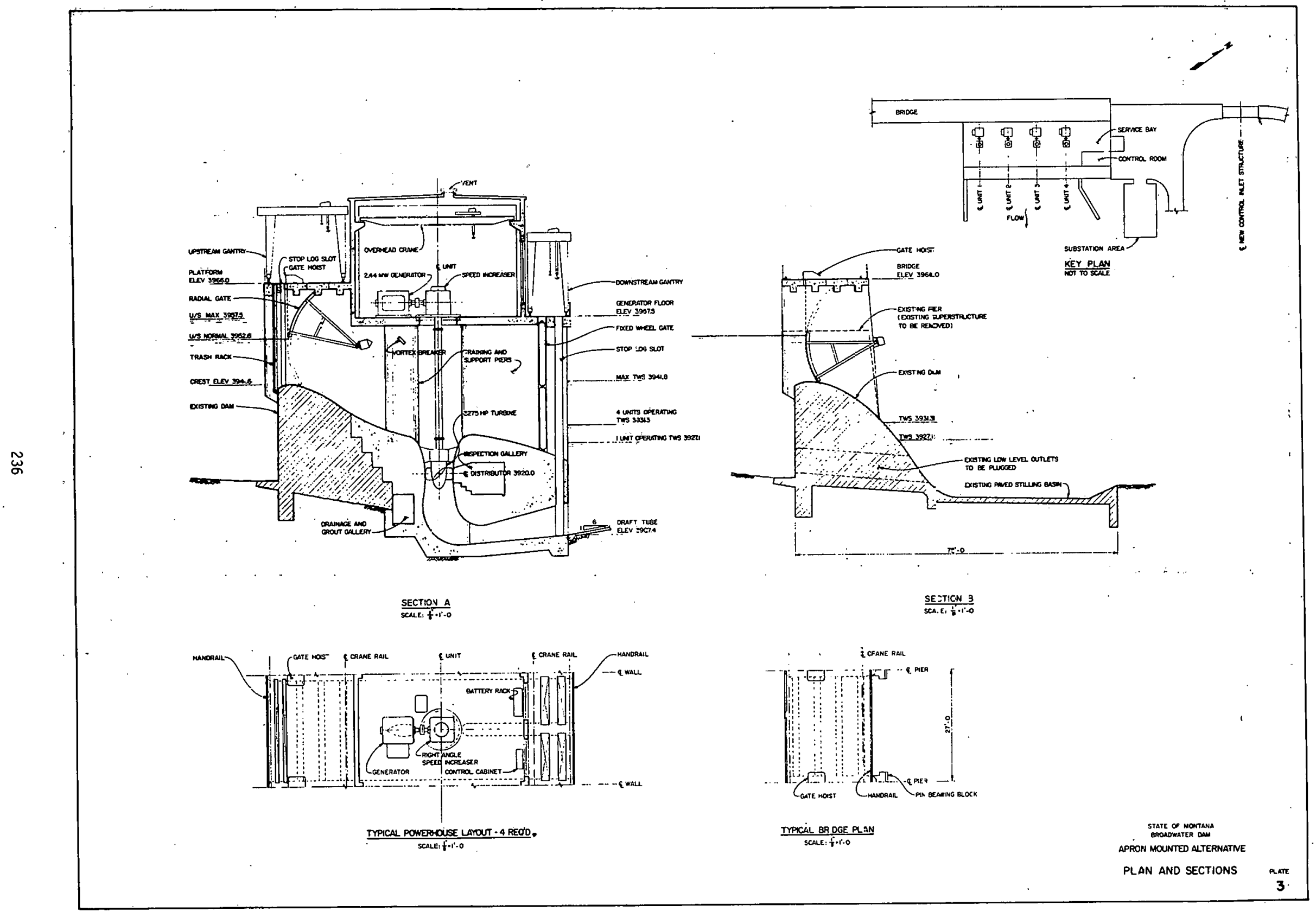



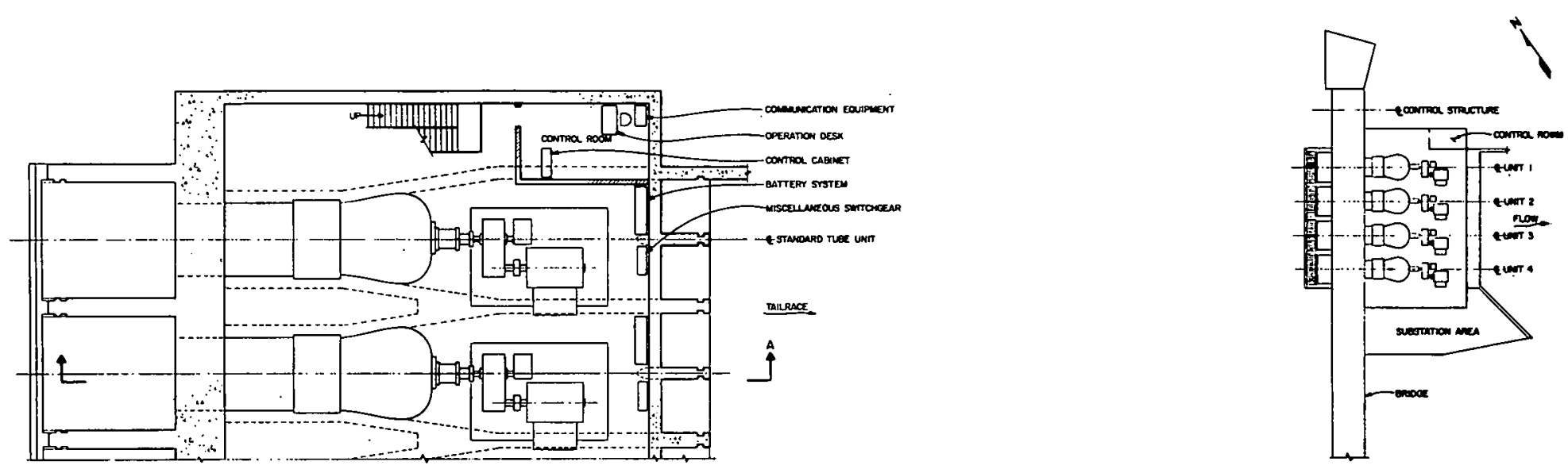

MALF PONERHOUSE PLAN

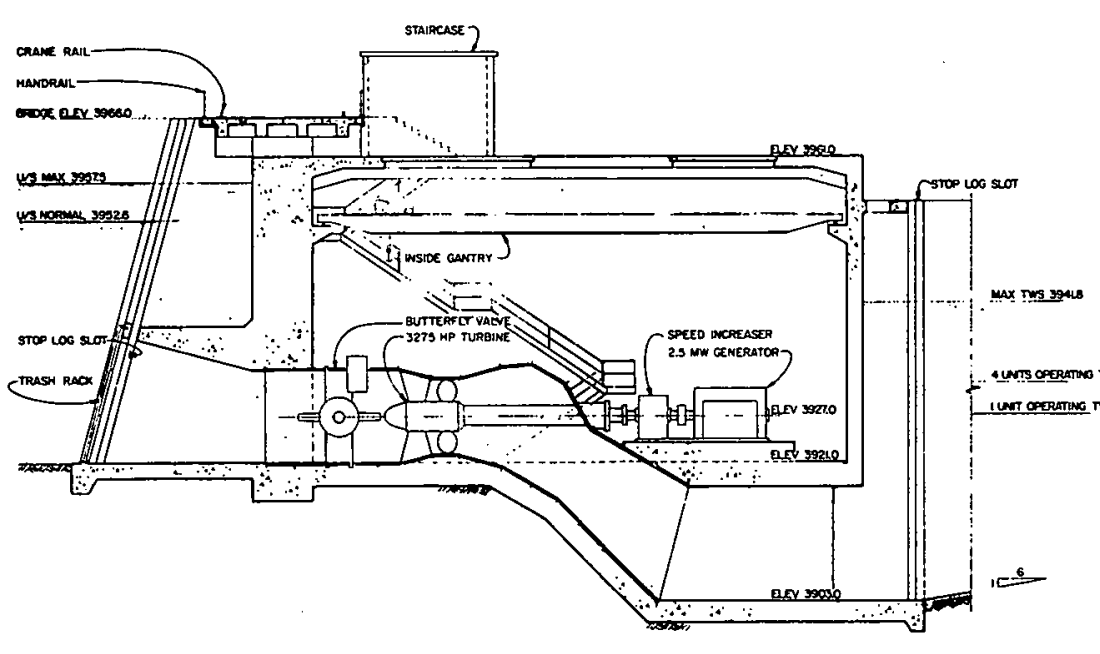

$\frac{\text { SECTiON A }}{\text { Sace it iti-o }}$

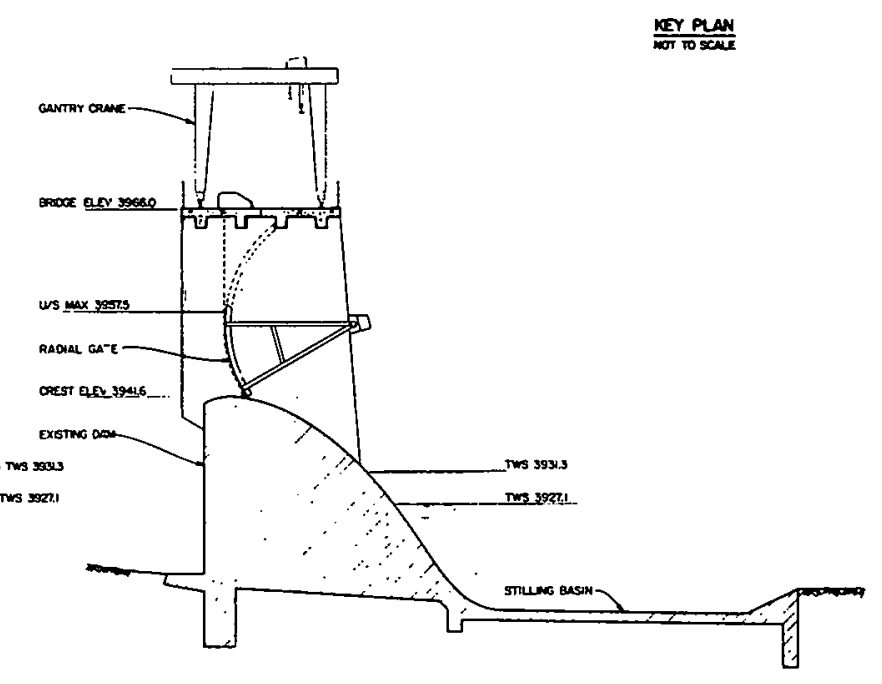

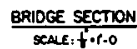




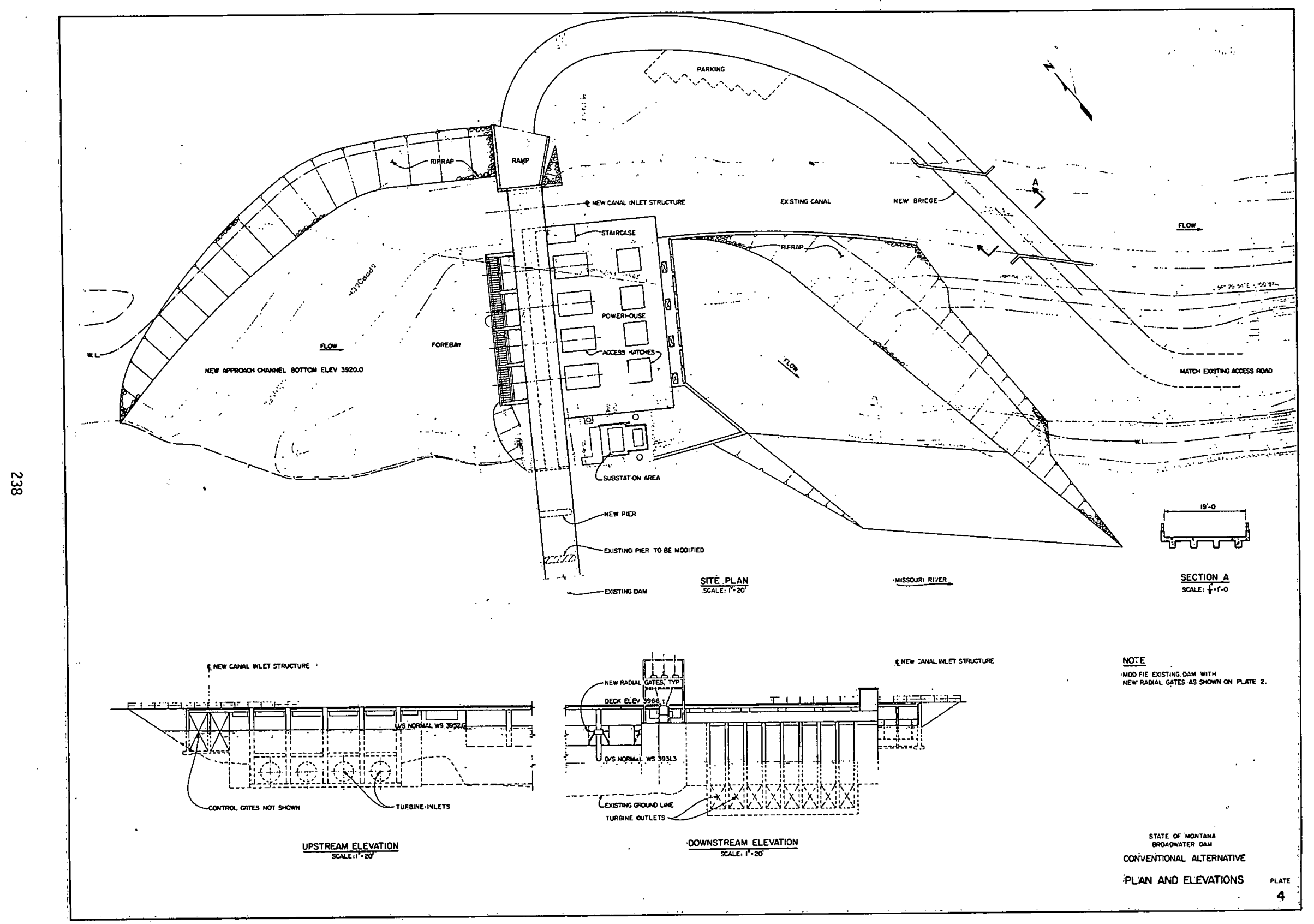




$$
\text { - }=
$$

